\title{
SEARCH FOR UNDERGROUND OPENINGS FOR IN SITU TEST FACILITIES IN CRYSTALLINE ROCK
}

\author{
Harold A. Wollenberg, Beverly Strisower, Donald J. Corrigan, \\ Alexander N.Graf, and Maura T. O'Brien \\ Lawrence Berkeley Laboratory \\ Berkeley, California \\ Howard Pratt and \\ Mark Board \\ Terra Tek \\ Salt Lake Gity, Utah \\ and \\ William Hustrulid \\ Colorado School of Mines \\ Golden, Golorado \\ Ocrober 1979 \\ Revised January 1980
}

Prepared lor the U.S. Departmenl of Energy under Contract No, W-7 405-ENKG-48 through a contract with the Office of Nuclear Waste Lsolation, Battelie Mermoriel Institule and the Nuclear Regulatory Commission.

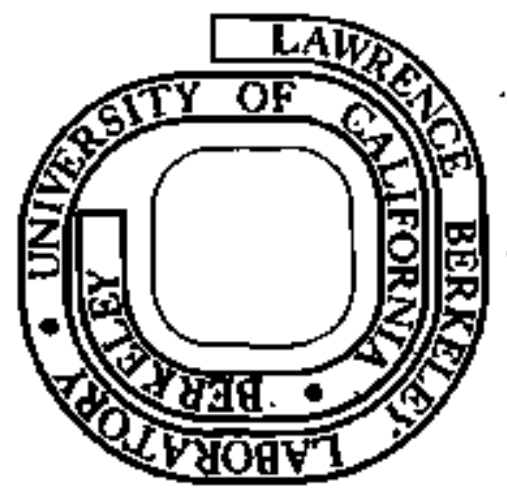

\section{TWO-WEEK LOAN COPY}

This is a Library Circulating Copy which may be borrowed for two weeks. : For a personal retention copy, call Tech. Info. Division, Ext. 6782 
SEARCH FOR UNDERGROUND OPENINGS FOR IN SITU TEST

FACILITIES IN CRYSTALLINE ROCK

\author{
Harold A. Nollenberg, Beverly Strisower, DonaId J, Corrigan, \\ Alexander N, Graf, and Maura T, O'Brien \\ Lawrence Berkeley Laboratory \\ University of Calfformia, Berkeley, CA \\ Howard Pratt and \\ Mark Board \\ Terra Tek \\ Salt Lake City, Utah \\ and \\ Wiltian Hustrulid \\ Colorado School of Mines \\ Golden, Colorado \\ October 1979 \\ Revised January 1980
}

This work was supported by the Assistant Secretary for Nuclear Energy, Office of Waste Isolation of the U.S. Department of Energy under Contract No, w-7405-ENG-48. Funding for this project was administered by the office of Nuclear Haste Isolation at Battelle Nenorial Institute.

Publication of this report was funded by High Level Waste Technical Developnent Branch, Division of Waste Management, Office of Nuclear Material Safety and Safeguards, U.S. Nuclear Regulatory Commission, Washington, D.C. 20555, under Interagency Agreenert DOE 50-80-36, N.R.C. FIN. No. B 3110-0. 



\section{ABSTRACT}

This report covers a project to identify existing underground openings which nay be utilized as facilitíes for geonechanical, geochenical and hydrogeologic tests pertinent to the isolation of radioactive wastes in crystaline rock. With a few exceptions, crystaline rocks in this study were linited to plutonic rocks and nedium to high-grade metamorphic rocks. A review of the literature was conducted, based prinarily on MAS, the Minerals Availability Systen of the U.S. Bureal of Mines and to $s$ lesser extent on CRIB, the Conputerized Resources Infornation Bank of the U.S. Geological Survey, and GEOREF. Nearly 1700 underground mines, possibly occurring in crystalline rock, were initially identified. Application of criteria, which included:

- Crystalline rock

- Depths be1on 600 feet

- Horkings of adequate size to provide for a Stripa-sized facility

- Norkings open within the past 10 years and not flooded or caved

- Norkings below the wster table

- Good rock support

resulted in the identification of 60 potential sites. Within this number, 26 nines ("c1ass 1") and 4 civil works were identified as having potential in that they fulfilled the criteria; these are sumarized in detail. Thirty nines ("class 2") may have simflar potential if information on one or more criteria is obtained; information on these mines is tabulated.

Wost of the nines identified are near the contact between a pluton and older sedimentary, volcanic and netamorphic rocks. However, some mines and the civil works are well within plutonic or setamorphic rock masses. Civil works, notably underground galleries associated with pumped storage hydroelectric facilities, are generally located in tectonically stable regions, in relatively homogeneous crystalline rock bodies.

A progran is recommended which would identify one or nore sites where a concordance exists between geologic setting, conpany amenability, accessibility and facilities to conduct in situ tests in crystalline rock. 
TABLE OF CONTENTS

$\begin{array}{lr}\text { Abstract } & \text { Page } \\ \text { Table of Contents } & \text { i } \\ \text { List of Figures and Tables } & \text { i1 } \\ \text { Acknowledgenents } & \text { rix } \\ \text { Introduction } & 1 \\ \text { I. Identification and Selection Processes } & 5 \\ \text { II. Sunmaries of Information } & 9 \\ \text { III, Conclusions and Reconnendations } & 21 \\ \text { IV. Descriptions of "c1sș 1" Mines and Civil Works } & 25 \\ M I N E S & 27\end{array}$

Arizona

$\begin{array}{ll}\text { Lakeșhore Mine } & 27\end{array}$

$\begin{array}{ll}\text { Miami East Mine } & 37\end{array}$

$\begin{array}{ll}\text { Sar Manuel/Kal anazoo Mine } & 47\end{array}$

\section{California}

Pine Creek Mine $\quad 63$

Colorado

Climax Mine $\quad 75$

$\begin{array}{lr}\text { Schwartzwalder Mine } & 89\end{array}$

Jrad Mine/Henderson Nine 99

Colorado School of Mines, Experimental Mine 109

Idaho

$\begin{array}{ll}\text { Lost Packer Mine } & 117\end{array}$

$\begin{array}{ll}\text { Coeur d'Alene District } & 125\end{array}$

Dayrock Mine $\quad 143$ 
Idaho (cont.)

Star-Morning Wine

Coeur Mine

Maine

Black Hawk (second pond) - Blue Hill Mine

\section{Minnesota}

Minnanax Project and Ely Prospect

163

Montang

Black Pine Mine

Butte Mining District and Butte Linderground Mines

Steward Mine

Granite-Bimetallic Mine

Nevada

Tén Piute District

New Jer sey

Mount Hope and Scrub Oaks Mines

New Mexico

Questa Molybdenum Mine

New York

Balmat-Edwards District Mines

Lyon Hountain District

South Dakota

Home stake Mine

\section{Tennessee}

Ducktown District 
Hashington

Holden Mine $\quad 295$

Wyoming

Sunrise Mine $\quad 307$

$\begin{array}{lr}\text { CIIL WORKS } & 315\end{array}$

Cal ifornia

Helms Underground Powerhouse - Punped Storage Project 317

Idaho

Bworshak Dam Site

Nevada

Nerada Test Site - Climax Stock

331

South Carolina

Bad Creek Pumped Storage Project

$\begin{array}{ll}\text { Bibliography } & 349\end{array}$

Index

Appendix 1 - Sources of Information 443

Appendix 2 - Mines in Crystalline Rocks Considered for Study 457 
LIST OF FIGURES AND TABLES

Page

I. Identification and Selection Process

6

Figure 1. Identification and selection process for potential underground sites

I . Sumaries of Information

Figure 1. Location of underground workings on 10,11 map of the United States

Table 1. "Class I" mines $12,13,14$

Table 2. "Class $2^{\text {th }}$ mines $16,17,18,19$

III. Conclusions and Recomendations

IV. Descriptions of "class 1" mines and civil works

MINES

Arizona

Lake shore Mine

Figure 1. Location map of the lakeshore ore body, Pinal County, Arizona (Hallof, 1974)

Figure 2. Preliminary geology of the lakeshore Mine area has been largely interpreted frow drill hole data. Cross section $A-A^{\prime}$ is seen as Figure 3 (Harper, 1969)

Figure 3. Geologic section A-A' of Lakeshore ore deposit (Harper, 1969)

Figure 4. North-south and east-west cross sections of Lakeshore deposit illustrating the three zones of mineralization: oxide, sulfide, and tactite (EMI, June, 1969)

Table 1. Lakeshore Mine rock properties

(Board, 1974)

Miami Eaşt Mine

Figure 1. Index map of Arizona showing location of Globe quadrangle (Peterson, 1951) 
Figure 2, Geologic sketch nap of Globe quadrangle, Arizona. Data from Ransome with nodifications (Peterson, 1951)

Figure 3a. Geologic plan and sections, Inspiration Mine, Gila County, Arizona (01mstead, 1966)

Figure 3b. Geologic map of Miami area (Peterson, 1962)

San Manuel/Kalamazoo Mine

Figure 1. Sketch map showing principal towns and topographic features in the area surrounding the San Manuel district, Arizona (Schwartz, 1953)

Figure 2. Geologic map of area around San Manuel and Tiger, Arizona (Schwartz, 1953)

Figure 3. Geologic map of the San Manue1 area (Lowe11, 1968)

Figure 4. Schenatic drawings showing possible origin of Kalanazoo ore body (Lowel1, 1968)

Figure 5. Geology of 1,475 haulage level (Thonas, 1966)

Figure 6. Idealized cross section looking northeast (Thonas, 1966)

Figure 7. Idealized longitudinal section looking northwest (Thomas, 1966)

Table 1. Summary of quartz monzonite Brazilian test data (Kendorski, 1976)

Table 2. Quartz monzonite conpression test stmmary (Kendorsk1, 1976)

\section{California}

Pine Creek Mine

Figure 1. Location nap of the Bishop, Cali- 
Figure 2. Geology of the Mount Tom quadrangle (Gray, 1968)

Table 1. Geologis colum (Gray, 1968) 66

Figure 3, Surface geology of Pine Creek thine 69 and vicinity (Gray, 1968)

Figure 4. Block diagram of Pine Creek Mine, California (Batenan, 1965)

\section{Colorado}

Climax Mine

Figure 1. Relationship of Climax to the Colorado nineral belt (Wallace, 1968) C1imax area (Wallace, 1968)

Figure 3. Diagramatic sections showing multiple intrusion and mineralization, and progressive tilting (Amax, 1974+)

Figure 4. Cross section, showing generalized geology and ore zones (Wallace, 1968)

Figure 5. Cut-gway diagran of Climax Mine (Anax, 1974-)

Figure 6. Production levels at Climax Mine (Anax, 1974+)

Figure 7. Phillipson level, showing generalized geology and ore zones (Wallace, 1968)

Schwartzwa1der Mine

Figure 1. Map of Colorado-Denver mountain area

Figure 2. Simplified geologic map of Ralston Buttes district, Jefferson County, showing the principal uranium deposits (Sims, 1964)

Figure 3. Simplified geologie nap of the district, Jefferson County (Sins, 1964) 
Figure 4. Geologic section of the Schwartzwalder Mine, Ralson Butte district, Jefferson County (Sins, 1964)

Figure 5. Recent cross section of Schwartzwalder Hine with level map (EMJ, Nov. 1978)

Urad Mine/Henderson Mine

Figure 1. Generalized surface geologlc map of Red Nowntain showing location of section 480 H (Ranta, 1976)

Figure 2. Generalized geologic section $480 \mathrm{H} \quad 102$ (Ranta, 1976)

Figure 3. The complexty and number of development openings needed for mining the Henderson are enormous . . . (Hoppe, 1976)

Colorado School of Mines, Experimental Mine

Figure 1. Location nap, Colorado School of Mines, experimental mine, Idaho Springs, Clear Creek County, Colorado

Figure 2. Geologic nap of Idaho Springs area (Lovering and Goddard, 1950)

Figure 3. Map showing location of experimental roon, Colorado School of Mtines, experimental mine, Idaho Springs, Colorado

Figure 4. Geology of the experimental room area 114

\section{Idẹpo}

\section{Lost Packer Mine}

Figure 1. Location map showing the Lost Packer 118 Mine, Custer County, Idaho

Figure 2. Geologic map of the Loon Creek Min- 119 ing district, showing the location of the Lost Packer Mine

Figure 3. Transverse section through Lost Packer vein, Loon Creek district, Idaho, looking north. (Umpleby, 1913) 
Page

Coeur d'Alene district

Figure 1a. Location map of the Coeur d'Alene 126 area (Chan, 1972)

Figure 1b. Location of Coeur d'Alene district in Shoshone Cotmty, Idaho

Figure 2. Coeur d'Alene mining district showing mines and major faults (Sorenson, 1947)

Table 1. Generalized statigraphic section, Coeur d'Alene district, Idaho (Hobbs and others)

Figure 3. Isometric drawing of regional sections centered on the Coeur d'Alene district showing the gentral thickening of the stratigraphic section to the north and east (Hobbs and others, 1965)

Figure 4, Zones of fault gouge and brecciation along 0sbum fault as seen in the main cross cut of the Star-Morning Nine (Hobbs and Fryklund, 1968)

Dayrock Mine

Figure 1. Generalized geologic cross section of the Dayrock tine, Coeur d'Alene mining district, Idaho (Fasmin, 1961)

Maine

Black Hawk (Second Pond)-B1ue Hill Mine

Figure 1. Location map of Blue Hill Mine, Hancock County, Maine

Figure 2. Basic geologic enviromments, State of Maine (Young, 1968)

Figure 3. Simplified geologic map of the Blue Hill area (Smith, 1907) 
Minnesota

Minnamax Project

Figure 1. Location map of Minnamax Project, 164 St. Louis County, Minnesota (EKJ, 1976)

Figure 2. Geologic map of southern part of Duluth complex (Bonnichsen, 1972)

Figure 3. Geologic map of Babbitt-Hoyt Lakes region (Bonnichsen, 1972)

Figure 4. Minnamax Exploration Shaft (EMJ, 1976)

Montana

Black Pine Mine

Figure 1. Location map of Black Pine Mine, Granite County, Montana

Figure 2. Geologic map of the area around the Black Pine Mine, Grani te County, Montana (Wallace, 1978)

Table 1. Generalized geologic column for the Black Pine wine area, Philipsburg mining district, Granite County, Montana (Ross, 1963, Emmons, 1913)

Figure 3. Geologic cross section of the Combination Vein, B1ack Pine Mine, in relation to the Spokane formation quartzite. Displacenents are shown along several faults, and early mine workings (Emmons and Cakkins, 1913)

Figure 4. Recent development drifts at Black Pine Mine. The main haulage drift is along Combination Vein (Figure 3) (White, 1976)

Butte Mining District and Butte Underground Mines

Figure 1. Location map of Butte Underground Mines, Silver Bow County, Montana 
Figure 2. Generalized geologic nap of the

Butte mining distriet and Boulder batho-

11th relative to major tectonic elements in Southeastern Montana (Meyer and athers, 1968)

Figure 3. Generalized rock colum for the Butte mining district, Montana, showing intrusive-vein-alteration sequence and avallable age dates of rock-alteration assemblages (Nitier, 1973)

Figure 4. Composite plan at 2800 and 3800 levels showing zones of nineralization .... in relation to the principal shafts of the district (Meyer and others, 1968)

Figure \$. Plan view of the State, Syndicate, and Anaconda vein systems near the center of the district at the 1800 level, high ore (Meyer and others, 1968)

Figure 6. Cross section view of Anaconda Vein, looking west, showing dips of Anaconda fissures (Meyer and others, 1968)

Figure 7. Map of the Leonard Mine at the 3600 level, Silver Bow County, Montana (Soc. Econ. Geol., 1973)

Figure 8. Map of the Leonard Mine at the 4800 level, Silver Bow County, Montana (Soc. Econ. Geol., 1973)

Figure 9. Map of the Steward Mine at the 4200 level, Silver Bow County, Montana (Soc. Econ. Geol., 1973)

Figure 10. Map of the Steward Mine at the 4400 level, Silver Bow County, Montana (Soc. Econ. Geol., 1973)

Granite-Bimetallic Mine

Figure 1. Location map, Granite-Bimetallic Mine, in Granite County, Montana

Figure 2. Generalized geology of the Philipsburg batholith and surrounding area showing location of the Philipsburg district (Prinz, 1967) 
Table 1. Stratigraphic succession in the 204 Philipsburg district (Prinz, 1967)

Figure 3. P1an and elevation of levels in Granite-Bimetallic Mine (Emwon and Calkins, 1913)

Nevada

Ten Piute district

Figure 1. Location map of Tem Piute 210

Figure 2. Geologic map of the Ten Piute 211 district (Tschanz, 1970)

Figure 3. Geologic map of Ten Piute (Lincoln) Mine property, Tschanz, 1970)

New Jerșey

Mount Hope and Scrub Oaks Mine

Figure 1. Index nap showing the location of 218 the Dover district (Sims, 1958)

Figure 2, Geologic map showing the location 220 of the Mount Hope and Scrub Oaks Mines in the Dover nining district, Morris County, New Jersey, (Sins, 1958)

Figure 3. Geologic nap and section of Side Hill adit, Mount Hope Mine, (Sins, 1958)

Figure 4, Vertical longtudinal projection of Taylor ore body, Nount Hope Hiлe [Sims, 1958)

Figure 5. Map and longitudinal projection of 228 main workings at Scrub Oaks Mine (Sims, 1958)

New Nexico

Questa Nolybdenam Mine

Figure 1. Map of Taos County showing location 232 of Queste Molybdenum mine (Schiling, 1960) 
Page

Figure 2. Generalized geology of Questa Mo1ybdenum kine area (Schilling, 1960)

Figure 3. Generalized rock section of the Questa Molybdenum Mine area (Schilling, 1960)

Figure 4. Questa Molybdenun Mine area, geologtc nap and D section

Figure 5. Block diagran of the Questa Molybdenum Mine, Taos County, New Mexico (Schilling, 1960)

New York

Balnat-Edwards District Mines

Figure 1. Index map, showing location of the Balmat-Edwards district, New York (Lea, 1968)

Figure 2. Generalized geologic map of the Balmat-Edwards district within the northwestern Adirondacks, showing the distribution of najor rock types and mineral deposits (Lea, 1968)

Figure 3. Geologic map of the Balmat-Edwards district: Edwards area (Lee, 1968)

Figure 4. Geologic map of the 1500-foot mining level: Edwards Mine (lea, 1968)

Figure 5. Edwards Mine: northwest-southeast section (Lea, 1968)

Figure 6. Section through No. 4 shaft, Balmat Mines, St. Joe Minerals Corp. (EMJ, Nov. 1976)

Lyon Mountain District

Figure 1. Map showing locations of the Chateaugay and 81 dines, Clinton County, New York. 
Figure 2. Geologic map of the Lyon Mountain area, Clinton Coumty, New York, showing the location of the Chateaugay and 81 Mines (Poste1, 1952)

South Dakota

Homestake Mine

Figure 1. Location maps of the Honestake 266 Mine, Lawrence County, South Dakota (Slaughter, 1968)

Figure 2. Geologic map of the lead district (Slaughter, 1968)

Figure 3. Precambrian geology in the vicin- 270 ity of the Honestake Gold Mine, Black Hi11s, South Dakota (Noble, 1949)

Figure 4. Distribution of the Precambrian sedimentary rocks and the netamorphic zones in those rocks in the lead district (Noble, 1948)

Figure \$. Relation of ore bodies to structure (Slaughter, 1968)

Figure 6. Cross-folded structures, 2600 level (Slaughter, 1968)

Figure ?. Cross-folded syncline, 2300 level 278 (Slaughter, 1968)

Figure 8. Idealized section of Homestake Mine (Homestake Mining Company, 1976)

Figure 9, Cross section of 9-1edge structure, showing open eut and fill stoping (Honestake hining Company, 1976)

\section{Tennessee}

Ducktown District

Figure 1. Location maps, Ducktown district, 286 Po1k County, Tennessee 
Figure 2, Reglonal geologic map of the Ducktown area (Magee and others, 1968)

Table 1, Stratigraphic sequence across the Ducktown region of the Great Smoky Mountains (Magee, 1968)

Figure 3. Cross sections of the Boyd and Eureka ore deposits. The drag fold pattern of the Boyd ore body is evident (Magee, 1968)

Figure 4. Horizontal plan views of the Boyd and Eureka ore deposits (Magee, 1968)

Washington

Holden Mine

Figure 1. Location maps - Holden Mine,

Chelan County, Washington

Figure 2. Geology of the Holden area (Youngberg, 1952)

Figure 3. Gross structural trends and major faults in the North Cascade Range of Nashington (Grant, 1969)

Figure 4, Idealized geologic cross section of the Holden ore body, showing ore zoning and its relationship to the wall rocks and intrusions (Yougberg, 1952)

Figure 5. Geologic structure of a west-east section of the Holden Mine, showing mineralization, mine leve1s, and No. 2 shaft. [Youngberg, 1952)

Wyoming

Sumrise Míne

Figure 1. Location map of Sunrise Mire, Platte County, wyoming. 


\section{Page}

Figure 2. Geologic map, vicinity Sunrise, 310 Wyoming (Carter, 1963)

Figure 3. Generalized sections of Sunrise Mine operations (ENJ, 1974)

\section{CIVIL WORKS}

\section{California}

Helms Underground Powerhouse - Pumped storage project

Figure 1. Location of Helms Project in Cali- 318 fornia, 60 miles east of Fresno

Figure 2. Original and hodified layout of underground powerhouse complex-He1ms Rumped Storage Project

Figure 3. Plan and profile, Helms Pumped Storage Project

Table 1. Rock properties and project characteristics

Idaho

Dworshak Dam Site

Figure 1. Dworshak Dam Site in Idaho, approx. 40 miles east of Lewiston

Figure 2. Geologlc map of the orofino Iegion, northern Idaho, (Johnson, 1947)

Nevada

Nevada Test Site - Climax Stock

Figure 1. Location map of the Nevada Test Site-Climax Stock area, Nye County, Nevada

Figure 2. Generalized geologic map of the surficial deposits (Hinrichs, 1968) 
Figure 3. Geologic nap of the Climax Stock 335 area (Ranspott, 1979)

Table 1. Summary of laboratory tests on 337 Clinax Stock quartz monzonite (Pratt, 1976)

Figure 4. Failure envelopes of toth intact and fractured Climax stock granodiorite under dry and saturated conditions, $240 \mathrm{~m}$ level (Heard, 1971)

Figure 5. Fallure strength as a function of confining poessure for dry samples and samples wi th excess weter, 240 m level (Duba and others, 1974 )

Figure 6. Layout of $420 \mathrm{n}$ level, Climax granite, showing new construction for spent-fuel test (Ranspott, 1979)

South Carolina

Bad Creek Pumped Storage Project

Figure 1, Location map of Bad Creek Project in Oconee County, South Caroling (Overstreet, 1965)

Figure 2. Vertical section through the waterways-Bad Creek Punped Storage Project (Nester, 1974)

Figure 3. Simplified geologic map of the Lake Jocasee area (0verstreet, 1965)

Table 1. Rock properties - Bad Craek area

Bibliography

Index

Appendix 1. Sources of Information

Exhibit 1. Printout of data on the San Manuel/ Kalamazoo the from the MAS data base (U.S. Bur. Mines Minerals Availability System) 
xriti

Page

Exhibit 2. Printout of data on the Crescent Mine fron the CRIB data base.

Exkibit 3. Bibliographic references dealing with the Leadville quadrangle, Colorado, fron GEOREF.

Appendix 2. Mines in Crystailine Rocks Considered for study

Table 1. Quantitative sumuary by state of underground sites reviewed and selected for study.

Table 2, Mines considered for study, listed 459 alphabetically along with state and county. 
During the compilation of this report the work of many authors was drawn upon. These contributions are gcknowledged in the report by reference to the appropriate publications.

In addition to the principal contributors and authors shown, we wish to acknowledge the following individuals and institutions:

Jon Stone and Peggy Edwards of the U.S. Bureau of Mines were most helpfuI in searching the Minerais Availability Systen (MAS) data base for information on mines in known rock types.

Maureen Johnson, U.\$. Geologica1 Survey, and Jerlene Bright and Pat Tracy, Uhiversity of oklahona, searched the CRIB data base; Carol Backhus of LBL's Mechanical Engineering Library assisted in searching the GEOREF data base; and Helen Reed, of Utah International, Ine. provided use of their mining library. Mrs. Beatrice Lukens, librarian of the Earth Sciences Librasy, Universty of Calffornia, Berkeley, was most helpful. Gary Murrie and Todd Gates, Danes and Moore Co., Cincinnati, Ohio, discussed with us their project to identify crystalline rock bodies of the U. $S$. and provided access to their files containing valuable information on this subject.

Other LBL personnel instrumental in providing support in preparing this report included Ellen Dianond, Dodie Kataque, Cynthia Childs, Bob Flower, and Lorraine Allen. This work was supported by the OHWI, Columbia Division of the U. S. Department of Energy under Contract W-7405-ENG-48. 
· $\quad$. 
SEARCH FOR UNDERGROUND OPENINGS

FOR IN SITU TEST FACILITIES IN CRYSTALLINE ROCKS

\section{INTRODUCTION}

The objective of this project was to identify existing underground openings suitable for performing geomechanical, geochemical, and hydrogeologic tests pertinent to the storage of radioactive waste in crystalline rock. Crystalline rock, for the purpose of this study, has been defined to Include intrusive igneous rocks and mediun- to high-grade metamorphic rocks. The undergrousd openings would be located at sufficient depth and would be of sufficient volume to conduct large-scale in-situ experiments. This project, covering active or recently inactive mines and civil works, was conducted simultaneously with a study (Cohen, 1979) to identify criteria for in-situ test facilities and to formulate a provisional program of experiments.

Concurrently, the Danes and Hoore Company conducted a preliminary assessnent of crystalline rock bodies in the $U$. $S$. which may acconodate a waste-isolation facility.

Based on a search of open literature, 26 "class $1 "$ sites were identified as having, possibly, the groatest potential for underground test facilities. Thirty sites were categorized as "class 2 " because data in the open literature were not sufficient to verify one or more established criteria. Potentialiy suitable underground openings in crystalline rocks, prinarily exploration adits, shafts, and drifts, which are not docunented in the open literature were not included in this profect report. 
This report summarizes a systematic search and analysis of the available literature on underground openings in crystalline rocks, Because of its preliminary nature the study was restricted to the open literature. Neither mining companies, state geologists and bureaus of mines, nor utility and transportation authorities were contacted.

There was generally not sufficient information in the open literature on the hydrologic settings of most of the underground workings. This is partially because it is difficult to define a water table in crystalline rocks; also, total water production and its component introduced by mining operations are data normally in company files. It is safe to state, however, that mines encompassing a broad depth range, for example the Honestake, with levels axcessible from depths of 1100 to over $8000 \mathrm{ft}$, would intersect a variety of hydrogeologic conditions.

The report consists of four sections, a bibliography, index, and two appendices as described below:

Section I - Identification and Selection Process - principal data bases, criteria, and the selection process.

Section_II - Summaries of Information - locations and tabulations of mines and civil works.

Section III - Conclusions and Recommendations - Sunary of findings and an outline of studies designed to refine the list of potential sites.

Section IV - Descriptions of "class 1" mines and civil works. Bibliography - a general bibliography of all literature searched, including the individual bibliographies for "class l" sites. Index - 1ists place and mine names referred to in the text and bibliography. 
Appendix 1 - Sources of Information - description of data bases used. Appendix 2 - Table giving the nuber of nines by state which were derived from various sources, and list of mines in crystalline rock which were considered. 



\section{IDENTIFICATION AND SELECTION PROCESS}

The process of identification and selection of potential underground sites is digrammed in Figure 1. It depended on the availability of information in the literature and personal knowledge of the authors. To identify candidate sites, a variety of information sources were used to collect data on the existing underground mines and civil works. Information was extracted from two mine data bases: The dinerals Availability System (MAS) of the U.S. Bureau of Mines and the U.S. Geological Survey's Conputerized Resources Information Bank (CRIB) . Additional sources utilized were GEOREF (the Geological Reference fil e prepared by the American Geological Institute), mining directories, various geological and mining engineering reports and tunneling and excavation reports. Data on the civil works were obtained from the open literature and consultants, Descriptions of the data bases and examples of printouts are given in Appendix 1. Also listed in the first appendix are the kinds of information obtainable fron these sources of information.

Based on underground mine information, a list of 5900 mines was extracted from the 130,000 mines on record in MAS, and an additional 120 sites were identified from other data bases. Thirty-four civil works sites

were added from discussions with consultants. After initial review the compiled list of surface and underground mines in crystglline and noncrystalline rock totaled approximately 6100. Application of the criteria described below resulted in identification of 60 underground sites in crystalline rock. 


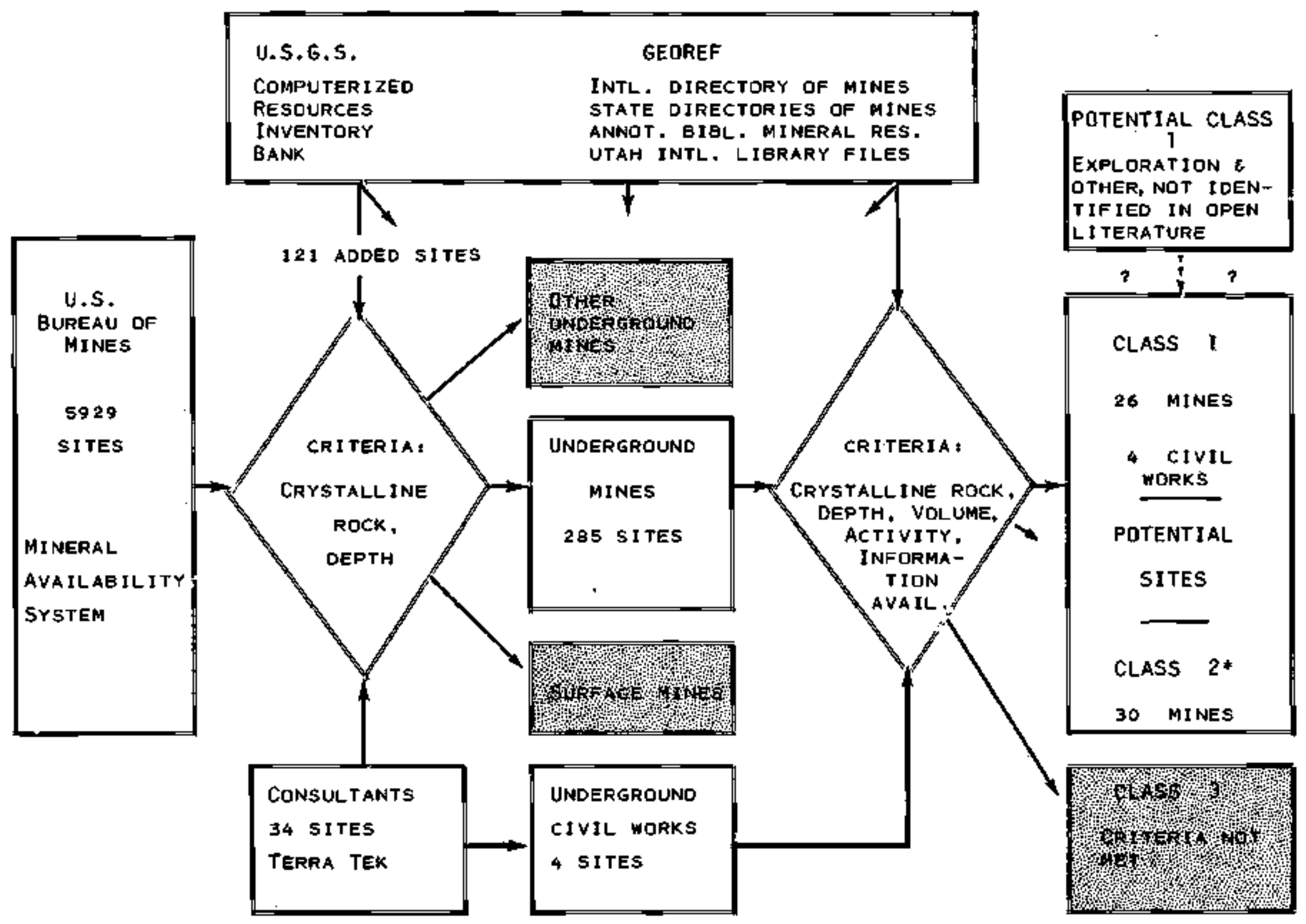

Figure 1. IOENTIFICATION AND SELECTIDN PROCESS For PGTENTI AL UNDERgRoUND Sites.

*all criteria met, some information not valioateo in upen literature. 
Along with information on mines in crystalline rocks, similar data were obtained from Mas on over 3000 mines in non-crystalline rocks. This data base is available for a preliminary characterization of underground workings in argillaceous, carbonate and volcanic rocks.

Criteria

The base list of underground sites was reduced by categorizing the openings on how well they fit the criteria defined below. The criteria were designed to include a broad spectrum of underground openings, within which conditions might approximate those of a waste repository in crystal1ine rock.

1) The underground workings or a sufficient portion must be located in crystalline rock (intrusive igneous or medium- to high-grade metamorphic rock). Exceptions are mines located in low- to medium-grade metanorphic rocks of Precambrian age in Idaho, Michigan, Minnesota, and eastern Wyoning. These mines are considered acceptable because of: (a) their location in tectonically-stable, mid-continent regions as in the case of the Michigan, Minnesota, and eastern Wyoning sites; and (b) because a number of then have been the sites of in situ geonechanical testing, resulting in a large amount of information characterizing the sites, especially the Coeur d'Alene mines of Idaho.

2) The site must be underground, at a depth greater than $600 \mathrm{ft}$.

3) An acceptable underground working should be of sufficient size to provide for an in situ testing facility, similar in size to the Strip experimental facility in Sweden. 
4) The workings should not have been closed for over 10 years, caved, sealed or flooded as reported in the literature and annual reports of mining activity.

5) It is desirable that the rorkings be located below the water table, though sites which have workings both above and below the water table nay provide access for tests comparing rock and hydrologic properties of the saturated and unsaturated zones.

6) The workings should encompass rock with physical and mechanical properties adequate to provide good support in new excavations and long-tern access for the experinental progran.

In the final review of underground sites, a site was designated as "class 1" if all of the criteria were net and verified in the open literature. A site was assigned "class $2 "$ stgtus if the criteria were believed to be met but it was not possible to verify one or nore of the parameters In the literature. Characteristics of the underground sites are sumarized in Tables 1 and 2 in the following section. 
II. SUMMARIES OF INFORWATION ON MINED OPENINGS

IN CRYSTALLINE ROCK

The selection process detailed in the previous section identified 26 mines and 4 civil works in erystalline and high-or medium-grade metanorphic rocks as "class $1^{t}$ sites for in situ testing facilities. These are listed in Table 1.

A second group of mines which appear to be suitable potential sites, but lack data on one or nore established selection criteria, are listed as "class $2^{+1}$ sites. Table 2 sumarizes information avaílable on "class $2^{\prime \prime}$ sites, and indicates which key criteria for each nine could not be verified.

Several mined openings are summarized under the heading "Civil Works." These include the Helns, Dworshak Dan, and Bad Creek Punped Storage Projects.

All of the "class $1 "$ and "class 2 " sites and the civil works are located on a map of the United States (Figure 1).

A summary description of each "class 1 " site is included, alphabetically by state, in the following portion of the report. Each sumary includes data on location and accessibility, geologic setting, description of mine or civil workings, and references. 
FIGURE 1. Location of Underground workings on map of the United States.

Class "l" Mines

Arizona

1. Lakeshore Mine

2. Miami East Mine

3. San Manuel/Kalamazoo Mine Galiformia

4. Fine Crenk Mine

Colorado

5. Climax Mire

6. Schwart zwalder Mine

7. Urad/Henderson Mine

8. Colorado School of Mines, Experimental Mine

Idaho

9. Lost Packer Mine

Coeur D'Alene District

10. Dayrock Mine

11. Star-Morning Mine

12. Coeur Mine

Maine

13. Black Hawk (Second Pond)-Blue Hill Hire

Minnesot:

14. Minnamax Project, E1y Prospect

Montana

15. Black Pine Mine

Butte Mining District and Butte

Underground Mines

16. Leonard Hine

17. Steward Mine

18. Granite-Binetallic Mine

Nevada

19. Tem Piute District

New Jersey

20. Moumt Hope and Scrub Oaks Mines
New Mexico

21. Questa Molybdenum Mine

New York

22, Balmat-Edwards District Mines

23. Lyon Mountain District

South Dakota

24. Honestake Hille

Hashingtor

25. Holden Hine

wyoming

26. Sunrise Mine

Class "2" Mines

Arizona

27. $\overline{\text { Bagdad Mine }}$

28. Oracte Ridge

California

29. Atolia District

Colorado

30. Black cloud Mine

Idaho

31. Kentuck Mine

32. Silver City Region

Michigan

33. Indiana Mine

34. Iroquois Mine

Minnesota

35. Ely Prospect

Montana

36. Butte Highlands Mine

37. Dacotah Mine

Nevada

38. Gooseberry Mine

39. Mill City Mine

40. Ruby Hill Mire

41. Searchlight District
42. Suntuit King Wine

43. Sutton No. 2 Mine

44. Taylor Mine

New Jersey

45. Stêrling Mine

New Mexico

46. Continental Underground

47. Groundhog Mine

North Carolina

48. Cranberry Magnetite

49. Tungsten Queen Mine

Tennessee

50. Ducktown District

Utah

51. Ontario Mine

52. Mayflower Mine

53. Park City Mine

Washington

54. Midrite Mine

55. Sherwood Mine

56. Sunrise Breccia Deposit

Civil Works

Californis

57. Helms Underground Powerhouse Idaho Puimed Storage Project

58. Dworshak Dam Site

Nevada

59. Nevada Test Site-C1inax Stock

South Carolina

60. Bad Creek Pumped Storage Project 


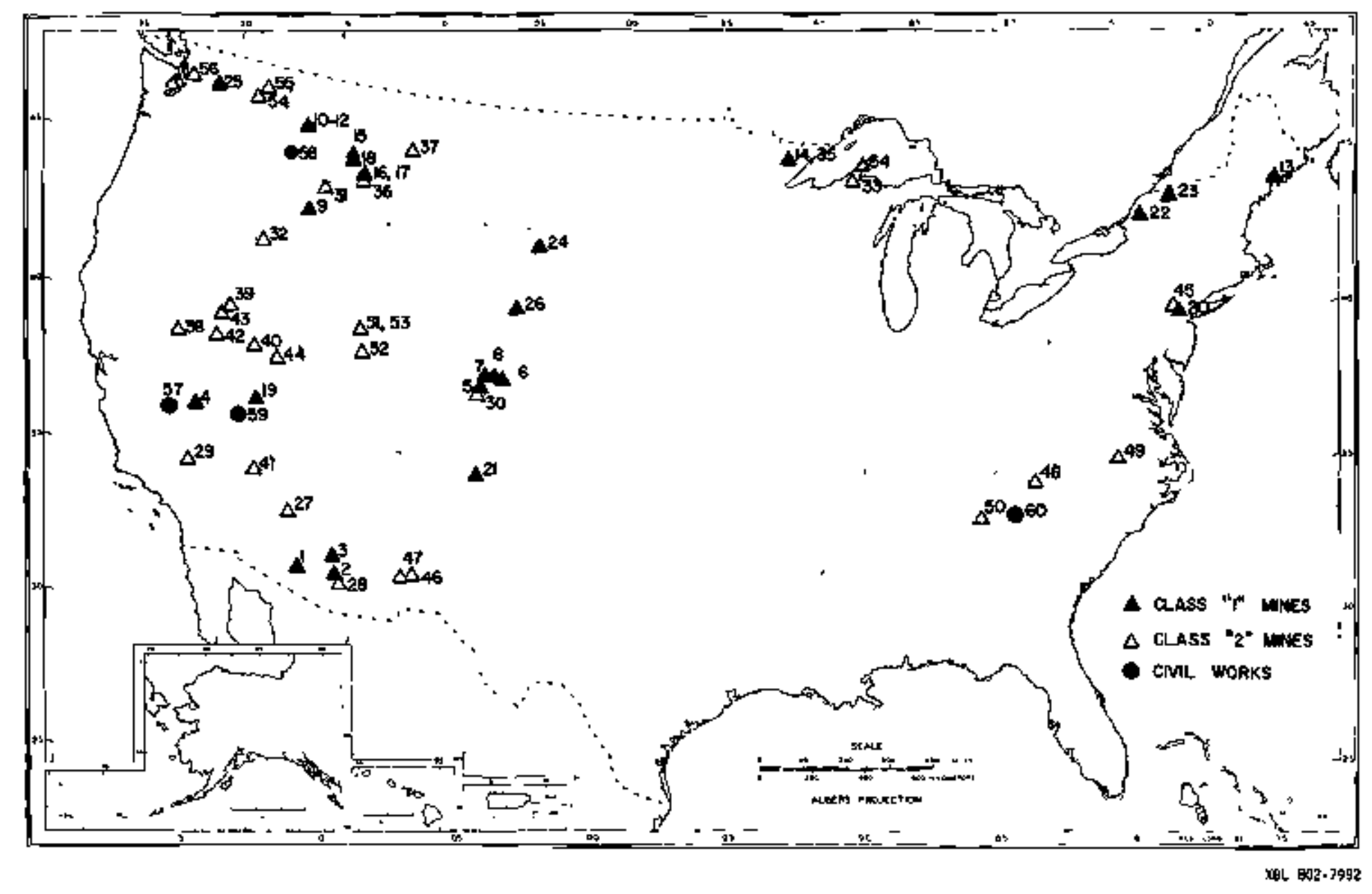

Used with permission of the Department of Geography, University of Chicago.

$\stackrel{\bullet}{*}$ 


\section{Table ] "CClass I" Wines}

\begin{tabular}{|c|c|c|c|c|c|c|c|}
\hline NWEER & STKTE & mutry & 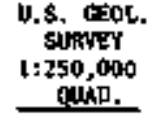 & OEAGorTY MZLED & POCK TYPE & OEPTA (FT) & Stinis \\
\hline & MALZONA & & & & & & \\
\hline $\mathbf{1}$ & Lakeshare Hine & Pinal & Treson & $\mathrm{Cu}, \mathrm{Fv}, \mathrm{Nu}, \mathrm{g}$ & Quartz Monzoniti. & 2000 & Mctive \\
\hline 2 & MLand East & Gile & Hersa & D, An, Na, Na & Scthst, Grenita & 34șo & Metive \\
\hline$s$ & 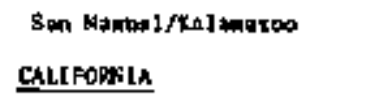 & Fingl & Tresos & $\mathrm{Cu}, \mathrm{No}, \mathrm{Mg}, \mathrm{Mu}$ & Quartz Monsonite & $660-2460$ & Aetif ve $(3937)$ \\
\hline 4 & $\begin{array}{l}\text { Pine Creak Htme } \\
\text { Tolaphpt }\end{array}$ & Inyo & $\operatorname{cold} f f$ ald & $\omega, m, C$ & Quatitz Manstanite & Over 1000 & Actjue \\
\hline s & CJinex whot & Whe & leodrille & No, $n, \$ n, s$ & Qundetz Nonzinite & 600 & Actires \\
\hline 8 & \$chneartiuld der Mine & Jefferson & Denrer & v & Gatiss. Sth1st & 2400 & Retive (19Tt) \\
\hline ? & $\begin{array}{l}\text { Urad Mline/ } \\
\text { Hendortoo Hino }\end{array}$ & $\underset{\text { Cruet }}{\text { Grand Clesr }}$ & baver & $\mathbf{H o}$ & $\begin{array}{l}\text { Precabrian tranite, } \\
\text { Tertiary Porphyry }\end{array}$ & $500-3000$ & netlue \\
\hline * & $\begin{array}{l}\text { Colorada \$ehool of bites } \\
\text { Experibintal Mine } \\
\text { 므셜 }\end{array}$ & Clear Crotek & Denver & - & 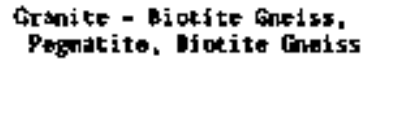 & Hax. 600 & hctive \\
\hline 9 & $\begin{array}{l}\text { Lest Poeker Nine } \\
\text { Coent d'Alene Distrikt }\end{array}$ & Custer & Chal115 & $M, C o, M$ & Mica Schist, Granodjorlte & jobon & Net dve [ [9978) \\
\hline 10 & Doyroek Hing & Shoshene & Whiluch & 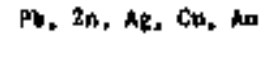 & Quartzits, Quartz Monzonito & $\$ 4000$ & $\begin{array}{l}\text { lnoctive, thut } \\
\text { accessibje }\end{array}$ \\
\hline 11 & Ster-4toming Wint & Sthoshonte & Mellate & $\mathrm{Pb}, \mathrm{Zn}, \mathrm{A}_{\mathrm{B}, \mathrm{N}}$ & Qusrtike, Mrqiblite & 5500 & Netive \\
\hline 12 & Coesur Wint & Shoshane & Millese & $A_{F}, C_{2}, P b, 2 m, N_{0}$ & 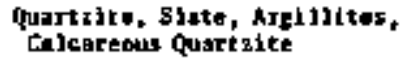 & $\$ 000$ & Nct Ire (19/5) \\
\hline & 쓰INE & & & & & & \\
\hline 13 & 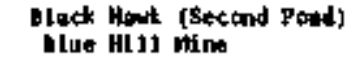 & Hancock $C_{0}$ & tengor & $\mathrm{Zn}_{\mathrm{n}} \mathrm{Cu}, \mathrm{Pb}, \mathrm{Fe}, \mathrm{A}_{\mathrm{g}}$ & $\begin{array}{l}\text { Schjst, Nephibolitits, } \\
\text { Wotequerteite }\end{array}$ & 1310 & $\begin{array}{l}\text { Imatetive }[9 / 7, \\
\text { on stand }\end{array}$ \\
\hline
\end{tabular}




\begin{tabular}{|c|c|c|c|c|c|c|c|}
\hline MHEER & 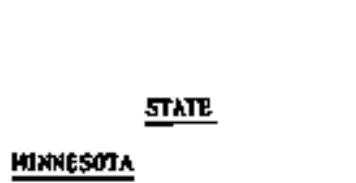 & conomrtr & 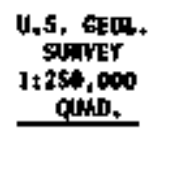 & COAHOpITI HFLED & MOXX TYYE & DEPTH (F) & STRTUS \\
\hline \multirow[t]{2}{*}{14} & Minmmax Projott & St. Loults & Two throts & 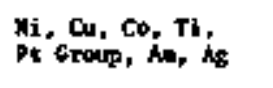 & $\underset{\substack{\text { Tractolific Int Intrive } \\
\text { (Gobro) }}}{ }$ & 2610 & Attive \\
\hline & monts새 & & & & & & \\
\hline \multirow[t]{2}{*}{15} & Bleck Pind Mise & Granitu & Mutt: & 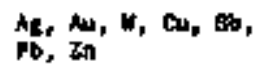 & Quertitte, Grapodiorite & 2300 & Metive \\
\hline & $\begin{array}{l}\text { Dot ke Distriet Undar- } \\
\text { eround Wimes }\end{array}$ & Silver Iow & Wut te & $\omega$ & Querti Montonite & $\$ 00000$ & Juectlve (1077) \\
\hline 16 & Leonard Mine & & & & & & \\
\hline 17 & Steward Mine & & & & & & \\
\hline 18 & $\begin{array}{l}\text { Granite-Bimetallic } \\
\text { NEEAana }\end{array}$ & trenite & Butte & 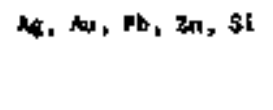 & Grupodiortite & 2625 & tnsactive 5 \\
\hline \multirow[t]{2}{*}{19} & Ter Plute & Lincoln & Coliente & 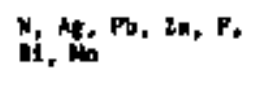 & $\begin{array}{l}\text { Doloolte, liwatione, shale, } \\
\text { sundstome, franite stock }\end{array}$ & 900 & Inectire (1979) \\
\hline & maN Jersey & & & & & & \\
\hline 20 & 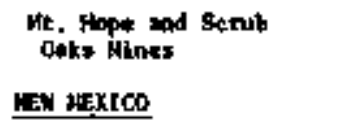 & Norrls & serminton & Re & Goelss & 2500 & Inaetive (197a) \\
\hline 21 & $\begin{array}{l}\text { Quests Holybdranes Hine } \\
\text { MEY roRI }\end{array}$ & Theos & Reton & Ho & Grenite & (Opea pit vith and & $\begin{array}{l}\text { Active (1977) } \\
\text { efground dovelopent) }\end{array}$ \\
\hline 22 & $\begin{array}{l}\text { lataut-Edwards tistriet } \\
\text { Kines: }\end{array}$ & $\begin{array}{l}\text { st. lomrace } \\
\text { ca. }\end{array}$ & Ogdasburrg & 2., $\mathbf{P t}, \mathrm{Cd}, \mathrm{F}_{\mathbf{\theta}}$ & $\begin{array}{l}\text { Merble, Dolonite, Evaperite, } \\
\text { contsss, Schl ste }\end{array}$ & $2100-3100$ & Active (1970) \\
\hline \multirow[t]{2}{*}{23} & Lyon Mountel' Distrlet & clime on & Lake & F* & Eneless & s1 $=2$ inse -2000 & 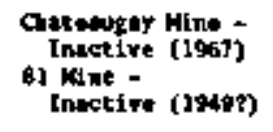 \\
\hline & SOUnH DNoorA & & & & & & \\
\hline$z$ & $\begin{array}{l}\text { Manustake Nino } \\
\text { MusHINGTOA }\end{array}$ & Leuronces & Mapid City & Nu, Ne & Senist & 8000 & Mctive \\
\hline is & $\begin{array}{l}\text { Mojde Nlpo } \\
\text { moutes }\end{array}$ & Cholen & coneretet & an & Grenito, Getwodiorite & to 5000 & Spoctive \\
\hline 26 & Sumprise Ylmo & Patte & Torrington & F* & Schil tt & $\begin{array}{l}\text { Probabjy } \\
\text { mequate }\end{array}$ & Activit (2977) \\
\hline
\end{tabular}




\section{Toble is cIvic molps}

\begin{tabular}{|c|c|c|c|c|c|c|}
\hline №ns:A & STATEANUEE & consy & 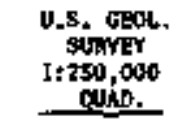 & ROCX TPPE & DEPTH (FT) & SThus $(10 / 29)$ \\
\hline & Colir Fonsth & & & & & \\
\hline \multirow[t]{2}{*}{37} & $\begin{array}{l}\text { Helmo Pubped - } \\
\text { Stordpe Projuce }\end{array}$ & frevne & Nariposa & Granodlorite & 41000 & Nender constraction \\
\hline & IDAHD & & & & & \\
\hline \multirow[t]{2}{*}{ st: } & Dworshak & Clearnter & Fullom & Granodiorite toel st & to 700 & Accast quast lonalis. \\
\hline & MEYHOA & & & & & \\
\hline \multirow[t]{2}{*}{59} & $\begin{array}{l}\text { Nobyde Test slto - } \\
\text { Cldmax Stock }\end{array}$ & Nyo & $\begin{array}{l}\text { Death Valley } \\
\text { l Los Vequs }\end{array}$ & Granodlortte & 1400 & Under edont ruction \\
\hline & SOUYH CARDLISA & & & & & \\
\hline 60 & $\begin{array}{l}\text { Bad Creek Poiped- } \\
\text { Storate Projutt }\end{array}$ & Ocones & Gre:Aाrile & Grenits-tmel is: & चeteo & Operatlng (?) \\
\hline
\end{tabular}




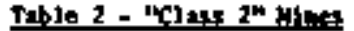

\begin{tabular}{|c|c|c|c|c|c|c|c|c|}
\hline 些。 & Hine Hate & $\begin{array}{l}\text { Location } \\
\text { Statet }\end{array}$ & Councy & $\begin{array}{l}\text { U.s. [eol. } \\
\text { Survey } \\
\text { Quadd } \\
\text { I: } 250,000\end{array}$ & Ominership & $\begin{array}{l}\text { Comodity } \\
\text { Milnod }\end{array}$ & Rock Type & Deth (ft) \\
\hline$\underline{n}$ & 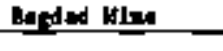 & Arliand & Yavapal & Preseott & Crprus Winims: Corp. & 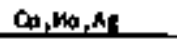 & Schixt, Prectubrian_Granite & $197(+1)$ \\
\hline 2t: & Oreclo nids & Arizond & Pine & Tussion & $\begin{array}{l}\text { Continental Coppor } \\
\text { Union_Copper }\end{array}$ & $C_{1}, A_{2}, A_{U}$ & Quarts jiorite, tapble & \\
\hline 29 & Ato13a Diotrick & CAliforala & $\begin{array}{l}\text { Sun Murnitr- } \\
\text { ding }\end{array}$ & Tronn & Atol ia Minlng $C_{0}$. & 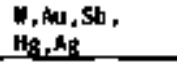 & $\begin{array}{l}\text { Qunst : Honzouitef } \\
\text { Dj-abace Dike }\end{array}$ & 1050 \\
\hline 30 & Bjock Clowd & Colorado & Lelke & Leadville & 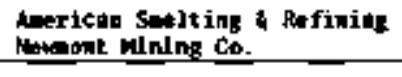 & 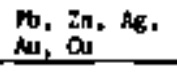 & $\begin{array}{l}\text { [ntrusives, Dolonite. } \\
\text { Litestrone, shale }\end{array}$ & 1200 \\
\hline 3) & Iefakuck Hing & Idplate & Lئlinl & Elle Chty & & $\mathrm{N}_{1} \mathrm{Zn}_{2} \mathrm{PO}_{\mathrm{O}}$ & Gatissic Granite & 300 \\
\hline$\underline{32}$ & $\begin{array}{l}\text { Sllwer } \\
\text { City Rapich }\end{array}$ & Idaho & Oryote & $\begin{array}{l}\text { Jorden } \\
\text { valley }\end{array}$ & & 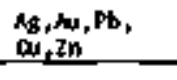 & $\begin{array}{l}\text { Granite, Mrorite, } \\
\text { Bastelt, Burolite }\end{array}$ & 2500 \\
\hline$\underline{33}$ & $\begin{array}{l}\text { Indiang } \\
\text { Ninde }\end{array}$ & Hithigsen & Ontourson & $\begin{array}{l}\text { Iron } \\
\text { BLver }\end{array}$ & Stace of Hichigen & $\mathrm{cu}$ & $\begin{array}{l}\text { Felate I gneous Intrusiv* } \\
\text { Unspectfled Extrusirs }\end{array}$ & 1380 \\
\hline 브 & $\begin{array}{l}\text { Iroquats } \\
\text { hine }\end{array}$ & Miehles & Koroanow & Hensoget & Universa) ofl Product. & ㅇs, 슨 & Unspocific Extrusive & 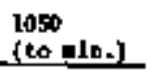 \\
\hline 35 & Ely Progratt & Minneriok: & Litat & $\begin{array}{l}\text { Twa } \\
\text { Hofterts }\end{array}$ & Intiornational Nickel & $\mathrm{Lu}_{1}, \mathrm{ki}$ & Trackolitic chblose & 1000 \\
\hline$\underline{36}$ & $\begin{array}{l}\text { Eutte } \\
\text { Hifhlands }\end{array}$ & Montena & $\begin{array}{l}\text { \$1 lwer } \\
\text { Bow }\end{array}$ & Butt: & $\begin{array}{l}\text { Butte High } 1 \text { ands } \\
\text { blning Co. }\end{array}$ & An & $\begin{array}{l}\text { Granice }(\eta), \text { Dolidites, } \\
\text { shales, Bunitzito }\end{array}$ & 1000 \\
\hline 37 & Dacatah Him & Montana & Cascende & $\begin{array}{l}\text { Great } \\
\text { Palla }\end{array}$ & Honerch Co. & 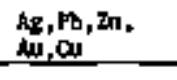 & Gnejsss, Diorite & 700 \\
\hline$\underline{\mathbf{s}}$ & $\begin{array}{l}\text { GooseberTy } \\
\text { Nime }\end{array}$ & mevidn & stovy & Reno & $\begin{array}{l}\text { Nostconst oil and } \\
\text { [as Cors. }\end{array}$ & $A N, A R$ & Dacite, intrusive Plug & s.s \\
\hline \$9 & Màdl_Clty & Meradt. & Purshlng & Lovelock & Tunetten Propertiles & 4,40, sh & $\begin{array}{l}\text { Gronod dorite Pegastits, } \\
\text { lilestone, Houffels }\end{array}$ & $\begin{array}{l}\text { Probebly ar } \\
\text { least lopo }\end{array}$ \\
\hline 槽 & $\begin{array}{l}\text { paby Mink } \\
\text { Hill Mins }\end{array}$ & Noride & Eurcket & H(J)ott & $\begin{array}{l}\text { Bictocood-Eustka } \\
\text { Ninive Co. }\end{array}$ & $A_{8}, \mathrm{~Pb}, 2 \mathrm{n}$ & $\begin{array}{l}\text { Dolonite. } \\
\text { Questiz diarite }\end{array}$ & $2+260$ \\
\hline \pm & $\begin{array}{l}\text { Soarehlight } \\
\text { Dlatriet }\end{array}$ & Kervade & Clsth & Kingenan & & 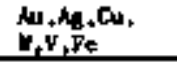 & 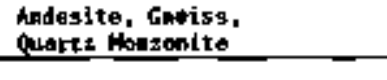 & 900 \\
\hline 12 & $\begin{array}{l}\text { Sumpit } \\
\text { Klng nine, }\end{array}$ & Norada & Ourchill & Rene & & & $\begin{array}{l}\text { Grandiorito, Quartt } \\
\text { Momsonite, Vajcanies }\end{array}$ & ${ }_{1509}^{500}$ \\
\hline$\underline{\mathbf{d 3}}$ & $\begin{array}{l}\text { Surt ton } \\
\text { Hot } 2 \text { Kine }\end{array}$ & - Nevadn & Dershine & Loreteck & $\begin{array}{l}\text { Contendsal Developosent } \\
\text { So. }\end{array}$ & - & Grmite & \\
\hline 4 & Taviont Mins & Hada & Wilte PIne & Ely & & W, & Limestrone, Qusrtz Worronite & \\
\hline 45 & $\begin{array}{l}\text { Startine } \\
\text { Mino }\end{array}$ & $\begin{array}{l}\text { Now } \\
\text { Jergey }\end{array}$ & Sens90x & Serenten & Ken derroy zinc Co. & z, & Martilo, atios & 3000 \\
\hline
\end{tabular}




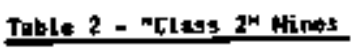

\begin{tabular}{|c|c|c|c|c|c|c|c|}
\hline Ma, & Hint Nate & State & Hine Status & Kinilfs Method & 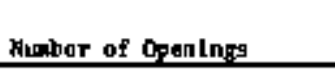 & $\begin{array}{l}\text { Type of } \\
\text { Equipantent }\end{array}$ & 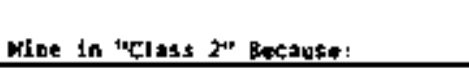 \\
\hline$\underline{27}$ & Landed Mint & AYtzona & Active 1975 & $\begin{array}{l}\text { Cot and Pill } \\
\text { lock Coring }\end{array}$ & $\begin{array}{l}2 \text { shafts } \\
\text { Tuandels }\end{array}$ & $\begin{array}{l}\text { Trecks Truck, } \\
\text { Pubber tir } \\
\text { LHE Units }\end{array}$ & $\begin{array}{l}\text { Sufficitont dopthi Adoquate } \\
\text { workings in eryatalline rotk? }\end{array}$ \\
\hline$\underline{20}$ & Oracle Ridge & Arizona & $\begin{array}{l}\text { iet ive, } \\
\text { Openod } \\
\text { lgta }\end{array}$ & $\begin{array}{l}\text { Open scopint. } \\
\text { Rom } t \text { pilisr }\end{array}$ & $\begin{array}{l}z \text { adjes } \\
\text { Yentilation Sheft }\end{array}$ & & $\begin{array}{l}\text { Dopth umbiom, sufficient } \\
\text { Morkings in quertz diorlce? }\end{array}$ \\
\hline 29 & Atolia Dbatrict & Callfornia & $\begin{array}{l}\text { Inactive } \\
1973,1976 \\
\end{array}$ & & & & How necently inaceive? \\
\hline$\underline{30}$ & $\begin{array}{l}\text { Mack Clood } \\
\text { Minte }\end{array}$ & Colotado & Activi 1953 & Cut and fist & 3 shafts & & Sufficient motkings in intrusire? \\
\hline 31 & Letencle bint & Tdatho & $\begin{array}{l}\text { Jngetive } \\
1976\end{array}$ & & $\begin{array}{l}\text { Nine voluas snall. } \\
\text { an } 5 \text { lerels }\end{array}$ & & $\begin{array}{l}\text { llow recently inatelve? } \\
\text { ddeguate tize? }\end{array}$ \\
\hline 32 & $\begin{array}{l}\text { \$ilver } \\
\text { City heitan }\end{array}$ & tdaho & tnactive & & & & $\begin{array}{l}\text { sctivity? Adequte warklnss } \\
\text { In Gyskajline rocks? }\end{array}$ \\
\hline$\underline{35}$ & $\begin{array}{l}\text { fndian } \\
\text { Hine } \\
\end{array}$ & Mich1rin & Devoloping & & & & $\begin{array}{l}\text { Closed or dercjoping? Conflictiat } \\
\text { inforiet ion needs to be resolved. }\end{array}$ \\
\hline$\underline{4}$ & $\begin{array}{l}\text { froquods } \\
\text { Hime }\end{array}$ & Hichsen & Closiod & & $\begin{array}{l}\text { Note: } 3.2 \text { willion toas } \\
\text { elned ares life of aline }\end{array}$ & & Flosed when? \\
\hline$\underline{\mathbf{3 5}}$ & E]Y Prospest & Ninnesote & Prospect & & Ontesthoft & & State of derologment: \\
\hline 36 & 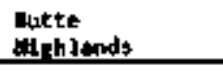 & Hent ont & Intctive & & $\begin{array}{l}5 \text { Shafts, } 3 \text { adits } \\
\text { on } 8 \text { lerels }\end{array}$ & & Forkinga In crybtalline roek? \\
\hline 37 & Decotah Mink & Hontann & $\begin{array}{l}\text { tnact tive } \\
1977\end{array}$ & & 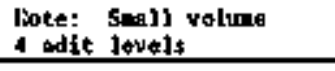 & & $\begin{array}{l}\text { Worting in erystall ine rocks? } \\
\text { Adequatto } \$ 1 \neq 4 \text { ? }\end{array}$ \\
\hline 30 & $\begin{array}{l}\text { Gonstberty } \\
\text { Hine }\end{array}$ & Mevida & Active loft & 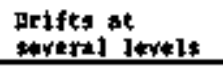 & & & $\begin{array}{l}\text { Warkings in int guslvet Rock } \\
\text { Itablitiky? }\end{array}$ \\
\hline 59 & Mill City & Merada & Axtive 1974 & & & & Work1ugs in erystgllime rock $f$ \\
\hline 40 & Rabr & Narde & $\begin{array}{l}\text { Don standlyy } \\
\text { Inactire } \\
\text { [1976] }\end{array}$ & & $\begin{array}{l}\text { Notez Nater Infjow o } \\
\text { major problem, pluzged } \\
1962\end{array}$ & & Morkings in qustrt2 diotitar \\
\hline 41 & $\begin{array}{l}\text { Stetarchliftht } \\
\text { Distriet }\end{array}$ & Wrida & Intactirt & & & & $\begin{array}{l}\text { Hou recently inactiret } \\
\text { workings in erystalline rockt }\end{array}$ \\
\hline 12 & $\begin{array}{l}\text { Sumati } \\
\text { Kinz Ning }\end{array}$ & Hevade & $\begin{array}{l}\text { Ineet Ive } \\
\text { (LB7s] }\end{array}$ & & & & $\begin{array}{l}\text { hdequot to dopthf } \\
\text { horkines in crystolline rock: }\end{array}$ \\
\hline $4 \mathbf{3}$ & $\begin{array}{l}\text { Sutton } \\
\text { No, } 2 \text { Hine }\end{array}$ & Mevade & & & & & Dapth unknowli itatcust \\
\hline 44 & Tertor PHe & Eerrede & Astive & & $\begin{array}{l}\text { Mote: } \operatorname{sindl} \\
\text { production }\end{array}$ & & $\begin{array}{l}\text { Depth unkmown; morkings in } \\
\text { eutrtz monzonitef }\end{array}$ \\
\hline is & $\begin{array}{l}\text { Ster1in: } \\
\text { Mtew }\end{array}$ & Men & setis 1976 & $\begin{array}{l}\text { Hydrasilc } \\
\text { eut and t11 }\end{array}$ & 2 openines & & $\begin{array}{l}\text { Morkings in thesest } \\
\text { Pillet unef }\end{array}$ \\
\hline
\end{tabular}




\begin{tabular}{|c|c|c|c|c|c|c|c|c|}
\hline Mas. & Nhe Na: & $\begin{array}{l}\text { tocation } \\
\text { stento }\end{array}$ & County & $\begin{array}{l}\text { U.S. Geol. } \\
\text { suryey } \\
\text { 9utad } \\
t: 250,000\end{array}$ & Domership & $\begin{array}{l}\text { Conodity } \\
\text { stinedd }\end{array}$ & Rock Type & Depth [ft] \\
\hline 16 & $\begin{array}{l}\text { Continunts) } \\
\text { Onfergrtand }\end{array}$ & _ Mexico. & Grant & $\begin{array}{l}\text { sliver } \\
\text { Gity }\end{array}$ & W Industries & $\begin{array}{l}\mathrm{Cr}, \mathrm{Zn}, \mathrm{du}, \\
\mathrm{N}_{0}, \mathrm{Pu}_{0}\end{array}$ & $\begin{array}{l}\text { Linescont, Herble } \\
\text { Homzonit o, Hornfels }\end{array}$ & 6000 \\
\hline 47 & $\begin{array}{l}\text { Groumdhot } \\
\text { Wine }\end{array}$ & Mexleo. & Grant & $\begin{array}{l}\operatorname{sil}(\sqrt{w r} \\
\text { clsy }\end{array}$ & h⿻119res & $2 \mathrm{n}, \mathrm{Pt}_{2}, \mathrm{CO}_{1}, \mathrm{NP}$ & $\begin{array}{l}\text { Sundstown, Qurtrite, } \\
\text { Shate, Gronodtorte: }\end{array}$ & \\
\hline 48 & $\begin{array}{l}\text { Cranborry } \\
\text { Hagsentike }\end{array}$ & $\begin{array}{l}\text { Morth } \\
\text { Garoltus }\end{array}$ & Nory & $\begin{array}{l}\text { minston- } \\
\text { Sslote }\end{array}$ & Grabubsek industrias & $\mathrm{Ft}_{\mathrm{t}}$ & Grantice, Gonets: & \\
\hline 49 & $\begin{array}{l}\text { Tungaten } \\
\text { Sugen Hin }\end{array}$ & $\begin{array}{l}\text { Nort } \\
\text { Caroline }\end{array}$ & Yunct & $\begin{array}{l}\text { Groens- } \\
\text { hopoto }\end{array}$ & 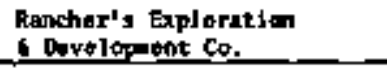 & 보군 & $\begin{array}{l}\text { Granodtorite. } \\
\text { 5chist, Gneiss }\end{array}$ & 2600 \\
\hline so & $\begin{array}{l}\text { Docktoun } \\
\text { Dlgtries }\end{array}$ & Tenneksw & Pall & Oanttan- & 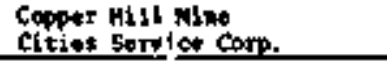 & Cu & 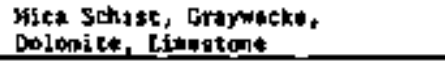 & $\begin{array}{l}3000 \\
2100 \\
\end{array}$ \\
\hline$\underline{\mathbf{s 1}}$ & Ontario Hilue & Unch & Sumit Co. & $\begin{array}{c}\text { Salt } \\
\text { takt city } \\
\end{array}$ & Motenda & 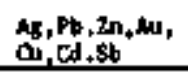 & 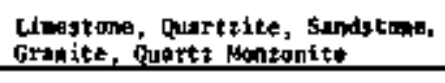 & 2495 \\
\hline$\$ 2$ & Hinter & Uteh & Moseck & $\begin{array}{l}\text { salt } \\
\text { Late city }\end{array}$ & Inited Park City Hines & 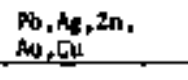 & $\begin{array}{l}\text { Linest mo. Durritite, } \\
\text { blorite Pogplory, Andesite }\end{array}$ & 240,0 \\
\hline$\underline{53}$ & $\begin{array}{l}\text { Satk } \\
\text { City bint }\end{array}$ & Utth & Swlt & $\begin{array}{l}\text { Sult } \\
\text { Lake Cłby }\end{array}$ & 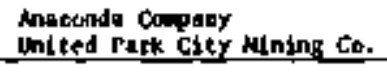 & $\begin{array}{l}\mathrm{Ag}, \mathrm{Pt}, \mathrm{AN}, \\
\mathrm{Cu}_{+} \mathrm{Zp}\end{array}$ & 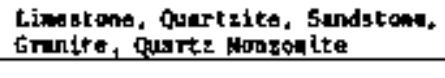 & 2000 \\
\hline$\$ 4$ & Nidalte Mine & Nabbinten & Stereans & Oxtengegan & Dening & $\mathbf{y}$ & 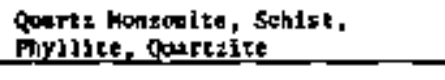 & $150(4)$ \\
\hline$\underline{55}$ & $\begin{array}{l}\text { Sharwood } \\
\text { viline }\end{array}$ & Wughing & Stopens & sendpolnt & 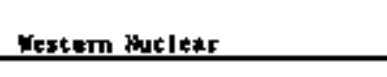 & y & & \\
\hline 36 & $\begin{array}{l}\text { Sucrlse Arraceis } \\
\text { Doposit }\end{array}$ & Mashingtion & Snothenolit & rakine & 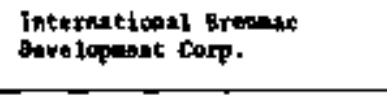 & 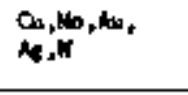 & Homfels, Quartz Diorite & $\begin{array}{l}\text { Mherel \$za. } \\
\text { tion - j500 } \\
\text { [t. thick }\end{array}$ \\
\hline
\end{tabular}


Thble 2 - "Cling 2" Mines (cantiound)

\begin{tabular}{|c|c|c|c|c|c|c|c|}
\hline No. & Min & stute & Hine Stetex & nintne Mntrod & 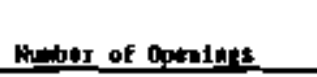 & $\begin{array}{l}\text { Trpe of } \\
\text { Equipentent }\end{array}$ & hlue in "Clasa P" Mecause: \\
\hline 46 & $\begin{array}{l}\text { Conk10eintol } \\
\text { Undernownd }\end{array}$ & New Mexico & Nec1ve 1978 & $\begin{array}{l}\text { Cot and fill } \\
\text { open stopive }\end{array}$ & 3 openingt & & Workings it connonitut \\
\hline 47 & $\begin{array}{l}\text { Groundioge } \\
\text { Mien }\end{array}$ & Nav kexlco & $\begin{array}{l}\text { Aet Ive: } \\
\text { Recpened } \\
\text { J969 }\end{array}$ & 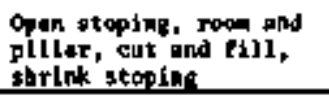 & 2 openinges & Panil & $\begin{array}{l}\text { Deptht lad ground conditionst } \\
\text { Workinet in tronodiontet? }\end{array}$ \\
\hline 4. & $\begin{array}{l}\text { Cranberry } \\
\text { Nafuntit: }\end{array}$ & $\begin{array}{l}\text { Horrh } \\
\text { Carolinat }\end{array}$ & Active 1976 & Sulfuce and onderrobound & & & $\begin{array}{l}\text { Deprh uncertoila; extent of } \\
\text { actitury }\end{array}$ \\
\hline 49 & $\begin{array}{l}\text { Tungaten } \\
\text { Quevelin Hink }\end{array}$ & $\begin{array}{l}\text { Worth } \\
\text { Carolina }\end{array}$ & $\begin{array}{l}\text { Iapective, } \\
\text { scandby }\end{array}$ & & & & $\begin{array}{l}\text { When imectivet fixtent of } \\
\text { vajkjings? }\end{array}$ \\
\hline$\underline{\text { so }}$ & $\begin{array}{l}\text { Ducktown } \\
\text { Distertet }\end{array}$ & Tennessert & $\begin{array}{l}\text { Copper H1ll } \\
\text { aine axtive }\end{array}$ & & & & $\begin{array}{l}\text { Sufficient extent of workinga } \\
\text { tn tirstelline rack? }\end{array}$ \\
\hline$\$ 1$ & Onturio Mins & Utm & Netive 1979 & $\begin{array}{l}\text { Cot and fill } \\
\text { stopta }\end{array}$ & 4 ihefts & & $\begin{array}{l}\text { Warkings sccestible to } \\
\text { crystalline rock? }\end{array}$ \\
\hline$\underline{\mathbf{s 2}}$ & $\begin{array}{l}\text { Mayflower } \\
\text { Nine }\end{array}$ & Ut冲 & $\begin{array}{l}\text { Inactivo } \\
\text { l969 }\end{array}$ & $\begin{array}{l}\text { Horitionizl cut and } \\
\text { fII, sam shrlakage } \\
\text { stopint }\end{array}$ & $\begin{array}{l}\text { I shaft, } \\
\text { tuphal }\end{array}$ & & $\begin{array}{l}\text { Mock scobillty and water problens; } \\
\text { Morktngr accoselble in erpstalline } \\
\text { rock? }\end{array}$ \\
\hline$\underline{\mathbf{5 3}}$ & $\begin{array}{l}\text { Park } \\
\text { Cisy Hin: }\end{array}$ & Nkath & $\begin{array}{l}\text { CJaged 1976 } \\
\text { Aetjwe } 1976\end{array}$ & Cut and fall & 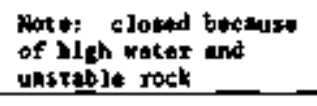 & Pant1 & $\begin{array}{l}\text { Rack stubility problins, Nortings } \\
\text { access [b]e in cryscilling tock? }\end{array}$ \\
\hline 5 & Midnite Mino & Woshingtor & Active 1979 & $\begin{array}{l}5 \text { ore bodies : } \\
\text { Dpen pit } 1957^{-}\end{array}$ & & & 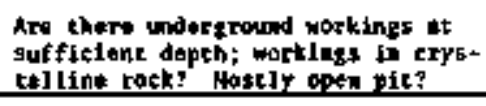 \\
\hline 55 & $\begin{array}{l}\text { Shanmod } \\
\text { Mint }\end{array}$ & Norithington & Netivy 3979 & & & & 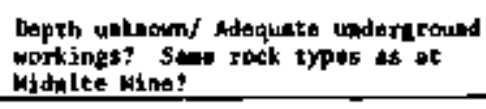 \\
\hline 56 & $\begin{array}{l}\text { Sunrise Brec- } \\
\text { cla Dpposit }\end{array}$ & rashlngton & Inecdve & & & & $\begin{array}{l}\text { Workings accessible in quarts } \\
\text { dlorbte? Depth of markingti }\end{array}$ \\
\hline
\end{tabular}





\section{I. CONCLUSIONS AND RECOMMENDATIONS}

\section{Sumnary and Conclusions}

Relying priwarily on information in the open literature, we have identified 30 "class 1 " sites in 14 states which may have potential for underground test facilities. These include, primarily, existing or recently inactive mines, and also civil works such as punped storage facilities. The search also suggests that another $30^{\text {th }}$ class $2^{\text {te }}$ sites in 14 states may have sinilar potential if adequate information on one or nore key criteria were available. The criteria include the following considerations :

- Crystalline rock

- Depths below 600 feet

- Workings of adequate size to provide for a Stripa-sized facility

- Workings open within the past 10 years and not flooded or caved

- Workings below the water table

- Good rock support

The locations of the 60 sites are shown on the map of the U.S., Figure 1 in the preceding section. Potential underground workings range in size from a few thousand lineal feet, having exployed or employing a few tens of niners, to several hundred miles, employing hundreds of miners. Depths range from near our threshold limit of $600 \mathrm{ft}$. to over $8000 \mathrm{ft}$. ${ }^{\text {"Class }} 1^{1 r}$ mines or civil works in tectonically stable mid-continent or eastern regions of the United States include one in Maine, two in Minnesota, two in New Jersey, two in New York, and one 1n South Carolina. The renaining "class $1 "$ sites are in the Rocky Mountain region and westward. of the civil works, pumped-storage facilities incorporating underground 
powerhouses and appurtenant galleries may offer the best prospects for in-situ test facilities because, even though they may be operating, access may still be available to test and support galleries.

It is expected that a comparable number of undergrotund openings, primarily exploration adits, shafts, and drifts, not mentioned in the open literature but probably documented in company files, may also exist. These workings may furmish access for test facilities in crystal1ine rock.

Wany of the workings in "class 1 " mines are in hydrothermal vein deposits, at or near contacts between plutonic and older sedimentary, volcanic or netamorphic rocks. Test facilities at these sites would therefore be located relatively near the margins of crystalline rock nasses. Notable exceptions are the clinax, Urad and Henderson nines in Colorado, nines in the Butte district, Montana, the San Manue1-Kalanazoo in Arizona, and mines in the Duluth Gabbro, Minnesota. All of these ore bodies are located we11 within plutons.

Mines within medium to high grade netamorphic rock nasses include the Honestake, South Dakota, the Schwartzwalder and Colorado School of Mines' experimental mine in the Colorado Front kange, the Mt. Hope - Scrub Oaks, New Jersey, and the Lyon Mountain district, New York.

Structural settings of mining districts are doninated by the aforementioned contact zomes, by strong folding and faulting in the case of mines in metamorphic rocks, and by zones of intersecting faults in the mines in plutonic rocks. Because of their stability requirenents, underground hydroelectric facilities in crystalline rocks are located in relatively stable tectonic settings, usually away from the contacts with other rock types. Accessible openings associated with hydroelectric facilities may 
offer rock property conditions most similar to those of potential waste isolation sites.

\section{Recommendatíons}

It is recommended that a program follow which would definitively evaluate the available and accessible underground workings. This program will result in the identification of one or more sites where a concordance exists between rock type and structural setting and depth, company anenability, accassiblity, facilities, and hydrogeologic setting.

The recommended program would encompass the following activities:

1) The appropriate companies or governmental agencites controlling "class ] or $2 "$ sites would be contacted to arrange discussions with designated personnel. These discussions would explore the willinghess of the corpanies/agencies to participate in the project and would serve to validate and increase the information developed in the prelininary description of the sites. It is expected that, following the initial company/ agency contact, the number of prospective underground workings would be significantly reduced. It is also possible that information on sone hitherto unknown potential sites would be obtained, resulting in some additions to the list of prospects.

2) During and following the discussions, plans would be made for the initial site visits, which would commence at the earliest convenience of company/agency personnel.

3) Concurrentiy, the results of the companion project (Cohen, 1979) to develop criteria for in-situ test facilities and to formulate a preliminary testing progran would be incorporated, providing 
criteria for assessment of the prospective sites.

4) With these criteria in mind and with the permission of and accompanied by company/agency personnel, the sites would be visited and evaluated.

5) The recommended program would culminate in a report covering:

(A) the criteria used to evaluate the sites;

(B) results of site visits:

(1) detailed descriptions of the location and accessibility of the site,

(2) detailed descriptions of the goologic settings and underground workings,

(3) geotechnical and hydrologic data base.

(4) detailed descriptions of facilities which would lend themselves to a test facility;

(C) recommendations of which sites, based on their technical merits, would best qualify for in-situ geonechanical, geochemical, and hydrogeologic tests relevant to the underground storage of radioactive wastes in erystalline rock. 
IV. DESCRIPTIONS OF "class 1" MINES AND CIV IL MORKS

A description of each "class 1" site is included, alphabetically by state, in the following portion of the report. Each swmary includes data on location and accessibility, geologic setting, description of mine or civil workings, and references. 

LAKESHORE MINEE

(OPERATED BY NORANDA EXPLORATION, INC., A SUBSIDIARY OF NORANDA MINES, LTD.)

LOCATION

The Lakeshore mine is located at $32^{\circ} 31^{\prime N}, 111^{\circ} 54^{\circ} \mathrm{H}$, within the boundaries of the Papago Indian Reservation, in Pinal County, approximately 28 miles south of Casa Grande, Arizona, and approximately 70 miles northwest of Tucson (as shown in Figure 1). The Lakeshore ore body lies under the southwest pediment of the slate Mountains. The surface elevation in the area is approximately 1800 feet.

GEOLOGIC SETTING

Data describing the regional geologic setting were extracted from Board (1977), Ha11of (1971), and Harper (1969).

Precambrian Pinal schist is the oldest exposed formation in the area, and it forms the core of the Slate Mountains. The Pinal schist is unconformably overlain by the late Precanbrian Apache Series which is exposed approximately $5 \mathrm{miles}$ north of Lakeshore. The Apache Series consists of the Pioneer shale (425 feet thick), the Dripping Spring quartzite (1085 feet thick), and the Mescal limestone (200 feet thick), Diabase intrusions are common in the units.

The Paleozoic formations in the area of the Slate Mountains are represented by the Troy (or Bolsa) quartzite, the Abrigo, the Martin, the Escabrosa, and the Horquilla formations, which include a varlety of sedimentary and metasedimentary rocks (quartzite, mudstone, dolonite, limestone, and siltstone]. The aggregate thickness of these formations way exceed 1600 feet in the southesstern part of the Slate Mountains near the Lakeshore property. 


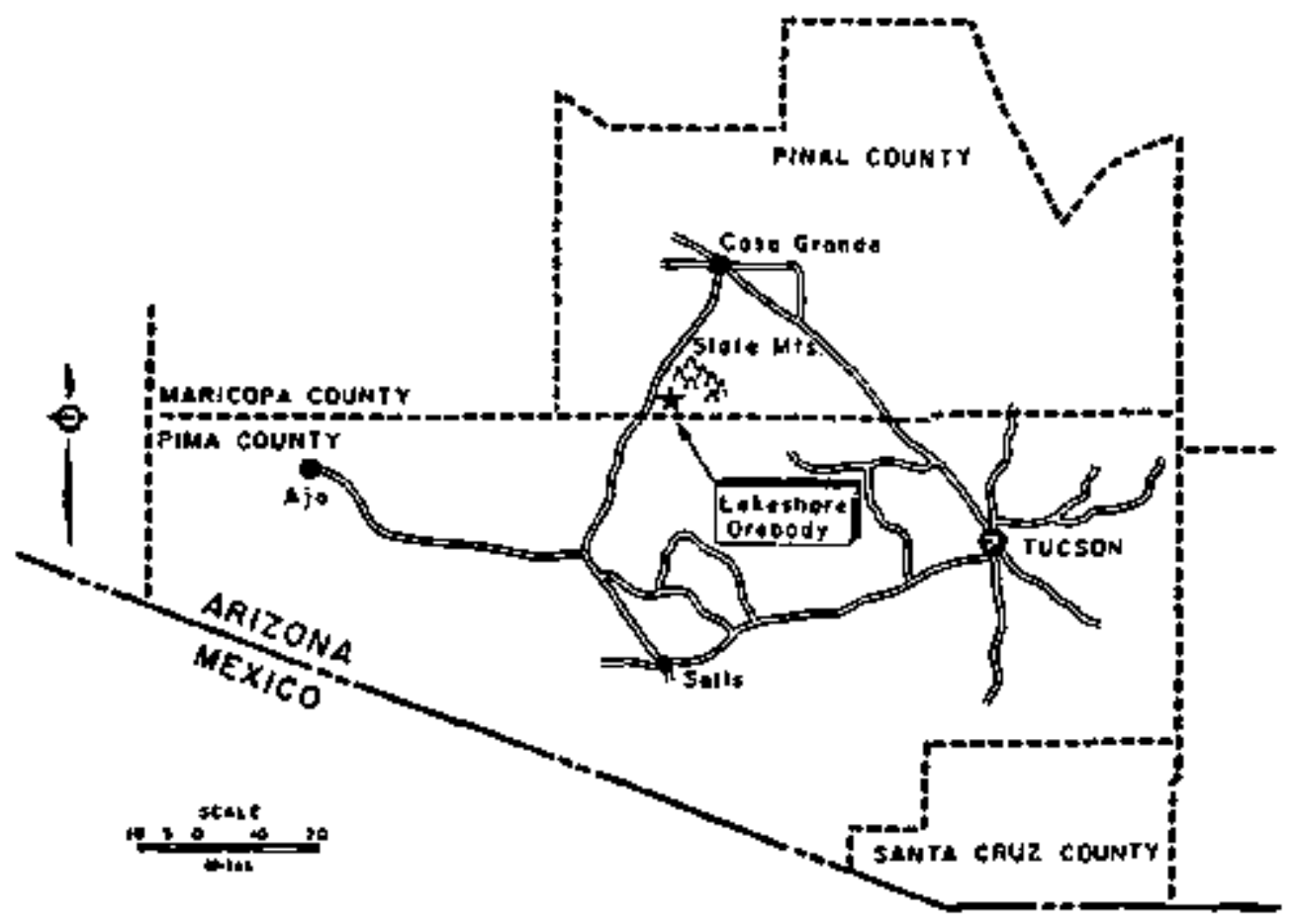

FIGURE 1. Location map of the Lakeshore ore body, Pinal County, Arizona (Hallof and Winniski, 1971). 
Recurrent volcanism and continental deposition characterized the Cretaceous and Early Tertiary in southern Arizona. The resulting thick accumulation of clastic and volcanic conglomerates and agglomerates are exposed at several locations in the Lakeshore area. Drilling at Lakeshore has intersected substantial thicknesses of andesite and andesite breccia in the imediate mine area. The andesitic volcanics unconformably overlie the Paleozoic and Upper Precambrian formations, while the andesite is overlain by a thick sequence of Tertiary fanglomerate and young Tertiary volcanics and conglomerate.

Mine Area

Information on the geologic setting of Lakeshore mine were extracted from Board (1977), Ha1lof (1971), Harper (1969), and Eks (1969).

A stock of quartz diorite and related porphyritic rocks of Tertiary age have intruded the Precambrian, Paleozoic, and Cretaceous formations previously described. The northern and eastern margins of the stock are exposed on the western slope of the Slate Mountains, while the southern and western margins are obscured by alluvium. Complex faulting in a wide zone along the assumed southern and western margins of the stock further complicates the relationship between the quartz diorite and the late Precambrian and Paleozoic rocks. Fanglomerate overlying the Cretaceous andesite thickens to 1100 feet over the western portion of the deposit.

The geology of the deposit is illustrated in Figures 2 and 3 . Figure 3 is a cross-section of the deposit, looking toward the north. The andesite-metasedinent sequence is bounded on the east by a steeply dipping normal fault. Quartz diorite is present east of the fault. This fault marks the eastern limit of the major subsurface deposit, as well as the 


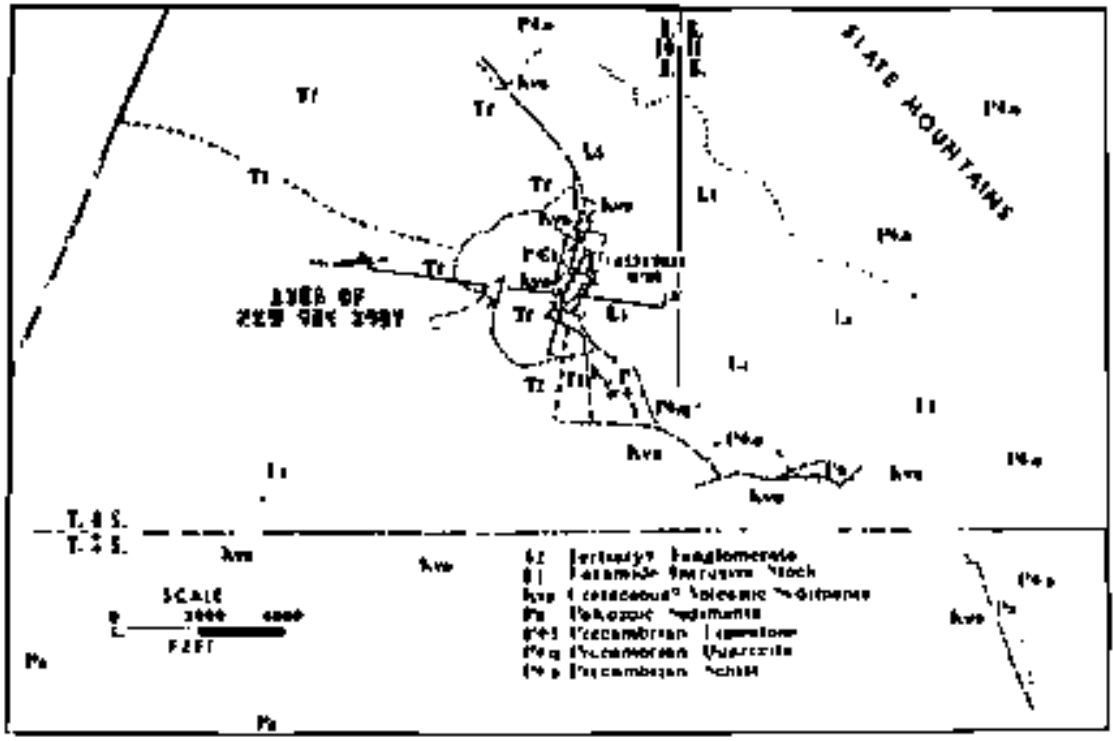

FIGURE 2. Preliminary geology of the Lakeshore mine area has boen largely interpreted from drill hole data. Cross section $\mathrm{A}^{-\mathrm{A}^{\prime}}$ is seen as Figure 3 .

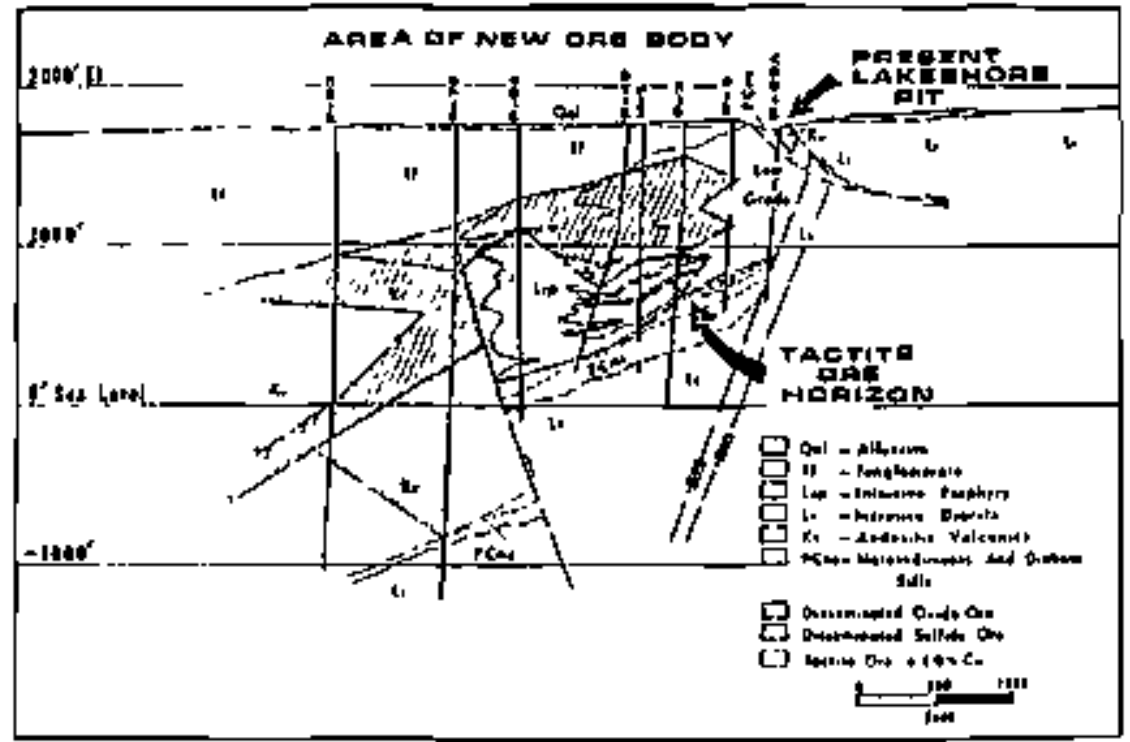

FIGURE 3. Geologic section $A-A^{r}$ of Lakeshore ore deposit. 
small open pit ore body. In the central part of the deposit, drill holes indicate that the formations strike northerly and dip westerly at about $25^{\circ}$.

A fine to medium grained prophyry of quartz diorite to quartz

monzonite composition intrudes the metasediments and andesite. Its relationship to the quartz diorite stock is not clear. The main mass of porphyry is located in the north central part of the deposit as an irregular body with fingers which extend upward and to the east.

The metasediments in the westerm part of the area are displaced approximately 700 feet below those in the central part of the deposit by a postoxidation, high angle reverse fault.

The andesites, porphyry, metasediments, diabase, and upper part of the underlying intrusive have been extensively shattered and are moderately to strongly altered. The andesite, porphyry, and metasediment-diabase sequence are the primary host rocks for the mineralization. The upper portion of the underlying intrusive occasionally contains disseninated sulfides.

The ore body has been divided into three distinct zones of mineralization which have been termed; (1) ozide zone, (2) sulfide zone, and (3) tactite zone. The oxide zone occurs in the upper portions of the ore body and consists primarily of leached and oxidized quartz monzonite porphyry and Cretaceous sedimentary and volcanic rocks. The sulfide zone underlies the oxide zone and includes a11 quartz monzonite porphyry and Cretaceous rocks which have not been oxidized. The thickness of the sulfide zone is variable and ranges from $200-400$ feet. The tactite zone occurs in a series of Paleozoic metasediments consisting of tactite, quartzite, diabase, hornfels and dikes of quartz monzonite porphyry. The tactite zone is highly variable in thickness (averaging 63 feet) and underlies 
the Cretaceous volcanics and sediments throughout the mine. Figure 4 illustrates the general relationship of ore types in the mine.

\section{MINE CHARACTERISTICS}

Information concerning the mine was extracted from Board (1977), COBBS Report, EMJ (1978, 1979), and Harper (1969).

The Lakeshore mine was first brought into production as an underground mine by Hecla Mining Company in April 1976. A weak copper market prompted Hecla to close the mine for an indefinite period beginning in September 1977. Maintenance expenses at the closed mine were approximately $\$ 600,000$ per month. Noranda Exploration Inc., a U.S. subsidiary of Noranda Mines Ltd. (Canada), has acquired the mine from Hecla/El Paso Natural Gas, and renegotiated leases with the Papago Indians. Noranda plans to begin mining 6000 stpd of ore by Septenber 1979.

\section{MINE FACILITIES}

When originally opened by Hecla, the mine employed approximate1y 1600 people, was designed with a daily ore capacity of $16,500 \mathrm{tpd}$, and mined 1 to 10 million tons of ore per year and 1 to 10 million tons of waste per year, extracting a total volune in excesses of $180,000,000$ cubic feet.

Based on its large size ( $l_{5}$ to 1 billion tons of ore) and layered characteristics, the deposit lends itself to an extraction plan which integrates mechanized underground wining techniques. Hecla's approach to mining the ore body was to develop a block caving operation based on highgrade sulfide ore in the tactite zone underlying the deposit during the early stages of the operation. In contrast, Noranda will reopen the mine 

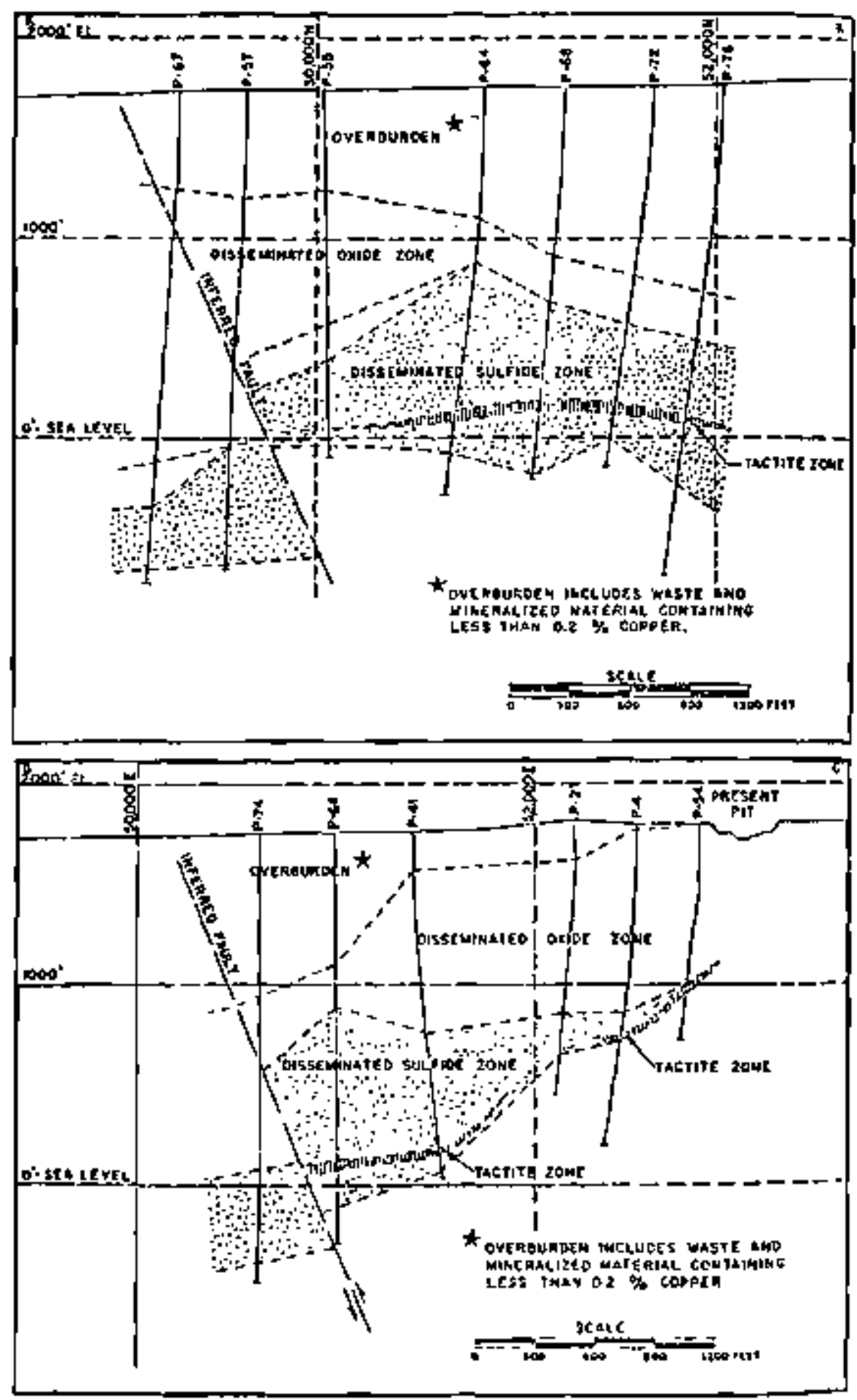

FIGURE 4. North-south and east-wost cross-sections of lakeshore deposit illustrating the three zones of mineralization: oxide, sulfide, and tactite (EWJ, June, 1969). 
based on extraction of copper oxide ore, while studying the sulfide ore's grade and quantity. From available data it is not known whether Noranda will be mining copper oxide ore fron the open-pit or from underground workings, or from both.

Access to the mine is by a twin decline on a $15^{\circ}$ slope providing entry to the ore body, and equipped with conveyors, provides the main ore handling facility. The length of the decline to a point beneath the central part of the deposit will be approximately 7500 feet. Information regarding the location and orientation (straight or switch-back) of the decline, and rock types penetrated was not available; the length and slope suggest that favorable rock types are among those encountered. However, published information does not indiciate the extent of undergrownd workings in crystalline rock types.

\section{Rock Mass Properties}

Table 1 lists the basic sulfide mine rock properties. Testing of the intact rock was conducted at the University of Arizona, Tucson, by White (Board, 1977). 


\section{TABLE 1}

\section{LAKESHORE MINE ROCK PROPERTIES}

\begin{tabular}{|c|c|c|c|c|}
\hline Rock Type & $\begin{array}{l}\text { Uniaxial Comp, } \\
\text { Strength (psi) }\end{array}$ & $\begin{array}{l}\text { Poisson's } \\
\text { Ratio }\end{array}$ & $\begin{array}{l}\text { Young's } \\
\text { Modulus } \\
\end{array}$ & $\begin{array}{l}\text { Internal Angle } \\
\text { of Friction }\end{array}$ \\
\hline & & & $\left(x 10^{6} \mathrm{psi}\right.$ & \\
\hline Tactite & 11,798 & 0.3 & 5.42 & 53 \\
\hline $\begin{array}{l}\text { Quartz } \\
\text { Monzonite }\end{array}$ & 14,912 & 0.19 & 9.00 & 31 \\
\hline Hormfels & 13,542 & 0.21 & 14.00 & 52 \\
\hline
\end{tabular}

Board (1977) 


\section{REFERENCES}

Board, M.P., 1977. Drift support desigr for the Thick Sulfide Mine, Finai County, Arizona. M.S. Thesis, University of Minnesota.

Cobbs Engineering, 1976, Survey of active and inactive mines for possib1e use as in situ test facilities, Offlce of Waste Isolation, 0ak Ridge, Report No. Y/OWI/SUB $76 / 16514$.

CRIB Data Base.

Engineering and Mining Journal: 1979, v.180(4) p.41

$$
\begin{aligned}
& 1978, v .179(9) \text { p.314 } \\
& 1978, v .179(7) \\
& 1978, v .179(1) \text { p.133 } \\
& \text { Mines Directory } 1978 \\
& 1969, \text { v.170(6) p.128, } 132
\end{aligned}
$$

Hallof, P.G., and Winniski, E. 1971, A geophysical case history of the Lakeshore ore body, Geophysics, v.36(6). p. $1232-1249$.

Harper, H.E., and Reynolds, J.R., 1969, The Lakeshore copper deposit: Miring Congress Jourral v.55(11), p. 26-30. 


\section{MIAMI EAST MINE \\ (OPERATED BY CITIES SERVICE COMPANY)}

\section{LOCATION}

The Miami East mine is located adjacent to the town of Hiami and approximately 6 miles northwest of Globe, Arizona, at $33^{\circ} 24^{\prime} \mathrm{N}, 110^{\circ} 53^{\prime} \mathrm{W}$ (Figure 1). The elevation at the mine is approximately 3500 feet, with several hundred feet of relief in the area.

GEOLOGIC SETTING

Regional

The regional geologic setting has been extracted from olmstead (1966), Peterson (1962, 1954), and Rubly (1938).

The rocks of the Globe-Miami district range in age from Lower Precambrian to Recent. Figure 2 is a geologic map of the region. The Precambrian Pinal schist, diabase of possible Mesozoic age, Willow Springs granodiorite, Schultze granite, dacite, and Gila conglomerate are inmediately connected with the Miami East deposit.

The Pinal schist is one of the ore deposit host rocks and is the oldest formation in the area. The Pinal schist makes up the bulk of the Pinal Range, which covers an area of 16 by 12 miles. The disseminated copper deposits of Miani occur in the northeast portion of the range. The schist consists of a sequence of metamorphosed sedimentary rocks, and is irregularly intruded by Precambrian quartz diorite, granite, and the Tertiary Schultze granite. The metamorphic sequence is composed of coarse-grained quartzmuscovite schist, fine-grained quartz-sericite-chlorite schist, and some 


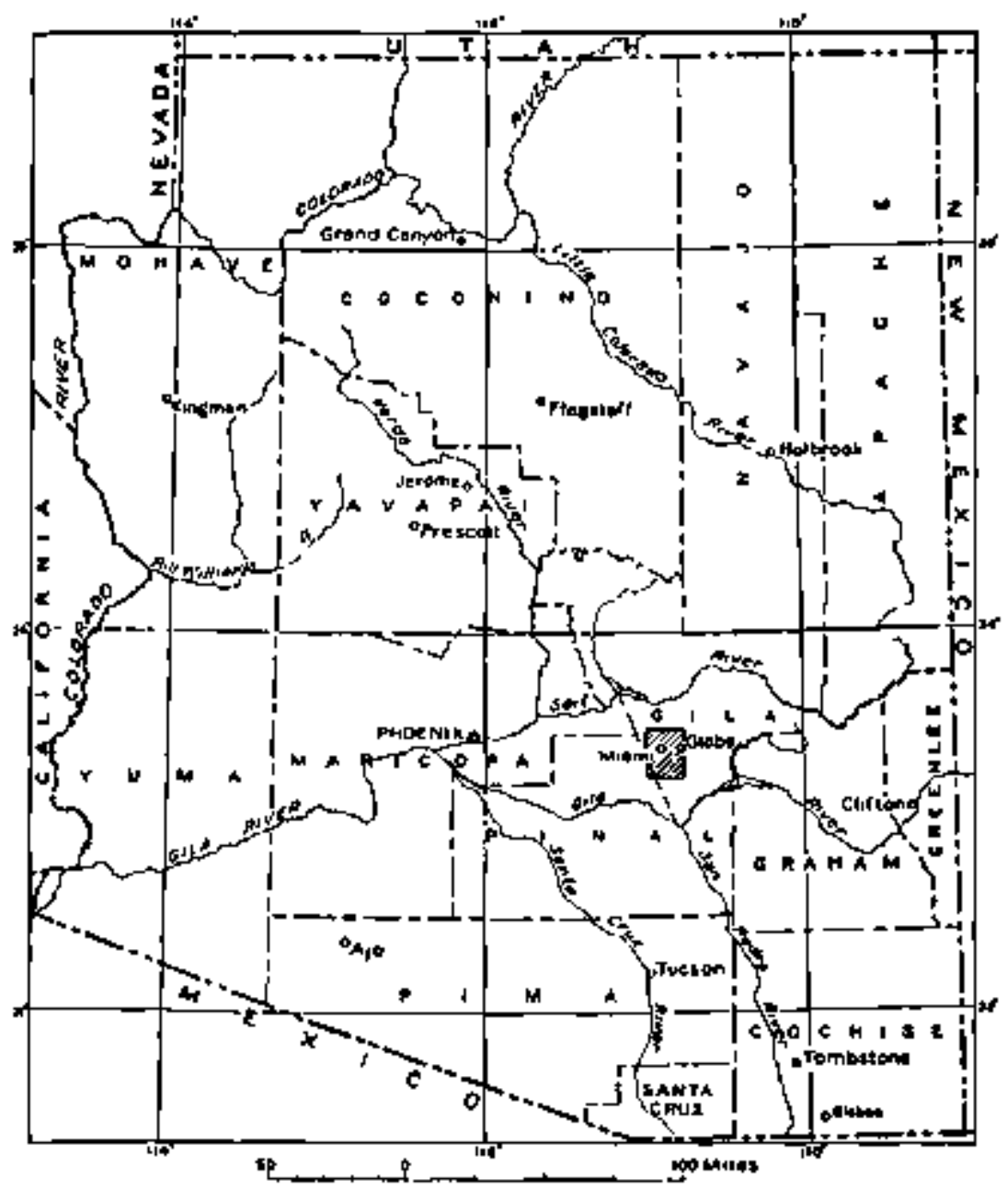

FIGURE 1. Index map of Arizona showing location of Globe quadrangle, (after Peterson, 1951). 


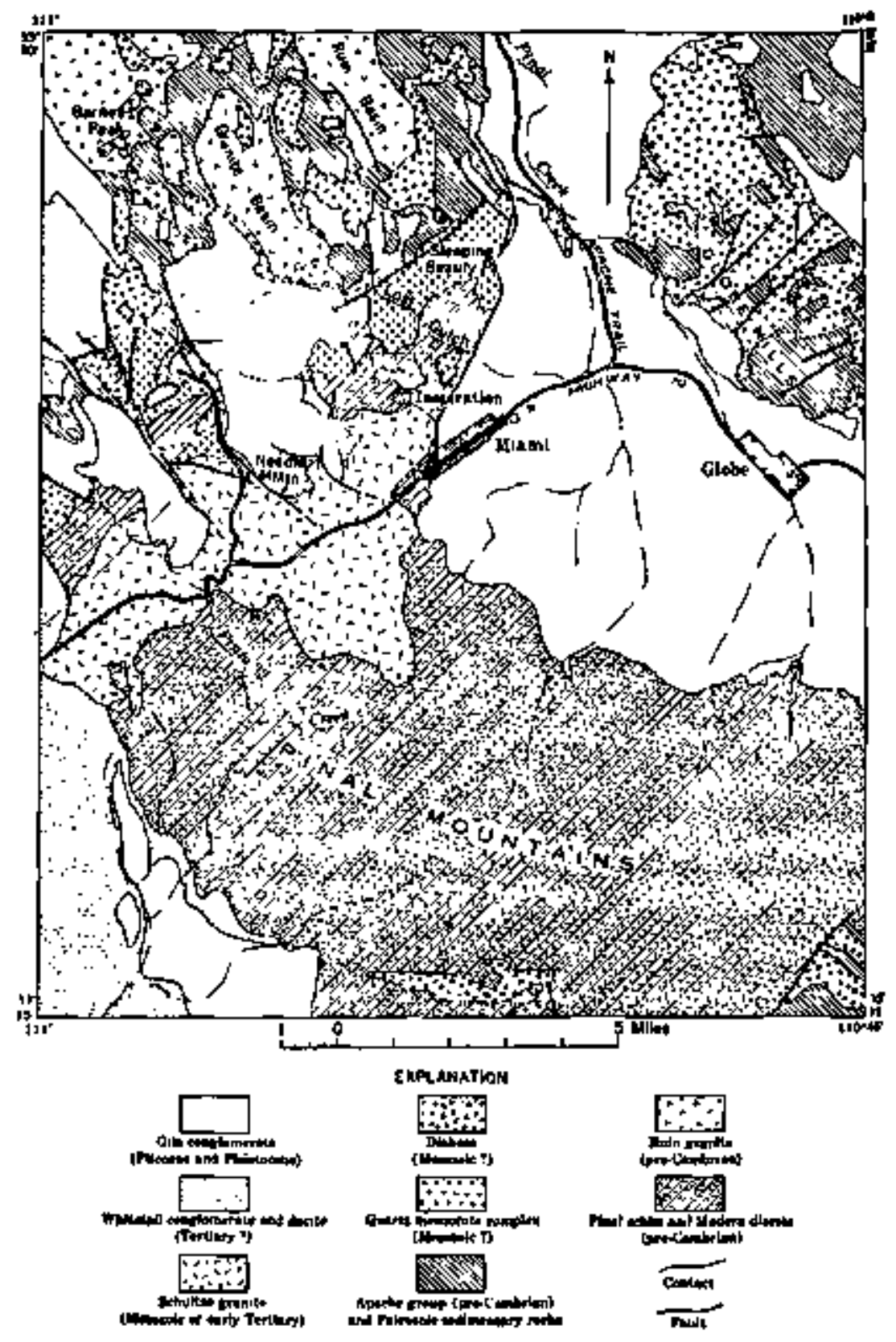

FIGURE 2. Geologic sketch map of Globe quadrangle, Arizona. Data from Ransone with nodifications, [after Peterson, 1951]. 
fine-grained amphibole schist. The general schistosity strikes about NSO $0^{\circ} \mathrm{E}$ and dips steeply to the southeast. The outlines of the ore deposits and the intrusion of granite porphyry cJosely parallel the orientation of schistosity.

Tertiary diabase intruded the metanorphic and sedimentary strata as irregular sheets, sills, and dikes.

The Tertiary Willow Springs granodiorite outcrops within several thousend feet of the Miami mine; however, it has no obvious relationship to the ore bodies in the area.

The rock most directly associated with the ore deposits is the Tertiary Schultze granite, which is believed to be contemporaneous with the copper mineralization. Facies of this rock contain part of the ore deposit and often border the ore zones. The schultze granite stock extends many miles south and west of Miami and constitutes a large portion of the northwest Pinal Mountains. Its composition varies between gronodiorite, quartz monzonite, and porphyritic quartz nonzonite. From the standpoint of the ore deposit, the most significant constituent of the Schultze granite is a granite porphyry, a separate narginal and younger facies of the Schultze. In some of the ore bodies in the area, half of the ore may be in granite porphyry, while the other half is in Pinal schist. The granite porphyry is a plug which intruded older facies of the Schultze granite and formed sill-1ike tongues in the schist.

The Tertiary dacite in the area is believed to represent the final stage of igneous activity. The massive dacite shows sheeting, which trends north-south and dips moderately to the west.

Massive thick beds of Plio-Pleistocene Gila conglomerate overlie much of the area. Bedding trends northwest-southeast and dips gently to the southwest. 


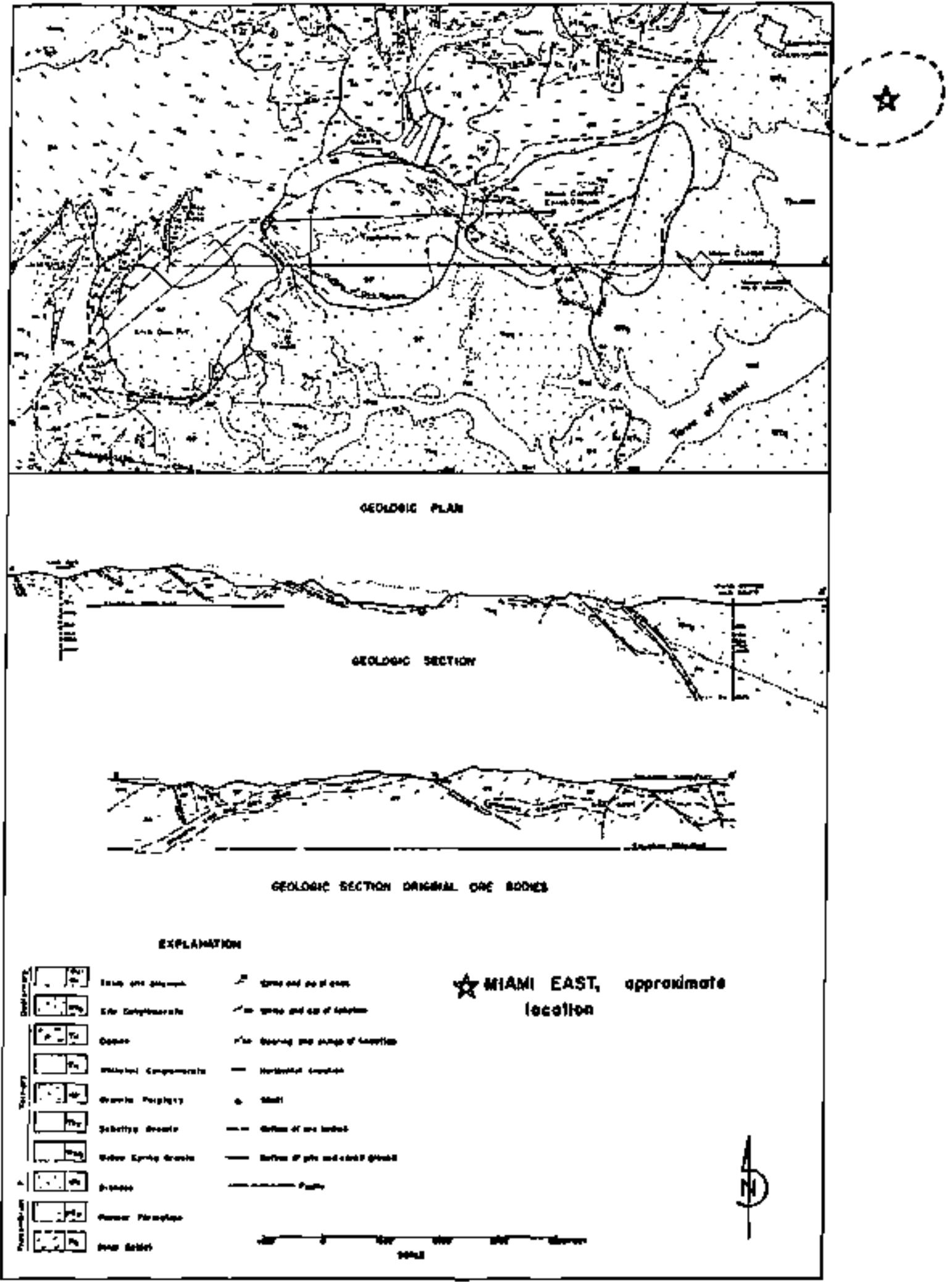

FIGURE 3a. Geologic plan and sections, Inspiration Mine, Gila County, Arizona (after 0lmstead, 1966). H.W. Olmstead and D.W. Johnson, "Inspiration Geology," in GEOLOGY OF THE PORPHYRY COPPER DEPOSITS, Spencer Titley and Carol Hicks, Editors, Tucson: University of Arizona Press, copyright 1966. 
MINE AREA

Data concerning the geology of the Miami East mine were not readily available in the literature. The information which was available suggested that rock-type relationships in the Miami East ore body are very similar to those in the Inspiration and Miami mines located several thousand feet to the southwest. Much of the following description of mine area geology is drawn from literature on local mines by olmstead (1966), Peterson (1962, 1954), Rubly (1938), and Skillings (1975).

The Niami East ore body is located approximately 2500 feet northeast of Shaft No. 5, as shown in Figure 3. The mineralized area is 3000 feet long, has a width of 1400 feet, and a maximum thickness of 400 feet. The deposit has a varying dip to the north and east with a maximun pitch of $34^{\circ}$. The ore body is situated nearly 2000 feet east of the original Miami deposit, and its top occurs at a depth of 2500 feet.

Structures in the mine area are related to the general structure of the Precambrian schist, which trends northeasterly and dips to the southeast. Locally, granitic intrusives have distorted and obliterated the schist structure, but the schistosity prevails as the major lineation that controlled mineralizing solutions. The geology of the local mine area is shown in Figures $3 \mathrm{a}$ and $3 \mathrm{~b}$.

Faults controlled the intrusion of the granite porphyry with which the ore bodies are associated. The Miami fault (a normal fault) strikes N25 ${ }^{\circ}$, dips about $50^{\circ} \mathrm{E}$, and drops the Gila conglomerate to the east of the exploited ore bodies, between 2000 and 3000 feet. This fault or the ancient break it followed may have had some pre-porphyry movenent. East of the mining areas, the ore bodies appear to be terminated by the Miami fault, although there are some indications that the ore did not reach the fault zone or that there is 


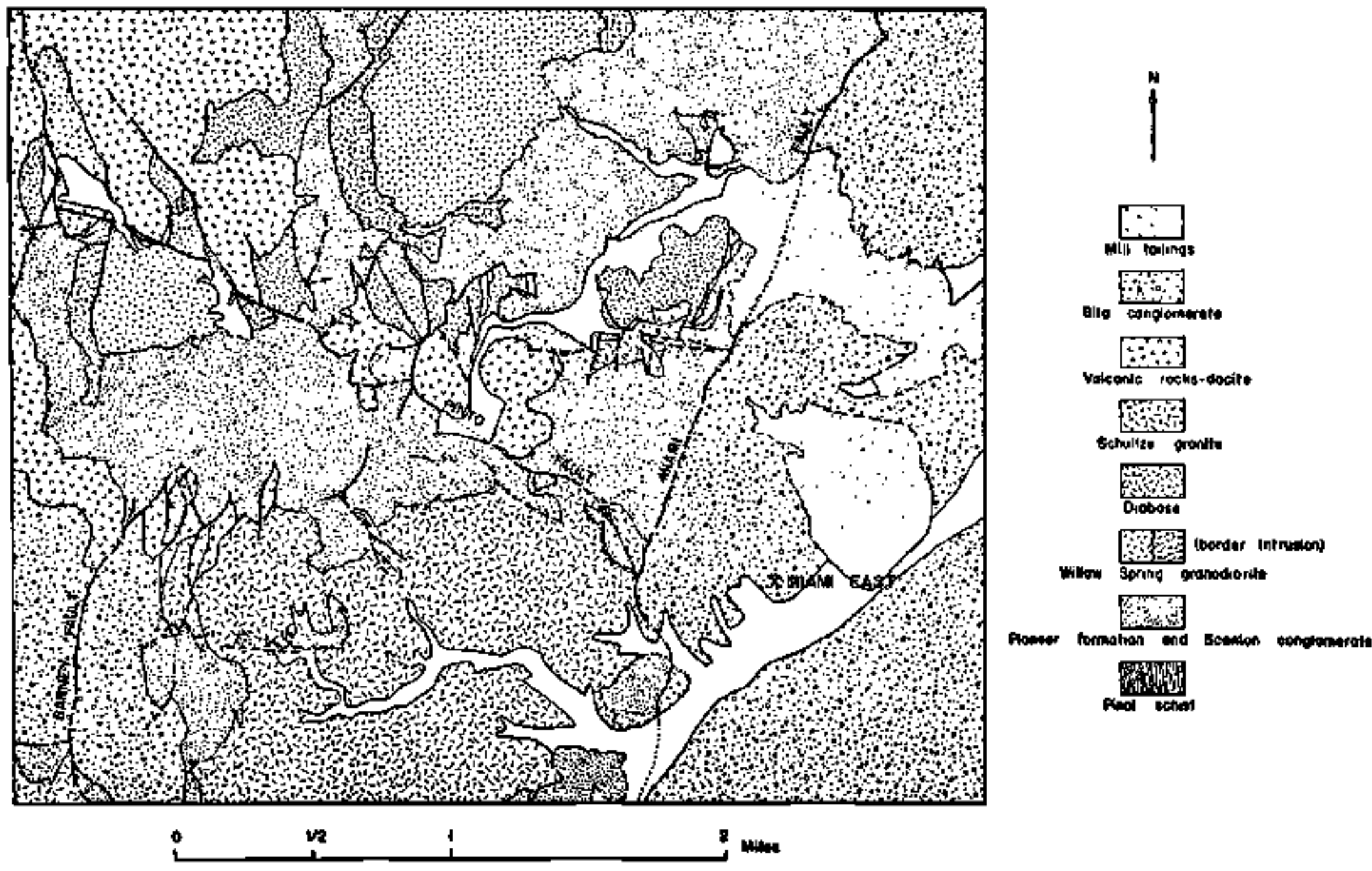

FIGURE 3b. Geologic map of the Miani East area, Gila County, Arizona (Peterson, 1962) 
a leached zone near the fault. Some ore in diabase occurs at considerable depth east of the Miami fault, and one drill hole disclosed secondarilyenriched sulfides lying below low-grade primary material near a branch of the Miami fault.

MINE FACILITIES

Data related to the Miami East mine facilities were extracted from Carter (1975), Skillings (1975), and Mining Annual Review (1978).

The Miami East mine of Cities Service Company contains an estimated 50 million tons of $1.95 \%$ copper ore. Underground mining at the original Miami mine was replaced by in-place leaching in 1959. The deeper Miani East ore body was confirmed by drilling in 1969, and a progran of shaft sinking and underground development was comenced. Production was expected to begin in 1976, however, after substantial development work, it was decided to place the mine on standby, which is the current status.

Two shafts were sunk on the Miami East project. The $12 \mathrm{ft-diameter}$ concrete lined No. 11 shaft, which provides domcast ventilation and serves as an escapeway bottomed at a depth below 3300 feet. The $14 \mathrm{ft}$-diameter concrete-lined No. 12 shaft, an exhaust and ventilation facility, was excavated to a final depth of 2900 feet. At the end of 1973 , the existing No. 5 production shaft was deepened from 1150 feet to 3500 feet, with stations developed at the 2900 and 3200 foot levels. The development drifts on the 2900 and 3200 foot levels of No. 5 shaft have been extended approximately 2500 feet to the ore body.

The Miami East ore body is mined by the modified horizontal cut and fill method; block caving was deemed undesirable due to a potential subsidence problem at the site. Production was planned to reach $5000 \mathrm{tpd}$. 
45

A typical stope will measure $8 \times 11$ feet in cross-section, advancing a 100 foot slot. Stope will be developed on 16 foot centers. Highly mechanized mining equipment will be used for ore recovery. Eimco 911 and 912 LLD' $^{\star}$ will load and transport ore to the mine's main rail haulage network. Ore haulage to the No. 5 shaft will initially utilize battery-powered locomotives. As full productive capacity is neared, these will be replaced by diesel-powered units.

The main haulage levels measure $11 \times 13$ feet in cross-section. Ground support will utilize a dry process shotcrete method, with additional rock bolting over shotcrete when necessary.

* LHD = Load, haul, dump. 
REFERENCES

Cartex, R., 1975, Miani East Mine Development Nears Completion:

Mining Engineering, v. 27, (S) p. 14 .

Dunning, C.H., 1959, Rock to Riches: Southwest Publishing Co., Phoenix, Arizona, p. 183-184, 200-201, 229-230, 262-264.

Fletcher, J.B., 1960, Ground Movement and Subsidence from Block Caving at Miami Mine: AIME Transactions, v. 217, p. 413-422.

MAS data base.

Nining Annual Review - 1978, p. 359.

Mining Magazine, 1975, Miani East Copper Deferred, v. 133 (Sept.), p. 157,159 .

Olmstead, H.W., and Johnson, D.H., 1966, Inspiration Geology, in Geology of the Porphyry Copper Deposits, Southwestern North Anerica, Titley, \$.R., and Hicks, C.L., eds., University of Arizona Press, Tucson, p. 143-150.

Peterson, N.P,, 1962, Geology and Ore Deposits of the Globe-Miami District, Arizona: U.S. Geo1. Survey Prof. Paper 342, 151 PP.

-...--, 1954, Copper Cities Copper Deposit, Globe-Wiami District, Arizona: Econoric Geology, v. 49 (4), p. 362-377.

-...-., Gilbert, C.M., and Quick, G.L., 1951, Geology and Ore Deposits of the Castle Dome Area, Gila County, Arizona: U.\$. Geol. Survey Bul1. 971, P. 1-11.

Rubly, G.R, 1938, Miami-Inspiration District: University of Arizona Bul1. 1, "Some Arizona Ore Deposits," Arizona Bureau of Mines, $v+9$, (1), Bull. 143, p. 66-72.

Skillings, D.N., 1975, Cities Service Co.'s Pinto Valley Copper Project: Skillings' Mining keview, July 19, 1975, p. 14-15, 18-21. 
SAN MANUEL/KALAMAZOO MINE

(OPERATED BY MAGMA COPPER COAPANY, A SUBSIDIARY OF NEWHONT CORPORATION)

\section{LOCATION AND ACCESSIBILITY}

The San Manuel mine is located just south of Tiger, Arizona in the old hat mining district of Pinal County, at $32^{\circ} 41^{\prime} \mathrm{N}, 110^{\circ} 42^{\prime} \mathrm{W}$ (Figure 1). The San Manuel deposit is located in sections 34 and 35, T.8S., R.26E, of the Gila and Salt River meridians. The Kalamazoo deposit is located in sections 3, 4, 9, 10, T.9S., R.16E. The San Manue1/Kalamazoo mine area is approximately 35 miles ( 46 miles by road) northeast of Tucson. The elevation in the mine area is approximately 3,200 feet, with several hundred feet of relief in the general area. The nearest railroad is at Winkelman on the Gila River, $20 \mathrm{miles}$ north of San Manuel and Tiger. Electric power and natural gas are available.

GEOLOGIC SETTING

Data describing the regional geological setting has been extracted from Creasey (1965), Lowell (1968), Kendorskj (1976), Ridges (1972), Schwartz (1953), and Thongs (1966). Figure 2 illustrates a simplified regional geologic setting. There is a rather limited variety of rocks exposed either on the surface or underground. The San Manue1/Ka lamazoo mine is located in an extensive area of Precambrian quartz monzonite, known as the oracle granite, which itself is part of a much larger granite mass on the north slope of the Santa Catalina Mountains.

The Oracle granite is considered to be the result of metasomatization of earlier rocks, possibly the Pinal schist. A northeasterly grain in the Oracle is evidenced by the alignment of xenoliths in the rock mass 


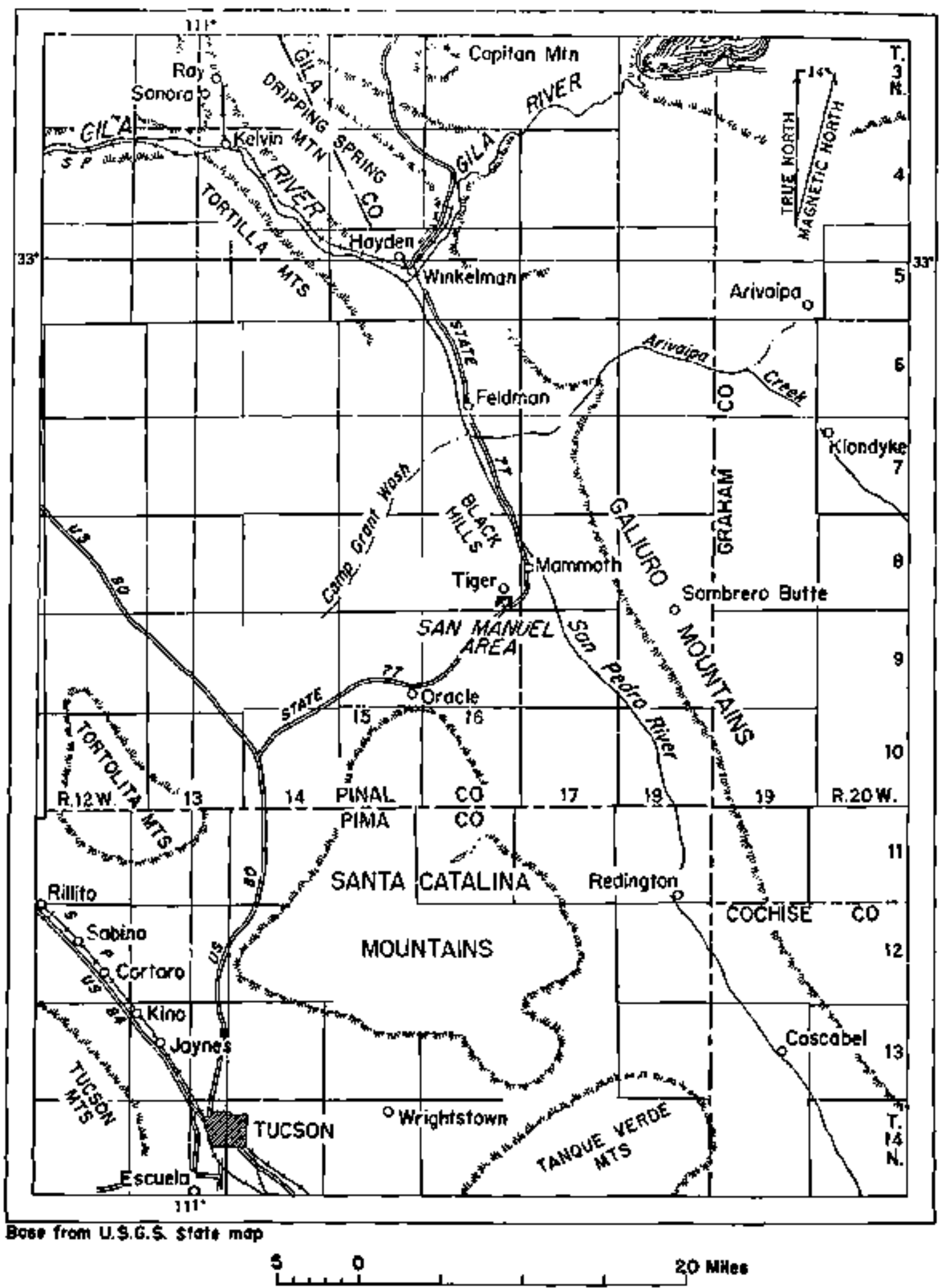

FIGURE 1. Sketch map showing principal towns and topographic features in the area surrounding the San Manuel district, Arizona (Schwartz, I953). 


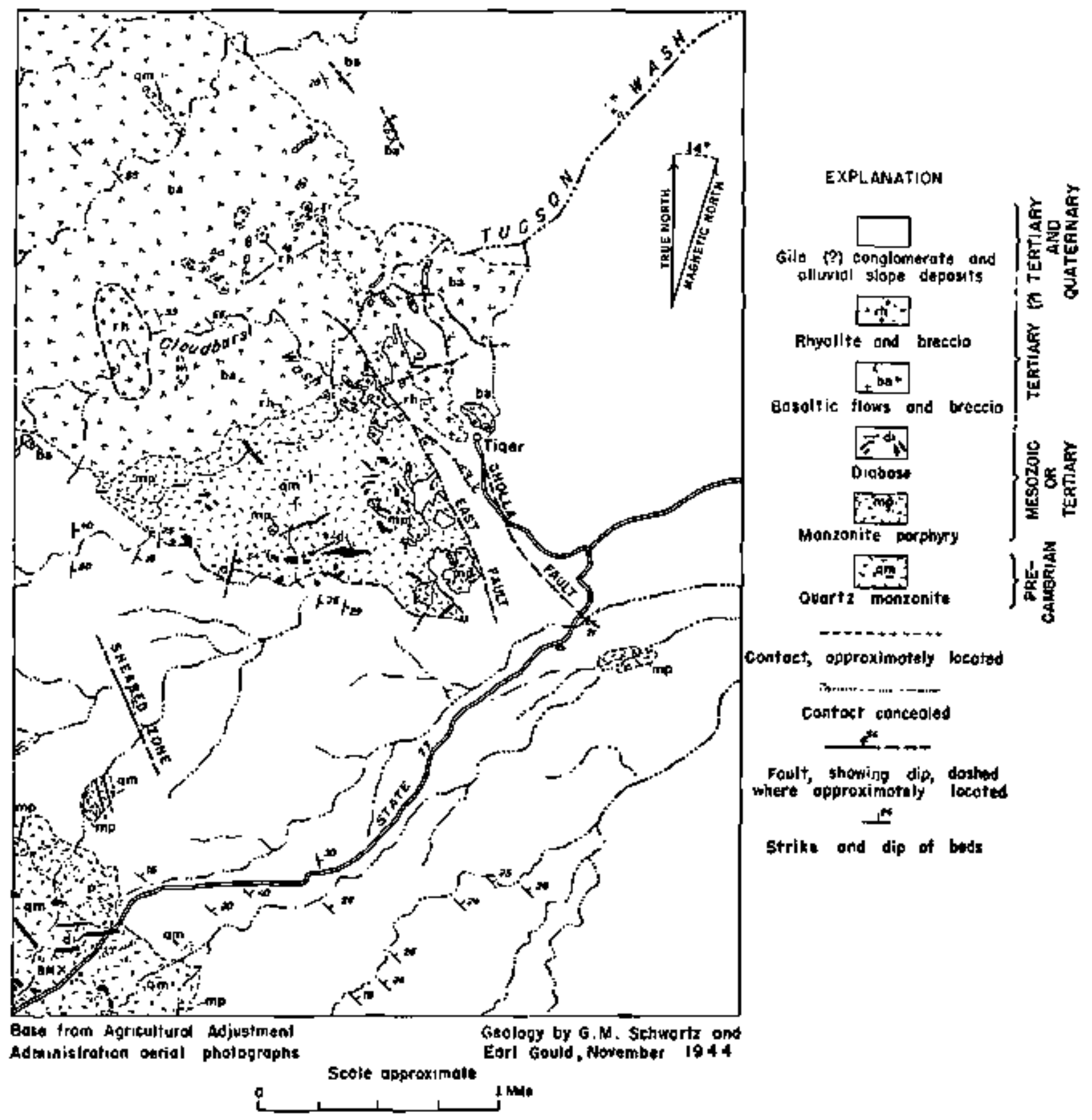

FIGURE 2. Geologic map of area around San Manuel and Tiger, Arizone (Schwartz, 1953). 
and the foliation of feldspars and mafics. The rock varies in composition from granodiorite to granite, and is deeply weathered.

The Oracle granite was intruded by monzonite porphyry or perhaps locally metasomatized during Laranide time. A complex relationship exists between the quartz monzonite and the monzonite porphyry. Recent investigations suggest that the monzonite porphyry comprises a dike and igneous mass swarm.

The sequence of episodes which followed the formation of the nonzonite porphyry consisted of: (1) intrusion of diabase dikes and irregular masses, which although altered and mineralized, appear to have acted as partial barriers to the movement of ore solutions; (2) a porphyry-type coppermolybdenum ore mineralization, assoctated with considerable alteration and centered on the monzonite intrusion; (3) post-ore Tertiary rhyolite, intruded in two main sheets; and (4) the deposition of the Gila conglomerate, late Tertiary and Quaternary, wich, with the exception of recent alluviun, is the youngest rock in the area, and is nomally unconformab1e to all the older rocks.

Figure 2 shows the geology of the region as described. Mine Area

The locations of the San Manuel/Kalamazoo ore bodies are shown in Figure 3. Data for this section were extracted from Lowell (1968, 1970), Kendorski (1976), Ridges (1972), and Thomas (1966).

Alluvial deposits lie unconformably on the Gila conglonerate. The Gila conglonerate is the most widely distributed surface rock type, and reaches thicknesses in excess of 1200 feet over the nine area. The extensively tilted and deformed conglomerate has a prevailing northwest strike, 


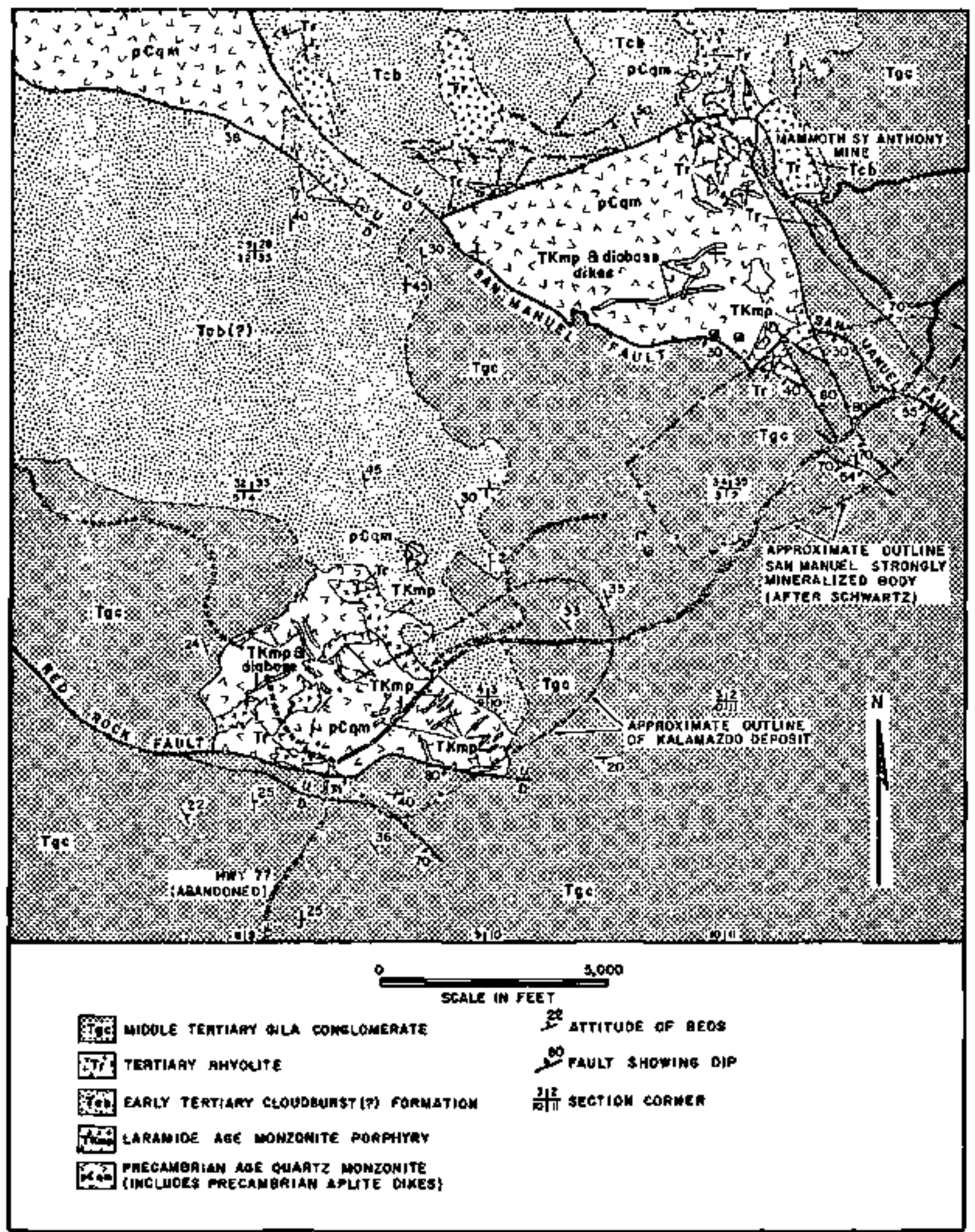

FIGURE 3. Geologic map of the San Manuel area (Lowell, 1968), 
with a dip of $25^{\circ}$ to $45^{\circ} \mathrm{NE}$. The quartz monzonite and monzonite porphyry are interrelated in such a complex manner that their detailed structural relationships are difficult to determine.

The conglomerate and underlying rocks are cut by many faults, only a small number of which have been accurately mapped. Of the recognized faults, the San Manuel fault, a normal fault, dipping $25^{\circ}$ to $30^{\circ} \mathrm{Sw}$ and bordering the southwest side of the exposed mineralized area, is the most significant. The San Manuel fault divided the original ore complex (which had previously experienced a tilt of approximately $70^{\circ}$ to the northeast) into two segments: the San Manue1 segment, and the Kalamazoo segment which is faulted sone 8000 feet down dip in the low angle normal fault. Figure 4 illustrates schematically the possible origin of the San Manuel/Kalamazoo ore bodies.

The original pre-faulting ore complex, based on a minimun 0.5 copper content, had the general shape of a flattened cylinder with an axial length in excess of 7700 feet and a diameter between $2500-5000$ feet. Mineralization and alteration for approximately coaxial cylindrical zones . Hydrothermal alteration is characteristic of most rocks in the mine area, with the exception of the Gila conglomerate and younger rocks. Based on the characteristic mineral assemblages, four types of alteration are recognized. A detailed discussion of prophyry alteration has been presented by Lowe1l (1970) .

Figures 5, 6, E 7, geologic maps of the 1,475 haulage level and' its respective cross-sections (NW-SE and SW-NE) in the San Manuel mine are characteristic of the general rock distribution/relationships found $i_{n}$ the San Manuel/Kal amazoo mines. The vast majority of tuderground workings are either in quartz monzonite or monzonite porphyry. 


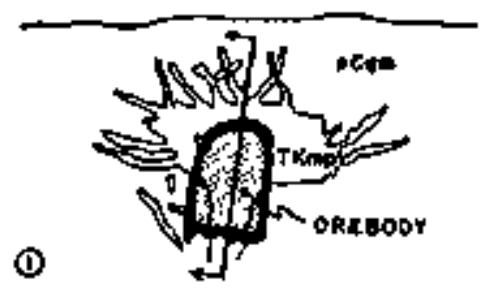

1. Prectanbrian quartz montonite (PCgm) was intrukded by a Laramizle age nunnzonite porphyty (TKmpl cilke sunats. A liollow cylindrical or plineshaped orcbody wilh dimensions of approximately $8,000 \times 3,500$ feet tyas formed. It was probabily rearly vertical and eentered on the thonsonite dike swarm (Section line show's position of Figure 7.)

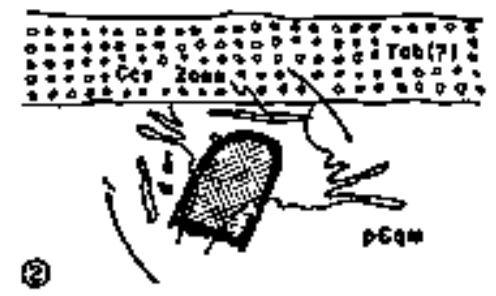

2. Tilling of the orebody was followed by trosion, then deposition of conglometate atri interbediled volcanics (Teb?), A thin clialcocite blarket (Ccs) has iorricd at the water table.

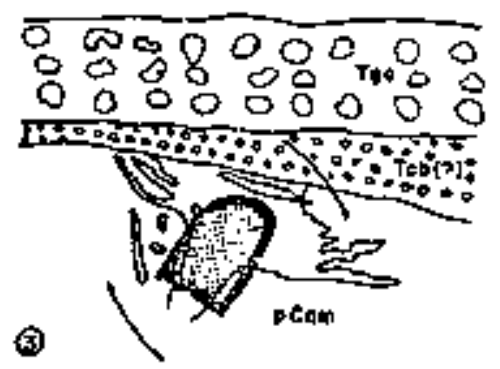

3. Continued tilline wat toltowed hy crosion of con-

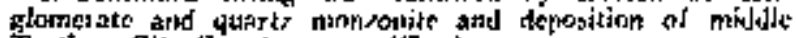
Tetliaty Gilh Conglodperate ( $T$ HC $)$.

FIGURE 4, Schematic drawings showing possible origin of Kalanazoo ore body (Lowel1, 1968).
○

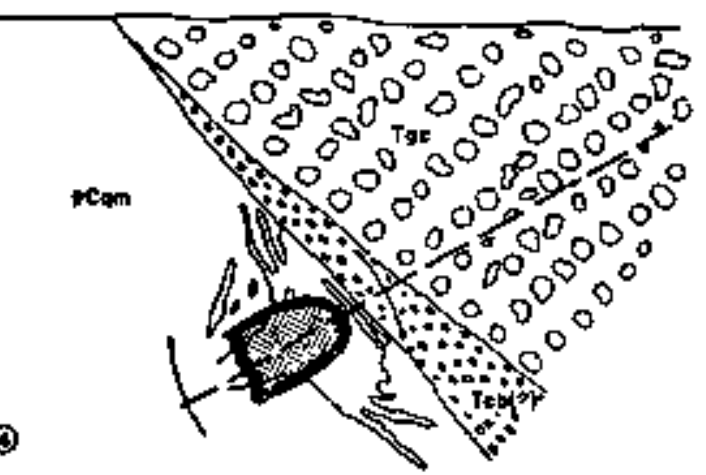

4. Orebody is nuw at a flat angle dus to continued tilting. An erotion surface is out on the tilted quartz monzonite and Gila Conglomerate. Incipient San Manuel fault is formed.

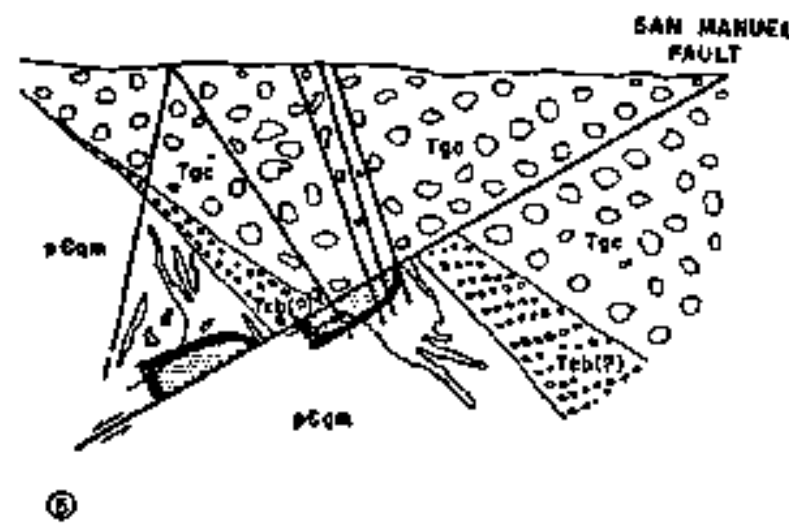

5. Upper partion af orebody is displaced approximately 8,D00 feet down the dip of the Sirl Kantul fault Some imitricale displacement tay hate octurled in the Kalamazoo segmenit.

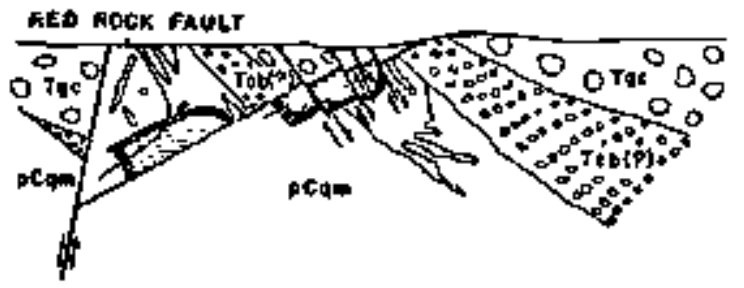

()

6 Ifiglorangle normal fantt displacements produced suball

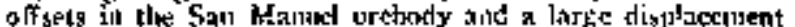
on the Red liock faull west of live Kalainizan orrebody. Frosicm exposed intrusive rocks and a corlltir of the Sall M1anual orchouly and prentuced oxidlation and limited chalco.

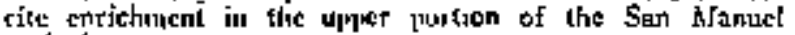
arehody. 

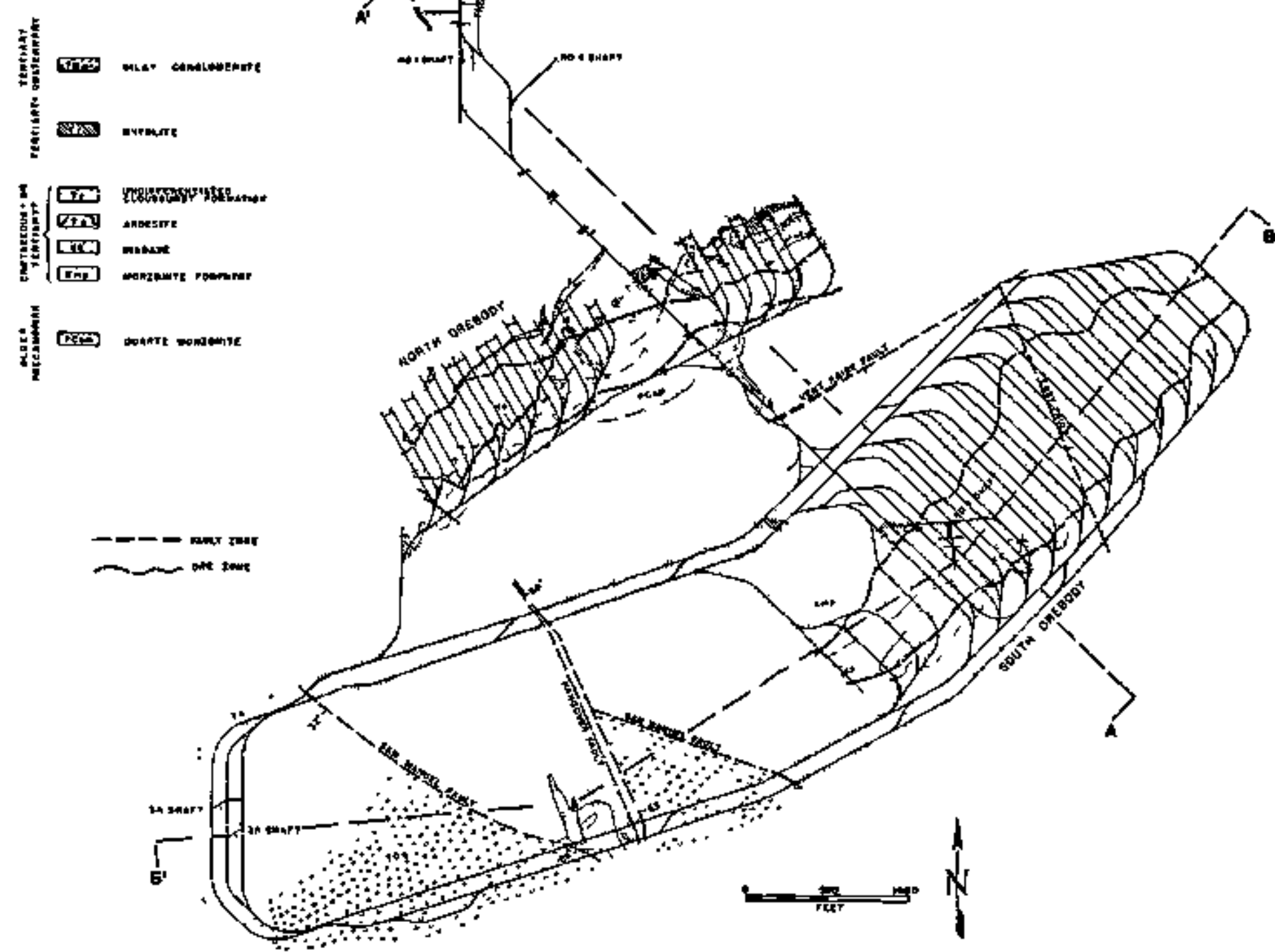

FIGURE 5. Geology of 1,475 haulage Leve1 (Thoras, 1966). By permission, L.A. Thomas, "Geology of the San Manuel Ore Body," in GEOLOGY OF THE" PORPHYRY COPPER DEPOSITS, Spencer T1tiey and Carol Hzcks, Editors, Tucson: Unuversity of Arszona Press, copyright 1966. 


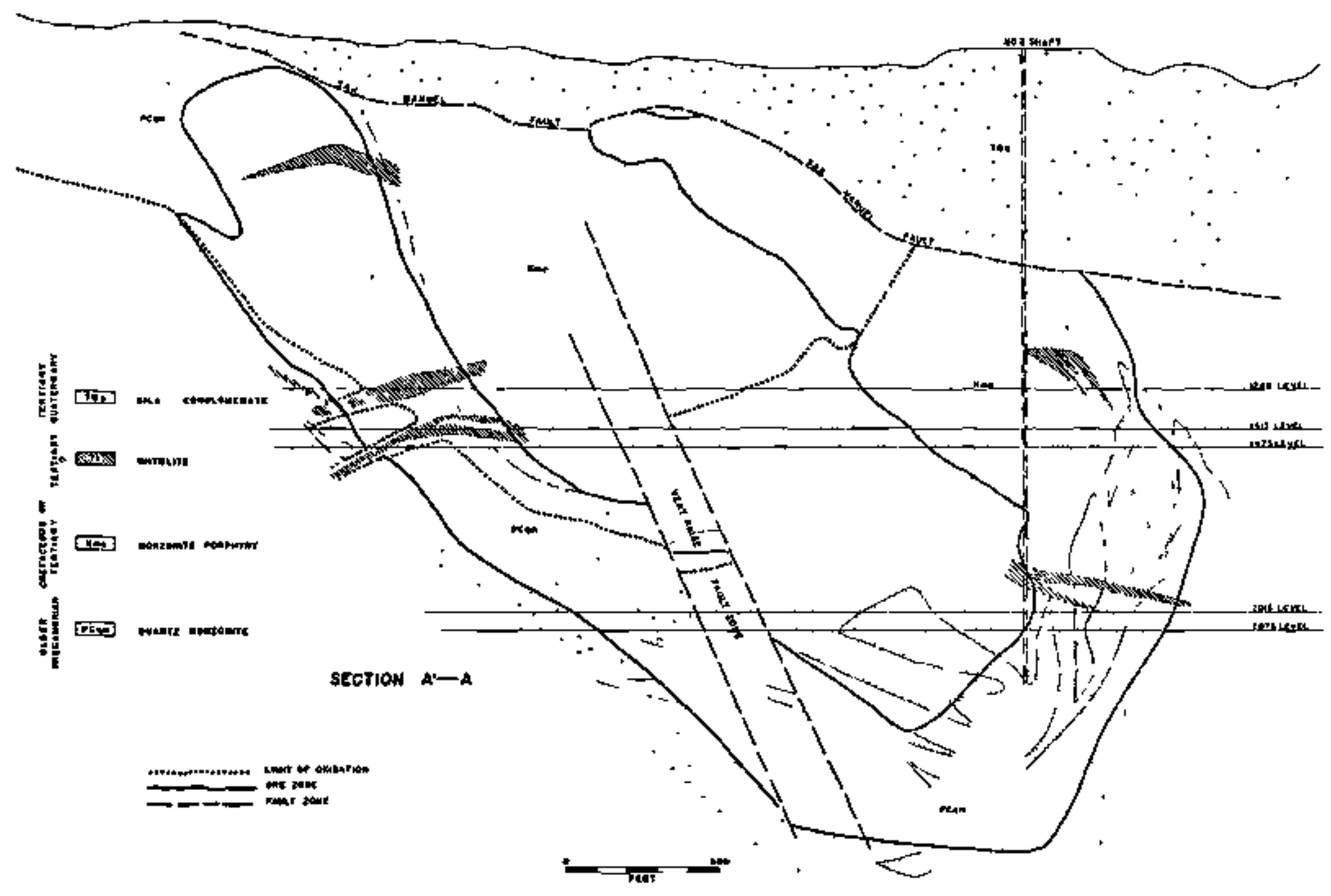

FIGURE 6. Idealized cross section looking northeast (Thonas, 1966).

By permis $\$ 10 n$, L.A. Thomas, "Geology of the San Manuel Ore Body,"

in GEOLOGY OF THE PORPHYRY COPPER DEPOSFTS, Spencer Titley and

Carol Hicks, Editors, Tucson: University of Arizona Press,

copyright 1966. 


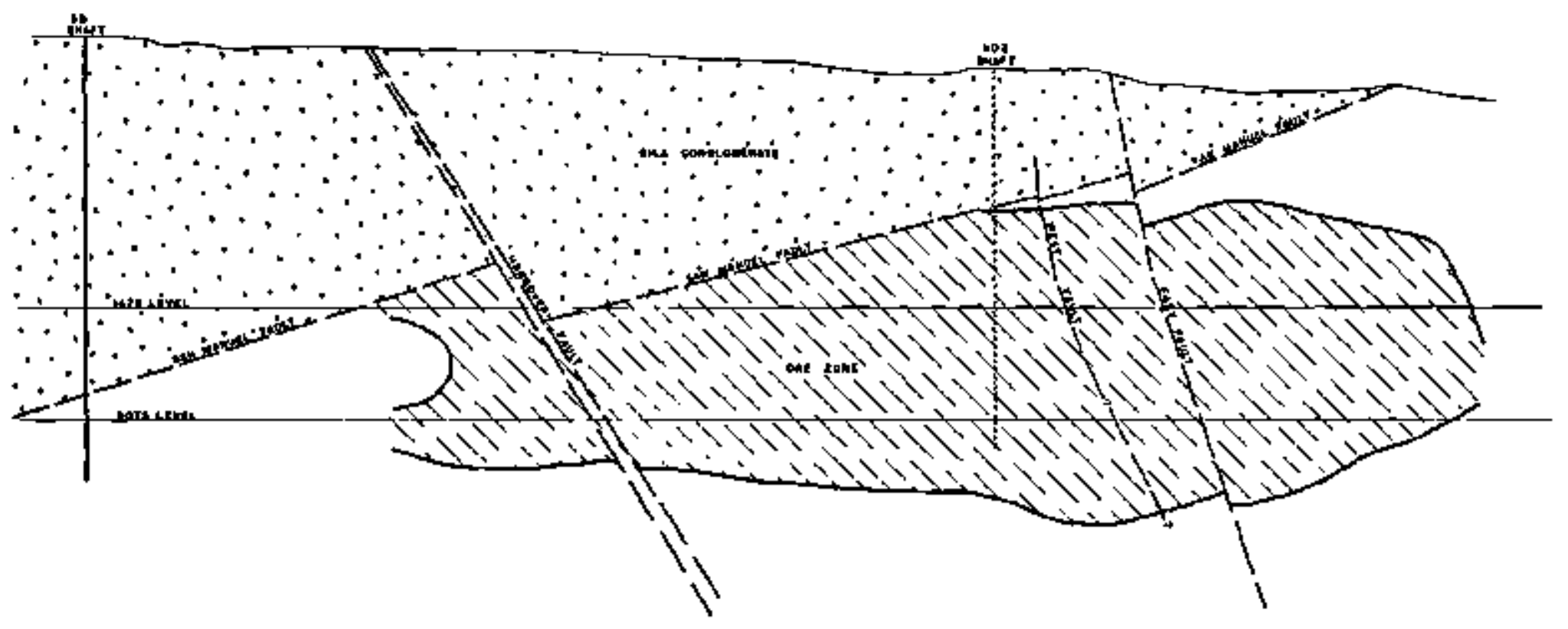

SECTION $\mathbf{E}^{+}-\mathrm{B}$

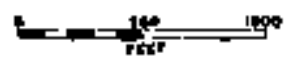

FIGURE 7. Idealized longitudinal section looking northwest (Thomas, 1966).

By permission, L. A. Thonas, "Geology of the San Manuel Ore Body, i"

in GEOLOGY OR THE PORPHYRY COPPER DEPOSITS, Spencer Titley and Carol

Hicks, Editors, Tucson: University of Arizona Press, copyright 1966. 


\section{Mine Facilities}

The data for this section were extracted from Hynd (1976), Jackson (1978), and Magna Copper Company. Hagma Copper Company, a wholly owned subsidiary of Newmont Mining Corporation, opened the San Manuel mine in 1956. Over 300 million tons of ore have been hoisted since the mine opened. Production currently runs at approximately $\$ 2,000$ tpd. Remaining ore reserves at San Hanuel are estinated to be in excess of 600 million tons. The present mining method is block caving.

Mining at San Manuel moved progressively down fron the 1,475 level to the $1,775,2,075$, and 2,375 levels. Development work is underway on the 2,675 level, whlch is scheduled for production in mid-1979.

A1l production at the mine has come from the San Manuel ore body; however, long-range development work is being done in the Kalamazoo ore body on the $2,950,3,440,3,530$ (pump station), and 3,740 levels. Since the start of production, 224 miles of horizontal workings, 152 miles of vertical workings, and 115 acres of undercut area have been driven or excavated.

Mine

The data for this section were extracted from Hynd (1976), Jackson (1978), and Magma Copper Company. At its current rate of production, San Manuel must complete 30,000-40,000 feet of developnent drifting ansually. Drifts outside the cave area are supported by square timber sets; H-beam caps with square timber posts; or by steel arc sets. Normal spacing of sets is 5 feet, but may vary with groumd conditions.

There are about $20 \mathrm{drill}$ junbos in the San Manuel mine, including a spare for each level. There are 73 drifters in the mine, of which 50 are typically in use at one time and 23 are spares. 
Ore stored in raises is transported to ore hoisting shafts by a trolley-operated railroad system. There are four hoisting shafts: 3A \& 3B (equipped with 6000 hp hoists) and 3C \& 3D (equipped with $7000 \mathrm{hp}$ hoists). Additional transportation factities at the mine include shafts: No. 1 (used for concrete supply, waste rock, and ventilation); No. 2 ssunk for exploration and quick development within the ore body proper, has been abandoned); No. 4 (used for ventilation and transportation of men and supplies), and No. 5 (service and development hoisting). The shafts range in depth from 2310 to 4123 feet.

Ventilation is supplied to the San Manuel mine at a rate of 1.2 million cfm of air. The ventilation department is designing a refrigeration system for the future, with a goal of maintaining a temperature of $80^{\circ} \mathrm{F}$.

A total of $6600 \mathrm{gpm}$ of water is pumped from the San Manuel mine, mainly froll the deep shafts. Increased flow is expected at the lower levels expecially in the Kalamazoo ore body. During early shaft development through the lower Kalamazoo horizon, water inflows reached 2300 gpm at a teraperature of $120^{\circ} \mathrm{F}$. Rack Mass Properties

The data for this section were extracted from an article by Kendorsi (1976). The fracture patterns mapped in the underground workings can be generalized as four sets: EW and NS, both vertical; $N 80^{\circ} \mathrm{E}$ to EW, vertical; and horizontal. Oriented compression and Brazilian tension tests on the quartz monzonite showed that the mappable fracture pattern is reflected in planar weaknesses in the rock. Tables 1 \& 2 sumarize the tests. 
TABLE 1. Summary of Quartz Monzonite Brazithan Test Data

\begin{tabular}{|c|c|c|c|c|c|c|}
\hline & \multicolumn{2}{|c|}{ Direction I } & Direction 2 & \multicolumn{2}{|c|}{ Direction 3} & $\begin{array}{l}\text { Owerall } \\
\text { Results }\end{array}$ \\
\hline Anisotropy planes & 030 & 105,165 & 045,150 & $\overline{060}$ & 105,165 & - \\
\hline Identiffcation & A & B C & $\mathbf{D} \quad \mathbf{E}$ & $\mathbf{F}$ & G $\mathbf{H}$ & - \\
\hline $\begin{array}{l}\text { Decrease in strength } \\
\text { from th percent }\end{array}$ & & 23,6 & 43,37 & & , 23,23 & 23 \\
\hline Density, $\mathrm{x}, \mathrm{g} / \mathrm{cm}^{\mathrm{s}}$ & & 2.65 & 2.65 & & 2.77 & \\
\hline $\begin{array}{l}\text { Tenvile strength, pst } \\
\text { x } \\
\text { s }\end{array}$ & & $\begin{array}{r}1474 \\
328\end{array}$ & $\begin{array}{r}1263 \\
224\end{array}$ & & $\begin{array}{r}1405 \\
335\end{array}$ & $\begin{array}{r}1389 \\
252\end{array}$ \\
\hline $\begin{array}{l}\text { Tosts in direction } \\
\text { breating along pre- } \\
\text { existing planes, } \\
\text { percent }\end{array}$ & & 63.9 & 44.4 & & 41.7 & 50.0 \\
\hline $\begin{array}{l}\text { Tegts in directions } \\
\text { that are highly altered } \\
\text { with rapged fajlure. } \\
\text { percent }\end{array}$ & & 16.7 & 16.7 & & 27.8 & 20.4 \\
\hline $\begin{array}{l}\text { Tests in direction } \\
\text { with a clean break }\end{array}$ & & 19.4 & 38.9 & & 30.6 & 29.6 \\
\hline
\end{tabular}

TAble 2. Quartz Monzonite Compression Test Summany

\begin{tabular}{|c|c|c|c|c|}
\hline & \multicolumn{4}{|c|}{ Direction } \\
\hline & 1 & 2 & 3 & $\begin{array}{l}\text { Overidl } \\
\text { Results }\end{array}$ \\
\hline Length (in.), $\mathrm{x}$ & 4.53 & 4.39 & 4.49 & 4.47 \\
\hline Density $\left(\mathrm{g} / \mathrm{cm}^{\mathrm{B}}\right), \overline{\mathrm{x}}$ & 2.65 & 2.62 & 2.74 & 2.67 \\
\hline $\begin{array}{l}\text { Unioxial compressive } \\
\text { strength (psi) } \\
\text { X } \\
\mathbf{S}\end{array}$ & $\begin{array}{r}11129 \\
3 \$ 514\end{array}$ & $\begin{array}{r}14700 \\
2050\end{array}$ & $\begin{array}{r}15300 \\
4600\end{array}$ & $\begin{array}{r}13500 \\
3900\end{array}$ \\
\hline $\begin{array}{l}\text { Modulus of elasticity } \\
\left.\text { (pei } \times 10^{5}\right) \\
t \\
\mathbf{s}\end{array}$ & $\begin{array}{l}6.9 \\
3.1\end{array}$ & $\begin{array}{l}7.0 \\
1.7\end{array}$ & $\begin{array}{l}8.4 \\
2.4\end{array}$ & $\begin{array}{l}7.4 \\
2.4\end{array}$ \\
\hline $\begin{array}{l}\text { Poisson's ratio } \\
\text { \& } \\
\mathbf{S}\end{array}$ & $\begin{array}{l}0.26 \\
0.14\end{array}$ & $\begin{array}{l}0.13 \\
0.07\end{array}$ & $\begin{array}{l}0.20 \\
0.12\end{array}$ & $\begin{array}{l}0.20 \\
0.12\end{array}$ \\
\hline $\begin{array}{l}\text { Tests in direction } \\
\text { failing slong weakness } \\
\text { planes, percent }\end{array}$ & 71 & 60 & 67 & 67 \\
\hline
\end{tabular}


REFERENCES

Buchanan, J.F., and Buchella, F.H., 1960, History and Developnent of the San Manuel Mine, AIME Trans., v. 217, pp. 394-41)2

COBBS Report

Creasey, \$.C., 1965, Geology of the San Manuel Area, Pinal County, Arizona, U.S. Geol, Survey Prof. Paper 471, 64p.

CRIB

Dunning, C.H., 1959, Rocks to Riches, Southwest Publishing Company, Phoenix, Arizona, pp. 233-239, 267-268.

Engineering and Mining Journal v. 179(1) p. 133-135.

v. $179(4)$ p. 142,144 .

v. $179(9)$ p. 314

Mines Directory 1978

Hynd, J.G.S., I.S. Clelland, and P.A. Gillett, 1976, The Construction of large Underground Excavations in Arizona Copper Mines, from Froceedings - 1976 Rapid Excavation and Tunneling Conference, las Veggs, Nevada, June 14-17, 1976, edited by R.J. Robbins and R.J. Conlon, AIME, pp. 570-590.

Jackson, D., 1978, Block Caving Keeps San Manuel Competitive with Neighboring Open-pit Copper Mines, Eng. Min. J. v. 179(6) p. 127-136.

Kendorski, F.S., and M.A. Mahtab, 1976, Fracture Patterns and Anisotropy of San Manuel Quartz Monzonite, Bulletin of the Association of Engineering Geologists, v, 13(1), pp, 23-52.

Knoerr, A.W., 1956, San Manuel--Anerica's Newest Large Copper Producer, Eng. Min, J. v. $157(4)$, pp. 75-100.

Lowell, J.D., and J.M. Guilbert, 1970, Lateral and Vertical AlterationMineralization Zoning in Porphyry Ore Deposits, Economic Geology, v. $65(4)$, pp. 373-408.

Lowell, J.D., 1968, Geology of the Kalamazoo Ore Body, San Manuel District, Arizona, Economic Geology, v. 63(6) p. 645-654.

Magna Copper Company, no date (eurrent), Detailed Description of San Manuel Mining Operation, 32p.

MAS

Ridge, J.0., 1972, Annotated Bibliographles of Mlneral Deposits in the Western Hemisphere, Geological Society of Americg, Memoir 131, pp. 250-252. 
REFERENCES (cont'd)

Schwartz, G.M., 1953, Geology of the San Manuel Copper District, Arizona, U.S. Geo1. Survey Prof. Paper 256, 63p.

Thomas, L.A., 1966, Geology of the San Manue1 Ore Body, in Geology of the Porphyry Copper Deposits - Southwestern North America, edited by S.R. Titley and C.l. Hicks, University of Arizona Press, Tucson, Arizona, pp. $133-142$. 

PINE CREEK MINE

(OPERATED BY UNION CARBIDE CORPORATION)

\section{LOCATION AND ACCESSIBILITY}

The Pine Creek mine is 1ocated at $37^{\circ} 22^{+} \mathrm{N}, 118^{\circ} 43^{\prime} \mathrm{W}$, in the Bishop District on the easterr escarpment of the Sierra Nevada west of the town of Bishop. California. Figure 1 illustrates the location of Bishop, approximately midway between Reno, Nevada and Los Angeles, Califormia. Outcrop relief exceeds 6000 feet; from an elevation of about 7400 feet on the floor of Pine Creek Canyon to a high point of 13,652 feet on the sumkit of $\mathrm{kt}$. Tom. Despite the high elevation, the mine is accessible year round by paved road from Bishop.

\section{GEOLOGIC SETTING}

\section{Regional}

Dat a for this section were extracted from Gray (1968), and Batenan $(1965)$.

The Pine Creek pendant, which contains the Pine Creek mine, is a lens of metanorphic rock nearly 7 miles long and as much as one mile wide. As shown in Figure 2, the pendant extends from the northeast face of the Basin Mountains northward across Horton Creek, Ht. Tom, and Pine Creek, to the south end of Wheeler Crest.

Figure 2 and Table 1 sumunarize the age relationships of the various. formations in the area. The pre-Tertiary rocks consist of a series of metan sedimentary and metavolcanic rock remnants enclosed by plutonic rocks of various compositions ranging from hornblende gabbro to alaskite. The 


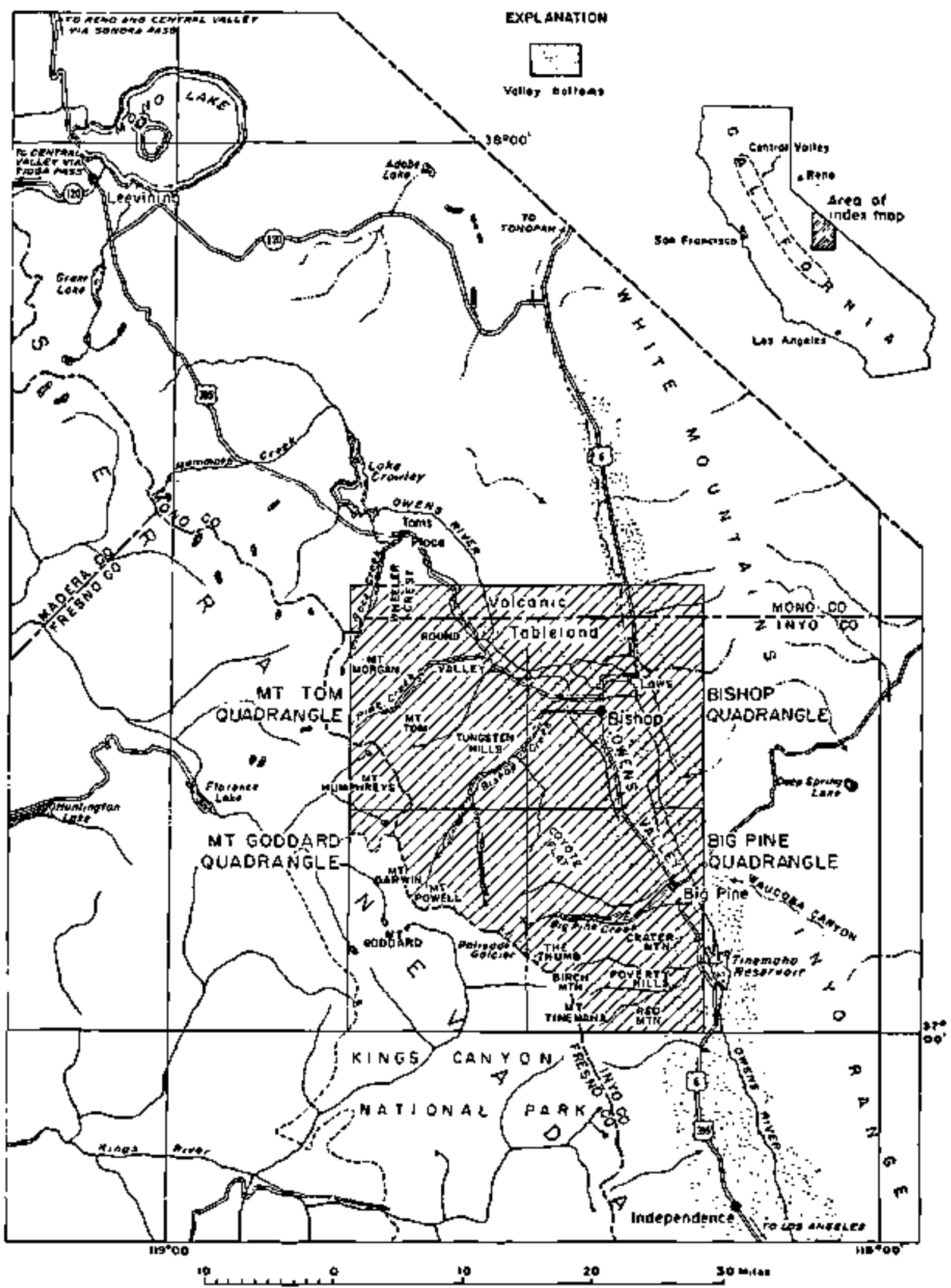

FIGURE 1. Location map of the Bishop, California area, from Bateman (1965). 


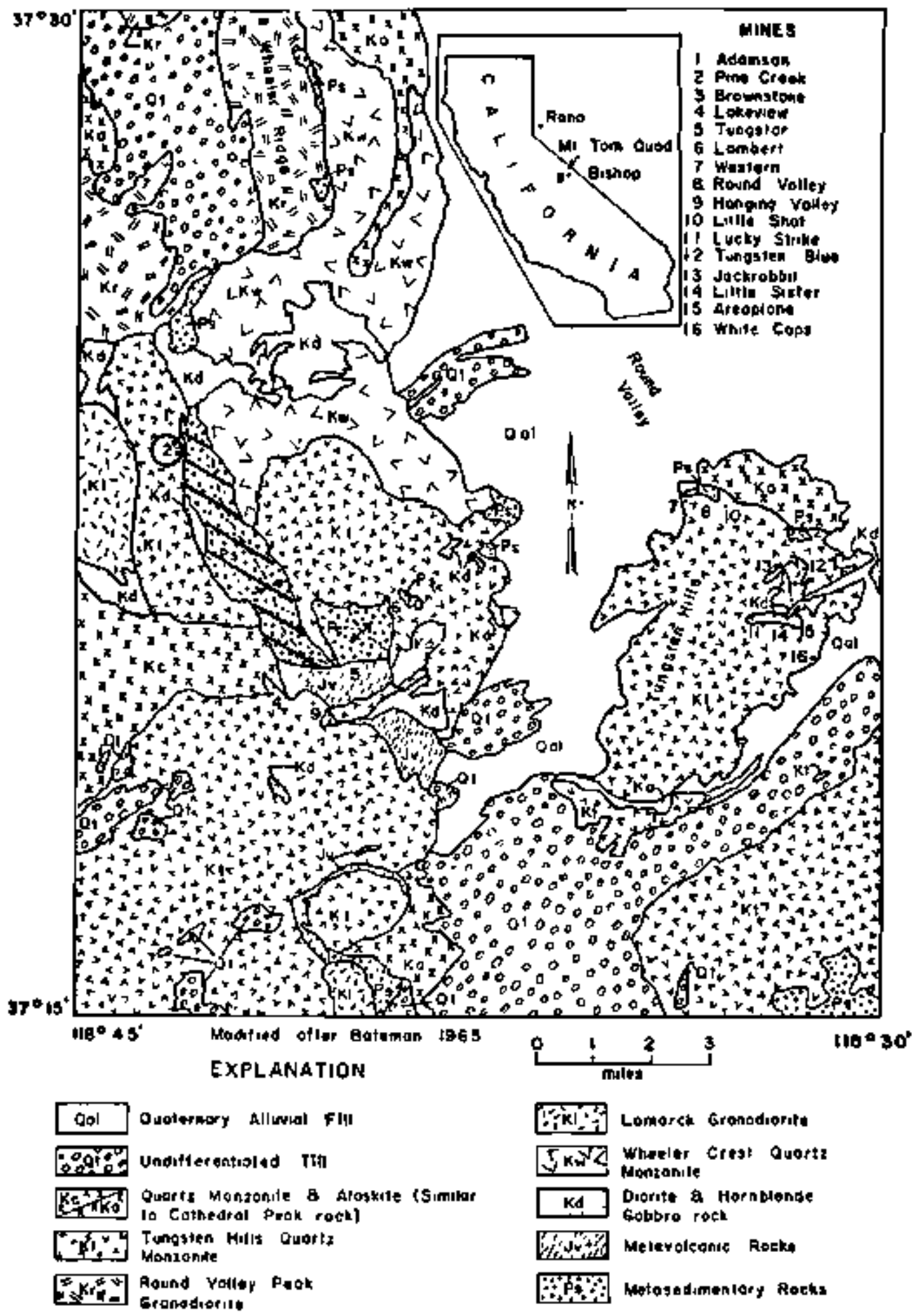

FIGURE 2. Geology of the Mount Tom Quadrangle, from Gray (1963). 
TABLE 1.

\section{Geologic Column}

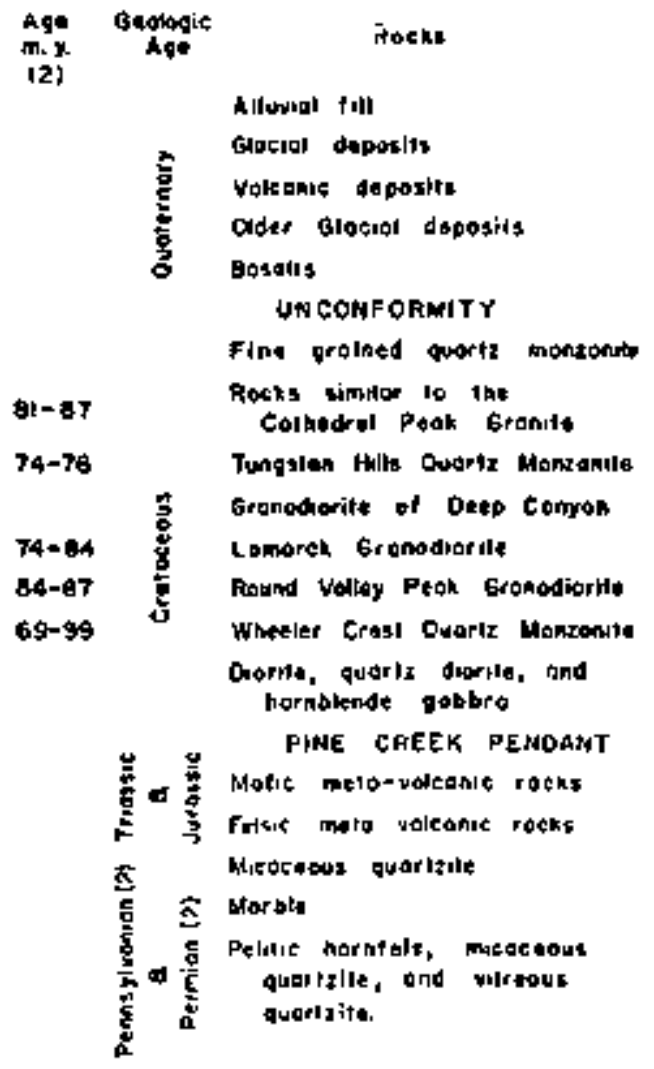

(from Gray, 1968) 
metasedimentary rocks (micaceous quartzite, pelitic hornfels, metachert, narble, calc-hornfels, etc.) consist of low- to intermediate-grade metanorphic equivalents of fine-grained sediments deposited during the Paleozoic era in a miogeosynclinal environment. The metavolcanics are Mesozoic in age, and were deposited in a eugeosynciinal environment, and consist of both felsic and mafic types. Strong folding followed the deposition of sediments and volcanics. During or after this time, magwa intruded the folded formations.

The metasedimentary rocks are distributed in a northwest-southeast pattern east of the metavolcanics. The metavolcanics are believed to be stratigraphically higher than the metasediments based on their occurrence along the east limb of a major Paleozolc syncline. Strontiun isotope ratios in the granitic rocks suggest that the magna was generated by melting sediments mixed with volcanics.

The intrusive rocks in the region are considered to be of Mesozoic age. The oldest intrusives are hornblende gabbros and quartz diorites. These were followed successively by intrusions of the Wheeler Crest Quartz Monzonite, the Lamarck Granodiorite, the Round Valley Granodiorite, the Tungsten Hills Quartz Monzonite, and alaskite dikes. The Tungsten Hills Quartz Monzonite is a light gray, medium-grained rock, prophyritic with phenocrysts of potassic feldspar. The rock is usually honogeneous, and little foliation is evident. The theeler Crest Quartz Monzonite is porphyritic with euhedral phenocrysts in a mediungrained groundmass. The Lamarck Granodiorite consists of quartz, orthoclase, and plagioclase, and ranges in composition fron granodiorite to quartz monzonite. Planar foliation is well developed near the margins of the lamarck, and is weaker toward the center. The Round Valley Peak Granodiorite has a composition similar to the Lamarek Granodiorite, but has a finer texture.

The contacts between intrusives are usally sharp and well-defimed. Metasedimentary and metavolcanlc rocks show little change as the granitic 
contact is approached. The tactites which contain the Pine Creek ore bodies are a product of material exchange along thin boundaries between marble and granitic tolts.

MINE AREA

Data for this section were extracted from Gray (1968) and Bateran (1956, 1965) .

Figure 3 illustrates the surface geology of the nine and vicinity. The Pine Creek ore bodies outcrop along the east wall of a cirque at the head of Morgan Creek, a southward flowing tributary of Pine Creek. The deposits lie along a 3000 foot segkent of the contact between quartz monzonite and the marble that flanks the west stde of the north part of the Pine Creek pendant. The Pine Creek mine is comprised of six deposits as shown in the cutaway diagram in Figure 4. From north to south they are: the Loop ore body, the North ore body, the Pinnacle ore body, the Main ore body, the South ore body, and the Bend ore body. Typically, the larger deposits have average dimensions on the order of 75 feet in width, 500 feet in length, and 2000 feet in vertical extent.

The lithology and structure of the northern two-thirds of the Pine Creek pendant, of wich the Pine Creek mine is part, are relatively simple. The mine area is near the north end of the pendant and on the west side of the marble, along a span where the outcrops of marble are narrowest. The width of the marble varies from 200 feet at the north end of the property to. 1000 feet at the south end. Tactite is present along most of the 3000 foot extent of contact in the mine area; however, the thicker masses of tactite which contain the ore badies compose about 1000 feet of the contact. Along the remaining 2000 feet of contact the tactite is either too thin or too low grade 


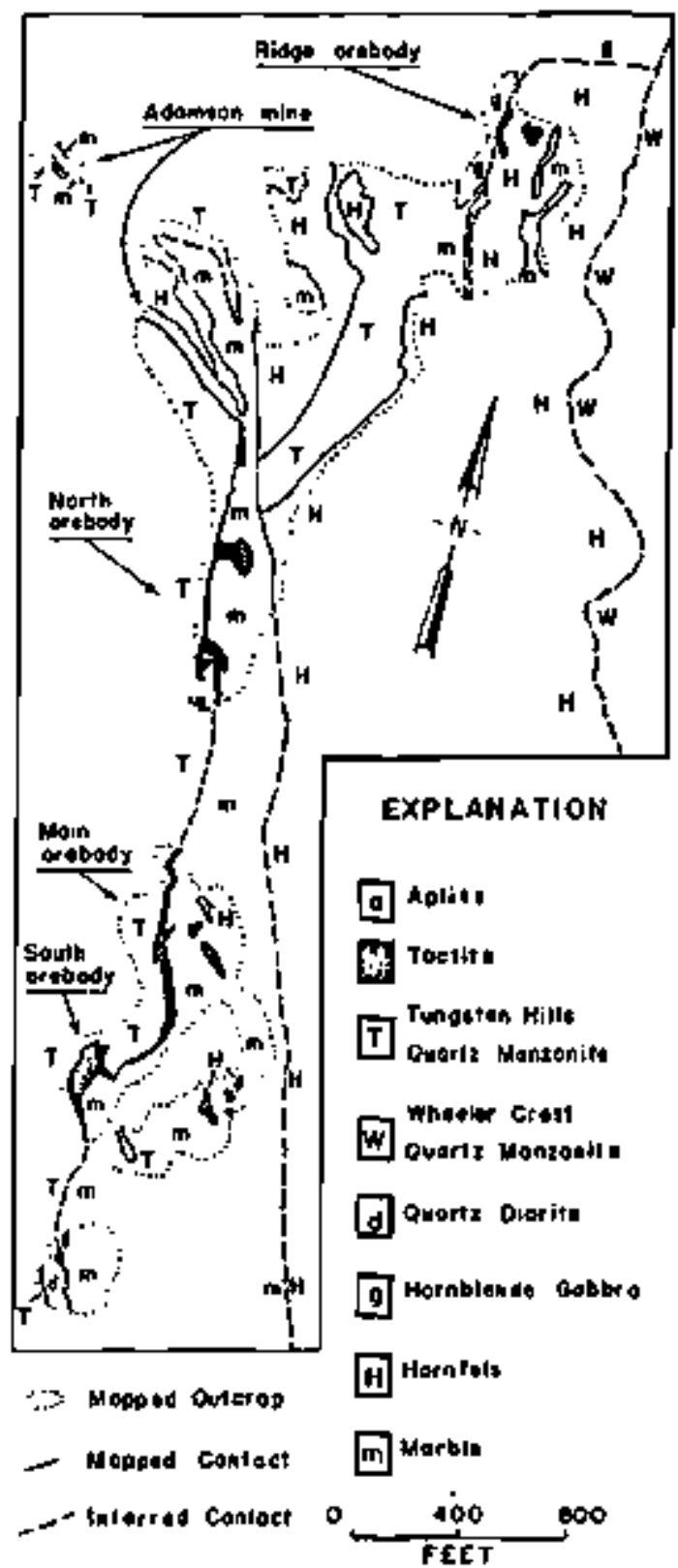

FIGURE 3. Surface Cieology of Pine Creck Mine and vicinity, from Gray (1968). 
to be exploited. Of the six ore bodies that make up the Pine Creek mine, only the Pinnacle ore body is totally enclosed in marble, while the others are in the margins of the marble adjacent to the Tungsten Hill Quartz Monzonite. The trace of the intruslve contact with the marble is quite distinct and generally very steep or vertical.

The primary ore control is the contact between the marble and Tungsten Hills Quartz Monzonite, where ore traps formed In irregularities in the granitic contact. The geometry of ore body extensions in the marble is frequently influenced by the original bedding.

Pre-ore faulting has not been an important element in the mineralization of the tactites. Underground post-mineral fractures are comononly parallel with a regional system of near-vertical joints developed in the quartz monzonite. The displacement on the majority of fractures is less than one foot, with occasional displacement of as much as 40 feet.

\section{MINE FACILITIES}

Data for this section were extracted from Bateman (1956, 1965) and Gray (1967) .

The Pine Creek mine was discovered in 1916, and has been operated by Unton Carbide Corporation since 1935. As of 1973, the mine had a production capacity of approximately 325,000 tons of ore per year containing about 6 million pounds of recoverable tungsten.

The mine is entered through adits and is developed by means of raises, levels, and sublevels. Figure 4 illustrates the mine workings and rock types as they existed in 1965. The main adits are level $C$, level $A$, the zero adit, and the Easy-going adit, at elevations of 11,215; 10,940;9430; and 8100 feet, respectively. Levels $A$ and $C$ intersect the Main, South, and North ore bodies, 


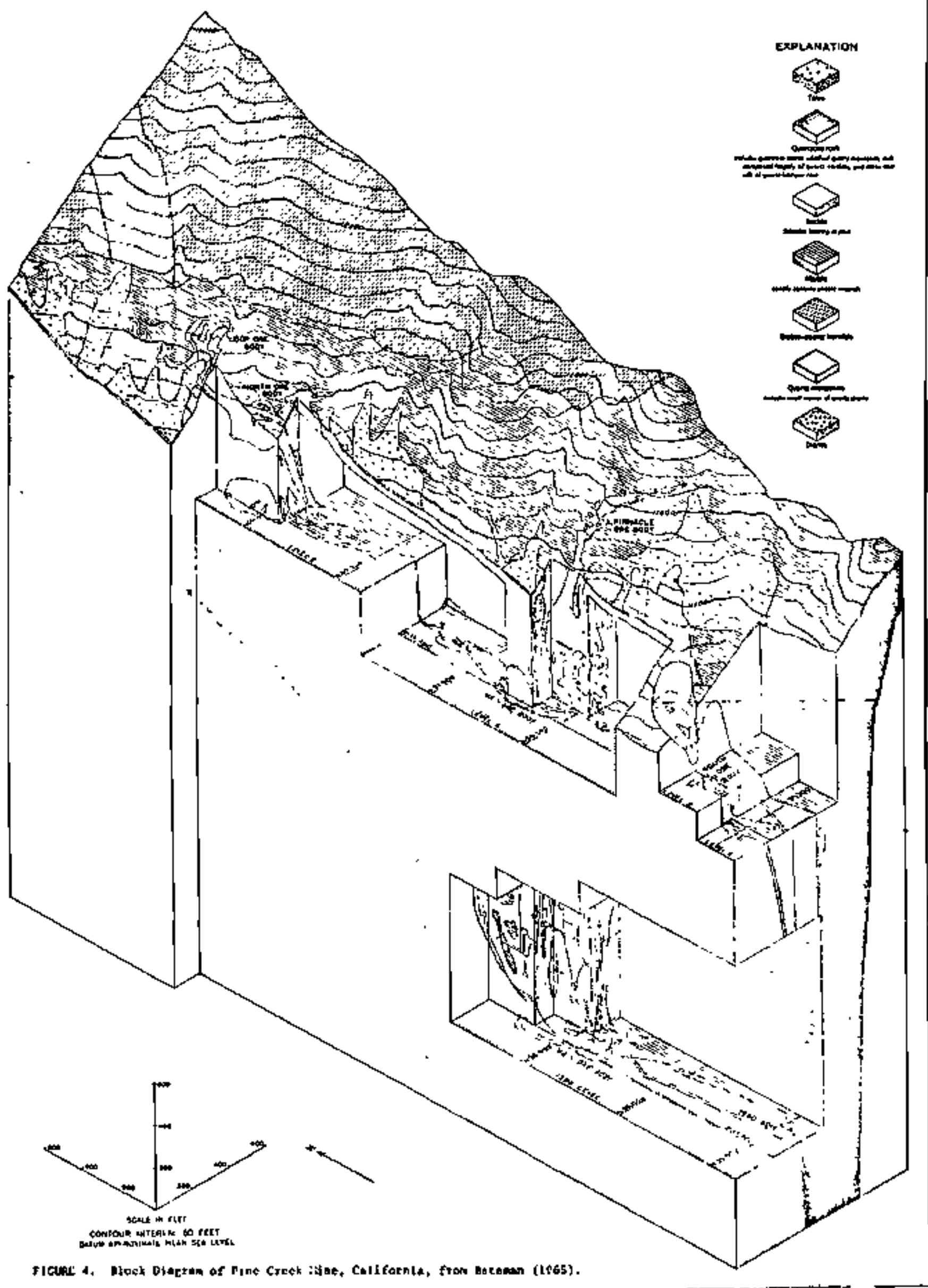


the zero adit intersects only the Main ore body, and the Easy-going adit is located about 1300 feet below the bottom of the present ore body.

The mine consists of two parts: (1) the part above level A ("old mine"), and (2) the deeper part between level $A$ and the zero adit. The "old mine" has been considered to be worked-out; however, higher tungsten prices may cause the reopening of the portion of the mine above level $\mathrm{A}$.

The available literature does not indicate which of the ore bodies are currently being mined, however, it is very probable that at least 3 of the ore bodies are dormant. As indicated on Figure 4 and based on the available cross-sections from Bateman (1965), there are substantial workings in the quartz monzonite. 


\section{REFERENCES}

Bateman, P.C., 1956, Economic Geology of the Bishop Tungsten District, California: California Division of Mines and Geology, Special Report $47,87 \mathrm{pp}$.

_.., 1965, Geology and Tungsten Mineralization of the Bishop District, California: U.S. Geol. Survey Prof. Paper 470, $208 \mathrm{pp}$.

Gray, R,F,, and others, 1968, Bishop Tungsten District, California: in Ore Deposits of the United States, 1933-1967, Ridge, J.D., ed., AIMF, p. 1531-1554.

MAS

Ridge, J.D., ed., 1972, Annotated Bibliographies of Mineral Deposits in the Western Henisphere, Geol. Soc. Amer. Menl. 131, Boulder, Co1o. p. 264-266. 



\section{CLIMAX MINE}

COPERATED BY CLIMAX MOLYBDENUM COMPANY, A SUBSIDIARY OF AMERICAN METAL CLIMAX, INC.)

LOCATION AND ACCESSIBILITY

The Climax depasit is situated just above Fremont Pass on the west slope of the Ten Mile Range, about 12 miles northeast of Leadville and about 65 miles WSW of Denver, Colorado, at $39^{\circ} 22^{\circ} \mathrm{N}, 106^{\circ} 10^{\prime} \mathrm{W}$ (Figure 1 ). The elevation of the mine area is approximately 11,500 feet with 3500 feet of local relief. Excellent all-weather roads connect climax with Leadville and Denver.

\section{GEOLOSIC SETTING}

Data for this section were extracted from ANAX (1974+), Vanderwilt (1955), and Wallace (1958).

As shown in Figure 2, Precanbrian erystalline rocks constitute most of the Ten Mile Range for several miles to the north, east, and south of Climax.

The Ртеcambrian biotite-quartz-feldspar schíst and gneisses of the Idaho Springs Formation are the oldest rocks in the region. Localiy these rocks have been metasomatized to granite, and reinjected along with scattered mafic dikes. Later in the Precambrian, the Silver Plume Granite intruded the Idaho Springs Forwation, in three closely related pulses.

During the Paleozoic Era approximately 5000 feet of sediments (Jimestone, sandstone, and conglomerate) were deposited. These sediments were metamorphosed to quartzites and dolomites. 


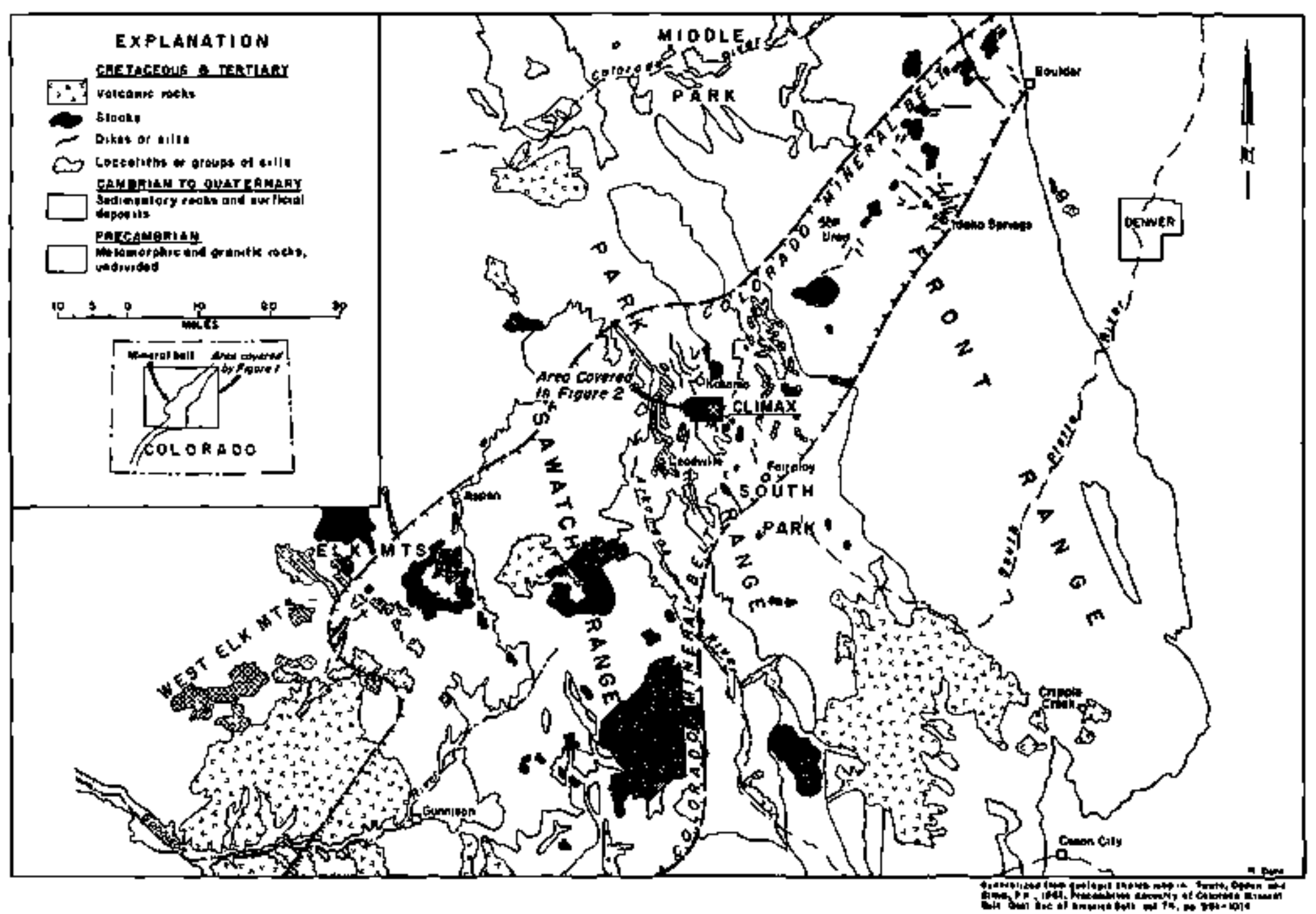

IIGURE 1. Re1ationship of C1imax to the Colorado Mineral Belt (Wallace, 1963). 


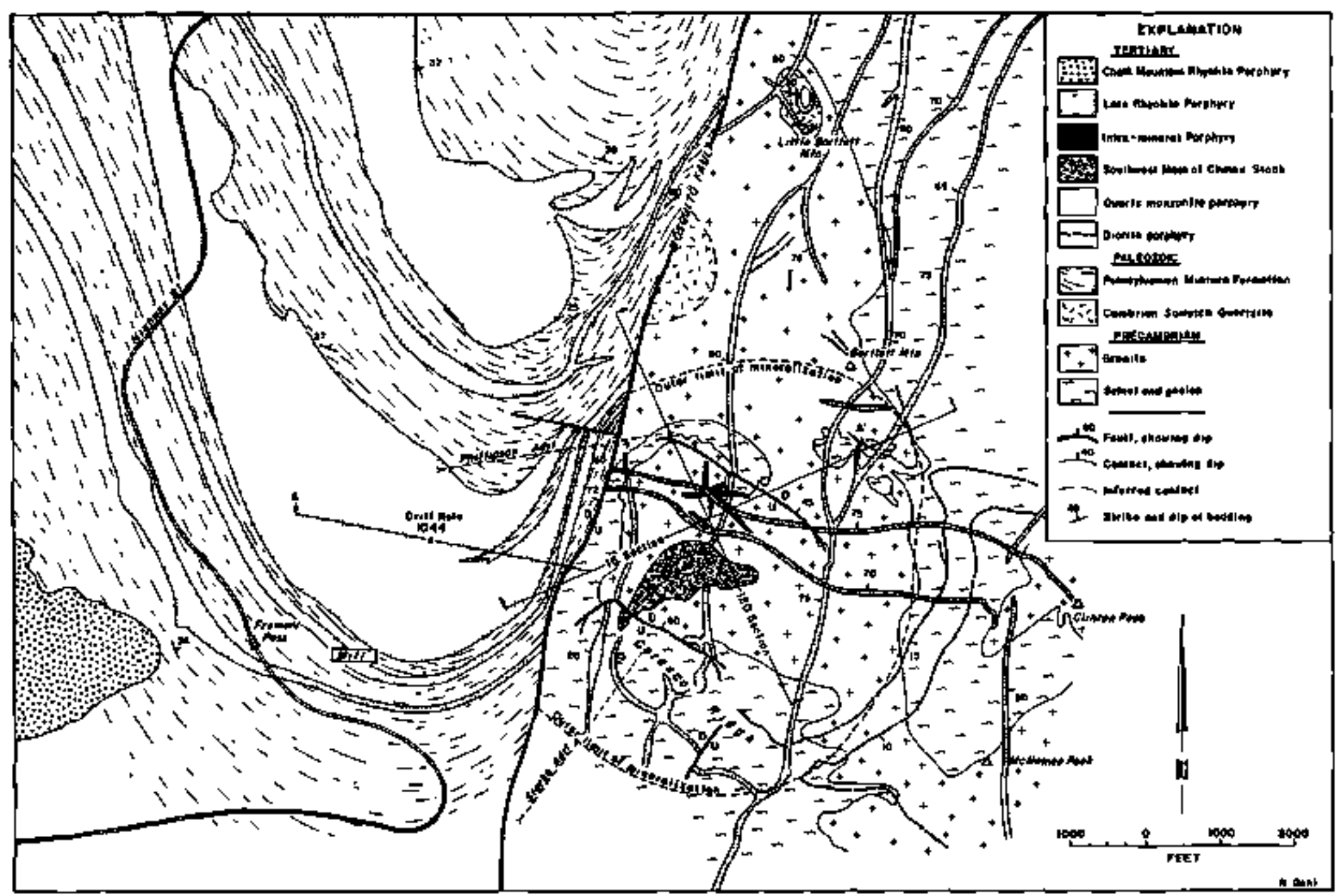

FIGURE 2. Generalized bedrock geology of the Climax area (Hallace, 1968). 
Mesozoic sedinentary rocks are exposed to the north and east of C1inax. There are no Mesozoic sedinents, or their equivalents, preserved in the nine area.

Tertiary dikes and stocks intruded the Precambrian crystalline rocks, and Tertiary sills and dikes cut the Paleozoic sediments. The intrusive bodies range in composition fron quartz nonzonite to diorite. Porphyry dikes are a comnon feature of the crystalline rocks north of Leadville. The porphyry dłkes represent the last phase of igneous activity in the region.

MINE AREA

Data for this section were extracted from AMAX (1974), Vanderwilt (1955), and Wallace (1968).

During the Tertiary Period three granitic stocks intruded the Climax area. The stocks were sinilar in composition and in close proxinity, but were not contemporaneous. Each stock created a molybdenum/tumgsten ore body, and was characterized by intense alteration.

The Southwest Mass of the Climax Porphyry was the first stock in the series. The intrusion caused fracturing in the adjacent country rock, which provided channels for ore-forming hydrothermal flutds. The Ceresco nolybdentm ore body was formed in the shape of an inverted bowl, approximately 3,500 $\mathrm{ft}$. in dianeter above the Southwest Mass, as shown in pigure 3a. Silicification occurred beneath the ore body, replacing the existing rocks with nearly pure quartz.

The area east of the Southwest Mass was intruded next by the Central Hass of the Clinax Porphyry. As in the previous intrusion, fracturing, upward thigration of hydrothernal fluids, and silicification were repeated, and the Upper ore body was created. The ore body located above the central 


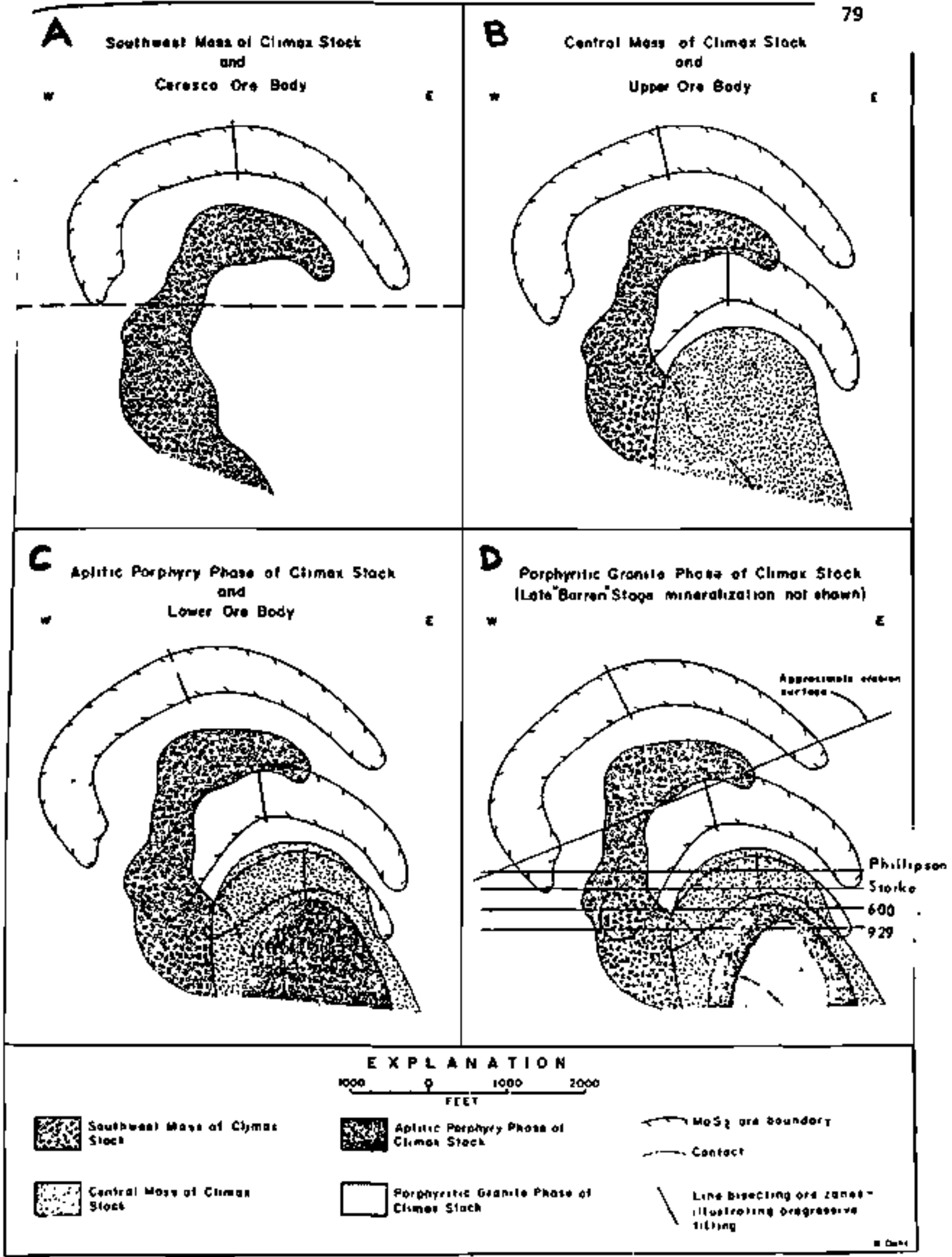

FIGURE 3. Diagrammatic sections showing multiple intrusions and minoralization, and progressive tilting (Anax, 1974t). 
Mass as shown in Figure $3 b$ is of similar shape but smaller than the Ceresco ore bady.

The Aplitic Phase of the Climax Porphyry was the last ore-related intrusion. It is located slightly east of the Central Mass, and experienced the sane series of mineralizing events. The resulting Lower ore body (and Lower ore body high-silica zone), the smallest of the three, is similar in shape to the others, and is located above the Aplitic Phase, as shown in Figure $3 \mathrm{c}$.

A fourth igneous stock, the Porphyritic Granite Stock, was intruded into the Aplitic Phase of the Climax Porphyry, as shown in Figure 3d. This non-ore bearing stock has associated with it several large dikes and numerous small dikes, which cut part of the ore bodies.

The emplacenent of igneous stocks was followed by intense faulting and fracturing. Major movements occurred along the Mosquito, South, and East Faults, showm on Figures 2 and 7 . The Mosquito Fault is a major structural feature of Central Colorado. Movement along the Bosquito Fault had a profound effect on the Climax mine. Approximately 9000 feet of vertical displacenent (west block down with respect to east block) has been recorded. The upward displaced east block, which contains the ore bodies, was subject to erosion and glaciation, which resulted in the destruction of most of the Ceresco ore body and the top of the Ipper ore body. The approxinate erosion surface is shown in Figure $3 \mathrm{~d}$ and 4.

\section{MINE FACILITIES}

Data for this section were extracted fron AMAX (1974+) and Vanderwilt (1955). American Hetal Clinax, Inc., the owner/operator of the Climax mine, was formed by a merger of Climax Molybdenum Company and Anertcan Metal Company, Ltd. , in 1957. Prior to 1957, Climax Nolybdenun Company operated the nine for 


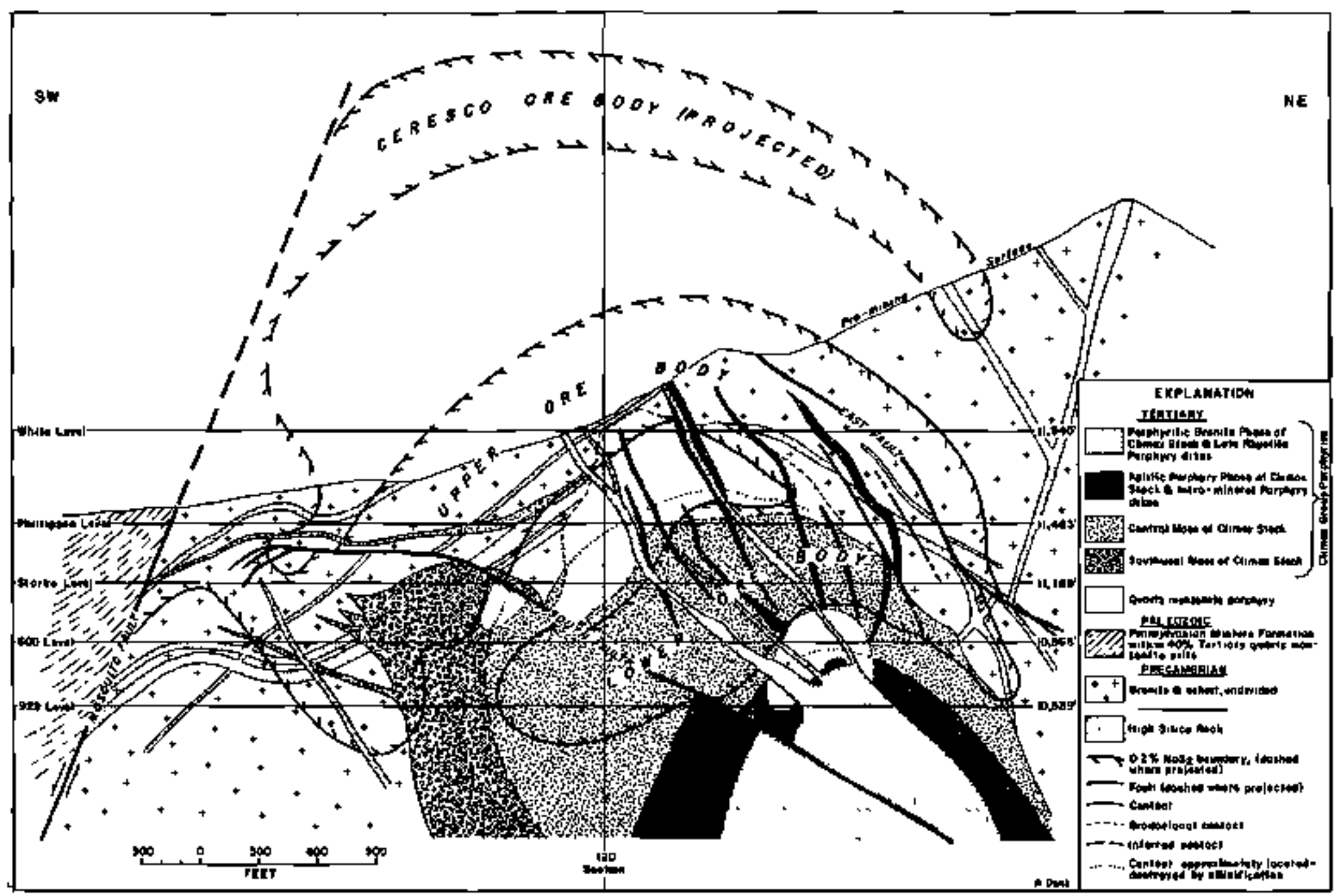

FIGURE 4. Cross section, showing generalized geology and ore zones (Wallace, 1968). 
about 40 years. The mine/plant enploys approximately 2500 workers. The mine operates three shifts per day, seven days per week, averaging 354 working days per year. The present rate of production is between 37,000 and 48,000 tons per day, depending on narket demands and plant efficiencies. As of 1972, the ore reserves at climax were estinated to be in excess of 450 nillion tons, of which $64 \%$ will be recovered by block caving.

Mining began at $\mathrm{Cl}$ inax in the Upper and white levels which were abardoned in the 1930's when production shifted to the Phillipson level. In the early 1950's a najor new production level, the Storke Leve1, was opened. The Storice Level now produces more than half the current daily production. Development of the Ceresco and lower levels was begm in the 1960's. In 1972 production started fron the new 600 level. In 1973 the first open-pit production began. The Phillipson and Ceresco leve1s were abandoned in 1974. The current production and abandoned levels are illustrated in a cut away view of the mines in Figure 5 , and individual production levels'are shown in Figure 6 .

A substantial amount of the mine workings must traverse igneous intrusive and netamorphic rocks, as shown in Figure 7, a geological plan view of the abandoned Phillipson Level.

The block caving nining method at the Climax mine is very efficient. The current operations are serviced by three shafts: No. 4 shaft, service and hoisting, $19 \mathrm{ft}$. diameter, $754 \mathrm{ft}$. deep, the shaft is enclosed underground and services the 600 and lower levels fron the Storke leve1; No, 5 shaft, service, $23 \mathrm{ft}$. diameter, $670 \mathrm{ft}$. deep; and No. 7 Shaft, ventilation, $29 \mathrm{ft}$. diameter, $370 \mathrm{ft}$. deep, services Storke and lower levels. Adis service the Phillipson and Storke levels, as shown in Figures 2,6 , and 7 . 


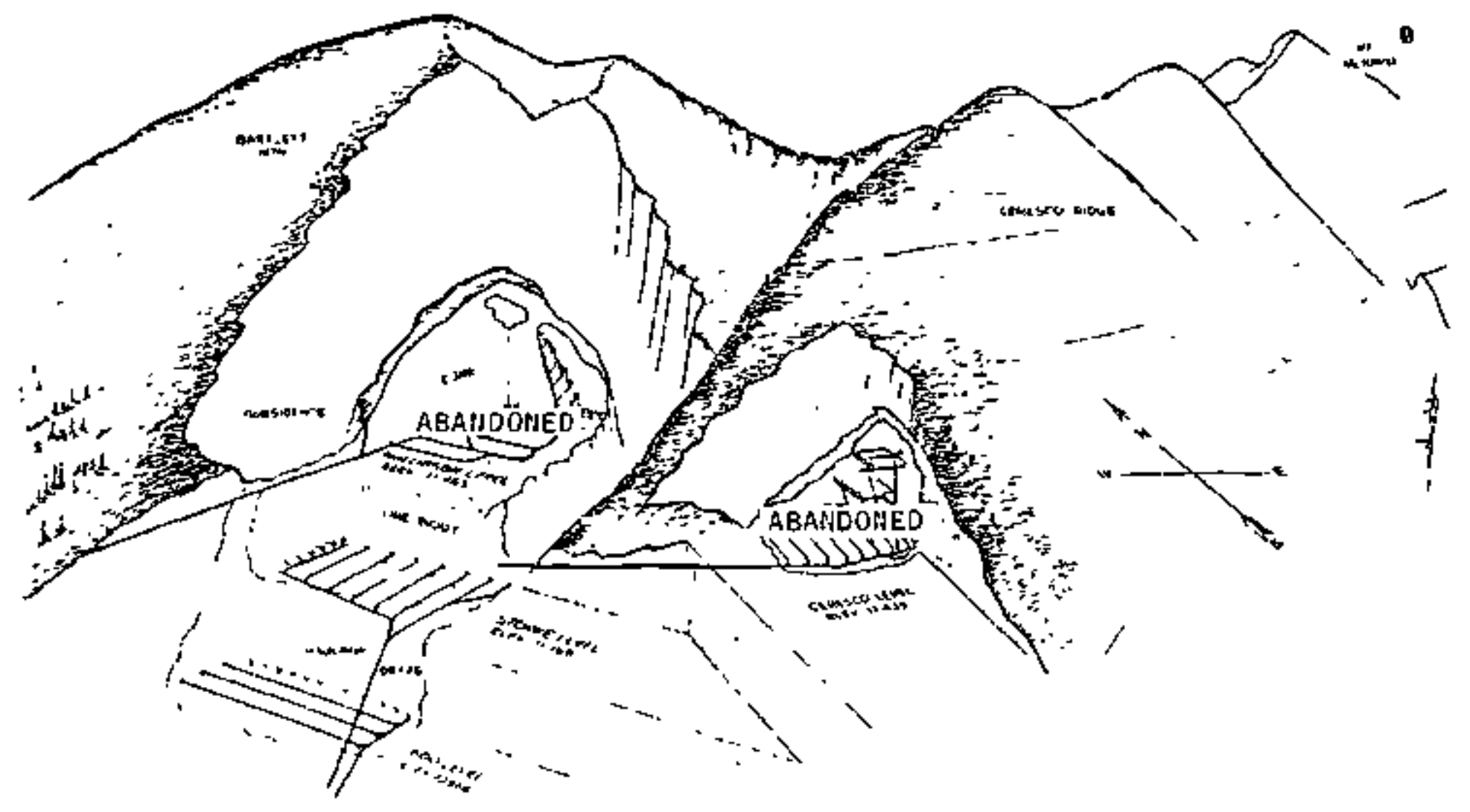

FIGURE 5. Cut-away diagran of Climax mine (Amax, 1974+). 

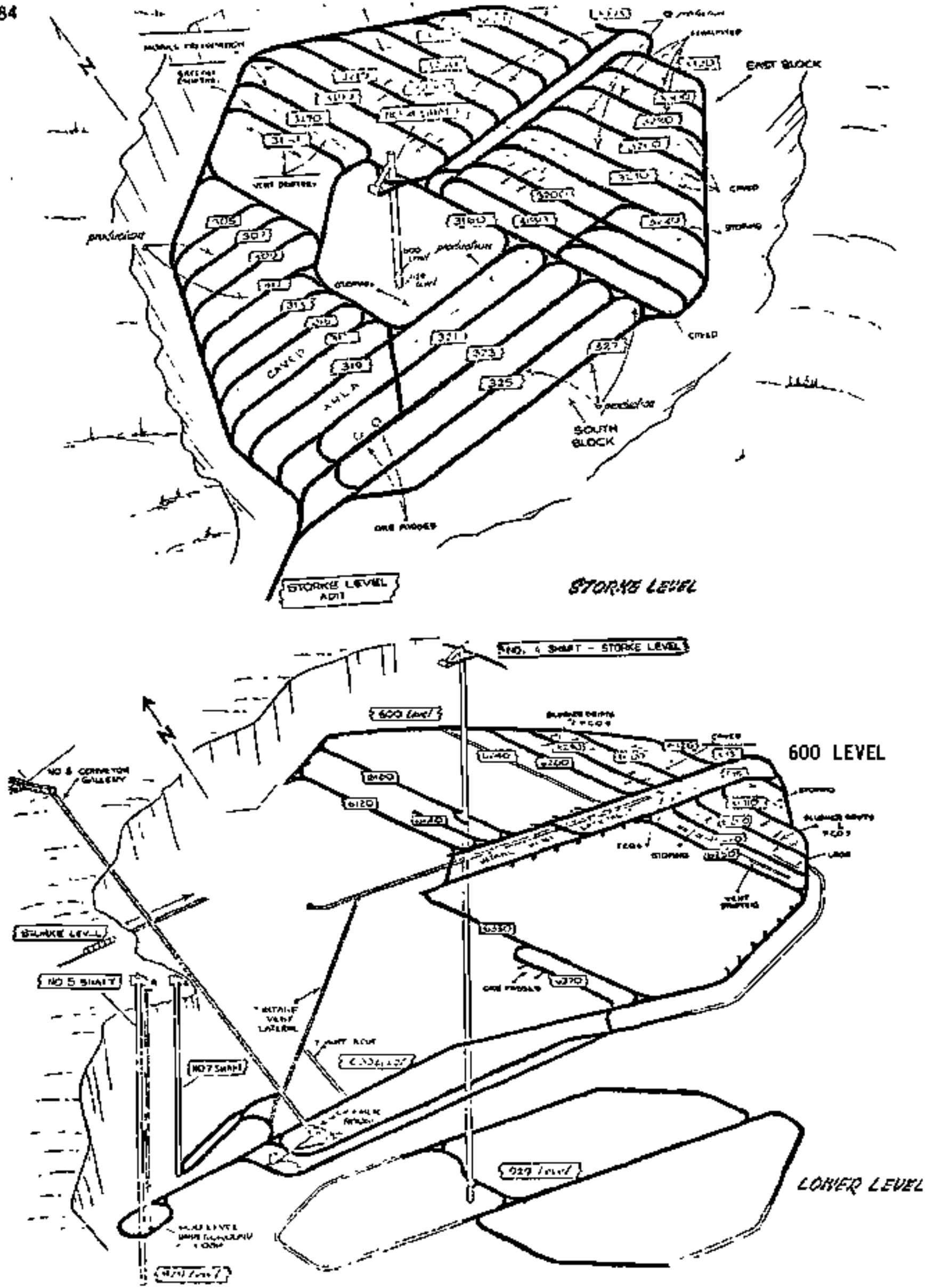

FIGURE 6. Production Levels at Climax mine (Amax, 1974+) 


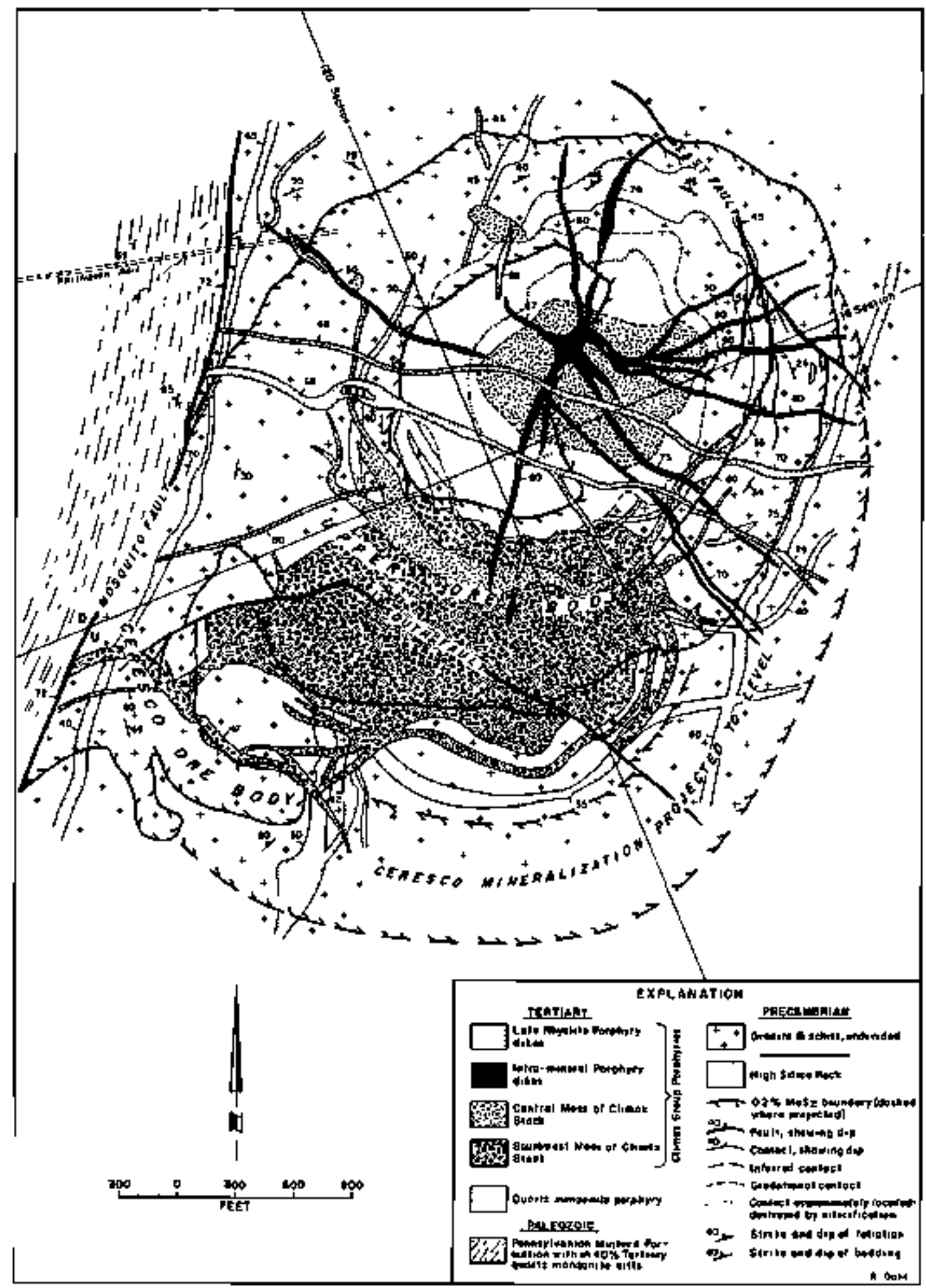

FIGURE 7. Phillipson Level, showing generalized geology and ore zones (Wallace, 1968). 
Support is provided by $12 " x 12$ " timber, or $5 \mathrm{ft}$. long roof bolts and shotcrete, or concrete legs with rock bolts. Haulage is by rail to the underground crushing plant, then by conveyor to the surface. Ventilation is supplied at a rate of $1.3 \mathrm{million} \mathrm{cfm}$. Al1 mine watex is collected in flumes and pumped from the sump across the Continental Divide to be reclained in the closed circuit aill water supply. Hater flow averages $400 \mathrm{gpm}$ with 5000 gpm peaks during spring runoff. 
REFERENCES

AMAX, 1974+, Report on history, geology, and mining operations at Climax: Climax Molybdenum Company, Molybdenum and Specialty Metals Divison of AMAX, Inc., $36 \mathrm{pp}$.

Butler, B.S. and Vanderwilt, J.H., 1933, The Climax Nolybdenum deposit, Colorado: U.S. Geol, Survey Bul1. 846-C, p. 195-237.

CRIB

MAS

Mining Annual Review, 1978, AMAX Company Report, p. 355.

Ridge, J.D., 1972, Annotated Bibliographies of Minera1 Deposits in the Western Hemisphere: Geol. Soc. Amer. Men. 131, p. 299-302.

Vandervilt, J.W. and King, R.J., 1955, Hydrothermal Alteration at the Climax Molybdenite deposit, AIME Trans., v, 202, p. 41-53.

Wallace, S.R. and others, 1968, Multiple Intrusion and Mineralization at Climax, Colorado: Ore Deposits of the United States, 1933-1967, Ridge, J.D., ed., Aner. Inst. Min. Metal. Petrol. Eng., New York, p. 605-640. 
. 
SCHWARTZWALDER MINE

(OPERATED BY COTTER CORPORATION)

LOCATION

The Schwartzwalder mine (also known as the Ralston Creek mine) is located at $39^{\circ} 50^{\prime} \mathrm{N}, 105^{\circ} 15^{\circ} \mathrm{W}$ in the Front Range on the southwest side of Ralston Creek in the northeastern part of the Ralston Buttes district, about 8 miles northwest of Golden, Colorado (Figure 1).

\section{GEOLOGIC SETTING}

\section{Regional}

Data for this section were extracted from Sins (1964) and Sheridan 〔1967).

As shown in Figure 2, netanorphic and igneous rocks of Precambrian age forn most of the bedrock of the Ralston Buttes district. In the northeastern part of the district, the Precambrian rocks are overlain unconformably by sedimentary rocks of Paleozolc and Mesozoic age. An interlayered succession of nica schist, gnelss, anphibolite, and quartzite comprises the Precambrian metamorphic rocks. 'The rocks in this succession are of sedinentary origin, and were intruded in the western and northern parts of the district by Precanbrian plutons, comprised of gramodiorite-quartz monzonite, quartz monzonite, and hornblende diorite and associated hornblendite.

The predoninant trend of layering, foliation, and the axial plane of major folds in the Precambrian netamorphic rocks is east to northeast. This trend is a product of major deformation accompanied by intrusion of the principal 


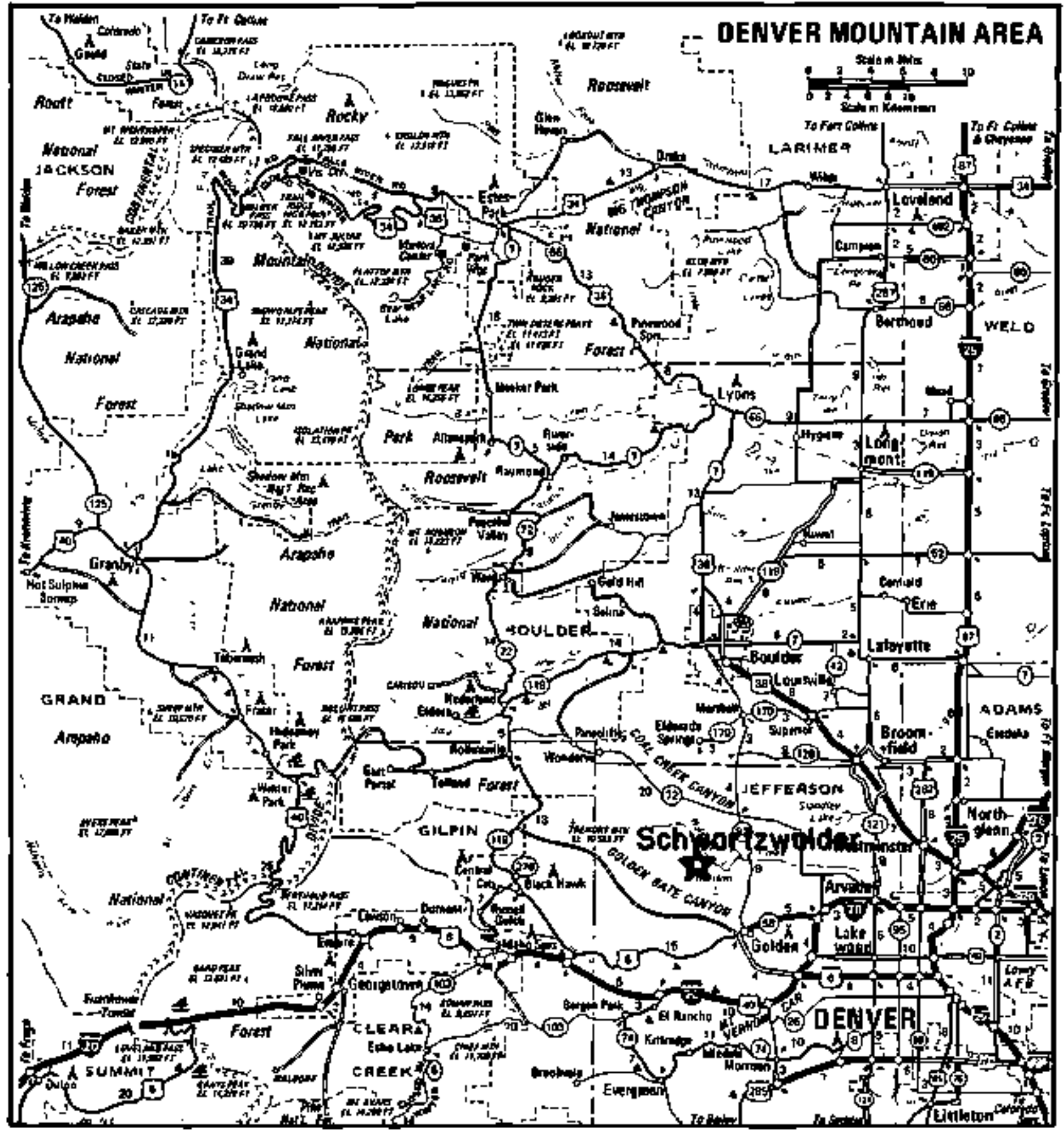

FIGISRE 1, Map of Colorado - Denver Mountain area. Basic map reproduced by permission of the Anerican Automobile Association, copyright owner. 

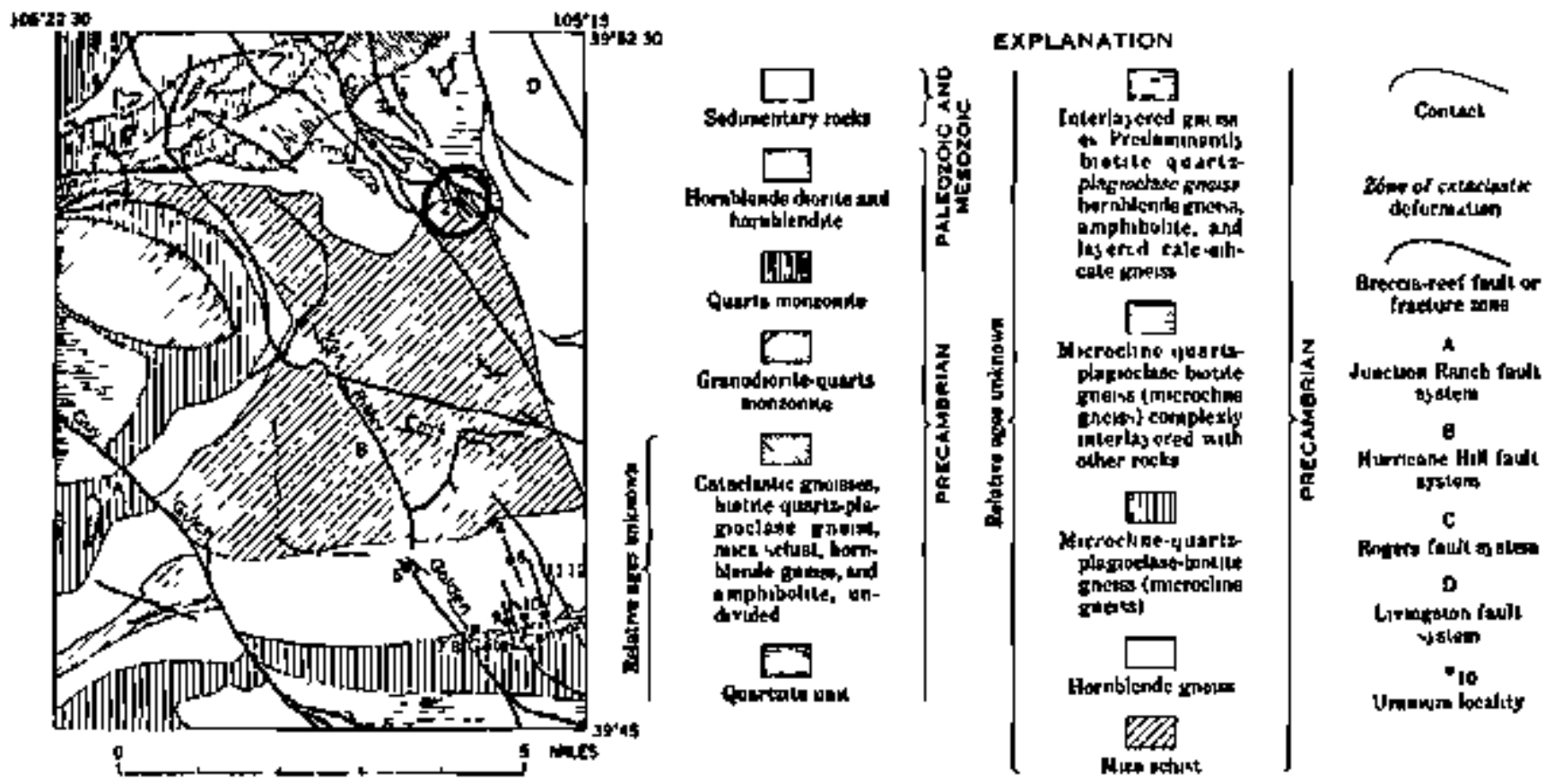

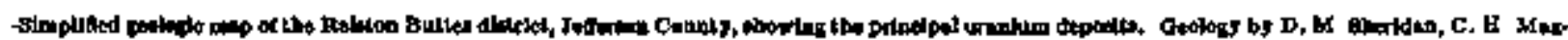

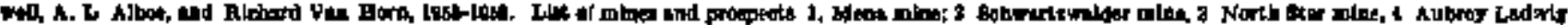

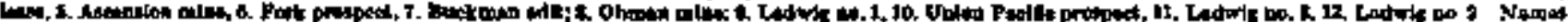

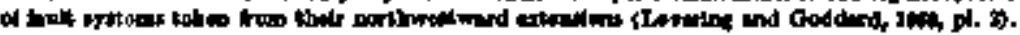

FIGURE 2 . 
igneous rocks. Four proninent northwestward trending fault systens cross the district, consisting of breccia reefs, related faults, and intensely fractured areas. It is believed that these faults were active during Precanbrian tine and agaln during the Laranide revolution.

Mine

Data concerning the nine geology were extracted fron Sims (1964), Sheridan (1967), and EMJ (1978).

The Schwartzwalder nine is in the transition zone along the contact between the nfea schist unit and the undivided hornblende gneisg unit, as shown in Figures 3 and 4 . Bedrock in the nine area is represented by three principal rock units: (1) mica schist in the southern part of the area, (2) hornblende gneiss in the central part, and (3) microcline gneiss interlayered with less abundant hornblende gneiss in the northern part. The hornblende gneiss is separated from the mica schist by a transteion zone 50-300 feet wide. The mine workings are primarily in this transition zone.

The rocks in the vicinity of the mine are folded into a fairly large syncline and an adjacent anticline, the axes of which plunge steeply to the southwest. In places the syncline is tight, nearly isoclinal, and in part overturned, while elsewhere it is more open. The predominant plunge and bearing of lineations in the area are respectively $60^{\circ}-70^{\circ} \mathrm{S}$ and $65^{\circ}-70^{\circ} \mathrm{W}$, approximately parallel to the najor fold axes.

Numerous faults and fracture zones of the Rogers fault system lie within the area, primarily between two major bounding faults. The bounding fault north of kalston Creek (a reverse fault) strikes northwest, dips steeply to the northeast, and has resulted in the displacement of the northeast 

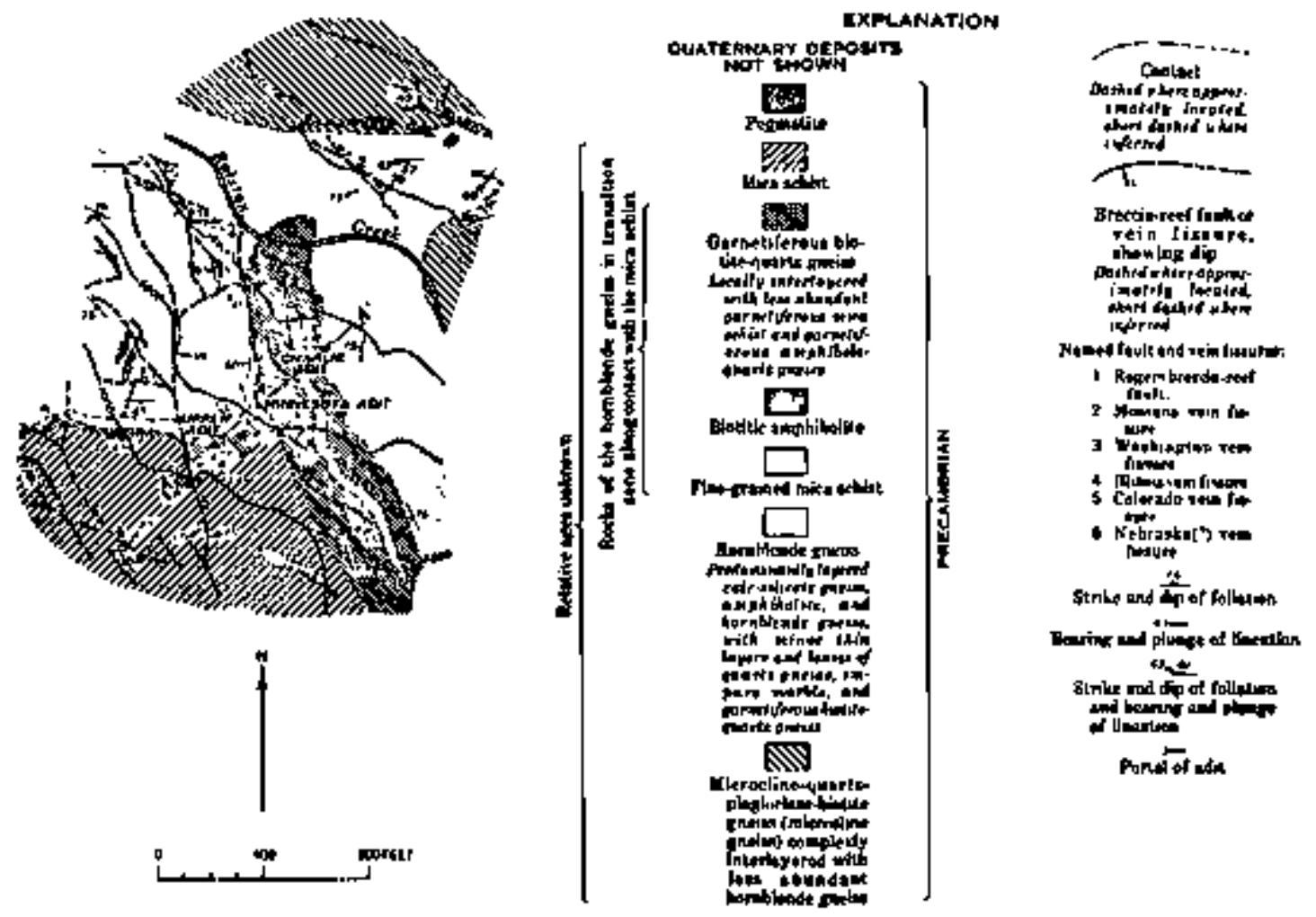

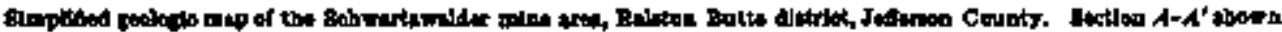

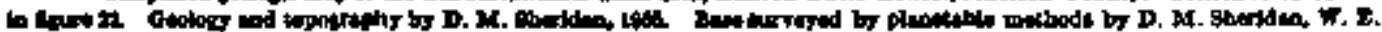

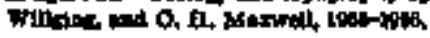

FIGURE 3. 


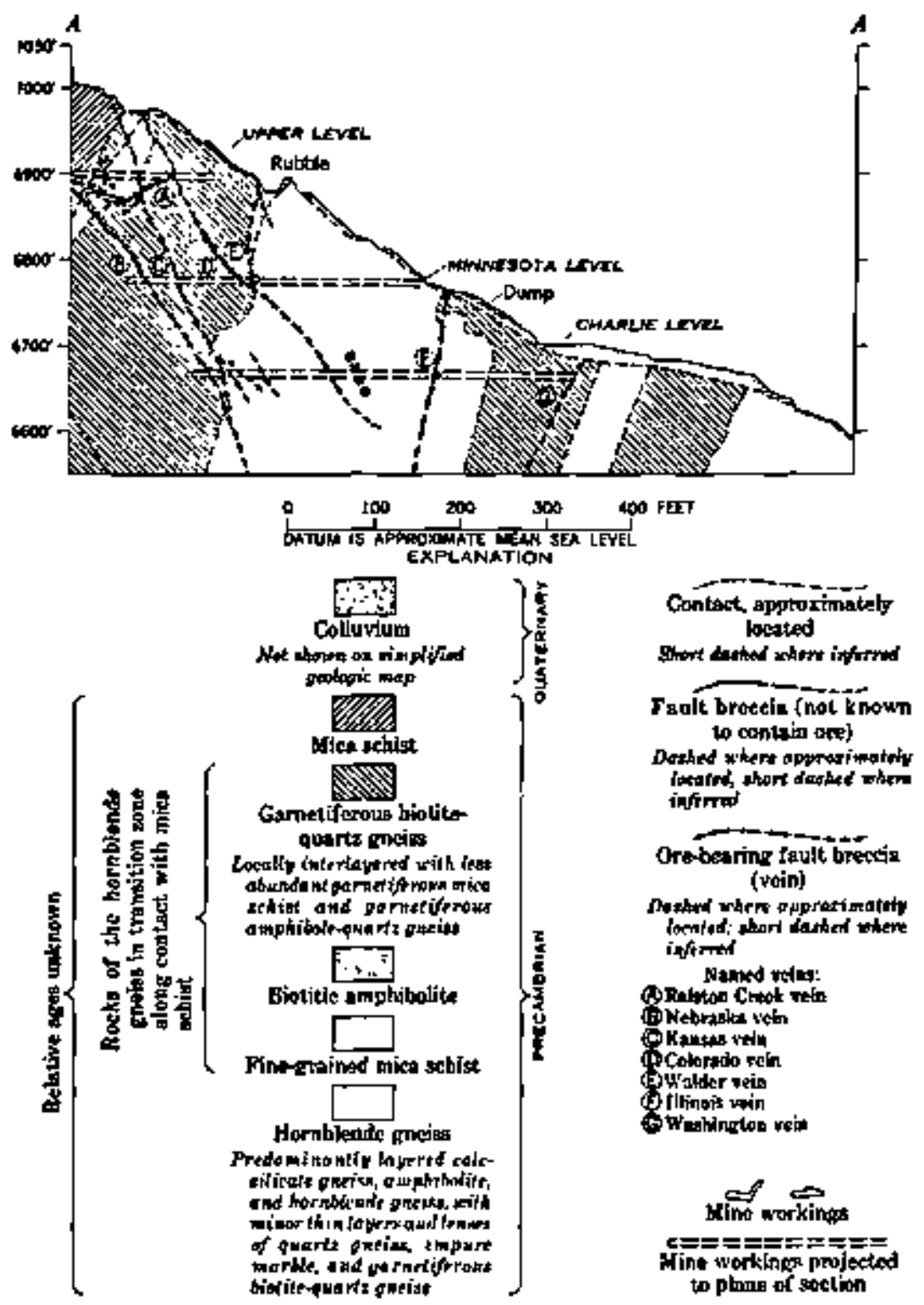

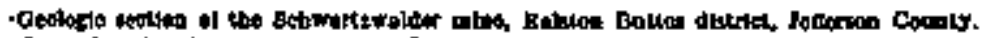

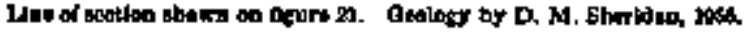

FIGURE 4. 
block upward and to the southeast, with a lateral displacement of about 2200 feet. The other bounding fault trends northwest and 1 ies approximately half a mile southwest of the mine. The block between the bounding faults is approxinately 3500 feet wide, trends about $N 50^{\circ} \mathrm{W}$, and is cut by a group of intricately branching and splitting faults. The history of movements along the various faults is complex, and at least three episodes of fracturing are recognized; however, the net displacenent along the subsidiary faults appears to be minimal. Some of the subsidiary faults are occupied by the mineralized veins which make up the Schwartzwalder ore body.

The pitchblende mineralized veins of the Schwartzwalder rine are typically dark-colored fault breccias and adjoining fractured wallrocks which are coated, filled, and veined by ore ninerals. The veins range in thickness from a fraction of an inch to as much as 8 feet, however, in places where they converge, stopes up to 35 feet wide have been mined. The locally mineralized, steeply dipping Illinois faut hosts the Schwartzwalder ores. In the mine, the fault can be seen as a breccla structure with mineralizatton on the second level, as an unmineralized shear zone on the ninth level, and as a mineralized coarsely crustified open fault with post-pitchblende calcite on the 11th level. The ore strike length is usually short in corparison with the mineralized dip length. The source of mineralizing fluids in unknown.

\section{MINE FACILITIES}

Data for this section were extracted from EML (1978).

Cotter Corporation acquired the Schwartzwalder mine in 1965, when the operation was producing about 70 tons of ore perday. Production has since expanded to $600 \mathrm{tpd}$, the maximum possible based on installed hoisting capacity. 
As shown in Figure 5, three intemal shafts provide access to the Schwartzwalder stopes: the No. 1 shaft, which is used only as an escape route; the No. 2, with two 60-inch compartments covering a vertical distance of 1300 feet; and the No. 3, with two 72-inch conpartments covering a distance of 1000 feet. Twenty levels at 100 foot vertical intervals extend from the surface down to an elevation of about 4430 feet. Development is current $1 \mathrm{y}$ being done on the 16th level.

Shrink stope methods, with jacklegs and stopers for drilling, are used to extract steeper veins. Slushers, trackless loaders discharging into Young Buggies, and 1-cu-yd-capacity front-end loaders expedite transfer of ore and muck to ore passes.

After mining terminates in a vein, stopes are sealed off to prevent the escape of radon gas and to streamline the mine ventilation. About $250,000 \mathrm{cfil}$ of air is downcast through the shafts by 75-hp fans. The air exhausts through an 8-ft dianeter, $2500 \mathrm{ft}$-deep ventilation raise completed in 1977.

Along with possibly providing access for rock mechanics and hydrological testing of high-grade metanorphic rock, the Schwartzwalder mine may also offer sites for the study of natural uranuim occurrences as analogs to the behavior of radioelements in a crystalline-rock waste-repository environment. 


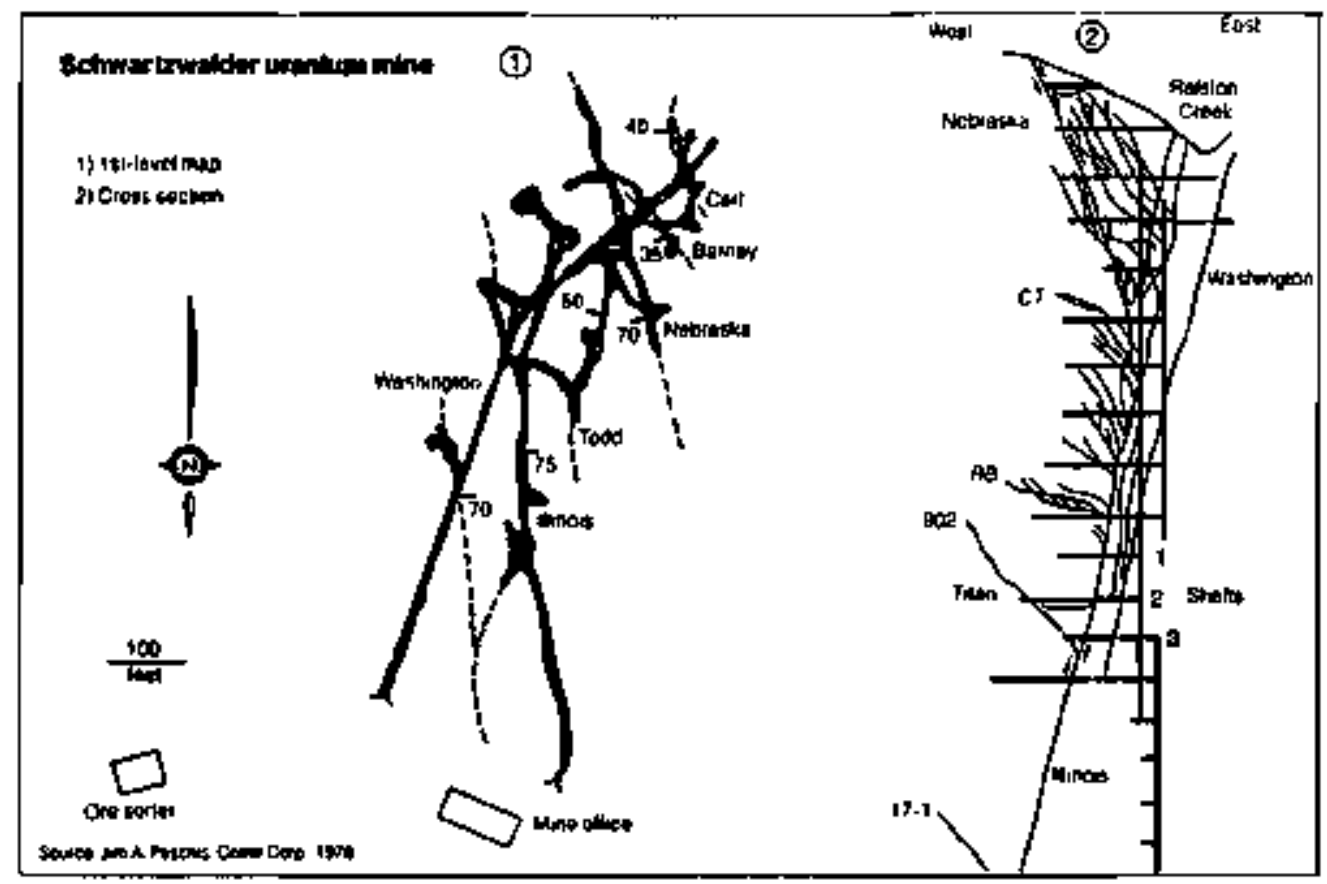

FIGLRE 5. Recent Cross-Section of Schwartzwalder Mine, with leve1 map. 
REFERENCES

CRIB

Engineering \& Hining Journa1, 1978, Cotter Corporation Moves Ahead on Several Fronts, v.l79\{11), p. 136-138.

NAS

Sheridan, D.M., Maxwel1, C.H., and Albee, A.L., 1967, Geology and Uranium Deposits of the Ralston Buttes district, Jefferson County, Colorado: U.S. Geol. Sirvey Prof. Paper 520, $121 \mathrm{pp}$.

Sims, P.K., and Sheridan, D.M., 1964, Geology of Uraniun Deposits in the Front Range, Colorado, U.S. Geol. Survey Bull. 1159, p. 1-4, 82-92. 
URAD MINE

HENDERSON MINE

(OPERATED BY CLIMAX NOLYBDENUM COMPANY, A SUBSIDIARY OF AMERICAN METAL CLIMAX, INC.)

\section{LOCATION}

The Urad and Henderson molybdenun mines are located at Red Mountain, about 8 miles west of the communty of Empire, in the Front Range of Colorado at $39^{\circ} 46^{1} \mathrm{~N}, 105^{\circ} 50^{\circ} \mathrm{W}$. As shown in Figure 1, the nires are about 50 miles west of Denver. The snaller Urad ore body crops out at the surface, while the Henderson ore body 1s located about 3700 feet beneath the 12,315 foot peak of Red Mountain. The Henderson mine is about 2000 feet below the Urad mine.

\section{GEOLOGIC \$ETTING}

Regional

Data on the geology of the region and the ore bodies was extracted fron Hoppe (1976) and Ranta (1976).

The regional geologic setting of the Urad and Henderson ore bodfes can be discussed jointly because of their proxinity to one another within the Red Nountain igneous conplex.

The Red Mountain igneous complex was intruded into the Precambrian Silver Plume granite near the convergence of two major fault zones. The Berthoud-Loveland and Vasquez fau1t zones are believed to have been key structural elenents in the emplacenent of the Red Mountain complex. The Berthoud-Loveland fault zone has a NE trend and lies southeast of Red 


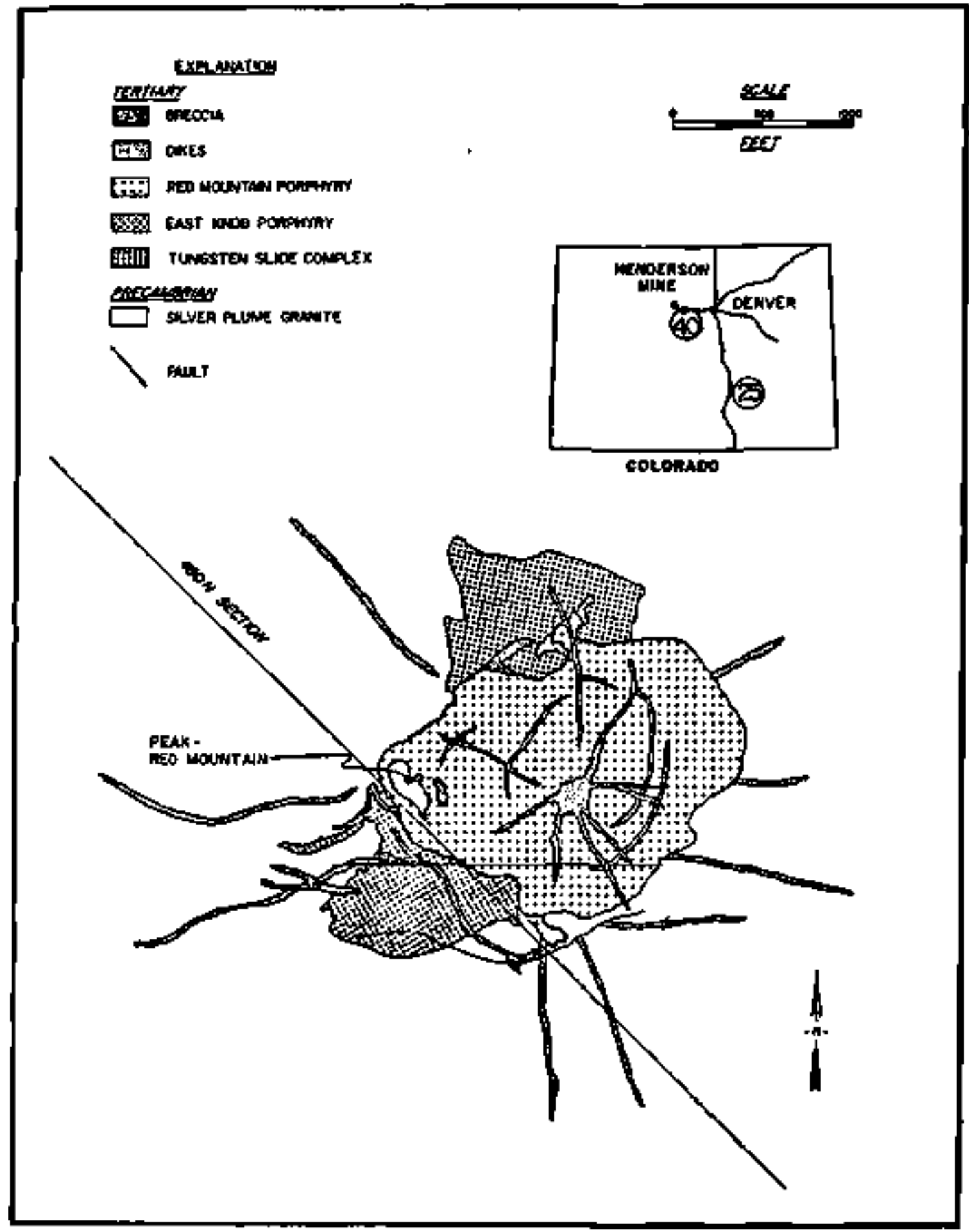

FIGURE 1. Generalized surface geologic map of Red Mountain showing location of section 48DH (after Ranta, 1976). 
Mountain, while the Vasquez fault has a NNE trend and lies northwest of Red Hountain.

The intrusive complex is exposed at the surface over an outcrop area of 1200 by 2500 feet, at 7500 foot elevation, the dianeter of the complex is approximately 5100 feet. Subvolcanic rhyolite porphyries, near the surface, change downard to nineralogically similar, fine-grained granite porphyries and to a fine- to medium-grained equigranular granite. These intrusions were enplaced in late oligocene to early wiocene time. Five major intrusive episodes, each with two or more phases, forned the Red Mountain intrusive complex.

\section{Geology of the Near-Surface Jrad Mine}

The geology of the Urad mine was extracted from łoppe (1976) and Ranta (1976).

The ore body originally contained approximately 13 million tons of plus $0.3^{\circ} \mathrm{MbS}_{2}$. The maximum dinensions of the ore body are 400 feet ride, 1200 feet long, and 1000 feet high.

The Tungsten Slide complex, the East Knob Porphyry, and the Red Mountain Potphyry are the three principal Tertiary intrusions exposed at the surface. The relationship of these intrusions is shown in plan view in Figure 1 and in cross-section in Figure 2. Radial and concentric dike and explosion breccia patterns suggest that the intrusions were of a shallow, subvolcanic nature. The ore at Urad is contained in a systen of fractures that transects the Precambrian Silver Plune granite and the Tungsten Slide Complex.

The Tungsten slide Complex consists of a breccia, in close association with the Crowded Quartz Porphyry and the Square Quartz Porphyry. The 


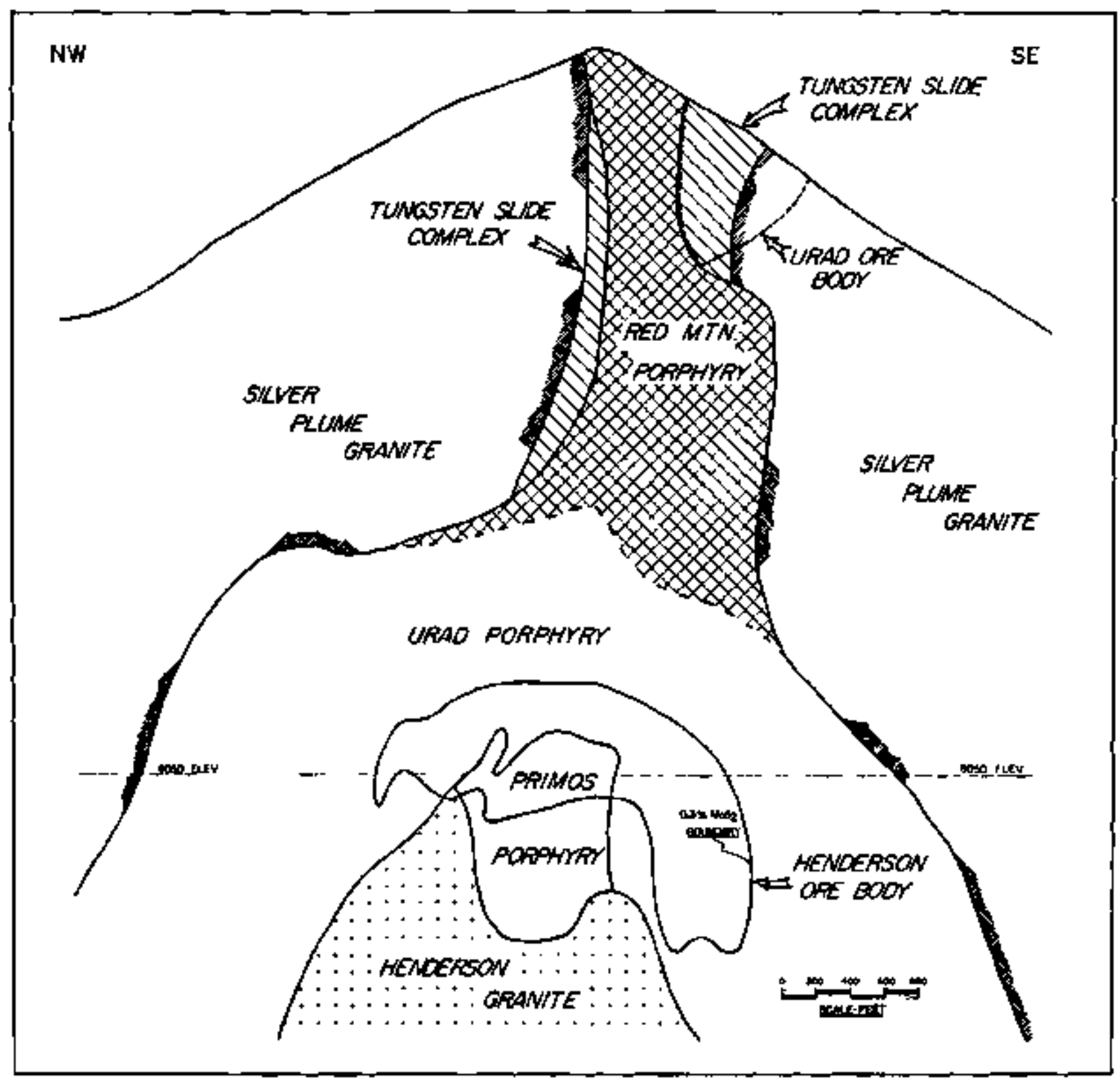

FIGURE 2. Generalized geologic Section $480 \mathrm{H}$, (after Ranta, 1976). 
Crowded Quartz Porphyry lies directly beneath the breccia, while the rhyolitic Square Quartz Porphyry occupies a lower, core position within the Tungsten S1ide Complex.

The northeastern part of the Red Mountain intrusive complex consists of Tertiary East Knob Porphyry. The rhyolitic East Knob Porphyry is strongly altered and pyritized, and locally contains presently-uneconomic mineralization.

The Red Mountain Porphyry cuts both the Tungsten Slide Complex and the East Knob Porphyry, and may have removed part of the Urad ore body. This rhyolitic porphyry plug forms the core of the Red Mountain intrusive complex, and may have fed a volcanic vent.

\section{Geology of the Deeper-Seated Henderson Mine}

Geology of the Henderson Mine was extracted from Hoppe (1976) and Ranta (1976).

The Henderson molybdenum ore body contains in excess of 300 million tons of ore, averaging $0.498 \mathrm{MoS}_{2}$. The deposit has the shape of an inverted cup, slightly elongate to the northeast. Ore body dimensions are approximately 3000 by 2200 feet with an average thickness of approximately 600 feet.

There is a transitional contact zone between the Red Mountain Poxphyry plug and underlying Urad Porphyry, some 2500 feet beneath the surface. Also shown in Figure 2 are the Primos Porphyry and Henderson granite, which make up the core of the Urad porphyry. Primos Porphyry solidified beneath the solid crystaliine hood of the Urad Porphyry intrusion, while the late Henderson granite occupies a similar position beneath the combined Urad-Primos hood. All of these deep-seated intrusions are granites. 
The Urad Porphyry forms the largest volume of any igneous rack in the colfulex, and is the host for the bulk of the Henderson molybdenum ore body and associated alteration halos.

MINE FACILITIES - Urad Mine

General

Climax Molybdenum Company purchased the Urad mine during the mid-1960's. Mining at the Urad has been intermittent since 1920. Beginning in 1967, C1imax Molybdenum Corp. produced 6.5 million lbs. per year of molybdenum at a daily ore nining rate of S000 tons. From 1967 to 1974 , the now-depleted Urad ore body produced 13.7 million tons of ore, averaging 0.49 percent $\mathrm{MoS}_{2}$.

Mine

Data for this section were extracted from Kendrick (1970).

The literature regarding the Urad pine does not give any information concerning the present condition or type of facilities available.

The Urad ore body was made up of two distinct rock types - a Tertiary fine-grained thyolite porphyry and a Precambrian coarse-grained granite. On the basis of these rock types, the block (inductive) caving mining plan had two major production levels. The flrst caving, an area of approximately 300 by 450 feet, was totally within the rhyolite porphyry. Access appears to be by adit rather than shaft. The second caving, about 300 by 300 feet, was entirely within the granite. 
MJNI: FrCJitTIES - Henderson mine

General

Clinax Molybdenum Company's Henderson mine began production in July 1976. Ore production began at approximately 3000 tpd and is expected to reach 30,000 tpd by 1980 . The mine enploys about 1300 workers. The ore body lies 3700 to 5400 feet beneath the crest of Red lountain, on the eastern edge of the continental Divide. The mine plant - headframes, shops, warehouse, offices, and auxiliary facilities are situated at the foot of Red fountain, in the Clear Creek Valley, some 1700 feet above the top of the ore body. The mine plant is located alongside U.S. Route 40, 50 miles west of Donver.

Mine

Data for this section were extracted from EMJ (January \& June, 1976, September 1975).

The Henderson mine project is a significant engineering achievenent based on the facts that its haulage turgel is the third longest railroad tunnel in the world, and its production shaft, at 28 feet in diameter and 3100 feet deep, is the largest in North America.

A mechanized panel-caving mining method is being used at Henderson. In panel caving, the ore body is divided into a series of panels that are defined by production drifts; each panel is 80 feet wide and of varying length. There are no pillars left between the panels, which are caved in sequence, progressing in two directions simultaneously. The first production leve1, the 8100 , is 2350 feet below the collar of the access shaft. The second production level, the 7700 , to be opened in later years, is 200 feet above the permanent main rail road haulage level. 
The Henderson mine is serviced by 4 shafts: No. 1 with a depth of 2440 feet; No. 2, 3100 feet and offset 2500 feet from the ore body; No. 3, 2290 feet; and No. 4, 1585 feet, located several miles away, which affords exhaust ventilation for the railroad haulage tunnel.

Thn No. 1 and No. 3 shafts, which are 23 feet in dianeter, are exhaust and intake ventilation airways. The No. 2 shaft has three-compartments and is equipped with a $24 \times 9$ foot man-material cage with a capacity for 100 men or a 20 -ton load, a double-deck man cage with 114 man capacity, and a chippy cage for a four-man shaft inspection team.

I'jgure 3 is a three dimensional view of the Henderson mine workings. Total lateral development exclusive of the railroad haulage tunnel exceeds 114,000 feet, including 13,000 feet of ramps.

Henderson's main haulage way for transferring ore from the 24 loading pockets cut above the 7500 level is a 52,000 foot long railroad tunnel. Ore is transported in 30-car trains from the 7500 level at $3 \%$ grade to the western porta] at elevation 8950 feet and then another 4 miles to the crusher at the mill site. The tunnel has dimensions of approximagely $16 \times 15$ feet, and is driven through granite on the eastern, underground end, then through Precambrian schists and gneisses. The metamorphosed rocks, which made up the bulk of the western drive, caused sone serious problens in tunneling through sections of wet, highly fractured, and squeezing ground.

It appears that there are substantial workings in Precambrian granitic and motanorphic rock, as well as in Tertiary gruplitic rock, which may furnish access for in-situ geomechanical and hydrologic testing. 


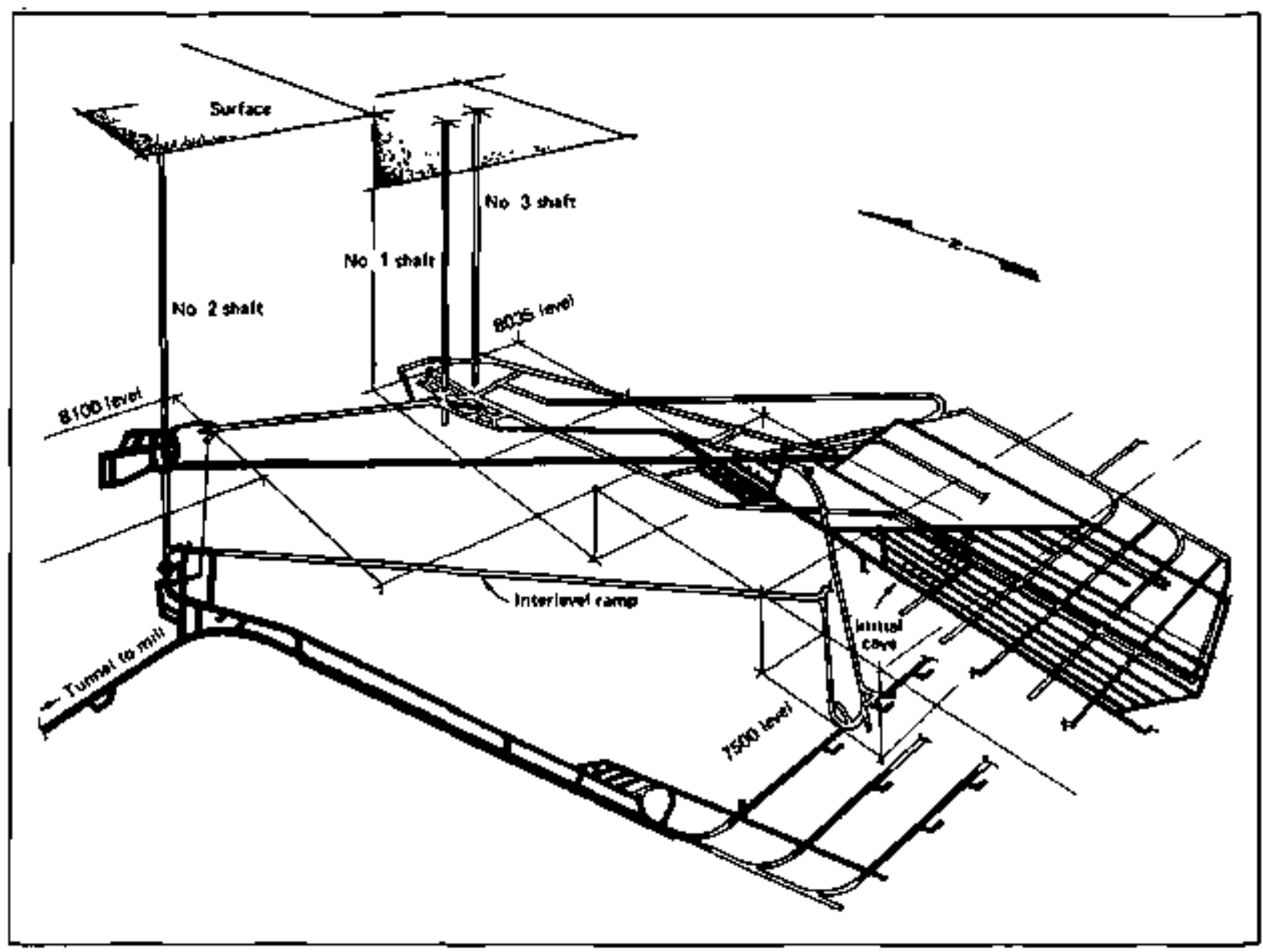

FIGURE 3. The complexity and number of development openings needed for mining the Henderson are enormous. Total lateral development, excluding the haulage turne1, will exceed 114,000 feet before production begins, including 13,000 feet of ramps, (after Hoppe, 1976). 
REFERENCES

\section{CRIB}

Eckel, E.B., 1947, La Plata District, La Plata and Montezuma count ies; in: Vanderbilt, J.W., ed., Mineral Resources of Colorado, Colo. Min. Res. Bd, p. 225-227.

Engineering \& Mining Journa1 1976, Climax Molybdentmin's new Henderson project set to go on stream in July, v. $177(6)$ p. 23, 27 .

1975, Henderson mine tumnel holed through by Amax after four and a half years work, v. $176[9]$ p. 37 .

1975. Automatic train transport at Henderson, v. 176(9) p. 105-106. 1965, Molybdenum, v. 166 (1) p. 69.

Goth, J.W., 1979, bolybdenum--Lower Output from By-Product Sources Contributes to Continuing Supply Tightness, Eng. Min. J., v. 180(3) p. 122, 129.

Hoppe, R., 1976, Amax Prepares to Cave the Henderson after a Decade and $\$ 400$ million iл Development, Eng. Min. J., v. 177(1) p. 92-98.

Kendrick, R., 1970, Induction Caving of the Urad Mine: Mining Congress Journal, v.56(10) p. 39-44.

Lovering, T.S., and Goddard, E.N., 1950, Geology and Ore Deposits of the Front Range, Colorado: U,S. Geol. Survey Prof. Paper 223, 313 pp.

Mining Annual Review, 1978, Individual Company Reports: AMAX, p. 355.

Ranta, D.E., and others, 1976, Geology of the Urad and Henderson Molybdenun Deposits-a Review; in: Professional Contributors of Colorado School of Mines - Studies in Colorado Field Geology, edited by R.C. Epís and R.J. Weiner, n. 8, November 1976, p. 477-485. 


\section{COLORADO SCHOOL, OF MINES, EXPERIMENTAL MINE}

\section{LOCATION AND ACCESSIBILITY}

The experimental mine of the Colorado School of Mines is located in the Front Range, indediately northeast of the tow of Idaho Springs, Clear Creek County, at latitude $39^{\circ} 44^{\prime} \mathrm{N}$, longitude $105^{\circ} 31^{\prime} \mathrm{W}$. The location is shown on Figure 1. Year-round access is provided by a road through Idaho Springs, approxinately $1 / 4$ mile from Interstate 70.

\section{GEOLOGIC SETTING}

The regional geologic setting has been described by Lovering and Goddard (1950), and the more localized setting by Moench (1964). Figure 2 il lustrates the simplified geologic setting of the Idaho Springs area. The nine is located in the Precambrian Idaho Springs Formation, considered to be the oldest rock unit exposed in the Front Range (Lovering and Goddard, 2950). The Front Range in this ares is generally composed of gneissic rocks which were intruded at least three times in the Precanbrian by igneous rocks. Three principal rock types occur in the Idaho Springs area. They are, in order of importance: granite-biotite gneiss, pegmatite, and biotite gneiss. The granite-biotite gneiss is composed of interlayered granite gneiss and biotite gneiss. The pegmatite is prinarily composed of quartz and feldspar, with some nica. The dark gray, fine-grained biotite gneiss is a minor rock type in the area.

Studies of the central portion of the Front Range have shown that the gneissic rocks were deforned at least twice (Moench, 1964). The first deformation was apparently plastic at high temperature and pressure, and was accompanied by regional netamorphism and the emplacenent of the intrusive 


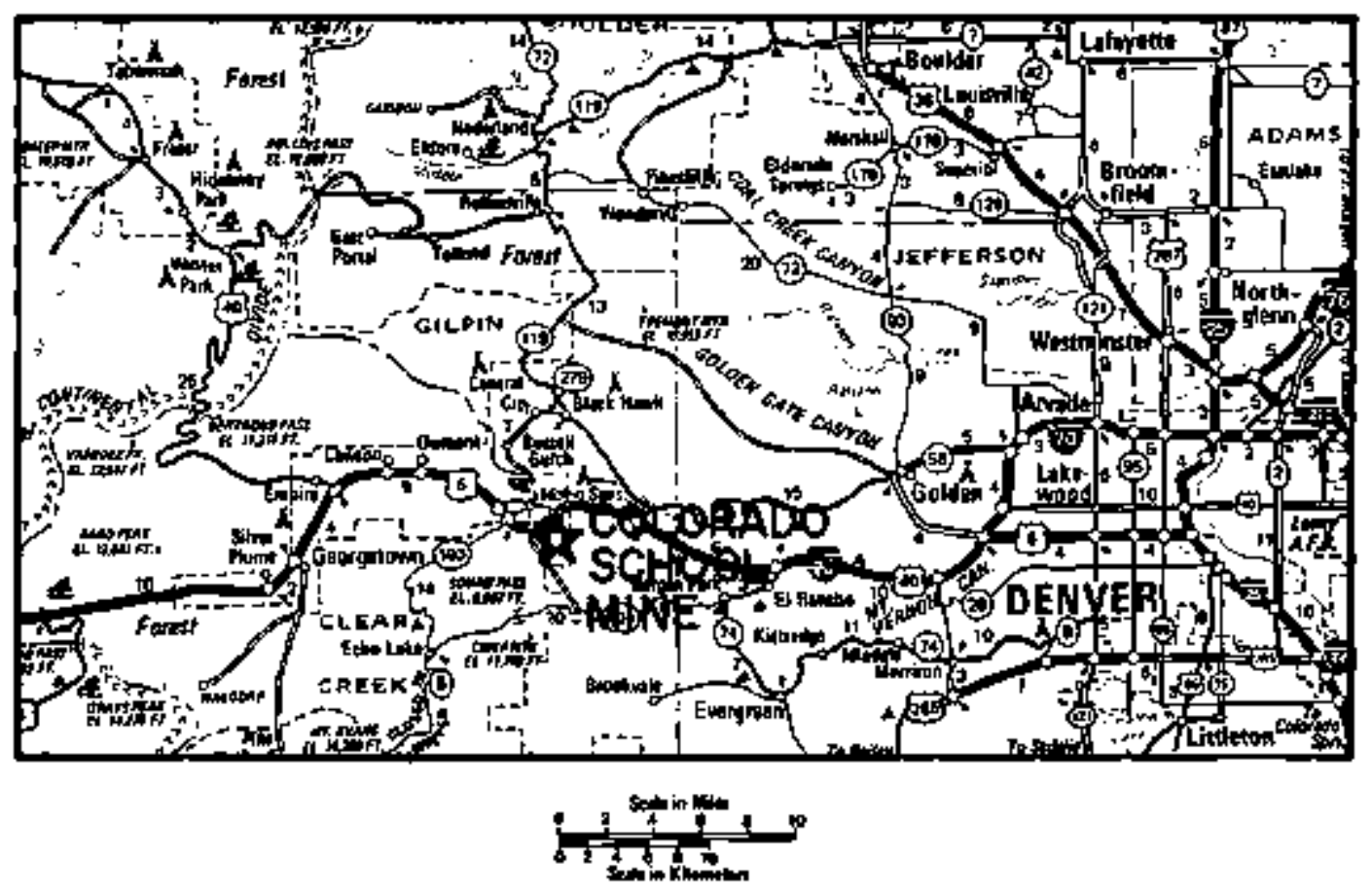

FIGURE 1, Location nap - Colorado School of Mines, Experimental Mine, Idaho Springs, Clear Creek County, Colorado, Basic map reproduced by permission of the American Automobile Association, copyright owner. 


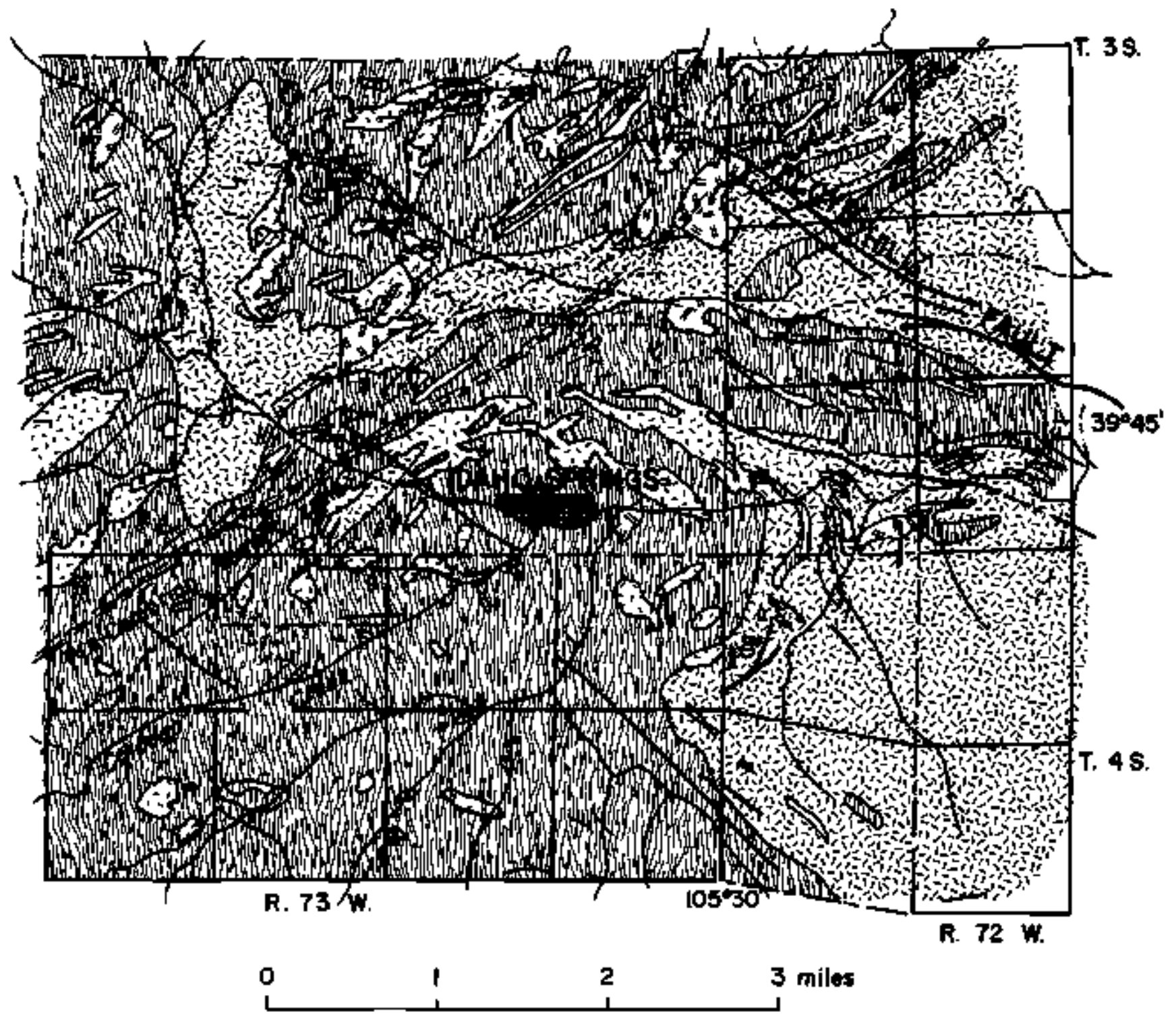

Tertiary Intrusives

[添 Pegmatite COLORADO SCHOOL of MNES, EXPERIMENTAL MINE

Granitic Rocks

Sind schist and gneiss

FIGURE 2. Geologic Map of Idtho Springs Area

(Compiled from Lovering and Goddard, 1950). 
bodies. The second deformation was cataclastic at low temperature and pressure and was restricted to the vicinity of the Idaho Springs - Ralston shear zone, located nearby to the south of the wine area. The first period of deformation produced large north-northeast trending folds, and the second produced intense cataclastic and numerous snall east-northeast trending folds. The area exhibits extensive jointing, with rehealing of the older joints during periods of defornation.

A plan of the mine workings is shown on figure 3 , and a simplified geologic plan and section illustrates lithology and structural features of an experimental area on Figure 4.

MINE CHARACTERISTICS

Rock-property data, size, facilities, and characteristics of the experimental mine are sumarized:

\section{Rock Properties:}

\begin{tabular}{|c|c|c|c|}
\hline Strength: & $\begin{array}{l}\text { Unconfined } \\
500 \mathrm{psi} \\
1000 \mathrm{psi}\end{array}$ & $\begin{array}{l}18.2 \pm 3.6 \mathrm{ksi} \\
21.2 \\
27.6\end{array}$ & $\begin{array}{l}\text { [uniaxial) } \\
\text { (trfaxial) } \\
\text { (triaxial) }\end{array}$ \\
\hline
\end{tabular}

Modulus (Ey) $8.36 \pm .91 \times 10^{6}$ psi

Rock Mass Modulus: $4.0-4.7 \times 10^{6}$ psi

Density: $\quad 2.63 \mathrm{gm} / \mathrm{cm}^{3}$

Poissons Ration: $.15 \pm .04$

In Situ stress: $\sigma_{\mathrm{v}}=456 \mathrm{psi}$

$\sigma_{\mathrm{H}}=575 \mathrm{psi}$

$\sigma_{x y}=43$ psi (shear)

Hydrologic Conditions: probably above water table

Size: $(1 \times 7 \times 3600=176,400)+(9 \times 20 \times 60)=12,960)=189,360 \mathrm{cu} \mathrm{ft}$. $\left(7000 \mathrm{~m}^{3}\right)$ Fig. 1 . 


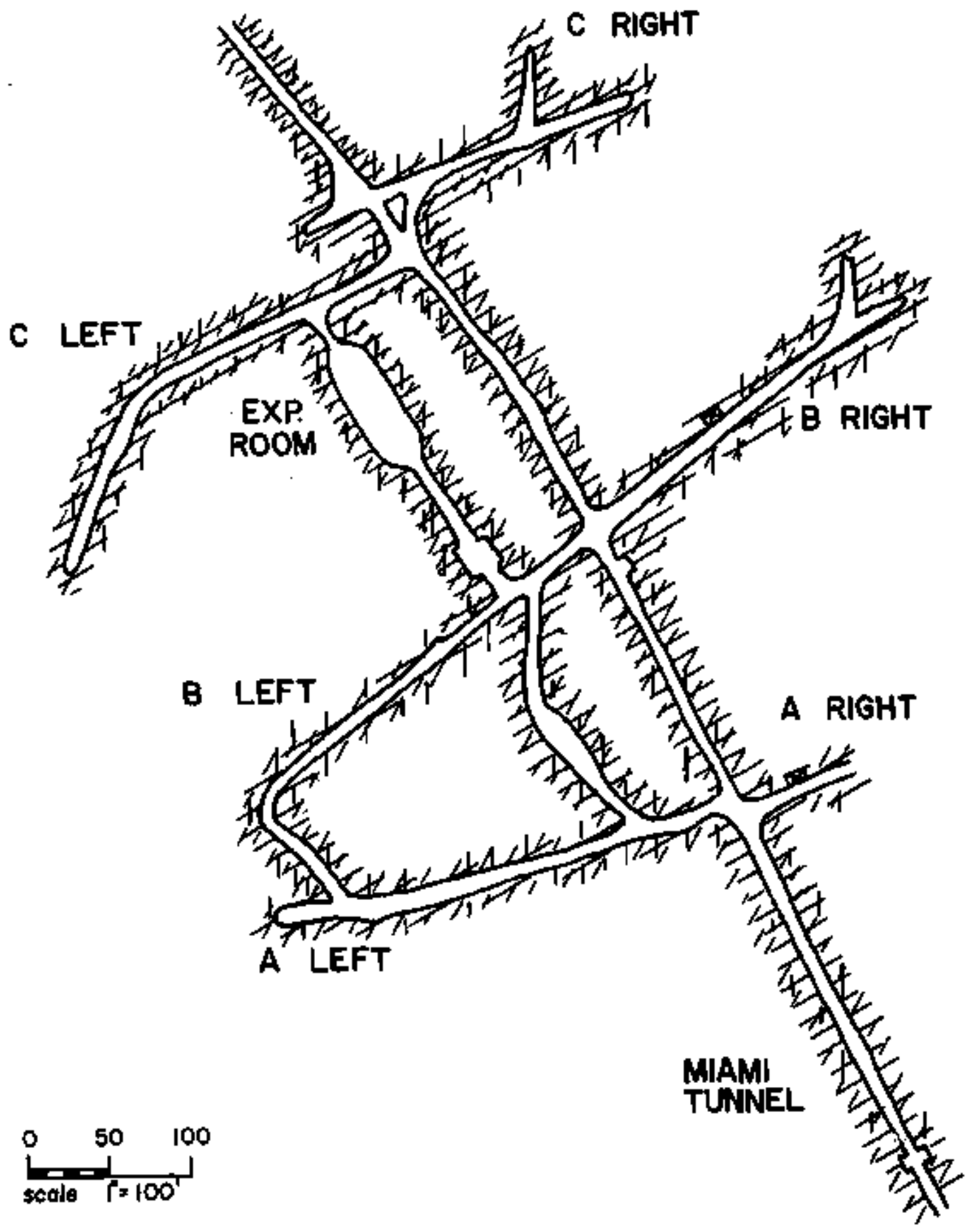

FIGURE 3. Map showing location of experimental roon, Colorado School of Mines, Experinental Mine, Idaho Springs, Colorado. 

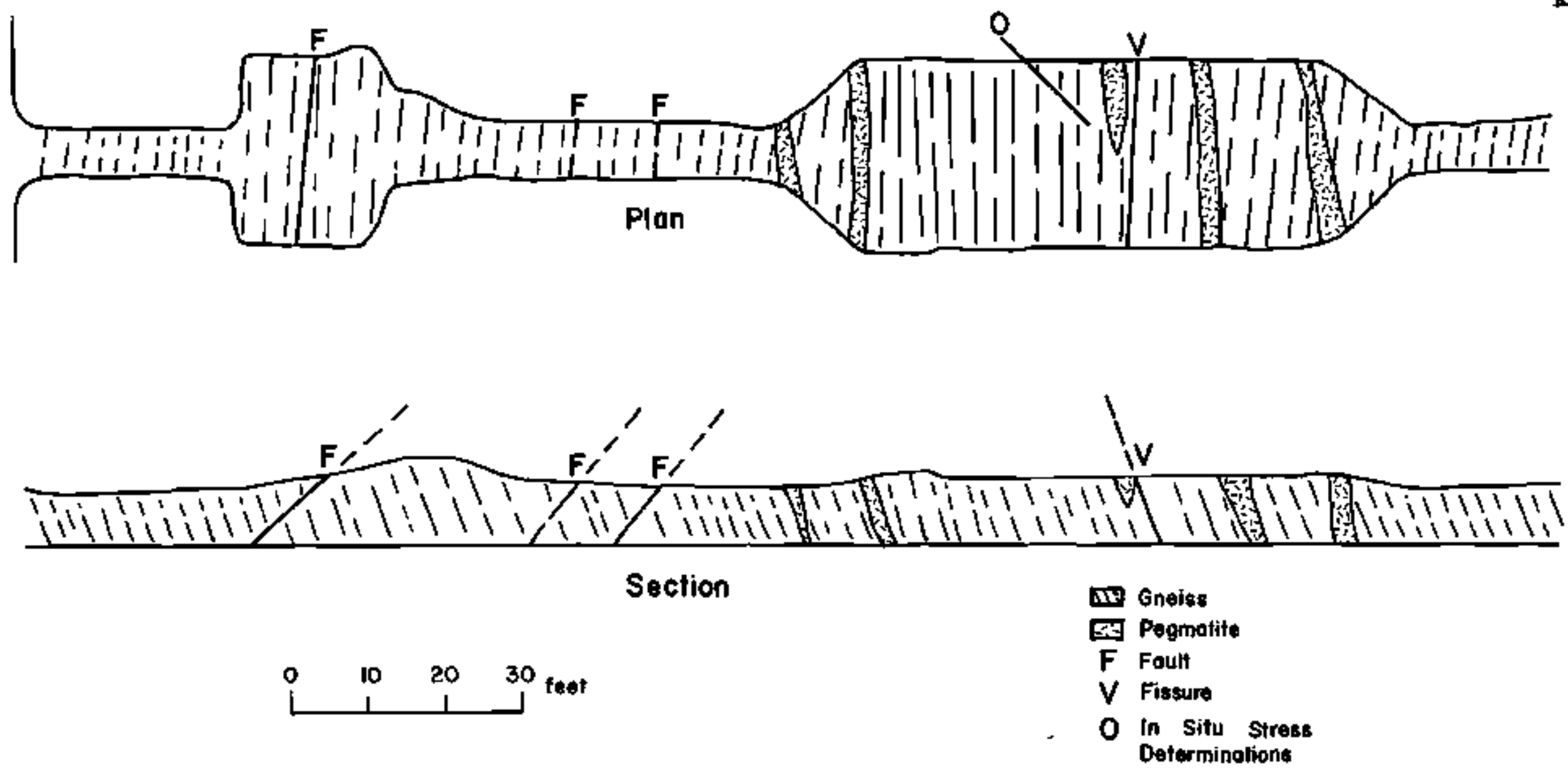

FIGURE 4, Geology of the experimental room area. 


\section{Facilities:}

Mechanical: Compressors

Electrical: Sufficient to conduct a large test progran

Transportation: $1 / 4 \mathrm{niles}$ on nacadam/dirt road off $\mathrm{I} 70$

\section{Characteristics:}

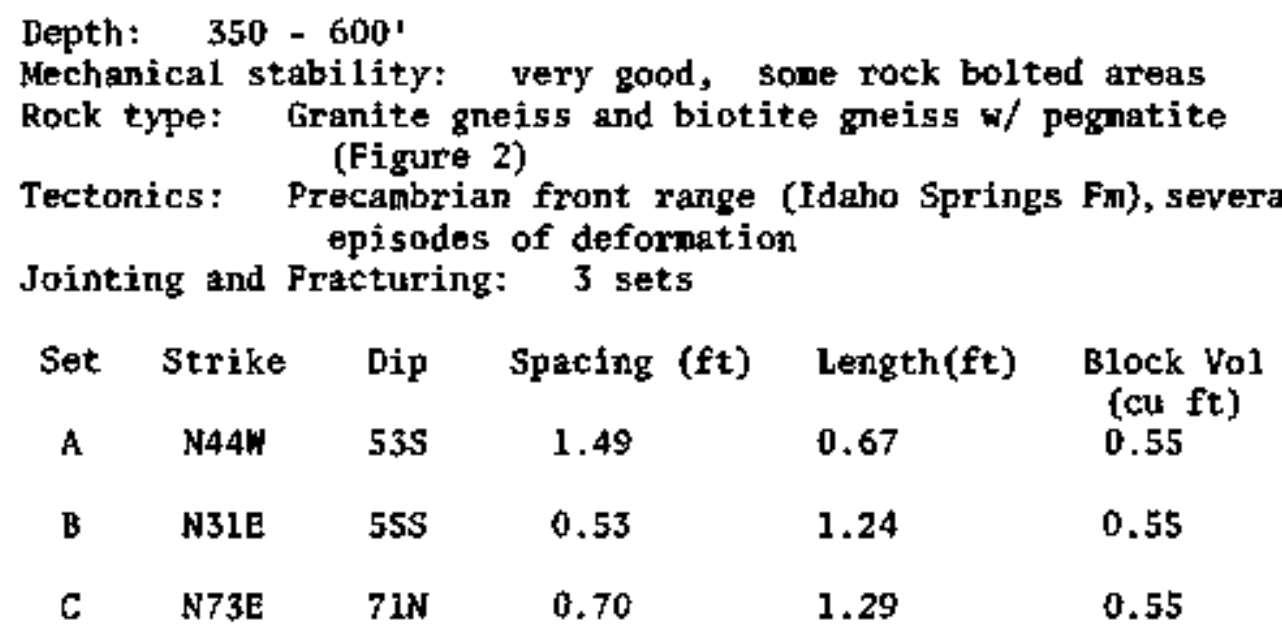

The nine is presently used by students and faculty nembers of the Colorado School of Mines for training and research projects. As part of their mining engineering education, essentially all of the underground excavation and maintenance is done by students. 
116

\section{REFERENCES}

Lovering, T.S. and Goddard, E.N., 1950. Geology and Ore Deposits of the Front Range, Colorado, U.S. Geol. Sumey Prof. Paper 223, 319 pp.

Moench, R.H. 1964. Geology of Precambrian Rocks, Idaho Springs District, Colorado, U.S. Geo1. Survey Bull. 1182-A. 
THE LOST PACKER MINE

(Ivers Mining Company)

LOCATION

The Lost Packer nine, a small gold, copper, and silver operation, is located in central Custer County 28 miles narth of Stanley, Idaho, at. $44^{\circ} 37^{\prime} \mathrm{N}, 114^{\circ} 53^{\prime} \mathrm{W}$ (Figure 1). Part of the Loon Creek District located in the Salnon Mountains, the nine lies at an elevation of $8600 \mathrm{ft}$.

The mine can be reached only by three dirt roads, either from Route 93 or Route 21, Because of the altitude and the fact that Route 21 is closed in winter access may be difficult.

\section{REGIONAL GEOLDGY}

The geology of the area has been described by Ross and Forrester, 1958, and Unpleby, 1911, and is illustrated in Figure 2.

The aldest rocks in the district are Precanbrian mica schist and quartzites which correlate with the Belt Series. (The Thompson Peak formation is the rock unit in the inmediate nine area.) They outcrop irregularly over an area of about two square miles in the central part of the district. These racks are truncated in most directions by late Cretaceous granodiorite and quartz-diorite outliers of the Idaho Batholith, but they are overlain to the north by quartz latite of Tertiary age (probably part of the Challis volcanic series). Few bedding planes are visible in these Precambrian rocks. Paleozoic rocks overlie the Precanbrian rocks in the south central part of the district. The two age groups are usually separated by a structural unconfornity, but it was not observed in the area of the Lost Packer mine. The Paleozoic rocks are fine-grained quartzites 

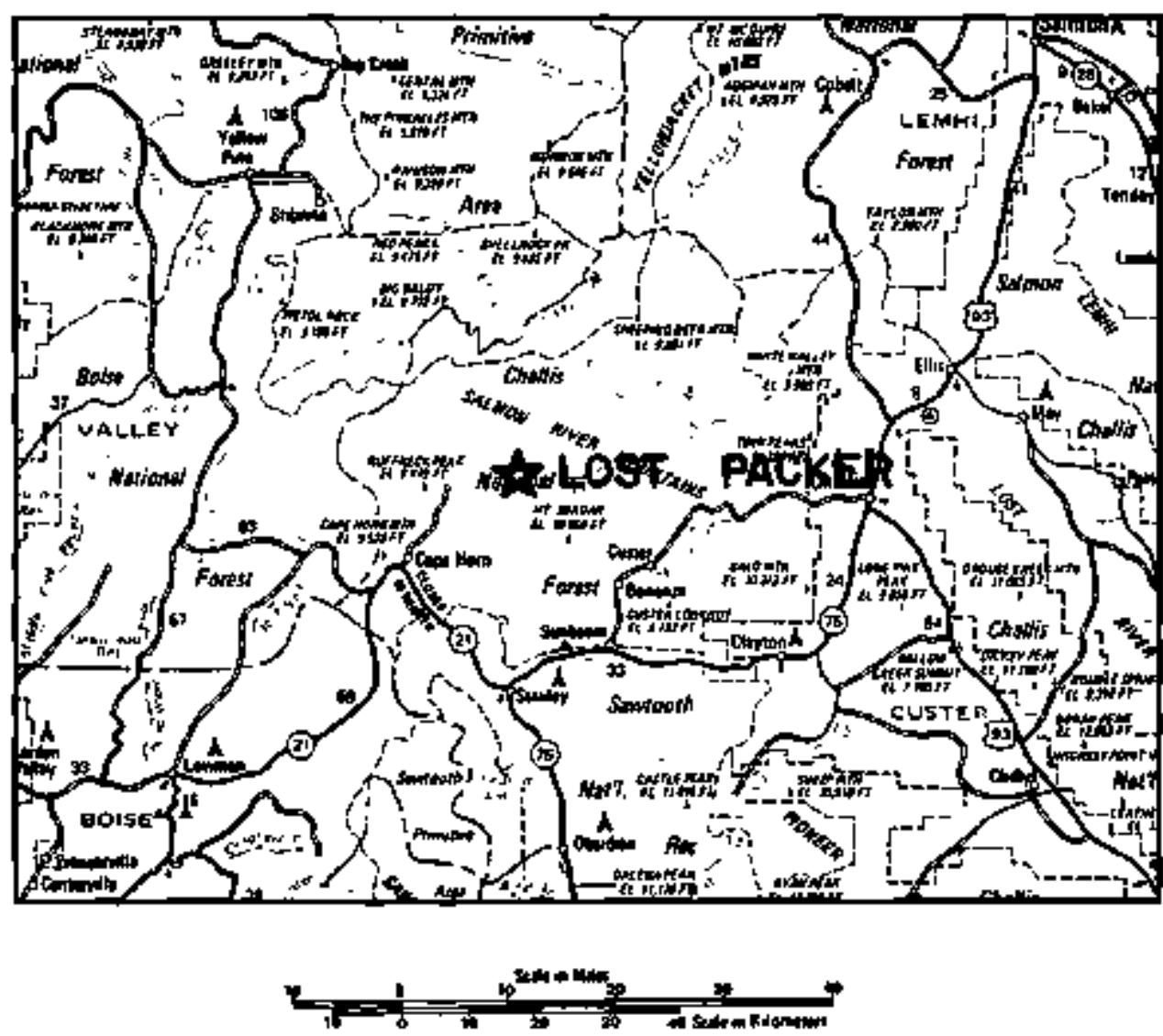

FIGURE 1. Location map showing the Lost Packer Mine, Custer County, Idaho. Basic map reproduced by permission of the American Automobile Association, copyright owner. 


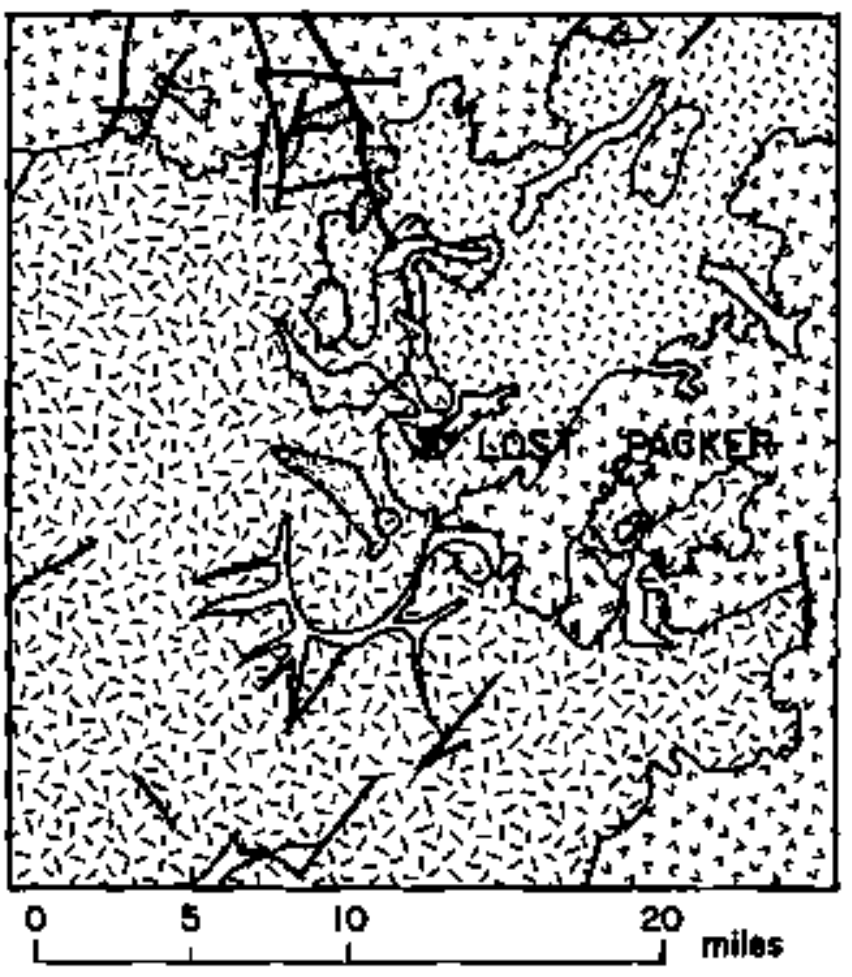

$\left[\begin{array}{l}0 \\ \hdashline\end{array}\right]$ Eocene intrusive rocks

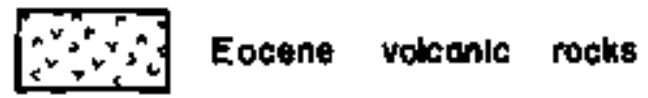

Esis's Mosozoic intrusive rocks

Fing Precambrian high-grade

Precombrion quartide with

FIGURE 2. Geologic nap of the Loon Creek nining district, showing the location of the lost Packer Mine. 
and blue dolomitic limestones which were considered by Ross and Forrester, (1958), to be, respectively, of Cambrian and Ordovician age. Some younger Paleozoic beds appear in other parts of Custer County. The late Cretaceous Idaho. Batholith, composed of granodiorite, quartz diorite, and quartz monzonite, extends into the Loon Creek District from the west, Outliers from it appear to the east of the Precanbrian metasediments and undoubtedly underlie the whole district. The granitic intrusions in the lost Packer nine are related to the batholith. Bikes and veins of granite porphyry and diorite porphyry, probable of Eocene age, also cut the area and the mine. Bond (1978) Indicates that the porphyries are capped by mixed Eocene, silielc and basaltic volcanic flows and reworked debris, surrounded by large granitic plutons and dike swarms, also Eocene age. The Idaho Batholith borders the Eocene intrustves to the west. Precambrian metasediments, lowgrade mica schist and quartzite, crop out 4 miles southwest of the mine (Ump1eby, 1911) (Figure 2). Based on the recent Idaho Geologic map (Bond, 1978), it appears that the netanorphic rocks may be mid- to high-grade. Gneissic rocks are found at the borders of the massive batholith intrusion (Ross and Forrester, 1958).

The direction of fracturing in the district is generally northeast to southwest (Bond, 1978). A strong schistosity in the Precambrian netasediments strikes west of north and dips southwest (Umpleby, 1911).

MINE GEOLOGY

The ore deposits of the Lost Packer nine occur in a fissure vein which is located in two host rocks: (1) a Precambrian mica schist, and (2) a Cretaceous quartz monzonite granodiorite-granite dike systen. The vein is offset and the ore often crushed by granite porphyry and diorite porphyry dikes. The dikes strike roughly parallel to the fissure vain but 
dip to the west less steeply than does the vein (Figure 3). The vein strikes $\mathrm{N}-\mathrm{S}$ and dips $75^{\circ} \mathrm{N}$. It varies in width from a few inches to 5 feet. The walls of the vein are well defined, and the vein is filled with gouge, sheeted schists, and/or lenses and stringers of ore. Ore minerals consist of coarse-textured milky-bluish white quartz with chalcopyrite; together with small anounts of pyrrhotite, pyrite, and siderite. The chalcopyrite is the main ore mineral and occurs as bunches, small patches, irregular grains, and interstitial fillings in a gangue of coarse quartz.

The gold is found mainty in the chalcopyrite and quartz. The age of nineralization is late Cretaceous to early Eocene (Umpleby, 1911; CRIB, $1974)$.

\section{FACILITIES}

The lost Packer mine, owned by Ivers Mining Company (801 Tribune Building, Salt Lake City, lttah) and operated by Ivers/Finland, is inactive and consists of six clains and two fractions. There are ten tumels with a total length of 10,000 feet reaching to a level of 1000 feet below the highest outcrop (Umpleby, 1911; CRIB, 1974). No report was found on when the mine became inactive. There is no information on the state of water in the wine.

The mine is reported as being explored in 1977 and to have three enployees (Idaho Dept, of Labor and Industrial Services, 1977).

A menorandum from U.S. Department of the Interior, Bureau of thines, released in 1979 reports that some form of activity occurred at the mine in 1978 . 


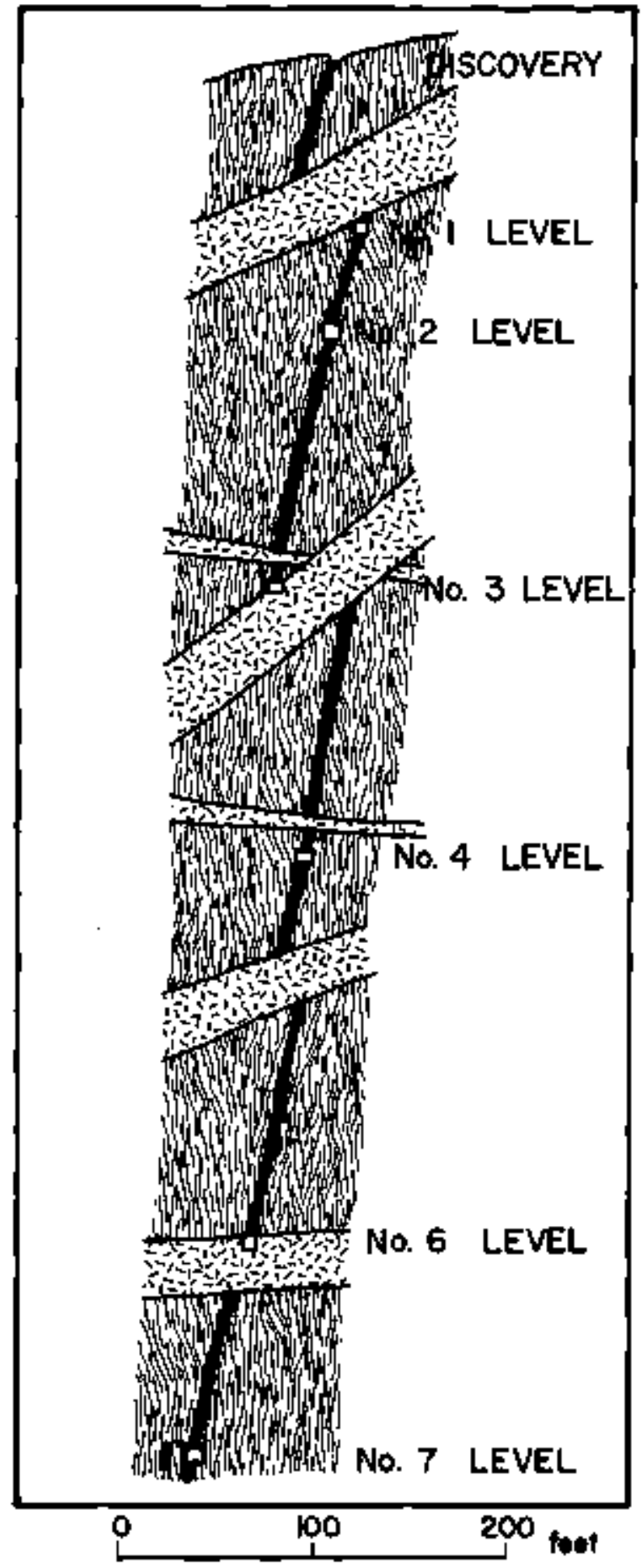

FIGURE 3. Transverse section through lost Packer veln, Loon Creek district, Idaho, looking north. Illustrates offsets in the veln caused by the intruston of dikes. (Unipleby, 1913) 
REFERENCES

Bond, J.G., compiler, 1978, Geologic map of Idaho: Idaho Dept. of Lands, Bur. of Hines and Geol, and U.S. Geol. Survey.

CRIB, 1974 .

Idaho Department of Labor and Industrial Services, 1977, The Kineral Industry of Idaho.

Ros\$, C.P. and Forrester, J.9, 1958, Outline of the feology of Idaho: Idaho Bur. of Mines and Geology Bull, 15.,74p.

Umpleby, J.B., 1911, A Preliminary Account of the Ore Deposits of the Loon Creek District: U.S. Geol. Survey Bull. 530.

United States Department of the Interior, Bur, of Mines Kenorandun, 1979, Active Mineral operations in 1978 - Idaho. 

THE COEUR D'ALENE DISTRICT, IDAHO

\section{LOCATION}

The Coeur d'Alene District contains some of the United States' deepest mines with a value of recorded base metal and silver production exceeding $\$ 2$ billion. The district is located in the panhandle of Idaho at $47^{\circ} 30^{\circ} \mathrm{N}$. $116^{\circ} \mathrm{W}$, between the cities of Hallace and Kellogg, 75 miles east of Spokane, Washington (Figure 1). Though the nines are in metamorphosed argillaceous rock, they are sufficiently deep and extensive, and have been characterized by rock mechanics research, to warrant their consideration in the context of this report.

GEOLOGIC SETTING

The distribution of nines, najor faults and intrusive rocks is shown on Figure 2 (fron Sorensen, 1947). The rocks of the Coeur d'Alene district comprise several units of the Precambrian Belt Series; their lithology and stratigraphy have been described by Hobbs and others (1965). The Belt Series is conposed predominantly of fine-grained, slightly metanorphosed quartzite and argillaceous quartzite. Small monzonitic intrusions and several varieties of dikes cut across the quartzite and vary in age from Cretaceous to late Tertiary. The Cretaceous nonzonite Gen stocks and the other intrusive rocks make up only a small part of the bedrock. However, they are important because of their tenporal and geographical relationship to the ore deposits.

The district is at the intersection of a north trending major anticlinal uplift and the west-northwest trending Lewis and C1ark 11ne. The Gen stocks crop out near the intersection and are aligned along the axis of the arch. The Osburn fault which strikes roughly east-west, is the doninant structural feature and bisects the district. The osburn, a right- 


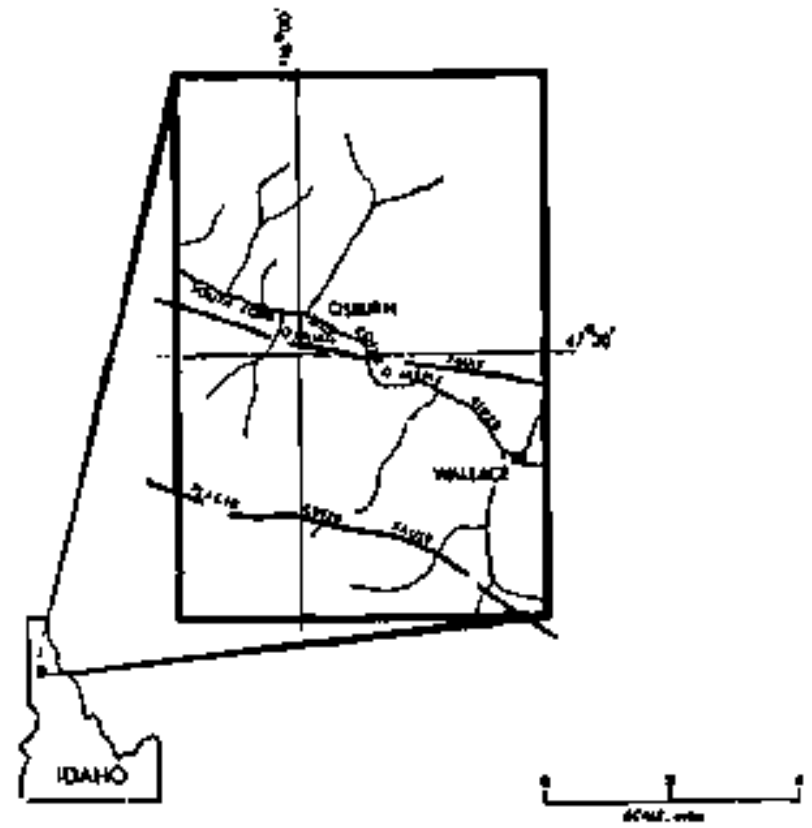

FIGURE la. Location map of Cocur d'Alene area (from Chan, 1972).

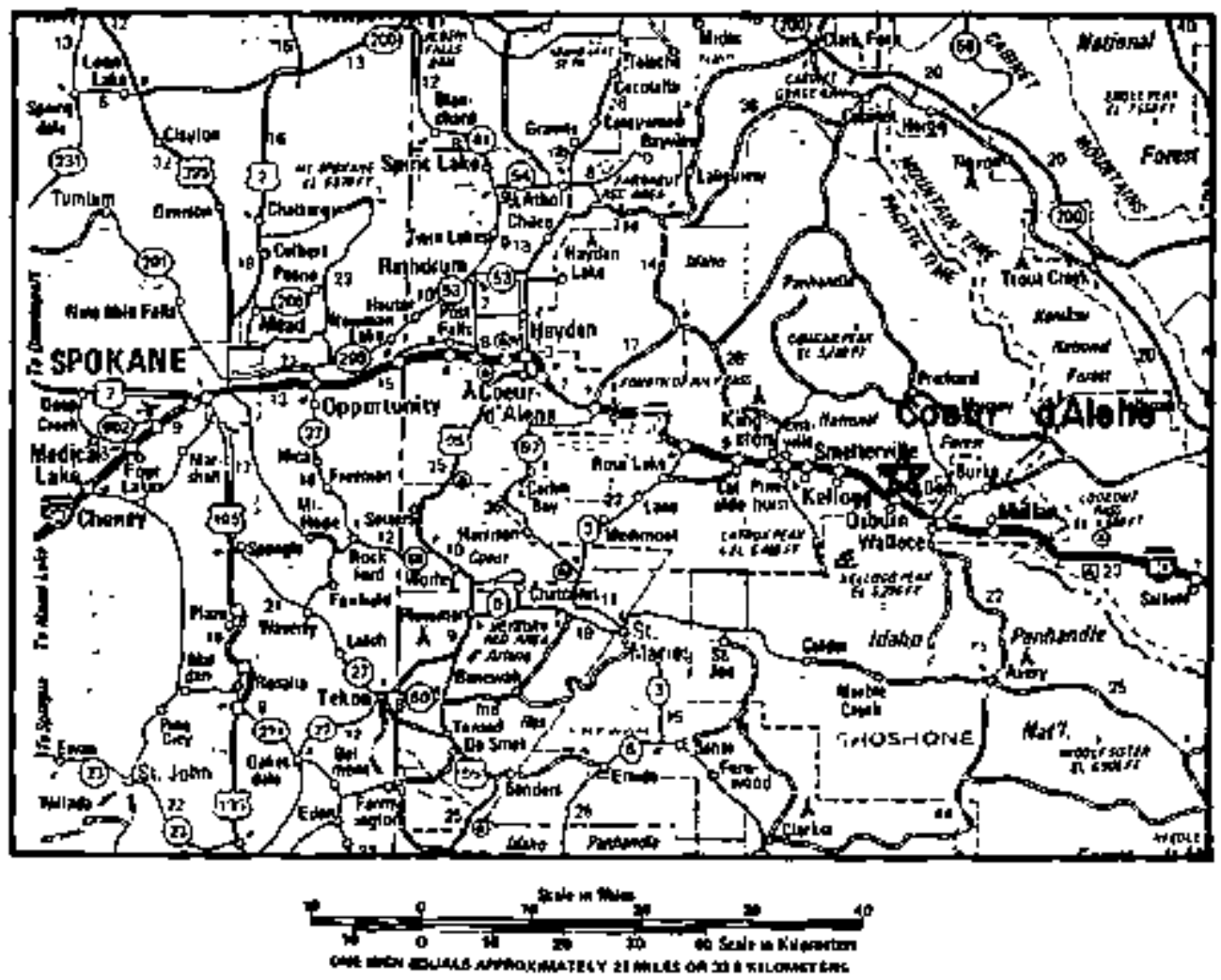

FIQURE 1b. Location of Coeur d'Alene District in Shoshone County, Idaho. Basic map reproduced by permission of the American Automobile Association, copyright owner. 


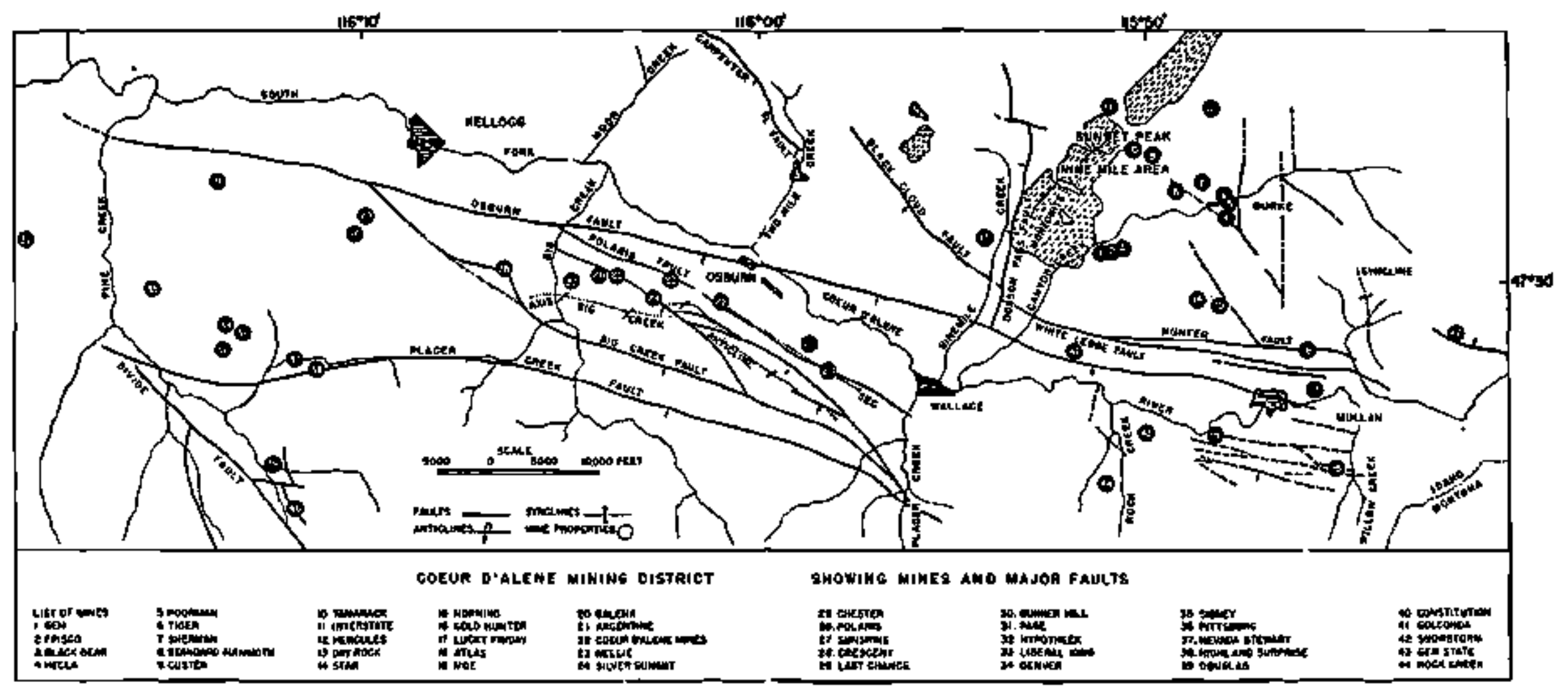

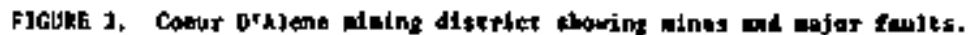
(Sorenton, 194)). 
latera1 strike-slip fault, offsets the major folds and other faults, and separates the northerm segment of the ore-bearing area from the segment to the south. The ore occurs in veins nostly in west-northwest striking fracture zones. The veins lie within a group of near-parallel separate mineral belts. Those mines north of the osburn fault include Hecla, Hercules, Standard-Mantoth, Tanarack, Dayrock, Frisco, and Star-Morning. The group on the south side of the osburn fault includes the Galena, Coeur, Sunshine, Crescent, Bunker Hill, and Page mines.

In general, the mine workings are in quartzite and argillaceous rocks. However, some mine workings [such as the Tanarack, Interstate, Gem, Frisco, and Dayrock nines) may extend into the Gen stocks and associated intrusives. The district includes the deepest $m i n e$ in the western herisphere, the Star mine, with workings extending to 8300 feet below the surface.

In the following sections, the lithology and structure of the district are described, followed by descriptions of three nines characteristic of the district.

\section{Lithology}

The lithology and stratigraphy of the Precambrian Belt Series have been described by Hobbs and others (1965 and 1968) and Sorenson (1947). The stratigraphic section is outlined in Table 1 and illustrated on Figure 3. The Belt Series is predoninantly argillite and quartzite. Regional metanorphism is evident in the recrystallization of quartz grains and the formation of micaceous minerals, chiefly sericite. Netanorphisn of sandy and muddy beds to quartzite and argillite is comon, with the quartzite grading to argilite. Sedinentary structures, such as mud cracks and ripple marks, abundant throughout the sequence. These features reflect a sha11ow water depositional environment for much of the series and a near balance between deposition and subsidence during much of Be1t time. Nowhere is the base of the Belt Series known to be exposed inside the district and 


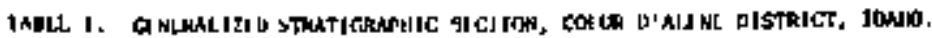

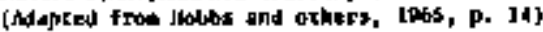

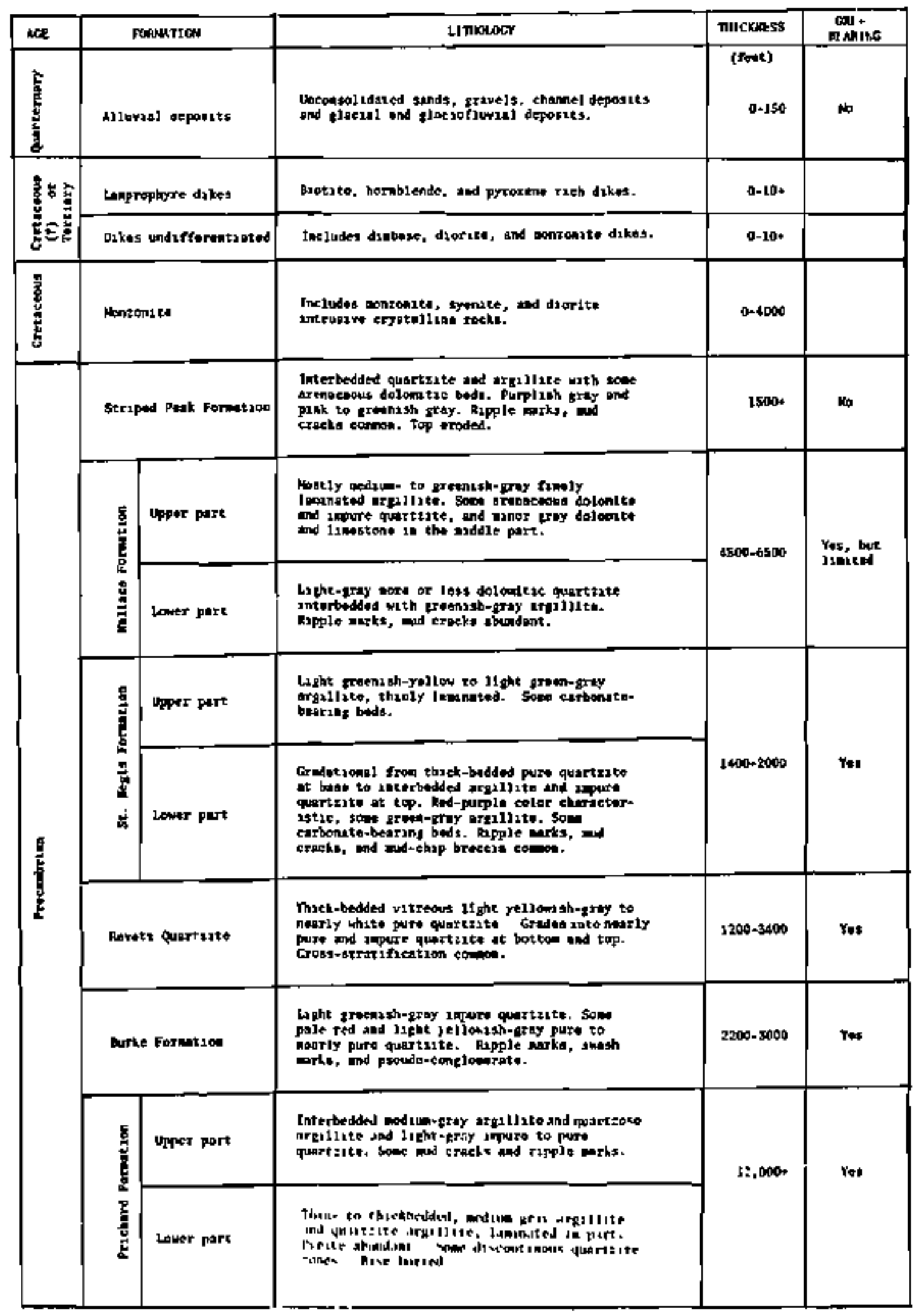




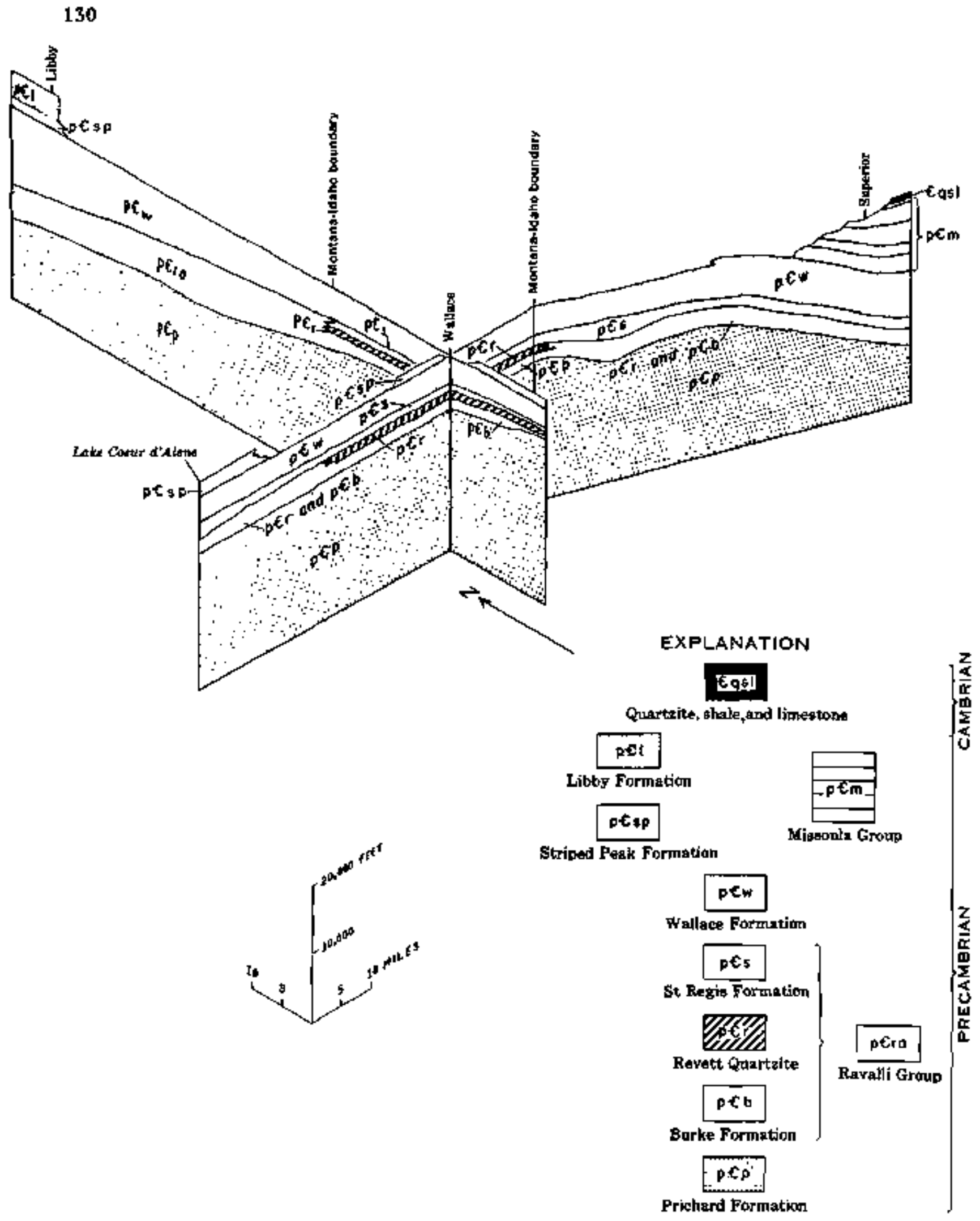

FIGURE 3. Isometric drawing of regional sections centered on the Coeur d'Alene district showing the general thickening of the stratigraphic section to the north and east (Hobbs and others, $1965)$. 
the thickest partial section, between 40,000 and $50,000 \mathrm{ft}$. (Campbe11, 1960), Occurs just east of the Coeur d'Alene district and trends northnorthwest. The Belt Series is divided into six units. They are, from oldest to youngest: the Prichard and Burke Formations, the Revett Quartzite, and the St. Regis, Wallace, and Striped Peak Formations.

The Prichard Fornation consists of dark gray to black argillite and argillaceous quartzite. A maximam thickness of $12,000 \mathrm{ft}$. is exposed; the thickness of the unexposed basal part is unknown. The upper section of the Prichard, up to $2000 \mathrm{ft}$. , consists of a transitional zone of alternating argillite and quartzite.

The overlying Burke Formation is composed of 2200 to 3000 feet of greenish-gray sericitic quartzite interspersed with some fairly pure quartzite. Sone argillaceous quartzite also occurs in the Burke Formation. The contact between the Burke Formation and the overlying Revett Quartzite is Indefinite, and a transition zone extends 500 feet or more.

The Revett Quartzite consists of massive, thick-bedded, gray to white quartz1te. Vitreous quartzite beds nake the Revett the most distinctive formation in the area. Within the district, the formation thickens from about $1500 \mathrm{ft}$. in the east to about $3400 \mathrm{ft}$. in the west.

The next overlying unt is the St. Regis formation which grades from interbedded quartzite and argillite to a dominantly thin-bedded argillite which is typically purplish-red to red in color. The upper section of the St. Regis Fornation is characterized by a chert-like, finely laminated argillite. The thickness varies from 1000 - $1400 \mathrm{ft}$. in sone areas.

The Wallace Formation is $4500-6000 \mathrm{ft}$. In thickness and consists of gray to white calcareous quartzite and gray to black calcareous argillite, dolomite, and limestone. 
The uppermost formation, the Striped Peak, consists of purplish, pink, and green quartzite and argillite. Only the basal $1500 \mathrm{ft}$. of the striped Peak lies in the district and its exposure is limited to small areas.

The Cretaceous monzonite stocks are made up of two nain bodies and several smaller ones, and are associated with the Idaho batholith. The bulk of the rock is monzonte but the composition ranges from syenite to diorite. The main bodies are known as the Gem stocks and are located north of Wallace and east of the Dayrock mine (Figure 2). The contacts on the east side of the stocks are generally steep or even overhanging, whereas the west boundartes dip somewhat less steeply to the west.

Diabase and lamprophre dikes which transect the district apparently represent two separate episodes of intrusion, and are of questionable Cretaceous and Tertiary age. The dikes commly are located along the prominent west-northwest faults and many have been sheared subsequent to thefr intrusion. The diabase dikes are nost numerous and most continuous south of the osburn fault. A large dike along the osburn fault is exposed in several mine workings and is probably fairly continuous. Another dike appears to be continuous from the Sunshine nine eastward to the Coeur d'Alene mine, a distance of about 3 miles, and it may extend farther. The lamprophyre dikes are abundantly exposed in mine workings. They are darkcolored, fine grained rocks characterized by biotite or hornblende phenocrysts. They are nost numerous north of the Osburn fault. The lamprophyre dikes are devoid of ore minerals, and some dikes clearly crosscut the monzonite stocks and the veins. Presumably the lamprophyre dikes represent one of the latest igneous episodes in the area, Other dikes include some silicic and intermediate rock types that are in part direct off-shoots fron the monzonite stocks and also some dikes of undetermined composition. 


\section{Rock Properties}

Rock properties and in-situ defornation behavior of the Revett Quartzite and St. Regis Formation (argillaceous quartzite) have been neasured by Chan and others (1972). In general, the quartzites were found to deform nearly 1inearly, starting at an applied stress of 5000 to 6000 psi and continuing to the ultimate strength of the rock. However, when rocks contain high percentages of carbonate, sulfide disseminations, and microfractures, or are highly argillaceous, the deformation becones non-linear. Details of these tests and deformation behavior of rock nasses in the Galena, Lucky Friday, Silver Suntit, and Star mines were reported in Chan and others (2972), in the Bunker H\$ll mine by Conway (1972), and in the Crescent nine by Skinner (1972). Regional Metanorphism

All Belt sedimentary rocks are weakly to noderately metamorphosed. The chlorite and biotite in the Prichard and Burke Fornations, far removed from the stocks, indicate the extent of regional metanorphism and show that it was low-mediun grade (Hobbs and others, 1965). Though the Belt Series rocks are predoninantly quartzite and argillite, in sone parts of the district, metamorphism has resulted in phyllite and schist.

Contact metamorphisn has occurred around the stocks. The nost widespread effect is an aureole of recrystallization, extending a few feet into the sedinentary units.

\section{Structure}

The regional structure of the Coeur d'Alene nining district is illustrated on the geologic map in Figure 2. The district is located at the intersection of the Lewis and Clark Line with a broad anticlinal arch that extends in a northerly direction fron the Idaho batholith to Kimberly, 
British Colunbia, Canada (Hobbs and Fryklund, 196B). The Lewis and Clark Line is a prominent zone of faulting, shearing, and complex folding that trends in an east-southeast direction. The Osburn fault is the mafor structure of the Lewis and Clark Line in the district. The rocks of the district are intensely deformed, and Hobbs and others (1965) describe the area as a "structural knot". The rocks are tilted, sheared, and faulted, and most dip at angles of $45^{\circ}$ or greater. Nearly vertical dips are connon and many beds are overturned.

faults are the dominant stmuctural feature of the Coeur d'Alene district and control the location of the ore deposits. The fauls have been grouped into four categories by Hobbs and others (1965):

(1) low-angle reverse faults

(2) early steep-dipping reverse and normal faults

(3) strike-slip and related nornal faults

(4) late normal faults.

The 0sburm fault, the major structural feature in the district, has a right-lateral displacenent of 16 miles. The Osbum divides the district into two parts that differ merkedly in structural characteristics (Wallace and others, 1961). North of the Osburn fault, the rocks are moderately deformed and the axes of the folds trend in a northerly direction. South of the osburn fault, the fold axes trend westerly and the folds are tightly compressed so that beds dip vertica11y and in sone cases are overturned. Between the Osburn fault and the Placer Creek fault, which roughly parallels the osburn $3-4$ niles to the south, are nunerous other faults that trend northwest. They form the connecting links between the two faults. Wost dip steeply to the southwest and are reverse, nornal, or strike-slip. The Crescent, Silver Sumbit, Consolidated Silver, and Coeur d'Alene mines 
are located along these falts. Two sets of faults predoninate north of Osburn fault. One set trends west-northwest and is subpara11el to the Osburn fau1t. The Lucky Friday mine is located within this set. The second set trends north and includes the location of the Dayrock wine. (Figure 2).

Fault gouge and zones of sheared, crumpled, or highly fractured rocks are associated with all the faults. Hobbs and others (1965), report that in quartzite:

"The strain along a fault is characterized by a relatively narrow zone of gouge bordered by a zone of breccia which grades outward into sma11 shears and joints. In comparison, along a fault of similar displacement in argillite, the strain produces a relatively wider zone of gouge surrounded by contorted and crumpled rock."

An example of zones of fault gouge and brecciation along the osburn fault is fllustrated in the Morning mine (Figure 4 ). Bedding-plane slippage and puckering are additional types of faulting or shearing that are common in the district.

Hobbs and others (1965) recognized differences in the structure and 1ithology on opposite sides of the Osburn fault and use this information to substantiate the 16 miles of right lateral strike-slip displacenent along the tault. On the other hand, Full (1955) believed that the geology is too complex to explain the displacentent on the Osburn fault as strikeslip. However, geologic evidence substantiates the observations that the pattern of faulting formed after the major period of folding . Displacement along strike-slip faults has offset fold-axes, and displacement on dip-slip faults has cut folds.

Mineralization is probably directly related to the structural history of the region and extends from Precambrian to Tertiary time. The veins of 
EXPLANATION

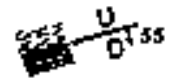

Fault and sheared zone Showing dip; U. wothromn side, D, downthrown snde

$$
x
$$

Anticline, showing plunge

$$
x
$$

Syncline, showing plunge

$$
\text { مئم }
$$

Strike and dip of beds

$$
+\infty
$$

Strike and dip of overturned beds

$$
20
$$

Strike and dip of foliation

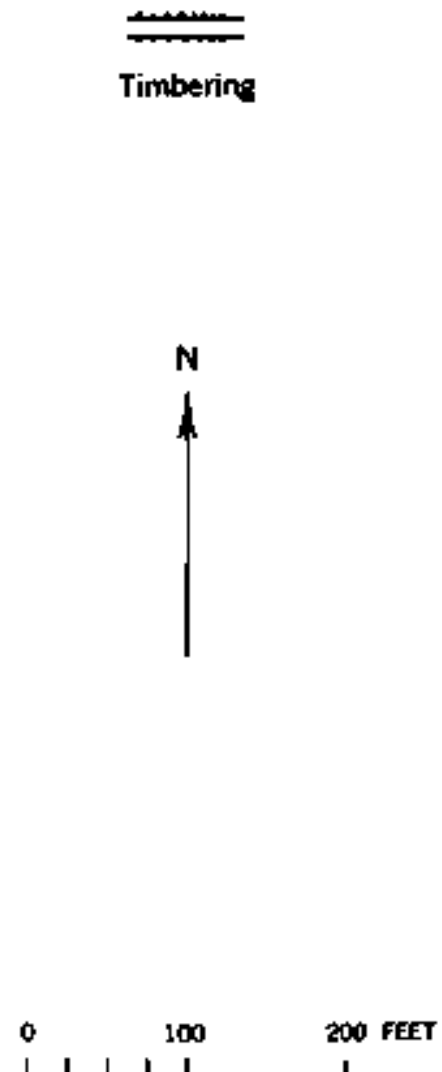

2500 it fitam oontal

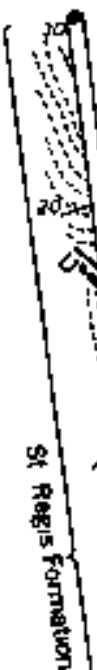

inite quatorte on Irest gurluxes

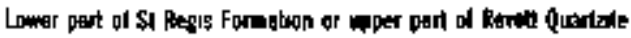
$\Delta$

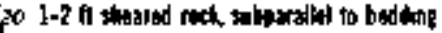

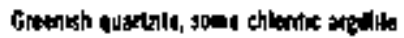

Ss

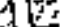

Cortun shiorilut lowe

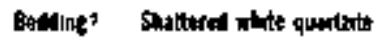

Broum quartate, highly shattered

Ores folds and puchuts

40 Terbediad, मू-] m,

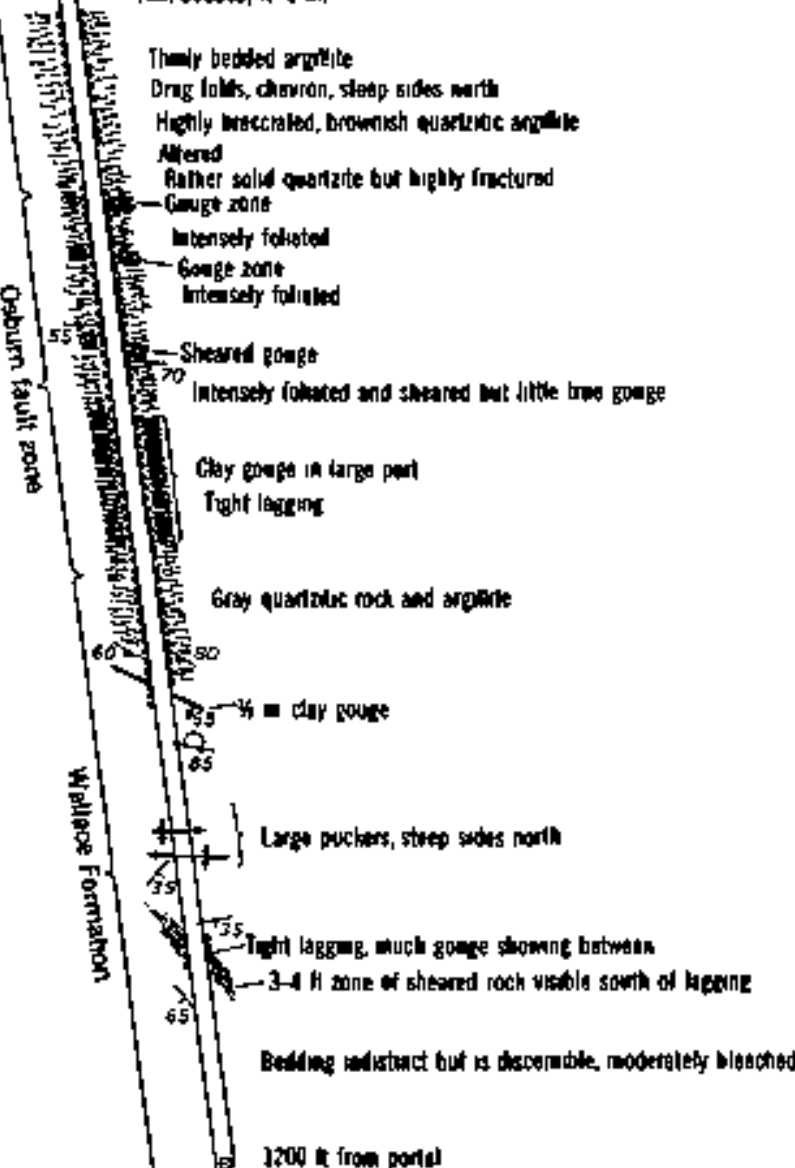

FIGURE 4. Zones of fault gouge and brecciation along Osburn fault as seen in the main cross cut of the Star-Morning mine (Hobbs and others, 1965). 
the major period of ore formation were probably localized along a system of throughgoing fractures that were opened after the intrusion of the nonzonite stocks. Thus, the major mineralization is Cretaceous or younger. Much of the structural pattern was present prior to the formation of the principal ore deposits; however, a major amount of strike-slip movenent took place after ore emplacement. Regardless of the differences in fault pattern and orientation in the district, all the major ore bearing zones have approximately the same orientation, N65 $\mathrm{W}$. The orientation of the zones of ore bodies is about $10^{\circ}$ to $15^{\circ}$ more northerly than the general trend of the osburn fault.

ORE DEPOSITS OF THE COEUR D'ALENE DISTRICT

The Coeur d'Alene district ore deposits have been described by severa1 authors, including Sorenson $(1947)$, Campbell and others (1961), Hobbs and Fryklund (1968), and Carter and Li (1976). The definitive study is the paper by Fryklund (1964). The major ore deposits are steeply dipping tabular replacement veins containing lead, zinc and silver. The veins range in thickness from less than an inch to a yard, and locally may be several times this thickness. Individual ore shoots are known to range in length from several feet to more than 3000 feet and sone nay exceed this length when fully developed. The important producing veins are nearly straight, parallel to subparallel, and trend about $\mathrm{N} 65^{\circ} \mathrm{W}$.

There were $s i x$ periods of mineralization, each distinguished by the ninerals it emplaced (Fryklund, 1964). Precambrian mineralization is represented by arsenopyrite-pyrite veins cut by uranitumbearing veins. Hydrothernal alteration al so occurred in the Precanbrian. Late in the Cretaceous, after enplacenent of the Gen stocks and monzonite, the main period of mineralization occurred. The metal-producing veins of gal ena, sphalerite, and tetrahedrite were intruded, and the surrounding country 
rock was recrystallized. The final phases of mineralization occurred in the Tertiary period. The first was a period of base metal mineralization. A second phase is represented by stibntte and scheelite-stibnite veins; these veins are older than the Tertiary diabase dikes. A third phase includes arsenopyrite and gold veins; these veins are younger than the diabase dikes.

The mineral belts are structural features. In sone p1aces the mineral belts parallel the trends of the fold axes; in others they cut across the axes at high angles. The monzonfte stocks interrupt the mineral belts but do not disturb the main trends of the belts that are aligned across them. Within the mineral belts the distribution of veins, shears, and fractures differs from place to place and apparently is affected by the physical properties of the country rock and other factors.

The length of the mineral belts ranges from 1-14 miles. The ore shoots are scattered in the mineral belts in a random pattern. The size of individual shoots covers a broad range, An example of a large ore shoot is the main ore body in the Star and Morning mines. This ore body neasures 3000 ft. long and $7500 \mathrm{ft}$. from its exposure at the surface to the lowest level mined. The maximum vertical extent is not knom; its width is up to $60 \mathrm{ft}$. The mineralization is clustered in two groups on opposite sides of the Osburn faut, localized along well-defined parallel or subparallel belts. As sumbarized by Hobbs and Fryklund (1968), the ore belts north of the Osburn fault are zoned concentrically around the Gem stocks; the major ore minerals are galena and sphalerite. The deposits south of the Osburn fault show no evidence of concentric zoning, the gangue ninerals show no order1y pattern, and the major ore ninerals are sphalerite, galena, and tetrahedrite.

Anong the 175 mines of the Coeur d'Alene district, which include 32 active mines (Idaho Dept, of Labor and Industrial Services, 1978), there 
are many deep underground workings in netamorphic rock. Two mines north of the 0sburn fault, the Dayrock and Star-Horning, and the Coour mine south of the fault will be described because of their characteristics and potential accessibility. Other mines in the district with potential because of rock type, depth of workings, and possible accessibility are the Lucky Friday, north of the Osburn fault; and the Consolidated Silver, Silver Summit, Crescent, Galena, and Sunshine south of the fault. 
REFERENCES - COEUR D'ALENE DISTRICT

Carter, R.A., and Li, T.M., 1976, Idaho's Coeur d'Alene district sets sights on record production: Min. Eng., v. 28 (7), p. 49-64,

Chan, S.S.M., Crocker, T.J., and Waddel1 G.G., 1972, Engineering properties of rocks and rock masses in the deep mines of the Coeur d'Alene mining district, Idaho: A IME Trans., v. 252, p. 353-360.

Chan, S.S.M., 1969, Suggested guides for exploration from geochemical investigation of ore veins at the Galena mine deposits, Shoshone County, Idaho: Quart. Colo. Sch. Mines, v. 64 (1), p. 139-168.

Conway, J., 1972, Physical properties of mine rocks, Bunker Hill Mine, Coeur d'Alene District, Idaho: AIME Trans., v. 252, p. 359, Appendix I.

Crosby, G.M., 1969, A preliminary examination of trace mercury in rocks, Coeur d'Alene District, Idaho: Colo. Sch. Mines, Quart. v. 64 (1) p. 169-194.

Fryklund, V.C., Jr., 1964, Ore deposits of the Coeur d'Alene district, Shoshone County, Idaho: U.\$. Geol. Sturvey Prof. Paper 445, 103 pp.

Full, R.P., 1955, Structural relations north of the Osburn fanlt, Coeur d'Al ene district, Shoshone County, Idaho; University of Idaho thesis.

Gott, G.B., and Botbol, J,M., 1975, Possible extension of minergl belts. northern part of Coeur d'Alene district, Idaho: U.S. Geol. Survey $J$. Res., v. 3 (1), p 1-7.

Hershey, 0.H., 1916, Origin and distribution of the ore in the Coeur d'Alenes: San Francisco kin. Sci. Press, $32 \mathrm{pp}$.

Hietanen, A., 1963, Idaho Batholith near Pierce and Bungalow, Clearwater County, Idaho: U.S. Geol. Survey Prof. Paper 344-D, $42 \mathrm{pp}$.

Hobbs, S.H., and Fryklund, V.C., Jr., 1968, The Coeur diAlene district, Idaho: in Ridge, J.D., ed., Ore deposits of the United States, 19331967, AIME, p. 1417-1435.

Hobbs, S.W., Griggs, A.B., Wallace, R.E., and Campbel1, A.B., 1965, Geology of the Coeur d'Alene District, Shoshone County, Idaho: U.S. Geol. Survey Prof, Paper 478, 139 p.

Hosternan, J.W., 1956, Geology of the Murray area, Shoshone County, Idaho: U.S. Geol. Survey Bull. 1027-P, p. 725-748.

Idaho Bureat of Mines and Geology, 1963, The Coetur d'Alene mining district: Idaho Bur. Min. Geol. Pamph, 133, $103 \mathrm{pp}$.

Idaho Department of Labor and Industrial Services, 1978, Fourth annual report on mine safety bureau: Idaho Dept. Lab. \& Ind. Serv., 56 pp. 
Mitchan, T,W., 1952, Significant spatial distribution patterns of minerals in the Coeur $d^{\dagger}$ Alene district, Idaho: Science, $v .115(2975), p .11$.

Reid, R.R., ed., 1961, Guidebook to the geology of the Coetr d'Alene mining district: Idaho Bur. Min. Geol. Pamph. 133, 103 pp.

Ross, C.P., and Forrester, J.D., 1958, Dutline of the geology of Idaho: Idaho Bur. Min. \& Geol. Bull. 15, 74 pp.

Ross, C.P., 1935, Copper in Idaho: In Copper Resources of the World, 16th International Geological Congress, p. 261-269.

Silverman, A., Long, A., and Kulp, J.L., 1960, Age of Coeur d'Alene mineralization: an isotope study: AIME Trans, , v. 217, p. 117-118.

Skinner, E.H., 1972, Sumary of physical properties from Crescent Mine, Coeur d'Alene District, Idaho: AIME Trans., v. 2\$2, p. 359-360, Appendix 2.

Sorenson, R.E., 1947, Deep discoveries intensify Coeur d'Alene activities: Eng. Min. J., v. 148 (10), p. 70-78.

Unpleby, J.B., 1924, The Osburn Fault, Idaho: J. Geol., v. 32 (7), p. 60I-614.

U.S. Bureau of Mines Minera1 Yearbook 1979, Area Reports, 1973: U.S. Bur. Min., v. 2, p. $246-7$.

Wallace, R.E., Griggs, A.B., Campbe11, A.B., and Hobbs, S.W., 1961, Tectonic Setting of the Coeur d"Alene District, Idaho: Idaho Bur. Min. Geol, Bul 1. 16, p. 3-5.

The Wallace Hiner: April 19, 1979

April 26, 1979

July 5, 1979

July 12, 1979 . 


\section{DAYROCK HINE}

(DAY MINES, INC.)

\section{LOCATION}

The Dayrock Mine lies 3 miles north of Wallace, Idaho, along Ninemile Creek Canyon, at a surface elevation of $3200 \mathrm{ft}$. Its 1ocation is shown on Figure 2 of the preceding section. The lead-silver-zinc nine is located at township $48 \mathrm{~N}$, range $4 \mathrm{E}$, section South $10,11,14$, and 15 . It was reported active in 1978 with seven employees (Idaho Dept. of Labor and Industrial Services, 1978). Currently, the mine is inactive and is being kept open for potential exploration.

GEOLOGIC SETTING

The geologic setting of the Dayrock mine was described by Hobbs and others (1965), Farmin (1961), Fryklund (1964), and Carter and Li (1976). A generalized geologic cross section, Figure 1, shows the rock type, geologic structure, and ore bodies to a depth of 1250 feet. The host rocks are the Precambrian Belt Series argillites and quartzites. The upper three-quarters of the nine is located in St. Regis argillites and the lower quarter is in underlying Revett Quartzite. Shearing and alteration have weakened the rock and there are abundant clay minerals and sericite in the argillite.

One of the Gen stocks lies approxinately $250 \mathrm{ft}$. east of the nine; however, its proximity is the result of moverent on the nearby Dobson Pass fault. A few dikes cut across the mine for lengths up to $100 \mathrm{ft}$. They are a1tered and softened, requiring timbering in the mine.

The ore is mainly galena, pyrite, sphalerite, and tetrahedrite with subordinate agounts of gangue minerals. The ore occurs in lenses, stringers and disseminations. 


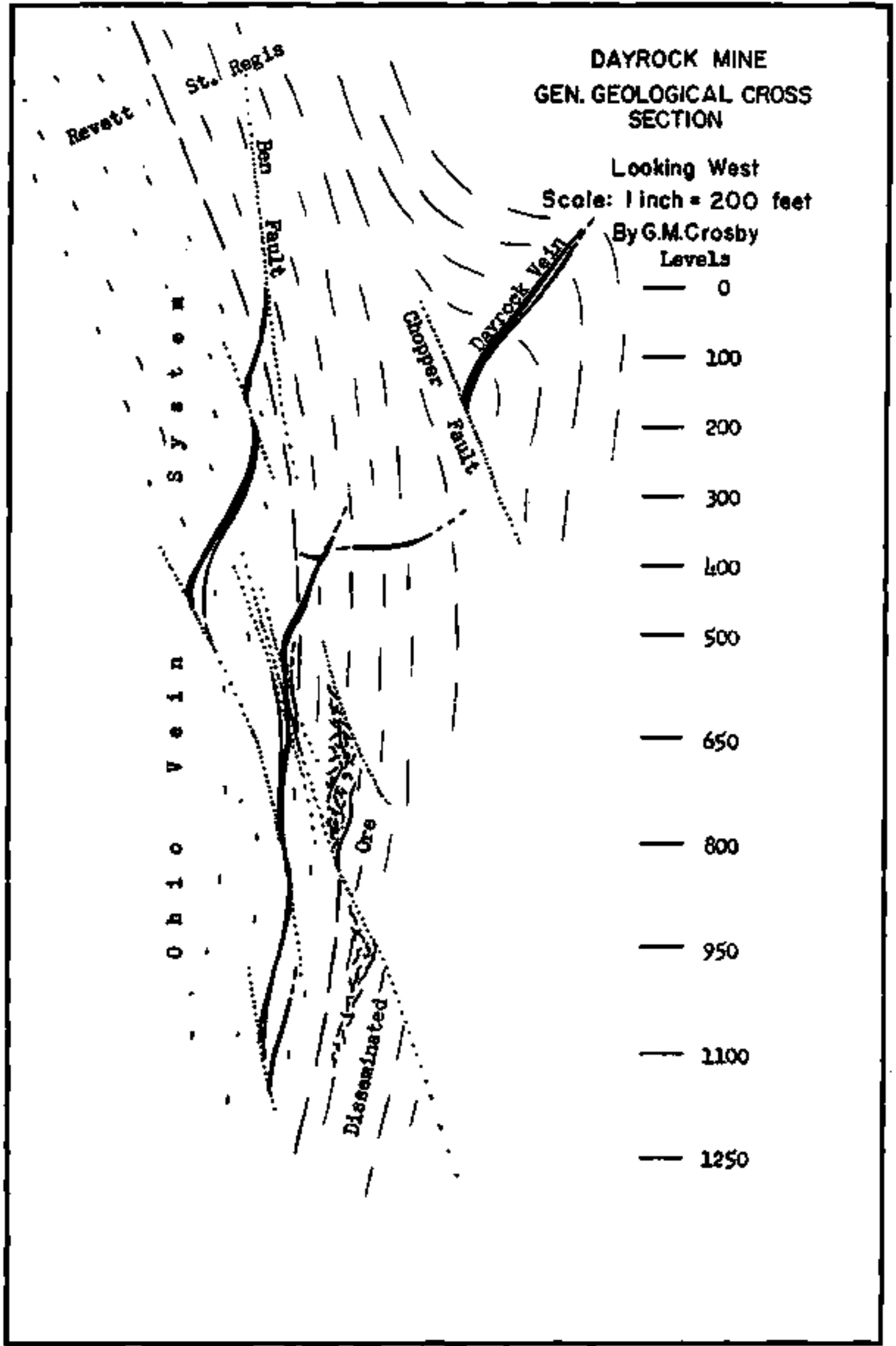

FIGURE 1. Generalized geologic cross section of the Dayrock mine, Coeur d'Alent mining district, Idaho (Farmin, 1961). 
STRUCTLRAL SETTING

The Belt rocks in the Dayrock mine strike northwesterly and dip northeasterly $45^{\circ}-80^{\circ}$. The mine area is bounded by the Dobson Pass fault on the east and the Blackcloud and Osburn faults on the south. The veins occupy fractures or shears in the host rocks and may be traced for up to hundreds of feet. Numerous stringers, pods, and disseminated bodies of ore mineralsare scattered between the veins.

Faulting in the Dayrock mine is complex (Hobbs and others, 1965). Normal faults cut the veins and displace then by as much as hundreds of feet, progressively lower to the west. Another set of faults with reverse movement up to $90 \mathrm{ft}$. parallels the veins, complicating the geology and mine developnent. The rocks and, to a lesser extent, the veins are dragfolded, especially near faults.

\section{MINE CHARACTERISTICS}

Notes on the Dayrock mine workings and nining method are based on few sources and a paucity of information. The workings are in quartzite and argillite and may extend into intrusive rock. They include a $300 \mathrm{ft}$. adit, a vertical shaft, and twnels at the $1400 \mathrm{ft}$. and $3000 \mathrm{ft}$. Ievels, and possibly others. A total of 900,000 tons of ore were extracted between 1923 and 1962 with a 3.6 million oz. silver content (Idaho Bureau of Mines and Geology, 1963). The mine workings are fairly wet and are timbered in the faulted and sheared areas (Acres, 1975). The lead, silver, and $z$ inc is vein mined by cut and fill (Cobbs, 1976). Some areas are backfilled with quartz sand. Haulage is accomplished by rail.

The Dayrock mine was reported mined out in mid-1974 (Carter, 1976); however, new exploratory drilling was completed in 1975 in an area west of the mineralized zones. Results were inconclusive and additional drilling or shaft sinking nay have been undertaken. 
REFERENCES - DAYROCK MINE

Acres American Inc., 1975, Federa1 Energy Adninistration Underground Storage Program, File 4074.07.

Carter, R.A, 1976, Idaho's Coeur d'Alene District sets sights on record production: Min. Eng., v. 28, (7) p. 49-64.

Cobbs Engineering, 1976, Survey of Active and Inactive Mines for Possible use as in situ test facilities: Office of Waste Isolation, Oak Ridge, Tenn., Report No. Y/OHI/SUB=76/16514.

Farjnin, R., 1961, Geology of the Dayrock mine, Coetur d'Alene District, Idaho: Idaho Bur. Min. Geol. Bu11. 16., p. 21-22,

Fryklund, V.C., JT., 1964, Ore deposits of the Coeur d'Alene District, Shoshone County, Idaho: U.S. Geol. Survey Prof. Paper 445., 103 p.

Idaho Bur: Min. Geol., 1963, The Coeur dralene Mining District in 1963: Idaho Bur. Min. Geol. Pamphlet 133, , 103 p. 


\section{STAR-MORNING MINE \\ [BUNKER HILL-HECLA MINING COMPANIES)}

\section{LOCATION}

The Star-Morning Unit represents the intersection of the Star nine workings on the west and Morning workings to the east. It is situated six niles northeast of Wallace, Idaho, and north of the osburn fault. The mine's location is shown on Figure 2 of the preceding section. The StarNorning ore shoot lies-in rocks of the Precambrian Belt Series in township $48 N$, range $5 E$, section 21 and 22 . The mine is reported active and contintling nomal operations with very good results during the first quarter of 1979 (Wallace Miner, Apr. 19, 1979). There were 360 employees at the Star mine and 2 at the Morning in 1978 (Idaho Dept, of Labor and Industrial Service, 1978). The Star and Morning nines are operated as a single unit, and are accessible by interconnecting tunnels at depth.

\section{GEOLOGIC SETTING}

The geologic setting of the Star-borning mine has been described by Hobbs and others (1965), Frytklund (1964), and Sorenson (1947), It is assuned that the geology of the Star-borning Init is similar to, and closeiy associated with, the Star and Morning mines; however, literature does not give sufficient detail to validate this assumption. The Star mine is 10cated entirely in Precambrian Revett Quartzite, while the top of the Morning mine is in the St. Regis Formation (argillite and quartzite), but because the contact between the Revett Quartzite and \$t. Regis Formation dips steeply eastward, most of the mine levels are in both formations. Beds in the Star and Morning mines generally strike slightly west of north, dip 
steeply, and are cut by the veins at high angles. A nonzonite dike is exposed in the upper level of the Star-Korning mine. Fine grained dikes with phenocrysts transect the mine. The largest dikes extend $5500 \mathrm{ft}$. fron the top of the nine with a maximun width of $70 \mathrm{ft}$. The dikes are associated with haloes of alteration that may extend $50 \mathrm{ft}$. or nore into the country rock on each side. The alteration includes chlorite and chloritized quartzite.

STRUCTURAL SETTING

The Star fault cuts the Star mine veins and is subparallel to then. The fault also offsets the monzonite dike. There is about $270 \mathrm{ft}$. of displacenent on the Star-Morntng ore shoot with the north side moving east on the Star 2300 level. More recent faults have developed thick gouge seams in the vein and along the hanging wall and footwall.

\section{MINERALIZATION}

The Star-Morning ore shoot is the largest in the Coetur d'Alene district. The vein in the Morning mine was stoped for about $6725 \mathrm{ft}$, with the last $1000 \mathrm{ft}$, below sea level, where the vein still contains ore. The ore shoot has not been mined to the same depth in the Star nine. Within the ore shoot, the vein is divided by large inclusions of country rock. The average vein width is about $10 \mathrm{ft}$.

The main ore body of the Star mine is in a nearly vertical shear zone strıking $N 79^{\circ} \mathrm{W}$ and has a gaximum length of $4000 \mathrm{ft}$, and an average stoping width of $10 \mathrm{ft}$. The competence of the ore veir is less than the wall rock. Physical properties of the quartzites collected from the lower levels of the mine show an average compressive strength of 26,000 psi (Chan and 
others, 1972), an average nodulus of elasticity of $8.5 \times 10^{6} \mathrm{psi}$, and an average tensile strength of 1500 psi (Haddell, 1966). Addittanal rock properties and in-situ measurements have been completed by Patricio and Beus (1976).

MINE CHARACTERISTICS

The Star-Morning Unit is mined by the horizontal cut and fi11 method. There are five shafts and extensive tunnelling at depths from 800 to 1400 feet below the surface. Actual ore tomnage is 282,000 short tons with a daily ore capacity of 1100 tpd and 852,000 tons proved reserves (E/MT, 1977). The mine is a leading producer of silver, zinc, and lead, with a cumulative ore tonnage of 20 million tons $(1894-1962)$ and 49 nillion ounces of silver (Idaho Bur. of Min. Geol., 1963).

The workings extend to a depth of $6720 \mathrm{ft}$. with a length of approximately $3900 \mathrm{ft}$. and width of $49 \mathrm{ft}$. (CRIB, 1976). The $\$$ tar and Morring mines-tunnelled through the mountain and joined workings in the late 1970 's; currently an exploratory tunnel is being driven to the Lucky Friday nine across the Hunter fault with five miles of tunnelling in barren rock. Recent exploration may have extended workings into plutonic rock. 
REFERENCES - STAR-MORNING MINE

Chan, S.S.H., Crocker, T.J., and Waddell G.G., 1972, Engineering Properties of rocks and rock masses in the deep mines of the Coeur d'Alene District, Idaho: AINE Transactions, v. 252 (12) p. 353-360,

Engineering \& Mining Journal, 1977 International Directory of Mining and Mineral Processing Operations: E/MJ, New York, $229 \mathrm{pp}$.

Fryklund, V.C., Jr., 1964, Ore deposits of the Coeur d'Alene District, Shoshone County, Idaho: U.S. Geol. Survey Prof. Paper 445, 103 p.

Gott, G.B., and Botbo1, J,M., 1975, Possible extension of nineral belts, northern part of Coeur d"Alene District, Idaho: U.S. Geol. Survey J. Res., v. 3 (1), p. I-7.

Hobbs, S.w., Griggs, A.B., Watlace, R.E., and Campbe11, A.B., 1965, Geology of the Coeur d'Alene District, Shoshone County, Idaho: U.S. Geol. Survey Prof. Paper 478, 139 p.

Idaho Bureau of Mines and Geology, 1963, The Coeur d'Alene District in 1963: Idaho Bur. Mines Geoi. Panph. 133, 103 pp.

Patricio, J.G.; Beus, M.J., 1976, Determination of the In Situ kodulus of Defornation in Hard Rock Mines of the Coeur d'Alene District, Idaho, Symp, Rock Mech., Proc. 17, Snowbird, Utah, p. 489.1-489.7.

Sorenson, R.E., 1947, Deep discoveries intensify Coeur d'Alene activities: Eng. Min. J., v. I48, (10), p. 70-78,

Wadde11, G.G., 1966, In-Situ measurements of rock deformation in a veintype deep mine: U.S. Bur. Mi̇es Report Invest. 6747, 47 pp. 


\author{
THE COEUR MINE \\ AMERICAN SNELTING AND REFINING COHPANY \\ (COEUR D'ALENE MINES CO+)
}

\title{
LOCATIOON
}

The newest silver mine in Idaho, the Coeur mine began operation Jume 1976 and currently ranks fifth in terms of production anong underground silver mines in the United States (Wallace Niner, Apr, 26, 1979). It is located along the Polaris fault, south of the Osburn fault, and 3.5 niles west of the city of Wallace. Its location is shown on Figure 2 of the preceding section. The mine came into production after 11 years of exploration and development costing $\$ 20$ nillion (Carter, 1976). The deposits lie in quartzites and slates, in the footwall of the Polaris fault. The mine has extensive workings to a depth of $4428 \mathrm{ft}$. and the 3400 foot level connects the Coeur to the Galena mine, $7500 \mathrm{ft}$. to the southeast.

\section{GEOLOGIC SETTING}

The geologic setting of the Coeur nine was described by Carter and li (1972), Hobbs and others (1965), and Fryklund (1964). The coeur orebearing veins lie in quartzites, argillite, and slate in the Precarbrian St. Regis-Revett transition zone. The transition zone extends from near the surface to the 3700 foot level. The veins strike from the northeast to northwest, dip steeply to the south, average over $5 \mathrm{ft}$. in width, and have an werage strike 2 ength of $750 \mathrm{ft}$.

The ore-bearing veins also occur along the footwall of the Polaris fault which is well exposed in several of the workings. A zone of gouge a few inches wide and several yards of sheared rock are comonly associated 
with the fault. On the adit level, the zone of gouge and sheared rock along the fault is more than $10 \mathrm{ft}$. wide. Very little specific geologic information on the new mine is available in the 1iterature.

\section{MINERALIZATION}

Most of the mineralization is contained in two veins. One vein has a strike length of $600 \mathrm{ft}$. and extends vertically for about $1000 \mathrm{ft}$. The second vein has a strike length of $800 \mathrm{ft}$. and a vertical extent of more than $1600 \mathrm{ft}$. These two veins having an average thickness of $5 \mathrm{ft}$. are the initial mining targets.

\section{MINE CHARACTERISTICS}

Conventional horizontal cut and fill nethods are used to mine the ore. Drifts are being driven on the veins to further develop ore blocks by raising. From the horizontal stope cuts, ore is slushed to chutes that feed the main haulage rail syster. Stopes are filled with mill tailings.

The mine workings include two shafts. The main shaft extends to a depth of $4430 \mathrm{ft}$. with the last $1134 \mathrm{ft}$. below sea level. Other mine developnent work includes a $2300 \mathrm{ft}$. ventilation ralse and development raises. A drift has been driven fron the Coeur 3400 foot level to the Galena mine 3700 foot level to serve as a secondary exit.

Production in 1977 was 118,600 short tons with daily capacity of 450 tpd (Eng. Min. J. Directory, 1977). The net production in 1978 was 152,000 tons extracted (Wa1lace Miner, July 5, 1979).

Recent development work has added more than 150,000 short tons of new ore to reserves (E/MJ, March 1979). Plans reported in March 1979 call for 
extending working levels of the Coeur mine (E/MJ, March 1979).

Mining equipment includes a rail haulage transport systen, and a double-drum hoist in the main hoisting area. 
REFERENCES - COEUR MINE

Carter, R.A., and Li, T.M., 1976, Idaho's Coeur d'Alene District sets sights on record production: Min. Eng. v. 28, (7) P. 49-64.

Engineering and Mining Joumal, 1976, Asarco's newly dedicated Coeur silver mine will be fourth largest in U.S.: E/MJ, v. 177, (7) p. 23-27.

Engineering and Mining Journa1, 1977, E/M International Directory of Mining and Mineral Processing Operations, MeGraw-Hi11, New York.

Fryklund, V.C., Jr+, 1964, Ore deposits of the Coeur d'Alene District, Shoshone County, Idaho: U.S. Geol. Survey Prof. Paper 445, 103 p.

Hobbs, S.W., Griggs, A.B., Wallace, R.E., and Campbel1, H. B., 1965, Geology of the Coeur d'Alene District, Shoshone County, Idaho: U.S. Geol. Survey Prof. Paper 478, $139 \mathrm{p}$.

Wallace Miner, July 5, 1979, District mine net profits at all-time high of $\$ 37,321,483 ;$ p. 1 . 
THE BLACK HANK (SECOND POND) - BLUE HILL MINE

(Kerr Amexican, Inc.)

\section{LOCATION}

The ore deposits are located at $44^{\circ} 22^{\prime} \mathrm{N}$ and $68^{\circ} 41^{\prime} \mathrm{W}$ in Hancock County, Maine, south of Blue Hill village which lies 14 miles west of E1lsworth and 30 air tiles from Bangor (Figures 1 and 2). REGIONAL GEOLOGY

The Hancock County area lies in the Southern Volcanic Belt (Doyle 1966). This belt is composed mostly of granite with smaller anounts of diorite and diabase. The granite of Devonian age (?) intrudes highly a1tered schists and anphibolites-the Ellsworth formation of Precanbrian to Ordovician age (?), the oldest fornation in the areg and the next in abundance. The formation strikes approximately north-south (Chin-Yuani, ti, 1942) (Young, 1968).

In the inmediate mine area, the country rock, the Ellsowrth fornation, strikes approximately north-south and is alnost surrounded by the intrusive granite on the east and the south. An intrusive diorite-diabase body bounds it on the west. (Figure 3)

Metanorphish and Structure

Metamorphisn of the rocks is of mediur to high grade. Folding and faulting is minor. This deformation is considered to be of Devonian age (MAS, 1979). The major structural features of the area strike NE-Sw, parallel to the regional structural pattern of Maine, when viewed as a whole, the granite intrusions also occupy a NE-SW belt. In the mine region, the strike of the schistosity is predominantly WNW-ESE and the dip is $50^{\circ} \mathrm{SW}$. However, local variation of these features can be large (Ching-Yuan li, (1942). 

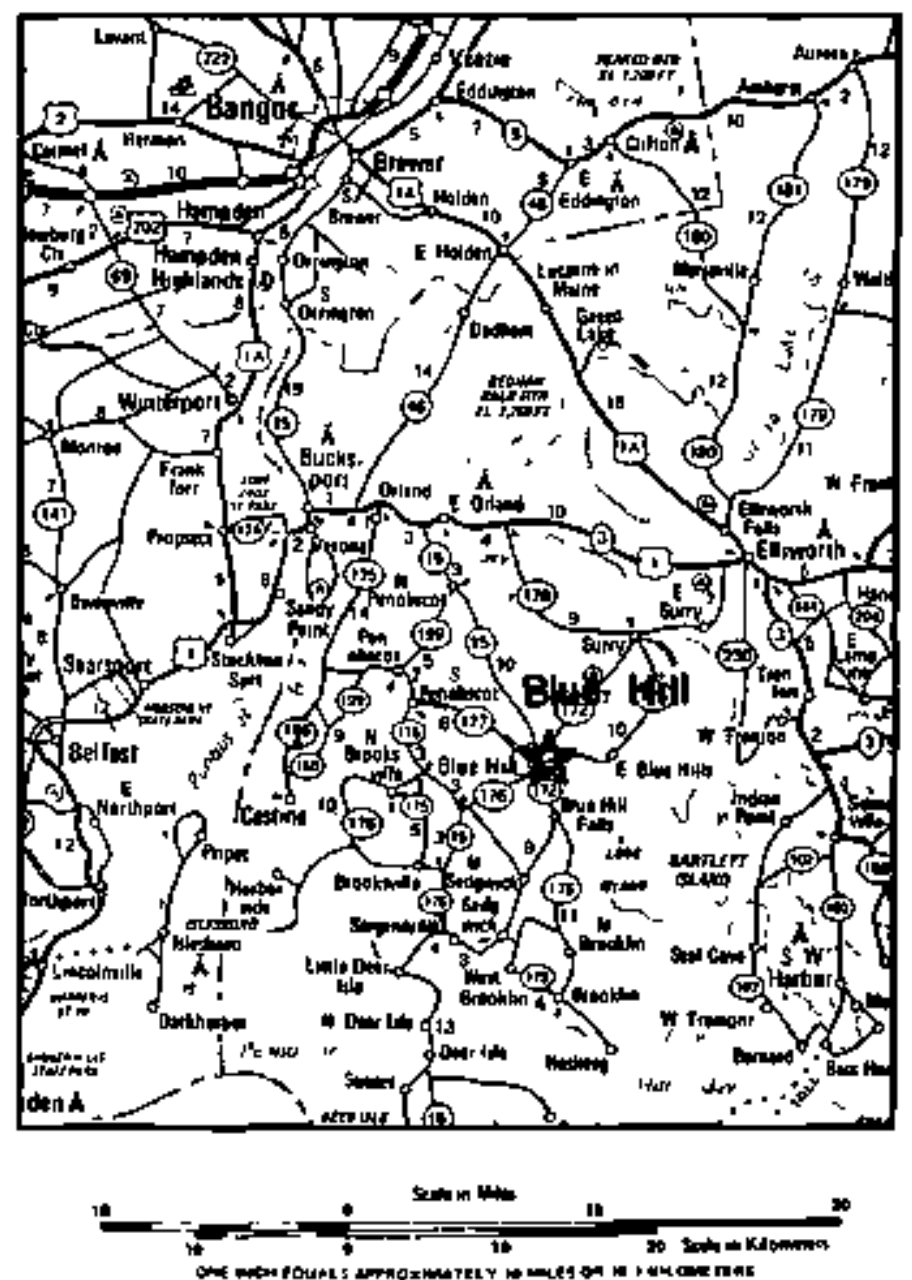

FIGURE 1. Location map of Blue Hill Mine, Harcock County, Maine. Basic map reproduced by permission of the American Autonobile Association, copyright owner. 


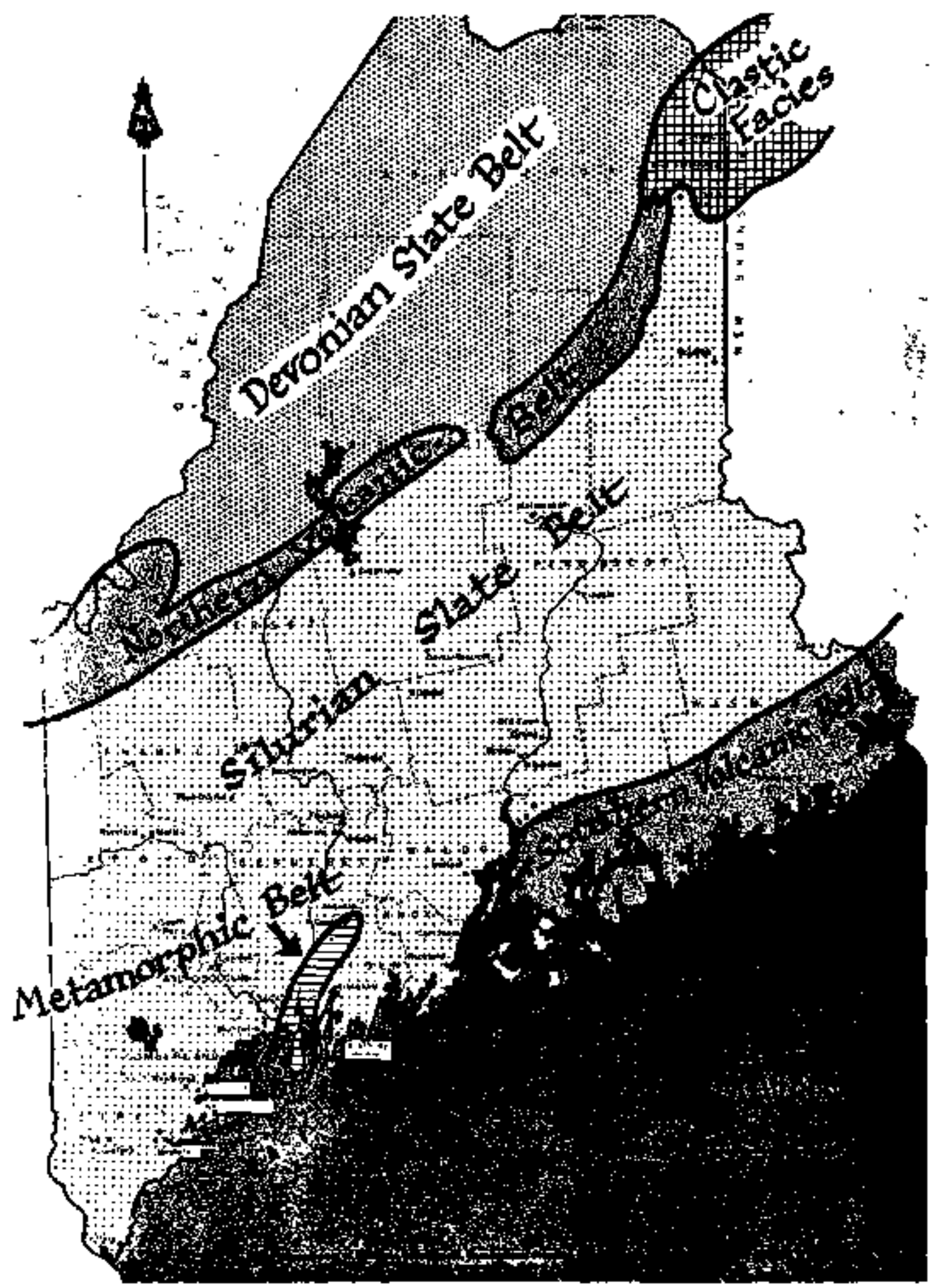

FIGURE 2. Basic geologic environments, State of haine (Young, 1968). 


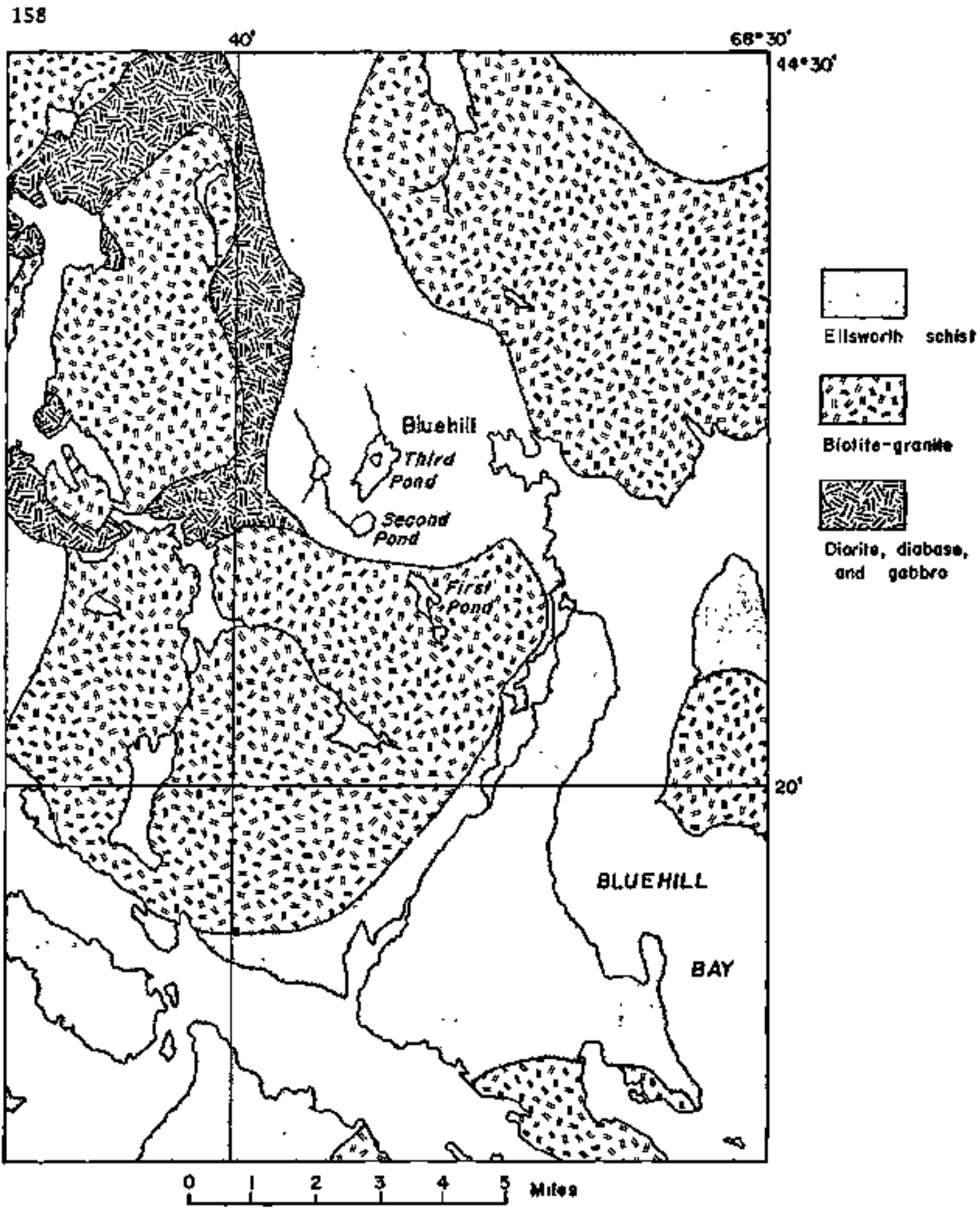

FlGURE 3. Simplified geologic map of the Blue Hill area (after Snith, 1907). 
Mine Geology

The Second Pond deposit occurs as a series of shallow dipping $\left(26^{\circ}\right)$ parallel ore zones wrapped around the nose of a gently folded southerly plunging anticline (CRIB, 1978). The ore bands are in highly altered schists and amphibolites of the Ellsworth formation and near granite intrusions and are thought to be genetically related to these intrusions (Young, 1968) (Ching-Yuan Li, 1942). The ore ninerals are chalcopyrite, sphalerite, galena, and pyrrhotite.

Hydrology

In thine, some tracts of land considered suitable for mineral rights staking are controlled by the state. These are usually called "public lots." Natural water bodies greater than ten acres are in this category (Young, 1968). Second Pond is one of the latter. This suggests that the mineralization is beneath a water body and is, evidently, the reason for the inclined shaft on this property. Hater renoval is therefore a problen in the mine because of the high water table. At present the Second Pond Mine is completely water filled. In fact, when the mine was put on standby, the water followed the departing ni ners (private comounication).

\section{FACILITIES}

The mining property is owned and operated jointly by Kerr American Inc. (subsidiary of Kerr Addison) and Black Hawk Mining ltd. (subsidiary of Denison Mines Ltd.), (3900 S. Tower, Royal Bank Plaza, Toronto, Ontario, Canada) which are Canadian companies. The ore reserves as of December 31, 1976, were estinated to be 140,200 tons. In 1973, ore reserves were estinated to be 670,000 tons (CRIB, 1977). In 1970, the 
shaft depth was 698 feet with lovels at $280,380,400,580$, and 680 feet. A trackless mining method was used.

Engineering and Mining Journal (1965) stated that the company was sinking an inclined shaft to 1300 feet. Young (1968) reported that a three compartment 1300 foot shaft was sunk and several thousand feet of development completed on the 380, 480, and 580 levels. CRIB (1977) stated that in 1968 , the shaft depth was 400 meters with levels of 116 , 146, and 177 meters.

Operations were halted in 1977 and the mine placed on standby because of low copper and zinc prices. In 1977, the total amount of nined ore was 144,964 tons (483 tons/day) (Canadian Mines Handbook, 1978-79) (The Minera1 Industry of Maine, Minerals Yearbook 1971). The Kerr Addison 1977 Annual Report indicates that mine openings were closed with concrete bulkheads at that time. Their 1978 report states that miring and milling operations were being conducted on a care and naintenance bas is only.

The mine is now inactive and filled with water. 
BIBLIOGRAPHY

Canadian Mines Handbook, 1978-79.

CRIB 1977.

Doyle, R.G., 1966, Base Metal Environnents and Exploration History in Maine: Canadian Mining Journal, v. 87, (4), pp, 138-140.

Engireering and Mining Journal 1965, v, 166, (1).

Kerr Addison Annual Report 1977.

Kerr Addison Annual Report 1978.

Li, Ching-Yuan, 1942, Genesis of some Ore Deposits of Southwestern Maine:

Geol. Soc. Aner. Bull, v, 53, (1), Pp. 15-51

MAS 1978.

Snith, G.0.; Bastian, E.S.; Brom, C.H., 1907, Geologic Atlas of the United States, Penobscot Bay, Maine, U.S. Geol Survey Folio 149, 14p.

Young, R.S., 1968, Mineral Exploration and Development in Maine: J.M. Ridge, ed., Ore Deposits of the United States, 1933-67, Amer. Inst. of Mining, Metallurgical and Petroleur Engineers, New York. 

MINNAMAX PROJECT

(OPERATED BY AMER ICAN METAL CLIMAX INCORPORATED)

\section{LOCATION}

The Minsamax project site is located approximately $\mathbf{S}$ miles SSE of Babbitt, and about 60 miles north of Duluth, Minnesota (Figure 1) at $47^{\circ} 37^{\circ} \mathrm{N}$ and $91^{\circ} 52^{1 \mathrm{~W}}$. The elevation of the area is about 1600 feet.

\section{GEOLOGIC SETTING}

Regiona 1

Data for this section were extracted from Bonnichsen (1972), Minnesota Department of Natural Resources (1977), and Phinney (1972). The Duluth Complex of northeastern Minnesota includes about 2500 square miles of Upper Precambrian anorthositic, troctolitic, gabbroic, and granitic intrusive rocks. The complex has an arcuate pattern extending fron Duluth northeastward into the northeasternmost tip of Minnesota, a distance of $150 \mathrm{miles}$. The complex was intruded along an unconformity between the overlying volcanics (North Shore Volcanic Group - mainly rhyolite) and underlying older rocks of Early and Middle Precambrian ages (Virginia Formation sediments, Biwabik Iron Formation, and Giant Range batholith). Radionetric dating indicates an age of approximately $1120 \pm 15$ million years for the Duluth Complex intrusives.

The region in which the Minnanax project is located is referred to as Babbitt-Hoyt Lakes, and is approxinately midway along the northwestern edge of the Duluth Complex, as shown in Figure 2. The geology of the Babbitt-Hoyt lakes region as well as the location of the Minnamax project is shown in Figure 3. 


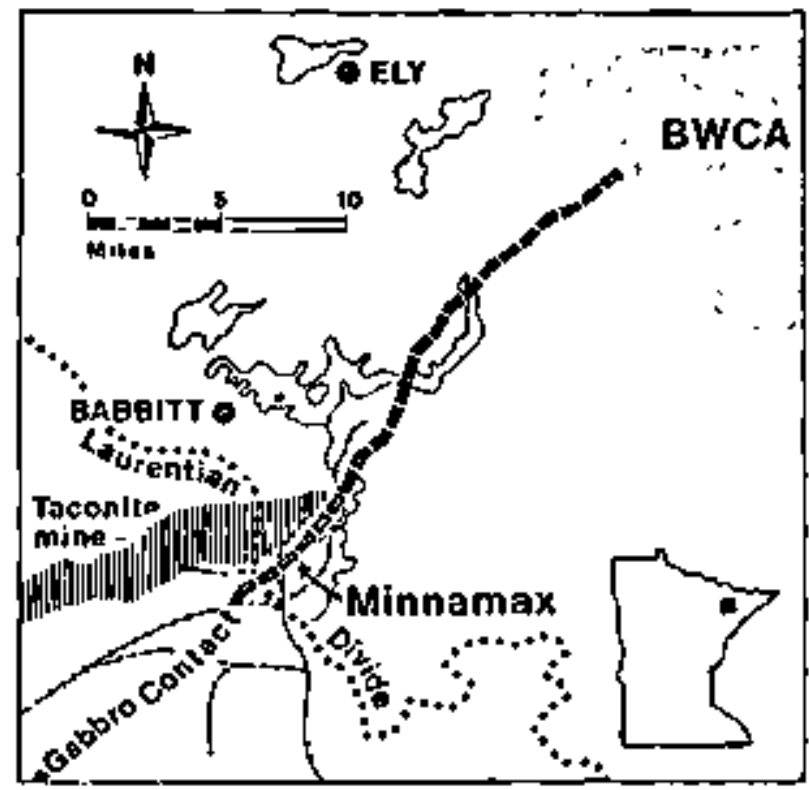

FIGURE 1. Location wap of Minnamax Project, St. Louis County, Minnesota (E/MJ, 1976). 


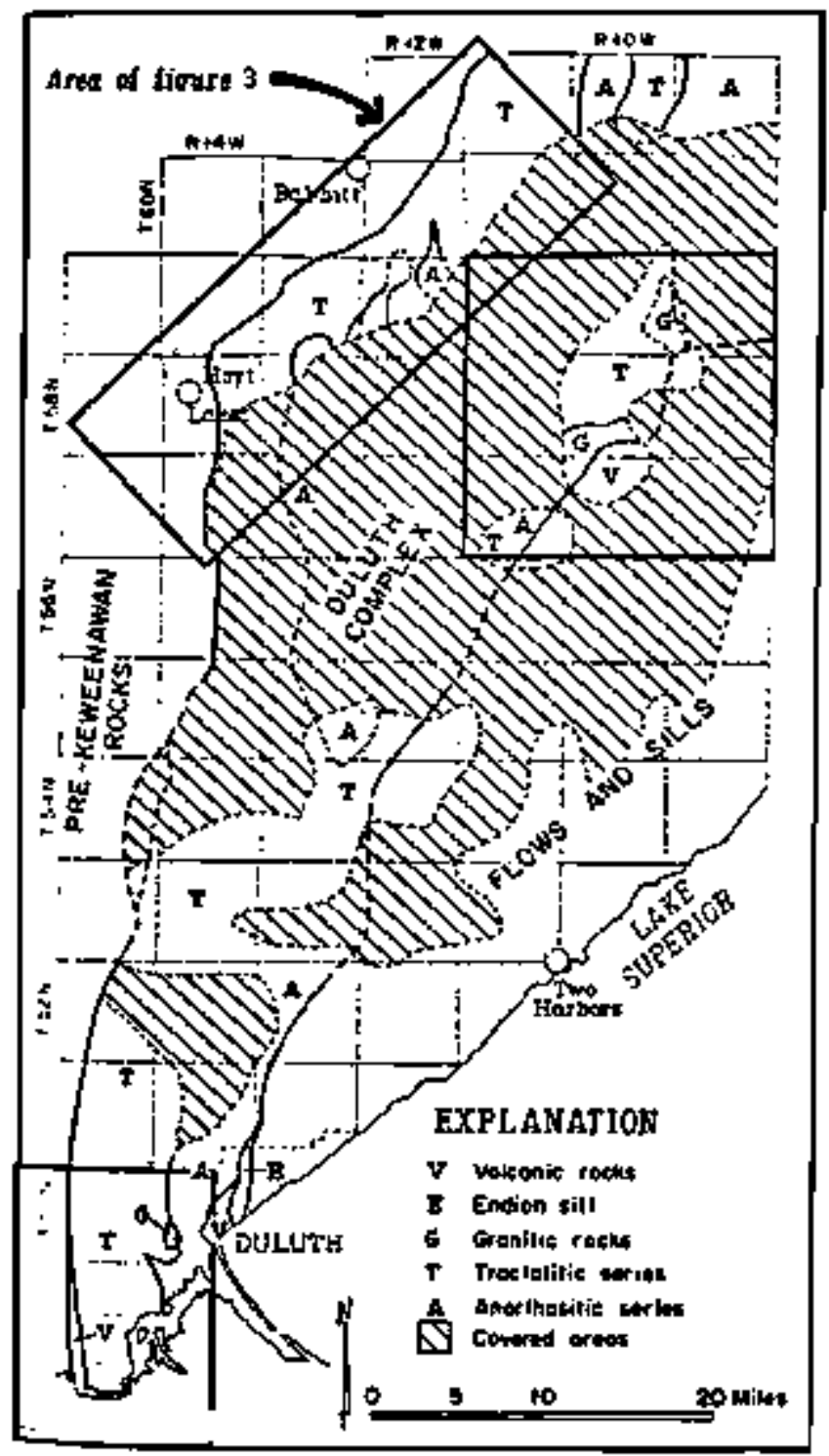

FIGURE 2. Geologic map of southern part of Duluth Complex (Bonnichsen, 1972).

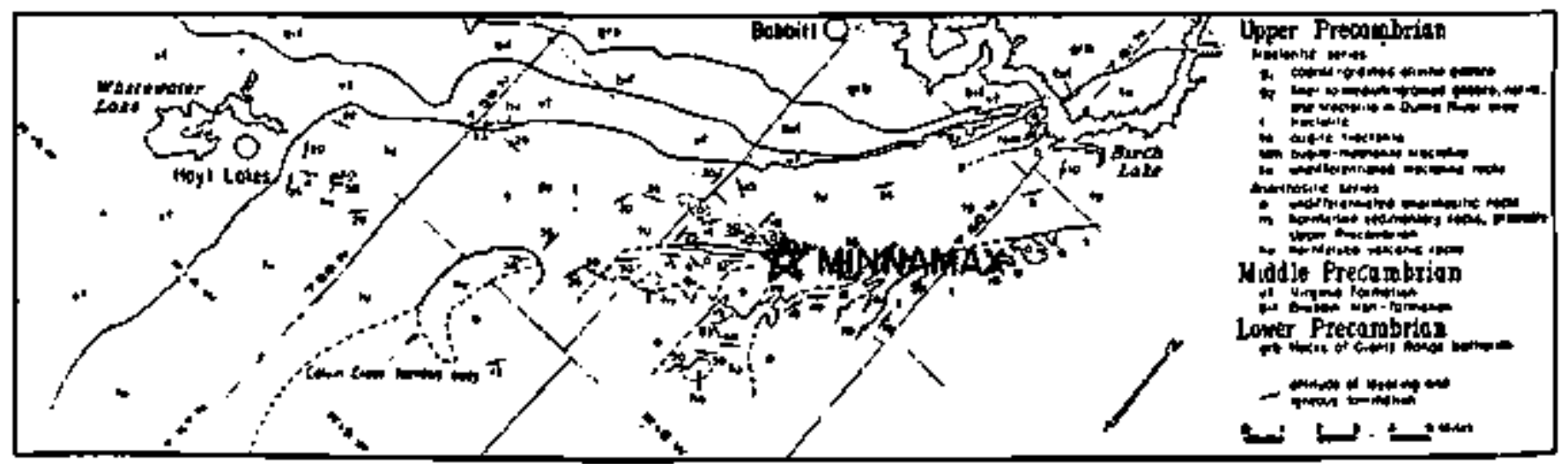

PI(UURE 3. Geologic maj of Babbitt-Hoyt lakes region (Bonnichsen, 1972). 
Tho major rock groups in the complex are recognized, a troctolitic series and an anorthosite series. The troctolitic series consists of troctolite (primarily calcic plagioclase and olivine), and augite troctolite, while the anorthositic series consists prinarily of gabbroic anorthosite and troctolitic anorthosite. The troctolitic series occurs adjacent to the western margin of the conplex. The anorthositic series generally is located east and southeast of the troctolitic series. Numerous inclusions of fine-grained, genera11y gramular hornfelses, ranging in size from a few inches to thousands of feet, are present in the southern half of the complex, and are especially abundant within the troctolitic series adjacent to the western margin. Hornfelses dertved from nafic volcanic rocks probably are nost abundant.

MINE GEOLOGY

The data for this section were extracted from Phinney (1972), and CRIB. Exposures are poor in the area of the Minnanax project, and the relationships anong the various units are not well understood. The host basal troctolitic gabbro of the Duluth Complex varles in grain size, nineral proportions, structural attitude, and texture. The exploration shaft and accessory tunnels are apparently in the Duluth Complex intrusive. The data available suggests that the main rock types in the mine workings are medium-grained troctolite grading locally into olivine gabbro; the texture in places may be pegmatitic. The copper/nicke1 mineralization is in the form of a sulfide segregation in the troctolitic intrusive.

The shape of the deposit is tabular, with dinensions of approximately 6000 neters in length, 115 meters in width, and 100 meters in thickness. The ore body strikes $N 45^{\circ} \mathrm{E}$ and has a dip of $17^{\circ} \mathrm{SF}$. The depth to the top of the ore body is about 430 meters. 
MINE FACILITIES

The data for this section were extracted from CRIB, EM] (1976), and .USGS (1979).

The Minnamax ore body was discovered by Bear Creek Mining Company in 1957, and was 1ater acquired by Anax Exploration, Inc. Amax has carried on a substantial amount of exploration since acquiring the property. A 14 foot dianeter shaft has been sunk to a depth of 1710 feet, as illustrated in Figure 4. Approxinately 6000 meters of drifting has been done from the shaft,

A decision to develop the prospect will not be made before 1980, and startup will require an additional 3 to 4 years.

Amax is permitting the U.S. Geological Survey and the University of Minnesota to use part of its Minnamax mderground workings to conduct a comprehensive series of stress measurements.

\section{ELY PROSPECT}

The Ely prospect of International Nickel Company is located approximately 15 miles east of Ely, Minnesota, less than 20 miles north of the Minnamax project. The geology of the Ely prospect is likely similar to Minnamax, since both are part of the troctolitic gabbro of the Duluth Complex. The underground workings at the Ely prospect consist of a shaft approxinately $1,000 \mathrm{ft}$, deep, $2400 \mathrm{ft}$. long, $8 \mathrm{ft}$. wide drift, and a $40 \mathrm{ft}$. wide, $180 \mathrm{ft}$. deep stope. A limited description of the site, along with a more complete discussion of hydraulic fracturing field tests, were given by Von Schonfeldt (1970). In this report the Ely prospect is categorized in group 2 because sufficient data are presently not available. 


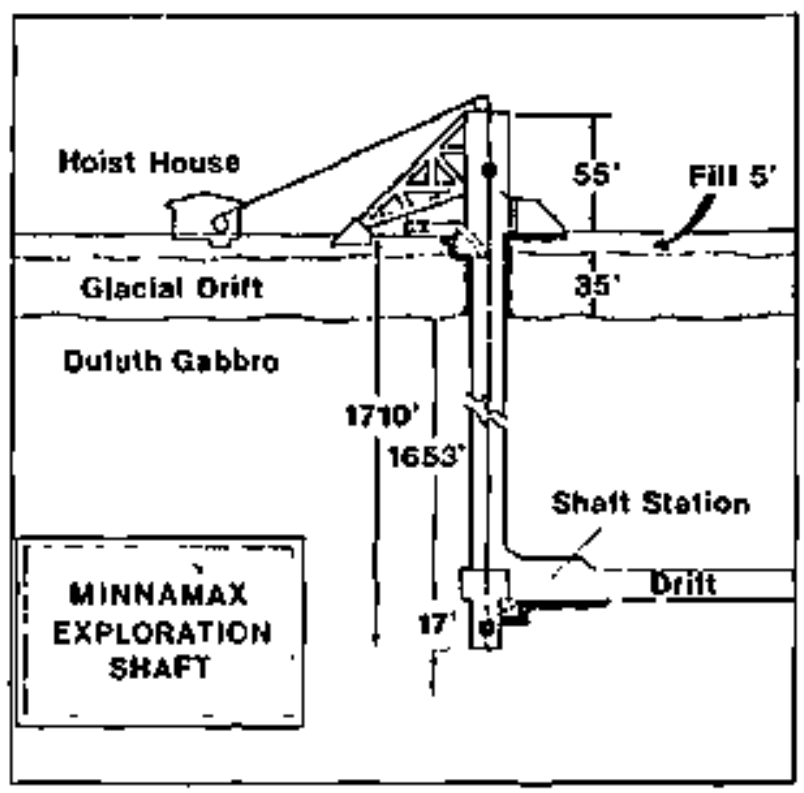

FIGJRE 4. Minnamax exploration shaft (L/N1J, 1976). 


\section{REFERENCES}

Bonnichsen, B., 1972, Southern Part of the Duluth Complex, in: Geology of Minnesota, A Centennial Volume, Minnesota Geol. Survey, St. Paul, Minn., p. 361-387.

CRIB

Engineering and Mining Journal, 1976, Anax steps up exploration at Minnamax copper-nickel prospect in Minnesota, v. 177(2), p. 17, 138.

Fairhurst, C., 1979. Inproved stress deternination procedures by hydratulic fractuxing, abstract in U.S. Geo1. Survey Open File Report of 79-387, p. 48 .

MAS

Minnesota Department of Natura1 Resources, Division of Minerals - Minerals Exploration Section, 1977, Mineral Resouxces of a Portion of the Duluth Complex and Adjacent Rocks in St. Louis and Lake Counties, Northeastexm Minnesota, Report 93, 74 F.

Phinney, W.C., 1972, Duluth Complex, History and Nomenclature, in: Geology of Minnesota, A Centennial Volume, Minn. Geol. Survey, 5t. Paul, Minn., p. 333-360.

Von Schonfeldt, H., 1970, An Experimental Study of Open-Hole Hydraulic Fracturing as a Measurenent Method with Particular Emphasis on Field Tests, Missouri River Division, Corps of Engineers, Technical Report MRD-3-70, November 1970, p. 37-68. 


.

- 
BLACK PINE MINE

(CONSOLIDATED COPPER CO.)

LOCATION AND ACCESSIBILITY

Black Pine Mine is an active small silver mine in the Philipsburg District, Granite County, Montana. Since $18 \$ 2$, it has been mined intermittently with an estimated cumulative production (1885-1964) of 2.6 million ounces of silver and 3000 ounces of gold (Krohn and Weist, 1977). Fomerly called the Conbination mire, it is located west of Henderson nountain at $46^{\circ} 27^{\prime} \mathrm{N}, 113^{\circ} 22^{\prime} \mathrm{W}$ at an elevation of $6500 \mathrm{ft}$. It is accessible by gravel road, $12 \mathrm{mi}$. northwest of the town of Philipsburg (Figure 1).

The Black Pine Mine is included among the "class 1" nines in this study, as representing an active mining district, and also for comparison with mines of the Coeur d'Alene District, Idaho. The Coeur d'Alene mines are located in quartzitic rock types similar to those of the Philipsburg district, but the structural settings of the two districts are distinctly different. The new development drifts at Black Pine may extend into the nearby intrusive rocks,

GEOLOGIC SETTING

The geology of the Black Pine mine area was briefly outlined by White (1976) and described in detail by Wallace and others (1978), Prinz (1967) and Emmons and Calkins (1913). It is an area of folded and faulted Precambrian sedimentary rocks that have been intruded by Cretaceous batholiths (Figure 2). The sedinentary rocks consist mainly of 1 inestone, dolomite, shale, quartzite, and phosphatic quartzite which, 


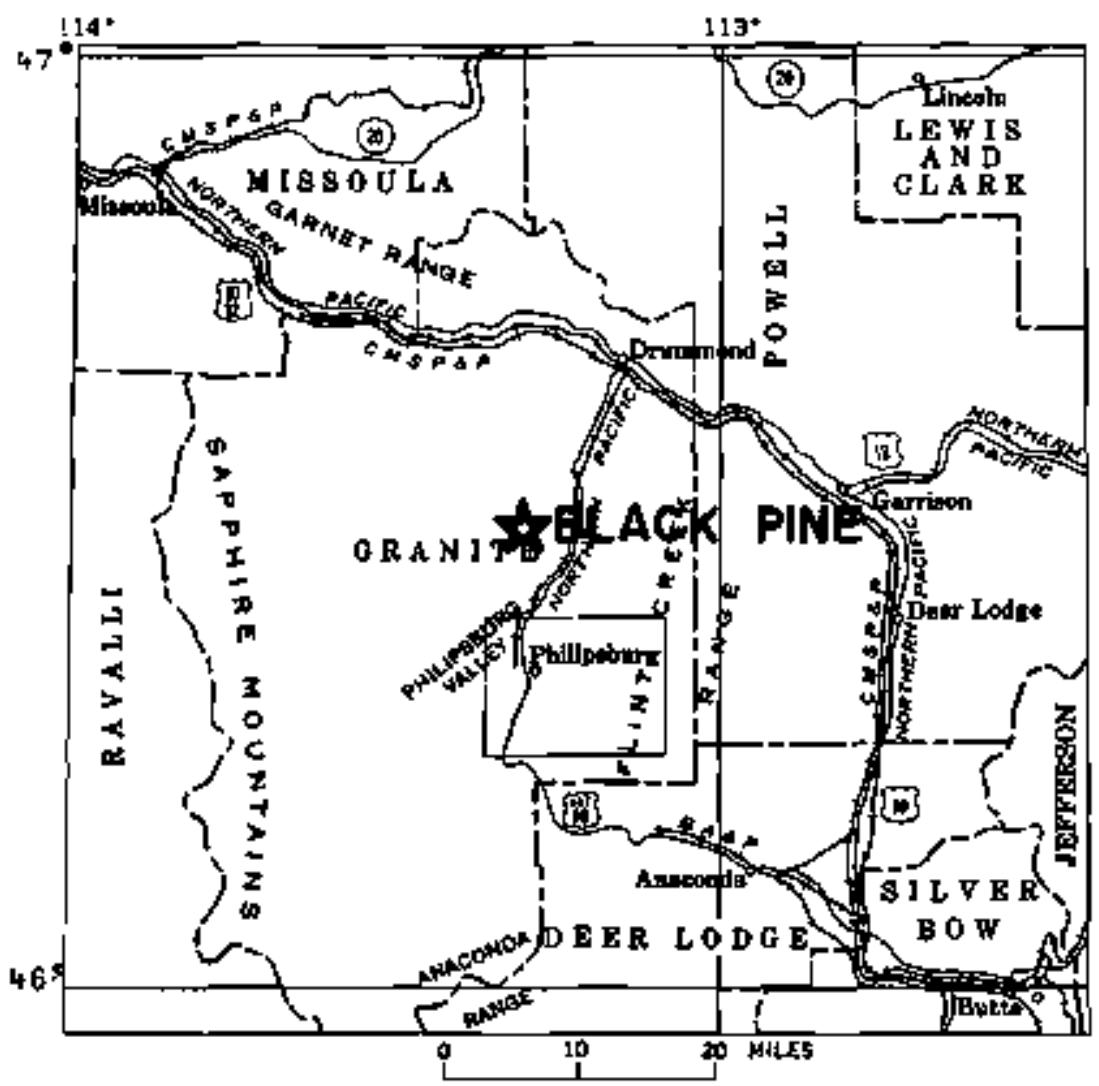

FIGURE 1. Location map of Black Pine mine, Granite County, Montana (Prinz, 1967). 


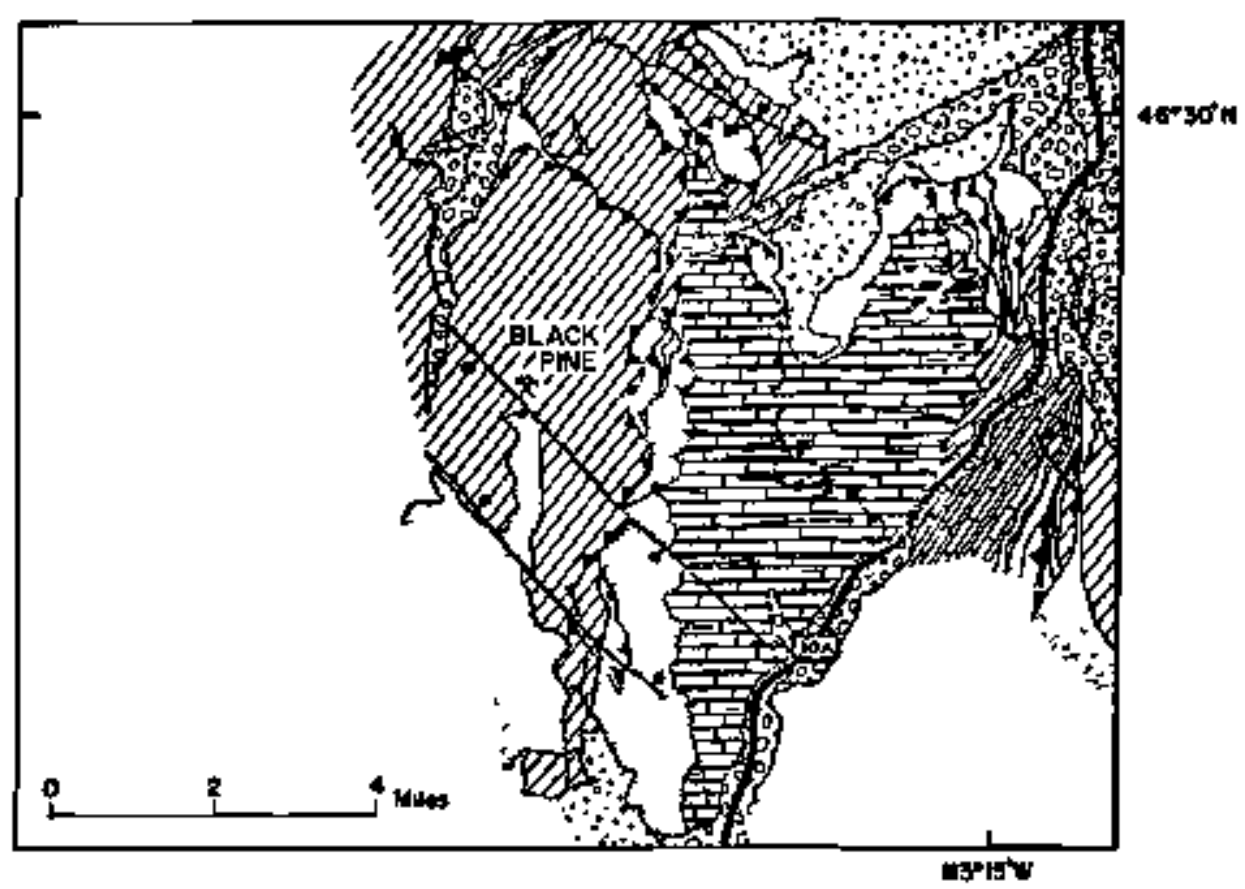

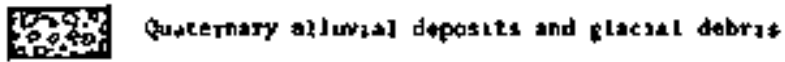

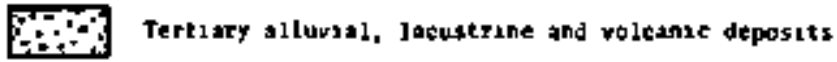

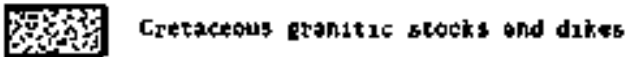

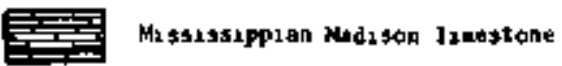

Precalibian ite. Shields Formation

[t:

17/7 (thit z-quortinte with cosrse pebbly zone botton and top

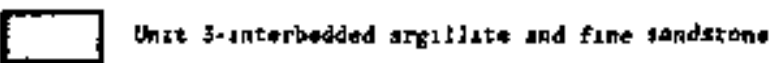

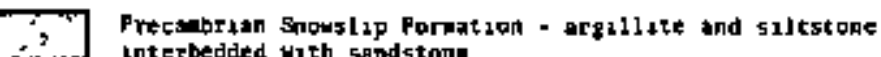
Interbedacd with sandstone

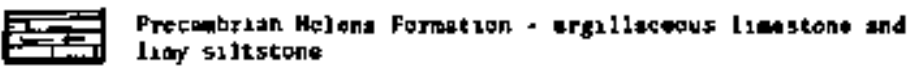

Thrust foult, truangles on uppur plate

F Nogmgl Eaule, bolls on dow-thrown side

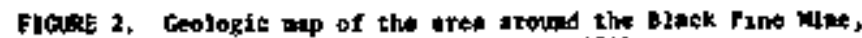

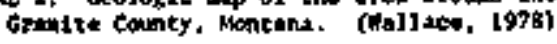


near the contacts with batholithic rocks, have been metamorphosed to marble, tactite, and hornfels. The stratigraphic sequence in the Philipsburg district is outlined in Tabte 1.

The oldest unit in the district is the Spokane Formation, equivalent to the Missoula Group of the Precambrian Belt Series (Ross, 1963). The Spokane Formation consists of a series of thin-bedded red to brown siltstone, massive gray to reddish brow quartzite and thin-bedded sandstone and shale, with an aggregate thickress of $5000 \mathrm{ft}$. (Ross, I963). The Spokane Formation is the only rock unit at the mine, and the ore, so far as is known, is confined to the quartzite nembers. The quartzite is slightly metamorphosed. Some secondary quartz has been added by circulating waters, and white mica or sericite has been developed from the clay between the grains of sand. otherwise, the quartzite has not been greatly metanorphosed. other units of the Belt Series that crop out in the area, but are not exposed in the mine, are Newland limestone and shale, Ravalli quartzite, and shale and Neihart quartzite and argilite. The rocks strike approximately $\mathrm{N} 30^{\circ} \mathrm{W}$ and dip from $10-20^{\circ} \mathrm{SW}$.

Intrusive igneous rock has not been reported in the nine, but more recent exploratory drifts may have intersected intrusives. The nearest known intrusive is a granodiorite porphyry dike about 1 mile north of the mine. The Philipsburg batholith, a Iarge granodiorite pluton, lies several miles south of the mine. The batholith is elliptical in plan and underiies an area of 45 square miles. Mineralization of the nine may be associated with the intrusion of the batholith, which is described in more detail in the section covering the Granite-Bimetallic mine. STRUCTURE

The structural setting of the Black pine mine is sinple compared to the highly contorted and faulted conditions in the Coeur dialene mines. 


\begin{tabular}{|l|l|l|}
\hline $\begin{array}{l}\text { Rock } \\
\text { Unit }\end{array}$ & Thickness & Description \\
\hline
\end{tabular}

\section{CRETACEOUS}

\begin{tabular}{|c|c|}
\hline $\begin{array}{l}\text { Philipsburg } \\
\text { Batholith }\end{array}$ & $\begin{array}{l}\text { Coarse grained granodiorite, } \\
\text { even textured to porphyritic, } \\
\text { associated stocks and dikes. } \\
\text { Radiometric age } 78-68 \text { mililon } \\
\text { yoars before present (Tililng } \\
\text { et a1, 1968). }\end{array}$ \\
\hline
\end{tabular}

\section{PRECAMBRIAN}

\begin{tabular}{|c|c|c|c|}
\hline \multirow{4}{*}{$\begin{array}{l}\text { Belt } \\
\text { Series }\end{array}$} & $\begin{array}{l}\text { Spokane } \\
\text { Formation }\end{array}$ & $\begin{array}{rl}1525 & \mathrm{~m} . \\
(5,000 \mathrm{ft} .\end{array}$ & $\begin{array}{l}\text { Massive gray to reddish-brown } \\
\text { quartzites, thin-bedded red to } \\
\text { brown siltstone and thin-bedded } \\
\text { sandstone and shale; mud cracks } \\
\text { and ripple marks present. }\end{array}$ \\
\hline & $\begin{array}{l}\text { Newland } \\
\text { Formation }\end{array}$ & $\begin{array}{c}\mathrm{I200} \mathrm{m} \\
{[4,000 \mathrm{ft}}\end{array}$ & $\begin{array}{l}\text { Calcereous shaies and impure } \\
\text { limestones characterized by } \\
\text { buff tints on weathered surfaces. }\end{array}$ \\
\hline & $\begin{array}{l}\text { Rava1li } \\
\text { Formation }\end{array}$ & $\begin{array}{c}600 \mathrm{~m} \\
(2,000 \mathrm{ft} .)\end{array}$ & $\begin{array}{l}\text { Gray quartzitic sandstone with } \\
\text { much dark shale in upper part. }\end{array}$ \\
\hline & $\begin{array}{l}\text { Neihart } \\
\text { Quartzite }\end{array}$ & $(1,000 \mathrm{ft})$ & $\begin{array}{l}\text { Pure thick-bedded light colored } \\
\text { quartzite. }\end{array}$ \\
\hline
\end{tabular}

TABLE 1. Generalized geologic column for the Black Pine Mine area, Philipsburg mining district, Granite County, Montana (adapted from Ross, 1963; and Ennons and Calkins, 1913). 
At Black Pine, the rock units are gently dipping and the ore-bearing veins lie along the bedding planes. Several normal faults traverse the area, while no thrust or strike-slip faults occur. The normal faults strike northwester1y, para1leling the strike of the quartzite with displacements up to $33 \mathrm{ft}$. However, some faults cut the quartzite strata at right angles to its strike.

The principal structural features originated during the Laranide orogeny after broad folding of the Precambrian sediments. The Spokane quartzites were thrust eastward over younger Paleozoic rocks and folding continued. Intrusion of the Philipsburg batholith south of the mine area followed the folding and faulting. The period of ore deposition then occurred along fissure veins. Normal faulting along bedding postdates nineralization and was the last event of the orogeny.

\section{MINERALIZAT ION}

The Black Pine ores occur in bedding fissures of the Spokane Formation. The stver-bearing replacenent veins are silica rich, and as a group range from a few inches to twenty feet in thickness. The average thickness is probably 3-5 ft. The veins are banded, and breccia zones parallel the layering and the walls in many places in the veins. The walls of the veins are generally sharp and comnonly marked by fault gouge.

The Conbination vein, the principal vein, is in quartzite and nearly everywhere conforns to the bedding of the country rock (Figure 3). General$1 y$, it is a simple fissure filling depostted in an open space along a single bedding plane; locally it is divided by large slabs of the country rock. The vein dips $10^{\circ}-30^{\circ} \mathrm{sw}$ and extends nore than $3500 \mathrm{ft}$. along the strike and an equel distance down dip. The hanging wall and footwali of the Combination vein are barren and unaltered. 


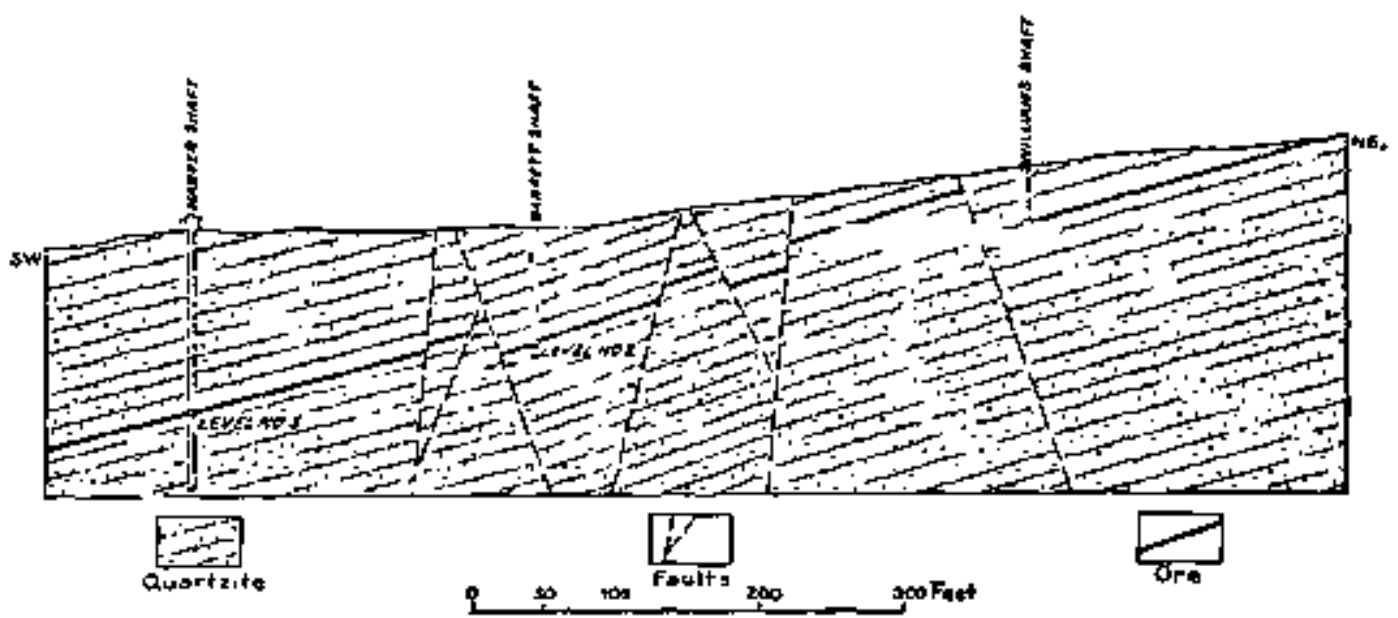

Cross section of the Combination lode, a bedding-plane fissure vein in quartzite. It is cut by normal fatuls across the bedding.

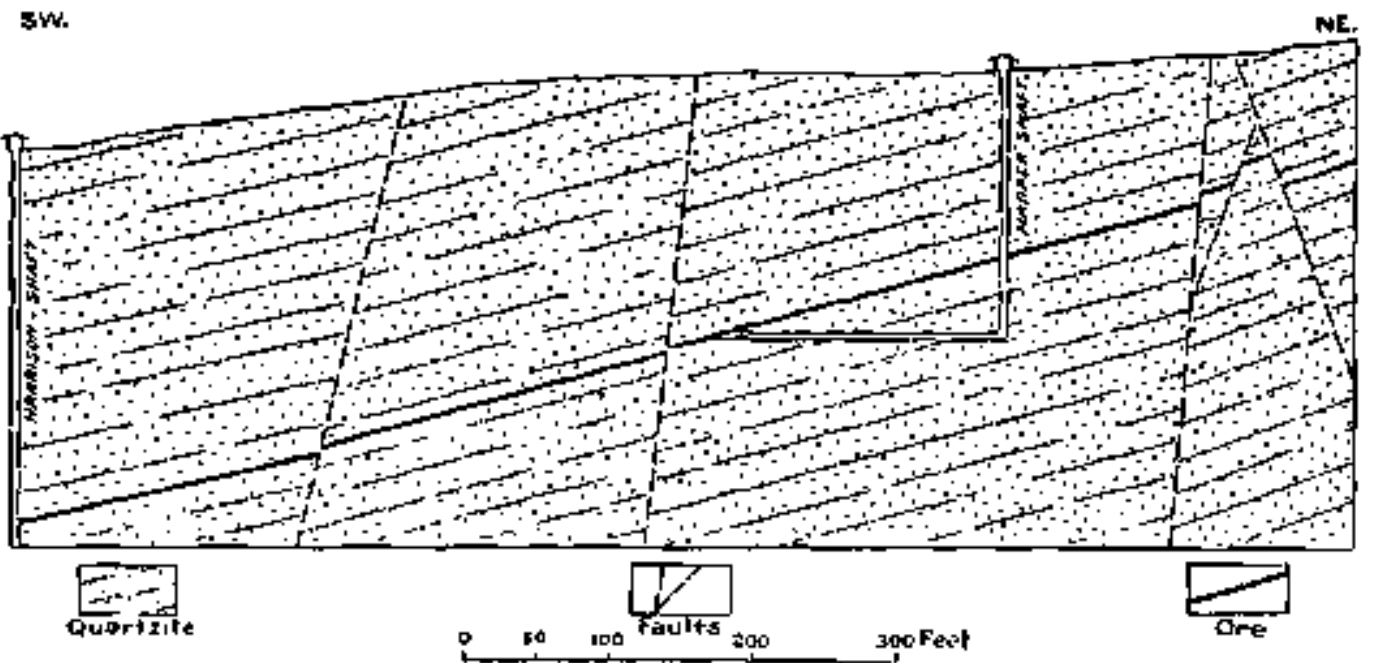
Cross section of Combfnation lode through Harper shaft to Harrison
shaft.

FIGURE 3. Geologic cross section of the Combination Vein, Black Pine Mine in relation to the Spokane Formation quartzite. Displacements are shown along several faults, and early mine workings (from Emons and Calkins, 1913). 
The structure of the ore-bearing veins is conparatively simple (F1gure 3). The veins follow the bedding planes of the quartzite, except in areas of post-ore faulting. On level 5 , near the Harper Shaft, the main vein strikes $N 30^{\circ} \mathrm{W}$ and dips $15^{\circ} \mathrm{SW}$, typical of the strike and dip of the vein at most places in the mine.

In addition to the Combination vein, three other mineralized veins are recognized: the Upper, the Tin Snith, and the Onyx. Only the Conbination vein was nined extensively in the past and is now being worked. The Tin Smith vein is located $150 \mathrm{ft}$. above the Combination vein, and contains oregrade material. Not much is known about the Onyx vein, located $400 \mathrm{ft}$. below the Conbination vein, as it is large1y unexplored. Nothing was reported about the Upper vein in the literature.

\section{MINE CHARACTERISTICS}

The nine was originally developed through eight vertical shafts and three tunnels (Enmons and Calkins, 1913). Four shafts and mine workings along the Conbination vein are illustrated in Figure 3 . The ore body is a large blanket deposit. Levels were excavated at about $100 \mathrm{ft}$. intervals down the dip of the vein and have a difference in elevation of about $20 \mathrm{ft}$. A long incline was driven on the main vein from a station near the botton of the Harper Shaft to the Harrison Shaft. In 1913, the workings comprised in all about $12,000 \mathrm{ft}$. of intersecting drifts, inclines, and crosscuts.

In 1970, Inspiration Consolidated Copper Co. acquired the Black Pine mine (White, 1976). The exploration progran included drifting in the ore and dianond drilling fron the sturface. The present development plan prior to stoping is reprinted from thite $(1976)$, in Figure 4 . Four shafts that were sunk in the early operations are presently being used. The Harper is used today as an exhaust shaft in the ventilation system. A second shaft, 
the Lewis, will be added to the ventilation systen when the main haulage reaches a length of $2200 \mathrm{ft}$.

The ore body is extracted in $100 \times 100 \mathrm{ft}$. ore blocks. Three panels are driven in each direction across the ore blocks with $6 \times 6$ ft. pillars left between panels to support the back. The stope headings are $6 \mathrm{ft}$. high by $15 \mathrm{ft}$. wide.

kock bolting provides roof support, with landing mat strips between bolts. The ground is competent, and a number of stopes fron early mining operations remain open.

The mine is essentially dry and does not require pumping for dewatering (White, 1976). However, Emuons and Calkins (1913), reported that nine workings below level 14 were flooded and above this level were accessible and in good condition after a long period of idleness (about 1897 to 1913).

Equipment includes Gardner Denver 83 jacklegs for drilling, Eimco 911 LHDS for mucking, Caterpillar 950 for loading ore, and Elmeo $980 T-10$ for haulage. Air is circulated by two 40-hp Joy Axivane fans with a 80,000 efm capacity. Several surface facilities are also present. 


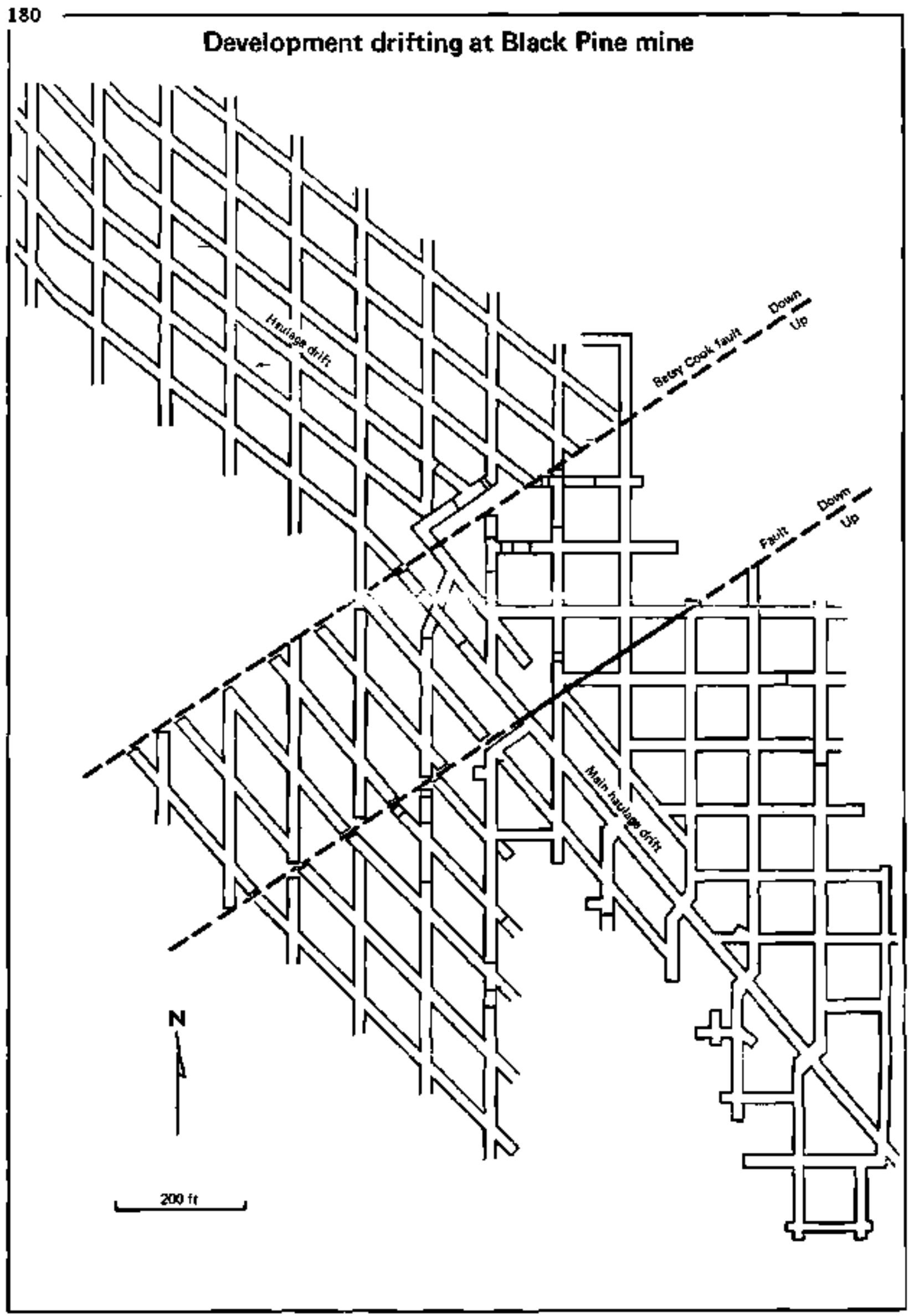

FIGURE 4. Recont development drifts at Black Pine mine. The main haulage drift is along Combination Vein (Figure 3) (from White, 1976). 


\section{REFERENCES}

Emons, W.H., and Calkins, F.C., 1913, Geology and ore deposits of the Philipsburg Quadrangle, Montana: U.S. Geol. Survey Prof. Paper 78, $271 \mathrm{pp}$.

Holser, H.T., 1950, Metanorphism and associated mineralization in the Philipsburg region, Montana: Geol. Soc. Amer. Bull, v. 61, p. 1053-90.

Krohn, D.H., and Weist, M.W., 1977, Principa1 information on Montana mines: Mont. Bur. Min. Geol. Spec. Pub. 75, p. 57.

Prinz, W.C., 1967, Geology and ore deposits of the Philipsburg District, Granite County, Montana: J.S, Geo1. Survey Bul1, 1237, $66 \mathrm{pp}$.

Ross, C.p., 1963, The Belt Series in Montana, U.S. Geol. Survey Prof. Paper 346, 122 pp.

Silverman, A., 1965, Econonic geology of the Flint Creek Range, Billings Geol. Soc. Ann. Field Conf. 16, p. 108-119.

Tilling, R+I,, Klepper, M.R,, and obradovich, J.D., 1968, K-Ar ages and time span of emplacenent of the Boulder batholith, Montana: Amer. Jour. Sci., v. 266, p. 671-689.

Wallace, C.A., Klepper, M.R., French, A.B., and Scarborough, D.M., 1978 , Preliminary geologic nap of the northwestern part of the Butte $I^{\circ} \times 2^{\circ}$ quadrangle, Hontana, U.S. Geol. Survey, Open File Report $78-371$.

White, L., 1976, Trackless mining on a small scale: Inspiration's Black Pine Silver oine: Eng. Min. J., v. 177, (9), p. 98-100. 


\section{BUTTE MINING DISTRICT AND BUTTE UNDERGROUND MINES}

(THE ANACONDA COMPANY)

\section{LOCATION AND ACCESSIBILITY}

The Butte district is composed of underground and surface mining operations in Silver Bow County, Montana at $46^{\circ} 1 \mathrm{~N}, 112^{\circ} 33^{\prime} \mathrm{H}$, (Figure 1). The mining district is located east of the city of Butte (population 223,000 ), surrounded by the Tobacco Root Mountains at an elevation of $\$ 700 \mathrm{ft}$. The area is accessible by air, rail and highway year round. GEOLOGY

The geology of the Batte district is described in detail by several authors; notably by Sales (1914) and more recently by Meyer and others (1968). In this review the general 1 ithology, structure, and minerali$z$ ation of the district are described, followed by brief descriptions of two accessible underground minds, the Leonard and Steward mines.

\section{LITHOLOGY}

The Butte district is underlain by the Boulder batholith which intruded into a central tectonic block bounded by faults and the lewis and Clark line* anent. The generalized geologic setting is illustrated in Figure 2 and a generalized lithologic column, vein-type and alteration sequence in Figure 3. The Boulder batholith is a composite of epizonal plutons that range in composition from gabbro to granite. The batholith and related intrusives were emplaced during a ten miliion year interval from 78-68 million years. Knopf (1957) and Klepper (1962) show that emplacement occurred in phases, beginning with intrusion of mafic bodies near the north and south portions of the present-day batholith, followed by massive granodiorite emplacements, and finally the Butte quartz monzonite. The Butte District is located in the 


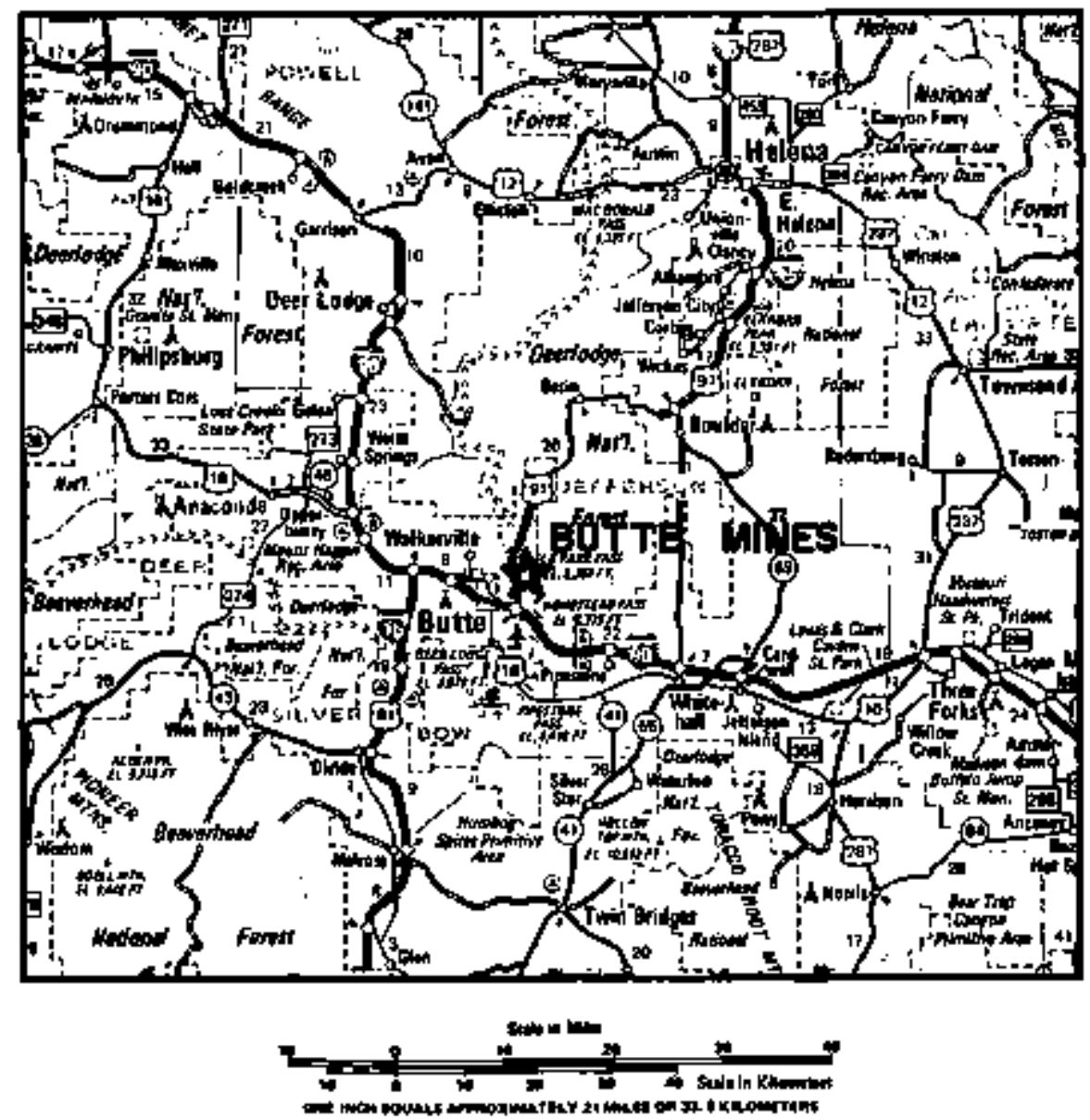

FIGURE 1. Location map of Butte underground nines, Silver Bow County, Montana. Basic map reproduced by permission of the Arerican Autonobile Association, copyright owner. 


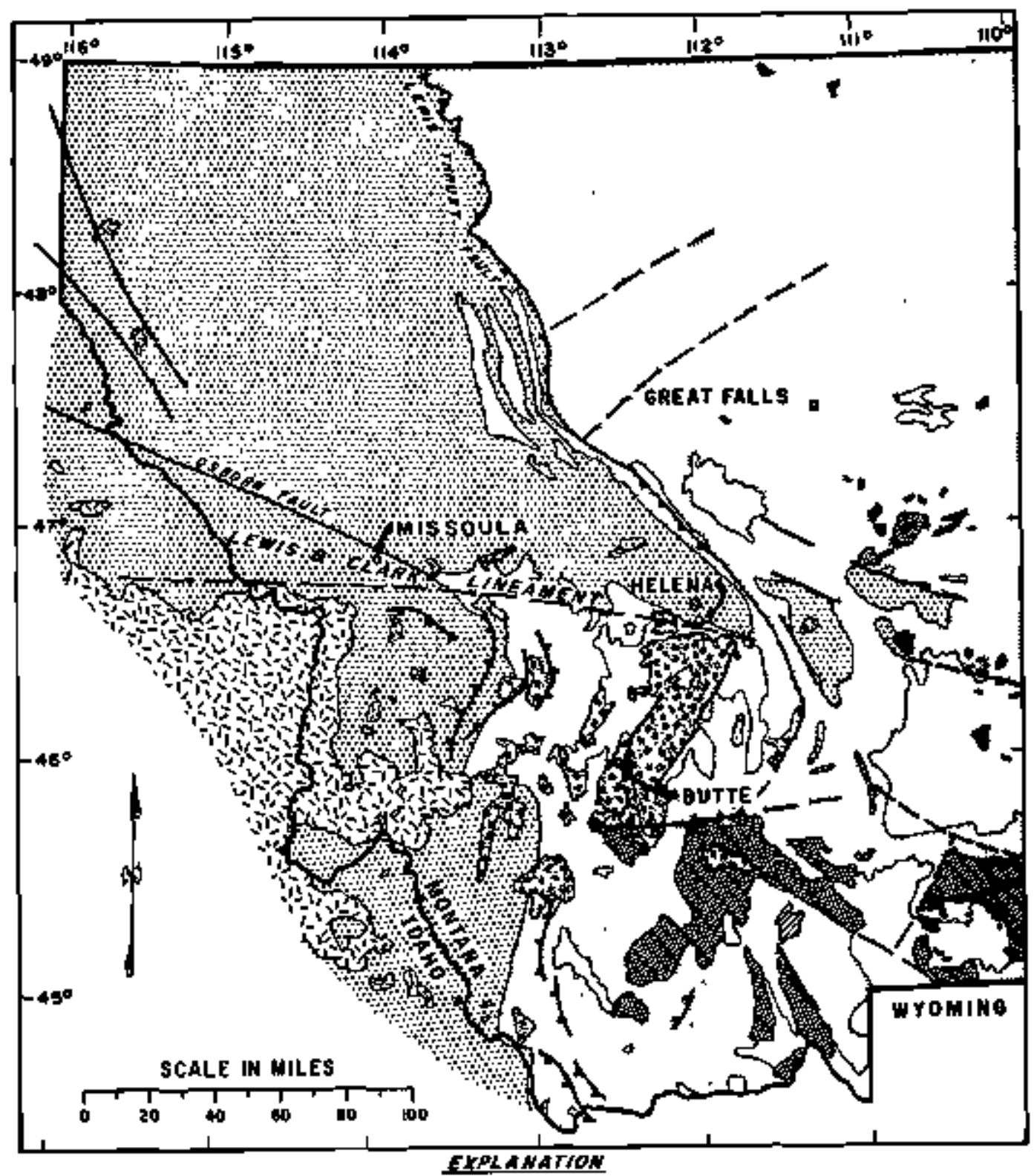

D PALEOZOIC A MESOZOIC FORMATIONG W. WROTERGZOIC AELT SERIES CRETACEOUS \& TERTIARY VOLCAMIES A. ARCHEAN GNE IQS. SCMIST A GRANITE EQTE OOULDER BATHOLITH O RELATEO INTRUEIVES EST IDAHO BATHOLITH A RELATED INTRUSIVES TERTHARY INTRUSIYES VIVI CAETACEOUS DIORITE-6ABERO INTRUSIVES - FaULTS

FIGJRE 2. Generalized geologic map of the Butte mining district and Boulder batholith relattve to major tectonic elements in southwestern Montana (from Meyer and others, $1968)$. 


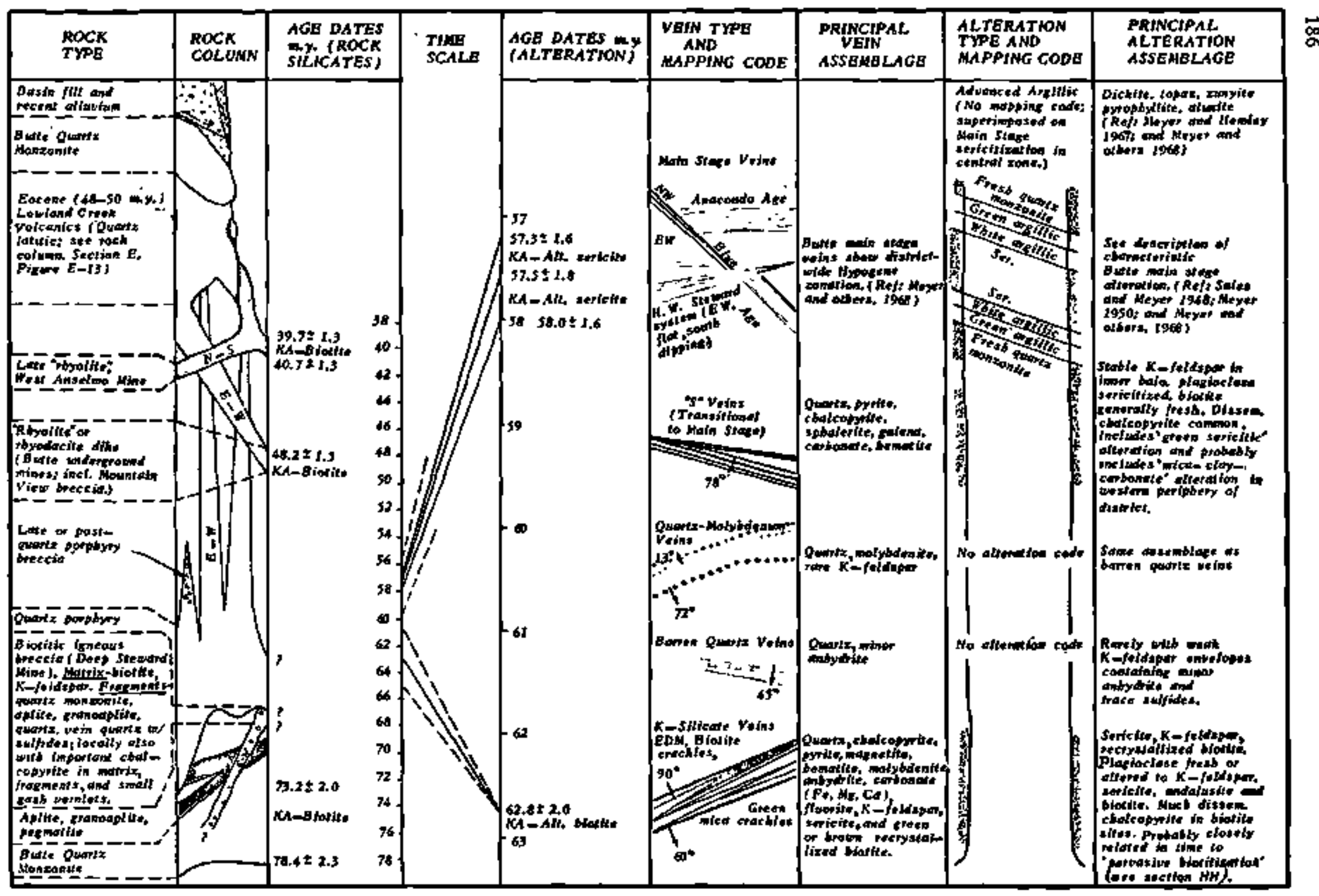

FIGURE 3. Generalized rock column for the Butte Mining District, Montana, showing intrusive-vein-alteration sequence and available age dates of rock-alteration assenblages, (from Miller, 1973). 
Butte quartz nonzonite which forms the nain mass of the bathol1th. Large dikes and snaller irregular bodies of younger quartz monzonite cut older rocks. Late nagnatic alaskite and aplite dikes cut all rock types and vary in size, shape, and texture.

The Butte mines worked fissure veins in the Butte quartz nonzonite. The Butte quartz monzonite is nedium to rather coarsely textured, homogeneous in composition, and contains about 65 percent $\mathrm{SiO}_{2}$ and equal parts of quartz and orthoclase. Plagioclase is abundant and the nafic ninerals present are hornblende and blotite. Isolated dikes and irregular masses of aplite and pegnatite, composed predoninantly of quartz and $\mathrm{K}$-feldspar, are scattered throughout the quartz nonzonite. The aplites and pegmatites are usually closely associated and, in some places, grade into the quartz monzonite. Most of the aplites are tabular and fill cracks in the quartz monzonite.

Quartz porphyry dikes and plugs are associated with the quartz nonzonite and were present in the district at the time of mineralization. They are irregular porphyritic dikes with prominent quartz phenocrysts, and cut the quart 2 monzonite. The dikes range from 10 to $50 \mathrm{ft}$. in width, are roughly parallel in trend, and have nearly vertical dips. They have been observed as deep as the 4200 foot level, still in dike-like form. The contacts of the quartz porphyry are sinuous with only moderate fragnentation of the quartz nonzonite.

Another set of intrusives locally called the "rhyolite dikes" followed the ore enplacement. They are rhyolitic or quartz latitic in composition and contain quartz phenocrysts and euhedral phenocrysts of albite and K-feldspar in a predominently aphanitic groundnass. The rhyolite dikes have offset and brecciated ore veins and locally metamorphosed the vein minerals. These dikes were intruded in two stages. The earlier stage strikes roughly eastwest and dips nearly vertically. It is essentially a single dike which 
188

crosses the entire district. It follows pre-existing planes of weakness, such as the Anaconda fissures, and the stewart and Middle faults. The second set of dikes, trending north-south, cuts the east-west dike, with "chilled" margins at the contact with that dike. Most of the north-south dikes extend to the surface and are a few hundred feet wide near the surface. They are less altered than the east-west dike. Radionetric dates using ${ }^{40} \mathrm{~K} /{ }^{40} \mathrm{Ar}$ indicate that the east-west dike is about 48 million years old and the northsouth dikes are about 40 million years old (Woakes, 1949).

\section{STRUCTURE}

The Butte district is located in a central tectonic block of an active mountain-building region. To the north, a thick sequence of Precambrian Be1t Series sediments is faulted and folded along axes parallel to the regional northwesterly Rocky Mountain trend and displaced northeastward as the Lewis thrust plate. The district is bounded on the south by a stable block of gneiss, schist, and granite which has resisted deformation since the Precanbrian. The central block is also bounded on the north by the Lewis and Clark lineament and on the south by an east-west lineament. This central mass has been an area of recurrent subsidence and deformation, and has migrated eastward relative to the adjacent blocks. It is postulated by Meyer and others (1968) that the eastern movement was retarded by the stable block to the south, inducing clockwise rotation. This rotational movement explains the northwesterly structural trend in the northem block. the northeasterly trend in the central block, and the northwesterly trend again in the southern block. It appears that the structural trend of the district was established before the main stage of nineralizartion, and the reverse "S" ourvature of structural trends influenced orientation of the Boulder batholith itself.

Structural developnent continued during and after nineralization (Proffett, 1973). Post-ore structures include intrusions, strike faulting along earlier veins, and movenent along several systems of faults with accompanying 
brecciation. These events are not described in more detail here as they have little effect on the underground nine workings.

In addition to the lineaments and thrust faulting in the district, there are several other fault systens. The Blue fault strikes north-westerly and offsets the Anaconda veins in a left lateral motion. The Steward fault system is the earliest of a series of northeast-striking normal faults which offset the Araconda fissures. The Rarus fault consists of a zone of $50 \mathrm{ft}$. or more of bifurcating individual fault gouges. The Middle fault system strikes slightly north of east and steeply dips to the south; the movement is apparently normal. The chief nember of the Continental fault systen is a north striking nornal fault, located at the eastern edge of the district. Topographic evidence indicates displacement of $1500 \mathrm{ft}$. and there are strong indications that movement since minerajization may be several times that much.

The extreme complexity of the fault patterns in the Butte district indicates that the structural epochs were not sharply defined or separated by periods of stability. There was much refaulting throughout and following mineralization.

\section{MINERALIZATION}

The main stage of mineralization occurred between phases of intrusion, uplifting and faulting. In genera1, mineralizazion in the large veins occurred as roughly concentric zones of zinc and manganese around a central zone of copper. Slightly offset from these zones and earlier structurally, is a zone of quartz-molybdenite veinIets occurring at the 2800 foot level and widening downward.

Butte is ane of the world"s outstanding examples of metal and inineral zoning. Three zones were outlined by Sales (1914). These zones are: 
(1) A central zone occupying an area of altered granite in which the ores are characteristically free of sphalerite and manganese minerals,

(2) An internediate zone in which the ore is predoninantly copper, but is seldon free from sphalerite, and

(3) A peripheral zone in which copper has not been found in comnercial quantities.

The approximate positions of theșe zones are illustrated in Figure 4 . The Iine between the Central and Intermediate zones is called the "Copper Front" and delineates the area within which ores of copper may be found in najor structures. The "Copper Front" includes some islands of copper ore lying outside of the zone of continuous copper mineralization. Most of these islands are connected along veins to the main copper zone at deeper levels. The association of wall-rock alteration and ore at Butte was the subject of a classic paper by Sales and Meyer (1948).

Nearly all the production from Butte has cone fron large veins and from zones of closely spaced fractures called "horsetail ore bodies." A plan view of three major veins is illustrated in Figure 5 .

Sales (1914) reported that the east-west striking veins were the first of the large veins in the district to open and receive mineralization. He named these the Anaconda system; a cross section view of one of the Anaconda veins is shown in Figure 6 . Five principal veins of the Anaconda system have been mined extensively along with 12 to 15 smaller veins and numerous splits and bifurcations. The average width of the Anaconda veins is between 20 and $30 \mathrm{ft}$, and locally the veins may extend to $100 \mathrm{ft}$. in width. These maximum widths generally occur in the zone of changing strike.

In the eastern part of the district the "horsetail zones" occur. These ore bodies are hundreds of yards long and up to $200 \mathrm{ft}$. in width, and have been mined over vertical distances as great as $2000 \mathrm{ft}$. The zones strike about $N 70^{\circ} \mathrm{E}$, perpendicular to the small individual mineralized fractures. 


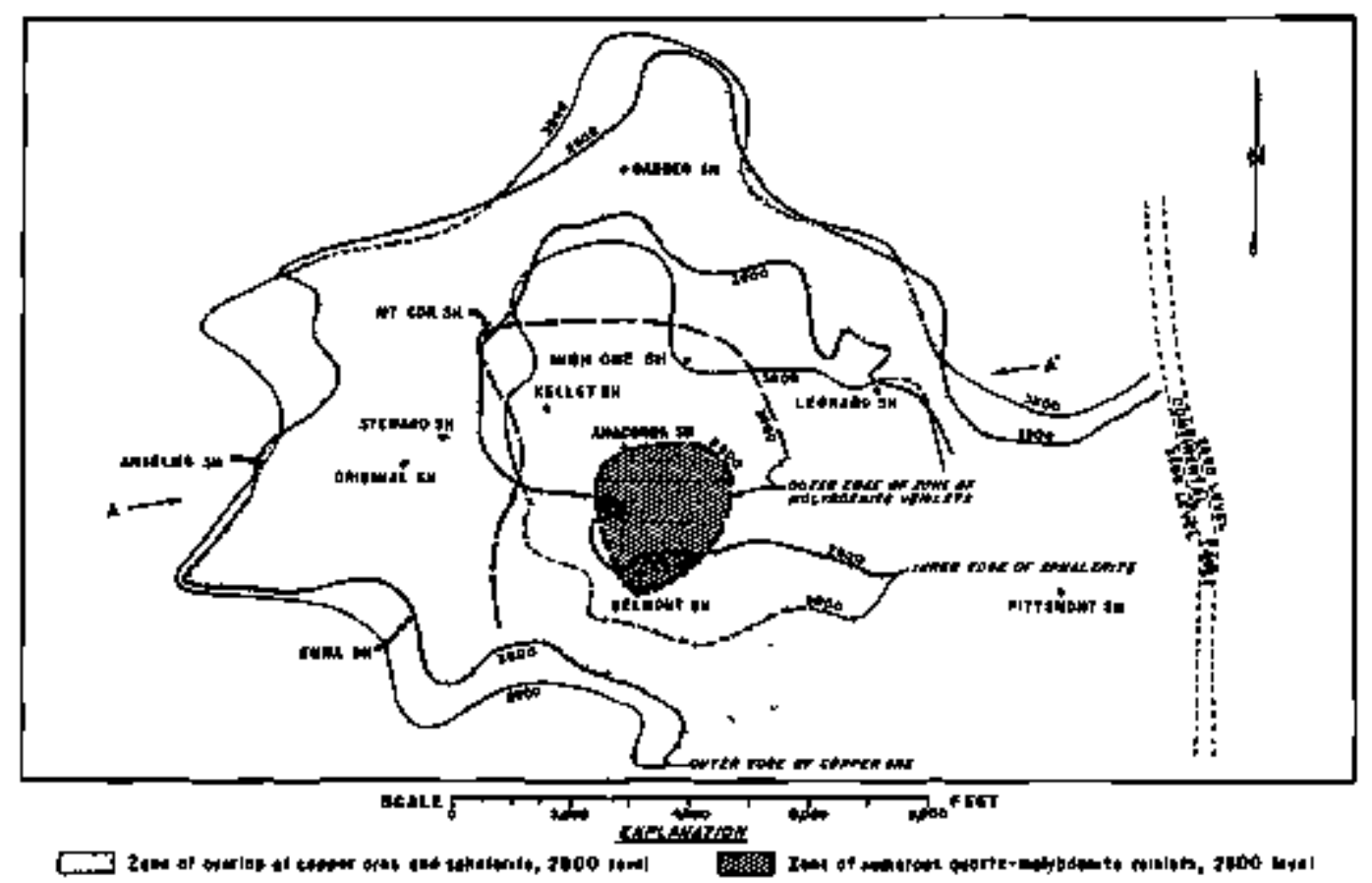

FIGTRE 4. Composite Plan at 2800 and 3800 Levels showing zones of mineralization within which there is no sphalerite nineralization, the zone beyond which there is no copper ore, and the outer edge of the zone of quartz-molybdenite veinlets, all in relation to the principal shafts of the district (Meyer and others, 1968). 


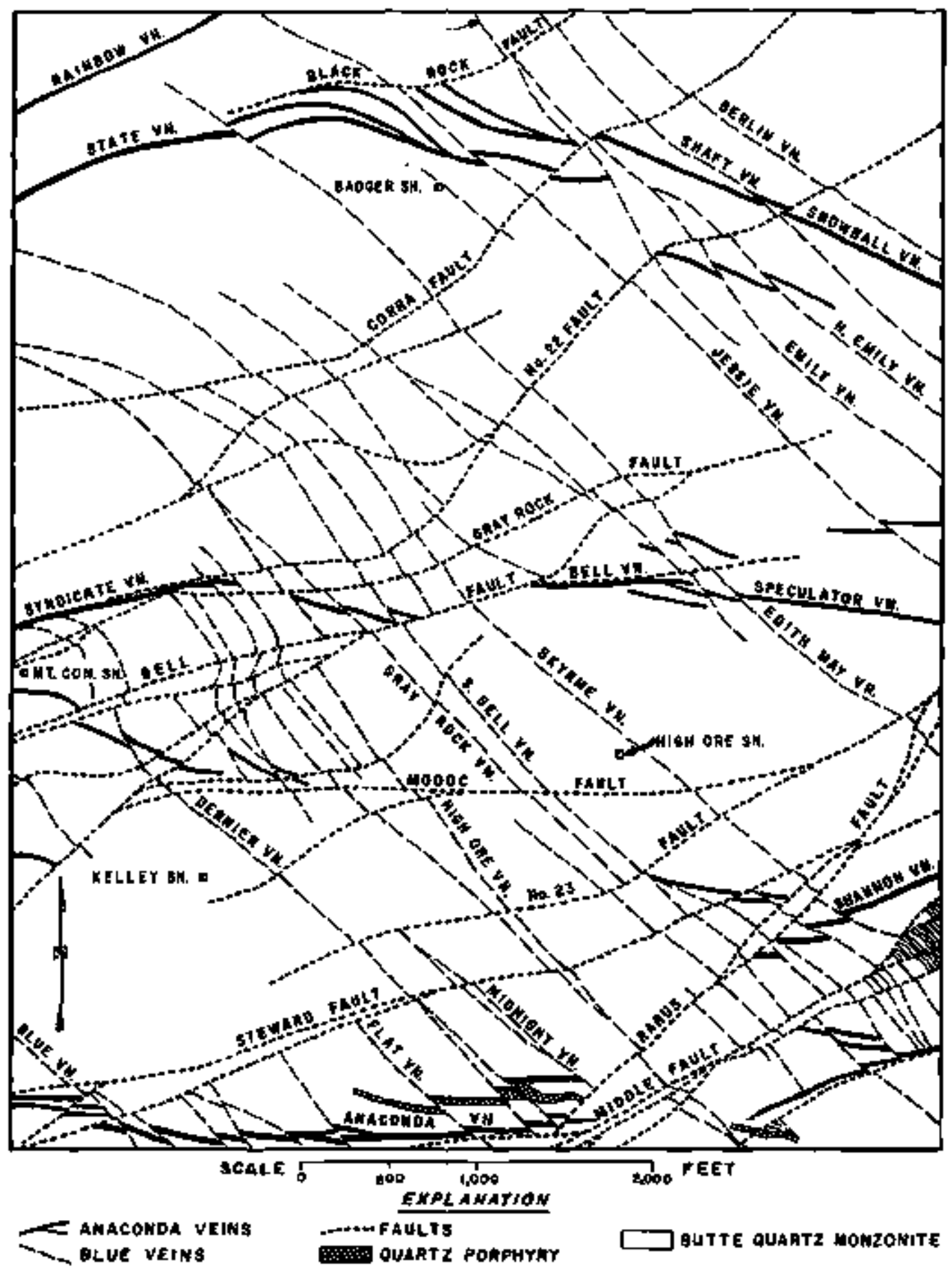

FIGURE 5. Plan view of the State, Syndicate, and Anaconda vein systems near the center of the district at the 1800 level, high ore. The Bell-Speculator eastward exten* sions of the Symdicate vein systen die out below this level, and the two zones which contain no Anaconda-age veins merge and expand with increasing depth (Meyer and others, 1968). 


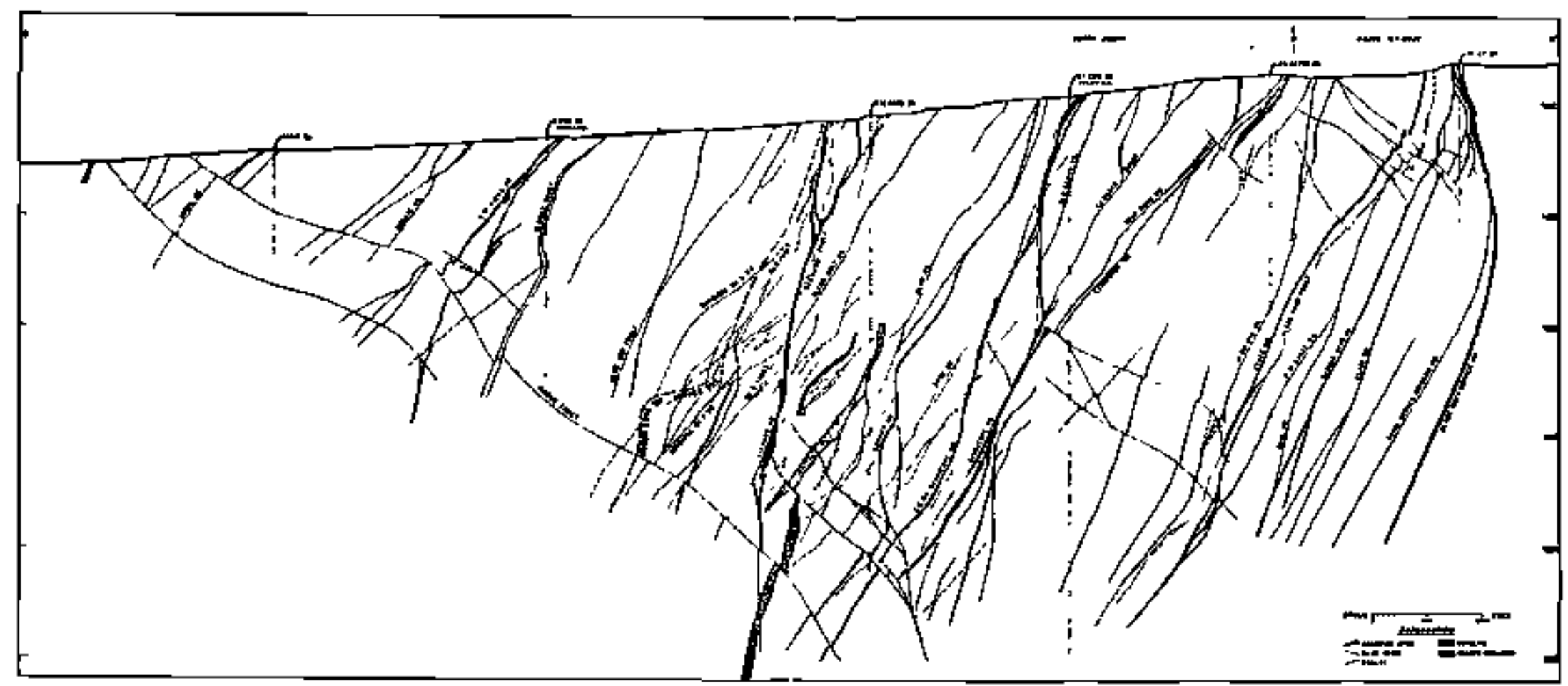

FIGURE 6. Cross section vien of inaconda Vein, looking west, showing dips of Anaconde fissures (tweyer and others, 1968). 
Each sna1l fracture or fracture zone contains a miniature ore shoot bordered on either side by gangue.

MINE DESCRIPTIONS

The Anaconda Company phased out all underground mining operations at Butte in November 1975 (Thomas, 1977). It was once the largest copper producing district in the United States, including both surface and underground workings, and has produced 16.2 billion pounds of copper, 4.8 billion pounds of zinc, and great quantities of manganese, lead, silver, gold, and other metals (Weyer and others, 1968). After almost a century of deep vein mining, more than 42 miles of vertical shafts have been sunk and thousands of miles of other underground passageways were excavated. Although the underground mines are not operating, a few deep workings are being naintained to facilitate reopening should mining become economically feasible (Thomas, 1977). Leonard Mine

The leonard mine was exploited for copper almost continuously from 1886 to 1967 and reopened in January, 1972. Three levels were active; the 3500 , 3600 , and 3800; with plans to reopen the 3400 and 3900 foot levels (Society Economic Geologists, 1973). The host rocks in the mine are Butte quartz monzonite, quartz porphyry, and aplite. The structural setting and mineralization of the area consist of $N 70^{\circ} \mathrm{E}$ trending, steeply-dipping horsetall ore bodies and east-west and northwest trending main stage veins. Post-minera1 rhyolite dikes cut across the mine between the Leonard and East Colusa shafts. Left lateral movenent is evident in the mine on some fault systems. Mine workings were active on veins west of the Middle fault, on horsetail ore bodies and selective veins between the Middle fault and No+ 20 fault. Figures 7 and 8 illustrate the workings at the 3600 and 3800 foot levels, respectively. 


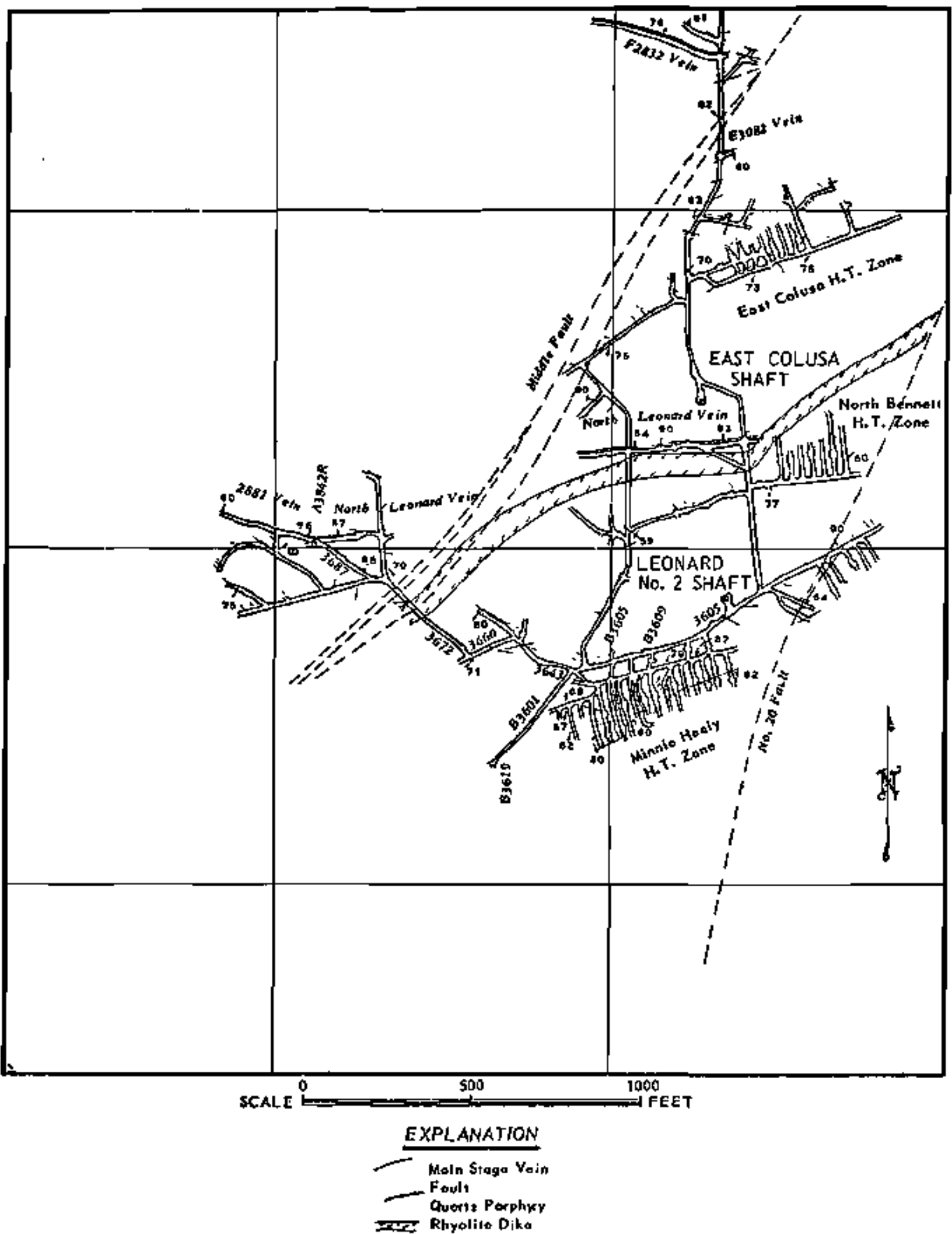

FIGURE 7. Map of the Leonard ndne at the 3600 level, Stiver Bow County, Montana. (Miller, 1973). 


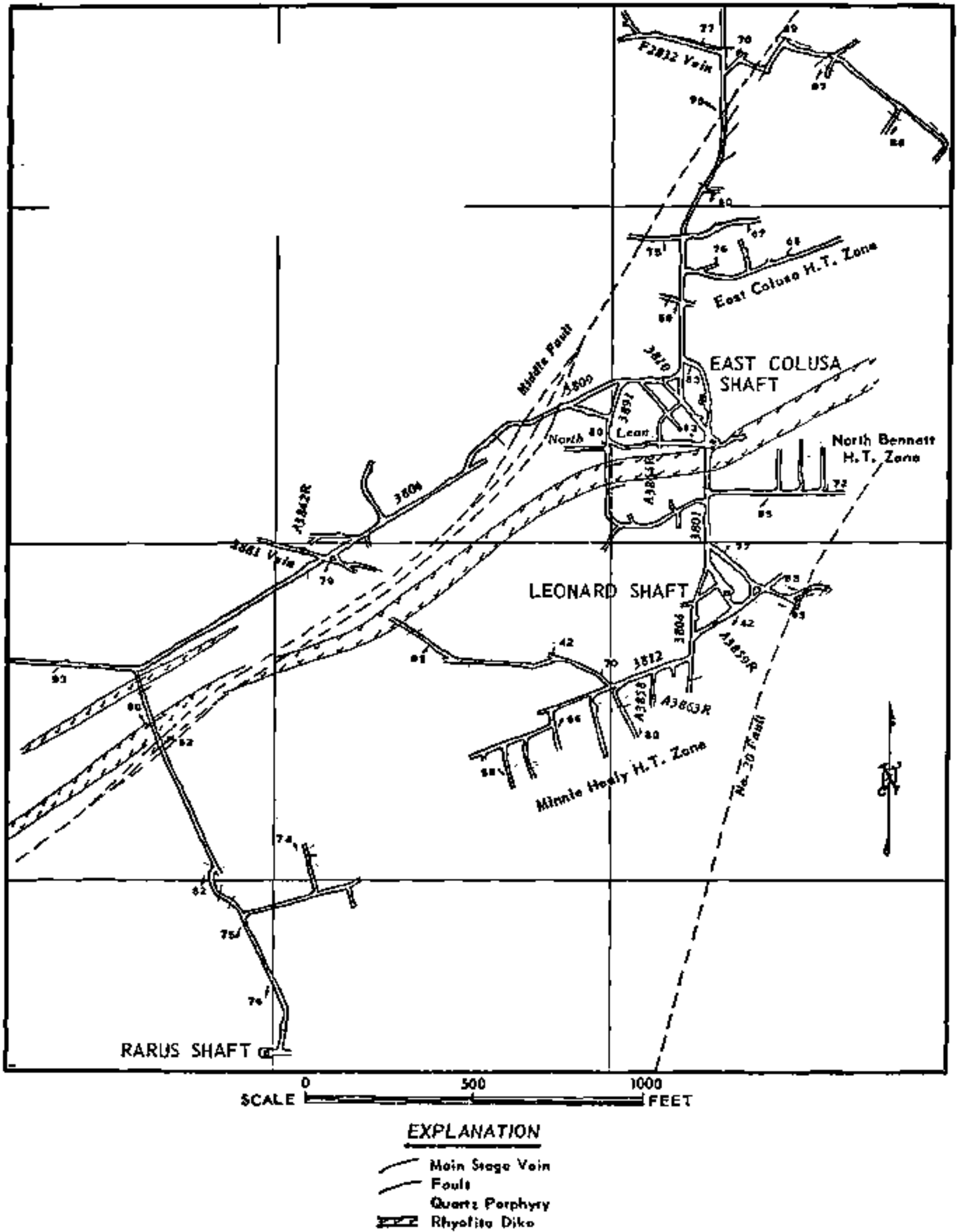

FICURE 8. Map of the Leonard tine at the 4800 Ievel, S1lver Bow County, Hontana, (Miller, 1973). 


\section{Steward Mine}

The Steward mine is one of the oldest underground workings, with copper mining beginning in 1879. It had nine levels active in 1973 and was being mined at a rate of 800 to 900 tpd. The active levels were the 3400,3800 , $3900,4000,4100,4200,4400,4500$, and 4600 foot levels.

The host rocks in the Steward nine are the same as at the leonard mine. The Steward mine illustrates the entire range of pre-Main Stage vein and a1teration events. The post-mineral Rarus fault cuts northeasterly through the mine and dips northwesterly. The fault has two main strands, each offsetting Main Stage veins right-laterally. The Middle fault and snaller paraflel faults strike northeasterly and dip steeply to the south in the mine. These structures cut and offset Main Stage veins 20 to $40 \mathrm{ft}$. left laterally.

In 1973, three systems of Main stage ore-bearing veins were reported being mined at the deeper levels of Stewart. Five veins were being exploited, and developwent headings on the 3900 and 4000 foot levels were being extended to the southeast. Further, trackless mining equipment was assisting development on the 4500 foot level. Figures 9 and 10 indicate mining activities on the 4200 and 4400 levels, respectively. 


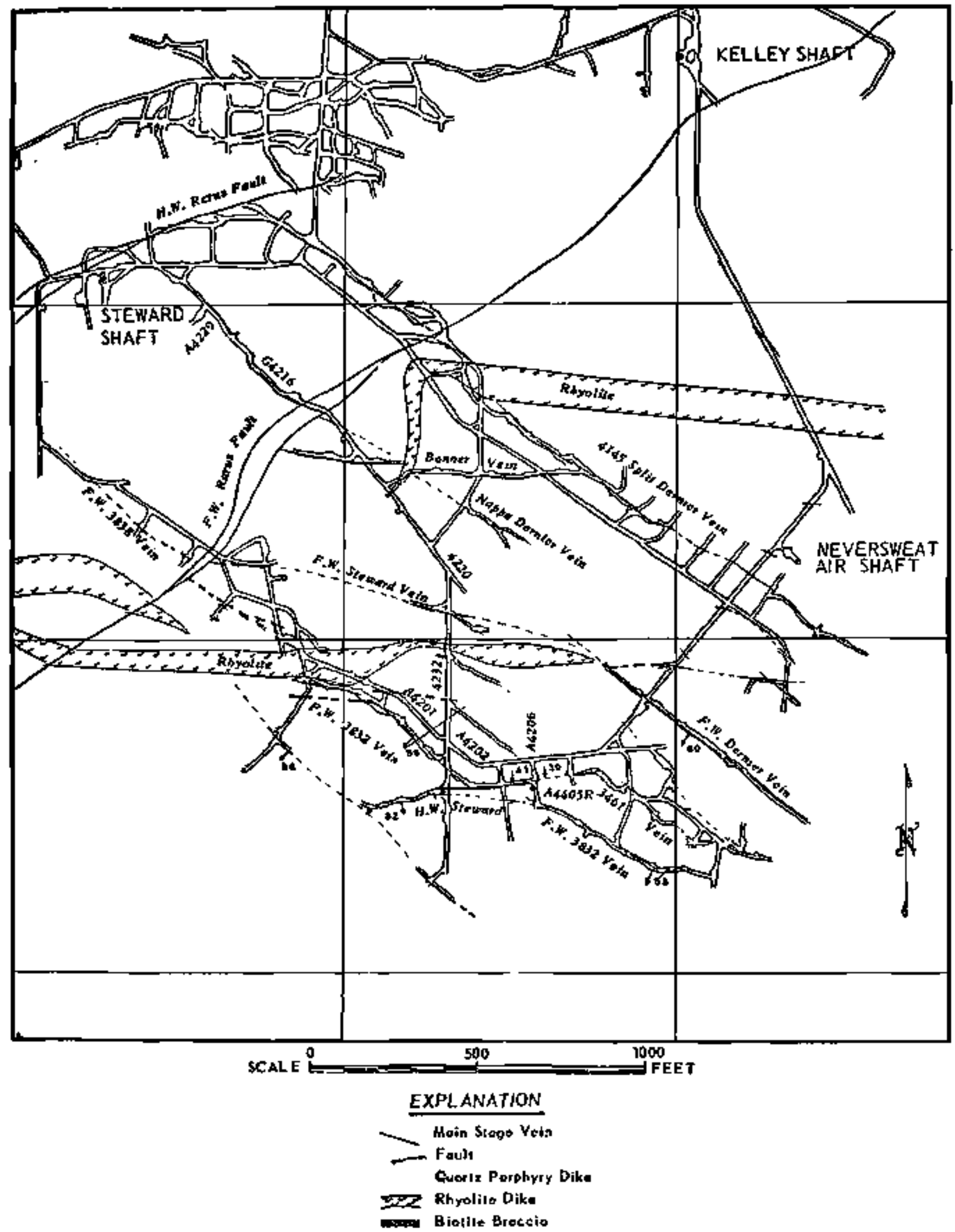

FIGIRE 9. Map of the Steward mine at the 4200 level, Silver bow County, Hontana. (Milier, 1973). 


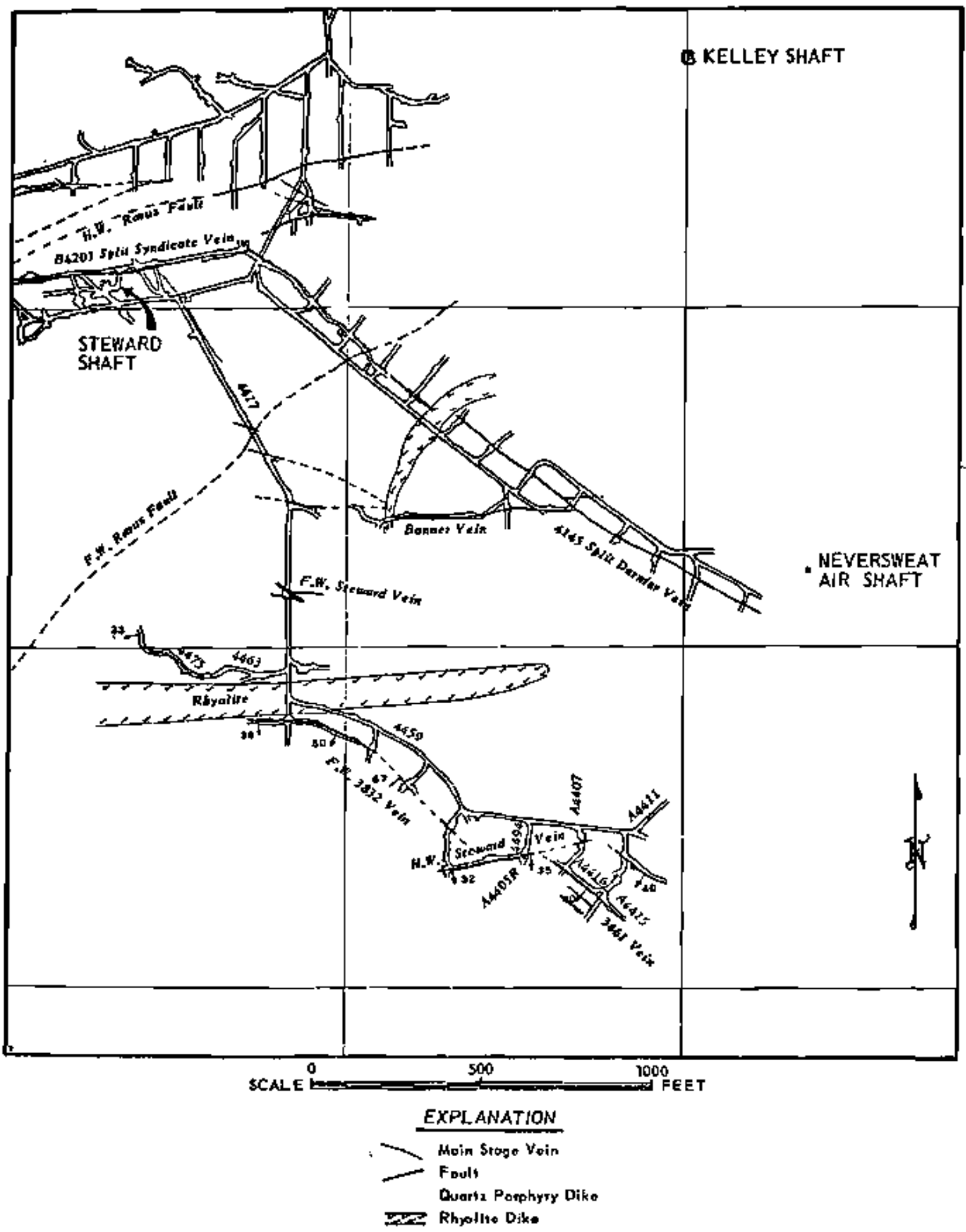

FIGURE 10. Map of the Steward nine at the 4400 level, S1lver Bow County, Montana. (Miller, 2973). 
REFERENCES

Billingsley, P., and Grimes, J.A., 1918, Ore deposits of the Boulder batholith of Montana: AIME Trans.,v. 58, p. 284-361.

Klepper, M.R., 1962, Enplacement of the Boulder batholith: AIME Rocky Mountain Minerals Conference, Butte, Montana.

Knopf, A., 1957, The Boulder batholith of Montana: Amer. J. Sci., v. 255, (2) P 81-103.

Meyer, C., Shea, E.P., Goddard, C.C., Jr., and staff, 1968, Ore deposits at Butte, Montana in: Ridge, J.D., ed., Ore Deposits of the United States, 1933-1967: AIME, New York, p 1373-1416.

Miller, R.N., 1973, Production history of the Butte District and geological function, past and present: Soc. Econ. Geol. Guidebook, Butte field meeting, F 1-11.

Proffett, J.M., Jr., 1973, Structure of the Butte district, Montana: Soc. Econ. Geo1. Guidebook, Butte field meeting, G 1-12.

Sales, R.H., 1914, Ore deposits at Butte, Montana: AIME Trans, v. 46, p. 3-109.

Sales, R.H. and Meyer, C., 1948, Mall-rock alteration, Butte, Montana: AIME, Trans., v. 178, p. 9-35.

, 1954, Genetic relation between granites, porphyries, and gssociated copper deposits: First Jackling Lecture, Min. Eng., v. 6 (5), p. 499505 .

Thonas, R+A., 1977, Montana's giant Berkeley pit girds for another 22 years, E/MJ, v. 178 (6), p. 107-109.

Woakes, M., 1959, Potasslum-argon dates of the nineralization at Butte, Montana, Master's thesis, Univ. of Calif., Berkeley, $43 \mathrm{pp}$. 


\author{
GRANITE - BIMETALLIC MINE \\ (PETER FRANK and WILLIAM ANTONIOLI, owners)
}

\title{
LOCATION
}

The Granite-Bimetallic Mine is located 2.5 miles southeast of the tom of Philipsburg, in Granite County, Montana, at $46^{\circ} 19^{\prime} \mathrm{N}, 113^{\circ} 15^{\prime} \mathrm{W}$, (Figure 1). The mine is on the western slope of the Granite Mountain Range at an elevation of $6780 \mathrm{ft}$. One of the principal producers of silver in the Philipsburg district, the mine was identified as being active in 1976, with ore reserves estinated at one million tons (U.S. Geol. Survey, 1976), and was inactive in 1978 (Lawson, 1979).

\section{GEOLOGY}

The geology of the district is described by Prinz (1967), Ridge (1972), and Enmons and Cajkins (1913). The Granite-Bimetallic mine is in an area of folded and faulted Precambrian and Paleozoic sedimentary rocks that were intruded by the Philipsburg batholith, stocks and dikes of Cretaceous age (Tilling and others, 1968), (Figure 2). The sedinentary rocks consist primarily of quartzite, shale and limestone, which have been metamorphosed near their contact with the batholith. The stratigraphic sequence is 1isted in Table 1. The oldest rocks, the Missoula Group quartzite of the Belt Series, are exposed in the core of a north-trending anticline. Above a slight unconformity is the middle Cambrian Flathead quartzite, which is overlain by the mid-Cambrian Silver Hill formation. The upper Cambrian consists of the carbonate rocks of the Hasmark and Red bion formations. Several miogeosynclinal sedimentary units lie unconformably above the Red Lion limestone; however, they do not crop out in the mine area. 


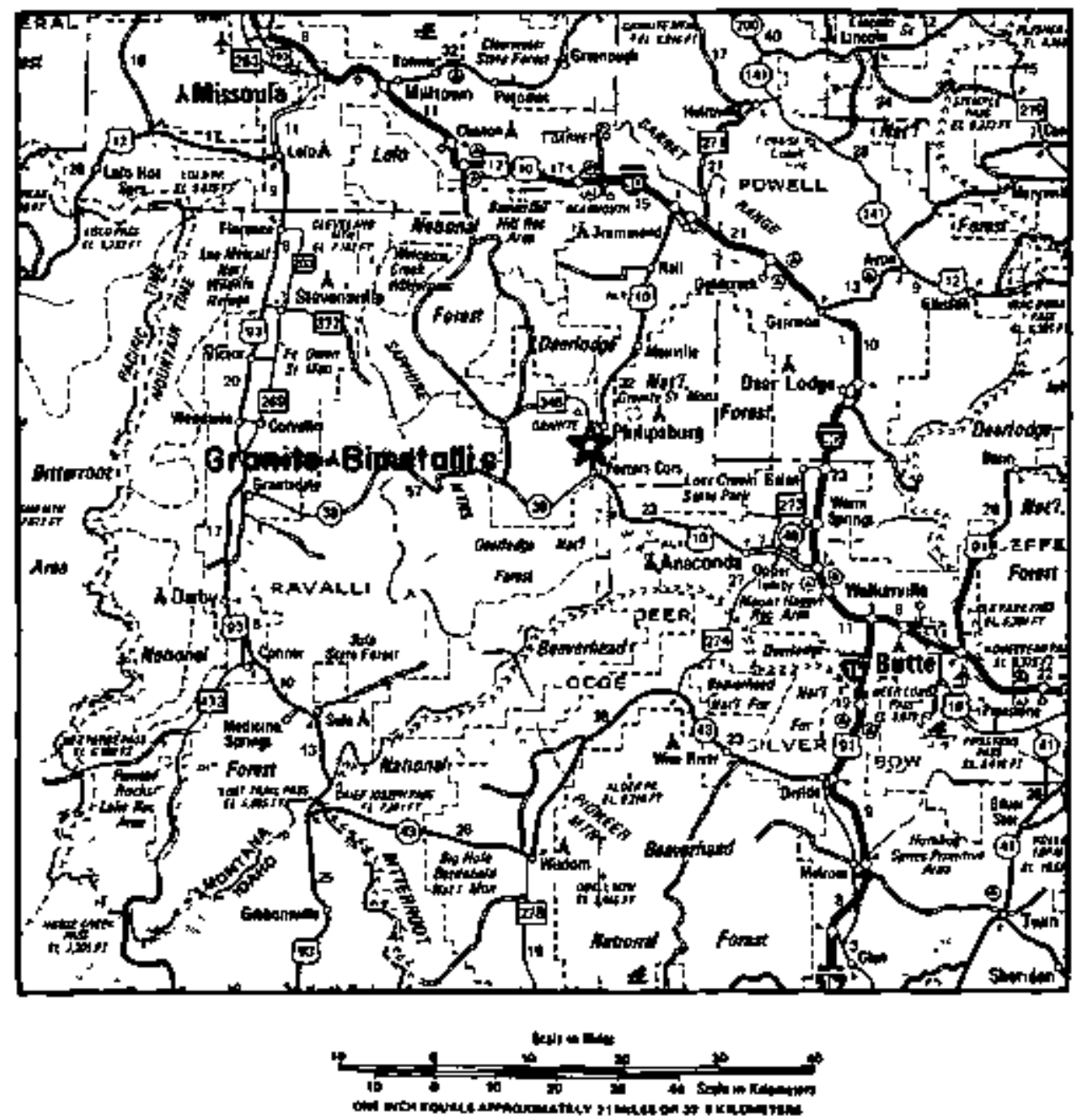

FIGURE 1. Location map - Granite-Binetallic Mine, in Grant te County, Montana. Basic map reproduced by permission of the American Automobile Association, copyright owner. 


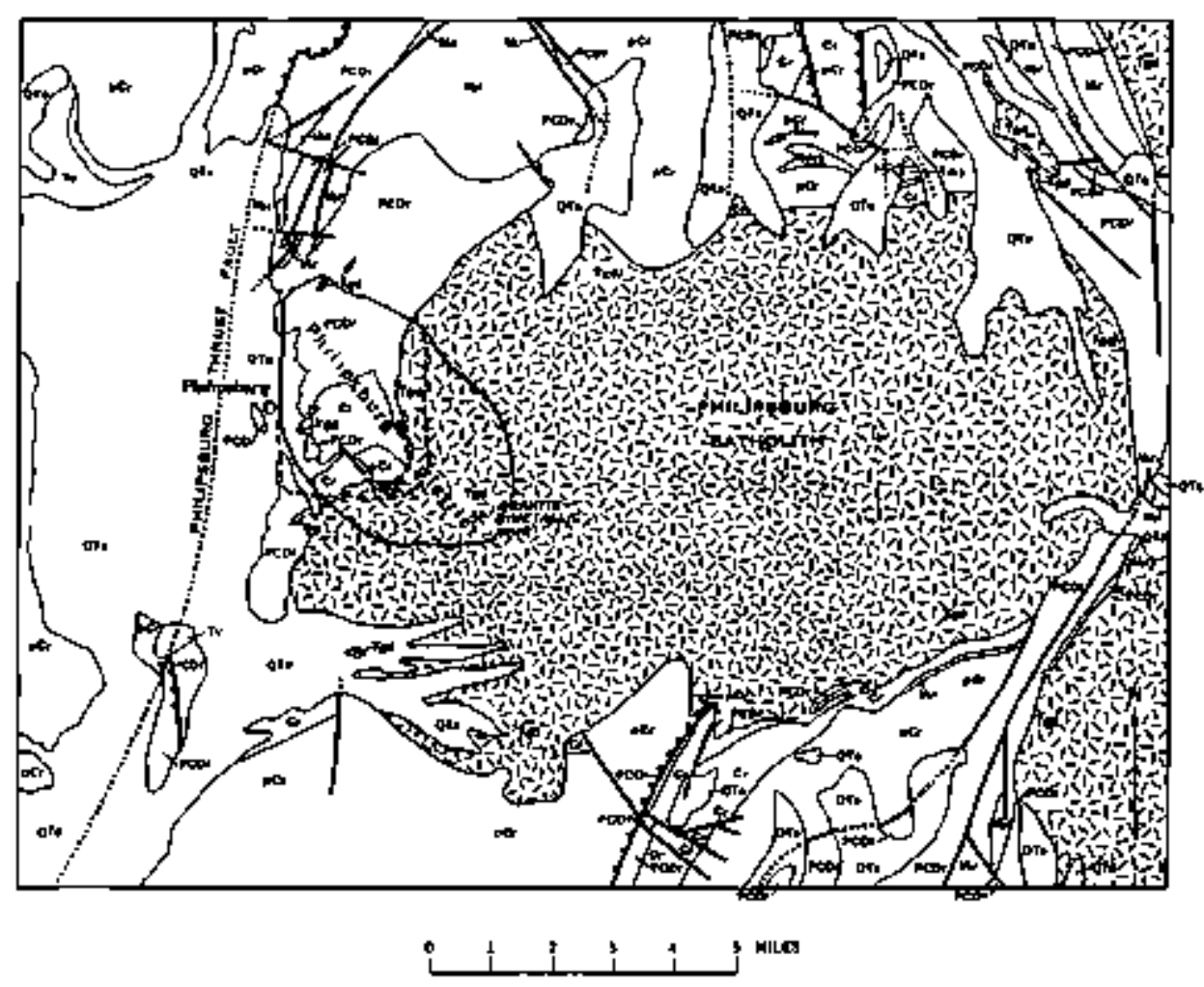

EXPLANATHON DEDIHENTARY MOCKK

ois.

Tetiers and Q4antman?

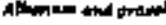

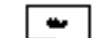

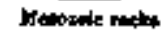
+on

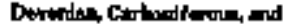

Tremian tocke

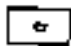

Combritan rude

ntis

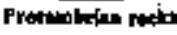
IGHEOUS MOCKB

?

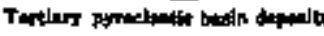
स्स:

Trether granodieris Tme

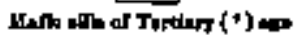

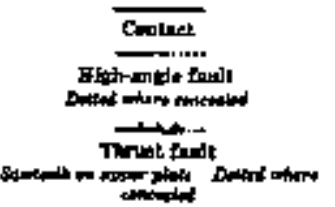

FIGURE 2. Generalized geology of the Philipsburg batholith and surrounding area showing location of the Philipsburg district (solid outline). The Granite-Bimetallic mine is located in the southeast area of the district (from Prinz, 1967). 


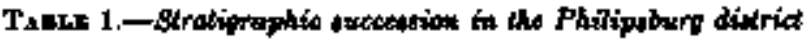

\begin{tabular}{|c|c|c|c|c|}
\hline & AR & Formation & Thitam & Chureter \\
\hline & Putraling & Ophomenthimed & 100 & 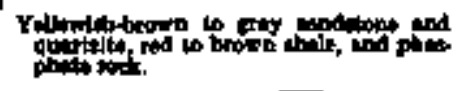 \\
\hline \multirow{2}{*}{ 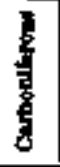 } & \multirow{2}{*}{ 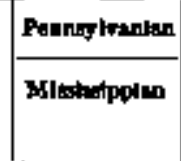 } & 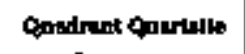 & $300-59$ & 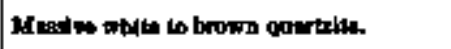 \\
\hline & & Meditah Ltroestoos & $1,000-1,500$ & 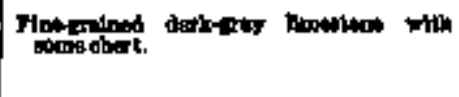 \\
\hline \multirow{2}{*}{\multicolumn{2}{|c|}{ Bopuning }} & IAfardon Ltumatom & $1,000-1,2=$ & 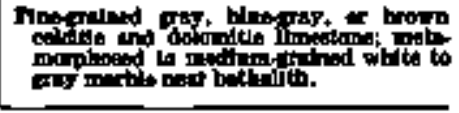 \\
\hline & & Magroed Pormelua & $20-20$ & 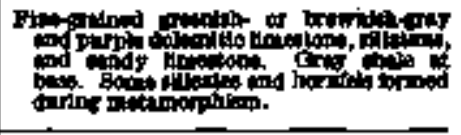 \\
\hline \multirow{4}{*}{$\frac{5}{3}$} & \multirow[t]{2}{*}{ Vpoer } & Rod Iton Pornation & $200-10$ & 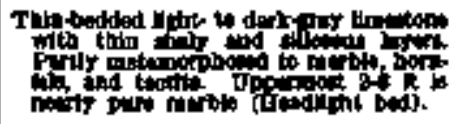 \\
\hline & & 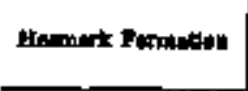 & 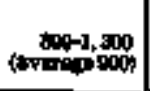 & 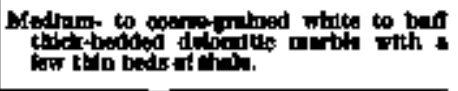 \\
\hline & \multirow[t]{2}{*}{ Shidals } & Allow Bull Fornustion & $200-80$ & 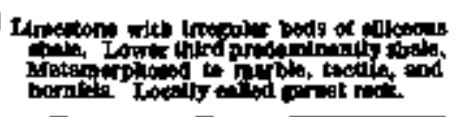 \\
\hline & & 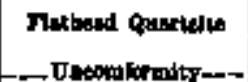 & $\mathbf{3} \mathbf{4}$ & 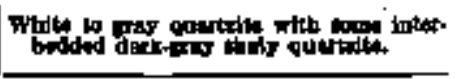 \\
\hline \multicolumn{2}{|r|}{ Proporturian } & Mitwoln Group & & 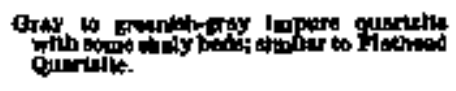 \\
\hline
\end{tabular}

(from Prinz, 1967). 
The Precanbrian and Paleozoic sedimentary rocks were intruded by the Philipsburg batholith, which is predominantly medium-grained granodiorite. The Philipsburg is one of the larger satellite plutons of the Boulder batholith (see the description of the Butte underground mines), and is associated with numerous stocks and dikes of similar composition. Although the bulk of the Philipsburg batholith is granodiorite there are older, nore mafic masses along the margins. The batholith is elliptical in plan and exterds over an area of 45 sq. mi. Most of the granodiorite is unweathered; however, it is intensely altered near the veins.

\section{STRUCTURE}

The structural setting of the region includes a broad north-northeast trending, north-plunging anticline truncated by the Philipsburg batholith. The anticline and the batholith are cut by a number of fault systens. In general, they fall into three grotaps: 1) pre-intrusive faults trending northwest and dipping steeply northeast, 2) post-intrusive faults striking easterly and dipping steeply south, and 3) post-intrusive faults striking northwest and dipping $45-60^{\circ}$ southwest. The faults are normal and displacements are rarely greater than $5-30 \mathrm{ft}$. Dikes and sills of granodiorite cut the sedimentary rocks near the batholith.

\section{MINERALIZATION}

The steeply-dipping veins of the mine are lacated in the western portion of the Philipsburg batholith. The deposits of the Philipsburg district are divided by Prinz (1967) into four groups: (1) steeply dipping quartz veins, (2) quartz veins along bedding planes, (3) manganese-rich replacement deposits, and (4) contact metasonatic magnetite deposits. Quartz veins (1) 
predoninate in the Granite - Bimetallic mine. They have been mined prinarily for silver, zinc and lead and cut both the batholith and the surrounding sedinentary rocks. The ore occurs as fissure-filling and as replacement deposits. In the mine, the veins strike west or northwest and dip steeply to vertical. Zoning is connon. The principal ore body is a tabular nass and measures fron 3-10 ft. in thickness and is about 4,600 ft. long (U.S. Geol. Survey, 1976). The deepest part of the mine is in the eastern portion where the ore extends downward more than $2600 \mathrm{ft}$. The Granite vein (Figure 3) is the largest and richest; it strikes about $N 78^{\circ} \mathrm{E}$ and dips genera1ly about $75^{\circ} \mathrm{S}$. Its average width varies fron 4-8 ft., and in sone places it widens to a maximum. of $26 \mathrm{ft}$.

\section{MINE CHARACTERISTICS and FACILITIES}

The Granite Mountain and Bimetallic mines were worked separately until 1898; since then they have been worked together as both are located on the same ore body. During early operation the mine was worked from five drift tunnels, two deep shafts and a long adit which drains the Granite Mountain mine between the 14 and 15 levels and the Bimetallic nine at level 10 . The Granite shaft is about $1550 \mathrm{ft}$, and the Bimetallic shaft is about $1800 \mathrm{ft}$. (Enmons and Calkins, 1913). The largest vein, the Granite vein, has been stoped for $4500 \mathrm{ft}$. along the strike and to depths of 2,600 ft. The aggregate length of workings reported in 1976 is $20 \mathrm{mi}$. (U.S. Geological Survey, 1976). The mine is drained by an 8,850 ft. tunnel from Douglas Creek Canyon, crossing the Bimetallic shaft at a depth of $1000 \mathrm{ft}$. and the Granite shaft at $1,450 \mathrm{ft}$. Below this level, the mine was purped (Emmons and Calkins, 1913). 


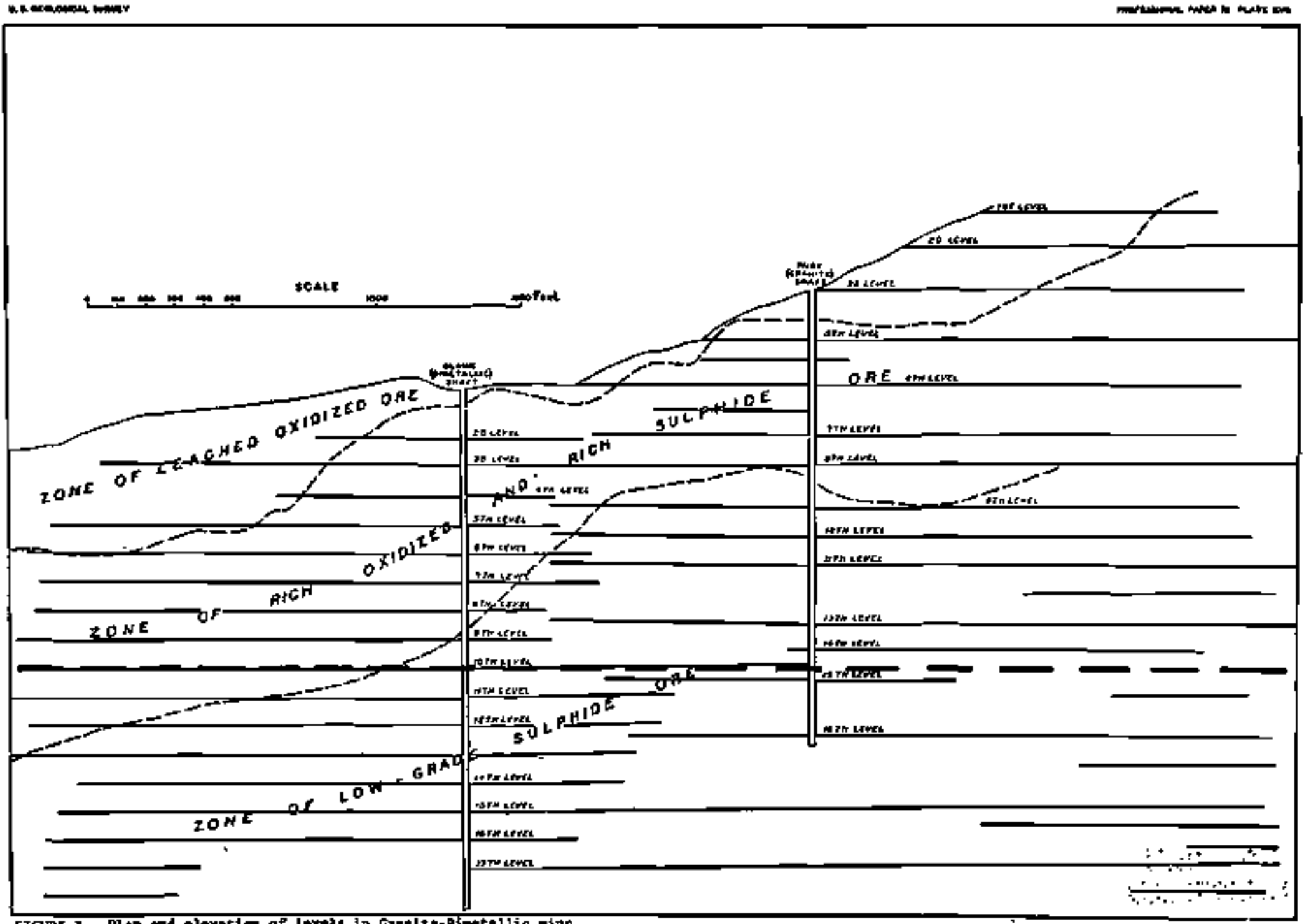

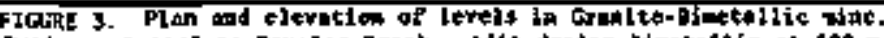

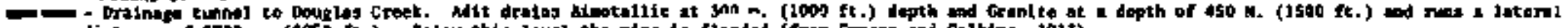

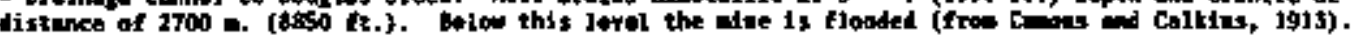


REFERENCES

Emmons, W.H. and Calkins, F.C., 1913, Geology and Ore deposits of the Philipsburg, Quadrangle, Montana: J.S. Geol. Survey Prof.Paper 78.

Krohn, D.H, and Weist, M, M., 1977, Principal information on Montana mines: Mont. Bur, Min. Geol. Spec, Pub. 75, p. 59.

Lawson, D.C., 1979, Directory of Mining Enterprises for 1978: Mont. Bur. Min. Geol. Bull, 109, p. 7.

Prinz, W.C., 1967, Geology and ore deposits of the Philipsburg District Granite County, Montana: 1.S. Geol. Survey Bu11. 1237, 66 pp.

Ridge, J.D., ed., 1972, Annotated Bibliographies of Mineral Deposits in the Hestern Hemisphere: Geo1. Soc. Amer. Mem, 131, p. 392-394.

Silvernan, A., 1965, Econowic geology of the Flint Creek Range, Billings Geological Society Field Conference No. 16. August 12-14, 1965, Univ. Mont., Missoula, p. 108-119.

Tilling, R.I., Klepper, M.R., and Obradovich, J.D., 1968, $K$-Ar ages and time span of emplacement of the Boulder Batholith, Montana: Aner. Jour, Sci.., v. 266, ( ) p. 671-689.

U.S. Geological Survey, 1976, Grante-Bimetallic Mine: CRIB. \#W013436. 
TEM PIUTE DISTRICT

(OPERATED BY UNION CARBIDE CORPORATION)

\section{LOCATION}

The Tem Piute mining district is located approx1mately 85 road niles west of Caliente and $100 \mathrm{miles}$ east of Tonopah, Nevada, in the Timpahute Range at $37^{\circ} 38^{\prime} \mathrm{N}, 115^{\circ} 38^{\prime}$ w. (Figure 1). The major tungsten deposits are located at the north end of Coyote Peak. Elevation in the mine area is approxinately 6,400 feet with several hundred feet of local relief.

\section{GEOLOGICAL SETTING}

\section{Regional}

The data for this section were extracted from Tschanz (1970).

As shown in Figure 2, the geologic nap of the Ten Piute district, the Timpahute Range is primarily composed of Paleozoic sedinents dipping steeply to the east. Permian rocks are present on the east side of the district. Mississippian rocks at the north end of the district have been intruded by two Tertiary granite stocks, each less than one mile in diameter. The dip of the bedding steepens northward along the west side of the stocks until the rocks are overturned; this is assumed to be the result of pregranite thrust faulting. The Devonion and older rocks in the man part of the district are thrust over the Chainman shale and younger rocks. In the southern foothills, the Devonian rocks make up the upper thrust plate, while north of Tempiute, they make up the lower plate. On the west side of the range, Middle Pennsylvanian rocks are in contact with Ordovician rocks, due either 


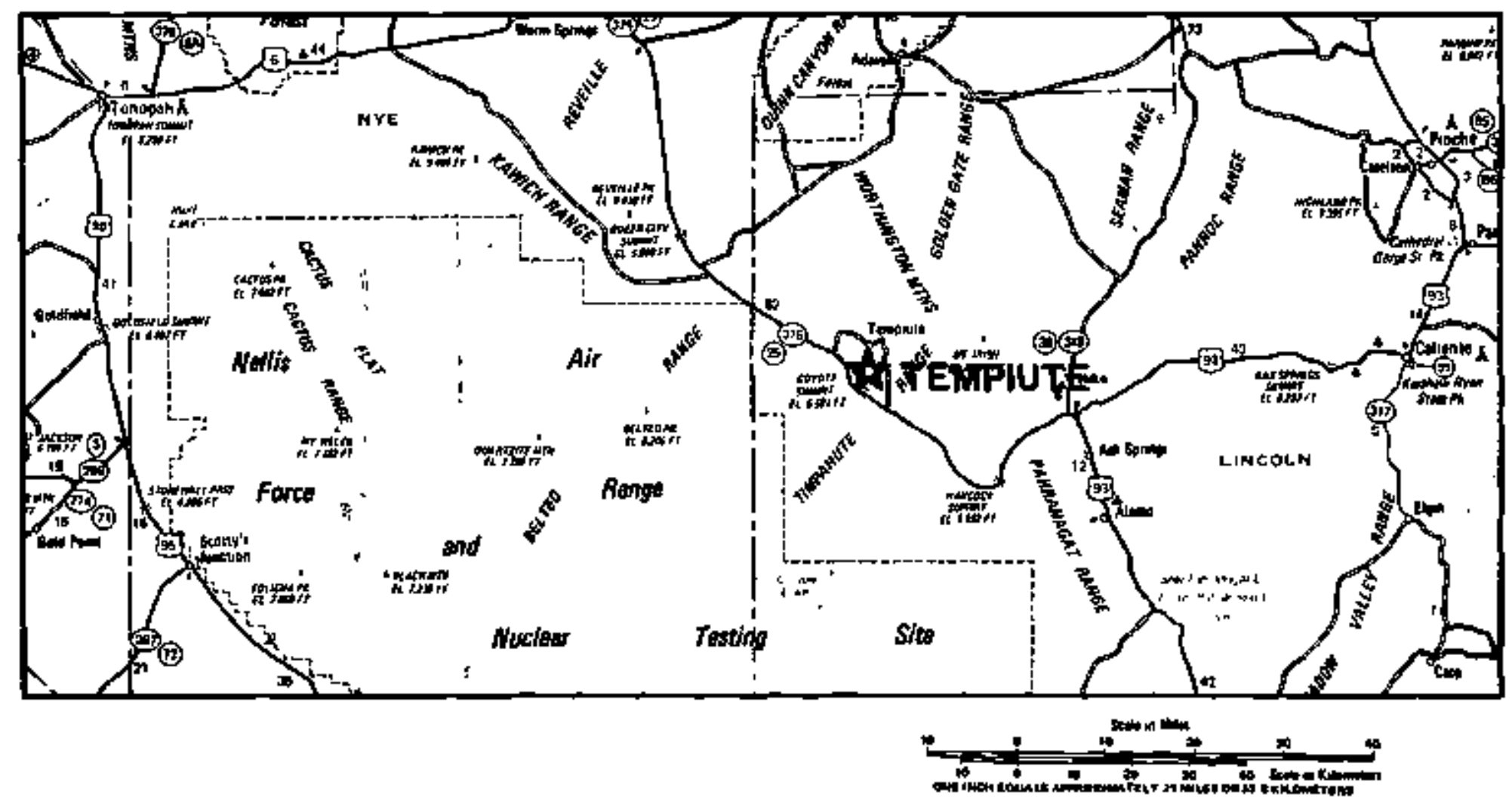

FIGURE 1. Location map of Tempiute operations, lincoln county, Nevada. Basic map reproduced by permission of the Anerican Automobile Association, copyright omer. 

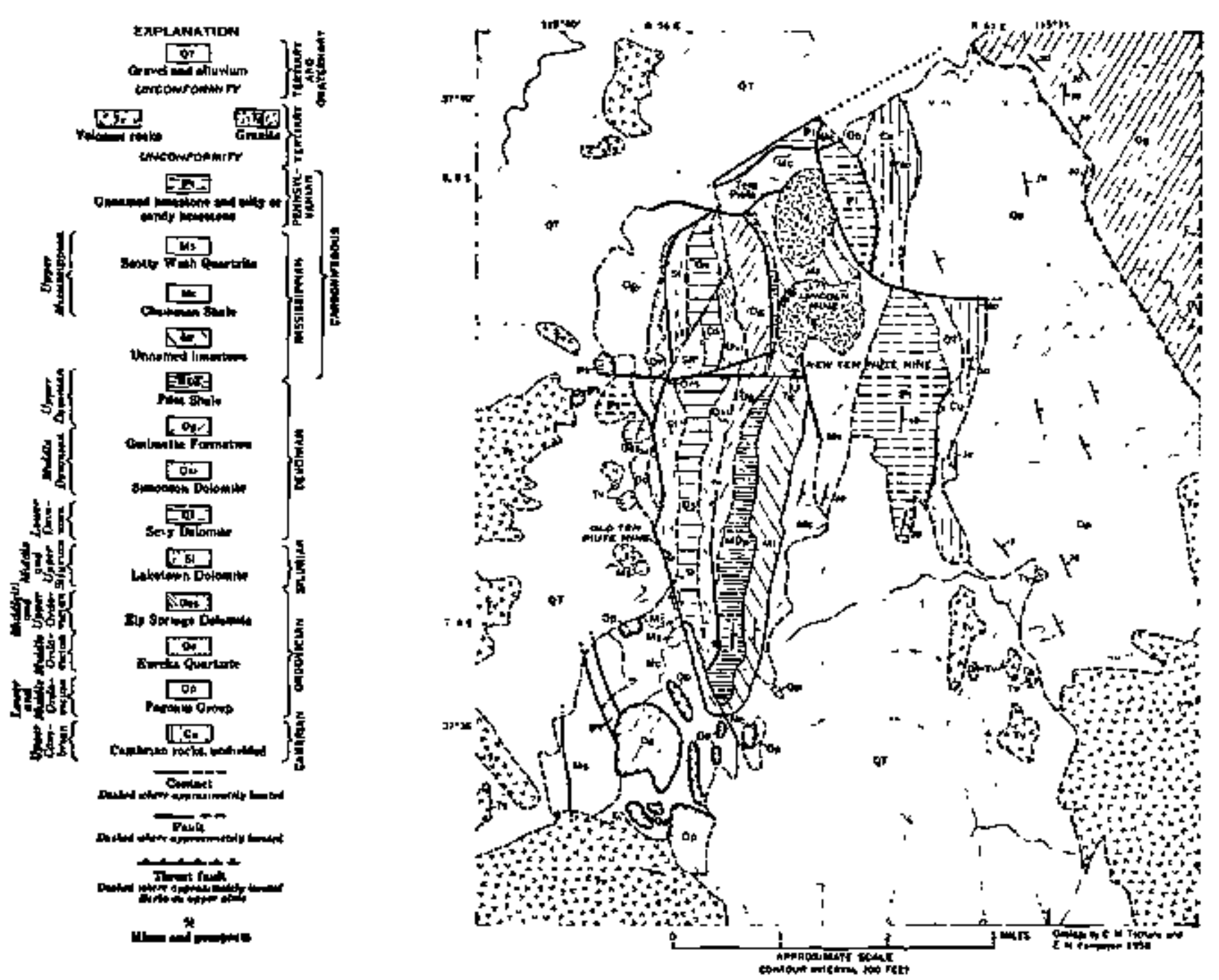

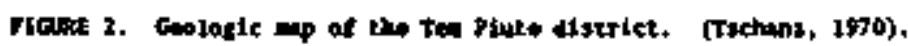




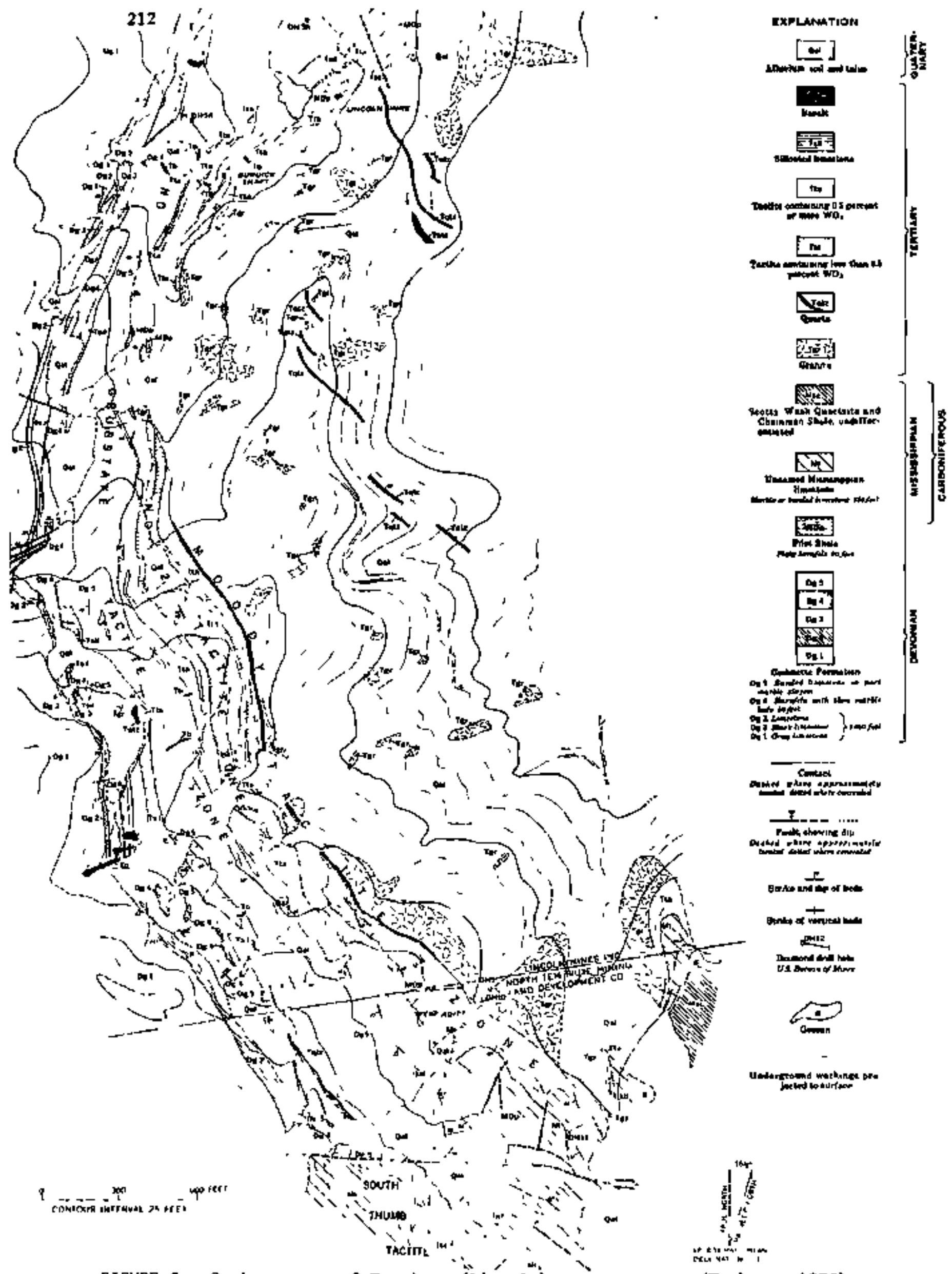

FIGLRE 3. Goologic unap of Tempiute (Liścolun) mine property (Tschenz, 1970). 
to thrusting or right lateral faulting.

\section{MINE AREA}

Data for this section were extracted from Tschanz (1970).

The tumgten deposits are found in or near thick bodies of tactite, at or near the contact between the Paleozoic rocks and the granite. As shown in Figure 3, there are three elongated bands of tactite parallel to the bedding of the Devonian and Mississippian limestones along the west side of the south granite stock. The south stock is conspicuously more altered and less resistant to weathering than the north stock. The grante and tactite are partiaily concordant with the Iimestone. The limestone is irregularly bleached and recrystallized as far as 700 feet from the granite contact; the tactite is irregularly developed as far away as 450 feet; and sllicated limestone is found even farther fron the contact, A contorted septum of Mississippian Iimestone 600 to 800 feet thick, which has been altered to tactite, separates the two stocks. The bedding in this septum is nearly vertical, and it strikes nearly east-west, perpendicular to the regional strike.

Two principal tactite zones are shown in Figure 3 . The No. 1, or Moody, zone is located along the west contact of the southern stock. The Noody zone extends for about 6,200 feet along the contact and is 15 to 110 feet thick, averaging about 40 feet thick in the Lincoln mine. The zone consists of bands of various forms of tactites. The second principal tactite zone is less continuous, less productive and does not extend to depth. The tactite is relatively uniform in grade through a vertical range of 1,300 feet. 


\section{MINE FACILITIES}

Data for this section were extracted from E4J (1974, 1977), Cobbs (1976), and Tschanz (1970).

Tungsten mineralization was discovered in the district in 1916, but was nat exploited until the nid-1950's. The mining lasted only a few years until 1957. Union Carbide became involved in the district in 1968, and made the decision to reopen the mine in 1974. A 1,000 ton per day tumgsten mining operation was begun in June 1977. Approximately 2 million pounds of tumgsten are produced amsually.

The originat lincoln mine was developed by nore than 20,000 feet of underground workings on six levels, the 100, 200, 300, 500,700 and 900 levels, with adits on the 100,300 , and 700 levels and an inclined shaft from the surface to the 900 level. Mining was by shrinkage stopes. The workings required little support.

Data on the current mining operation are sparse. It is assuned that the Lincoln mine has been reopened and developed further. The new mine is a combination of tracked and trackless mining. The volume of the mine is at least 90 million cubic feet.

The distribution and amount of underground mine workings in the intrusive rocks are not known. However, the similarity between the Tem Piute district and the Pine Creek mine suggest that there probably are sone rorkings in the intrusive. 


\section{REFERENCES}

Cobbs Engineering Co., 1976, Survey of active and inactive nines for possible use as in situ test facilities, Office of Haste Isolation, Oak Ridge, Tenn., Report No, Y/OWI/SUB-76/16514.

CRIB

Engineering and Mining Journal

--EMJ International Directory of Mining and Mineral Processing Operations, 1977

--1977, Union Carbide revives Nevada Tungsten Mine, v.178[6], p.129

--1974, Union Carbide developing Nevada Tungsten Property, v.175(11), p.13

Tschanz, C.M.; Panpeyen, E.H., 1970, Geology and Mineral Deposits of Lincoln County, Nevada, Nevada Bur. Mines, Bul1. 73, p. 140-147. 

MOUNT HOPE AND SCRUB OAKS MINES

NEN JERSEY

(Halecrest Co., Inc.)

\section{LOCATION AND ACCESSIBILITY}

The Mount Hope and Scrub Oaks mines are located in Morris County, New Jersey, in the Dover District, one of the oldest mining regions in the United States. The district, in the New Jersey highlands, is 18 miles long and 4-S miles wide, and is within 30 miles of New York City. The Houmt Hope mine is at Mount Hope, 3 milles north of Dover; the Scrub 0aks mine is 2 miles west of Dover. The approximate location is $40^{\circ} 54^{\mathrm{N}} \mathrm{N}$ and $74^{\circ} 35^{\prime}$ W (Figure 1 ).

The region has a good network of primary and secondary roads and all areas are readily accessible. (U.S. 46 and State 10 cross the district east to west and U.S. 202 and 206 extend north to south. The town of Dover is on both the Delaware, Lackwanna, and Westem Railroad and the Central Railroad.)

\section{GEOLOGIC SETTING}

\section{Regional Lithology}

The geological setting of the Dover district was described by Sims (1958).

The district is part of the New England physiographic province. Topography is controlled by the effects of stream erosion on bedrock structure and lithology and consists of northeastward trending ridges separated by val leys 200 to 300 feet deep. Altitudes are 500 to 1100 feet. The Hisconsin glacial terminal moraine crosses the central part of the district.

The bedrock consists of Precambrian metasedimentary rocks, mignatites, and intrusive igneous rocks which are cut by snall Triassic diabase dikes. In the northwestern portion of the district the Precambrian rocks are disconformably 


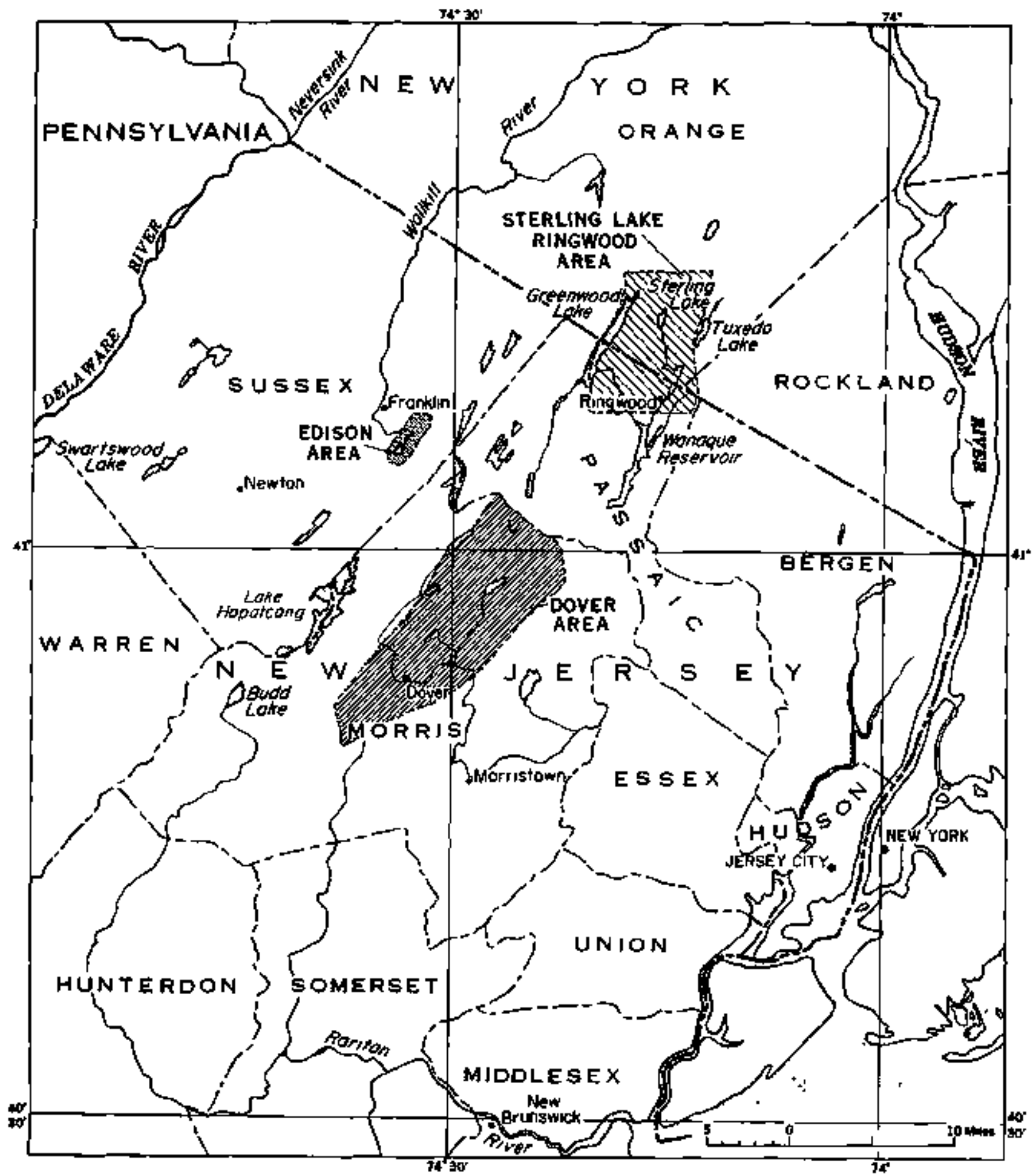

rIGURE 1. Index mep showing the location of the nower fistrict (Sims, 1958). 
overlain by steeply dipping early Paleozoic sedimentary rocks. Quaternary surficial deposits cover the bedrock in a discontinuous and usually thin 1ayer (Figure 2).

The oldest Precanbrian metasedimentary rocks are widely distributed and make up about 25 percent of the bedrock. They are high-grade metanorphics: marble, pyroxene gneiss, skarn, amphibolite, biotite-quartz-feldspar gneiss, oligoclase quartz-biotite gneiss, and related types. These rocks have been isoclinally folded and intruded by igneous sheets and phacoliths. The thickness and age sequence of the metasedimentary rocks is poorly understood because of their complex structure and the abundance of younger igneous rocks.

The inferred age order (oldest to youngest) of the Precambrian intrusive rocks is quartz diorite, albite oligoclase granite (alaskite), albite quartz pegmatite, and hornblende granite plus related facies. A NW-SE traverse across the Dover District, normal to the regional strike through the Mount Hope mine area, intersects the following rock types: hornblende granite, quartz diorite and related facies, oligoclase quartz-biotite gneiss, albite oligoclase granite, hornblende granite, biotite quartz-feldspar gneiss, alaskite, hornblende granite, alaskite, oligoclase quartz-biotite gneiss, alaskite, hornblende granite (Simps, 1958). As can be noted fron the presence of gneisses in the district, the metanorphism is high grade.

\section{REGIONAL STRUCTURE}

\section{Faulting}

Northeast trending faults bound the Precambrian rocks and separate them from Paleozoic and Mesozoic strata. The faults are considered to be Triassic or younger. The Green Pond fault which separates Precambrian rocks from Paleozoic rocks is the one large fault in the district. The smaller faults of 


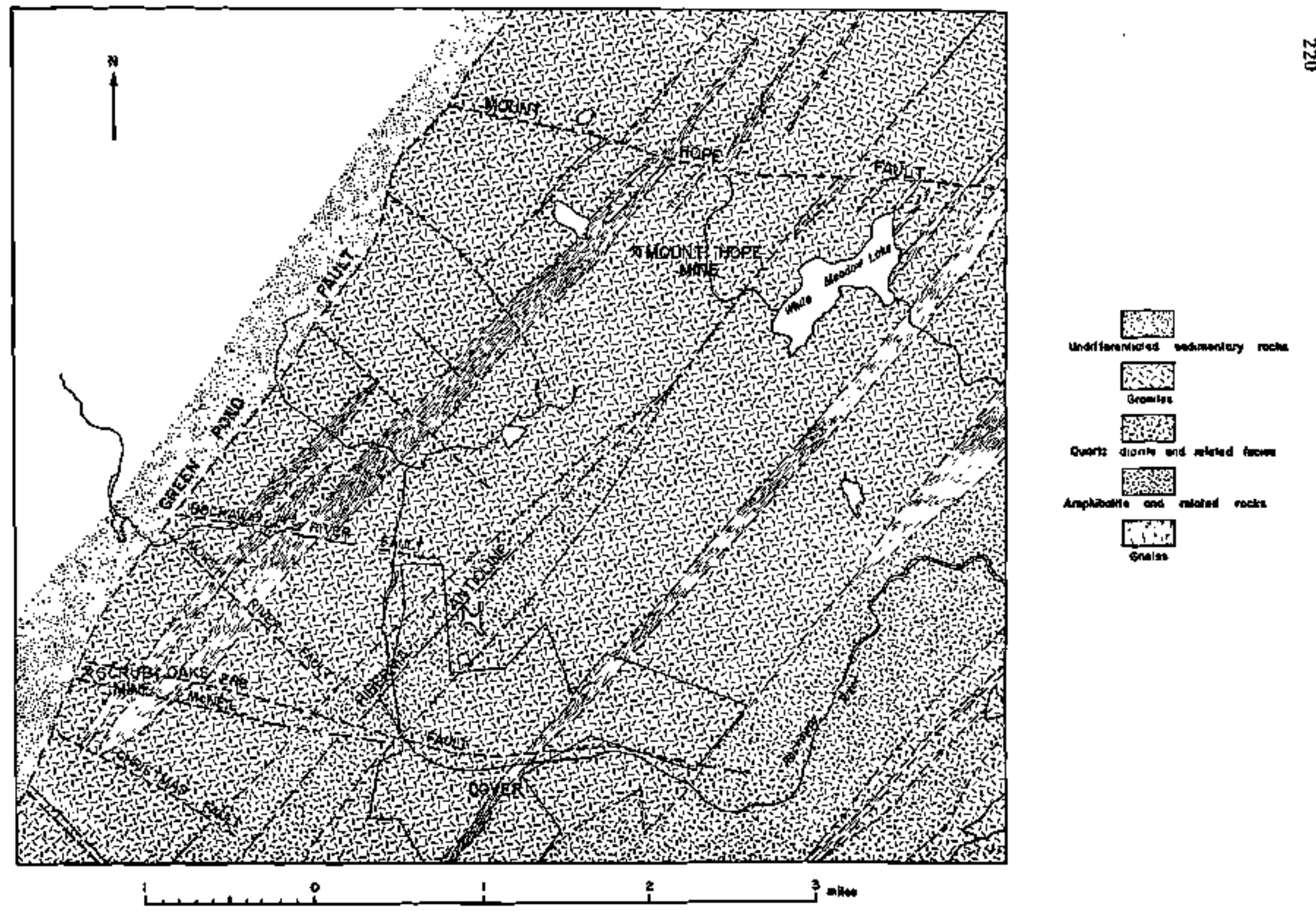

FIGURE 2. Geologic map showing the location of the Mount Hope and Scrub oaks Mines in the Dover mining district, Morris County, New Jersey. (Sins, 1958) 
the district, most exposed only in the nines, cause serious mining problems. With reference to regional trends, smaller faults can be classified as transverse, longitudinal, and oblique. Transverse faults are bigh angle gravity types striking northwest and dipping steeply southwest. The Mount Hope fault, striking $N 78^{\circ} \mathrm{W}$ and dipping $80^{\circ} \mathrm{SW}$, is in the mine area and is a transverse fault. Longitudinal and oblique faults are reverse faults striking northeastward and dipping moderately to steeply northwestward.

\section{Folding and Foliation}

In the Dover District, the Precambrian rocks trend northeast and dip steeply southeast with considerable local variation. This pattern is produced by northeastward-trending isoclinal and open folds and conformable granite sheets on the fold limbs. The folds, ranging in width from a few feet to over a mile, plunge to the northeast. This structural pattern was developed in Proterozoic time with little subsequent deformation. The direction of principal tectonic stress was to the northwest. Metasedimentary rocks formed parallel layers or belts on fold limbs, foliation is parallel to the original bedding. Igneous rocks were intruded later into the deformed coumtry rock, accompanied by development of skarns in pre-intrusive carbonate rocks. Dominant granitic foliation developed before the final crystallization of the magme, and in some places secondary foliation is superposed on the original foliation. A11 rock types show very uniform lineation which is usually parallel to the fold axes and plunges $27^{\circ} \mathrm{N} 52^{\circ} \mathrm{E}$ on the average.

\section{MOUNT HOPE MINE GEOLOGIC SETTING}

The Dover district contains 91 mines, 58 of which have produced iron ore. Iron ore has been mined intermittently since the early 18 th century. 
Many of the nines are abandoned now. There are seven ore belts in the district. The wharton ore belt contains most of the large mines, including the Hount Hope and Scrub Oaks. This belt is 10 miles long and 900-3000 feet wide. It extends from near Ironia to about 1 nile northeast of Nount Hope village.

The 300 year-old Mount bope mine has workings in nine ore bodies. It is said to be the oldest operating mine in the United States with production back to 1710 . It may have been worked as early as 1665. Surface and underground mining were enployed.

The bedrock at the Mount Hope nine consists of metasedimentary rock, mixed metamorphic rocks, and granites. The most abundant netasedimentary rock, oligoclase-quartz-biotite gneiss, is exposed at the surface as well as throughout nost of the mine. Alaskite (a1bite-oligoclase granite) is the most widespread rock type. The mine rocks are deformed into isoclinal folds trending and plunging northeast. The most prominent fold is the overturmed Mourt Hope syncline, illustrated In Flgure 3. Oligoclase-quartz-biotite gneiss comprises the limbs of the syncline and ore deposits occupy both linbs. The axial trace trends $N 45^{\circ} \mathrm{E}$ and the axis plunges $12^{\circ}-20^{\circ} \mathrm{NE}$. The principal fault associated with the mine is the transverse Mount Hope fault. Longitudinal faults are combion and cause serious mining problens, though they are not continuous for long distances.

The Mount Hope iron ore deposits are of Precambrian age and occur in various metasedimentary and igneous rocks, Massive magnetite ore (containing 35-60\% iron) is found in most deposits. The ore occurs in belts or ranges forming steeply dipping vein-type bodies essentially conforming to the greissic wall rock structure with strike and dip parallel to the foliation and plunge paraliel to the lineation. The important ore bodies are nostly lath shaped. 



FIGURE 3. Geologic map and section of Side Hisll adit, Mount hope mine (Sims, 1958). 
Principal iron ore bodies occur as metasomatic replacenent in (1) oligoclase-quartz-biotite gneiss, (2) hormblende skarn, (3) pyroxene skarn, (4) albite-oligoclase-granite (alaskite), and (5) reconstituted amphibolite and microantiperthite granite.

Low grade iros ores occur in amphibolite, interlayered blotite-hornblende-pyroxene-feldspar gneiss and granite pegmatite. The ore minerals in order of abundance are: magnetite, henatite, martite, ilmenite, pyrite, pyrrhotite, and chalcopyrite.

The Mount Hope magnetite deposits occur as replacement bodies in gneiss and hormblende skarn. Figure 4 illustrates sone of the mine workings.

MOUNT HOPE MINE HYDROLOGY

Water inflow into the kount Hope mine is approximately $350 \mathrm{gpm}$ from surface runoff and seepage fron local lakes. There is no infornation as to whether this included water introduced by mining operations (personal comumication). The Acres report (1975) indicates that the inflow into the Mount Hope nine is $400 \mathrm{gpm}$ above the 1700 foot level. Sims (1958) states that the Mount Hope fault in the mine workings is a shattered brecciated $z$ one. This zone may produce water at a rate of several hudred gallons/ninute when the fault is intersected, but when the fault is tapped at lower levels, the flow diminishes abrupt $1 y$.

\section{MOUNT HOPE MINE FACILITIES}

The Hount Hope nine was owned, as of 1978, by Halecrest Company, Inc. (Talmadge Road, Edison, New Jersey). It is located in a rural hilly area on a three square mile site. The nine had a number of different owners, and was inactive fron 1959-1977 (SRI - World Minerals Accessibility Report, 1976). 


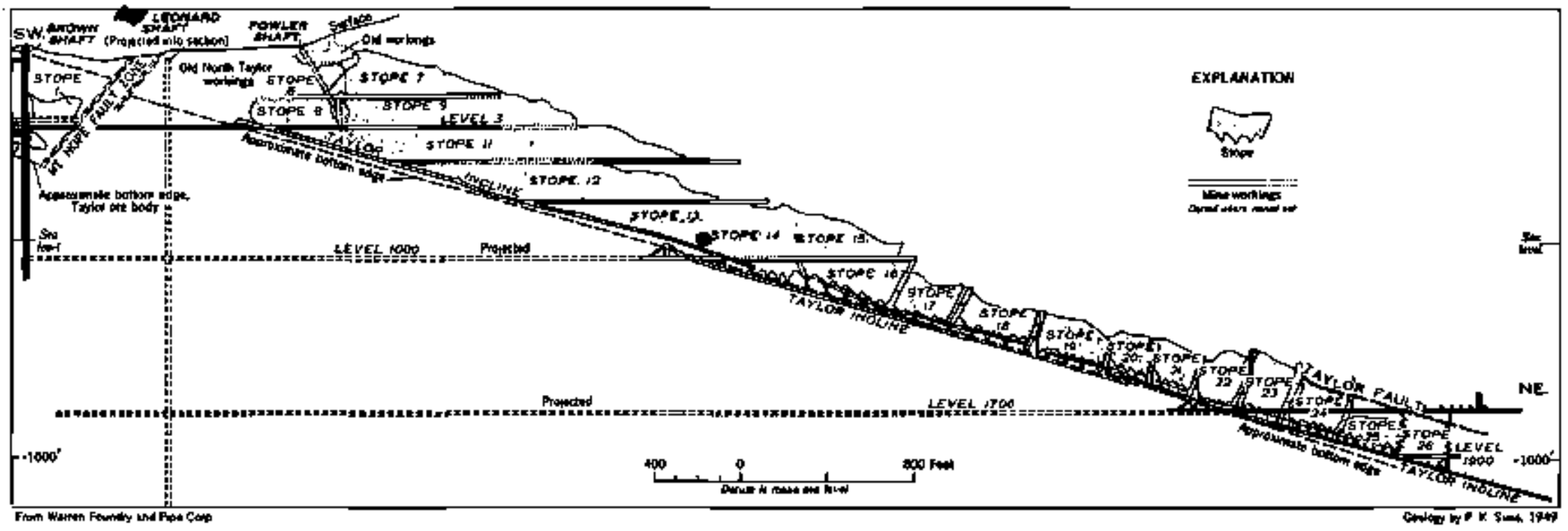

FIGIIRE 4. Vertical longitudinal projection of Taylor ore body, Mount Hope minc (Sims, 1958). 
The Mount Hope mine was considered by the Jersey Central Power and light Co. as a potential site for a pumped-storage hydroelectric facility. As described by Richert (1974), a surface reservoir would be connected with underground powerhouses and reservoirs which would be excavated from the mine workings. The mine was reopened in October 1977 and closed in February 1978 because of a reed for more capital. It is not known if it has reopened again (Engineering and Nining Journal, 1978).

MOUNT HOPE MINE WORKINGS

The vertical three-compartment shaft is 2800 feet deep with levels at $1000,1700,2100$, and 2500 feet. The 1000 foot level has road workings, the 1700 foot level extends one mile south and one mile north of the shaft, the 2 to0 foot level is one mile long, and the 2500 foot level extends 3000 feet to the northeast and southwest. Drifts and haulage ways are generally $9 \times 11$ feet with various larger stoped-out areas (Acres, 1975). Several types of mining methods have been employed, in order of time: (1) open pit, (2) underground open stopes (stull timbered) (3) shrinkage stoping, and (4) sublevel stoping. The mine has been kept pumped out (Acres, 1975).

MOUNT HOPE AINE EQUIPWENT

A lift and general utilities are available. The equipment is moth-balled but sound (Acres, 1975, and personal communication).

At the time of closing 150 men were eaployed (E/MJ, 1978).

$52 x$ thousend tons per day of ore were produced when the mine was in operation. The available ore reserves proven are $5 \times 10^{6}$ tons, probable $15 \times 10^{6}$ tons, and possible $30 \times 10^{6}$ tons. There is sufficient ore for twenty years operation (E/NJ Directory, 1977-1978). 
SCRUB OAKS MINE GEOLOGIC SETTING

The Scrub oaks mine, lacated 2 miles west of Dover, operated - internittently from 1856-1950. The bedrock in the area is covered with u to 40 feet of unconsolidated debris. The principal rocks exposed in the mine are alaskite, the host rock for the ore, and wicroantiperthite granite. The average strike of foliation in the nine is $N 33^{\circ}$, dip is $50^{\circ} \mathrm{SE}$. The lineation plunges about $28^{\circ} \mathrm{N}, 52^{\circ} \mathrm{E}$. It is thought that the mine is situated on an isoclinal fold linb. Two transverse faults offset the ore body into three segments. Figure 5 shows the faults and workings in the mine.

\section{SCRUB OAKS MINE FACILITIES}

The Scrub Oaks mine was omed by the Alan Hood Steel Company of Conshohocken, Pennsylvania in 1975 (Acres, 1975). It has been shut down and capped since Hay, 1966 and is probably flooded. A fault was encountered in the shaft and blasting also created many fractures in the surrounding rock. The mine workings (Figure 5) consist of a four-comartment inclined shaft 3000 feet long on a $55^{\circ} \mathrm{dip}$, and $\mathrm{six}$ working levels 250 feet apart vertical1y. The shaft is in country rock and 100 feet into the ore footwall and is connected to the main haulage levels in the ore body footwall by cross cuts. Mining was done by shrinkage stoping without timbering or filling (Sims, 1958). The Acres report (1975), however, refers to mining by the longwall sublevel mining method. The total crude ore mined between 1918 and 1950 was reported to be $10.5 \times 10^{6}$ long tons; in $1950,6.3 \times 10^{5}$ tons were mined. 

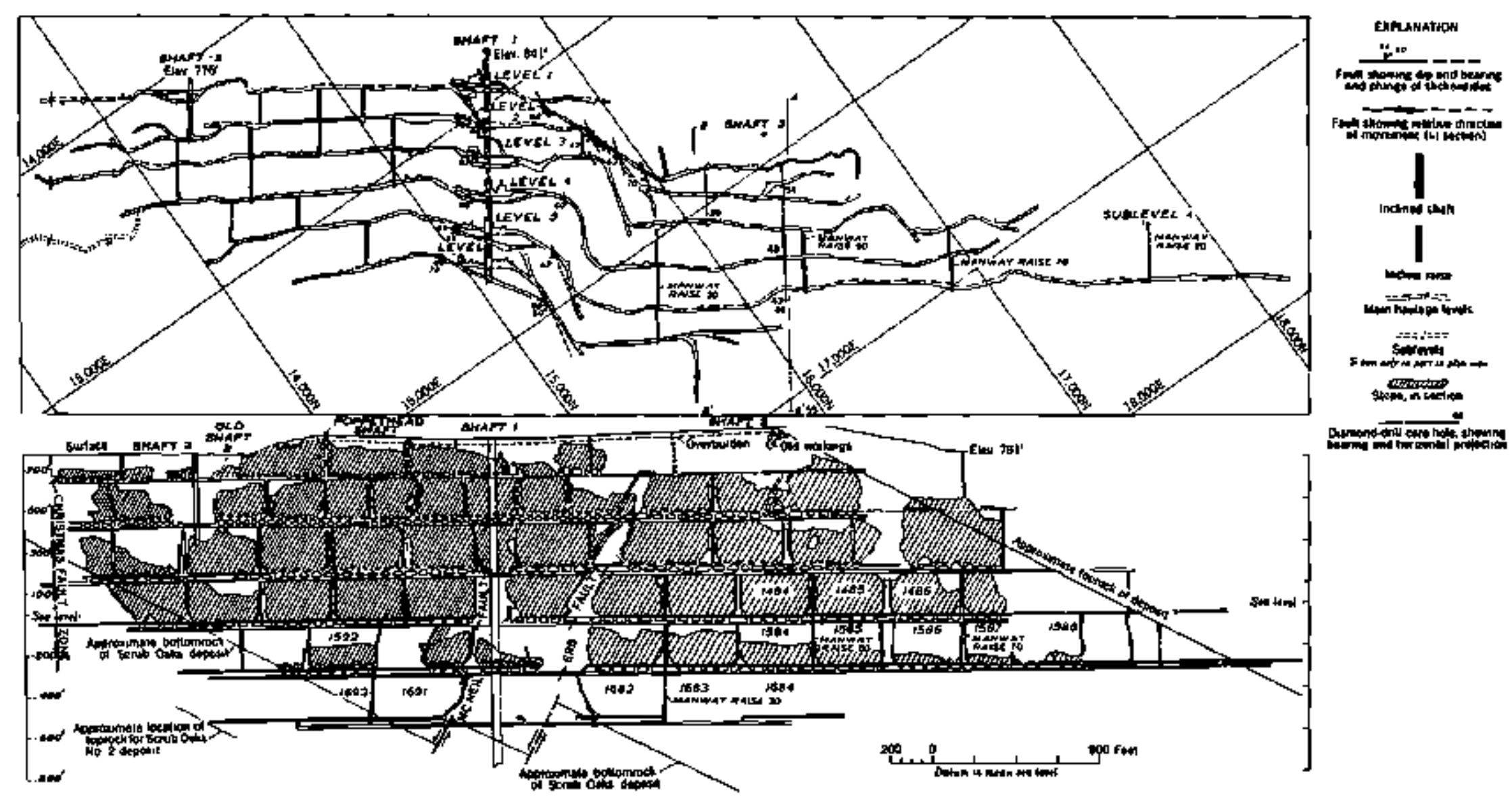

arrons

FIGURE 5. Map and longttudinal projection of main workings at Scrub Oaks mine (Sims, 1958 ). 


\section{REFERENCES}

Acres American Inc, 1975, Federal Energy Administration Underground Di1 Storage Program, Progress Report to August 31, 1975, File 4074.07.

Engineering 尼 Mining Journa 1, 1977, 1977 E/MJ International Directory of Mining and Minera1 Processing Operations, McGraw-Hil1, Inc. New York.

Engineering \& Mining Journa 1, 1978, v. 179 (4), p. 146.

Richert, R.C., 1974, Mount Hope Project, Studies of an underground site for developing peak capacity: in "Electric Power and the Engineer" conference papers, Specialty Conference, Boulder, Colorado, Amer. Soc. Civil Eng,, New York, p. 265-277.

Sins, P.K., 1958, Geology and Magnetite Deposits of Dover District, Morris County, New Jersey; J.S. Geo1. Survey Prof. Paper 287, 162 pp.

Stanford Research Institute - World Minerals Availibility Report, v. 3, I976. 

QQUESTA MOLYBDENLM MINE

(MOLYBDENUM CORPORATION (MOLYCORP))

\section{LOCATION AND ACCESSIBILITY}

The Questa Molybdenum Mine is located at $36^{\circ} 42^{\prime} \mathrm{N}, 105^{\circ} 30^{\prime} \mathrm{W}$, on the western slope of the Taos Range in the Sangre de Cristo Mountains of northern New Mexico [Figure 1]. The underground mine is adjacent to a large open pit operation, 6 niles east of the town of Questa in Taos County. The altitude of the uppermost workings of the mine is nearly 8900 feet above sea level. Both underground mine and open pit are owned and operated by Molybdenum Corporation (Molycorp Inc.).

The mine portals range in altitude from 8000 to 9000 feet. The mill, haulage adit, and dump are located along Red River Canyon, 5-6 miles east of Questa. The adits of the older workings are along Sulphur Gulch, an intermittent tributary of the Red River.

State Highway 38, a graded gravel road (in 1956), passes the mine and camp and connects the mine to Questa and Red River.

\section{GEOLOGIC SETTING}

The geologic setting is illustrated in Figure 2 and has been described in detail by Carpenter (1968), MkKinley (1957), and Schilling (1960 and 1956). A generalized stratigraphic section is shown in Figure 3. The Taos Range is made up of Precambrian metamorphic and granitic rocks overlain by Tertiary volcanics and late Paleozoic sediments. Tertiary granitic rocks, including tihe ore bearing units, intrude the older rock and in turn are capped with Quatemary grave1s and alluvium. The ore body occurs in the Tertiary sulphur Gulch soda granite stock. Wost of the veins are in contact, or close to the contact with the granite and the velns rough1y parallel the contact. The ore zone is over $1500 \mathrm{ft}$. long. 


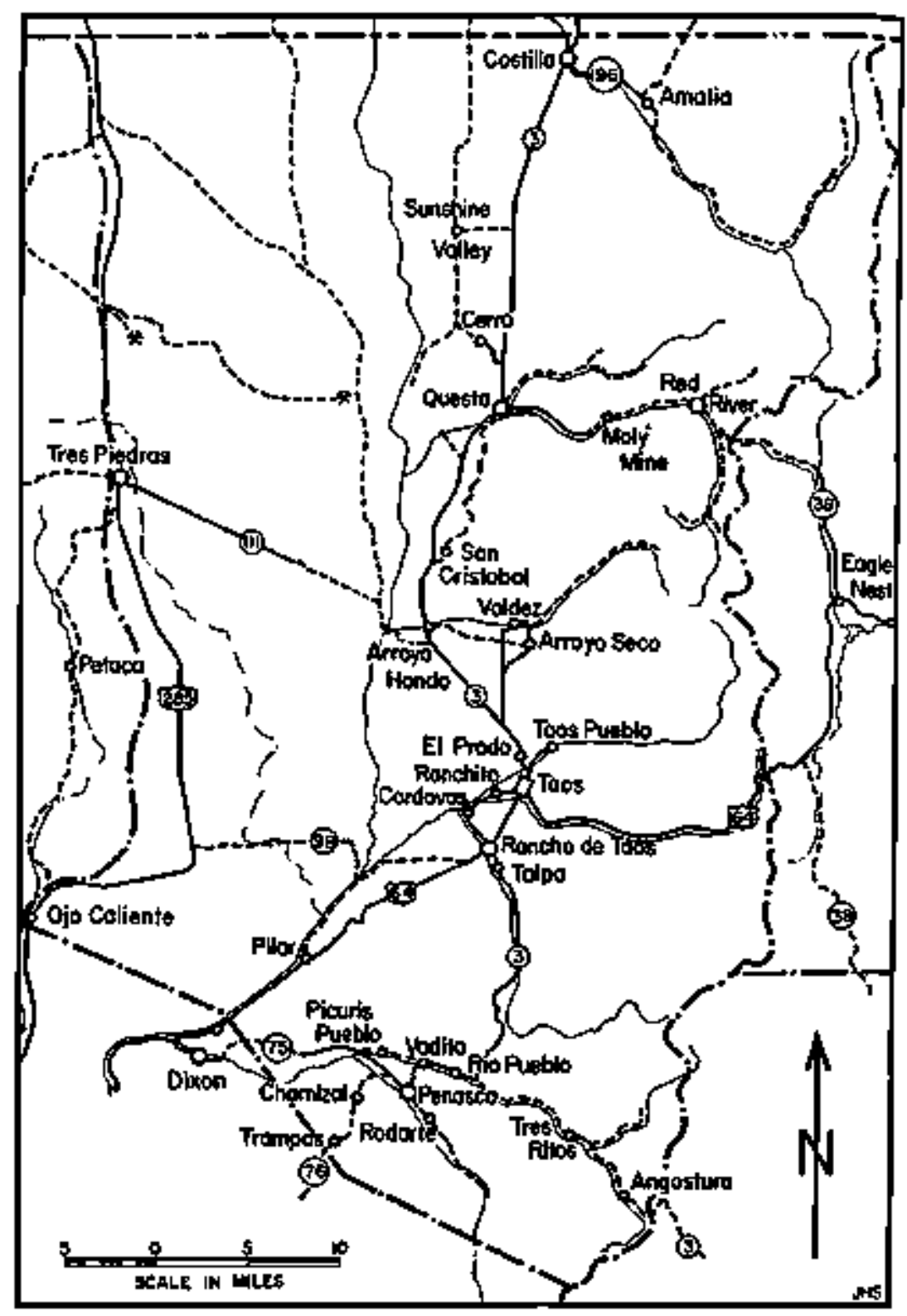

FIGURE 1. Map of Taos County, New Mexico, showing location of Questa Molybdenum mine (from Schilling 1960). 


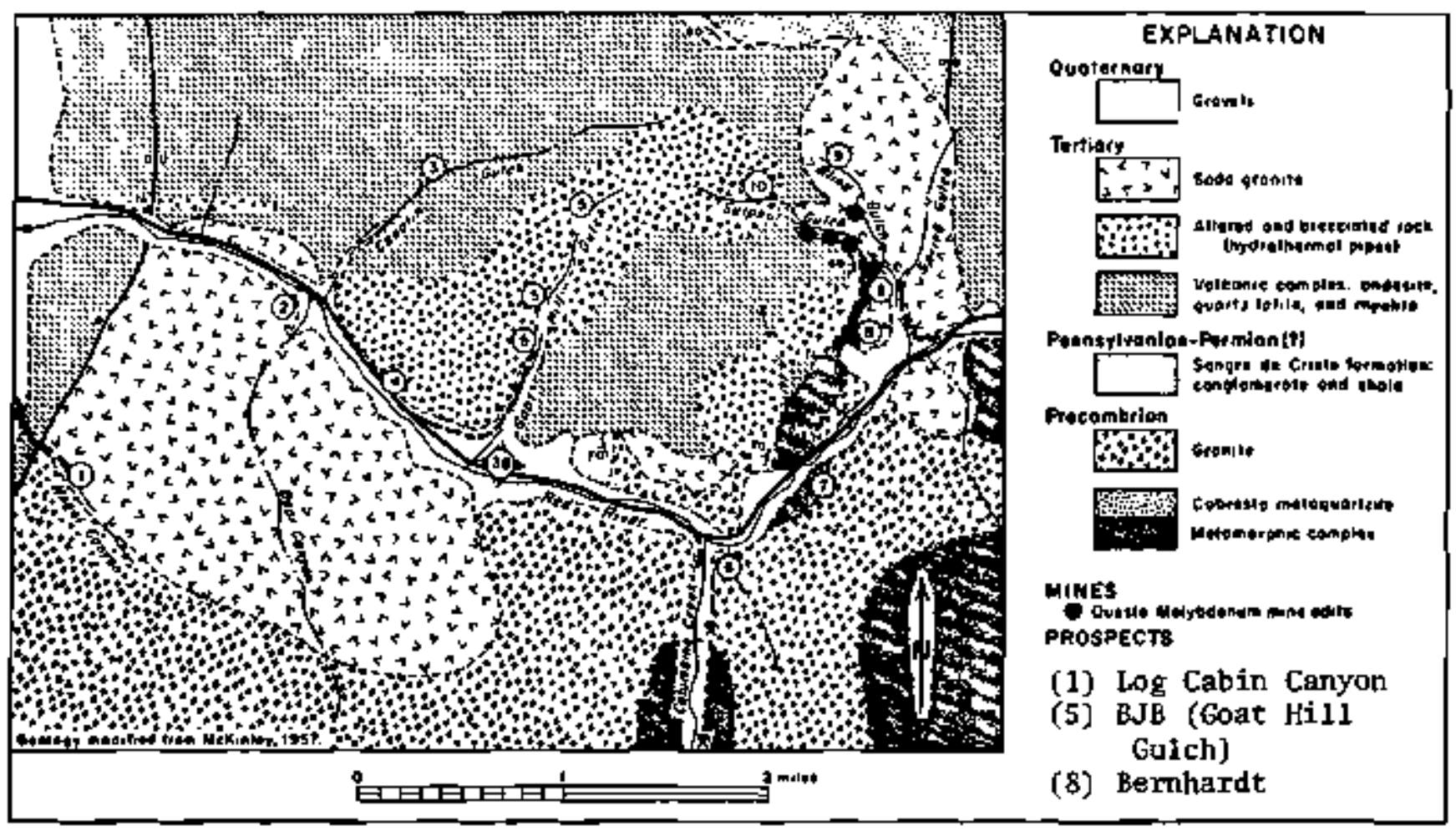

FIGURE 2. Goneralized geology of Questa Molybdonum mine area (from Schilling 1960). 


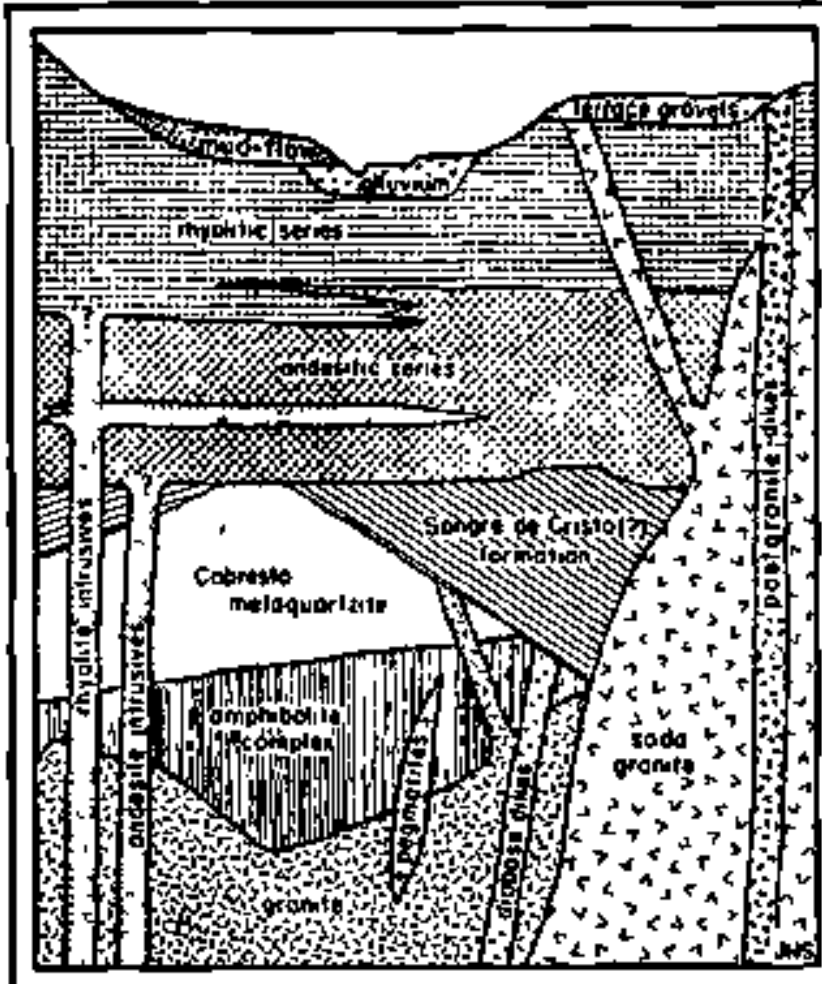

\begin{tabular}{|c|c|c|}
\hline BOFE & DMT & LITAOLOGY \\
\hline \multirow[t]{3}{*}{ Quoletenory } & \multirow{2}{*}{$\frac{\text { allunum }}{\text { mud-ftow }}$} & 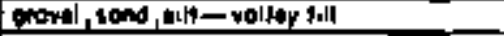 \\
\hline & & 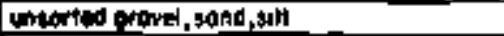 \\
\hline & miroct romils & gronel \\
\hline \multirow[t]{5}{*}{ Tertionty } & 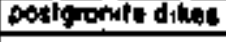 & 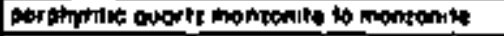 \\
\hline & 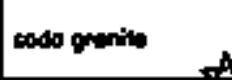 & 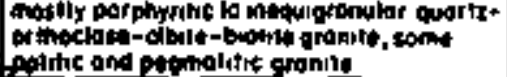 \\
\hline & 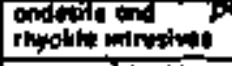 & 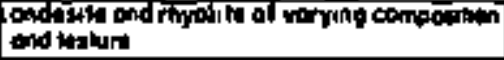 \\
\hline & \multirow{2}{*}{ 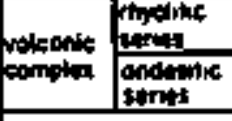 } & 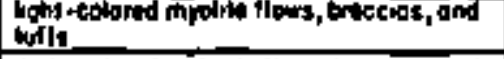 \\
\hline & & 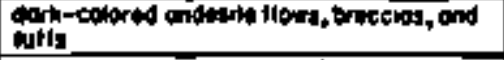 \\
\hline Pennspivanton- & sompre on Griatoks & 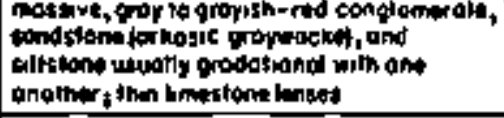 \\
\hline \multirow[t]{5}{*}{ Pricombrion } & Hobose alas & 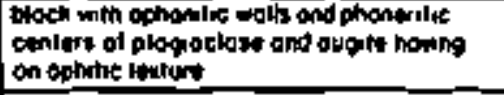 \\
\hline & 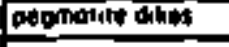 & 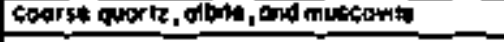 \\
\hline & ponto & 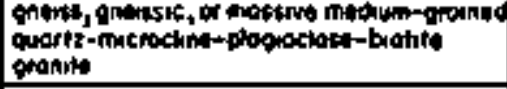 \\
\hline & Cobration & 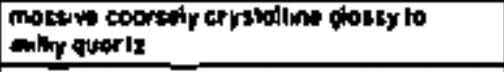 \\
\hline & $\begin{array}{l}\text { omphtiolitis } \\
\text { complat }\end{array}$ & 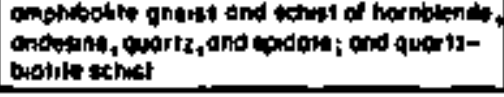 \\
\hline
\end{tabular}

เ

$\downarrow$ kilybdonite ore veins

FIGURE 3. Generatized rock section of the Questa Molybdenum mine area (from Schiling, 1956). 


\section{LITHOLOGY}

The Precambrian metamorphic rocks include amphibolites, schists, and quartzites. The amphibolite complex covers large areas both east and west of the mine. A detailed geologic map and cross section, parallel to the main haulage adit (Moly tunnel) is illustrated in Figure 4. For orientation a cutawny diagram of the rine (as of 1956) is shown in Figure 5 . The quartz biotite schist of the amphibolite complex crops out in the main haulage adit (Moly tunne1). These rocks are found also in the long crosscuts extending south from the main drive of 2 tunnel level. The rocks range from massive to foliated, and can be separated into four varieties: (1) massive, coarsegrained; (2) massive, medium-grained; (3) gneissic; and (4) coarse-grained schist.

The Precambrian granite covers large areas in the vicinity of the mine and is exposed along the main haulage adit. It has been divided by Schilling (1956) into three varieties: (1) granite gneiss; (2) gneissic granite; and (3) massive granite. The granite intrudes the amphibolite complex and meta-quartzite. It is overlain unconformably by PensylvanianPermian (?) sediments and a late Tertiary volcanic complex.

Pegnatites in dikelike bodies intrude the amphibalite conplex, meta-quartzite, and, less commonly, the Precambrian granite. Severa1 diabase dikes crop out in the vicinity of the mine. The largest dike strikes generally $\mathrm{N} 60^{\circ} \mathrm{E}$, with a vertical dip and an average width of $25 \mathrm{ft}$.

A thick, complex sequence of Tertiary volcanic rocks crops out at all levels in the mine. The volcanics, including andesite, quartz latite, and rhyolite flows, breccias and tuffs, are almost completely altered in some areas.

Late intrusives, ranging fron monzonite to granite in composition and plutonic to transitional in texture, crosscut the volcanic sequence. As an illustration, the soda granite occurs in several areas near the mine (based on observation at the surface and $7800 \mathrm{ft}$. leve1 (Carpenter, 1968). One 


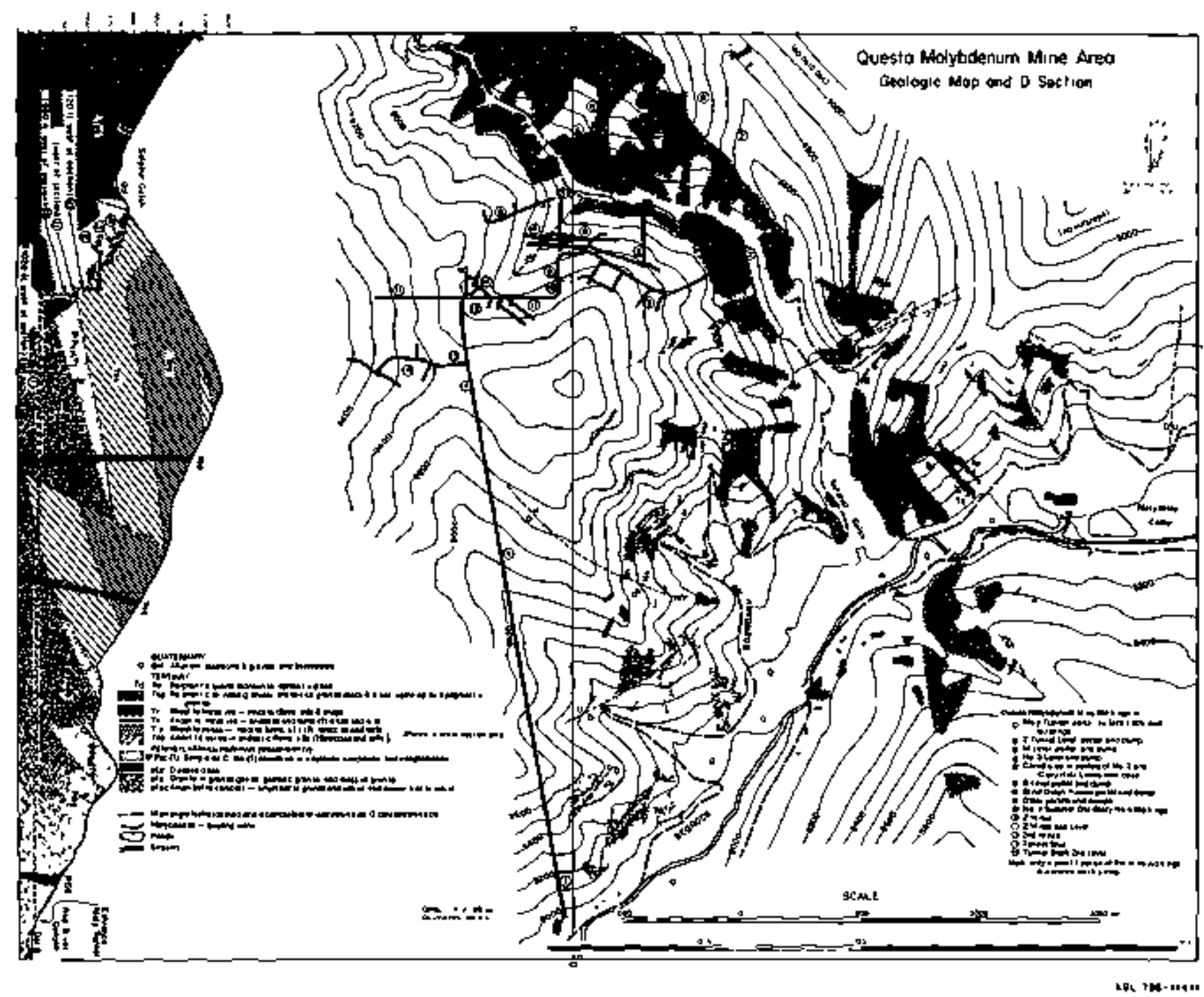

FIGURE 4. Questa Molybdenun Mine area, geologic map and D section. 


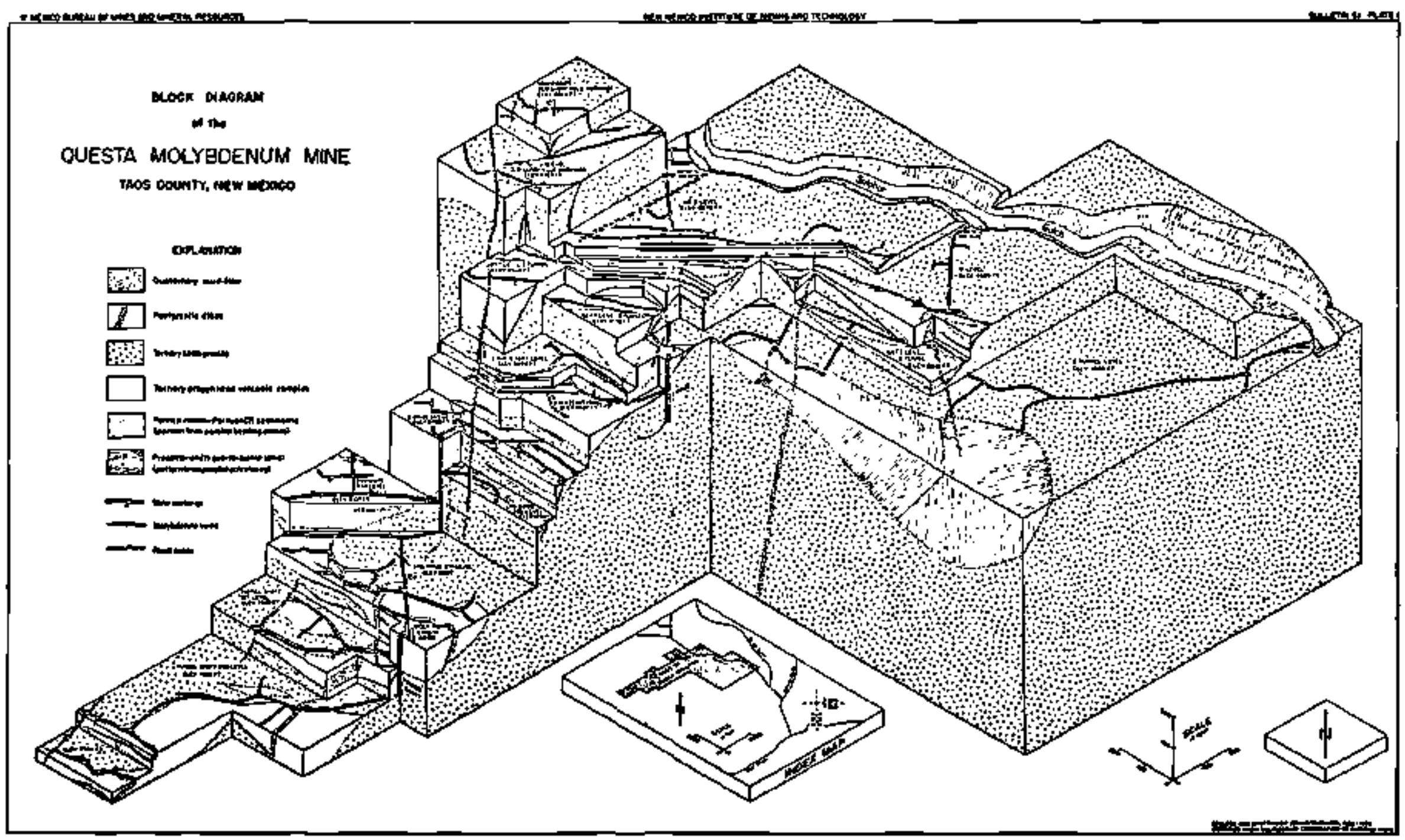

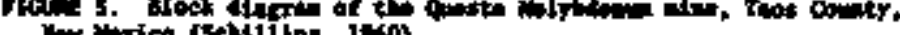

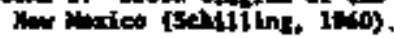


north-trending occurrence, the Sulphur Gulch Stock, covers an elliptical area $0.7 \times 15$ miles. The top of the stock is domed with gentle dips; its sides dip more steeply. The soda granite is inequigranular to porphyritic at the margins of the stock. Coarser inequigranular granite nakes up the core of the stocks. The pegmatitic and aplitic phases of soda granite, In contrast, are in sharp contact with each other. However, these phases make up less than $1 \%$ of the soda granite, by volune, and are not significant in the mine workings.

The region is capped with Quaternary gravels and alluviur. Mud flows have occurred in the Quaternary gravels and talus along many of the canyons and are of special interest because of the danage they have caused to mine facilities.

\section{MINERALIZATION}

The underground mine workings at Questa are in a group of molybdenitebearing veins. The ore occurs in the Sulphur Gulch soda granite at or near the contact. Most vefns paraliel the contact and range fron less than 1 inch to over 7 feet in thickness, and are largely quartz and nolybdenite. The veins were deposited as fissure fillings, probably during the late Tertiary and on the basts of their mineralogy are classified as mesothermal.

\section{STRLCTURAL SETTING}

The structure of the Taos Range of the Sangre de Cristo Mountains is extremely complex. The mine is located in an east-west down-faulted zone several miles wide, in which structural features combine to form a pattern quite different from the rest of the range. This zone apparently has served to localize the soda granite intrusives. 
The Taos Range has been uplifted and tilted eastuard along a fault zone paralleling the western edge of the range. The high angle Frontal fault crosses east of the mine and has a total estimated displacement of $6000 \mathrm{ft}$. (Schilling, 1956). Several high angle faults were noted underground. They cut the soda granite and older rock and show horizontal displacenents of a few to tens of feet. Along the soda granite contact several post-soda granite dikes are intruded along these faults. Thrust faulting, though common to the Taos Range, was not observed in the vicinity of the mine.

The Sulphwr Gulch soda granite is extensively fractured. The fractur ing is roughly parallel to the contact and is called sheeting. It is concentrated in the outer 50 feet of the granite and commonly cuts across irregularities. Sone of the sheeting fractures curve toward the contact, reversing in dip as they approach the contact. This sheeting apparently was formed by the upward force of the intruding soda granite.

In the mine area, fracturing and faulting are irregular, except for the regional east-west striking, vertically dipping fractures common to the Taos Range.

Evidence of a1teration at depth is found in the Holy tunnel. Here disseminated pyrite occurs iл Precambrian granite. Porphyritic alteration of the rocks (indicated in Figure 4) surrounds the soda granite stocks and decreases rapidly away from the granite.

\section{HYDROLOGY}

The mine is located at $8000-9000 \mathrm{ft}$. elevation in the Taos Ragge. The water table is probebly within a few tens of meters of the surface and the mine workings would then be tens to hundreds of feet below the water table and well within the saturated zons. Water from the levels above the 
haulage adit drains by gravity, while water from the workings below the haulage adit drains into a sump at the botton of the tunnel shaft and is punped out.

MINE CHARACTERISTICS

The mine has nore than 35 miles of workings with a vertical extent of 1200 feet and is divided into three areas. They are Sulphur Gulch north workings, Sulphur Gulch south workings, and Tunnel Shaft workings. The Sulphur Gulch south workings are mined through adits. The Tunnel Shaft workings are mined through a vertical winze and the Moly tunnel. The main haulage adit (location shown in Figure 5, the geologic cross-section rough1y parallels adit) cuts across the Precambrian granite and amphibolite complex, Tertiary volcanic rocks and the soda granite. The maximum depth of workings is 1600 feet. The depth and extent of workings as reported in 1956 are shown in Figure $\$$.

The mine is developed in an irregular pattern following the irregularity of the vein syster. Adits, drifts, crosscuts, raises, and winzes occur at intervals of 15-100 feet vertically. Machine mucking is used in all easily accessible dxifts. The rock, when granite, is moderately hard and ustually stands well without timbering; the altered volcanics are broken and require timbering. Surface tracks extend from the adits to the nine ore bins and dump.

\section{MINE ACTIVITY}

The Questa mine has been in almost continuous operation since 1920, when the Molybdenum Corporation acquired the property. Total production data are classified but production was estinated to exceed $\$ 10$ nillion in 
1968 (Kottlowski, 1969). The production in $196 \mathrm{~S}$ was estimated at $20 \mathrm{mi}$ lion $1 \mathrm{~b}$. (Schilling, 1965).

The Molybdenum Corporation received fron the Defense Minerals Exploration Adninistration an exploration contract for $\$ 255,250$ in 1957 , and the Molybdenum Corporation was required to spend an equal anount (New Mexico Bureau of Mines and Mineral Resources, 1977). An intensive exploration progran was carried out in 1957, including a geochemical survey, extension of the lowest level in the mine, and core drilling both from the surface and underground. Again in 1975-76, extensive exploration was undertaken. Molybdenum Corporation joined in partnership with Kennecott and \$5.7 nillion was spent for exploration of the Goat Hill, Log Cabin, and Southwest Zone ore bodies. Exploration included 130,000 feet of drilling (World Mining, June 1977). The Goat Hill reserves are estimated at 140 million tons, however, the known workings are located in altered volcanics, and two of the three adits had caved prior to 1960 (Schilling, 1960). The log cabin reserves are estimated at 50 million tons. The Log Cabin workings prior to 1960 (1ocation shown in Figure 2) include an adit driven 750 feet into a mountain with the last 500 feet in the soda granite (Schilling, 1960). Details of the 2975-76 exploration were not availabje from the literature for either location. No reserve estinates were given for the southwest zone, nor was the location identifiable from the literature. Since recent exploration has been undertaken in these areas, and the Log Cabin workings are located in crystalline rock, this site may be a potential candidate. In the sumner of 1977, mad and rock slides closed the Holybdenum mine (open pit?) for the rest of the year (Ha1l Street Journa1, Friday, December 2, 1977), costing the corporation about one half year's production (1976 production at $11.5 \mathrm{million} 1 \mathrm{~b}$. ). 
In May 1979 Nolybdenum Corporation initiated a $\$ 200$ million project Skillings Mtning Review, May 5, 1979) to develop a large underground mine to begin operation in 1983 at a rate of 18,000 tons/day. At approximately the same time, 1983, the open pit operations would close. Preproduction construction for the new underground workings include shaft sinking, outfitting, and underground development. A work force of 800 will sink a $24 \mathrm{ft}$. diameter service shaft along wtth a $14 \mathrm{ft}$. diameter ventilation shaft (Engineering and Nining Journal, February 1979). The project is estimated to produce 18-20 nitlion pounds per year of molybdenum for at least 20 years. Block caving nethods will be used to mine the ore. An electrtc rail haulage systen will trank ore to a decline and a conveyor will transport it to the surface, No other mine activity or equipment information was available from the literature. 


\section{REFERENCES}

Carpenter, R.H., 1968, Geology and Ore Deposits of the Questa Molybdenum Mine Area, Taos County, New Mexico: in, Ridge, J.D., ed., Ore Deposits of the United States, 1933-1967, American Institute of Mining, Metallurglcal, and Petrol eum Engineers, Inc., New York, v. 2, p. $1328-1350$.

Engineering and Mining Journal, 1979, v.180(2) p. 11 . $1978, v .179(12)$ P. 28 .

Kottlowski, F.E., and Foster, R.W., 1969, Exploration for Mineral Resources: New Mexico Bur. Min. Circ, 101, p. 114.

Mekinlay, P.F., 1957, Geology of Questa Quadrangle, Taos County, New Mexico: New Mexico Bur. Min. Bull, 53, 23 pp.

Molybdenum Coxporation of America (Nolycorp), Annual Report 1972, 1973, 1974, $1975,1976, \& 1977$.

New Mexico Mines and Mineral Resources, 1977, Anntal Report, July 1975 June 1976.

Schilling, J.H., 1956, Geology of the Questa Molybdenum (koly) Mine Area, Taos County, New Mexico: New Mexico Bur. Min. Bul1. 51, 87 pp.

,------ 1960 , Mineral Resources of Taos County, New Mexico: New Hexico Bur, Min, Bull, 71, p. 36-43.

Skilling's Mining Review, May 5, 1979.

U.S. Geologic Survey, 1976, Computerized Resources Information Bank, (CRIB) data base.

Va 11 Street Journa1, Decerber 2, 1977, p. 25

Septenaber 2, 1977, p. 22

January 4, 1978, P. 9

Ju1y 25, 1977, p. 12.

World Mining, June 1977. 



\section{BALMAT-EDWARDS DISTRICT MINES}

(St. Joseph Zinc Co.)

\section{LOCATION}

The Balmat-Edwards district is located in the northwestern portion of the Adirondack Mountains in Lawrence County, upper New York State. General coordinates are $44^{\circ} 15^{\prime} \mathrm{N}, 75^{\circ} 15^{\prime} \mathrm{w}$. Within the district are several zinc mines of interest: the Balmat $\$ 1,2,3$, and 4 ; the Edwards; and the Hyatt mines. These are located about 10 miles ESE of Gouverneur, New York (Figure 1). The district extends for 10 miles from Sylvia Lake and Balnat NE to Edwards.

\section{GEOLOGIC SETTING}

The district lies in the northeast striking belt of Grenville lowlands mostly underlain by highly deformed Precambrian netasedimentary rock. It is bounded on the northwest by undisturbed Paleozoic sedimentary rock and on the southeast by igneous gneisses of the Adirondack massif. The general trend of exposed forwations, topography, and structure, roughly NE-SW, is the same as that of the Grenville lowlands (Figure 2) (Lea, 1968).

The Precambrian rocks in the region range fron older quartzite, quartz-biotite gneiss, and dolomitic marble to intrusive syenites and granitic gneisses of the Adirondack msssif, to younger Precanbrian granite gneisses. The ore bodies occur as replacements in the various types of dolomitic marble as lenses, pods, and tabular bodies. They are of Precambrian age. The ore ninerals are sphalerite, pyrite, and galena, with ninor amounts of pyrrhotite and chalcopyrite. 


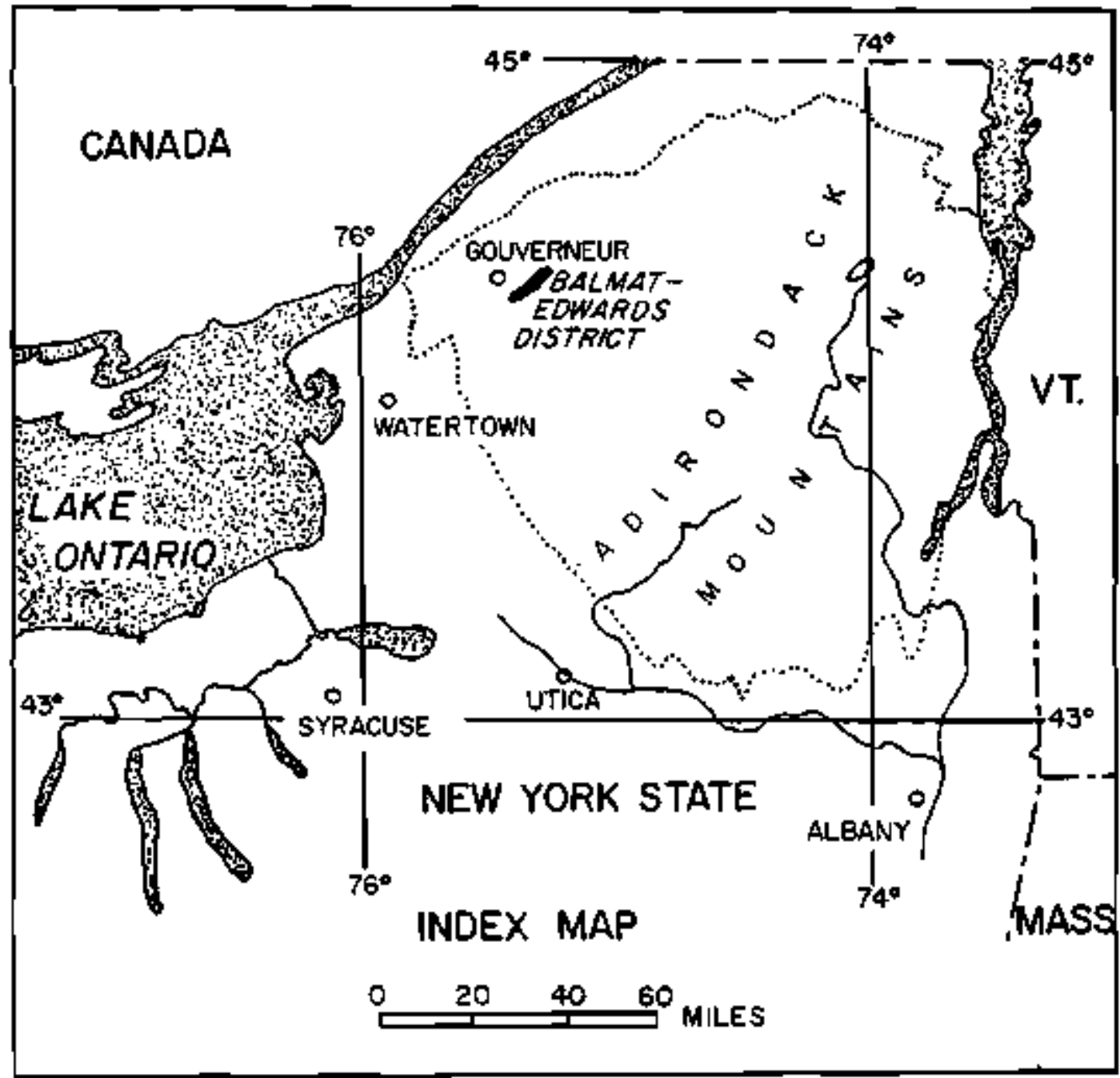

FIGURE 1. Index Map, showing location of the Balmat-Edwards District, New York. (lea, 1968) 


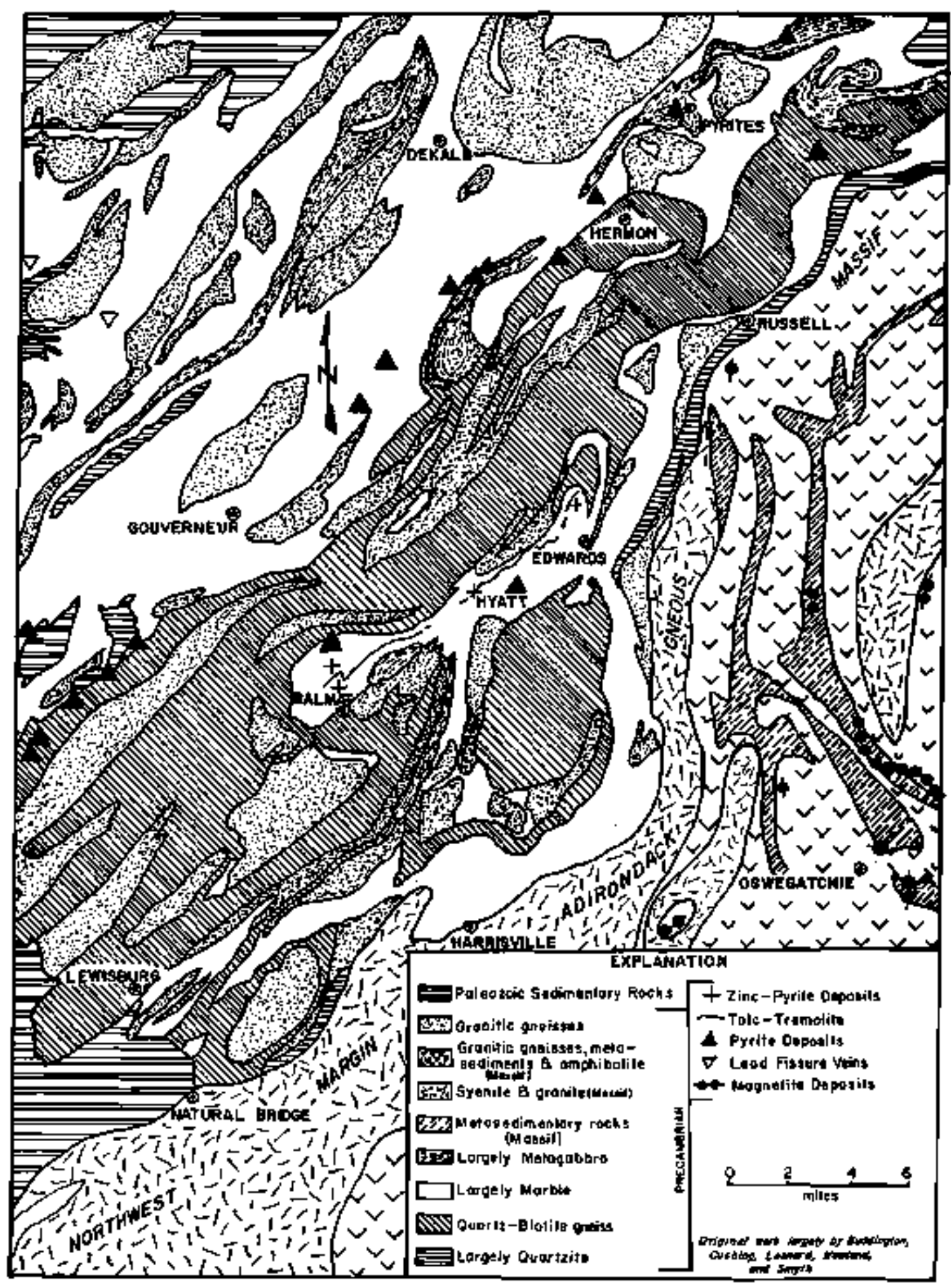

FIGURE 2. Generalized Geologic Map of the Balmat-Edwards District within the Northwestern Adirondacks, showing the distribution of major rock types and mineral deposits. (Lea, 1968) 


\section{Structure}

The structure of the northwestern Adirondacks has been divided by Buddington (1962) into three major structural units. They are: (1) a unit of mostly granitic gneiss and minor metasedimentary rocks in the extreme northwest; (2) the Grenville lowland unit, a broad belt 25-30 miles wide composed of $70 \%$ metasedimentary rocks with minor granitic intrusions, in the southeast; and (3) the nain igneous complex southeast of the lowlands.

The Grenville unit is considered by Engel and Engel (1958) to be anticlinoria1. In the Balmat-Edwards area, the southeastern flank of the dominant anticlinorium is overturned to the northwest. There were two major Precambrian folding deformations in the area: (1) a primary one which produced the regional northeast trend (fold axes) with a northwest dip and . (2) \& secondary folding which produced crossfolds intersecting the regional trend and plunging north to northwest. The ore bodies are located in the complex folds (in overturned limbs of anticlines or synclines) developed by the interaction of the two defornations, in competent and inconpetent beds (Buddington, 1962, Brown, 1956).

\section{Metarorphism}

The relatively high grade of metamorphism is indicated by the gneisses and also by high-temperature features of the mineralization. The mineralization is thought, however, to originally have been premetamorphic, and later remobilized by the metamorphism.

\section{Hydrology}

No general information on the district water table and water regime was found. However, an article in the Engineering and Mining Journal 
November 1976 states that all three of the mines in the Balmat area produce $750 \mathrm{gpm}$ and that most mine water originates above the 1300 foot leve 1 underground. There is no information as to how much of this inflow is due to mining activity. Lea, (1968) reports that there has been a water problen in the Balmat \#3 mine because of the location of an aquifer, the Potsdan sandstone, above it.

\section{MINE FACILITIES}

The Balnat-Edwards district mines are owned and operated by St. Joseph Zinc Co. (Oliver Plaza, Pittsburg, Pa. 15222) a subsidiary of St. Joseph Mineral Corp. (250 Park Avenue, New York, 10017, 212/953-5000), Four mines were actively in operation as of 1976 (E/MJ 1976); they were the Edwards mine (Figures 3-5) (depth almost a mile down dip at an average $40^{\circ}$ plunge), Balmat \#2 (at least 2300 feet), Balmat \#3 ( 883 feet), and Balmat \#4 (Figure 6) (2500 feet). Balmat $\# 2$ and 3 nines are connected to Balmat \#4 and their ore along with that of \#4 is hoisted through the \#4 shaft. The main Balmat ore bodies may be seen in Figure 6 in projection. The Edwards nine was inoperative from June 1978 to at least the first quarter of 1979 because of a strike (St. Joseph Minerals Corp. 1978 Annual Report and St. Joseph release 1979). CRIB (1977) reports that the Edwards mine would be exhausted by 1980 .

In $1977,1.1945 \times 10^{6}$ tons $(3982$ tons/day) were mined (St. Joseph Minerals Corp, Annual Report 1977). As of 1971, the proven ore reserves were $5.4 \times 10^{6}$ tons. Therefore at the 1977 tonnage renoval rate, the present reserves will be depleted in about 3 years. It should be noted, however, that the ore bodies are erratically located because of regional complex folding and faulting. 


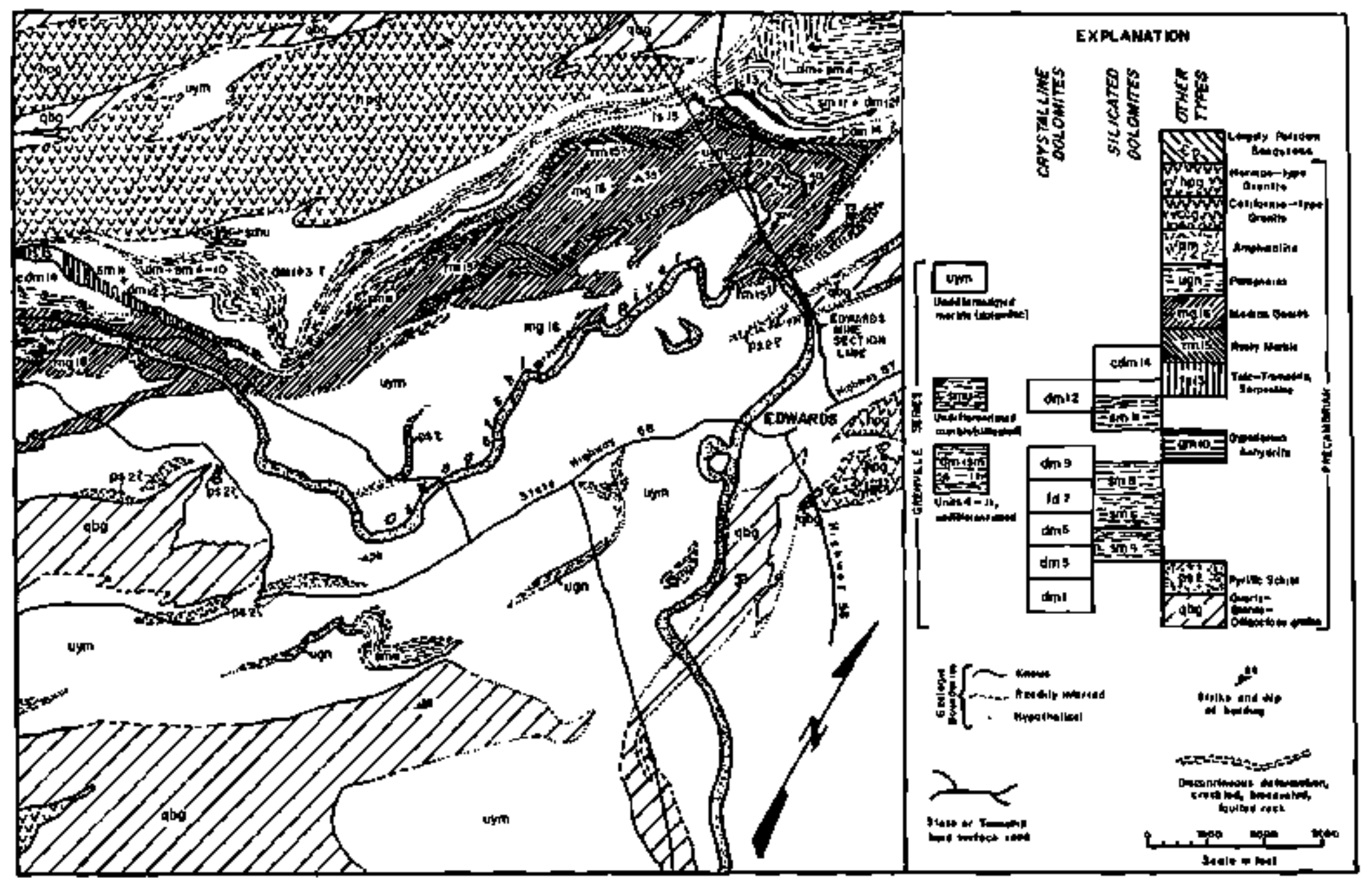

FIGURE 3. Geologle Map of the Balmat-Edwards District: Edwards Area. (Lea, 1968). 


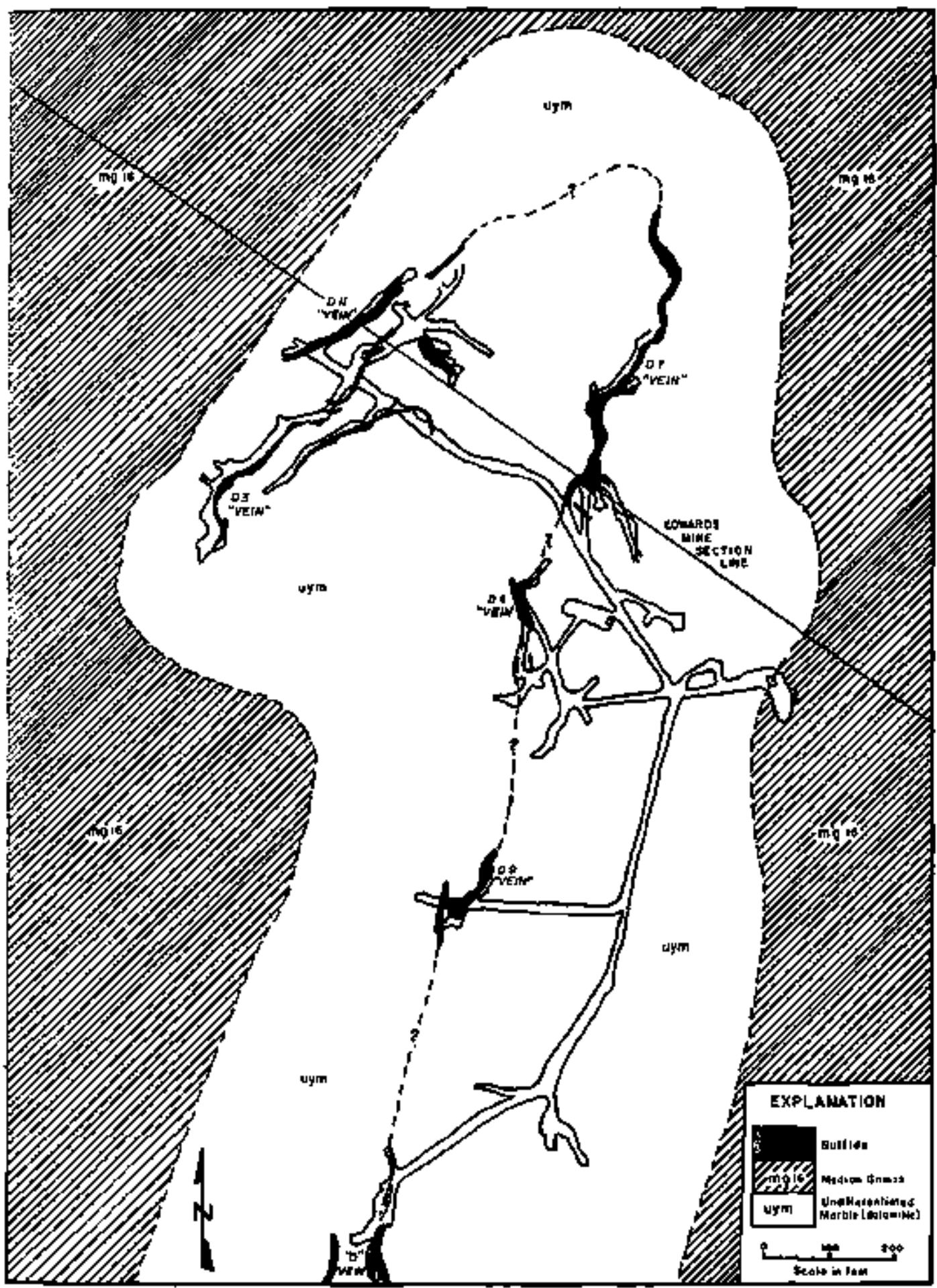

FIGURE 4, Geologic Map of the 1500-Foot Mining Leve1: Edwards Mine. (Lea, 1968) 


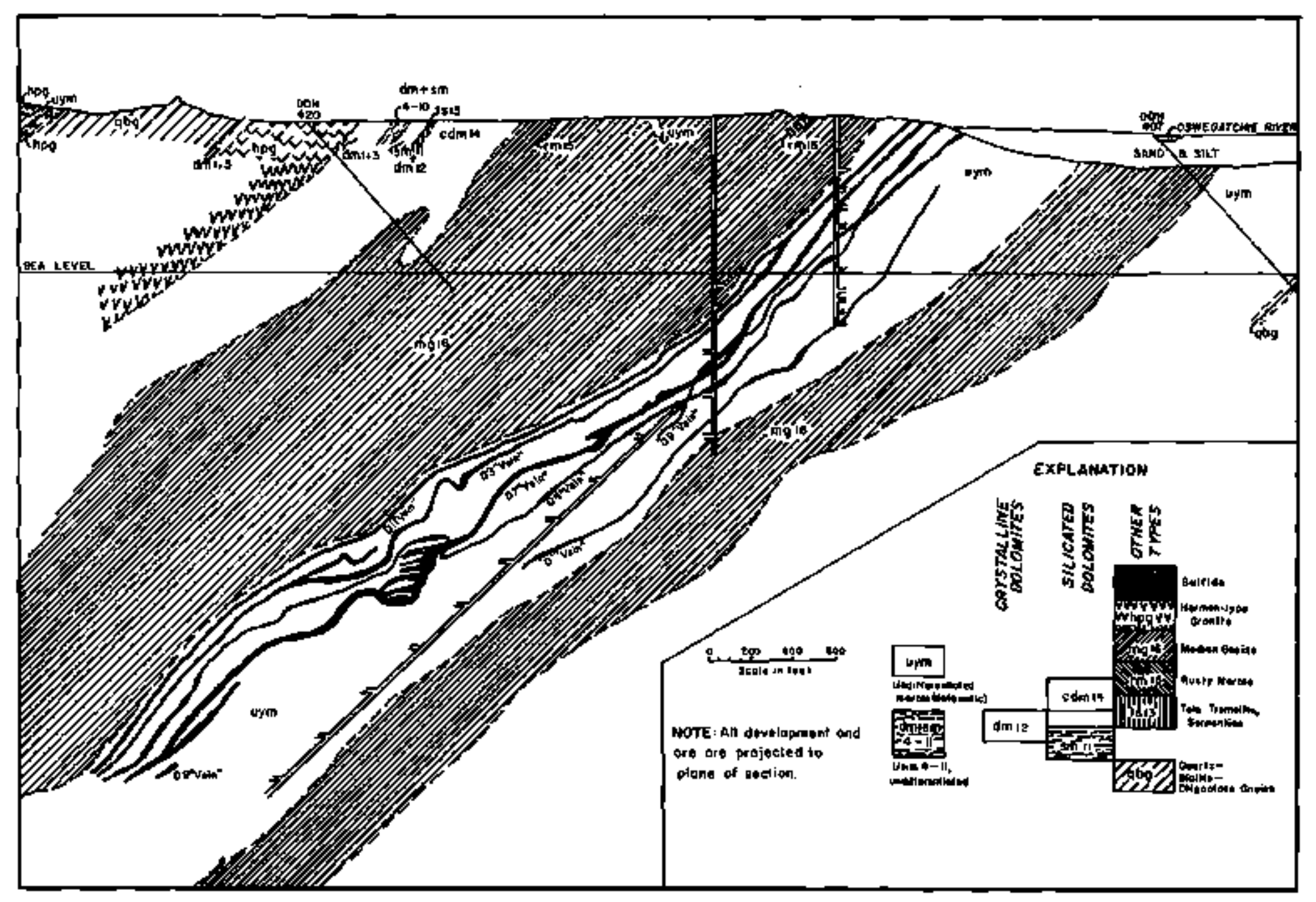

FIGURE 5. Edwards Mine: Northwest-Southeast Section. (Lea, 1968). 


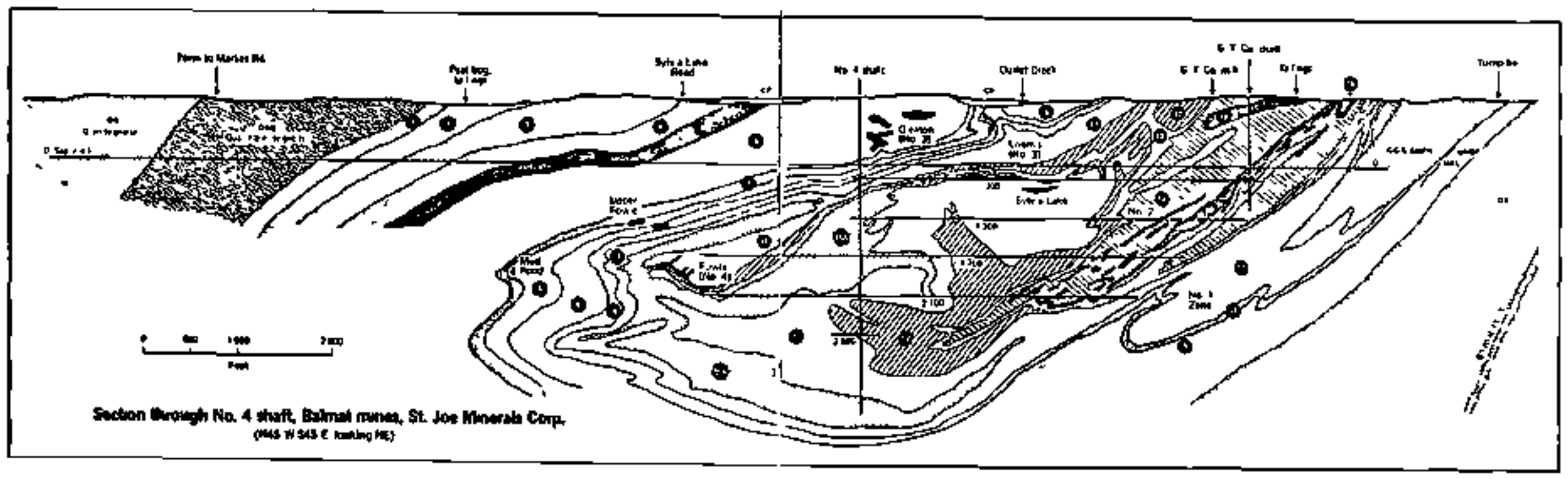

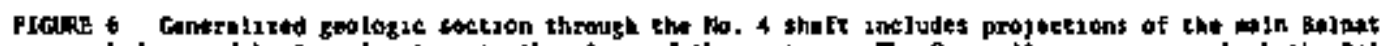
ore hodzes and haulate levels onto the plane of the section. The Grenvilie seriss, in which the balmet

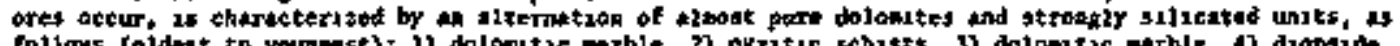

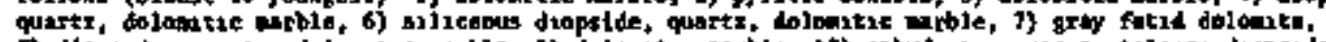

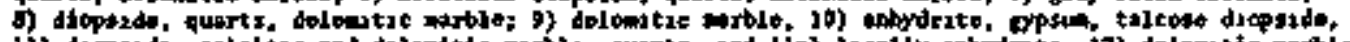

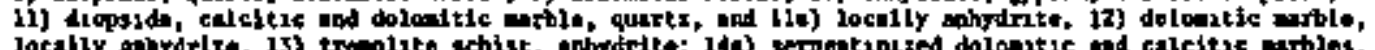

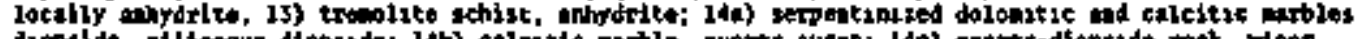

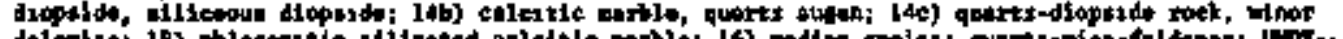

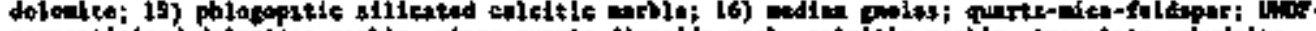

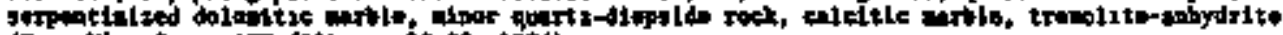
(Eng, thin. 1, v. IT (11), p. 6z-95, 1976) 
It is expected that nore ore nay be located in the future. Probable reserves may be $8.4 \times 10^{6}$ tons as of 1976 (E/MJ 1976). Engineering and Mining Journal (1976) reports that St. Joseph can be expected to be mining the Balnat District until the end of this century.

\section{MINE OPERATIONS}

Slusher stopes to large roon and pillar stoping are used because of the complexity of the ore body. Drifts which are arched may be in either the footwall, hanging wall, or in ore, because of ore location variability. Roof bolts are usually the only support necessary. They are $5 / 8$ inch diameter and 4-6 feet long with $6 \times 6$ inch plates on a $4 \times 4$ foot pattem. In soft ground resin bolts are used. In fractured areas, chain link fence and/or roof nats with bolts are needed. TrackJess hauling 1s used with battery locomotives, Plymouth 6-8 ton diese 1 locomotives, and Sien 10 ton trucks. Hoisting equipnent for Balpat wines are for \#2 - 8.5 ton hoist, \#3 - 3 ton hoist, \#4 - 11 ton hoist. The latter can handle 287 tph. No. 4 shaft also has a 10 ton service hoist (E/MJ 1976).

The Edwards mine cross-section and plan views (Figures 4 and 5) show that sone workings extend into the gneissic rock. While the other mines may also have such drifts into the gneiss, the maps available do not show such workings. The Hyatt mine, while of small production, is operating and may be a prime candidate since, fron MAS data (1978), gneiss and schist lie over and under the ore. 


\section{BIBLIOGRAPHY}

Brown, J.S., and Engle, A.E.J., 1956, Revision of the Grenville stratigraphy and structure in the Balmat-Edwards district, Northwest Adirondacks, New York: Geol. Soc. Amẹr. Bull., v. 67 (12) p. 1599-1622.

Buddington, A.F., and Leonard, B.F., 1962, Regional Geology of the St. Lawrence County Magnetite District, Northwest Adirondacks, New York: U.S. Geol. Survey Prof. Paper 376, $145 \mathrm{pp}$.

CRIB

Engel, A.E.J., and Enge1, C.G., 1953, Grenville Series, in: The Northwest Adirondacks Mountains, New York, Part I, Genergl Features of the Grenville Series: Geol. Soc. Amer. Bull., v. 64 [12), Part 1, p. 1013-1047.

Engineering and Mining Journa1, 1976, v, 177 (11), p. 92-99.

1ea, E.R., and De11, D.B. Jr., 1968, Z1nc Deposits of the Balmat-Edwards District, New York in: Ridge, J.D., ed., Ore deposits of the United States, 1933-1967, Aner. Inst. Min. Metal1. Petrol. Eng., New York.

\section{MAS}

St. Joseph Minerals Annual Report, 1978.

St. Joseph Minerals Special Release, 1979. 



\section{LYON MOUNTAIN DISTRICT}

\section{LOCATION AND ACCESSIBILITY}

The magnetite deposits of the Lyon Mountain district are located in far northeastern New York State, at $44^{\circ} 44^{\prime} \mathrm{N}, 73^{\circ} \mathrm{S5} \cdot \mathrm{W}, 25$ miles slight 1 y north of west from Plattsburg and 145 miles slightly west of north from Albany. Access is by State Highway 374 , an a 11 weather road. Two mines, the Chateaugay, located in the village of Lyon Mountain, and the 81 mine, approximately $1 \mathrm{mile}$ NNE of Standish, have been worked in recent years (Figure 1).

\section{GEOLOGIC SETTING}

\section{lithology}

The geologic setting of the Lyon Mountain district was described by Poste1 (1952).

Four major ore bodies comprise the district: the 81 , the Chateaugay, the Parkhurst mines, and the Phillips vein, located in the southwest-northeast trending Lyon Mountain ore belt (Fìgure 2). Most of the metanorphic and igneous rocks of the district have gneissic structures as a result of the Grenville metanorphic episode. The oldest rocks in the district are sedimentary rocks of the Precambrian Grenville Series but these rocks do not occur in the mineralized area. The oldest felsic igneous rock in the district is the Hawkeye granite gneiss, outcropping 1 to 1.5 miles southeast of the ore be1t; its axis is orlented roughy parajlel to the ore belt. A younger quartz syenite gneiss crops out 10 miles south of the ore belt. The youngest rock in the district is the Lyon Mountain granite gneiss which contains the ore belt. Pegmatites are common in the district and are foumd in all mines. Dikes of varying composition also transect the area and are all younger than 


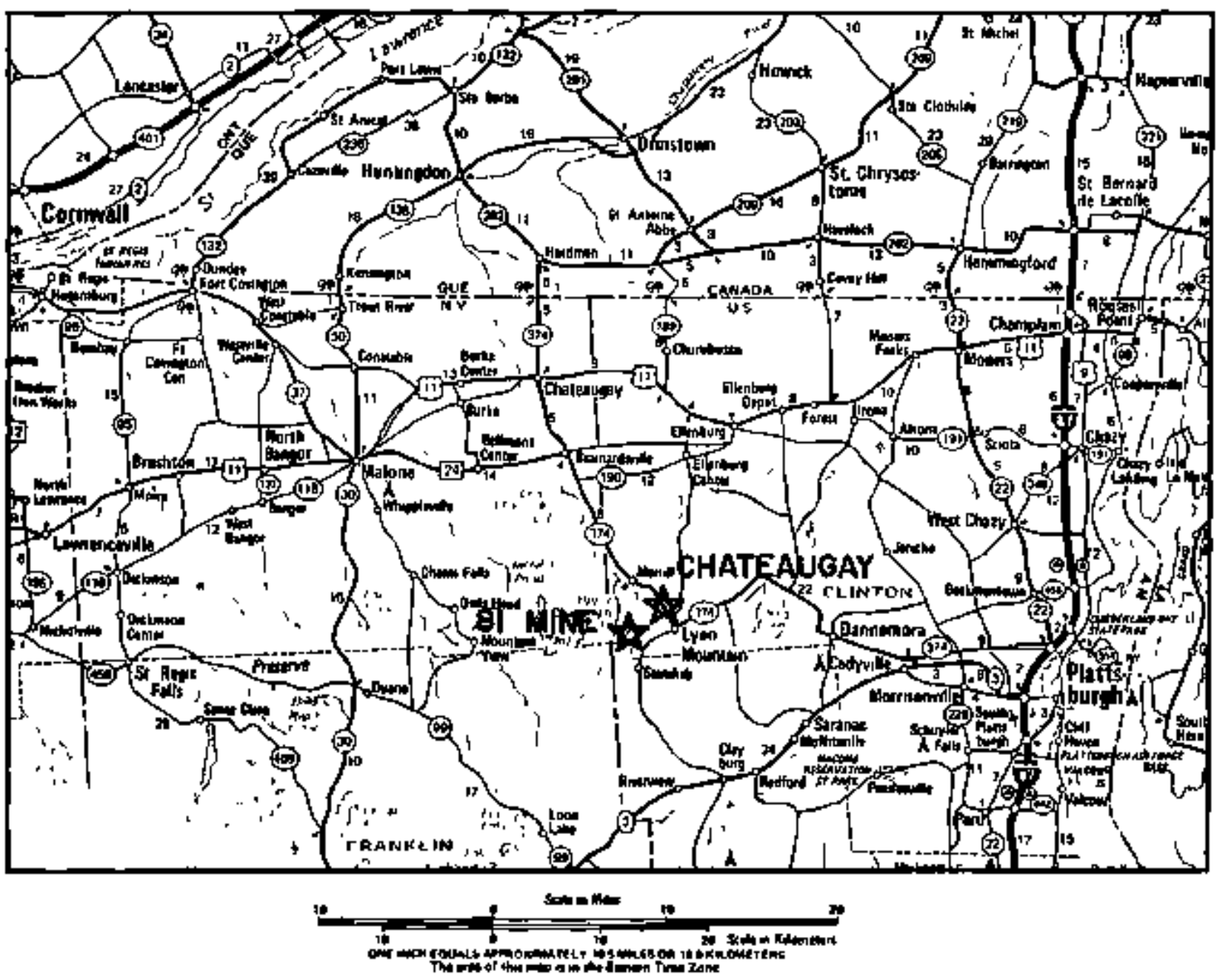

FIGURE 1. Map showing locations of the Chateaugay and 81 Mines, Clinton County, New York. Basic map reproduced by permission of the American Automobile Association, copyright owner. 


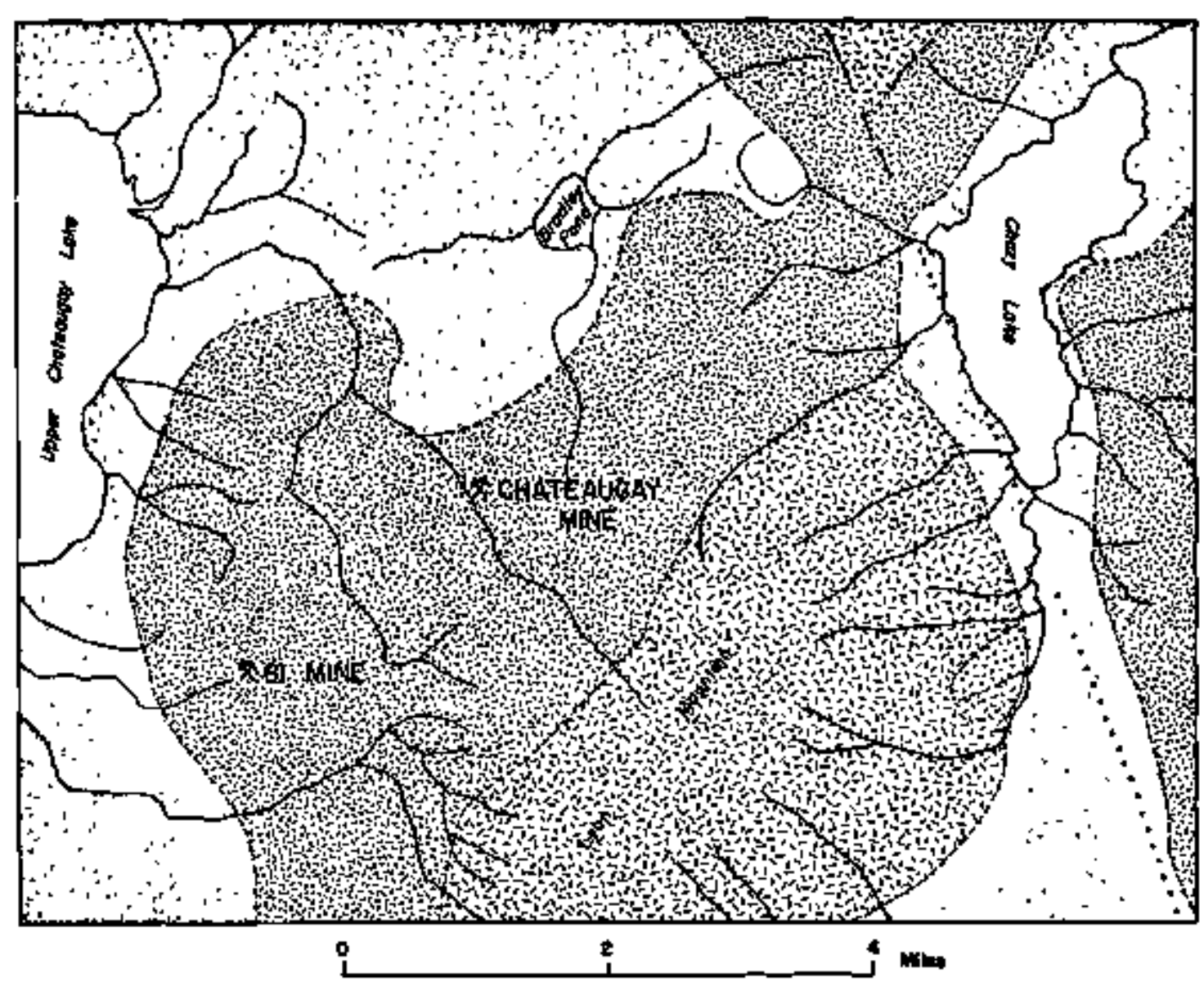

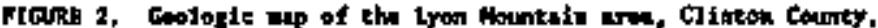

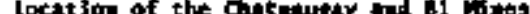
(Postel, 1952)

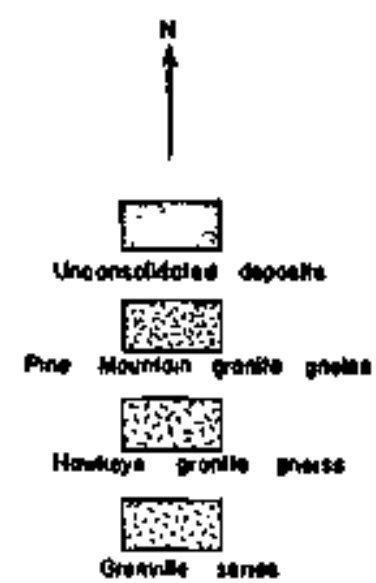


the Lyon Mountain granite gneiss. Numerical rock ages do not appear in the literature on the ore belt area or its surroundings. Metamorphism and - intrusive relationships suggest that the ore bodies developed at the time of Grenville orogeny, about 1 million years ago (Ridge, 1972, Postel, 1952). The presence of schist and gneiss indicates that metanorphism was medium to high grade. The principal ore nineral is magnetite. The ore deposits probably were forned by hydrothermal solutions derived fron the granitic magnas (Ridge, 1972).

The Precanbrian rocks are encompassed in isoclinal, overturned, and open folds. Generally, the folds plunge to the north or northeast but a few al so plunge to the south. Sone synclines in the Lyon Mountain granite gneiss are economically important because many of the district ore bodies are located in their limbs. For example, the 81 mine ore body occurs in the 81 syncline north of the town of Standish, and the ore in the Chateaugay mine in the village of Lyon Hormtain occupies two synclines, the east and west, which are separated by an anticline.

Both large and small faults transect clinton County. Sma11 normal and reverse faults with a few inches of displacenent are noted in the ore district. The evidence for the large faults, a11 normal, is based on the presence of brecciation, discordant strike of gneisses, and topographic features. An example is the Chazy Lake Fault which strikes NNH, east of Lyon Mountain. In the Chateaugay mine two sets of faults are found. One set strikes east While the other strikes northeast, both having vertical dips.

Foliation occurs in varying degrees in all Precambrian rocks in Clinton County. In genera1, the direction of foliation is northeast, especially 
in the ore district areas. Lineation usually trends northward or a 1ittle east of north with a moderate plunge in the same direction. This trend is usually close to the strike of the follation plane in which the lineation Dccurs (Poste1, 1952).

MINE GEOLOGY - Chateaugay, 81, and Parkhurst Mines

The ore at Chateaugay mine is a replacement of a pyroxene-contaminated microcline-microperthite granite gneiss and plagioclase granite gneiss, and occurs as cigar-like shoots in two symelinal structures which plunge in a northeast direction. The ore bearing limbs strike $N 30^{\circ} \mathrm{E}$ and $\operatorname{dip} 60-65^{\circ} \mathrm{NH}$. The ore at the 81 mine replaces plagioclase grantite gneiss, and occurs on the heel and northwest limb of a syncline; the limb strikes $N 45^{\circ} \mathrm{E}$. There is a small anticlinal fold between the southeast limb at the 81 mine and the Chateaugay mine. The host rock has a strong mineral lineation which plunges $20^{\circ} \mathrm{NE}$. The ore body at the Parkhurst mine is reported to be walled by schist (Postel, 1952).

\section{FACILITIES}

Very little information was found on facilities. The total ore output from the Chateaugay mine in the period 1871-1948 was $15 \times 10^{6}$ long tons. In 1948 , the output was $1.5 \times 10^{6}$ long tons. Postel states that the mine geologist for Republic Steel Corporation at Lyon Mountain Village was planning a detailed description of the Chateaugay and 81 mines which would undoubtedly give pertinent information. The mise was still producing in 1956 (Hinerals Yearbook, 1956). The mine was permanently closed in 1967 (Minerals Yearbook, 1967). 
The 81 mine was opened in 1840 but not mined continuously until 1848. It was shut down in 1902. In the late 1940's, Republic Steel Corp. investigated the deposit again and started production in 1948-1949. Contracts were let to build a six-compartment vertical shaft to 2500 feet underground (Skillings Mining Review, August 28, 1948).

There is no information on the Phillips" vein. It may never have been mined. No further information has been found on the Parkhurst nine other than the fact that it is flooded, and produced $4 \times 10^{4}$ tons of ore between 1889 and 1892 . 
REFERENCES

Minerals Yearbook 1956 - The Mineral Industry of New York.

Minerals Yearbook 1959 - The Mineral Industry of New York.

Minerals Yearbook 1967 - The Minera1 Industry of New York.

Postel, A.W., 1952, Geology of Clinton County Magnetite District, New York: L.S. Geol. Survoy Prof. Paper 237, 88 pp.

Ridge, J.D., ed., 1972, Annotated Bibliographies of Mineral DepositsWestern Henisphere, Geol. Soc. Arer. Men. 131, Boulder, Colo., $681 \mathrm{pp}$. 

HOMESTAKE MINE

LEAD, LAWRENCE COUNTY, SOUTH DAKOTA

(Honestake Mining Co.)

\section{LOCATION AND ACCESSIBILITY}

The Homestake mine is located at Lead (pronounced "leed"), Lawrence County, in the Black Hills of southwestern South Dakota at $44^{\circ} 15^{\prime N}$ and $103^{\circ} 50^{\prime} \mathrm{W}$.

lead is 35 miles northwest of Rapid City, South Dakota fron which it is readily reached by Highways 90 and 14 (Figure 1 ).

The mine, which extends to a depth of $8000 \mathrm{ft}$. , is the largest gold producer in the western hemisphere and has operated almost continuously since 1876. It produces native gold, with silver as a najor accessory metal and a smal1 amount of copper (CRIB, 1974; E/MJ, 1976; Slaughter, 1968 ).

\section{GEOLOGIC SETTING}

The geologle setting of the Lead district is illustrated in figure 2 . The Homestake mine is located in Precambrian schists, formerly mudstones which, along with other rock types, were folded and intruded by igneous rocks and then metanorphosed. The total thickness of the schists at Lead is about 2000 feet. Great compression of the schists resulted in a plastic rock flow and the production of tightly closed isoclinal folds. Refolding and deformation of the isoclinal folds resulted in the present configuration of a conplex synclinorium. Mast metamorphism took place in the Precambrian time during or following the first folding period. The netamorphosed rocks were severely eroded and covered with Paleozoic and Mesozoic sediments. In early Tertiary tine large amounts of igneous rocks intruded this rock sequence. The whole region was then uplifted and eroded so as to produce the present surface (\$1aughter, 1978; Nobel and Harder, 1948). 

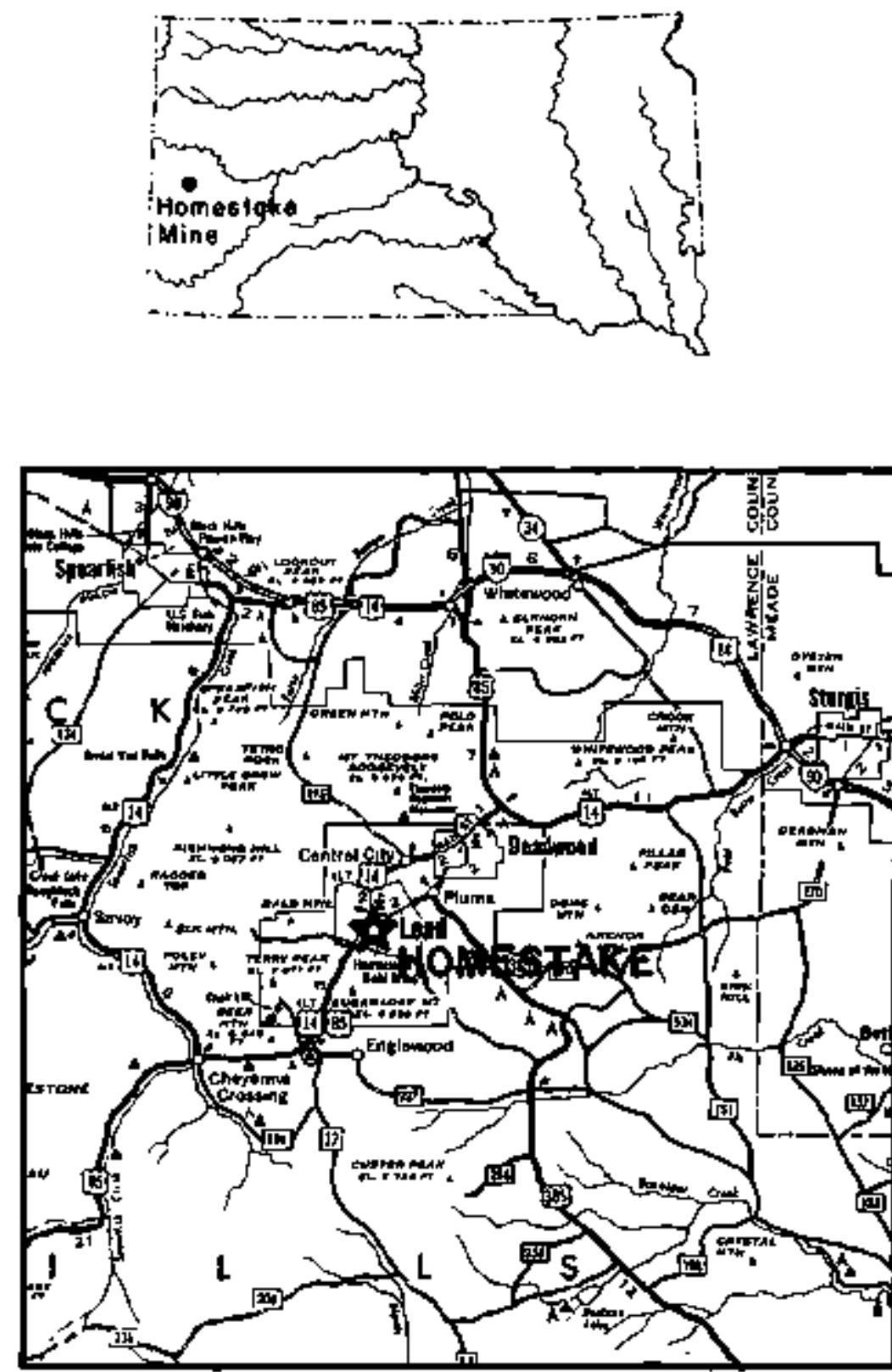

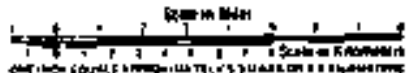

FIGURE 1. Location maps of the Homestake Mine, Lawrence County, South Dakota (upper map from Slaughter, 1968; lower map. basic map reproduced by permission of the American Automobile Association, copyright owner). 


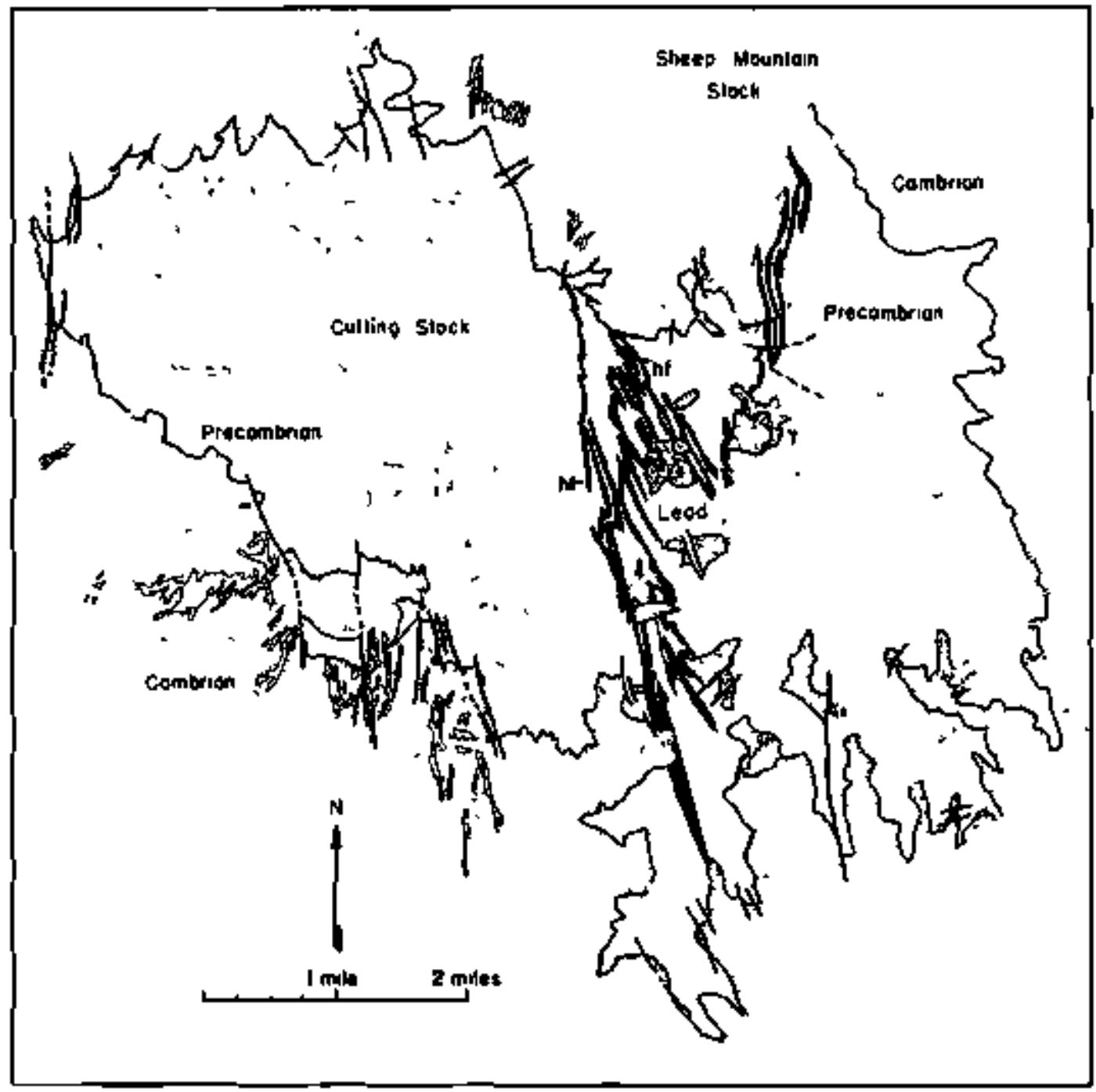

FIGURE 2. Geologic Map of the lead District. The surrounding Cambrian Deadwood Formation is stippled. Tertiary intrusive rocks are within the dotted outlines. Sil1s in the Canbrian strata, small dikes, and Tertiary gravel deposits are onitted. The Precambrian Honestake formation is shown in solid black. The white areas within the stippled areas are mine workings in the Cambrian rocks, both open pit and underground. (S1aughter, 1968). 
Noble and Harder (1948) have established the following stratigraphic colum for this region:

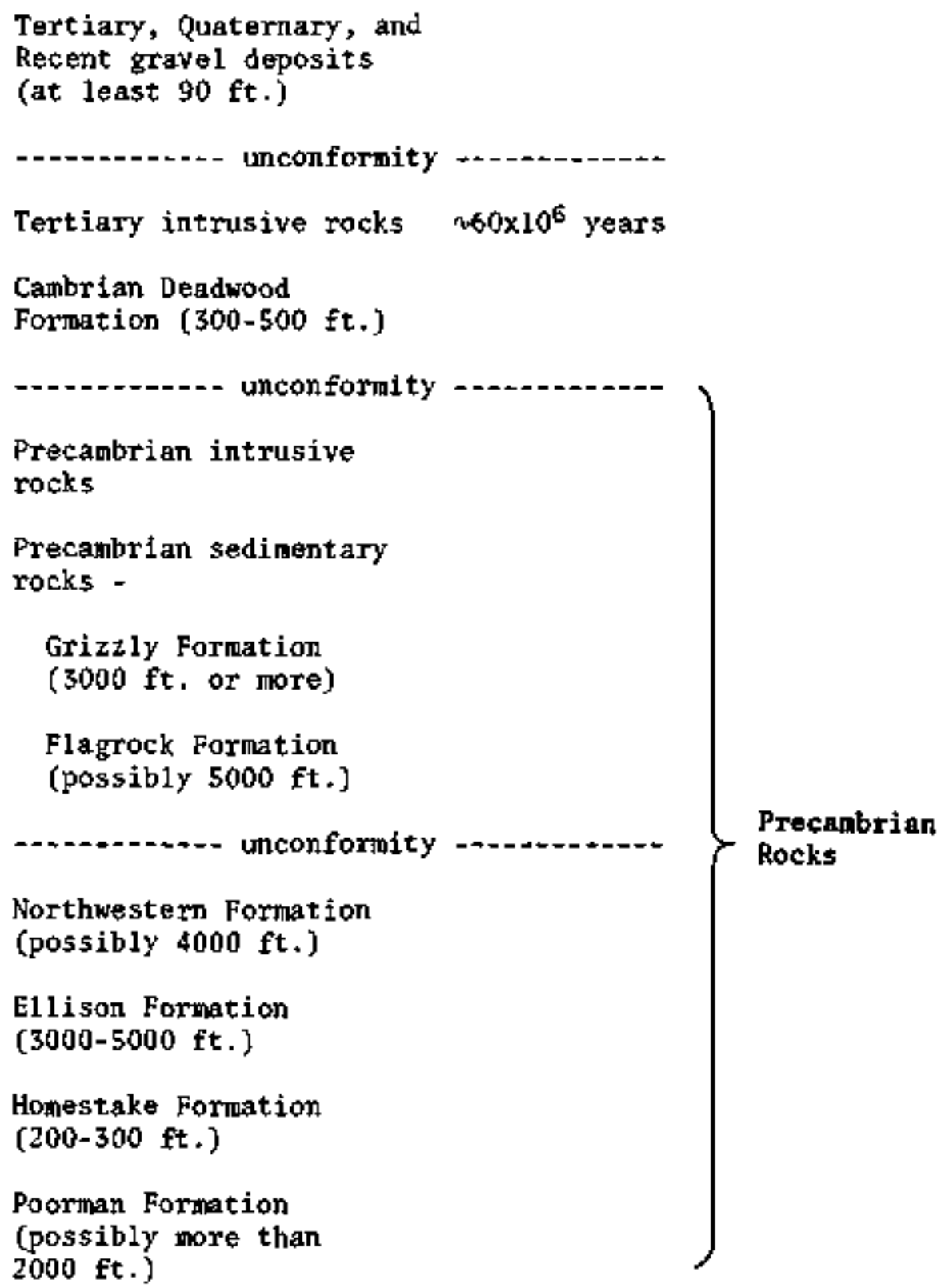

A description of the rock units, from oldest to youngest, follows. The oldast formation, the Pocerman, is mainly a gray phyllite, but some parts of it are slaty and schistose. The Homestake Formation is a 
sideroplesite-q̧uartz-cunuingtonite schist, having a reddish to brownish hue, sometiraes green (due to chlorite). Small white quartz veins, and pods and seans of gray to white quartz are common. The Homestake ore bodies occur in this formation. The Ellison Fornation is composed of phyllites and schists with large amounts of dark quartzite. The phyllites have a sandy texture. Primary structural features such as bedding, cross-bedding, or other types are not found. The Northwestern Formation is made up of phyllites, schists, and a little slate. Most of this fornation is also structureless. The Flagrock Formation is composed of many rock types. The nost abundant is a light gray sericitic phyllite or schist. There are also soft sooty black schists or phyllite with pyrite, quartzite, and sideroplesite schist (converted to cumbingtonite in some places). A fine grained sericitic gray to dark gray phylite is the comoron rock in the Grizzly Fornation which also has very few bedding structures.

The Precambrian intrusive rocks are amphibolites, thought to have originally been gabbro. Above the unconformable contact with the Precambrian, the Upper Cambrian Deadwood formation consists of a quartz pebble conglomerate which grades upward into a light brown quartzite, overlain in turn by a brown sandy dolonite with thin partings of green shale. The remainder of the Deadwood formation in the Lead District is thin-bedded green and gray glauconitic shale with some beds of linestone and dolomite and some intraformational limestone conglowerate.

The Tertiary intrusives are of granitic and syenitic composition and are fairly abundant in the Lead district (Figures 2 and 3) (S1aughter, 1968; Nobe1 and Harder, J948). 


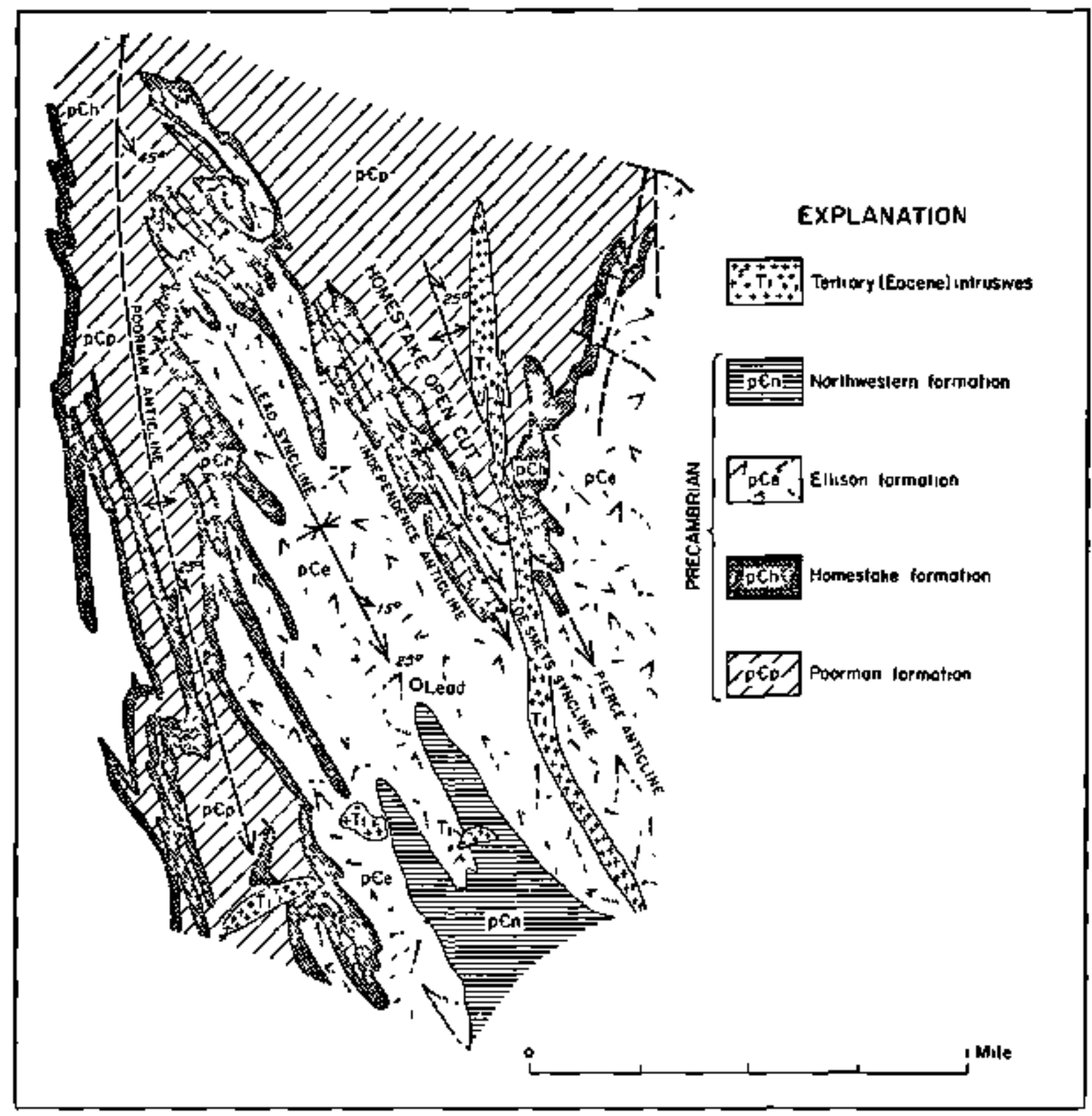

FIGURE 3. Precambrian geology in the vicinity of the Homestake Gold Mine, Black Hills, South Dakota. (Hendrix, 1962, sfter Noble, 1949). 
sideroplesite-quartz-cumaingtonite schist, having a reddish to browish hue, sometimes green (due to chlorite). Small white quartz veins, and pods and seams of gray to white quartz are common. The Honestake ore bodies occur in this formation. The Eliison Formation is composed of phyllites and schists with large anounts of dark quartzite. The phyllites have a sandy texture. Primary structural features such as bedding, cross-bedding, or other types are not found. The Northwestern Formation is made up of phyllites, schists, and a Iftele slate. Most of this formation is also structureless. The Flagrock Fornation is composed of many rock types. The most abundant is a light gray sericitic phyllite or schist. There are also soft sooty black schists or phyllite with pyrite, quartzite, and sideroplesite schist (converted to cumningtonite in sone places). A fine gratned serictic gray to dark gray phylite is the common rock in the Grizzly Formation which also has very few bedding structures.

The Precambrian intrusive rocks are amphibolites, thought to have originally been gabbro. Above the unconformable contact with the Precambrian, the Upper Cambrian Desdwood formation consists of a quartz pebble conglomerate which grades upward into a light brown quartzite, overlain in turn by a brown sandy dolonite with thin partings of green shale. The remainder of the Deadwood formation in the Lead District is thin-bedded green and gray glauconitic shale with some beds of linestope and dolcmite and some intraformational limestone conglomerate.

The Tertiary intrusives are of granitic and syenitic composition and are fairly abundant in the Lead district (Figures 2 and 3) (S1aughter, 1968; Nobel and Harder, 1948). 


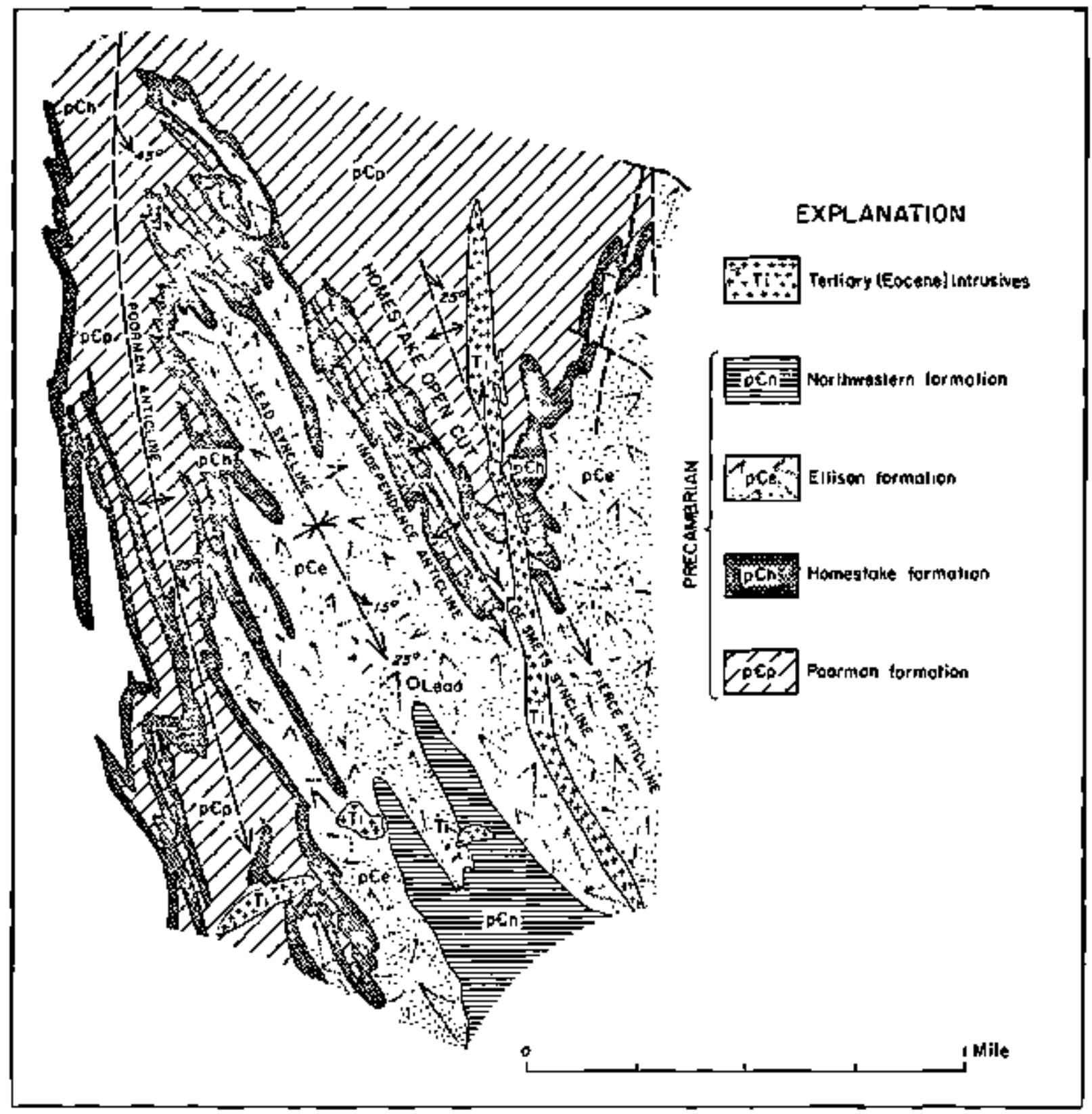

FIGURE 3. Precambrian geology in the vicintty of the Horestake Gold Mine, Black Hills, South Dakota. (Hendrix, 1962, after Noble, 1949). 


\section{METAMORPHISN}

The Precambrian rocks in the lead district have been progressively - regionally metamorphosed. The degree of metamorphism increases from southwest to northeast across the district (Figure 4), from a biotite zone representing low to mediug grade, to a garnet zone of middle to high grade, to a high-grade staurolite-kyanite zone.

The ore bodies are found on $1 y$ in the biotite and garnet zones. The carbonate, sideroplesite of the Homestake formation, is altered to cummingtonite (amphibole) on the garnet isograd. The cummingtonite isograd determined by Nobel and Harder (1948) is very close to the gaxnet isograd, There is also sone evidence for retrogressive metanorphism, as shown by the alteration of garnet to quartz-sericite and iron oxide, and of biotite to sericite (Noble and Harder, 1948; Slaughter, 1968).

\section{REGIONAL STRUCTURE}

The lead District is located in one of the roughly east-west oriented dotnes of the northern Black Hills, whose dimensions are $10 \times 12$ miles. In the center of the dome is the Cutting stock, a Tertiary granite porphyry, which intruded the Precambrian and Paleozoic rocks. The Deadwood Formation and other Paleozoic rocks have been domed and faulted by the Tertiary porphyry intrusions. Dikes of the porphyry intruded along many of the faults. The Precambrian rocks are not strongly faulted; the other deformations present are most likely due to the Tertiary intrusions (Nable, Harder and Slaughter, 1949; S1aughter, 1968].

The primary Precambrian rock structure in the Lead district (shown in Figure 3) is dominated by the Poorman anticline and the Lead sync1ine. The axial plane of the Poorman strikes a little west of north, dips east, and 


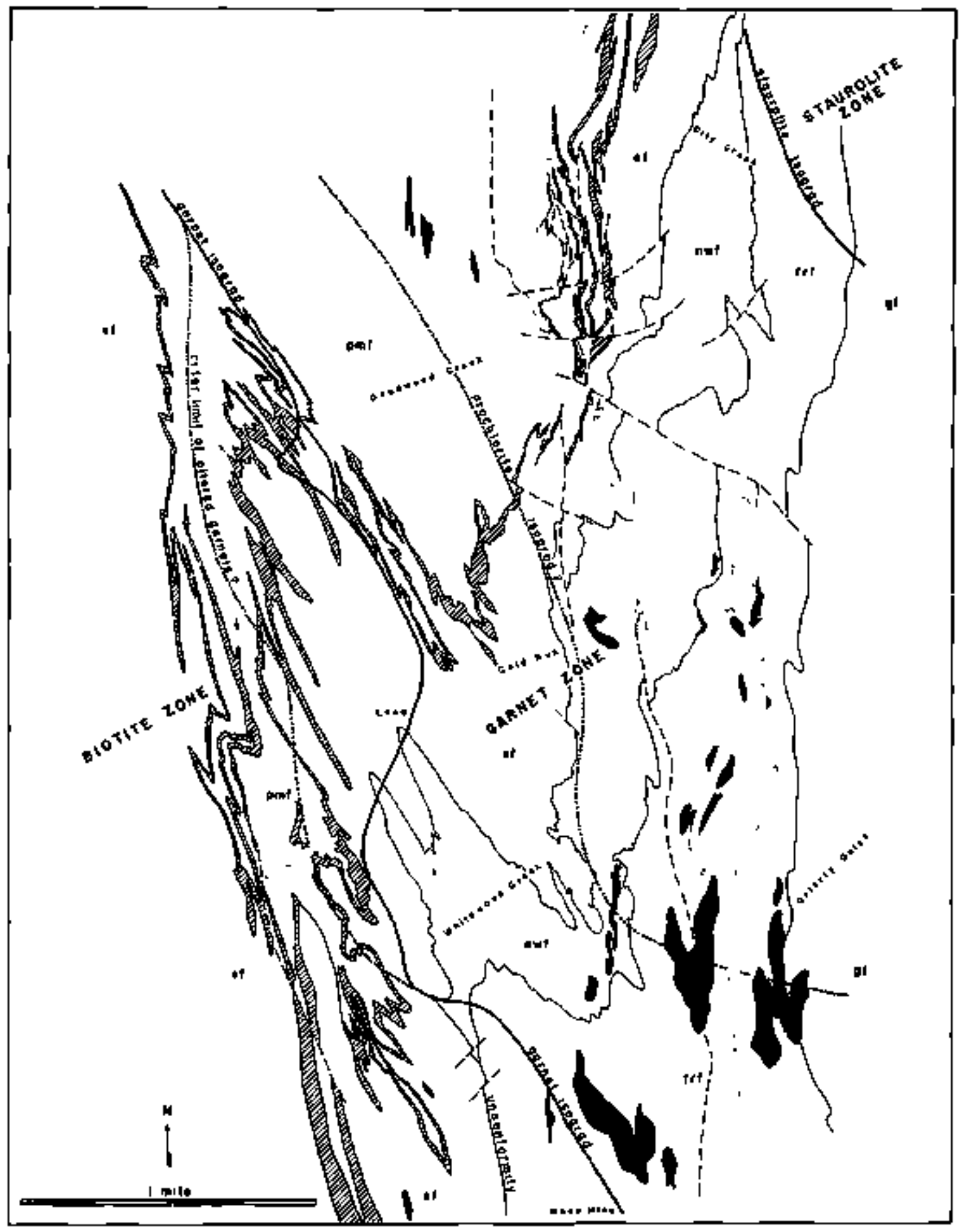

FIGURE 4. Distribution of the pre-Canbrian sedinentary rocks and the metamorphic zones in those rocks in the Lead district. Large anphibolites are in solid black. Faults are shown by dashed lines. Poornan formation, pmf; Ellison fornstion, ef; Northwestern formation, nwf; Flag Rock formation, frf; Grizzly formation, $\mathrm{gf}_{\text {; }}$ Homestake formation, cross hatched. (Noble, 1948). (Reprinted with permission of the Geological Soclety of Anerica.) 
plunges $25^{\circ} \mathrm{SE}$, The limb between the Poornan anticline and the structure to the east, the Lead syncline, contains many very narrow smaller anticlines and synclines. To the east of the above structures are the tight isocling1 folds of the Independence anticline, the De Snet syncline, the Pierce anticline, and the Caledonia syncline. All axial planes and fold linbs dip about $65^{\circ}-70^{\circ} \mathrm{E}$ and the folds plunge southeast. The overall structural relationships of the region are those of ninor folds related to the dominant Poorman anticline. Two features are not in accord with this relationship. The first is that axial planes west of the Pierce anticline strike northwest but axial planes east of this anticline strike north or northeast. The second feature is the crossfolding of the isoclinal axial planes (Figure 3 ). This crossfolding, like the isoclinal folding, was produced by slipping along shear planes. These folding types cannot always be distinguished fron each other. The crossfolding nay have been caused by the Tertiary intrusion (Figure 3).

\section{FAULTING}

Major faulting is not comon in the area of the Homestake nine, but one fault near the eastem edge of the district has been traced throughout the full length of the area. It strikes a little west of north and dips steeply. Sma1l faults have been mapped at many places in the nine. They also have a strike simflar to the fault mentioned above and may dip steeply east or west.

\section{GLEAVAGE}

In most of the isoclinally folded areas, cleavage and bediing are straight and very parallel. However, four general types of relations between 
cleavage, bedding, and shear planes are found: (1) on the limbs of isoclinal folds cleavage and bedding are parallel, (2) in other isoclinal folds a second cleavage set is inclined to the first set and the bedding, (3) isoclinal folds with cleavage and/or shear planes cutting the bedding (the intersection angles may range from a few degrees to $90^{\circ}$ on the crest of the folds), and (4) some isoclinal folds have cleavage which intersects the bedding and shear planes, intersecting both of the other structural features (Slaughter, 1968; Noble, Harder and Slaughter, 1949).

\section{MINE GEOLOGY}

The ore bodies, confined primarily to the Honestake formation, are selective Precambrian and/or Tertiary age replacements of the sideroplesite cunningtonite schist. The ore is localized in certain parts of the Homestake formation by zones of relatively high permeability thought to be caused by cross folding. Nobel and others (1949) recognized six ore-bearing structures ("ledges"); in order of importance, they are: Main Ledge (Pierce anticline), 9 Ledge (Lead syncline), Caledonia, now worked out (Caledonia syncline), 7 Ledge (Lead syncline), 11 Ledge (Lead syncline), and 5 ledge (De Smet syncline) (Figure 5). More recent reports indicate that eight ledges have been, or are, under production. The synclines and anticlines containing the ore bodies are tight isoclinal folds dipping steeply east and plunging southwest. They probably developed by shear folding with the possibility that earlier transverse compression bending may have also contributed. Small faults have been napped at many places in the mine. They strike a little west of north and dip steeply east or west. The six irregular pipelike, podlike, and lenselike ore bodies are localized in areas of a second stage of crossfolding, superimposed on the original isoclinal folds. The axial planes of the isoclinal and crossfolds 


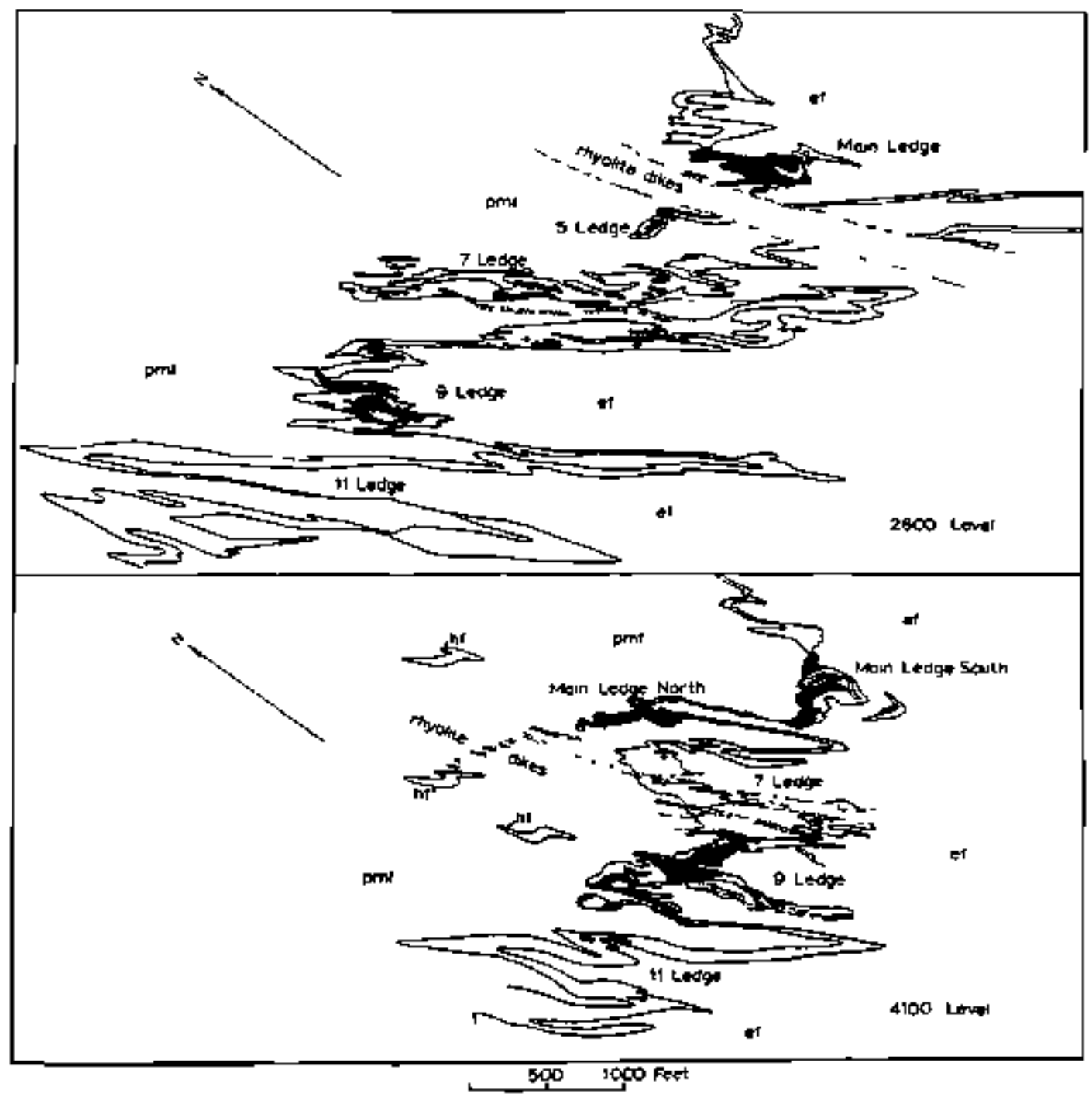

FIGURE 5. Relation of Ore Bodies to Structure. The outline of the Honestake Fornation is shown on 2600 and 4100 levels. The changing relationship of the ore-bearing structures to each other brings about a marked shortening of total strike length of the whole group of folds. Ore is solid black, dikes are dotted. Poorman Formation, pnf; Ellison Formation, ef. (Slaughter, 1968) 
intersect at angles of $20^{\circ}-30^{\circ}$ and less in some cases. The ore bodies occur at the intersections of shear planes of the second stage folding with either limbs or axial planes of the isoclinal folds. The 5 Ledge ore body in the De Snet syncline (Figures 6 and 7) best shows this ore localization.

\section{MINERALIZATION}

The ore bodies are hydrothermal replacenents of the cummingtonite or sideroplesite schist to mainly chlorite with many veins and masses of quartz with minor amounts of pyrrhotite, pyrite, and arsenopyrite. The gold is found finely disseminated in the quartz. The gge of the gold mineralization is still controversial. The usual opinion is that most of the gold mineralization is of Precambrian age with minor amounts introduced in the Tertiary (S1aughter, 1968; Noble, 1950).

\section{MINE FACILITIES}

The Homestake gold mine (illustrated schematically in Figure 8 ) is a multilevel nine with a volume of $44,200,000$ cubic feet (E/MJ, 1976; Cobbs, 1976). There are two main shafts, the Yates and Ross Shafts, which reach 5000 feet underground. There are four winzes, No. 3, from the 4100 to the 5000 foot level; No. 4, from the 4850 to the 6800 foot level; No. 6, fron the 4550 to the 8000 foot leve1; and the No. 7 winze, from the 6800 to the 8000 foot level. All ore and waste rock is brought to the surface by the shafts and winzes. (About 1000 mine employees are raised and lowered each day,) There are also four ventilation shafts.

Mining operations are conducted on 34 levels from 1700 to 8000 feet. Levels above 1100 feet (mostly worked out) are spaced 100 feet apart. Below this level, they are spaced at 150 foot intervals. There are now over 200 


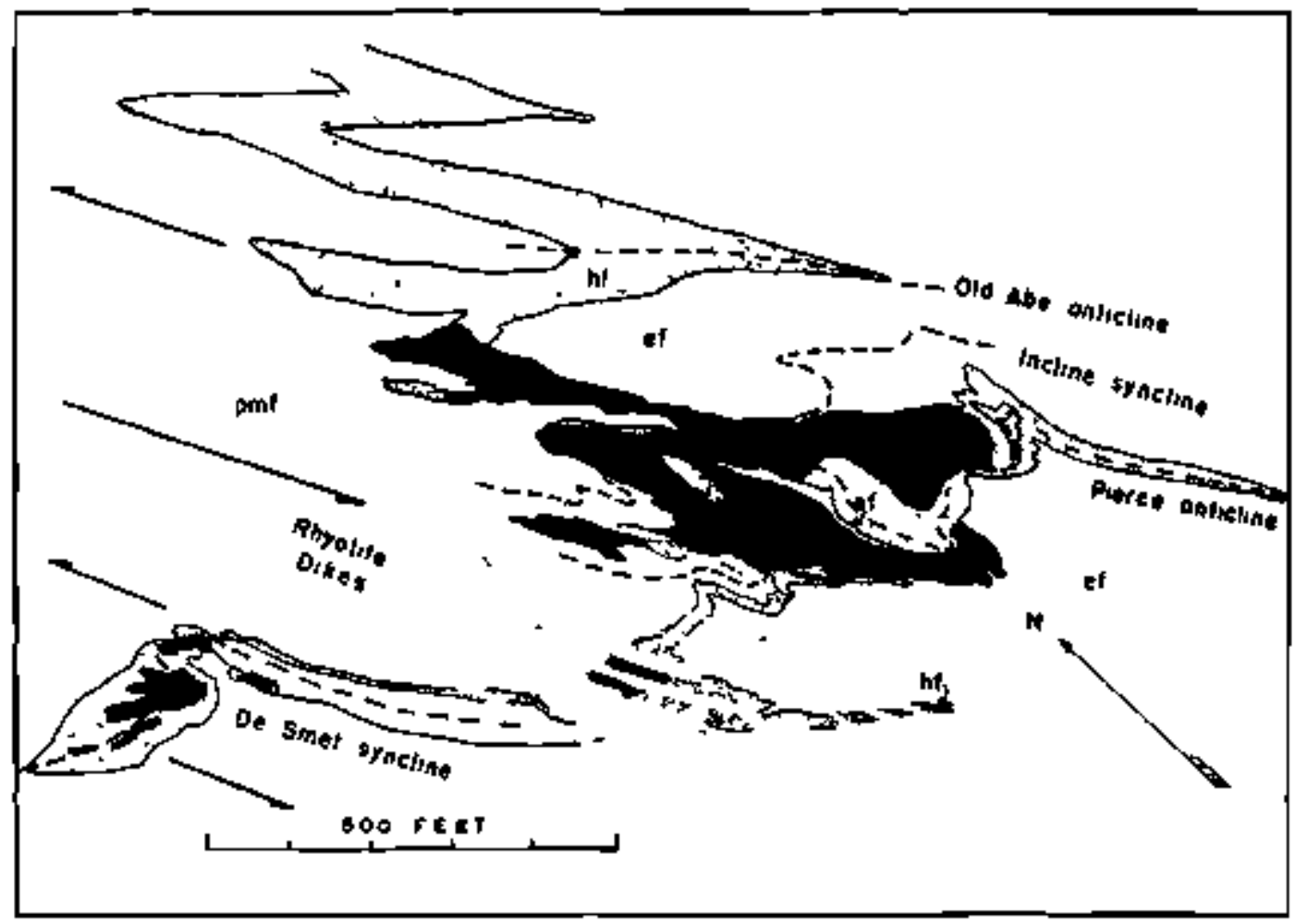

FIGURE 6. Cross-Folded Structures, 2600 Leve1, Ore-bearing parts of the Homestake Formation are solid black; non-orebearing parts are stippled. Poorman Formation pnf; Ellison Formation, ef. Dikes are dotted. Traces of axial planes of the folds are shown by dashed lines. Relative directions of displacements in the crossfolded zones are shown by axrows. (Slaughter, 1968) 


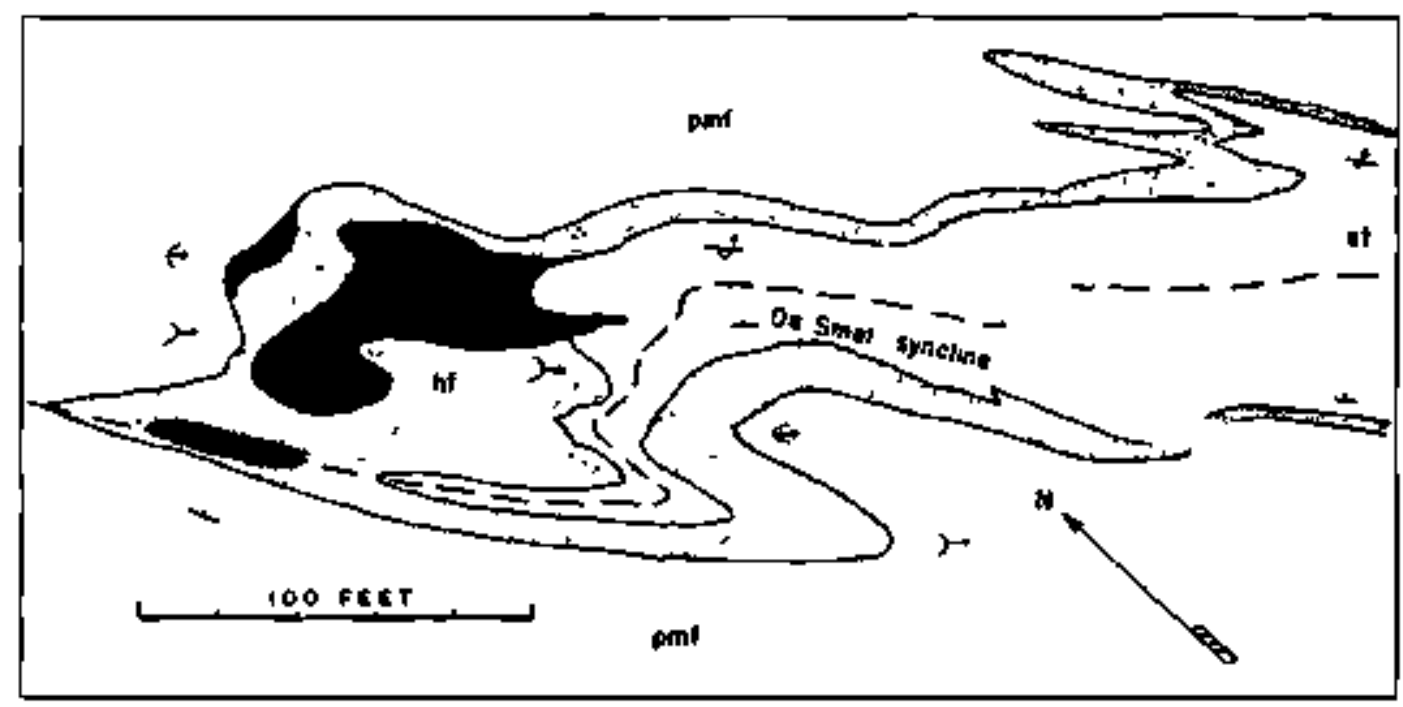

FIGURE 7. Cross-Folded Sync1ine, 2300 Level, Ore-bearing parts of Honestake Formation are solid black; nonore-bearing parts are stippled. Poorman Formation, punf; Ellison Formation, eft. Trace of axial plane of syncline is shown by dashed lines. Tertiary dikes are dotted. (S1aughter, 1968) 


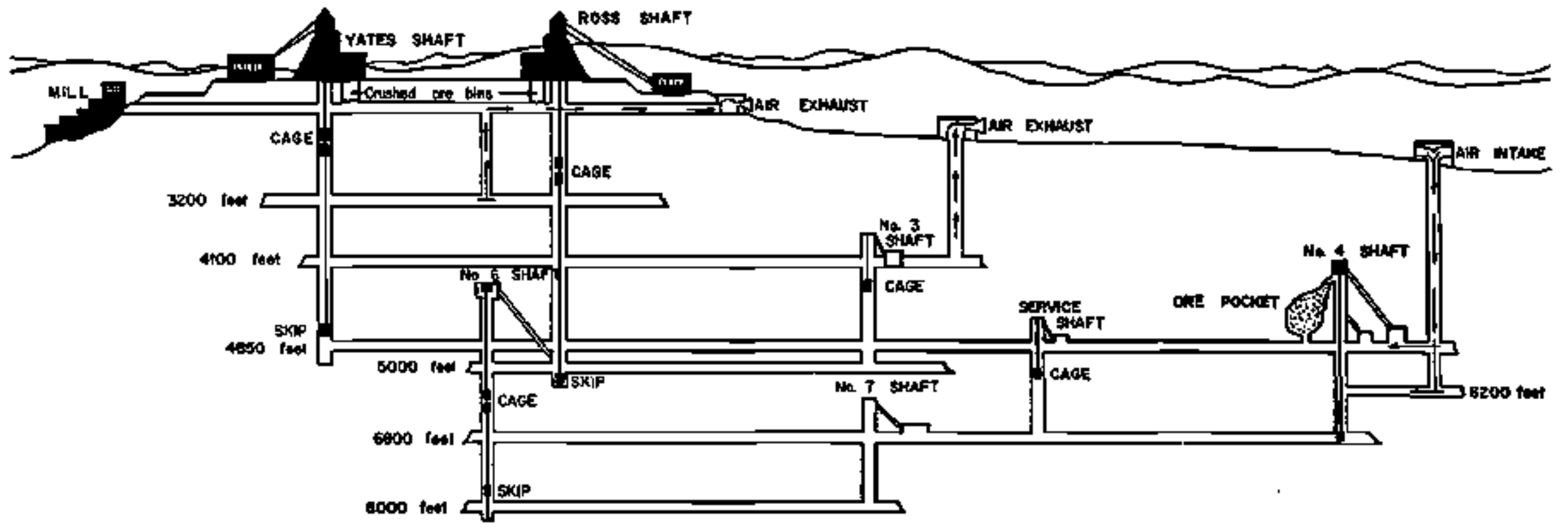

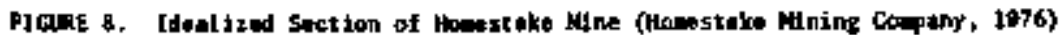


miles of workings on all the levels (Figure 8 ). Drifts and crosscuts are $7^{\circ} \times 7^{\prime}$ in the upper mine levels and $7.5^{\prime} \times 7.5^{\prime}$ in the lower levels. The mining of the ore bodies is mostly by horizontal cut and fill stoping, since the rock is in most cases very competent (Figure 9). Timbered cut and fil1 stoping, shrinkage stoping, and blast hole stoping are also used. The mined-out stopes are back filled with 'sand' from mill tailings (Homestake Centennia1, 1976; Homestake Annual Report, 1977). Removal of ore is done by the use of air rock drills (Jumbos), blasting, slushers, etc. The ore is then dumped into waiting ore cars. The mine has two rail haulage systens, an 18 inch track gauge for upper levels and a 30 inch track gauge for lower levels. Electric and compressed air locomotives are used to transport the ore to the shaft ore bins. The ore is then loaded into ore skips of 9-10 ton capacity and transported to the surface by high speed hoists. There are presently 250 miles of opendrift, more than $12 \mathrm{~S}$ miles of rail and $100-120$ stopes in various stages of development.

In some mine areas, rock stability problens have resulted in the use of patterned rock bolting, e.g. the 19 ledge area. The system is a $5 \times 5$ foot pattern of 5 foot rock bolts overlapped by $5 \times 5$ foot pattern of 8 foot bolts. The reasons for the rock stability problems are: (1) some rock is less metanorphosed, and (2) the ore bodies do not have a straight but an undulating plunge which results in fractures at right angles to the ore plunge. When horizontal openings are cut in ore which plunges $30^{\circ}-40^{\circ}$, the fractures tend to knit together, but when the plunges reach $85^{\circ}$, the rock is much less stable. Rock stability decreases with depth, requiring more rock bolting, chain link fencing, steel mats, and timbering to support this pressure (Homestake Contennial, 1976; Homestake Nining Annual Report, 1977). 


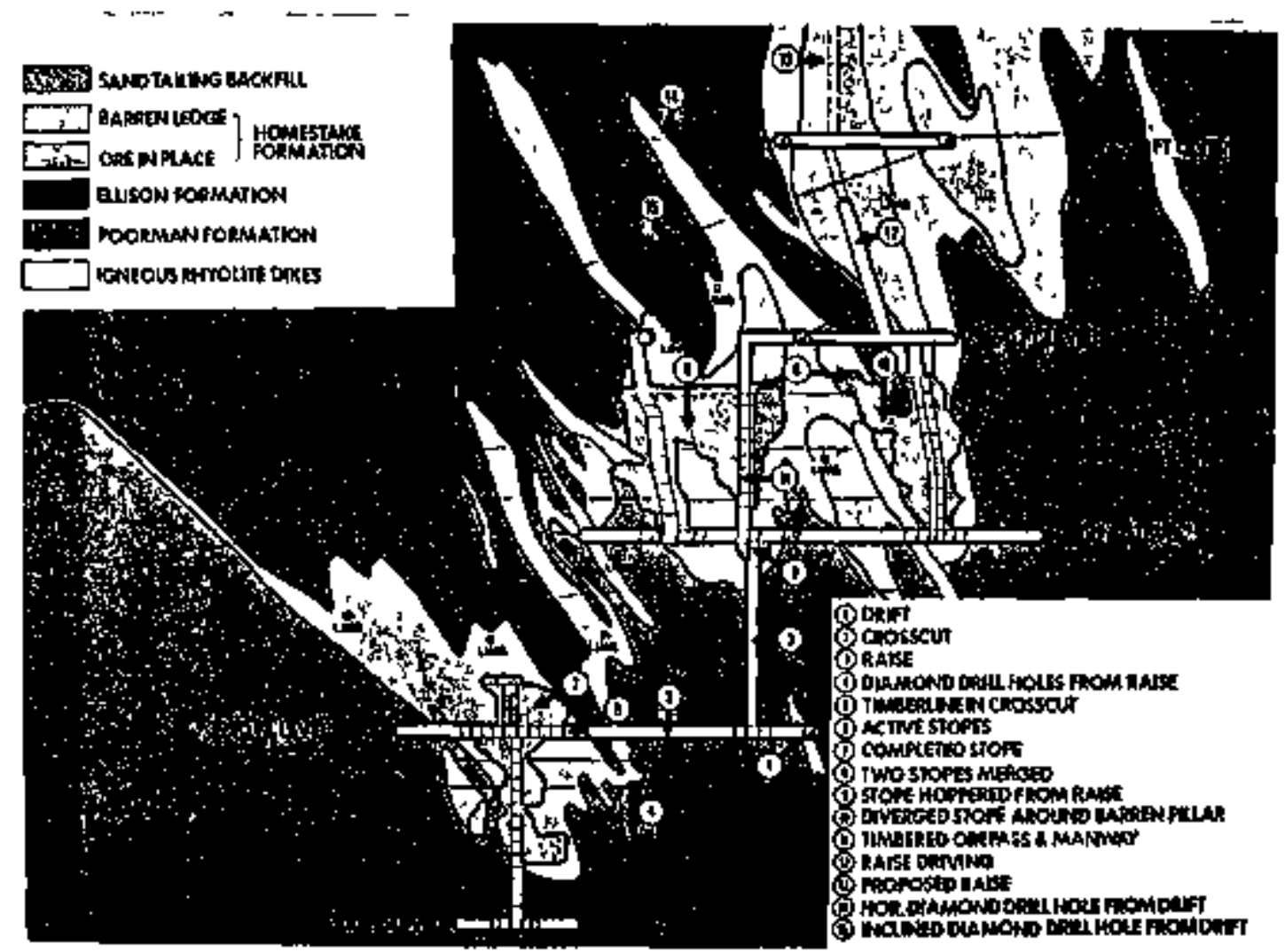

FIGJRE 9. Cross section of 9-Ledge structure, showing Open Cut-and Fill stoping. (Homestake Mining Company, 1976) 


\section{MINE VENTILATION}

Rock surface temperatures at deeper levels reach more than $130^{\circ} \mathrm{F}$, accompanied by mine air of high hunidity. Ventilation is accomplished by the shafts mentioned above and the use of large ventilation fans, vent tubes, and portable 30 and 60 ton air refrigeration units. As of 1976, 800,000 to 900,000 cubic feet of air was removed per ninute. A new water chilling ventilation system (water at $42^{\circ}-45^{\circ} \mathrm{F}$ ) is now being tested for use at the deeper mine levels.

\section{EXPLORATION AND DEVELOPAENT}

CRIB 1974 reports that in $1973,22,634$ feet of drifting and 8150 feet of raising were completed. E/MJ, May 1976, states that drifting was to be accelerated to 67,000 feet per year, and that in 1975 the following improvements were made at the 5900 and 6800 foot levels: track drifting, 2000 feet; diamond drilling, 6500 feet; conventional raising, 318 feet; and borehole raising, 554 feet.

In 1977, mining continued in the Main, $7,9,11,12,13,19$, and 21 Ledges between the 1700 and 6800 foot leve1s. There were 107 active stopes at the year end. New ore was found in the upper levels of 9 Ledge and in the 12, 19, and 21 Ledges between the 5600 and 7100 foot levels. Drifting was completed between No. 6 and No. 7 shafts on the 7100 foot level. The amount of diamond drilling for the year was 72,000 feet. Drifting was being done on the 7400 and 8000 foot levels a1so, and No. 7 shaft was being extended from the 7100 to the 8000 foot level (Homestake Mine Annual Report, 1977). 
ORE RECOVERY AND RESERVES

The Homestake mine has been in continuous operation since 1876 .

- From that time to 1976 the total production was $1.15 \times 10^{6}$ tons of ore milled. Present production is $25200-5500$ tons per day. 


\section{REFERENCES}

Cobbs Engineering 1976, Survey of active and inactive mines for possible use as in situ test facilities, Office of Waste Isolation, Oak Ridge, Temn, , Report No. Y/OWI/SUB-76/16514.

CRIB 1979

Engineering and Mining Journal, $1976 \mathrm{v} .177$.

Hendrix, T., 1962, Guidebook, Field Geology in the Rocky Mountains (Geology G 429), Indiana University, Bloonington.

Homestake Mining Company 1976, 1876 Homestake Centernial 1976, 93 p.

Homestake Mining Company, 1977, Annual Report.

Homestake Mining Company, 1978, Annual Report.

Nobie, J.A., Harder, J.0., 1948, Stratigraphy and metamorphism in a part of the Northern Black Hills and the Homestake Mine, Lead, South Dakota, Geol. Soc. Amer. Bull. v. 59 (9) p. 941-975.

Noble, J.A.; Harder, J.0.; Slaughter, A.L., 1949. Structure of a part of the Northern Black Hij]s and the Homestake Mine, Lead, South Dakota, Geol. Soc. Amer. Bull, v. 60 (2) p. 321-352.

Noble, J.A., 1950, Ore mineralization in the Homestake Gold Mine, Lead, South Dakota, Geol. Soc. Amer. Bull, v. 61 (3), p, 221-252.

Slaughter, A.L., 1968, The Homestake Mine, in: Ridge, J.D., ed., Ore Deposits of the United States, 1933-1967, Amer. Inst. Min., Metali, , Petrol. Eng., New York, p. ]437-1459. 
THE DUCKTOWN DISTRICT

(Cities Service Co. \}

\section{LOCATION}

The Ducktown District (Copper Basin) is located in the extreme southeast comer of Tennessee in Polk County in a topographic basin somewhat greater than 100 square miles. Elevations in the basin range from 1500-1800 feet above sea level with the encircling nountains rising to 4200 feet above sea level. The latter are heavily wooded but the cover in the basin has boen almost completely removed in a 36 square mile area.

The mines are located a few miles from the towns of Ducktown and Copperhill at $35^{\circ} \mathrm{N}, 84^{\circ} 20^{\prime} \mathrm{W}$ (Figure 1). The ore deposits outcrop along resistant ridges striking northeastward and occur as massive tabular sulphide bodies, ranging in size from 250,000 tons to $20 \times 10^{6}$ tons (Magee 1968).

\section{REGIONAL. GEOLOGY}

\section{Lithology}

The regional geologic nap (Figure 2) and the stratigraphlc sequence of the Ducktown District (Table I) are taken from Magee (1968). The Athens shale and Knox Group of Ordovician age occur 15 miles northwest of the district. The Great Smoky fault zone separates them from the underlying early Cambrian Chilhowee Group (sandstone, shale, and conglomerate). The Precambrian Sandsuck formation (quartzites, phyllites, impure limestone, liny shale) of the Walden Creek Group unconformably underlies the Chilhowee Group.

The older Great Smokies Group conformably underlies the Walden Creek Group and is composed of intertedded metagraywackes, conglomerates, mica schists, quartzites, chlorite-garnet schists, and chlorite-garnet-staurolłte 

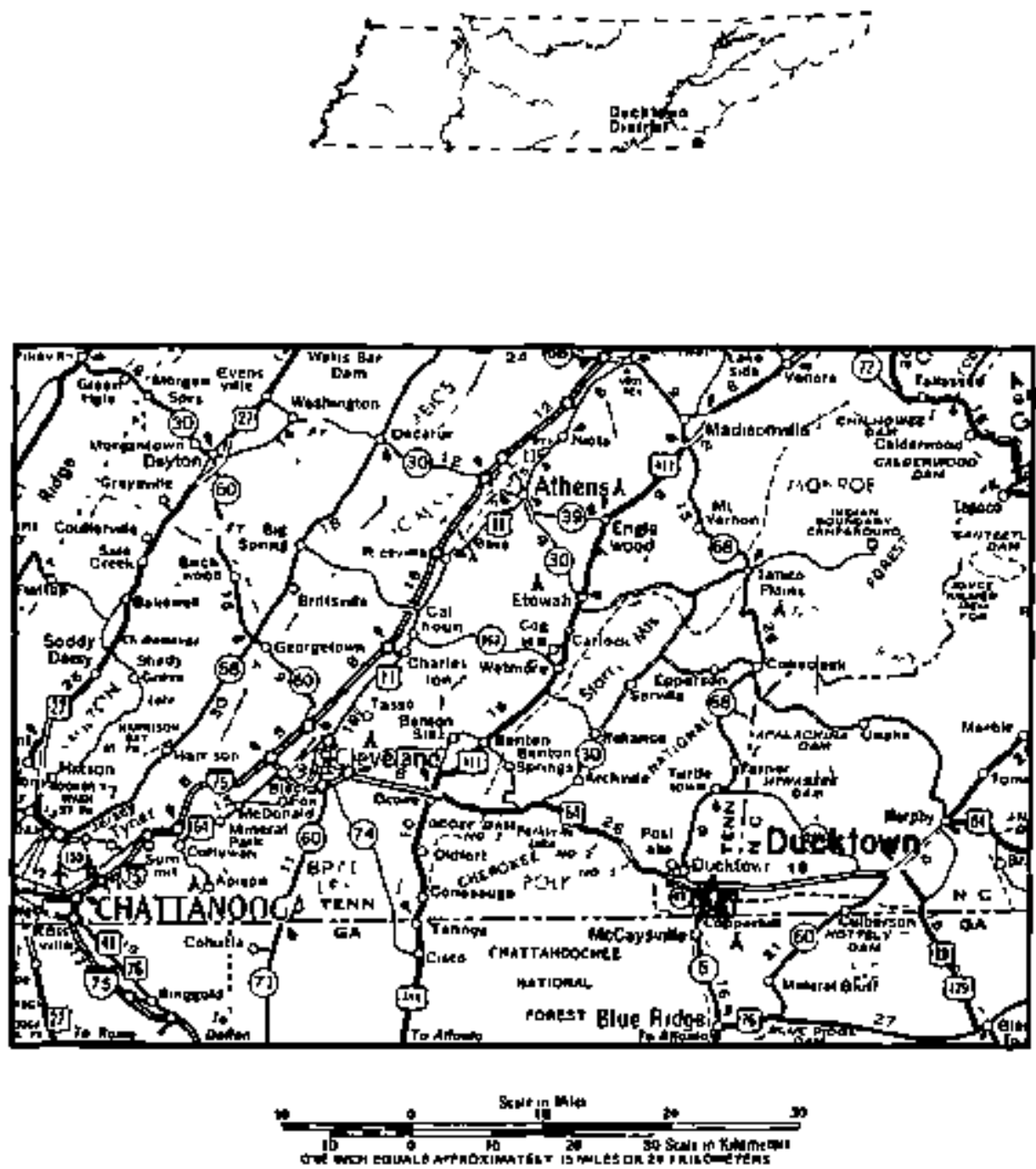

FIGURE 1. Location maps - Ducktown District, Polk County, Tennessee. lower map, basic map reproduced by permission of the American Automobile Association, copyright owner. 


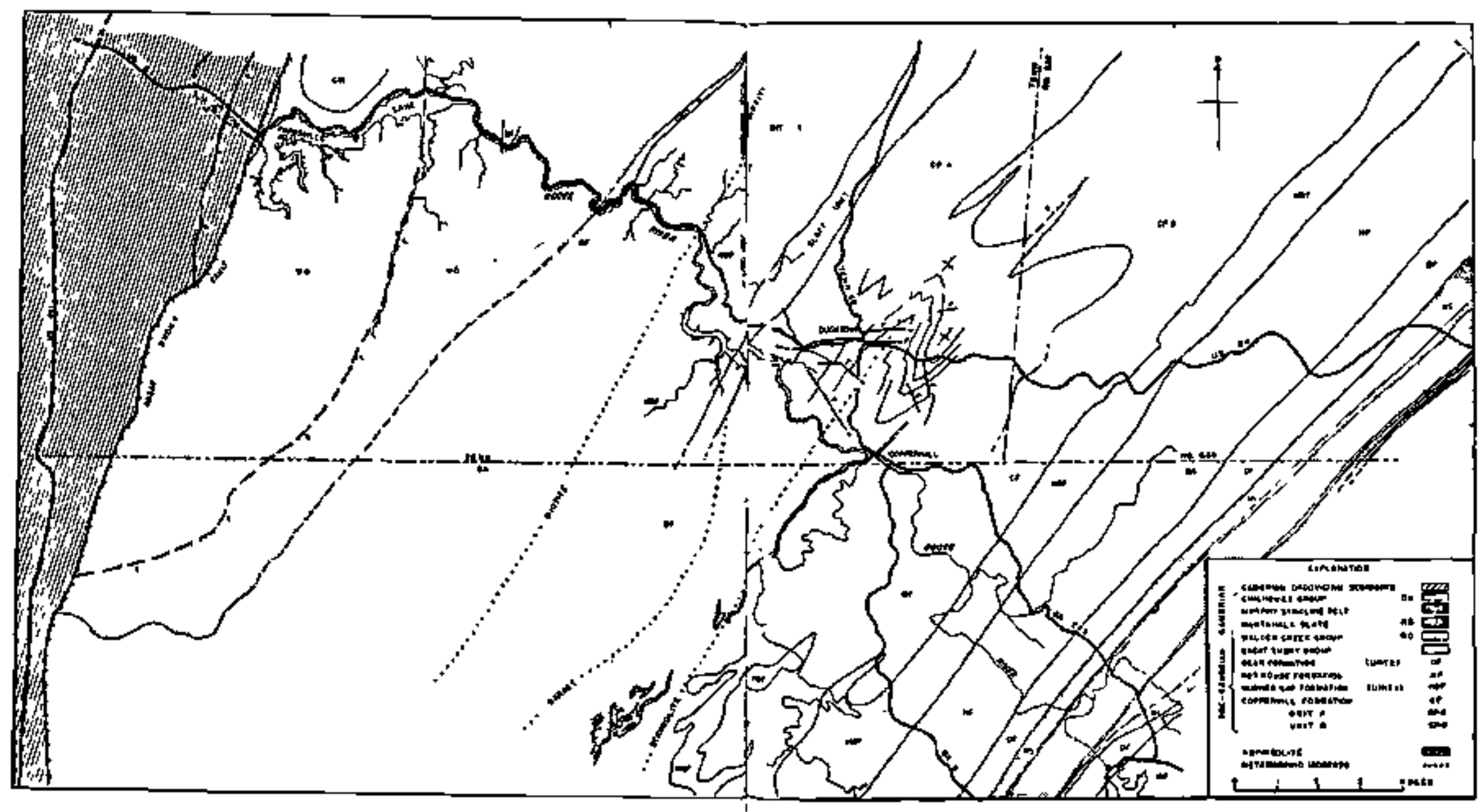

PIGURE 2. Regitma1 Geologic Map of the Ducktom Area, coupiled frod the Geologic Map of Temnosste, 2966 (25); Tentessee Coppor Compuny wap, 1947; Hurgt, V.J. (11, 12,

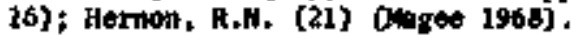




\begin{tabular}{|c|c|c|c|c|c|}
\hline Ane & Serien & Group & \multicolumn{2}{|c|}{ Nordinwert farmotlont } & Soulthodat formatlont \\
\hline Ordipvition & & $\begin{array}{l}\text { Clickanango } \\
\text { Knox }\end{array}$ & \multicolumn{2}{|c|}{ 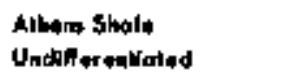 } & \\
\hline \multirow[t]{3}{*}{ Combran } & & Chilnower & $\begin{array}{l}\text { Netpo Sandyts } \\
\text { Niahols Sheto }\end{array}$ & & \multirow[b]{2}{*}{ 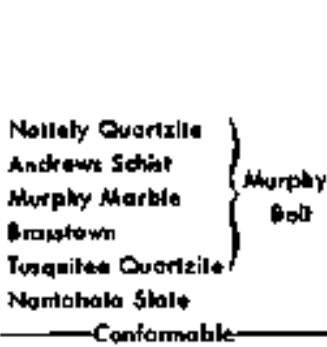 } \\
\hline & & & Diteonfo & & \\
\hline & & Wakdm Crank & Soadbeck & & \\
\hline Precombrion & Ocoura & Great \$nokr & $\begin{array}{l}\text { [16] } \\
\text { Dadn } \\
\text { Hughes top } \\
\text { Coppentill }\end{array}$ & 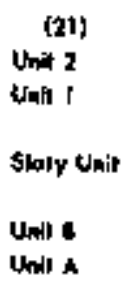 & $\begin{array}{l}\text { Oadan } \\
\text { Hughn Gap } \\
\text { Hen Howne } \\
\text { Coppontill }\end{array}$ \\
\hline
\end{tabular}

Table I. Stratigraphic sequence across the Ducktown Region of the Great \$noky Mountains (Magee 1968). 
schtsts. These formations 811 lie in the southern portion of the Blue Ridge Province,

The rock types in the district are metaromphosed precambrian sedinents composed of 60 percent graywacke, 30 percent mica schist, and 10 percent wetaconglonerate (netg-arkose, quartzite, chlorite-garnet schists, and chlorite-garnet-staurolite schists). Thicknesses of the metagraywackes range from a few feet to greater than 500 feet. Wha schist beds are a few inches to 20 feet thick but sometimes exceed 200 feet.

Metamorphic intensity and structural complexity increase across the Great Smoky Group from west to east.

\section{Structure}

Intense deformation and recrystallization have occurred in the area. There are two major jortheast plunging folds - the Burra anticline and the Coleman syncline each of which contain smaller superposed folds. General schistosity and bedding dip from $45^{\circ}-80^{\circ}$ southwesterly and the general strike is $N 35^{\circ} \mathrm{E}$. Snall dones and basins, which may have influenced ore localization, are found in the central anticlinal area. Schists are strongly foliated and crinkled. The angle between schistosity and bedding is $0-15^{\circ}$ but may be greater in fold noses. The netamorphisn ranges fron the chlorite to kyanite grades, i.e., between low to high grade metamorphism; retrogressive metamorphism is also evident in the country-rock and ore. There are three najor fault systems in the area. They strike N.E., N.W.. and E. -W.

\section{ORE DEPOSIT GEOLOGY}

Ore bodies are usually of tabular shape, conforming to the regional strike and dip of the bedding. They plunge southwest in contrast to the 
northwest plunge of the major anticlinal bodies. The three regional fault systems are evident in the ore bodies along with fracturing and smaller faults; crossfaulting is evident associated with the smaller ore bodies. Most ore levels and tabular bodies have a sharply-defined footwall, usually of unaltered graywacke. The hanging wall is usually schistose rock, which may be sonewhat inconpetent (Figures $3 \mathrm{k}$ ). Two modes of ore enplacenent have been proposed: (1) hydrothernal' replacement of 1imestone lenses

(Emnons and Laney, 1926), and (2) hydrothermsl replacement of favorable zones in 1ime-bearing schistose layers and shear breccia (Nagee 1968). The latter view is presently favored.

\section{HYDROLOGY}

Nothing definite has been found in the litergture with respect to water tables or percolation in the area. However, reports from Acres (1975) and Thomas Lomenick (personal combunication) indicate that there is considerable water inflow in the nines since continuous pumping is necessary when operating *

\section{MINE FACILITIES}

The presently operating workings are owned and operated by Cities Service Company (110 west 7th Street, Tulsa, Oklahoma). The mine and plant at Copperhi11, Polk County, Tennessee enploy 2,150 men.

Underground mining is by long hole blasting. Present production is 53 tons of copper metal/day (World Nines Register 1979-80). As of 1978, there were five shafts; mining is by open stoping, haulage is by rail (International Directory of kining and Mineral Processing Operations, 1978). The Minerals Yearbook of Tennessee (1975) states that $\mathrm{Cu}$ metal production was 

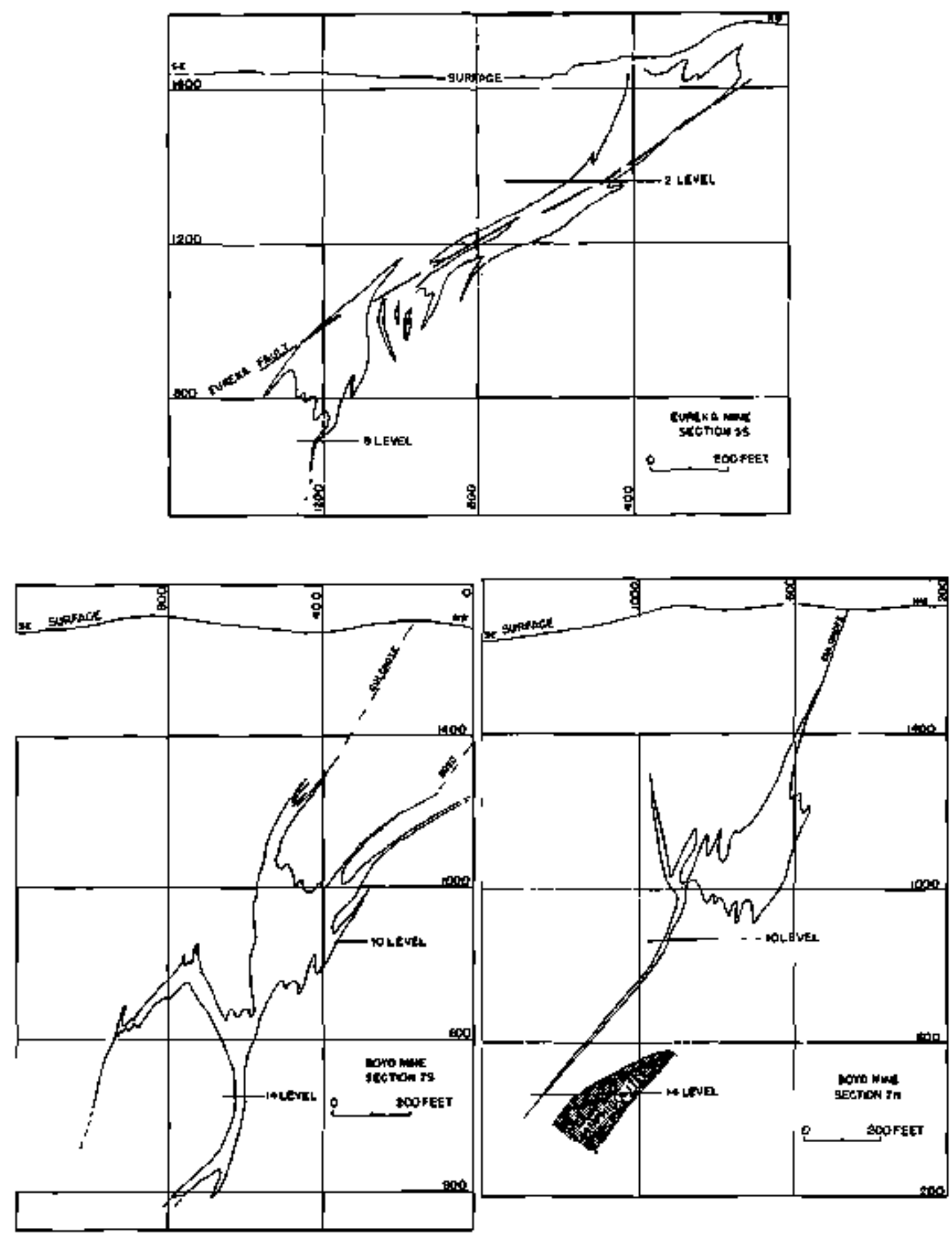

FIGURE 3. Cross sections of the Boyd and Eureka ore deposits. The drag fold pattern of the Boyd ore body is evident (Magee, 1968). 


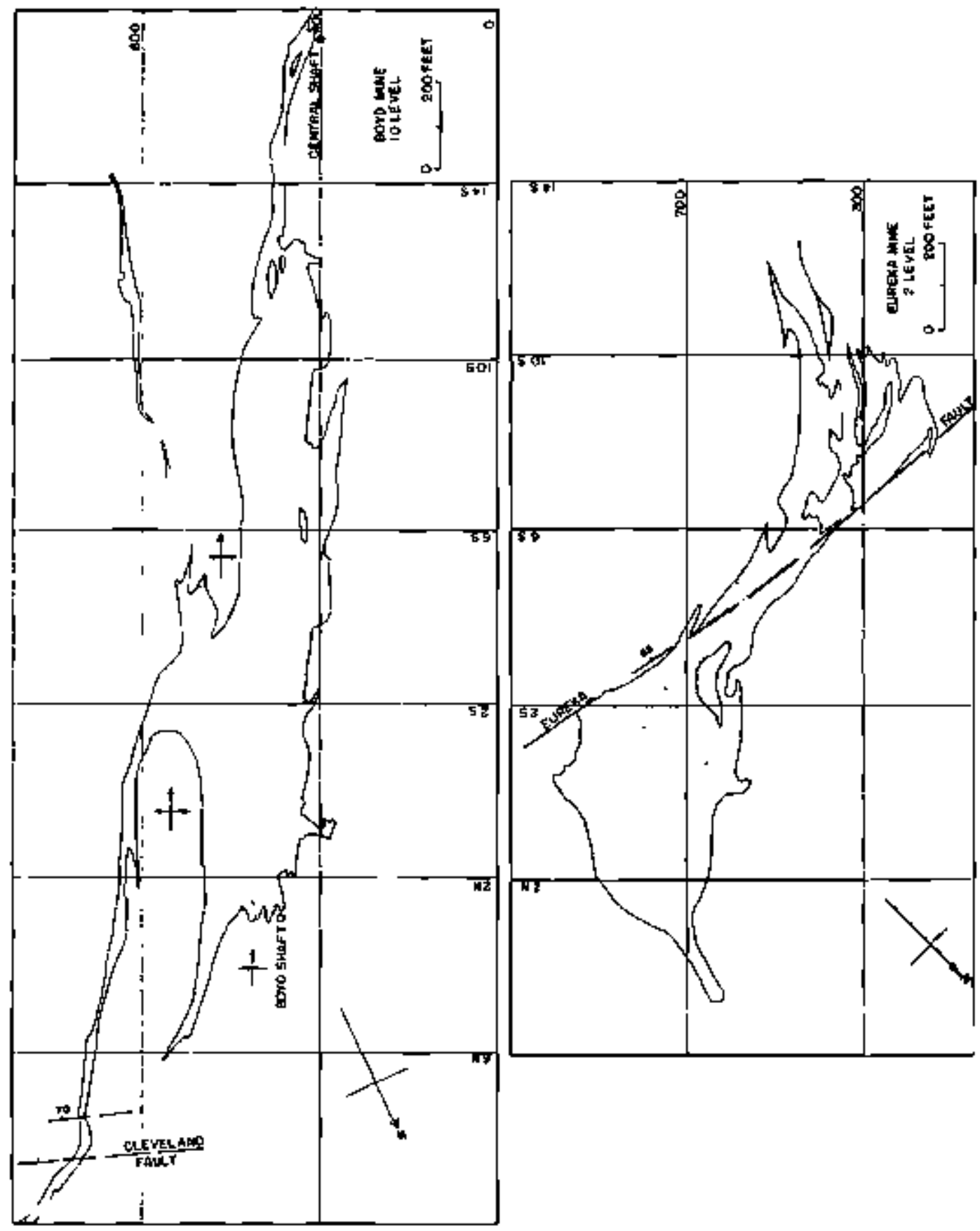

FIGURE 4. Horizontal plan views of the Boyd and Eureka ore deposits (Magee, 1968). (Reprinted with pezmission of AIME, New York.) 
then at a rate of 10,041 1bs./year and that the company's Copperhill operations included four mines (Boyd, Calloway, Cherokee, and Eureka Mines) at depths of 1000-3000 feet underground.

In 1965 five mines were operating with some operations at 2400 feet depths (L1oyd, 1965).

At present, it is not possible to determine from the literature the abundance or extent of underground workings in the schistose rock at Ducktown. For that reason the district is considered to be in "class $2 "$ in this report. 
REFERENCES

Acres Anerican 1975, Federal Energy Administration Underground Oil Storage Program, File 4074.07.

Enmons, W.H, and Laney, F.B., 1926, Geology and Ore Deposits of the Ducktown Hining District, Tennessee: U.S. Geol. Survey Prof. Paper 139.

International Directory of Mining and Min. Proc. Operations, 1978.

Lloyd, R.J., 1965, Tennessee Department of Conservation, Division of Geology, Tennessee Rocks and Minerals Rep., Rept. No.

Hagee, M., 1968, Geology and Dre Deposits of the Ducktown District, in: Ridge, J,D., ed., Ore Deposits of the United States, 1933-1967, Amer. Inst. Min., Meta]l,, Petrol. Eng., New York. p. 207-241.

The Minerals Yearbook of Tennessee, 1965 (Mineral Indust, of Tennessee). World Mines Register 1979-80. 
HOLDEN MINE

(HOWE SOUND COMPANY)

\section{LOCATION AND ACCESSIBILITY}

The Holden mine in Chelan County, Hashington, is situated at $48^{\circ} 12^{\prime} \mathrm{N}$, $120^{\circ} 45^{\prime \prime} \mathrm{W}$, on the east slope of the Cascade Mountains on Railroad Creek, which flows eastward into Lake Chelan (Figure 1). The mine was Washington's largest producer of copper, gold, and zinc from 1938-1958. Silver, molybdenum, and other metals have also been mined. The ground facilities are now owned and operated by the Lutheran Church as a canp and retreat center. The mine was owned by Howe Sound Co. and is presently owned by the Lutheran Church.

The Holden mine is located at $3435 \mathrm{ft}$. elevation, in a rugged mountainous region with relief of $6000 \mathrm{ft}$. or more between valley floors and ridge tops. All of the valleys show evidence of glaciation. The mine is reached by a 40 mile boat or airplane trip from Chelan to Lucerne, a small resort commuity on the west shore of lake Chelan, and thence by automobile 11 miles from Lucerne to Holden.

GEOLOGIC SETTING

The geologic description of the region is based principally on work by Youngberg and Wilson (1952), and also on reports by Grant (1969), and Tabor and Crowder (1969). The Holden mine is situated in gneiss, schist, and quartzite of a roof pendant cut by intrusive igneous rocks.

The oldest units whose ages are in the range Precanbrian to Early Paleozoic are metasedimentary rocks of the pendant. They were divided by Youngberg and wilson (1952) into three formations: the Martin Ridge and Buckskin schists, and Femow gneiss; these are illustrated in Figure 2. The Martin Ridge schist is an argillaceous anphibole schist with alternat- 


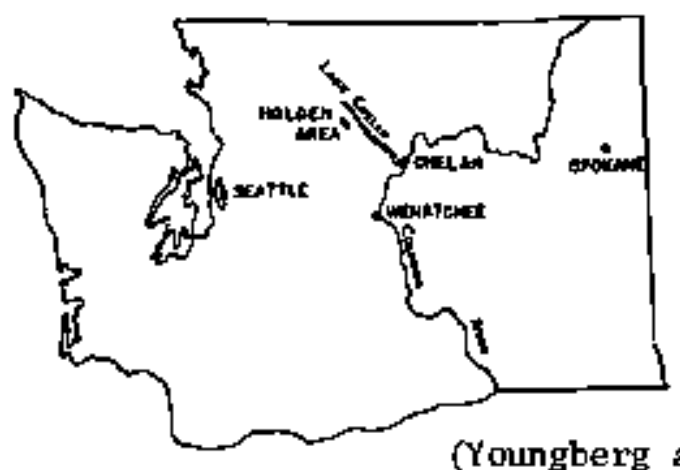

(Youngberg and wilson, 1952)

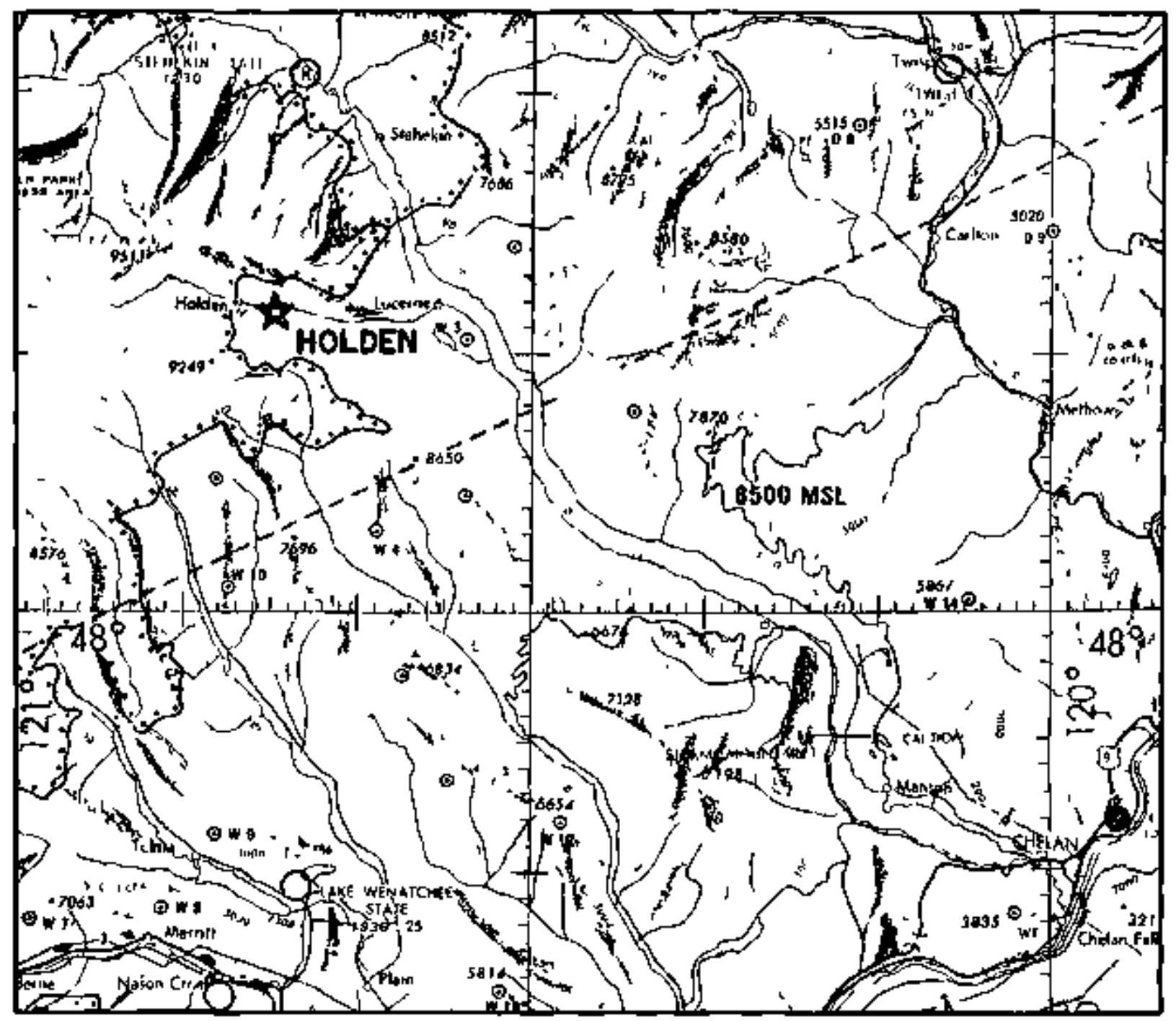

SIKTUTE AMES

[0]

FIGURE 1. Location maps - Holden Mine, Chelan County, Washington. 


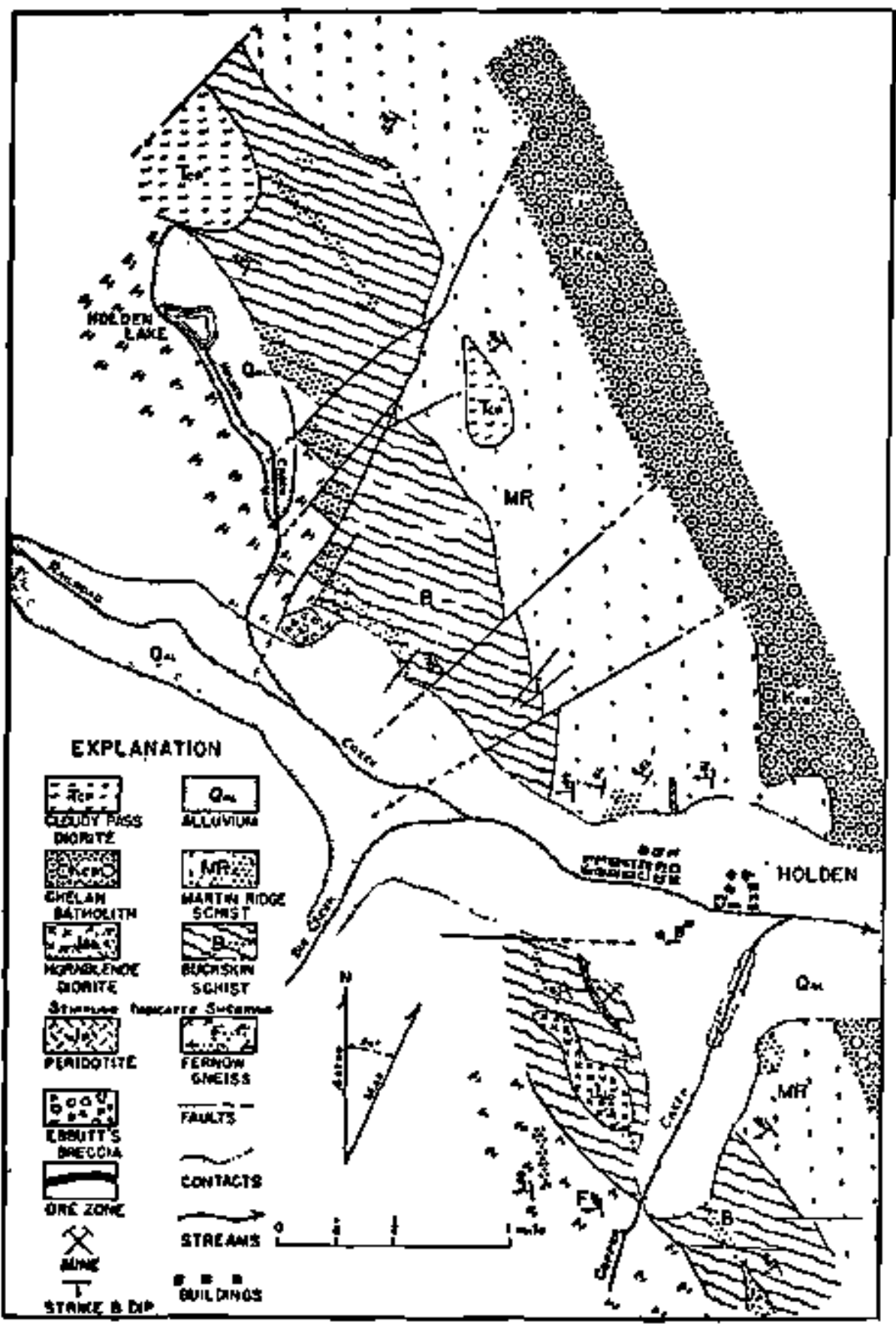

FIGURE 2. Geoiogy of the Holden area (from Youngberg and Wilson, 1952). 
ing bands of quartzite which vały in thickness to two inches. A persistent inarble bed occurs above the contact of the Buckskin with the Martin Ridge formation. This bed varies in thickness from 2-10 feet. The total thickness of the Martin Ridge schist is about $3300 \mathrm{ft}$. The Buckskin schist is predominantly quartz-amphibole, but contains two horizons of intermittent marble beds and calcareous schists. In some areas the schist has been altered. The formation has a thickness of 3000 to 3500 feet. The Fernow gneiss has an appearance of granitic gneiss, but is made up of a thick series of quartz-amphibole gneisses. The total thickness of the formation was not reported. Youngberg and Wilson (1952) state.

\footnotetext{
"The sequence of deposition of the sediments is not clear. It would appear that the gnelssic rocks of the Fernow unit are older than the less metamorphosed Buckskin schists and Martin Ridge argillites, which would require the beds to be overturned, as the Fernow gneisses now lie stratigraphically gbove the Buckskin and Martin Ridge schists."
}

The igneous rocks of the region are numerous and occur as plutons, dikes, sills, stocks, and extrusives. They vary in age from Jurassic to Pleistocene with three principal episades during the Cenozoic. The compositional range of the intrusive rocks is broad, including peridotite, diorite, granodiorite, and aplite dikes. The three phases of Cenozoic igneous activity, as described by Tabor and Crowder (1969), sre the quartz diorite Cloudy Pass batholith; andesitic to dacitic breccia, tuff, and lava of Gammo Ridge; and in late Pleistocene and Recent time, the growth of the dacitic Glacier Peak volcano, 15 miles southwest of Holden mine.

The peridotites are generally coarse-grained, massive, and hornblenderich. They occur as dikes and elliptical bodies and cut the mine workings 
at severa1 levels. They are Jurassic in age, the oldest intrusives in the tine area.

The quartz-hornblende diorite varies in texture from mediun to coarse grained and occurs as a massive body to the south of the mine ore zone. Youngberg and Wilson (1952) report the intrusive and the metamorphics around its periphery show evidence of granitization, biotization and chloritization.

The dioritic rocks, the nost comon plutonic rocks in the area, were intruded in two phases. The first phase, the Chelan batholith, which is Cretaceous in age, crops out on the surface east of the Holden rine area; a dike of Chelan diorite is exposed in the 1500 and 1600 foot levels of the mine. The second phase, the cloudy Pass batholith, was emplaced in the Tertiary and is similar in composition to the Chelan batholith. It is exposed west of the mine, and at several leveis in the mine, as are cloudy Pass dioritic dikes.

Aplite and other dikes cut the dioritic rocks at numerous places in the mine. They are fine grained and vary in width from an inch to a yard. Other dikes are granodiorite and quartz diorite in composition and have chilled borders.

STRUCTURAL SETTING

The regional structure of the Holden nine and north Cascade area was described by Grant (1969) and Youngberg and wilson (1952). The structural trend in the Holden mine area, part of the North Cascades, is predominantly northwesterly. The metamorphic rocks form the lower limb of an overturned fold with a northwest trending axis. Several small drag folds are present and some are overturned. The ore deposits are contained in the drag folds and are limited by the extent of folding. The fold axis plunges at about $60^{\circ}$ southeast. 
The region is transected by both normal and thrust faults. Figure 3 illustrates the broad regional structural trends and major faults. The Swamp Creek thrust fault is located west of the nining area, and the Lake Chelan transverse fault occurs south of the mine. Displacement on some of the normal or steeply dipping faults ranges from 60 to $1500 \mathrm{ft}$. Shear zones, which are the principal loci of mineralization, forned between the competent and incompetent metasedimentary umits.

\section{MINE GEOLOGY AND MINERALIZATION}

The Holden nine ore deposit is in a roof pendant that has been intense1y metamorphosed and over1ies batholithic rocks. The pendant is made up of gneiss, schist, and quartzite, and is cut by granitic dikes. The rock is hard and abrasive and the geology complex. The deposits are of hydrothernal origin (Park, 1968) and are associated with the Cloudy Pass dioritic intrusions.

An idealized cross-section of the ore deposits and geology of the mine showing the 1400,1500 , and 1600 foot levels is illustrated in Figure 4. The copper-gold-silver ores are disseminated in the biotite schist and quartzite of the roof pendant. Ore ninerals also occur in small quantities in the diorite. There are some masses of sulphide minerals, but, in general, the ore minerals are present as small scattered grains. The nolybdenum primarlly occurs in well-defined quartz veins cutting granitic rocks. Zinc mineralization is concentrated near the footwall of the ore body. Copper and gold are distributed throughout without any apparent relationship to levels or geologic structure. There has been little or no alteration of the host rocks at their contact with the veins.

The zone of mineralization has an average strike of $\mathrm{N} 30^{\circ} \mathrm{W}$ with a dip of $60^{\circ}-70^{\circ} \mathrm{St}$. The ore zone is 40 to $75 \mathrm{ft}$. wide and has an exposed length of 1400 to $1600 \mathrm{ft}$. 


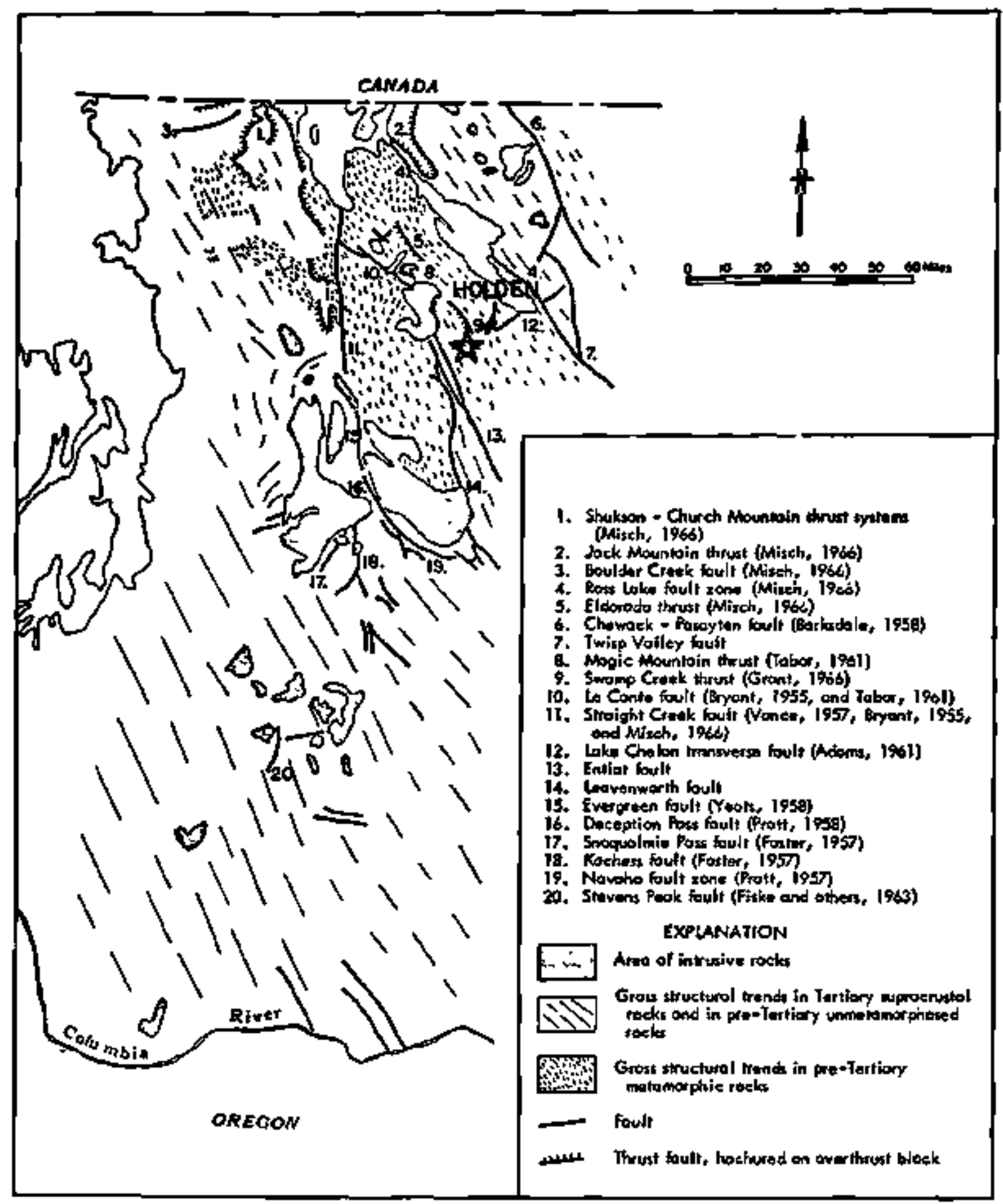

FIGURE 3. Gross structural trends and major faults in the North Cascade Range of Washington (after Grant, 1969). 


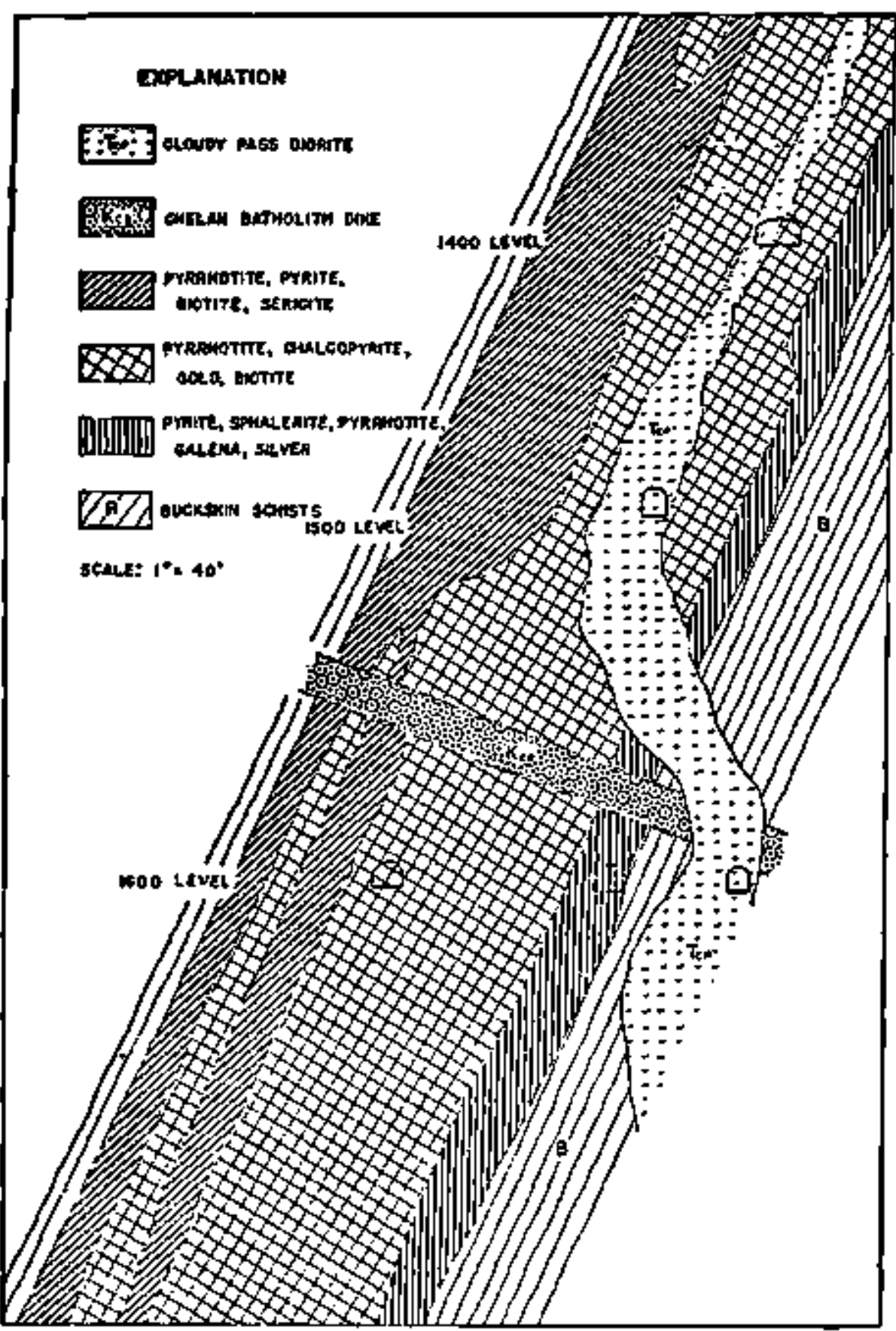

FIGURE 4. Idealized geologic cross section of the Holden ore body, showing ore zoning and its relationship to the wall rocks and intrusions, (After Youngberg and Wilson, 1952.) 
MINE CHARACTERISTICS

The mine is located below the groundwater table; however, several workings are $\pm n$ dry areas. The mine extends to a depth of $5200 \mathrm{ft}$.

Horkings consist of a main adit, two shafts, a ventilation shaft, and over $18,000 \mathrm{ft}$. of workings at more than sixteen levels. The main adit is on the 1500 foot level, is $10 \times 10 \mathrm{ft}$. in cross-section, and extends 4800 ft. into the mountain (Figure 5). The original mine developnent included several intermediate levels serviced by the No. 1 shaft, a vertical shaft about $936 \mathrm{ft}$. deep. These levels were connected by severa1 main ore passes extending above the main haulage level, A second 4-compartment shaft, sunk in 1941-44, has a cross-section of $121 / 2 \times 19 \mathrm{ft}$. The hoistroon for the No. 2 shaft is in good rock and has dimensions of $100 \times 50 \times 40 \mathrm{ft}$. The No. 2 shaft was driven as a raise full size for $170 \mathrm{ft}$, above the main haulage level. Below this level, a series of pilot raises were driven, connecting the $1500,1600,1775$, and 1950 foot levels and the shaft was sunk to the 2800 foot level. There is a ventilation tunnel that extends westward from the No. 2 shaft for about $5000 \mathrm{ft}$. This tunnel is about $8 \times$ $10 \mathrm{ft}$. in section and portals to the strface. There are at least 247,566 ft. of drifts, cross-cuts, and raises, and $231,922 \mathrm{ft}$. of diamond drill holes (thntting, 1956). The mine has been closed since 1958; however, recent exploration work, in mid-1960's and mid- to late-1970's, indicates that nany levels are accessible and dry. Levels below 1400-1500 ft, are flooded.

\section{MINE FACILITIES}

According to V.C. Stephens, consultant to Terra Tek, who managed the mine in the 1950's, the Holden Campsite is a beautiful camp consisting of sixteen large houses, six bunkhouses, hospital, large cookhouse and dining 


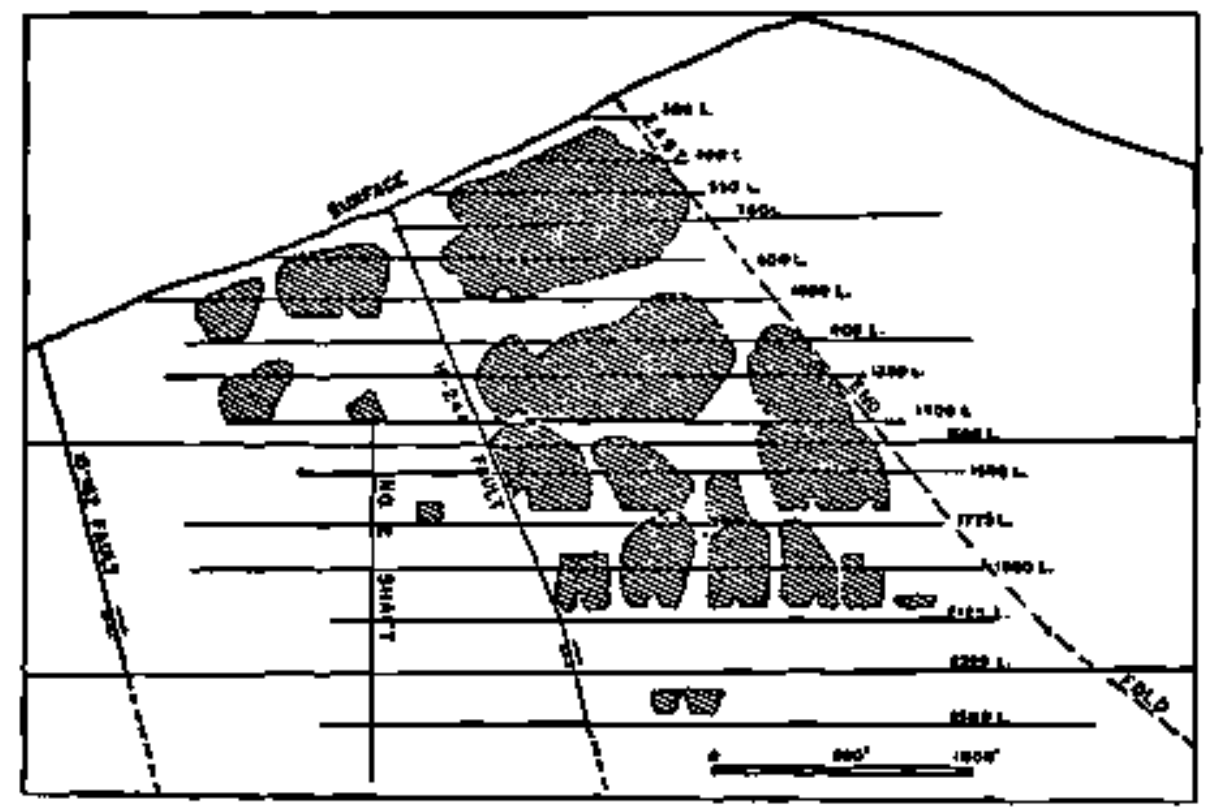

FIGURE 5. Geologic structure of a west-east section of the Holden Mine, showing mineralization, mine leve1s, and No, 2 shaft. (After Youngberg and Wilson, 1952.) 
facilities, and a large recreation hal1. The campite is owned and operated by the Lutheran Church. Dock, tug, barges, and all necessary facilities are available on lake Chelan, both at the town of Chelan and the village of wocerme, Washington. 
REFERENCES

Carzon, J.J., 1945, Changing mining methods at the Holden Mine: AIME Trans., v. 163, p. 73-95.

Grant, A.R., 1969, Chemical and physical controls for base metal deposition in the Cascade Range of Hashington: Wash. Div. Min. G Geol. Bull. 58, $107 \mathrm{pp}$.

Huntting, M.T., 1956, Inventory of Hashington Minerals, Part II, Metallic Minera1s, v. 1: Wash. Div. Min. E Geol. Bull, 37, p. 48.

------, 1943, Mineral properties in Che1an Co., Wash: Wash. Div, Geol. Report Inv. n. 9, p. 34-36.

Moen, H.S., 1976, Silver occurrences of Washington: Wash. Div. Geol. \& Earth Resources Bul1. 69, p. 30-33,

Park, C.F. Jr., 1968, Mineral Deposits of the Pacific Coastal Region: in, Ridge, J.D., ed., Ore deposits of the Inited States. 1933-1967, Amer. Inst. Min. Metal1., Petrol. Eng., New York.

Purdy, C.P., Jr, 1954, Directory of Hashington Mining Operations 1954: Wash. Div. Min. \& Geol. Inf. Circ. 23, 73 pp.

Soderberg, R.l., 1948, Nining methods of the Holden mine, Howe Sound Co., Chelar Division, Holden, Washington: U.S. Bur. Mines Geol. Inf. Circ. 7448 , p. 39 .

Tabor, R.H., and Crowder, D.F., 1969, On batholiths and volcanoes - intrusion and eruption of Late Cenozoic magmas in the Glacier Peak area, North Cascades, Washington: U.S, Geol. Survey Prof. Paper 604, 65 pp.

Youmgberg, E.A., and Hilson, T.L., 1952, The geology of the Holden mine: Econ. Geol., v. 47, (1), p. 1-12. 


\author{
SINRISE MJNE \\ (OPERATED BY COLORADO FUEL AND IRON CORPORATION)
}

\title{
LOCATION
}

The Sunrise mine is located in the Hartvi11e-Sunrise district of Platte County, Hyoming, (Figure 1) approximately 7 miles north of Guernsey and $100 \mathrm{mizles}$ northeast of Cheyenne at $42^{\circ} 20^{\prime} \mathrm{N}, 104^{\circ} 42^{\prime} \mathrm{W}$. The surface elevation is about $\mathbf{4 8 7 0}$ feet, with severgl hundred feet of local relief.

\section{GEOLOGIC SETTING}

\section{Regional}

The data describing the regional geologic setting were extracted fron Carter (1963), Harrer (1977), and EWJ (1974).

The Precambrian rocks in the region, exposed in the Hartville uplift (oldest to youngest), are represent ed by the Whalen Group, which consists of the following sequence: Federick schist, ninimum thickness about 3000 feet; a nassive blocky to schistose dark-green rock composed of quartz, chlorite, biotłte, epidote, hornblende, and plagioclase, possibly an altered pyroclastic or series of lava flows; Whalen dolomite, thickness 400 to 2000 feet; a white to pink dolonite marble, cherty in places, with minor bands of quartzite and schist; Good Fortune schist, 500 to 1000 feet thick; a white to dark-gray quartz-\$tricite schist, often highly graphitic and pyritic; and the "Upper Blocky" schist, up to 100 feet thick, a dark-greenish blocky quartz-biotite-chlorite schist. The entire whalen Group has been isoclinally folded and regionally metamoxphosed to approximately the greenschist facies. 


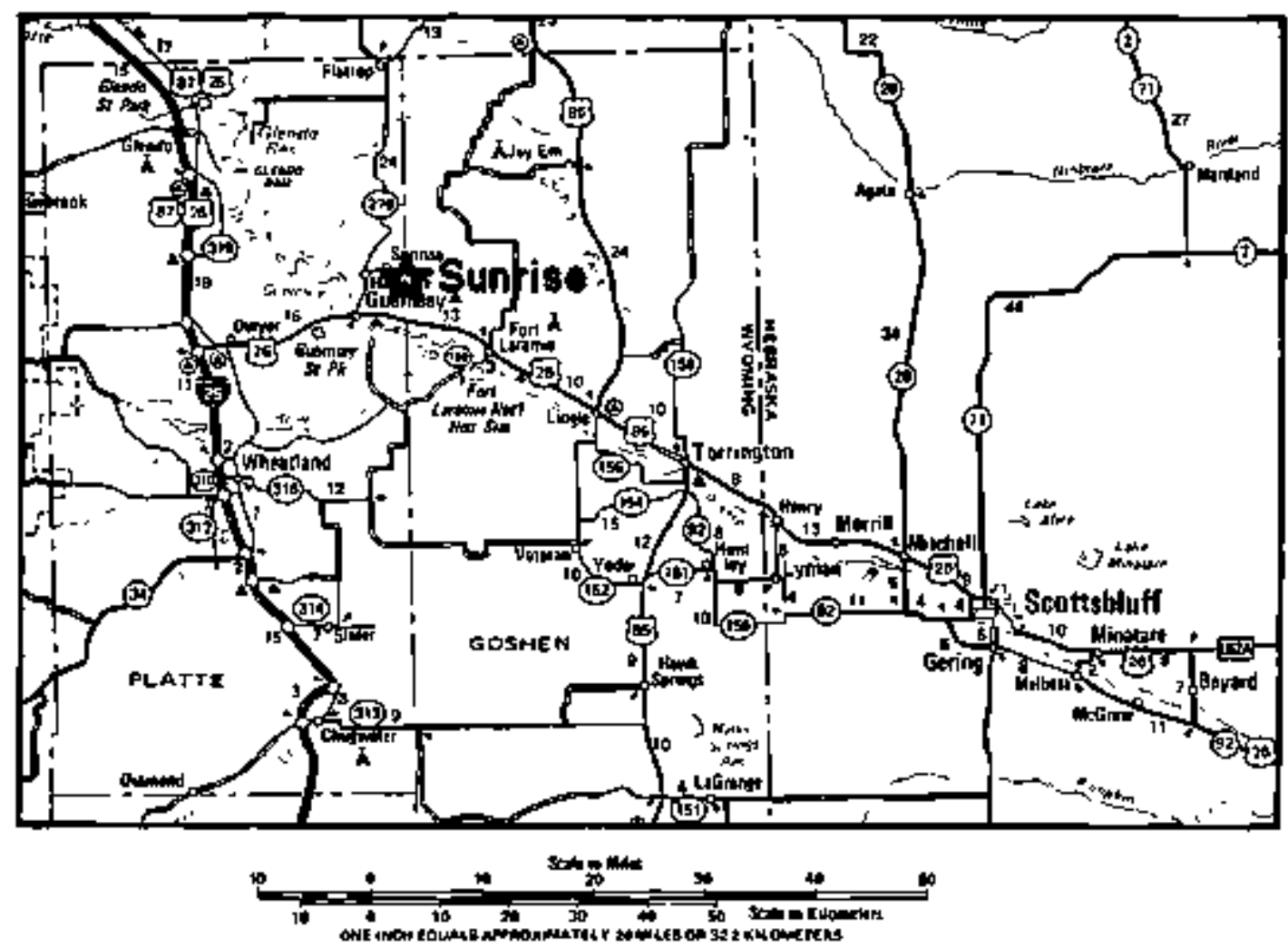

FIGURE 1. Location map of the Sunrise Mine, Platte County, Wyoring. Basic map reproduced by permission of the American Automobile Association, copyright owner. 
Limestone and quartzite of the Carboniferous Guernsey and Hartville Formations cap the higher hills and nesas. Sandstone of the Miocene Arikaree Formations is present sporadically in the valleys. Figure 2 is a geologic map of the region.

\section{Local Geologic Setting}

The large henatite iron-ore bodies in the Hartville-Sunrise district are within a folded and faulted belt of steep to vertically dipping metasediments of Precambrian age that crop out along the east edge of the Hartville domal uplift between Guernsey and McCann Pass, seven miles northeast. Much of the iron formation is under a flat to gently dipping cover of Paleozoic linestones - dolonites, quartzites, and sandstones. The iron ores are princlpally red, earthy hematite and hard, steel-gray to bluish-black specular hematite. Wall rock contacts vary from gradationa1 to sharply defined. Bands of gangue and low-grade henatite occur in the ore bodies and require separation. The schist walls are weak and cave readily.

At the Sunrise mine, the main ore body is an S-shaped lens in plan view, $\$ 0$ to 600 feet thick and 1600 to 2100 feet long, occurring in a tight synclinal fold with a general south plunge. The hematite occurs in the lower part of the Good Fortune schist, usually close to the Whalen dolonite contact. It should be noted that the rocks at the Sunrise mine are apparent1y tow-grade metanorphics.

\section{Mine Facilities}

Data concerning the mine facilities were extracted fron EMJ (1974) and Harrer (1966). 


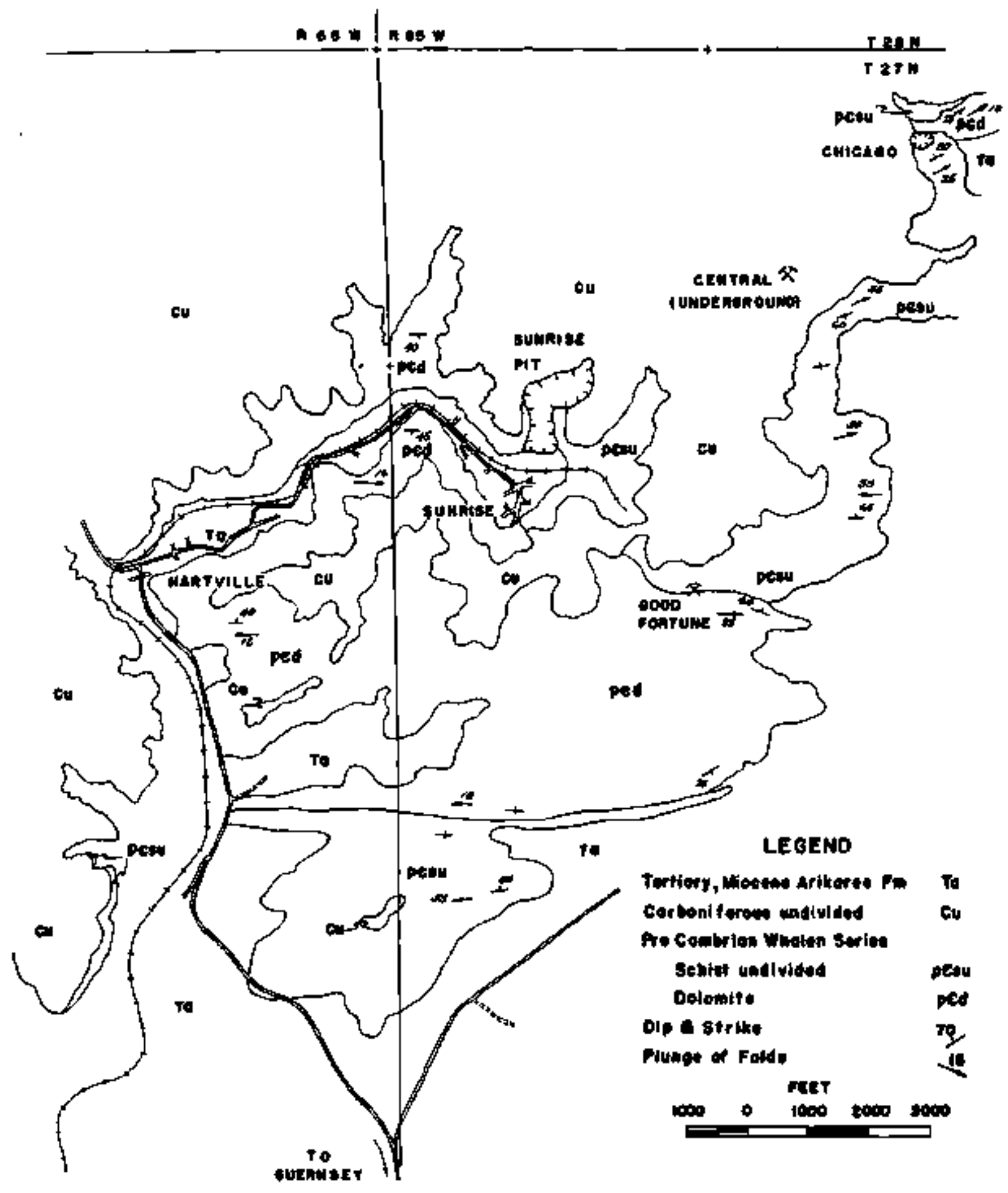

FIGURE 2. Geologic map, vicinity of Sunrise, wyoning, (Carter, D.A., Sunrìse I ron Mine, Wyoning, p. 264-266, Figure 1. From: Guidebook to the Geology of the Northern Denver Basin and Adjacent Up1ifts, 1963, Rocky Mountain Association of Geologists, Denver.) 
The Colorado Fuel and Iron Corporation acquired the Sunrise mine property in 1900. The mine was operated as an open pit until about 1930, when the mine was gradualy converted to underground block caving with some sublevel caving. Approximately 500,000 tons of concentrates are currently produced annualy at the Sunrise mine.

The deepest development is on the main ore body of the Sunrise mine. In 1966, mining was being conducted 750 feet below the surface, with known reserves continuing to greater depths.

As of 1974, new mine projects have been underway to enhance the mine's capabilities. While production has been coming from the seventh and third levels, another associated but separate ore body is also under development on the seventh level. Access to this area is being developed by a decline equipped with conveyor belt haulage. A ventilation shaft 9 feet in diameter was completed in 1974 .

Block caving was introduced at Sumrise in 1929 . Blocks $350 \mathrm{ft}$. sq. by $200 \mathrm{ft}$. high are undercut and blasted. Ore is then drawn out through a pattern of finger raises below the undercut leve1, as shown in Figure 3 . Approximately 3600 tons of ore are hoisted daily to the surface by two 10-ton capacity skips. 
FIGURE 3.

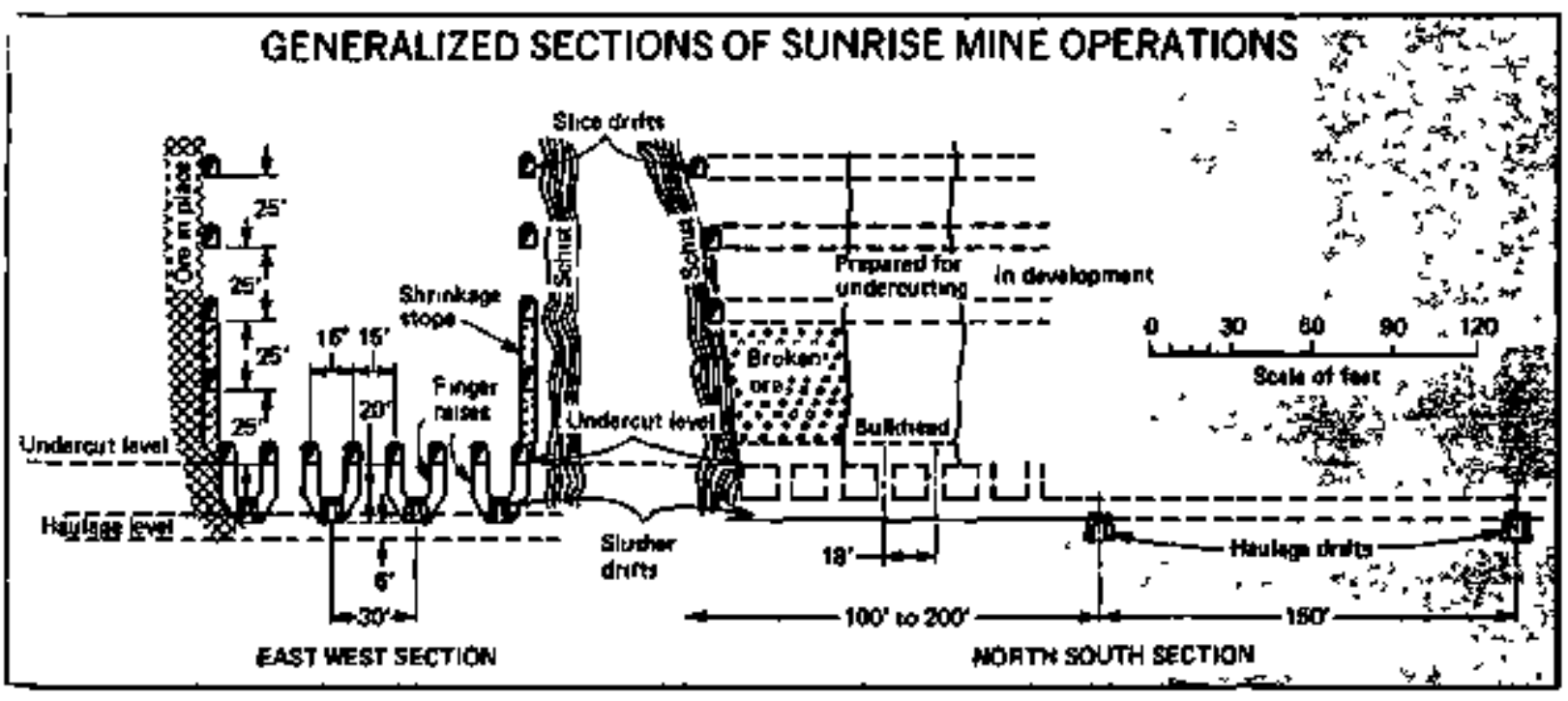

(Eng. Myning J. v. 175, (11), p. 151, 1974) 
REFERENCES

Ball, S.H., 1907, The Hartville Iron Ore Range, Wyoqing: U.S. Geol. Survey Bu11. 315, Part 1, p. 190-205.

Carter, D.A., 1963, Sunrise Iron Mine, Myoning, in: Guidebook to the Geology of the Northerm Denver Basin and Adjacent Uplifts, Rocky Mountain Association Geologists, l4th Field Conference, 1963, Denver, Colorado, p. $264-266$.

Engineering and Mining Journal, 1974, CFGI's Inderground Sunrise Mine Supplies Pueblo Mi11s: EMl, v. 175(11), p. 151-152.

Harrer, C.M., 1966, Hyoming Iron-Ore Deposits: U.S. Bur. Mines Inform. Circ. 8315, p. 39-42.

MAS data base.

Rupp, G.H., 1939, Block Caving at the Sunrise Iron Mine, Wyoning: AIME Tech + Pub, 1067, 16 pp. 

CIVIL WORKS

\section{INTRODUCTION}

Large underground galleries and related shafts and tunnels comprise several hydroelectric generation facilities. Where they are described in the literature, the geologic settings of these facilities are usually treated in less detail and the engineering aspects given greater coverage than those of mines, because lithology and structural setting are key factors in ore location. Hydroelectric facilities incorporating underground galleries are generally located in tectonically stable regions, in relatively homogeneous crystalline rock bodies.

Among hydroelectric installations, pumped storage facilities often utilize underground powerhouses. In 1974 there were 25 punped storage facilities in the United States with 10 more under construction (Stout, 1974). In this section of the report, we briefly describe as examples two purped starage sites in crystalline rock; gad Creek of South Carolina in granite and Helms of California in quartz monzonite; which may contain ppenings accessible for in situ tests. The Dworshak dam site, Idaho, in gneiss, is a1so described. At Dworshak, test adits in the abutments of the dari and a large underground crushing chamber may still be accessible.

Also considered in the category of civil works is the underground spent-fuel test facility, presently under construction at the Nevada Test Site.

To assess the number, location, and availability of openings in underground hydroelectric projects, it will be necessary to contact the appropriate govermmental agencies, utility companies, and/or company associations such as the Electric Power Research Institute. 


\section{REFERFHCE}

Stout, J.J., 1974, potential pumped storage projects that would use existing reservoirs: in Engineering Foundstion Conference, Converting existing hydro-electric dans and reservoirs in pumped storage facilities, Frank1in Pierce College, Rindge, N.H., published by Aner. Soc. C1vil Engineers, New York, p, 221-252. 


\title{
CIVIL WORXS
}

\begin{abstract}
HELMS UNDERGROUND POWERHOUSE - PUMPED STORAGE PROJECT
\end{abstract}
(Pacific Gas and Electric Co,)

\section{LOCATION}

The Helns project of the Pacific Gas and Electric Co. (PG\&E) is located on the North Fork of the Kings River, about 60 niles east of Fresno, Californta, at $37^{\circ} 02^{1} \mathrm{~N}, 118^{\circ} 58^{\prime} \mathrm{N}$, the project location is shown in Figure 1. The pumped-storage project is expected to ultimately produce $1000 \mathrm{mN}$. The underground powerhouse, as shown in Figure 2, is situated between two reservoirs; Courtright, at an elevation of 8200 feet; and Wishon, at 6550 feet (a profile of the project is shown in Figure 3). The depth to the powerhouse is approximately 1000 feet.

\section{GEOLOGIC SETTING}

The geologic setting of the Belns project area was mapped by Bateman (1965). The predominant rock unit is the Dinkey Creek horrblende granodiorite (Kdc in Figure 3). The Dinkey Creek pluton of the Sierra Nevada batholith is of Cretaceous age, and covers several hundred square miles. A small plutan, the lineated quartz monzonite of last Peak (Klp), intruded the Dinkey Creek granodiorite. The Dinkey Creek granodiorite is in contact with a more felsic pluton, the Mt. Givens quartz monzonite (Kmg), at the vicinity of the dan impounding Courtright Reservoir. A pendant of prebatholithic quartzite (Qte) lies just south of, and above, the underground powerhouse workings. The workings are reportedly outside the zone of poor rock conditions associated with the contact between the granodiorite and the quartzite (Haimson, 1976). Bateman's map (1965) indicates that the foliation of the Dinkey Creek granodiorite in the vicinity of the powerhouse strikes northwesterly and dips nearly vertically. 

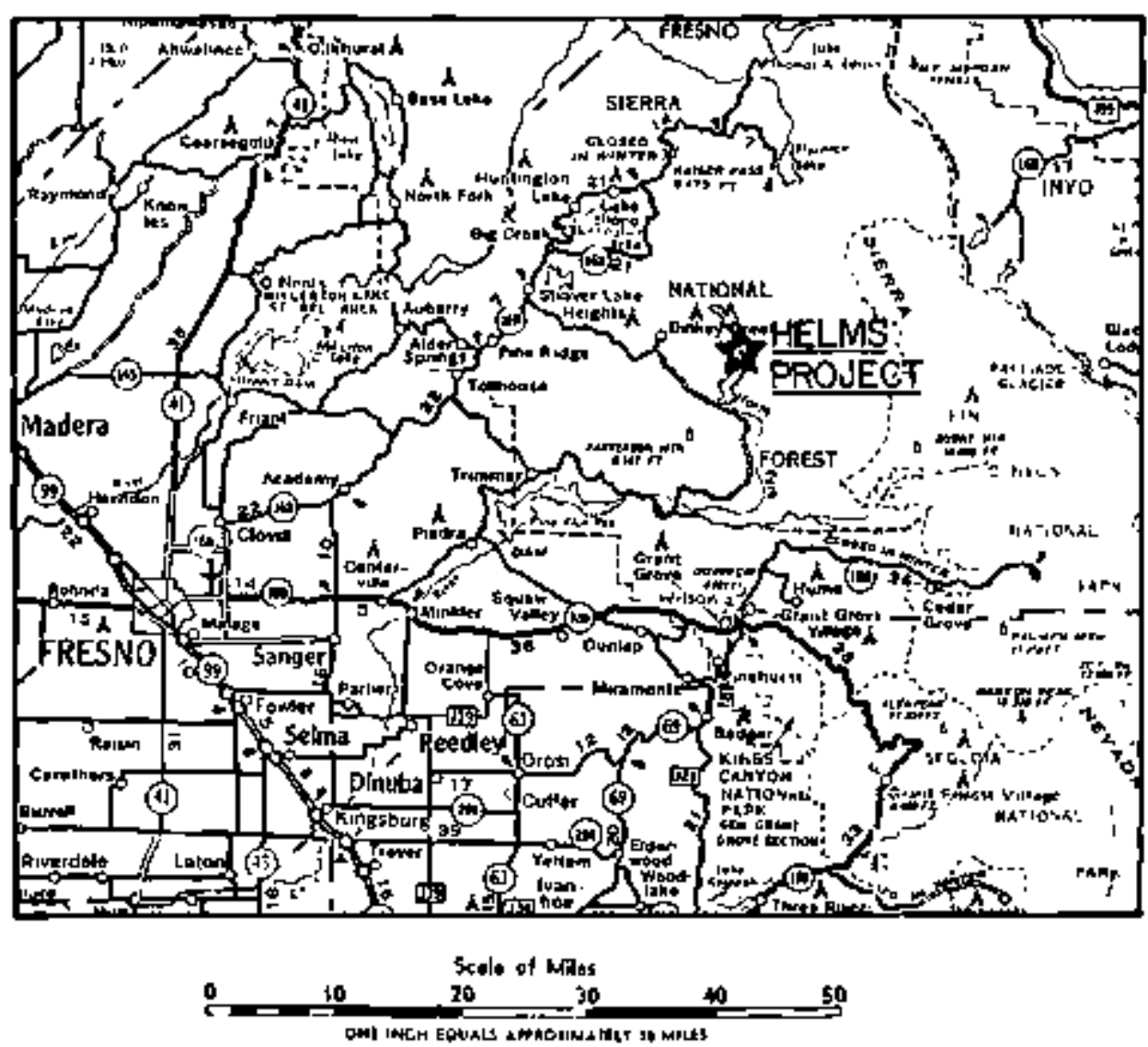

FIGURE 1. Location of He1ms Project in California, 60 miles east of Fresno. Basic map reproduced by permission of the American Autonobile Association, copyright owmer. 


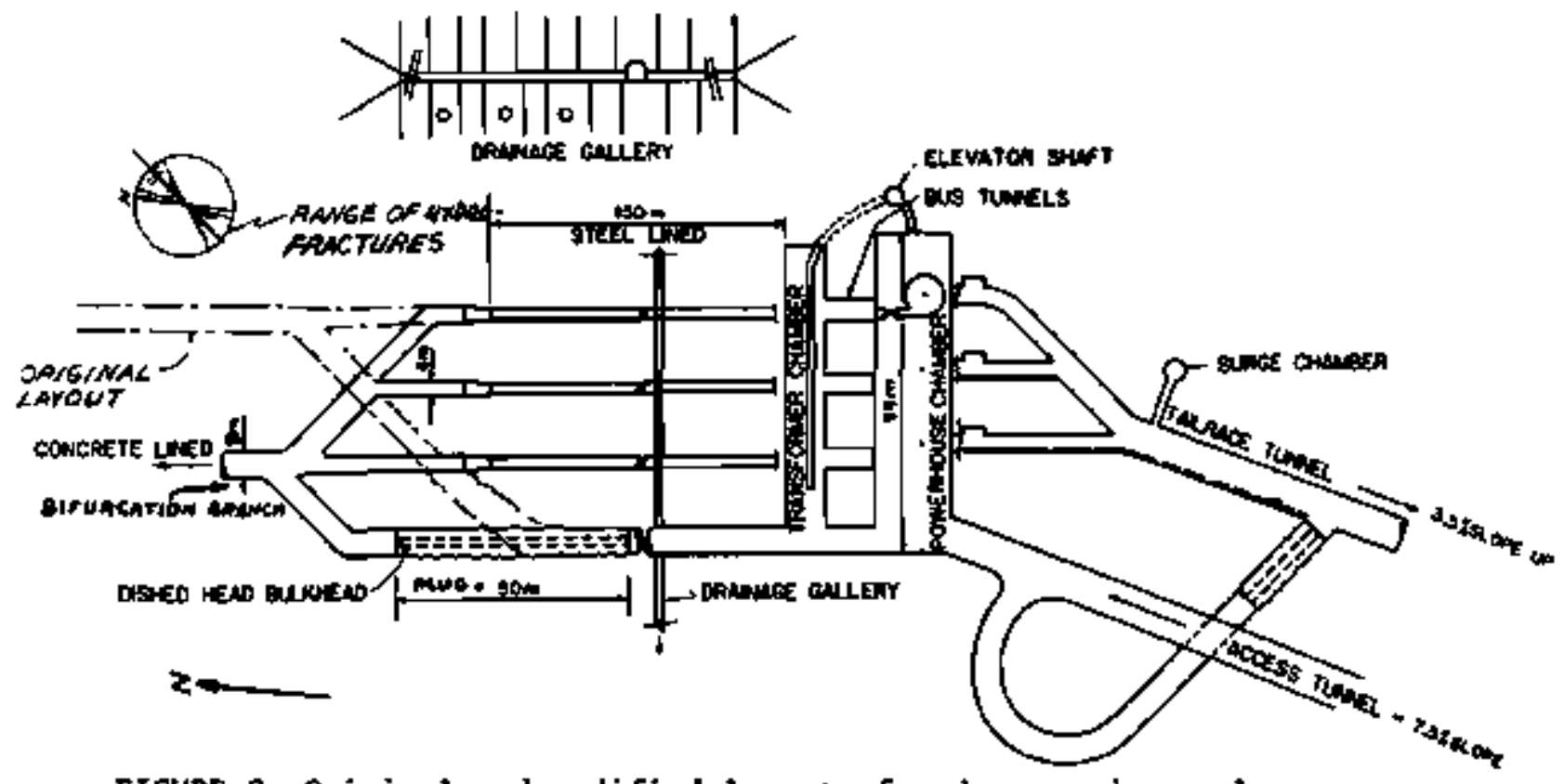

FICURE 2, Original and modified layout of underground powerhouse complex--Helms Pumped Storage Project (Hlainson, 3976). 

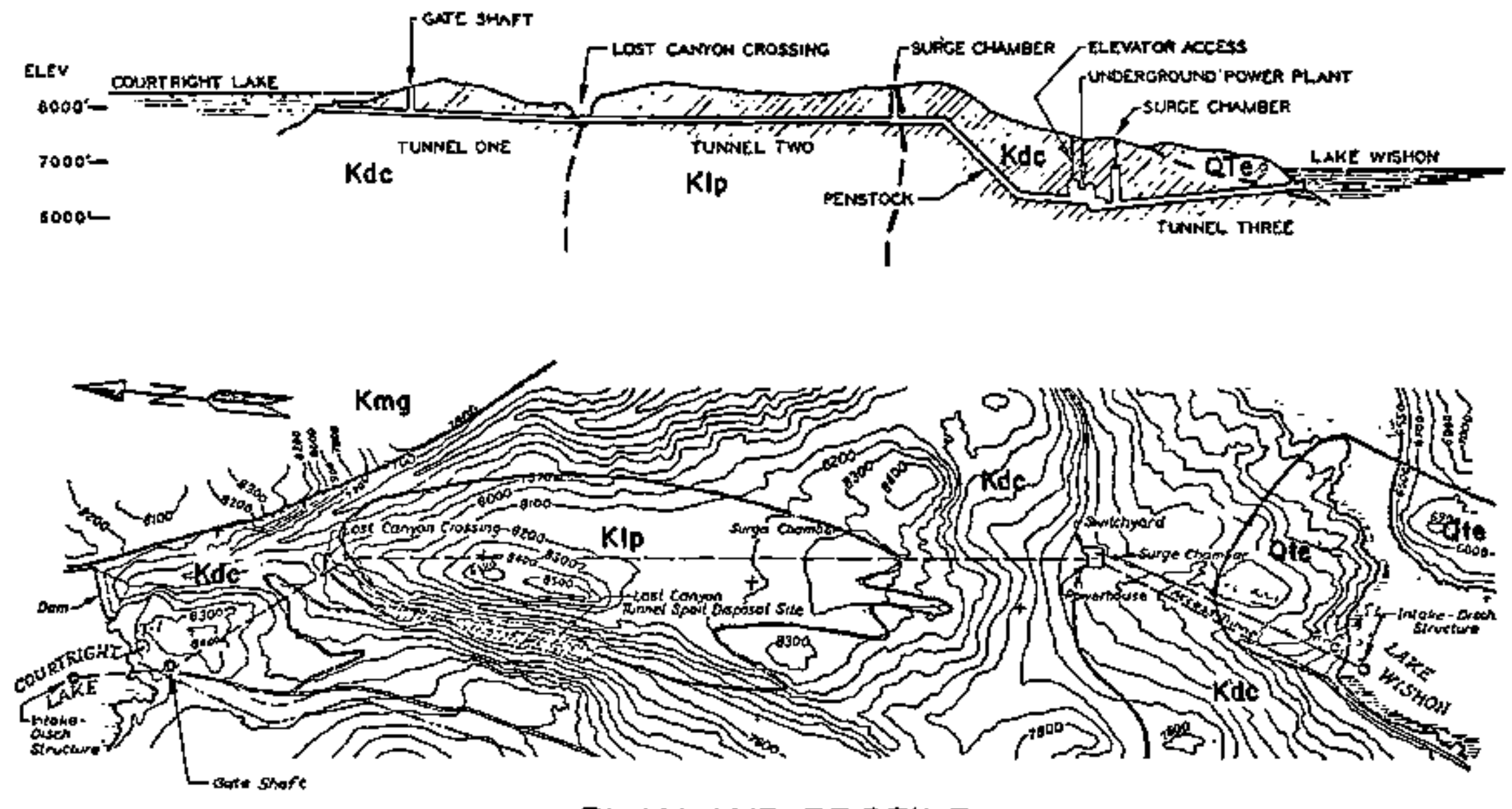

PLAN AND PROFILE

FIGURE 3.

HELMS PUMPED STORAGE PROJECT

LEGEND:

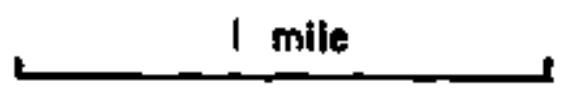

ATTACHMENT 2

ENG. EsT. NO. \$120

Klp - Lineated Quartz Monzonite of Lost Peak

Kmg - Mt. Givens Quartz Monzonite and Granodiorite

(Geology after Bateman, 1965)

Kdc - Dinkey Creek Granodiorite

Qte - Quartzite 
Geotechnical parameters are listed in Table 1. Rock structure and rock properties in this table were obtained from the paper by Haimson (1976). Thonas Doe, staff hydrogeologist at LBL, as a student of Haimson at Hisconson, participated in field investigations at the Helms Project. Discussions with Doe indicate that, since the Helms pumped-storage project is still under construction (\$ummer, 1979), there may be access at present and in the near future for further studies of the mechanical and hydrologic properties of the granodiorite. It is also possible that discussions with PGGE may indicate that some openings will be accessible for long-term studies. 


\author{
T A B L E 1 \\ Structure - Cubic joint system (2-8 m spacing) \\ Rock Properties $-\sigma_{\text {unc }}=1-1.3 \mathrm{~kb}, E=4-8 \times 10^{5} \mathrm{bars}$, \\ $v=0.2-0.3$, \\ tensile strength = 100-150 bars \\ Stress $-\sigma_{H}(\max )=95$ bars, $N 25^{\circ} \mathrm{E}$ \\ $\sigma_{H}(\min )=54$ bars, N65 $\mathrm{W}$ \\ $\sigma_{v}=82$ bars \\ Hydrology - below water table
}

Project Characteristics

$$
\begin{aligned}
& \text { Depth - } 300 \text { m } \\
& \text { Volwne }-98 \mathrm{~m} \times 25 \mathrm{~m} \times 36 \mathrm{~m}=88,000 \mathrm{~m}^{3} \text { (powerhouse), } \\
& 93 \mathrm{~m} \times 15 \mathrm{~m} \times 15 \mathrm{~m}=21,000 \mathrm{~m}^{3} \begin{array}{c}
\text { (transformer } \\
\text { chamber). }
\end{array}
\end{aligned}
$$

(Data from Haimson, 1976). 


\section{REFERENCES}

Bateman, $P_{+}, 1965$, Geologic Map of the Blackcap Mountain Quadrangle: U.S. Geol. Surv, map GQ-42B.

Haimson, B. C., Pre-excavation deep-hole stress measurements for design of underground chambers-case histories, in: Robbins, $R$. J., and Conlon, R. J., ed., Proc. 1976: Rapid Excavation and Tunneling Conference, Las Vegas, Nevada, June 14-17,-1976, Nherican Inst, of Mining, Metallurgical and Petroleum Engineers, New York. 


\author{
CIVIL WORKS \\ DWORSHAK DAM SITE \\ (U.S. Bureau of Reclanation)
}

LOCATION

The Dworshak Dan site is located on the North Fork of the Clearwater River, near the town of Orofino, Idaho (w40 miles east of Lewiston), at $46^{\circ} 31 \mathrm{~N}, 116^{\circ} 18^{\prime} \mathrm{W}$ (Figure 1). The dan, with a crest length of $r 3000$ feet and a height of 673 feet, was completed in 1972. It was built by the U.S. Corps of Engineers and is presently under the jurisdiction of the Bureau of Reclamation.

Prior to construction, rock-mechanics tests were done at depths of 300 to 700 feet in adits in the abutments to determine in-situ deformation properties (Deere and others, 1969). Sone of these workings may still be accessible as well as a large "glory hole" and underground crushing facility for preparation of concrete aggregate fron dam-site crystalline rock.

\title{
GEOLOGIC SETTING
}

The geologic setting of the region surrounding Dworshak Dam was described by Johnson (1947) and is illustrated in Figure 2. The rock at the site is granodiorite gneiss of the Orofino Series, considered by Johnson to have originally been a siliceous sedimentary rock of Beltian (Late-Precambrian) age, metamorphosed in the Mesozoic to its present crystalline form by hydrothermal solutions associated with the Idaho Batholith. The granodiorite gneiss is schistose and banded, its color is light to moderate gray, its granularity ranges from fine to coarse. Microscopic examination is needed to distinguish the granodiorite gneiss from hormblende and biotite quartz-diorite gneisses which also occur in the region. Occasionally quartz veins and basaltic dikes 


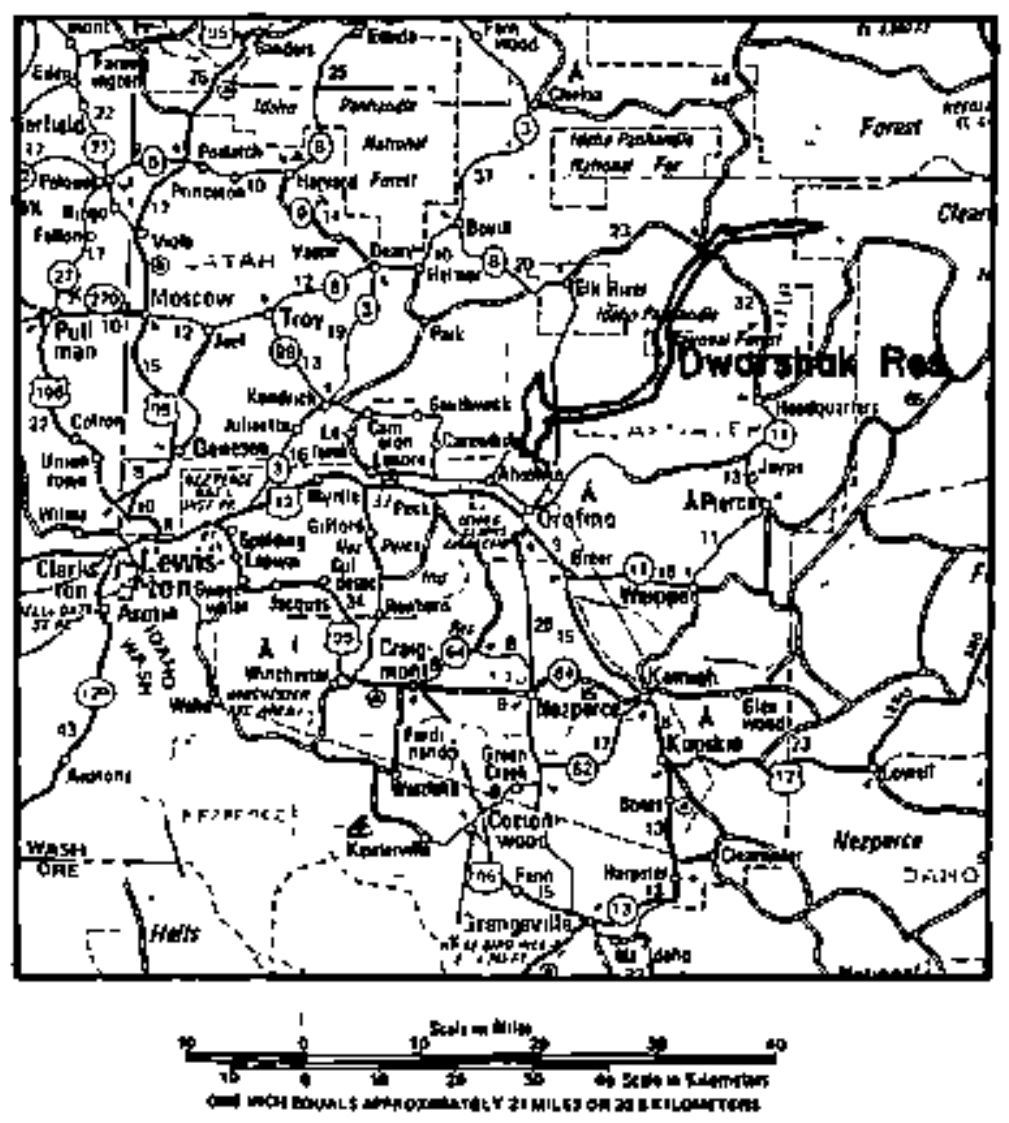

FIGURE 1. Dworshak Dan \$ite in Idaho, approxinately 40 miles east of Lewiston. Basic nap reproduced by perrission of the Anericar Alutomobile Association, copyright owner. 


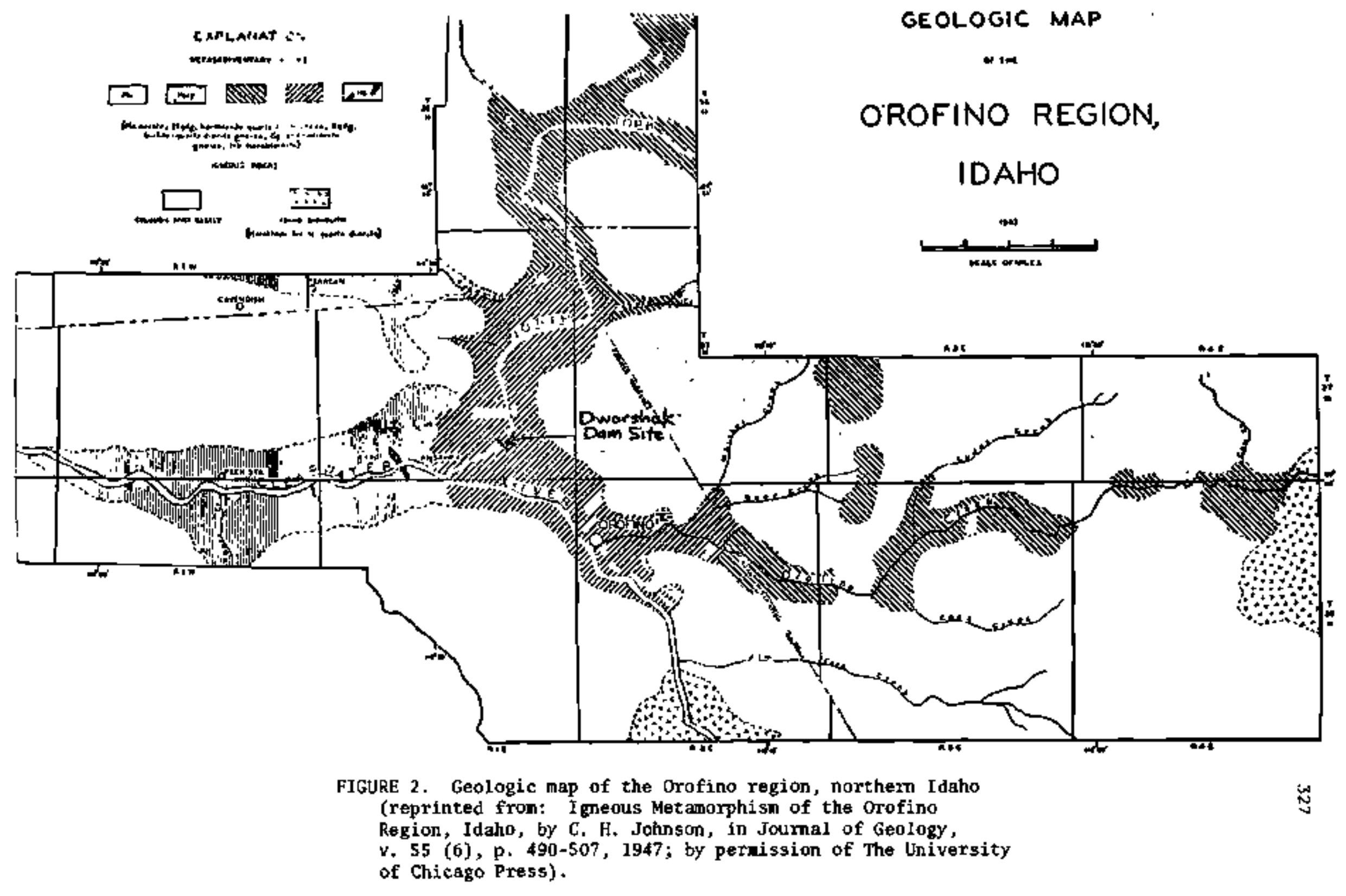


cut the granodiorite gneiss. Petrographic examinations reported by Leere and others (1969) showed that the dam-site gneiss was foliated with biotite flakes aligned paralle1 to the foliation. Johnson (1947) observed that bedding in the Orofino Series was not completely obliterated by metamorphism. Regional strike ranges from nearly east-west to $\mathrm{N} 45^{\circ} \mathrm{W}$; dips are to the north and vary from $15^{\circ}$ to nearly vertica1. At the site, foliation strikes roughly parallel to the cross-strean axis of the dam, and dips $450^{\circ}$ upstrean. A prominent joint set dips at $290^{\circ}$ to the foliation.

Rock-property data is sumarized from in-situ and laboratory measurements at depths of 300 to 700 feet by Deere and others (1969):

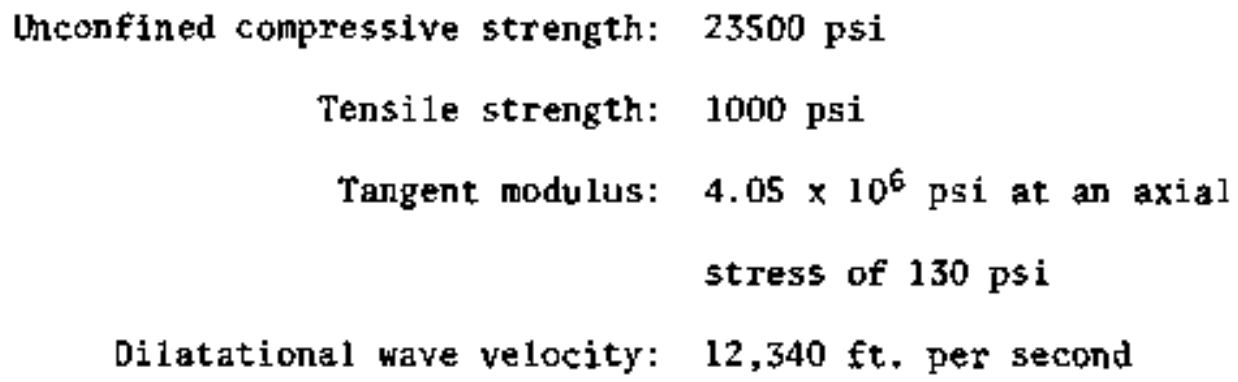

Because of the possibjity of access to test adits and the glory-hole-crusher workings, their availability for in-situ mechanical and hydrologic testing in crystalline rock at appropriate depths should be investigated, 
REFERENCES

Deere, D.U., Merritt, A.H., and Coon, R.F., 1969, Engineering classification of in-situ rock: Tech. Report no. AFWL-TR-67-144, Air Force Weapons Laboratory, Kirkland AFB, New Mexico.

Johnson, C.H., 1947, Igneous metamorphism in the Orofino region, Idaho: J. Geol., v. 55, (6) p. 490-507. 

NEVADA TEST SITE-CLIMAX STOCK

(U.S. GOVERNHENT/DOE)

\section{LOCATION}

The Climax Stock at the Nevada Test Site (NTS) is located approximately 5 miles from Area 12 camp, N40 miles north of Mercury, Nevada, and 90 airIine miles northwest of Las Vegas, Nevada, at $37^{\circ} 14^{\prime} \mathrm{N}, 116^{\circ} 04^{\prime} \mathrm{W}$. Figure 1 is a location map showing the clinax Stock, NTS and geographical 1 andmarks. GEOLOGIC SETTING

Data for these sections were extracted from Terra Tek (1975), Eckel (1968), and Ramspott (1978).

The generalized geologic setting is illustrated in Figure 2, which includes a cross section through the Climax stock.

The NTS site is located on the northeast side of the Las Vegas-Walker Lane shear zone in a region of thick Paleozoic mlogeosynclinal sedimentary accumulation. Sedinentary rocks account for approximately 30 percent of the outcrops in the region, while the remainder consists of intrusives overlain by volcanics. Regional structure is expressed in generally north trending mountain ranges in the northern part of the NTS. Several different geologic settings occurring in the region are characterized as follows:

(1) Mesozolc intrusives are represented by the granodioritic quartz monzonite Climax and Gold Meadow Stocks, each exposed over several square miles.

(2) The Ranier and Pahute Mesas are examples of a thick sequence of Tertiary volcanics overlying an eroded Paleozoic sedimentary basenent. The Tertiary volcanics range up to 5,000 feet in thickness and may be capped by a resistant welded tuff. The tuff units range from ash-flow and ash-fall tuffs to highly welded tuffs. 


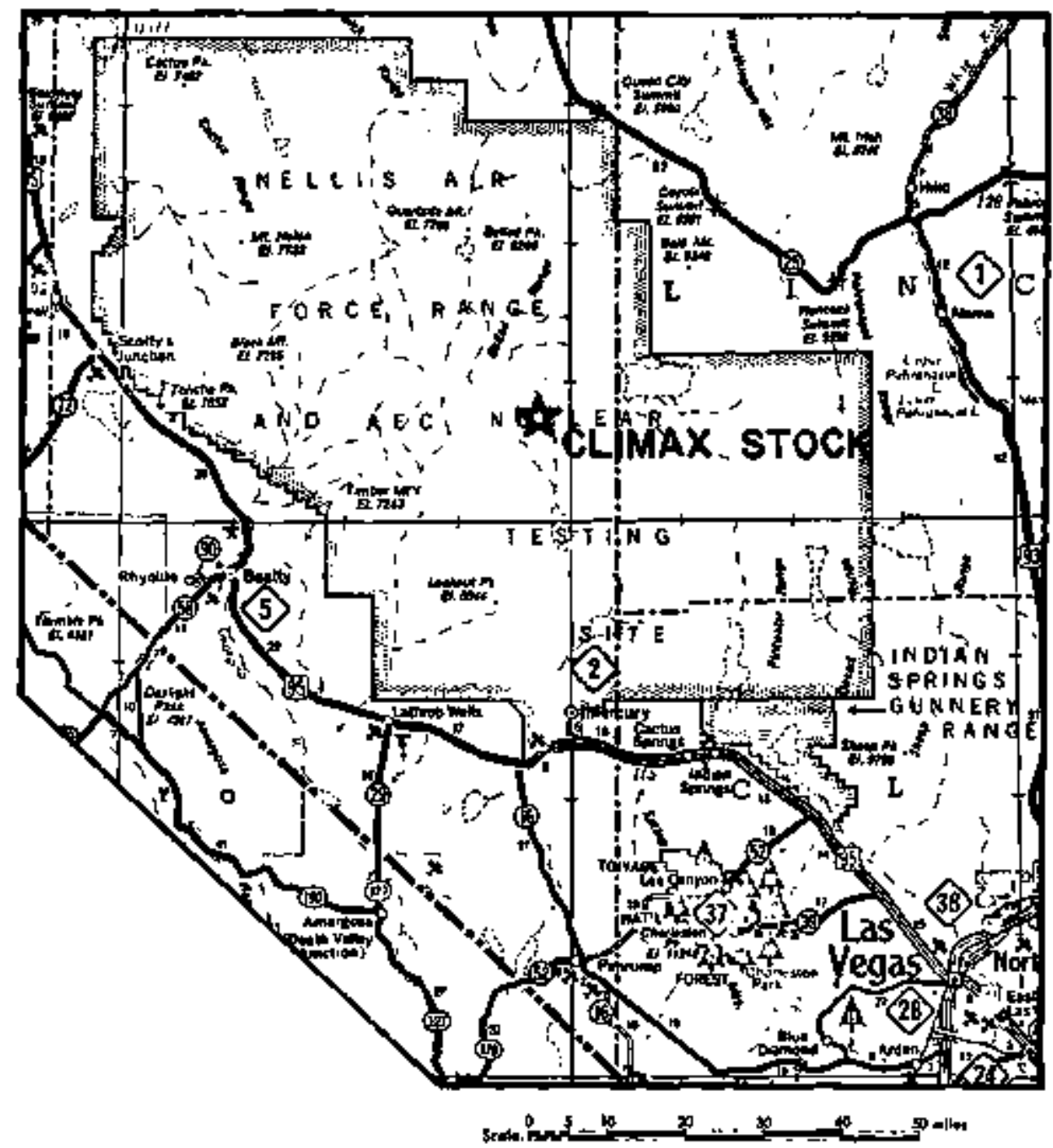

FIGURE 1. Location map - Climax Stock, Nye County, Nevada. Base map used with the permission of the Nevada Departinent of Transportation. 

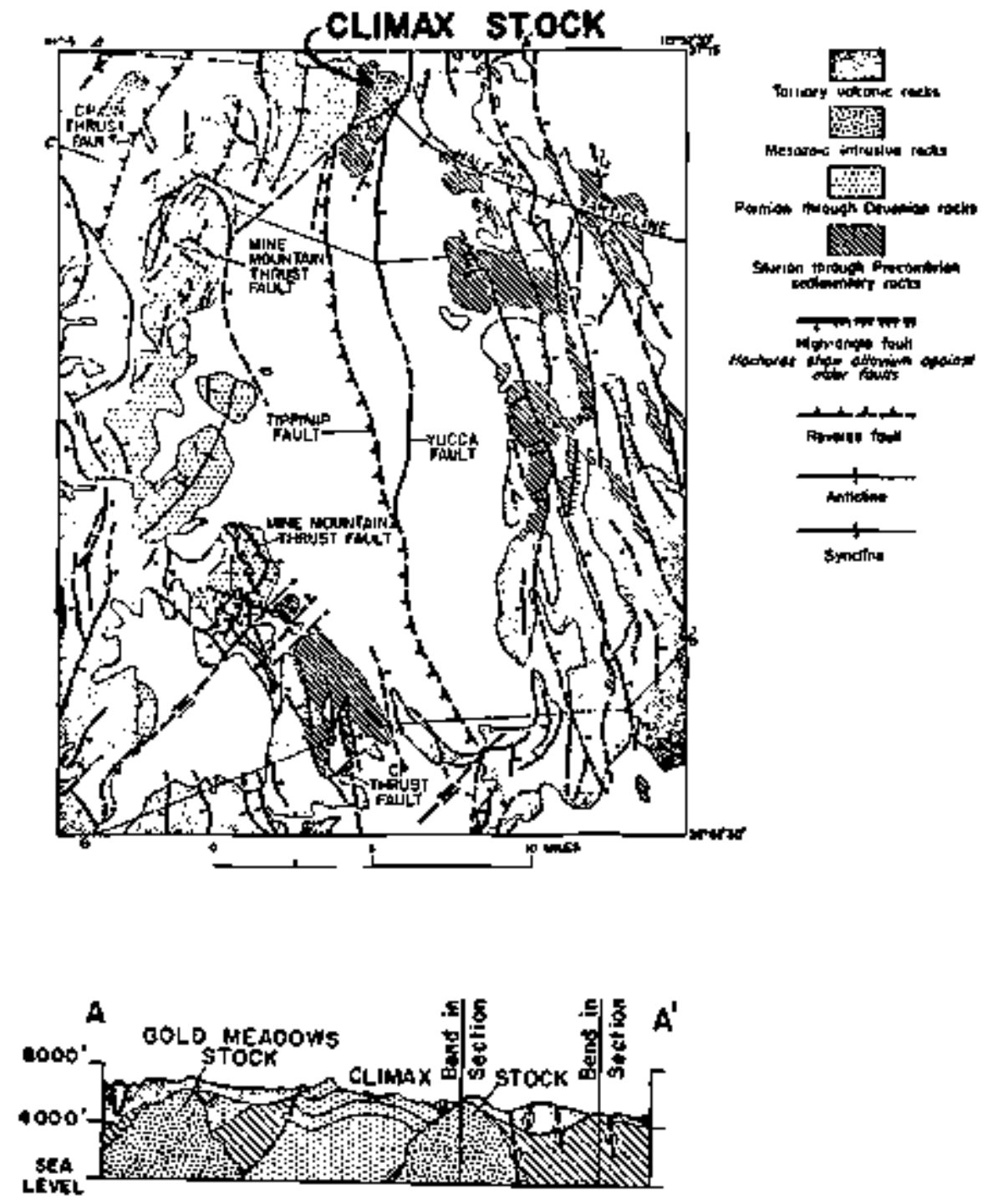

FIGIRE 2. Generalized geologic map of the Yucca Flat Area and cross section through the Climax Stock. Inpatterned areas are surficial deposits. (Hinrichs, 1968). (Courtesy, the Geological Society of Anerica.) 
(3) Alluvial valleys are characterized by a thick sequence of underlying sedimentary rocks. At Yucca Flat the alluvium and tuff reach a thickness of 3,500 feet, and over1ie Paleozoic carbonat rocks and some intrusives at depth.

The geologic structure of the region is somewhat typical of the Basin and Range province: alluvial valleys bounded by high angle normal faults. Normal faulting associated with volcanic structures occurs beneath the alluvial valleys. Several major thrust faults have been identified as significant features with respect to the distribution and movement of ground water.

A great deal of geological and geophysical work has been performed at WTS, in the form of geological mapping, joint frequency maps, geophysical borehole logging, and gravity, magnetic and seismic surveys. Much of this work has been sumparized in a compendiun of reports (Eckel ed., 1968).

The area is located in earthquake zone 2 .

\section{Climax Stock}

The underground opening being considered as a candidate site is located in the Climax Stock. As shown on Figures 2 and 3 , the stock, of Mesozoic age, intruded Precambrian and Pajeozoic clastic and carbonate rocks. Geophysical evidence suggests that the Climax stock expands conically from a surface area of several square miles to an area of approximately 60 square miles at a depth of three thousand feet. The C1imax stock is structually controlled, elongate in the north-south direction, and bounded on the east and west by faults. Minor faults transect the intrusive joints typically spaced from several inches to several feet apart. The $420 \mathrm{~m}$ level is apparent $1 y$ above the regional water table, and the rock at that level appears to be msaturated. Approximately 1 to 2 wt water is localized in fractures and pores. 

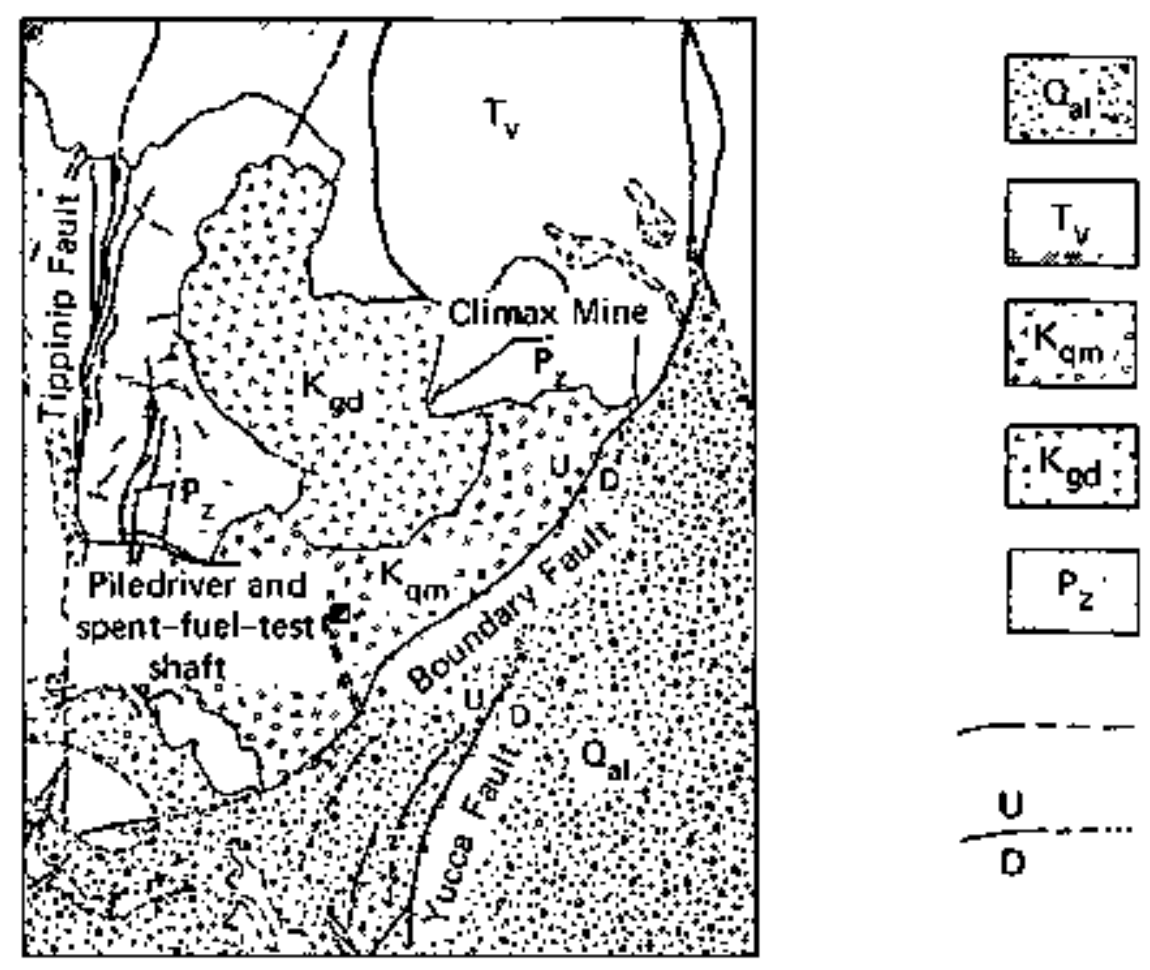

Quaternary

alluvium

Tertiary volcanics

fundifferentiated

tutt|

Cretaceous

Climax stock

(quartz monzonite)

Cretaceous

Climax stock

(granodiorite)

Paleozoic undivided

ilimestone, dolomite. shale, quartzite)

Contact (dashed where approximately locatod

Fault fdashed where approximately located, dotted where concealed)

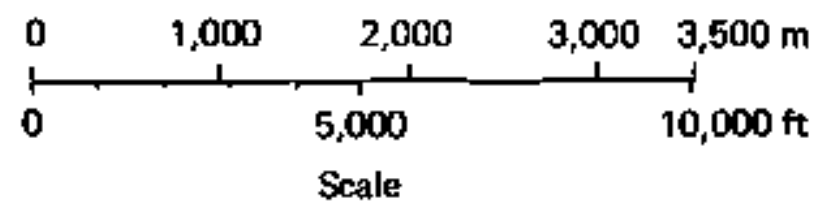

Shaft

FIGURE 3. Geologic nap of the Clinax stock area (modified from U.S.G.S. map by Barnes et al.), (Ramspott, 1979). 
laboratory tests of rock properties of the Climax stock granodiorite and quartz monzonite, conducted by the Lawrence Livermore Laboratory are summarized in Table 1 and figures 4 and 5. Underground Opening Facilities

The layout of the underground facilities and the current testing progran have been described by Ranspott (1979). The shaft and tumnel complex previously constructed for the PILEDRIVER underground nuclear test, are presently being utilized for a spent fuel test facility. As show in Figure 6, further excavation on the $420 \mathrm{n}$ level has been done by lawrence Livermore laboratory in preparation for the spent fuel tests.

Mechanical equipuent at the site includes hoist and ventilation apparatus to service the $1,400 \mathrm{ft}$. shaft and drifts on the $420 \mathrm{~m}$ 1evel. 
TABLE I

SUMMARY OF LABORATORY TESTS ON CLIMAX STOCK QUARTZ MONZONITE

SAMPLE SOURCE

PHYSICAL PROPERTIES

Dry Bulk Density $\left(\mathrm{gm} / \mathrm{cm}^{3}\right)$

Grain Density $\left(\mathrm{gn} / \mathrm{cm}^{3}\right)$

Total Porosity (8]

Permeability ( $\mu d)$

THERMAL PROPERTIES

Conductivity (watt $/ \mathrm{m}^{\circ}{ }^{\circ} \mathrm{C}$ )

versus pressure 2

versus temperature $\underline{\text { G-1 }}$

3.6

0.12

$\underline{\mathbf{G}-2}$

$2.635 \pm .036$

$2.723 \pm .027$

$3.221 \pm .716$

0.10

3.7

LARGE CORE

$2.92 \div 25^{\circ} \mathrm{C}$

$2.76 \div 100^{\circ} \mathrm{C}$

$1.95+200^{\circ} \mathrm{C}$

MECHANICAL PROPERTIES

Compressive Strength (GPa)

$$
\begin{aligned}
& \sigma_{3}=0 \mathrm{MPa} \\
& \sigma_{3}=3.4 \mathrm{MPa} \\
& \sigma_{3}=6.9 \mathrm{MPa} \\
& \sigma_{3}=10.3 \mathrm{MPa} \\
& \sigma_{3}=20.7 \mathrm{MPa} \\
& \sigma_{3}=41.4 \mathrm{MPa}
\end{aligned}
$$$$
0.20 \pm .03
$$$$
0.20 \pm .03
$$

$$
\begin{aligned}
& 0.275 \pm .007 \\
& 0.282 \pm .044 \\
& 0.337 \pm .027 \\
& 0.452 \pm .016 \\
& 0.569 \pm .032
\end{aligned}
$$

YOLNG'S MODULUS (GPa)

$$
\begin{array}{rlrl}
\sigma_{3} & =\mathrm{MPa}^{1} & 48 \pm 5 & 51 \pm 5 \\
\sigma_{3} & =3.4 \mathrm{MPa} & & 66.7 \pm 5.9
\end{array}
$$

1 Taken from previous test results on G-1 and G-2 core.

2 Not pressure dependent in the range of 0 to $34.5 \mathrm{MPa}$. 
$\underline{G-1}$

$\sigma_{3}=6.9 \mathrm{MPa}$

a $\sigma_{3}=10.3 \mathrm{MPa}$

$\sigma_{3}=20.7 \mathrm{MPa}$

$\mathrm{g}_{3}=41.4 \mathrm{MPa}$

DYNAMTC

POISSON'S RATIO

$\sigma_{3}=0 \mathrm{MP}^{1}$

$\sigma_{3}=3.4 \mathrm{MPa}$

(9) $\sigma_{3}=6.9 \mathrm{MPa}$

$\mathrm{a}_{3}=10.3 \mathrm{sPa}$

$\sigma_{3}=20.7 \mathrm{MPa}$

e $\sigma_{3}=41.4 \mathrm{MPa}$

DYNAMIC

BULK HODULUS (GPa)

Static

Dymanic

ULTRASONIC VELOCITIES

( $\mathrm{km} / \mathrm{sec})$

P-wave

S-wave

TENSTLE STRENGTH $(\mathrm{MPa})^{3}$

$16 \pm 2$
$0.21 \pm .02$

$0.22 \pm .02$

$0.35 \pm .02$

$0.27 \pm .06$

$0.31 \pm .05$

$0.31 \pm .05$

$0.28 \pm .05$

0.240

0.253

$0.245 \pm .012$

49.4

$44.5 \pm 4.4$

$\begin{array}{lll}6.058 & 5.767 & 5.501 \pm .208 \\ 3.541 & 3.317 & 3.185 \pm .080\end{array}$

$14 \pm 2$

${ }^{3}$ Brazil test. 


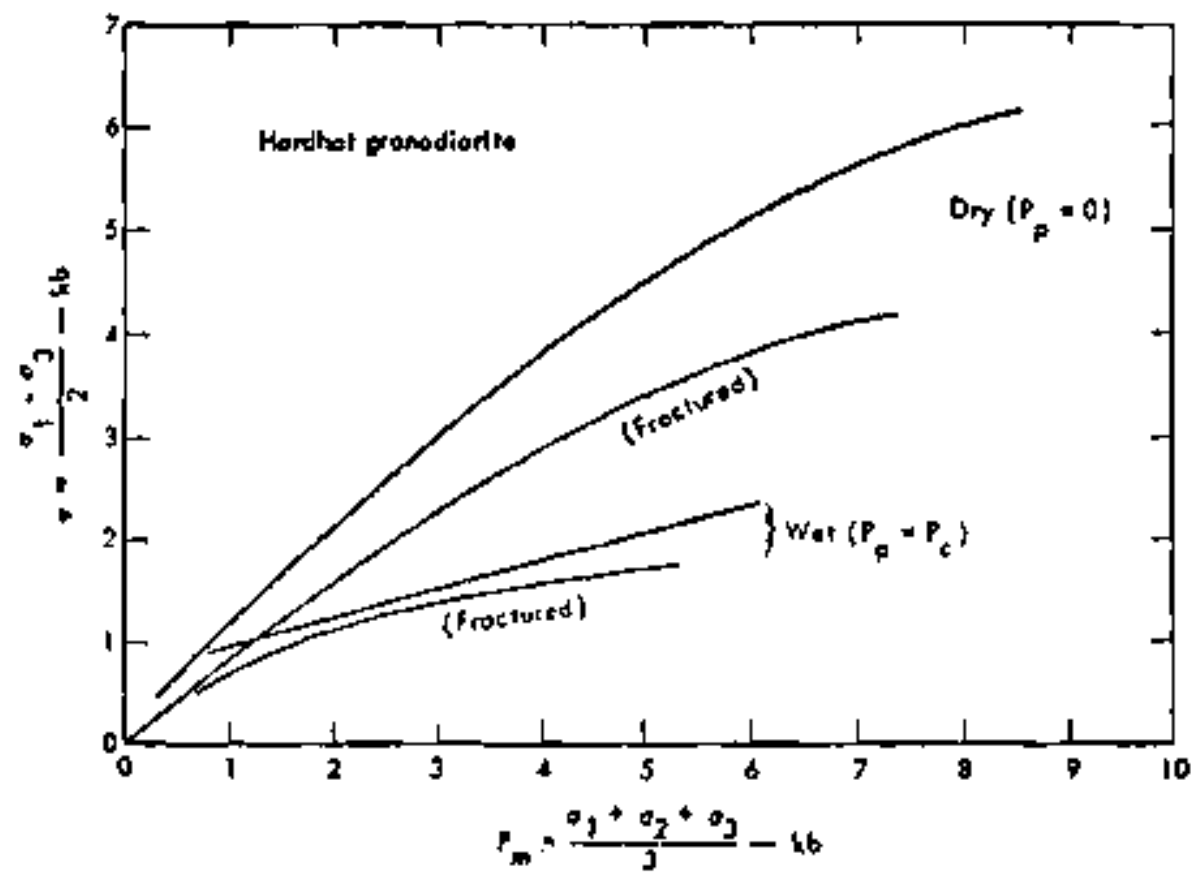

FIGIIRE 4. Failure envelopes of both intact and fractured Clinax Stock granodiorite under dry and saturated conditions 240-m level. (Heard, 1971). 


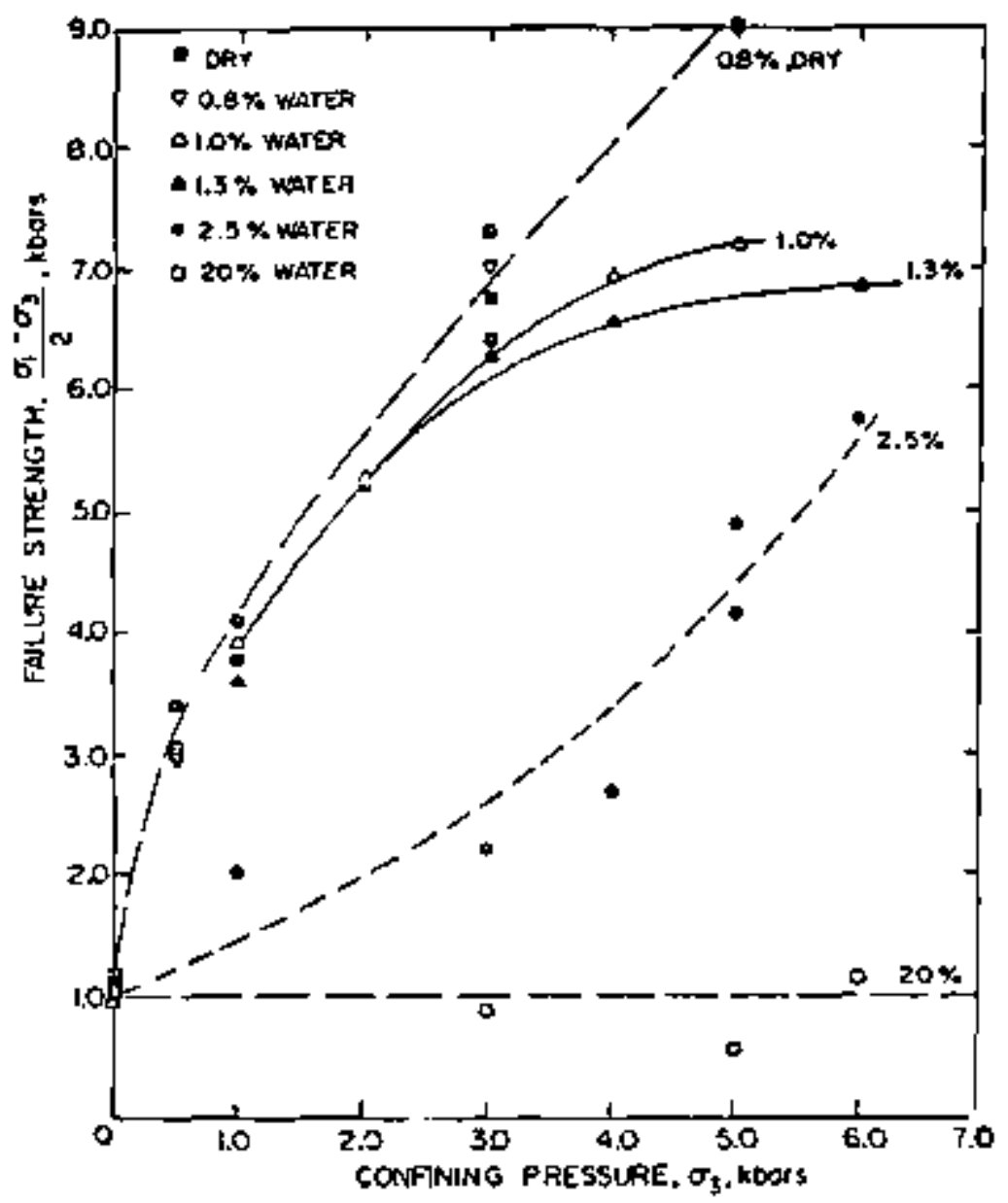

FIGURE 5, Failure strength as a function of confining pressure for dry samples and samples with excess water, 240 n level. (Duba and others, 1974). 


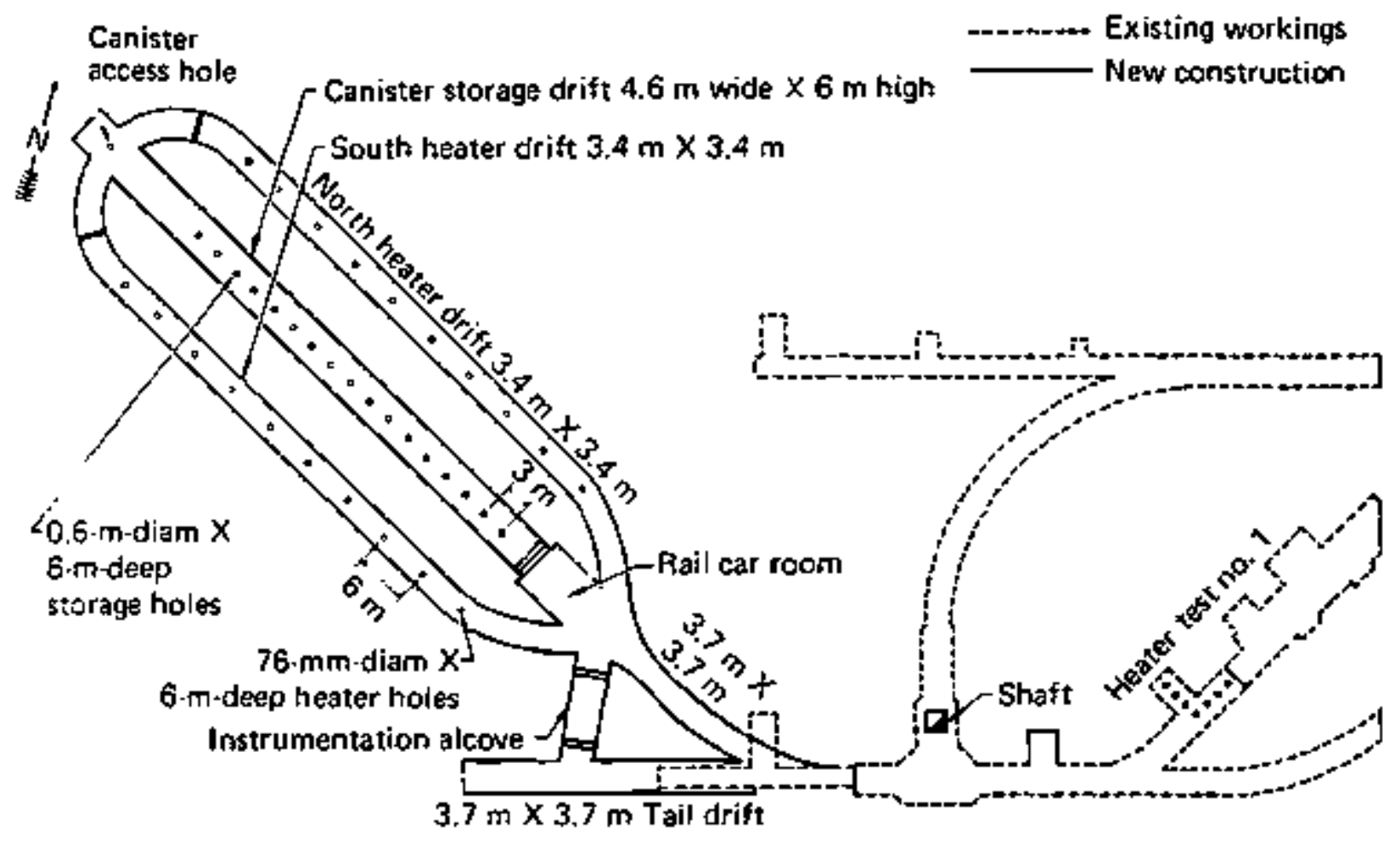

FIGURE 6. layout of 420-m level, climax granite, showing new construction for spent-fuel test, (Ramspott, 1979). 


\section{REFERENCES}

Duba, A.H., Heard, H.C., Santor, M.1. 1974, Effect of FIuid Content on Mechanical Properties of Westerly Granite, Lawrence Livermore Laboratory, livermore, Ca., UCRL-51626.

Ecke1, E.B. ed., 1968, "Nevada Test Site", Geol. Soc. Aner. Menoì 110.

Heard, H.C., 1970. The Influence of Environment on the Inelastic Behavior of Rock, Proc. Symp. Engineering with Nuclear Explosives, U.S. Dept. Comnerce, Springfield, Va, , v. 1, p. 127-141.

Hinrichs, E.N., 1968, Geologic structure of Yucea F1at Area, Nevada, in: Eckel, E.B., ed., Nevada Test Site, Geol. Soc. Amer. Men. 110, p. 239246 .

Pratt, H.R., R. lingle and T. Schranf, 1979, laboratory Measured Material Properties of Quartz Monzonite, climax Stock, Nevada Test Site, TR 79-50, submitted to Lawrence livermore Laboratory.

Pratt, H. R., Green, S. J., Jones, A. fl., and Brace, H. F., 1975, Physical and Mechanical Properties of Selected Geologic Materials - A Compendium, TR $75-3$.

Ranspott, L.D., 1979, Waste-Isolation Projects: FY 1978, Lawrence Livermore Laboratory, UCRL-50050-78.

Ranspott, L.D.; Ballou, L.B.; Carlson, R.C.; Montan, D.N.; Butkovich, T.R.; Dumcan, J.E.; Patrick, W.C.; Wilder, D.G.; Brough, W.G.; Mayr, M.C., 1979, Technical Concept for a Test of Geologic Storage of Spent Reactor Fuel in the Climax Granite, Nevada Test Site, Lawrence Livermore Laboratory, Report UCRL-52796, $47 \mathrm{pp}$.

Terra Tek, Inc., 1975, A Geology Compendium of the Continental United States - with Application to Deep-Based Systens, DNA 3874, prepared for Defense Nuclear Agency. 


\section{CIVIL WORKS}

\section{THE BAD CREEK PUJMPED STORAGE PRQJECT}

(Duke Power and Light Co.)

\section{LOCATION}

The Bad Creek project of Duke Power and Light Co., described by Hester and Edmonds (1974), is located on the southeastern edge of the Blue Ridge escarpment, approximately 40 air miles Dconee County, South Carolina, at $34^{\circ} 57^{\prime} \mathrm{N}, 83^{\circ} 04^{\prime} \mathrm{w}$. As shown in the location map (Figure 1) and the cross section (Figure 2), the underground workings are immediately west of the Whitewater River arm of Lake Jocasee. The pumped-storage project's upper reservolr is formed by impounding Bad Creek and West Bed Creek at an elevation of 2310 feet; Lake Jocasee, at an elevation of $w 1100$ feet, serves as the lower reservoìr. The underground powerhouse is situated at a depth of 4900 feet, its dimensions are $90 \times 445$ feet in plan, its height 130 feet.

\section{GEOLOGIC SETTING}

Geologic descriptions of the site are sparse in the open literature. According to Haimson (1976), the powerhouse chamber is excavated in the Toxaway gneiss, a medium- to coarse-grained, well-foliated rock. However, plotting the location of the project on the geologic map of the the crystalline rocks of South Carolina (Overstreet and Bel1, 1965) indicates that the underground workings are in the Whiteside granite of the Blue Ridge belt. Overstreet and Bell (1965) describe the Whiteside granite as typically faintly to strongly gneissic, but massive in some places. It is primarily a white to Iight-gray biotite - muscovite granite, but phases of muscovite granite, biotite granite, and, rarely, mica-free granite are also present. 

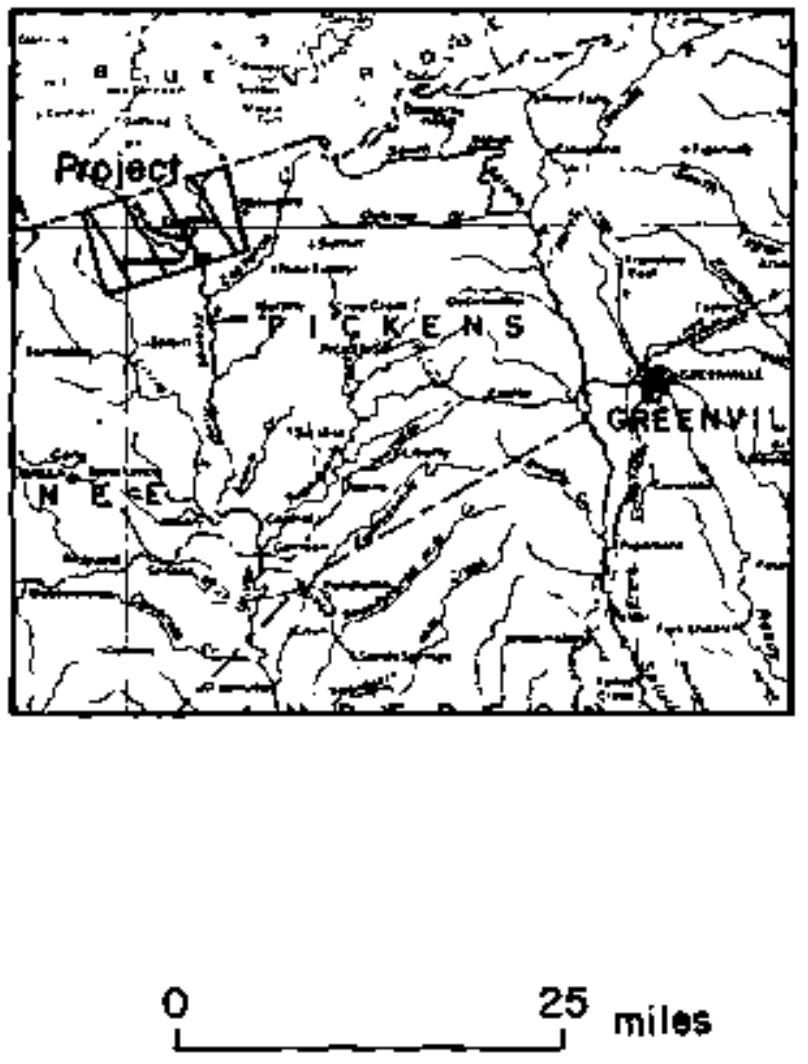

FIGURE 1, Location nap of Bad Creek Project in Oconee County, South Carolina (from Overstreet and Bell, 1965). 


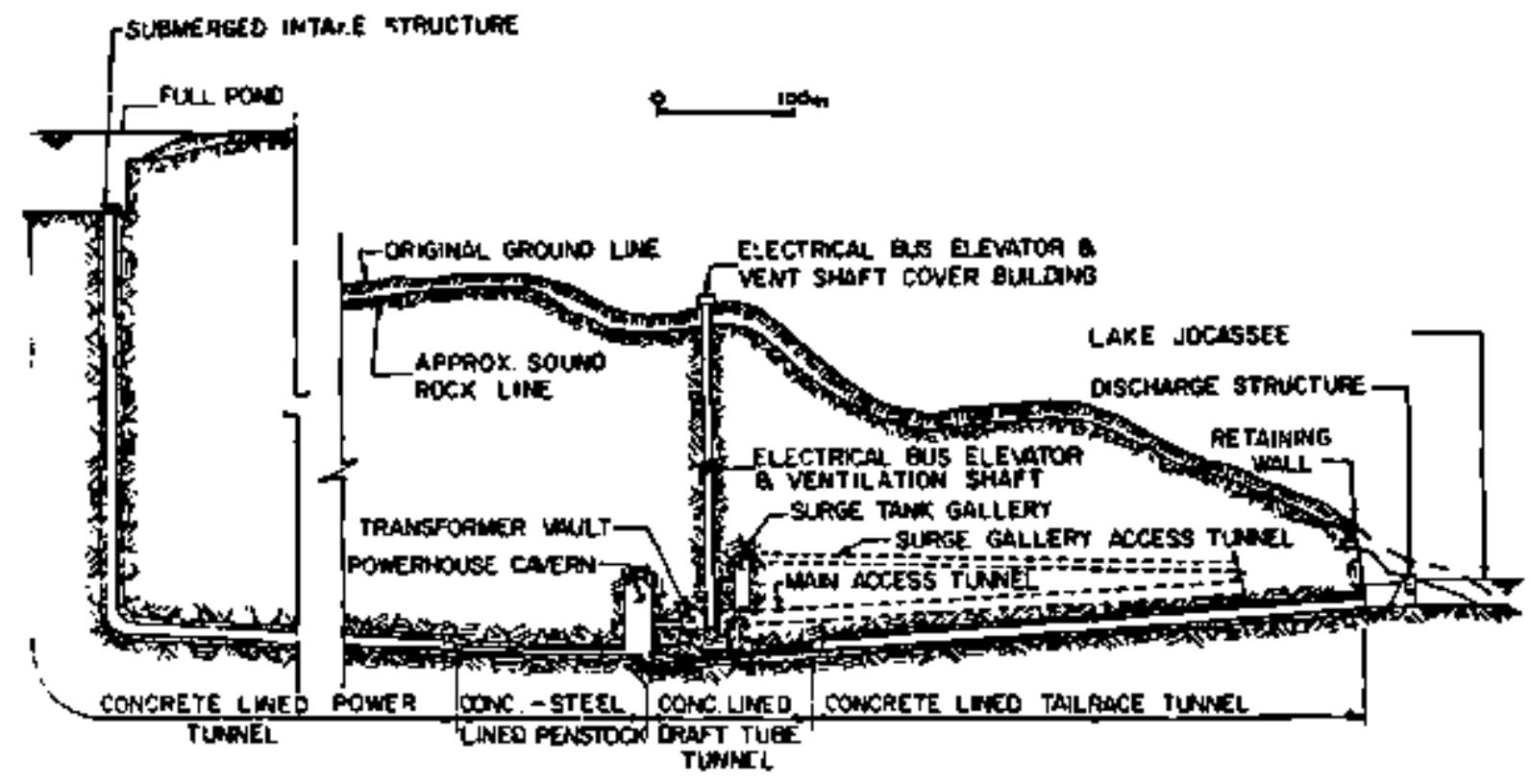

Figure 2. Vertics) soction through the waterways--Bad Croek Pumped \$torage Project (fron Hester, J.G, and Edmonds, R.F., Bad Creek Pumped Storage Project, In; Electric Power and the Civil Engineer, Conference Papers, Specialty Conference, Boulder, Colorado, 1974, Anerican Society of Civil Engineers, New York). 


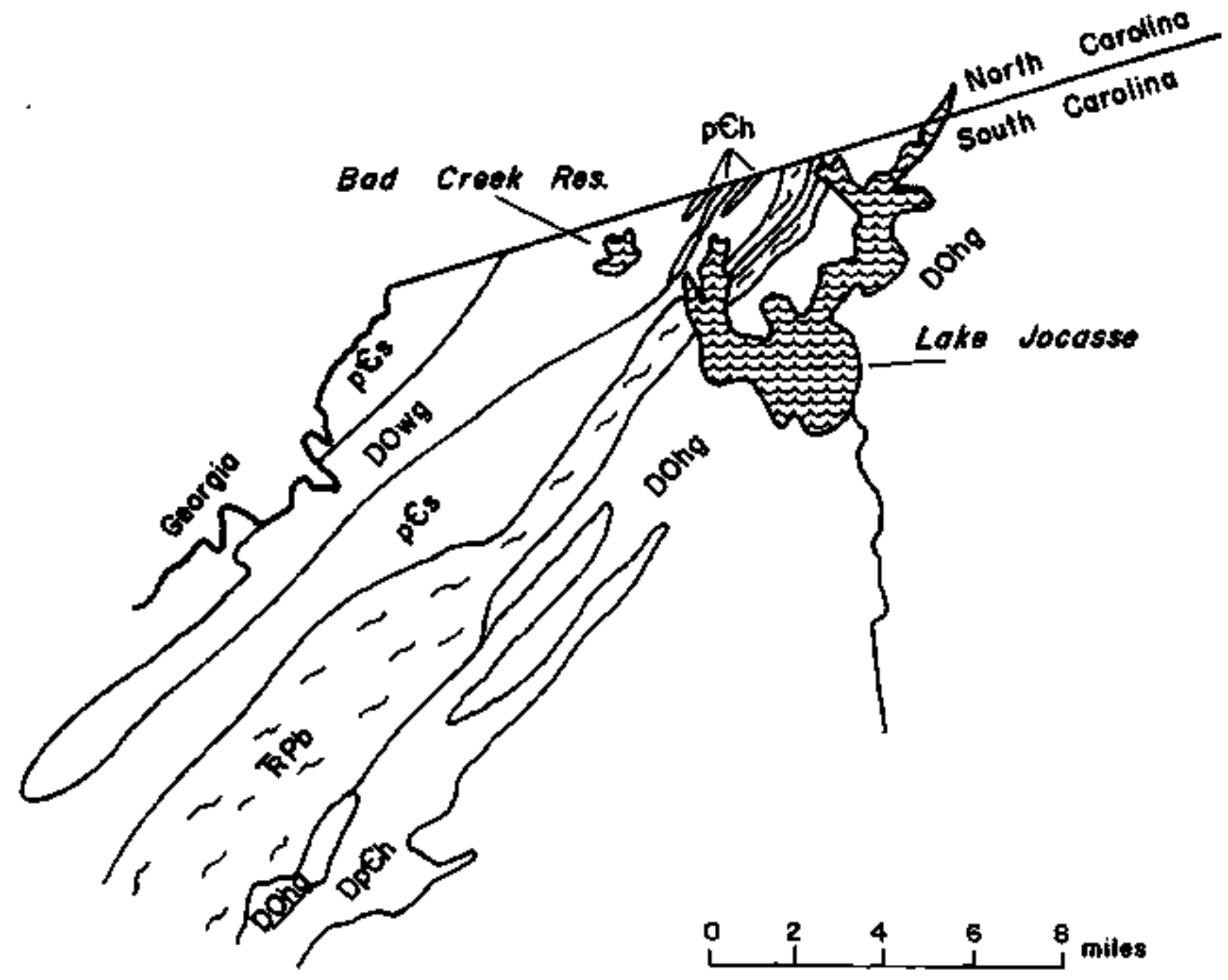

FIGURE 3. Simplified geologtc nap of the Lake Jocasee area (Overstreet and $B e 11,1965$ ).

\section{LEGEND}

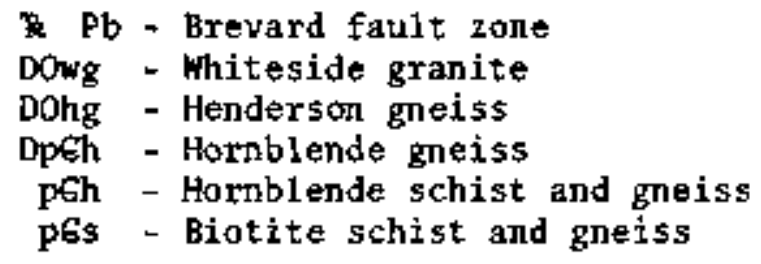


Three principal directions of foliation in the gneiss were observed by Haimson and his co-workers (Haimson, 1976). Two foliation directions conform well to the direction of measured horizontal principal stresses. Rock properties are sumarized from the paper by Hainson (1976) in Table 1 .

Table 1

Maximun horizontal stress: 228 bars at a depth of $230 \mathrm{~m}$.;

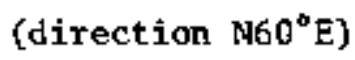

Minimum horizontal stress: 159 bars (direction $\mathrm{N3} 0^{\circ} \mathrm{W}$ ) The third follation direction is approximately E-W.

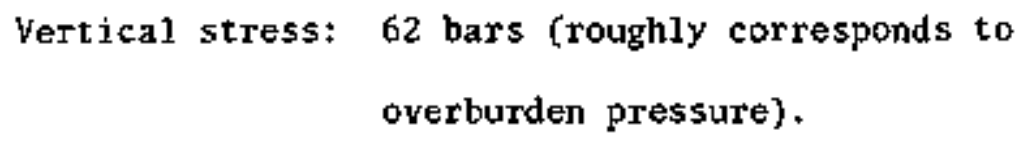
overburden pressure).

More detailed information on the geologic setting, resolution of the uncertainty in nomenclature of the bedrock at the Bad Creek site, as well as information on ease of access to, and availability of, underground workings for geotechnical tests, can only be obtained by discussion vith company and government geologists. 


\section{REFERENCES}

Haimson, B.C, 1976, Prepxavation deep-hole stress measurements for design of underground chambers--case histories, Ch. 36 in Proceedings, 1976 Rapid Excavating and Tunneling Conference, Las Vegas; American Institute of Hining, Hetallurgica 1 and Petroleum Engineers, New York.

Hester, J.G., and Edmonds, R.F., 1974, Bad Creek pumped storage project; in: Electric Power and the Civil Engineer, Conference Papers, Specialty Conference, Boulder, Colo., pub. by Amer. Soc. Civil Engineers, New York,

Overstreet, W.C., and Bell, H. III, 1965, The crystalline rocks of South Carolina, U.S. Geol. Survey Bull. 1183, $126 \mathrm{pp}$. 


\section{B I B L I O G R A P H Y}

This bibliography includes all the references used to furmish information on individual civil works, mines or mining districts as listed at the end of each aine description. Al so included are references pertinent to underground workings not in classes 1 and 2 ,

The bibliography, while large, is not exhaustive. It was compiled for the specific needs of this report. 


\section{BIBLIOGRAPHY}

Acres American, Inc., 1975, Federal Energy Adrinistration, National strategic oil storage program: Phase I, Underground mined storage, Preliminary feasibility analysís and site identification.

Acres American, Inc., 1975, Federal Energy Adninistration underground oil, storage program: Progress Report to August 31, 1975, File 4074-07.

Acres American, Inc., 1976. Federal Energy Administration, Strategic petrolem reserve: Phase I, Addendum, Underground mined storage, Preliminary feasibility analysis and site identification, $95 \mathrm{p}$.

Acres American, Inc., 1978, Review of potential host rocks for radioactive waste disposal in the southeastern United States - southern Piedmont sub-region, Acres American, Buffalo, fos: Savannah River Laboratory, Aiken, South Carolina.

Adair, D.H., and others, 1960, Intrusive igneous rocks of east central Nevada, Guidebook to the geology of east central Nevada, 11th Annual Field Conference, p. 229-31.

Adams, J.W., and Stugard, F., Jr., 1956, Walj-rock control of certain pitchblende deposits in Golden Gate Canyon, Jefferson County, Colorado, U.S. Geol. Survey Bull. lo30G, p. 187-209.

Adkinson, W.L., Kelley, J.S., and Newman, K.R., 1975, Lithology and palynology of tertiary rocks exposed near Capps Glacier and along Chuitna River, Tyonek Quadrangle, southern Alaska, U.S. Geol. Survey Open File Report 75-21, $58 \mathrm{p}$.

Agarwal, R.K., Eben F.C., and Taylor, C.E., 1973, Rock mechanics program at Grace Mine, abstract, Min, Eng., v. 25, no. 8, p, 33.

Ageton, R.W., 1967, Stress ellipsoid determination in a rock burst prone area at a depth of 4000 feet, Galena Mine, Hallace, Idaho, U.S. Bur. Mines Rept. Invest. RI 6997, $23 \mathrm{p}$.

AIME, 1941, Mining Engineers Handbook, 2 vols., 3rd edition.

AIME, 1970, Hor1d symosium on mining and metallurgy of lead and zine.

Albers, J.D., 1961, Gold deposits in the French Gulch - Deadwood district, Shasta and Trinity Counties, California, U.S. Geol. Survey Prof. Paper 424C, p. Cl-C6.

Alling, H.L., 1942, The Adirondack magnetite deposits, in Newhouse, H.H., ed., Ore deposits as related to structural features, Princeton Univ. Press, New Jersey, p. 143-146.

Amax, 1974, Report on history, geology, and mining operations at Climax, Climax Molybdenum Co., Molybdenum and Specialty Metals Division of Amax, Inc., 36 p. 
Anderson, A.L., 1930, Sequence of ore deposition in northern Idaho, Econ. Geol, v. 25, no. 2, p. 160-175.

Anderson, A,L, 1946, Lead-silver mìnerglization in the Clark Fork district, Bonner County, Idaho, Econ. Geol, v. 41, no. 2, p. 105-123.

Anderson, A.L., 1953, Gold-copper-lead deposits of the Yellowjacket District, lemhi County, Idaho, Idaho Bur. Mines E Geol. Pamphlet 94, p. $27-32$.

Anderson, A.l., 1961, Thorium mineralization in the Lemhi Pass area, bemini County, Idaho, Econ. Geol., v. S6, no. 1, p. 177-197.

Anderson, A.L., 1947, Geology of the lead-silver deposits of the Clark Fork sistrict, Bonner County, Idaho, U.S. Geol. Survey Bu1l. 944B, p. $37-117$.

Anderson, C.A., Scholz, E.A., and Strobell, J.D., Jr., 1955, Geology and ore deposits of the Bagdad area, Yavapai County, Arizona, U.S. Geol. Survey Prof. Paper $278,103 \mathrm{p}$.

Anderson, G.J., 1968, The Marquette district, Michigan, in Ore deposits of the United States, 1933-1967, AIME, Now York, v. l, p, 508-517.

Anderson, M.N., 1973, Undeground mining, Mining Eng., v. 25, no. 2, p. 54-55.

Anderson, R.A., 1967, Graben structure in the Coeur d'Alene district, Econ, Geol, v. 62, no. 8, p. 1092-1094.

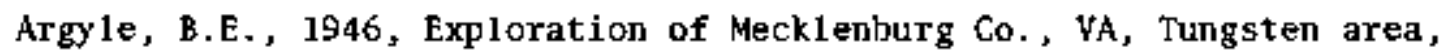
U.S. Bur. Mines, RI 3857, 5 p.

Arizona Bur. Mines, 1950, Artzona zinc and lead deposits, Part I, Arizona Bur. of Mines, Geol. Ser. I8, Bul1. I56.

Arizona Republic, 1969 , December 30, p. 25.

Arnold, R.G., Coleman, R.G., and Fryklund, V.C., 1962, Temperature of crystallization of pyrrhotite and sphalerite from the Highland Surprise Mine, Coeur d'Alene distriet, Idaho, Econ. Geol., v. 57, no. 8, p. $1163-1174$.

Ash, J.L., Russe11, B.L., and Romme1, R.R., 1974, Improved subsurface investigation for highway tunnel design and construction, $v, l$, Subsurface invostigation system planning, Report FITWA-RD-74-29, Federal Highway Administration, Office of Research and Development, Wasliżngton, D.C. 20590, 398 p.

Asher, R.R., 1968, Geology and mineral resources of a portion of the Silver City region, Dwyhee County, Idaho, Idaho Bur. Mines Geol., Pamph. $138,106 \mathrm{p}$.

Asher, J.M., ed., 1978, National waste terminal storage program progress report for period october 1, 1976, to September 30, 1977, Office of Weste Isolation, Dak Ridge, Report Y/OHI-9, 403 p. 
Aubury, L., 1908, Copper resources of California, Calif. State Mining Bur. Bu11. 50, p. 132.

Ba11, S.H., 1907, The Hartville iron-ore range, Hyoming, in Enonons, S.F., Ecke1, E.C., eds., Conzributions to economic geology, 1906, Part I, Metals and nonmeta1s, except fuels, U.S. Geo1. Survey Bull. 315, p. 190-205.

Ballard, T.J., and Clayton, A.B., 1948, Investigation of the Ore Knob Copper Mine, Ashe County, North Carolina, U.S. Bur. Mines Report Invest. RI-4341, $8 \mathrm{p}$.

Ballou, L.B., 1978, Terminal storage $R$ and D - Studies of NTS rocks (C1imax Granite), in Ramspott, L.D., ed., Haste isolation projects FY 1977, Lawrence lívermore Laboratory, Report UCRL-50050-77.

Bancroft, H., 1914, Ore deposits of northeastern Washington (including a section on the Republic mining district, by $W$. Lindgren and $H$. Bancroft), U.S. Geol. Survey Bull. 550, 215 p.

Barnes, M.P., and Simos, J.G., 1968, Ore deposits of the Park City district with a contribution on the Mayflower Lode, in Ore deposits of the United States, 1933-1967, AIME, New York, v. 2 , p. 1103-1126.

Barton, W.R., and Ratte, C.A., 1978, Minerals in the economy of Veranont, U.S. Bur. Mines State Mineral Profiles SMP-2.

Basu, D., and Sclar, C.B., 1976, Genesis of the Grace Mine magnetite deposit, Morgantown, Berks County, Pennsylvania, Geol. Soc. Amer. Abstr. Prog., 89th Annua1 Heeting, Denver, Colorado, November g-11, 1976 , v. 8, no. 6, p. 769-770.

Bateman, A.M., 1942, Economic minera1 deposits, J. Wiley \& Sons, New York, $898 \mathrm{p}$.

Bateman, P.C., Erickson, H.P., and Proctor, P.D., 1950, Geology and tungsten deposits of the Tungsten Hills, Inyo County, California, Calif. J. Mines and Geol., v, 46, no. $1,23-42$.

Bateman, P.C., 1956, Economic geology of the Bishop Tungsten district, Califormia, Calif. Div. Mines Spec. Rept. 47, 87 p.

Bateman, P.C., 1965, Geology and tungsten mineralization of the Bishop district, California, U.S. Geol. Survey Prof. Paper 470, $208 \mathrm{p}$.

Bateman. P., 1965, Geologic map of the Blackcap Mountain Quadrangle, U.S. Geol. Survey Map GQ-42B.

Bayley, W.S., 1904, The Menoninee iron bearing district of Michigan, U.S. Geol. Survey Monograph 46, 513 p. 
Bayley, R.W., Dutton, C.E., and Lamey, C.A., 1966, Geology of the Menominee iron bearing district, Dickinson County, Michigan, and Florence and Marinette Counties, Wisconsir, U.s. Geol. Survey Prof. Paper 513, $96 \mathrm{p}$.

Bayley, R.W., 1968, Ore deposits of the Atlantic City district, Fremont County, Hyoming, in Ore deposits of the United States, 1933-1967, AIME, New York, v. 1, p. 589-604.

Bea11, J.V., 1973, Copper in the United states - A position survey, Mining Eng., v. 25, no. 4, p. 35-47.

Beck, W.A., 1946, Exploration of the Piedmont Manganese be1t, McCormick County, So. Carolina, and Wilkes County, Georgia, U.S. Bur. Mines RI $3858,5 \mathrm{p}$.

Becraft, G.E., Pinckney, D.M., and Rosenblum, S., 1963, Geology and mineral deposits of the Jefferson City Quadrangle, Jefferson and Lewis and Clark Counties, Montana, U.S. Geo1. Survey Prof. Paper 428, $101 \mathrm{p}$.

Becraft, G.E., Weis, P.L., 1963, Geology and mineral deposits of the Turtle Lake Quadrangle, Washington, U.S. Geol. Survey Bul1. 1131, $73 \mathrm{p}$.

Behre, C.H., Jr., 1953, Geology and ore deposits of the west slope of the Hosquito Range, Colorado, U.S. Geol. Survey Prof. Paper 235, $176 \mathrm{p}$.

Belitzky, B., 1977, Soviet Science, the Soviet Answer to nuclear waste, New Scientist, v. 74 , no. 1048, p. 128-129.

Beltrame, R.J., 1977, Directory of information on Cuyuna range, geology and mining, Minn. Geol. Survey, Inf. Circ. 12, $22 \mathrm{p}$.

3enedict, H.C., 1952, Red metal. The Calumet and Hecla story, Univ. Mich. Press, Ann Arbor, 257 p.

Bemett, E.H., and Galbraith, J.H:, 1975, Reconnaissance geology and geochemistry of the Silver City, South Mountain region, Owyhee County, Idaho, Idaho Bur. Mines $\&$ Geol. Pamph. 162, 88 p.

Bennington, K.E., 1951, Paragenesis, Chewelah district netalliferous deposits, Washington State College, MS thesis.

Berg, H.C., and Cobb, E.H., 1967, Hetalliferous lode deposits of Alaska, U.S. Geol. Survey Bul1. 1246, 254 p.

Berg, R.B., 1971, Current geologfcal and geophysical studies in Montana, Mortana Bur. Mines Geol. Special Pub. 56, $15 \mathrm{p}$.

Bergendahl, M.H., and Koschnann, A.H., 1971, Ore deposits of the KokomoTeлmile district, Colorado, U.S. Geol. Survey Prof. Paper 652, 53 p. 
Biewesderfer, 6.K., and Leske, R.H., 1961, Ground water control at Grace Mine, Mining Congress J., v. 47, no. 10, p. 39-44.

Billings Geologica1 Society, 1952, Somenberg, F.P., ed., Guidebook Third Annual Field Conf., 3 - Black Hills and Williston Basin, Septenber $4-7,1952,149 \mathrm{p}$.

Billings, M.P., 1942, Structural geology, Prentice-Hall, Inc, Englewood Cliff5, New Jersey, Chapt. 18-Plutons, p. 285-320, Chapt. 19 Emplacement of large plutons, p. 321-335.

Billingsley, P., and Grimes, J.A., 1918, Ore deposits of the Boulder Batholith of Montana, AIME Trans., v. 58, p. 284-361.

Binghar, J., ., ]957, Grace Mine, Mining Eng,, v, 9, no. 1, p. 45-48

Blaír, B.E., 1955, Physical properties of mine rock, Part III, U.S. Bur. Mines Rept. Invest. 5130, $69 \mathrm{p}$.

Blake, W.P., 1888 , The rainbow lode, Butte City, Hontana, AIME Trans., v. $16, \mathrm{p} .65-80$.

Blake, W., 1971, Rock burst research at the Galena Mine, Wallace, Idaho, U.S. Bureau Mines Tech. Prog. Rept. 39, $22 p$.

1972, Destressing tests at the Galene Mine, Wallace, Idaho, Soc. Mín. Eng, AIME Trans., v, 252, no. 3, p. 294-299.

Board, M.P., 1977. Drift support design for the Thick Sulfide Mine, Pinal County, Arizona, MS thesis. University of Minnesota.

Bond, J.G., compiler, 1978, Geologic map of Idaho, Idaho Dept. of Lands, Bur. Mines Geol, , and U.S. Geol. Survey.

Bonham, H.F., 1969, Geology and mineral deposits of Washoe and Storey Counties, Nevada, (with section on industrial rock and mineral deposits by K.G. Papke), Nevada Bur. Mines Bull. 70, $140 \mathrm{~g}$.

Bonnjckson, B., 1972, Southern part of Duluth complex, in Geology of Minnesota, a Centennial Volume, Minn. Geol. Survey, St. Paul, p. $361-387$.

Bostrom, R.C., and Sherif, M.A., 1970, Disposal of waste material in tectonic sinks, Nature, $v .228$, no. 5267, p. 154-156.

Boutwel1, J.M., 1904, Iron ore in the Uinta Mountains, Utah, in Contributions to econonic geology 1903, Emmons, S.F., Hayes, C.N., eds., U.5. Geol. Survey Bull. 225, p. 221-228.

Boutwell, J.M., 1912, Geology and ore deposits of the Park City district, Utah (with contributions by $\mathrm{l}_{+} \mathrm{H}$. Woolsey), U.S. Geol. Survey Prof. Paper 77, 231 p. 
Brimhal1, 6., Jr., 1973, Mineralogy, texture and chemistry of early wal1 rock a1teration in the deep underground mines and continental area, Butte district, Montana, in Soc. Econ. Geo1. Butte Field Meeting Guldebook, Anaconda Co., Butte, Montana, p. H1-H4.

Brimhall, G.H., Jr., 1979, Lithologic determination of mass transfer mechanisms of multiple-state porphyry copper mineralization at Butte, Montana, Vein formation by hypogene leaching and enrichnent of potassiun-silicate protore, Econ. Geol, v. 74, no. 3, p. 556-589.

Broderick, T.M., and Hoh1, C.D., 1935, The Michigan copper district, in Copper resources of the world, I6th International Geol. Congr., Hashington, D.C., v. 1, p. 271-2B4.

Broderick, T.M., Hohl, C.D., and Eidemiller, H.N., 1946, Recent contributions to the geology of the Michigan copper district, Econ. Geol., v. 41 , no. 7, p. $675-725$.

Broderick, T.M., 1956, Copper deposits of the Lake Superior region, Econ. Geol, v, 51, no. 3, p. 285-287.

Brookmyer, B., 1978, Pennsylvania's Cornwal1-type iron mines, Rocks Miner., v. 53, no. 3, p. 135-139.

Brooks, A.H., 1907, The mining industry in 1906, U.\$. Geol. \$urvey Bull. 314A, p. $19-39$.

1910, The mining industry in 1909, U.S. Geol. Survey Bu11. 442A, p. 20-46.

1912, The mining industry in 1911, U.S. Geol. Survey But1. 520A, p. 17-44.

1913, The mining industry, U.S. Geol, Survey Bull, 542A, p. 18-51.

1914, The Alaskan mining industry in 1913, U.S. Geol. Survey Bull. \$92A, p. 45-74.

1915, The Alaskan mining industry, U.S. Geol. Survey Bull. 622A, p. 15-68.

1916, The Alaskan mining industy, U.5. Geol., Survey Bul1. 642A, p. $16-71$

1918, The Alaskan mining industry in 1916, U.S. Geol. Survey Bull. $662 \mathrm{~A}, \mathrm{p}, 11-62$.

1921, The future of Alaska nining, U.S, Geol. Sarvey Bul1. 714A, p. 5-57.

Brooks, A.H., and Martin, G.C., 1921, The Alaskan nining industry in 1919, U.S. Geol. Survey Bull. 714A, p. \$9-95.

Brooks, A.H., 1922, The Alaskan mining industry in 1920, U.S. Geol. Survey Bull. 722A, p. 7-74. 
1923. The Alaskan mining industry in 1921, U.S. Geol. Survey Bull, $739 A$, p. $1-50$.

Brooks, A.H., and Capps, S.R., 1924, The Alaskan mining industry in 1922, U.S. Geo1. Survey Bull. 755A, p. 3-56.

Brooks, A.H., 1925, Alaska's mineral resources and production, 1923, U.S. Geol. Survey Bull, 773A, p. 3-52.

Brooks, T.S., Punpelly, R., and Rominger, C., 1873, Upper Peninsula, 1869-1873, Geo1. Survey Mich., v. 1, \$67 p.

Brosege, W.P., and Pessel, G.H., 1977, Preliminary Reconnaissance Geologic Map of Survey Pass Quadrangle, Alaska, U.S. Geo1. Survey Open File Map 77-27.

Brown, G.C., 1916, Siskiyou County, Calif. Min. Bur. Rept. 14, p. 810827 .

Brown, J.S., and Engel, A.E.J., 1956, Revision of Grenville stratigraphy and structure in the Balmat-Edwards district, northwest Adirondacks, New York, Geol. Soc. Aner. Bull, v, 67, no. 12, p. 1599-1622.

Brown, J.S., 1968, Ore deposits of the northeastern United States, in Ore deposits of the United States, 1933-1967, AחE, New York, v.1, p. $1-19$.

Brom, L.A., 1970, Strain distribution around underground openings, Data Bank: Underground openings rock deformation messurenents - Abstracts, Technical Report 3 , Office of Chief of Engineers, Department of the Army, Washington, D.C., 256 p.

Brown, A.C., 1971, Zoning in the thite Pine copper deposit, Ontonagon County, Michigan, Econ. Geo1, v. 66, no. 4, p. 543-573.

1973, Mineral assemblages in the White Pine cooper district, northern Milchigan (USA), p. 65-83, In Probleme der Paragenese, Topical Report of Iagod, $v .4$, Internationa Union of Geological Sciences, International Association on the Genesis of Ore Deposits, c 293 - Erkundungs Geologie, Veb Deutscher Verlag für Grundstoffindustrie, Leipzig.

1974. An epigenetic origin for stratiform $\mathrm{Cu}-\mathrm{Pb}-\mathrm{zn}$ sulfides in the lower Nonesuch Bhale, white Pine, Michigan, Econ. Geol., V. 69, no. 2, p. 271-274.

Brunton, G.D., and McClain, W.C., 1977, Geologic criteria for radioactive waste repositiories, Office of Waste Isolation, Oak Ridge, Report Y/OWI /TM-47, $12 \mathrm{p}$.

Buchanan, J.F., and Buchella, F.H., 1960, History and development of the San Manuel Mine, AIrE Trans., V. 217, p. 394-404,

Buddington, A.F., 1959, Granite emplacement with special reference to N. America, Geol. Soc. Amer. Bul1., v, 70, no. 6, p. 671-747. 
Buddington, A.F,, and Leonard, B.F., I962, Regional geology of the St. Lawrence County magnetite district, northwest Adírondacks, N,Y., U.S. Geol. Survey Prof. Paper 376, 145 p.

Buddington, A.F., 1963, Metasomatic origin of large parts of the Adirondack placoliths, A discussion, Geol, Soc. Aner. Bull, V. 74, no. 3, p. 353-354,

1966, The precambrian magnetite of New York and New Jersey, Econ. Geo1., v. 61, no. 3, p. 484-510.

Bureau of Mines, 1967, Ryan Lode, Heavy Metals Sit, Rept, 12 (Jan)

Burbank, w.S., 1935, Copper-bearing ores of Colorado, in Copper resources of the world, 16th International Geological Congress, George Banda Publishing Co., Menasha, Wisc., p. 253-260.

Burbank W.S., and Luedke, R.G, 1961, Origin and evolution of ore and gangueforning solutions, Silverton Caldera, San Juan Mountains, Colorado, U.S. Geol, Survey, Prof. Paper 424C, p, C7-Cl1.

1968, Geology and ore deposits of the western San Juan Mountains, Colorado, in Ridge, J.D., ed., Ore deposits of the United States, 1933-1967, AIME, New York, v. 1, p. 714-733.

Bush, J.B., and others, 1960, The Chief oxide-Burgin area discoveries, East Tintic district, Utah, A case history, U.S. Geol. Survey studies and exploration, Econ. Geol., v. 55, no. 6, p. 1116-1147, part 1 - U.S. Geol. Survey Studies and Exploration, Lovering, T.S., and Morris, H.T.

Bush, J.B, and Cook, D.R., 1960, The Chief Oxide-Burgin area discoveries, East Tintic district, Utah, A case history, Part II - Bear Creek Mining Company studies and exploration, Econ. Geol, v. \$5, no. 7, $1507-1540$.

Butler, B.S., and Loughlin, G.F., 1916, A reconnaissance of the Cottonwood-American Fork mining region, Utah (with notes on history and production by V.C. Heiles), U.S. Geol. Survey Bul1. 620-I, p. 165-226.

Butler, B.S., and others, 1920, Ore deposits of Utah, U.S. Geol. Survey Bull. 111, $672 \mathrm{p}$.

Butler, B.S., and Burbank, W.S., 1929, The copper districts of Michigen, U.S. Geo1. Survey Prof. Paper 144, 238 p.

Butler, B.S., and Vanderwilt, 1933, The Climax Molybdenum deposit, Colorado, U.S. Geo1. Survey Bu11. B46C, p. 195-237.

Butler, B.S., and Wilson, E.D., 1938, Bagdad Mine, Eureka district, in Geology and ore deposits of the Tombstone district, Arizona, by $\bar{B} . S$. Butler, E.D. Wilson, and C.A. Razor, Ariz. Bur. Mines, Geol, Series 10, Bu11 143, p. 98-103.

Byerly, D.W., 1976, Report of investigation, underground 1imestone mines in the Ohio region, Office of Waste Isolation, Oak Ridge, Report Y/OWI/SUB- 4251/2, $20 \mathrm{p}$. 
Caddey, S.W., 1974, Structural geometry of the $J$ vein, the Bunker Hill Nine, Kellogg, Idaho, PhD thesis, Univ. Idaho, Moscow, $481 \mathrm{p}$.

Cairney, T., 1973, Utilization of disused coal mines as water storage reservoirs, J. Hydrol., v. 19, no. 3, p. 251-258.

Calif. Div. Mines, 1935, Report of the state mineralogist, Resources of Siskiyou County, Calif. Div. Mines Report 31, p. 255-388.

Calif. Div. Mines \& Geol., 1979, Mines and mineral producers in California, 1978, Calif. Div. Mines Geol. Spec. Pub. 43.

Calif. J. Min, Geol., 1947, v. 43, no. 4, p. 425-427. 1956, v. 52 , no. 1, p. $255+259,270$.

Calkins, F.C., 1909, A geological recommaissance in northern Idaho and northwestem Montana (with notes on the econonic geology, by P.P. MacDonald), U.S. Geol. Survey Bull. 384, 112 p.

Calkins, F.C., and Butler, B.S., 1943, Geology and ore deposits of the Cottonwood - American Fork area, ltah, U.S. Geol. Survey Prof. Paper 201, 152 p.

Callaghas, E., and Lemonon, D.M., 1941, Tungsten resources of the Blue Wing district, Lemhi County, Idaho, v.\$. Geol. Survey Bull. 931A, p. 1-21.

Callahan, W.H., 1966, Genesis of the Franklin-Sterling, New Jersey, ore bodies, Econ. Geol., v. 61, no, 6, p. 1140-1141. 1977, The history of the discovery of the zinc deposit at Elnwood, Temnessee, Concept and consequence, Econ. Geol, v. 72, no. 7, p. 1382-1392.

Calson, D.K., and Clsrk, H.B., 1956, Lode gold mines of the AlleghenyDownieville area, Sierra County, Calffornia, Calif. J. Mines \& Geol., v. 52, no. 3, p. 237-272.

Cameron, E.N., and others, 1954, Pegratite investigations, 1942-45, in New England, U.S. Geol. Survey Prof, Paper 255, 325 p.

Cammarota, V.A., and others, 1976, Trip report to Tennessee zinc mines, Bur. Mines Menorandum, Jan. 8, 1976, p. 3.

Canadìn Mines Handbook, 1978-79.

Canney, F.C., 1965, Geochersical prospecting investigations in the copper belt of Vermont, U.S, Geol. Survey Bull. 1198B, $28 \mathrm{p}$.

Cannon, W.F., 1976, Hard iron ore of the Marquette range, Michigan, Econ. Geol, v. 71, no. 6, p, 1012-1028. 
Caxpenter, R.H., 1968, Geology and ore deposits of the Questa Nolybdenum Mine area, Taos county, New Mexico, in Ridge, J.D. ed., Ore deposits of the United States, 1933-1967, AIME, New York, v. 2, p. 1328-1350.

Carr. W.J., and Trimble, D.E., 1961, Upper paleozoic rocks in tile Deep Creek Mountains, Idaho, U.S. Geol. Survey Prof. Paper 424C, p. C181C184.

Carter, D.A., 1963, Sunrise Iron Mine, Wyoning, in Guidebook to the geology of the northern Denver basin and adjacent uplifts, Rocky Mountain Assac., Geologists, 14th Field Conf., 1963, Denver, Colo., P. 264266.

Carter, R.H., 1975, Miami East Mine development nears completion, Mining Eng., v. 27, no. 5, p. 14 .

Carter R.H., and Li, T.M., 1976, Idaho's Coeur d'Alene district sets sights on record production, Mlning Eng., v. 28, no. 7, p. 49-64.

Carzon, J.J., 1963, Changing rining methods at the Holden Mine, AIME Trans, v. 163, p. 73-95.

Gater, F.H., and Crowder, D.F., 1967, Geologic map of the Holden Quadrangle, Snohomish and Chelan Counties, Washington, U,S. Geol. Survey Quad. Map, $Q Q-646$.

Cater, F.W., and others, 1973, Mineral resources of the Idaho primitive area and vicinity, Idaho (with a section on the Thunder Mountain district, by B.F. Leonard, and a section on aeromagnetic interpretation, by W.E. Davis, U.\$. Geol. Survey Bull. 1304, 431 p.

Cathcart, S.H., 1922, Metalliferous lodes in southern Seward Peninsula, U.S. Geo1. Survey Bul1. 722F, p. 163-261.

1922, Metalliferous lodes in southern Seward Peninsula, Alaska, U.S. Geoi. Survey Bu11, 722F, p. 163-261.

Champlin, J.B.F., Thomas, R.D., and Brownlow, A.D., Laboratory testing and evaluation of porous perneable rock for nuclear waste disposal, U.S. Bur. Nines Rept. Invest. 6926, 33 p.

Chan, S.S.M., 1967, Mineraloglcal and geochenical studies of the vein minerals fron the Galena Mine, Shoshone county, Idaho (abstract), Diss. Abstr., Sect. B, Science and Eng., v. 28, no. 4, p. 1574B.

1969 , Suggested guides for exploration from geochenical investigations of ore veins at the Galena Mine deposits, Shoshone County, Idaho, Colo. Sch. Mines Quart., v. 64, no. 1, p. 139-168.

Chan, S.S.H., Crocker, T.J., and Waddel, G.C., 1972, Engineering properties of rocks and rock masses in the deep mines of the Coeur d'Alene mining district, Idaho, AIME Trans., v. 252, p. 353-360. 
Chan, S.S.M., and Crocker, T.J., 1972, A case study of the in situ rock deformation behavior of the Silver Sumeit Mine, Coeur d'Alene mining district, Can. Rock. Mech, Symp., Proc. 7, p. 135-151.

Chapin, T., 1914, lode developments on Seward Peninsula, U.S. Geo1. Survey Bu11. 5921, p. 397-407.

1919, Mining in the Fairbanks district, U.S. Geol. Survey Bul1. 692F, 408 p.

Chinn, w., 1970, Structural and mineralogical studies at the Homestake Mine, Lead, South Dakota, Diss. Abstr. Int., v. 31, no. 4, p. 2061 B.

Clark, L.D., and Miller, F.K., 1968, Geology of Chewelah Mt. Quad, Stevens County, Washington, Washington Div. Geol. Map GMS.

Clark, W.B., 1970, Gold districts of California, Calif. Div. Mines 8 Geol. Bull, 193, p. 19-24.

Clark, T.H., and Starn, C.W., 1968, The geologic evolution of North America, The Ronald Press Co., New York, $434 \mathrm{p}$.

Clayton Silver Mines, 1978, Annual Report, 8 p.

Cobb, E.H., 1972, Metallic mineral resources map of the Ambler River Quadrangle, Alaska, U.S. Geo1. Survey Map MF454.

1972, Metallic mineral resource map of the Fairbanks Quadrangle, Alaska, U.S. Geol. Survey Map Mf4lo.

1972, U.S. Geo1, Survey Open F1le Report 508, p. 33-35.

1973, Placer deposits of Alaska, U.S. Geol. Survey Prof. Paper $1374,213 \mathrm{p}$.

Cobbs, J.N., Engineering, Tulsa, 0k1ahoma, 1975, Study of mined storage caverns, Report ORNL/SUB-75/64509, Office of Waste Isolation, Oak Ridge, Terr., $161 \mathrm{p}$.

Cobbs Engineering, 1976, Survey of active and inactive mines for possible use as in situ test facilities, Office of Waste Isolation, Dak Ridge, Report Y/OWI/\$UB-76/16\$14.

Cohen, L., l'nderground test factlities to resolve scientific and technical questions on isolating high-level nuclear waste in fractured rocks, Lawrence Rerkeley Laboratory report 1.BL-9691, in preparation, 1980 .

Collier, A.J., 1904, The tir deposits of the York region, Alaska, U.S. Geol. Survey Bul1. 229, $61 \mathrm{p}$. 1904, Quicksilver, tin, tungsten, chromiun, and nickel-tin deposits of the York region, Alaska, in Contributions to economic geology, 1903 , U.S. Geo1. Survey Bu11. 225, p. 157-160.

1905, Recent development of Alaskan tin deposits, U.S. Geol. Survey Bu11. 259, p. 120-127. 
Collins, L.G., 1968, Trace ferrides in the magnetite ores of the $\mathrm{Nt}$. Hope Mine and the New Jersey Highlands, Econ. Geol., v. 63, no. 2, p. 193-195.

Colony, R.J., 1921, The magnetite iron deposits of southeastern New York, New York State Museur Bu11. 249-250, p. 118+120.

Colorado Bureau of Mines, 1971, A sumary of mineral industry activities in Colorado 1970 , [p. 16-2B, Mining activities by districts; p. 6285 , Mining operations of Colorado).

Colorado Mining Association, 1978, The 1978 Mining Year book, 81st National Western Mining Conference \& Exhibition, Feb., 1978, Colorado Mining Association, Denver.

Colson, J.B., 1961, The Geology of the Sunshine Mine, in Guidebook to the geology of the Coeur d'Alene mining district, Idaho, Idaho Bur. Mines \& Geo1. Bu11. 16, p. 30-34.

1963, Geologic features of the Sunshine Mine, Idaho Bur. Mines \& Geo1. Pamph. 133, p. 69-72,

Conway, J., 1972, Physical properties of mine rocks, Bunker Hill Mine, Coeur d'Alene district, Idaho, AIf Trans., v. 252, p. 359, App. 1.

Cook, 1954, Mining Geology of the Seven Devils Region, Idaho Bur. Mines of Geol. Pamph. 97, p. 13.

Cook, D.R., ed., 1961, Geology of the Binghan mining district and northern Oquirrh Mountains, in Guidebook to the Geology of Utah 16, Utah Geol. Soc., 145 p.

Cording, E.J., Hendron, A.J., Jr., and Deere, D.U., Rock engineering for underground caverns, Symposium underground rock chambers, Phoenix, Arizona, p. 567-600.

Cording, E.J., and others, 1975, Methods for geotechnical observations and instrumentation in tunneling, Dept. Civil Eng., Univ. I11inois at Urbana-Champaign, Report No. UI Lلj-Eng 75 2022, v. 1, 292 p.

Corn, R.M., 1975, AIteration-mineralization zoning, Red Mountain, Arizona, Econ. Geol., v. 70, no. 8, p. 1437-1447.

Cornwall, H.R., and others, 1947, Detajled geologic maps of recently active copper mines, Houghton and Keweenaw counties, Michigan, U.S. Geol. Survey Open File Rept. 43 p.

Cornwal1, H.R, and Wright, J.C., 1956, Geologic map of the Lauriun Quadrangle, Michigan, U.S. Geo1. Survey Map MF47.

Geologic map of the Hancock Quadrangle, Michigan, U.S. Geol. Survey Map MF46. 
Cornwall, H.R., 1972, Geology and mineral deposits of southern Nye County, Nevada, Nevada Bur. Mines Geol. Bull. 77, $49 \mathrm{p}$.

Council, R.J., 1954, The commercial granites of North Carolina, North Carolina Div. Min. Res. Bull. 67.

Courtright, T.R., 1974, Geology of the upper Boxelder Creek area, Larimer County, Colorado, MS thesis, Colorado

Cox, M,W., 1968, Van Stone Mine area (lead-zinc), Stevens County, Washington, in Ridge, J.D. ed, Ore deposits of the United States, 1933-1967, AIME, N̄ew York, v. 2, p. 1511-1520.

Cox, D.P., and others, in United States Mineral Resources, Brobst, D.A., and Pratt, W.P. eds., 722 p.

Creasey, S.C., and Quick, G.l., 1955, Copper deposits of part of Helvetia mining district, Pima County, Arizona, U.S. Geol. Survey Bull. 1027F, p. 301-323.

1955, Geology of the San Manuel area, Pinal County, Arizona, U.S.

Geo1. Survey Prof. Paper 471, 64 p.

1967, General geology of the Mammoth Quadrangle, Pinal County, Arizona, v.S. Geol. Survey Bull. 1218, $94 \mathrm{p}$.

\section{CRIB}

Crosby, G.M., 1959, Gem stocks and adjacent orebodies, Coeur d'Alene distriet, Idaho, Min. Eng., v. 11, no. 7, p. 700 .

1969, A preliminary examination of trace mercury in rocks, Coeur i'Alene District, Idaho, Colo. Sch. Mines Quart, v. 64, no. 1 , p. 169-194.

Crowder, D.F., 1959, Granitization, migmatization, and fusion in the northern Entlat Mountains, Washington, Geol. Soc. Amer. Bull,, $\checkmark$. 70 , no. 7, p. $827-878$.

Crump, R.M., and Beutner, E.L., 1968, The Benson Mines iron ore deposit, St. Lawrence County, New York, in Ridge, J.D., ed., Ore deposits of the United States, 1933-1967, AIME, New York, v. 1, p. 49-71.

Culver, H.E., and Broughton, H.A., 1945, Tungsten resources of Washington, Washington Div. Geol, Bul1, 34, 89 p.

Cummins, A, and Given, I., eds., 1973, SME Engineering Handbook.

Czamanske, G.K., and Hal1, N.E., 1975, The Ag-Bi-Pb-Sb-S-Se-Te mineralogy of the Darwin lead-silver-zinc deposit, Southern California, Econ.

Geo1., v. 70, no. 6, p. 1092-1110. 
Dale, T.N., 1907, The granites of Maine, U.S. Geol. Survey Bul1. 313, $202 \mathrm{p}$.

Dare, W.L+, 1959, Underground mining methods and costs at three Selt Wash uranium mines of Climax Uranium Co., v.S. Bur. Mines Inf. Circ. IC $-7908,36 \mathrm{p}$.

Davidson, E.S., and others, 1955, Bedrock geology of the Mohawk Quadrangle, Michigan, U.S. Geol. Survey Map GQ54.

Davidson, A., and Wyllie, P.J., 1965, Zoned magnetite and platy magnetite in Cornwall type ore deposits, Econ. Geo1., v. 60, no. 4, p. 766-772.

Davis, L.E., 1949, The psilomelane mineral of the Butte district, Montana, BS thesis, Montana School of Mines, Butte, Montana.

Deere, D.U., Merritt, A.H, and Coon, R.F, 1969, Engineering classtficattion of in situ rack, Tech. Report AFHL-TR-67-144, Air Forces Weapons lab., Kirkland AFB, New Mexico.

Dellinger, B., 1956, Underground mining - the trends in 1956, Mining Eng., v. 9, no. 2, p. 177-190.

Desai, $A_{+} J_{+}$, and others, Geologic investigation, prediction and construction, evaluation for the cooling water tunnels, Seabrook, N.H., Nuclear Power Station, in Robbins, R.J., and Con1on, R.J., eds., Rapid excavation and turneling conference, Las Vegas, Nevada, June 14-17, 1976, p. 39-63.

Di11, D.B., and De Lorraine, H., 1978, Structure, stratigraphic controls and genesis of the Balmat zinc deposit, northwest Adirondacks, New York, Geol. Soc. Amer. Abstr. Prog., v. 10, no. 7, p. 389.

Dillon, J.T., and Presse1, G.H., 1977, Alaska DGEgS Annual Report.

Dings, M.G., and Robínson, C.S., 1957, Geology and ore deposits of the Garfield Quadrangle, Colorado, V.S. Geol. Survey Prof. Paper 289, $110 \mathrm{p}$.

Dir, Reg. Standards, 1974, Classification, engineering properties and field exploration of soils, intact rock and in situ rock masses, $256 \mathrm{p}$.

Ditto, A.H., and Krizek, J.J., 1976, Implications of rock rechanics to Carr Fork project mine design, 17th sympoitum on rock mechanics, Snowbird, Utah, August 25-27, 1976, 3A6.1-3A6.3

Doe, T., 1978, Dry mines study notes.

Dowding, $\mathrm{C}_{+} \mathrm{H}_{\mathrm{H}}, 1976$, Comparison of predicted and encountered geology for seven Colorado tunnels, in Robbins, R.J., and Conlon R.J., eds., Rapid excavation and tunneling conference, Las Vegas, Nevada, June 14-17, 1976, AIME, How York, p. 19-38. 
Doyle, R.G., 1966, Base netal environments ard exploration history in Maine, Canadian Mining J., v. 87, no. 4, p. 138-140.

Dravo Corp., 1974, Aralysis of large scale non-coal underground mining methods, U.S. Bur. Mines Open File keport 36-74, NTIS PB 234-555.

Drewes, H., 1962, I. Stratigraphic and structural controls of mineralization in the Taylor mining district near Ely, Nevada, U.S. Geol. Survey Prof. Paper 4S0B, p. B1-B3.

Duba, A.H., Heard, H.C., and Santor, M. L., 1974, Effect of fluid content on mechanical properties of westerly granite, Lawrence Livernore Laboratory, Lfvermore, Calif., UCRL-51626.

Dumning, C.H., 1959, Rock to riches, Southwest Publishing Co., Phoenix, Arizona, F. 83, 84, 179-184, 200, 201, 204, 226, 227, 229, 230, 233$239,261,262-264,267,368$.

Dutton, C.E., and Zimener, P.H., 1968, Iron ore deposits of the Menominee district, Michigan, in Ridge, J.D., ed., Ore deposits of the United States, 1933-1967, AIME, New York, v. 1, p. 538-549.

Dutton, C.E., and Bradley, R.E., 1970, Lithologic, geophysical, and mineral connodity maps of precambrian rocks in Hisconsin, U.S. Geol. Survey Map I631.

Eakin, H.M., 1915, Tìn mining is Alaska, U.S. Geol. Survey Bull. 622B, p. $81-94$.

1918, Lode mining in the Juneau gold belt, U.S. Geol. Survey Bu11. $662 \mathrm{~B}, \mathrm{P}+77-92$.

Earl, K.M., 1950, Investigation of the Douglas copper deposit, Hancock County, Maine, U.S. Bur. Mines RI 4701, 17 p.

Eastlick, J.T., 1968, Geology of the Christmas Mine and vicinity, Banner mining district, Arizona, in Ridge, J. $D_{+}$, ed., Ore deposits of the United States, 1933-1967, AIME, New York, v,2, p. 1191-1211.

Ebbley, A.E., Jr., and Schumacher, J.l., 1949, Examination, mapping and sampling of tine shafts and underground workings, Leadville, Lake County, Colo., U.S. Bur. Mines RI 4518, 115 p.

Eckel, E.B., 1947, La Plata district, La Plata and Montezuma Counties, in Vanderwilt, J.W., ed, Mineral resources of Colorado, state of Colo., Min. Res. Bd., 547 p.

1949, Geology and ore deposits of the La P1ata district, Colorado (with sections by J.J. Williams, F.W. Galbraith, and others), U.S. Geol. Survey Prof. Paper 219, 179 p. 1968, Nevada test site, Geol. Soc. Amer. Merr. 110.

Econ. Geol., 1938, v. 33, p. 554-567. 
Edgerton, C.D., 1974, The mine map repository - a source of mine map data, U.S. Bur. Mines Inf. C1rc, $8657,9 \mathrm{p}$.

Elevatorski, E.A., 1978, Uranium ores and minerals, Minobras, Dana Point, Calif., $89 \mathrm{p}$.

Emmons, W.H., and Calkins, F.C., 1913, Geology and ore deposits of the Philipsburg Quadrangle, sontana, U.S. Geol. Survey Prof. Paper 7B, $271 \mathrm{p}$.

Emons, W.H., and Laney, F.B, 1926, Geology and ore deposits of the Ducktown mining district, Tennessee, U.S. Geol. Survey Prof. Paper $139,114 \mathrm{p}$.

Emuons, S.F., Irving, J.D., and Loughlin, G.F., 1927, Geology and ore deposits of the Leadville mining district, Colorado, L.S. Geol. Survey Prof. Paper 148, $368 \mathrm{p}$.

Engel A.E.J., and Engle, C.G., 1953, Grenville series, in The northwest Adlrondacks Hountains, New York, Part I, General features of the Grenville series, Geol. Soc. Amer. Bull., v. 64, no. 12, p. 10131047.

Eng. Min. J., 1939, The Bunker Hill and Sullivan Enterprise today, $v$. 140 , no. 8, p. 35-82. 1965, v. 166 , no. 1 . 1965, Molybdenum, v. 166 , no. 1, p. 69. 1965, U.S. steel's Atlantic City ore mine first taconite producer in the west, v. 166 , no. 3, p. 73-92.

1965, White Pine pours biljionth pound, v. 166, no. 10, p. 83. 1965, Geochemistry yields Silver Bonanza, v. 166, no. 8, p. 109-110. 1967, v. 168, no. 7, p. $87-91$.

1969, Hecla describes lakeshore ore body and general operating plans, v. 170 , no. 6, p. 128, 132 .

1974, Anaconda will develop Carr Fork copper deposit in Utah's Oquirrh Mountains, v. 175 , no. 10, p. 21.

1974, Union Carbide developing Nevada tungsten property, v. 175, no. 11, p. 13 .

1974, Sherwood undertakes new underground aine development, $v, 175$, no. 11, p. 21.

1974, The Dayrock Mine, v. 175, no. 6, p. 212. 
1974, CF \& I's underground Sunrise Mine supplies Pueblo Hil1s, v. 175, no. $11, \mathrm{p} .151,152$.

1975, Henderson Mine tumnel holed through by Amax after four and a half years work, $v, 176$, no. 9, p. 37 .

1975, Automatic train transport at Henderson, v. 176, no. 9, p. $105-$ 106.

1976, Ainax steps of exploration at Minnanax copper-nickel prospect in Minnesota, v. 177, no. 2, p. 17, 138.

1976, Climax Molybdenum's new Henderson project set to go on stream in July, v. 177, no. 6, p. 23, 27.

1976, Asarco's newly dedicated Coeur silver mine will be fourth larges in U.S., v, 177, no. 7, p. 23-27.

1976, Hodern plant aids St. Joe processing of elusive balnat ores, v. 177 , no. 11, p. 92-99.

1976, St. Joe Minerals: Growing through diversification, $v, 177$, no. 11, p. $69-124$

1976. New exploration and development at leadt frosting on Honestake's looth błrthday cake, v. 177, no. 5, p. 90-97.

$1977, \mathrm{E} / \mathrm{MJ}$ Survey, of mine and plant expansion, $v .178$, no, $1, \mathrm{p}$ 5770 .

1977, Union Carbide revives Nevada tungsten mine, v. 178, no. 6, p. 129.

1977. International directory of mining and mineral processing operation, McGraw Hill, New York, $229 \mathrm{p}$.

1978, San Manuel Mine, v. 179, no. 1, p. 133-135.

1978, Magma copper, v. 179, no. 4, p. 142, 144.

1978, Coeur Mine, v. 179, no. 4, p. 146.

1978, lakeshore Mine, v. 179, no. 7, p. 123.

1978, Lakeshore Mine, v. 179, no. 9, p. 314

1978, Cotter Corp. noves ahead on several fronts, v. 179, no, 11, p. $136-138$.

1978, Mines Directory 
1979, Noranda to reopen Lakeshore Mine on Papago land, v. 180, no. 4, p. 41 .

Ensign, C.0., Jr, and others, 1968, Copper deposits in the Nonesuch Shale, Whtle Pine, Michigan, in Ridge, J.E., ed., Ore deposits of the U.S., 1933-1967, AIME, New York, v. 1, p. 460-488.

Erickson, A.J., Jr., 1968, Ontario Mine, east flank ore bodies, in Erickson, A.J., Jr., Phillips, W.R., and Garmoe, N.J., eds., Park City district, Utah, Guidebook to the geology of Utah, No. 22, p. 56-65.

Epenshade, G.H., 1947, Tungsten deposits of Vance County, N.C., and Mecklenburg County, VA., J.S. Geol. Survey Bull. 948A, 17 p.

Ettinger, I.A., and Short, M.N., 1935, The Magna Mine, Superior, in Copper Resources of the World, 16th International Geological Congress George Banda Publ, Co., Menasha, Wisc., p. 207-213.

Evans, L.L. 1977, Geology of the Brushy Creek Mine, Vibormum Trend, southeast Missouri, Econ. Geo1., v. 72, no. 3, p. 381-390. 
Fairhurst, C., 1979, Improved stress determinations by hydraulic featuring, U.S, Geol. Survey Open File Report 79-387, p. 48.

Farmin, R., 1961, Geology of the Dayrock Mine, in Guidebook to the geology of the Coeur d'Alene mining district, Idaho: Idaho Bur. Mines \& Geol. Bull. 16, p. 21-22.

Farquhar, O.C., 1974, Geological survey of potential cavern areas in New England, Dept. Geol. \& Geogr. Report Lc 74-81924, $360 \mathrm{p}$.

Fenix and Seisson, 1978, Mineability study of the terminal waste storage program - Eleana Investigation, DOE Nevada Operations Offlce Report NWO-0038-35, 15 p.

Ferguson, H.G., 1913, Lode deposits of the Allegheny district, Calif.: U.S. Geol. Survey Bull. 580, p, 176-177.

Ferguson, H.G., and Ganrett, R.W., 1932, Quartz veins of the Allegheny district, Caltf., U.S. Geol, Survey Prof. Paper 172, p. 98-101.

Fletcher, J.B., 1960, Ground movement and subsidence from block caving at Miami Mine, AIVE Trans., v. 217, p. 413-422.

Flint, R.F., 1957, Glacial and pleistocene geology, John Wiley Sons, New York, $553 \mathrm{p}$.

Foose, M.P., and Slack, J.F., 1978, Premetamorphic hydrothermal origin of the Tungsten Queen vein, Hanne district, North Carolina, as indicated by mineral textures and minor structures, U.S. Geol. Survey Open File Report 78- 427, 39 p.

Forbes, R.B., and others, 1973, Alaska D.G. \& G.S. Annual Report.

Forrester, J.D., 1972, skarn formation and sulfide mineralization at the Continental Mine, Fierro, New Nexico, Pho Thesis, Comell Univ.

Fox, K.F., Jr., Rirehart, C.D., and Enge1s, J.C., 1977, Plutonism and orageny in north-central Washington - Timing and regional context, U.S. Geol. Survey Prof. Paper 989, 2 p.

Fritts, C.E., 1970, Alaska Div. Mines a Geol. Geology Report. 1970, Geological Report 39, State of Alaska, Dept, of Natural Resources .

Fryklund, V.C., Jr., and Harner, R.S., 1955, Cominents on minor elements in pyrrhotite: Econ. Geol., v. 50, no. 3, p. 339-344,

Fryklund, V.C., Jr., 1961, General features of the ore deposits of the Coeur d'Alene district, Idaho, in Guidebook to geology of the Coeur d'Alene Mining district, Idaho: Idaho Bur. Mines Geol. Bull. 16, p. 6-8. 
1964, Ore deposits of the Coeur d'Alene district, Shoshone County, Idaho, U.S. Geol. Survey Prof. Paper 445, $103 \mathrm{p}$.

Ful1, R.P., 1955, Structural relations north of the Osburn Fault, Coeur d'Alene district, Shoshone County, Idaho; Iniversity of Idaho thesis.

Fullagar, P.D., Brown, H.S., and Hagner, A.F., Geochenistry of wall rock alteration and the role of sulfurization in the formation of the Ore Knob sulfude deposit, Econ. Geol., v, 62 no, 6, p. 798-825.

Fulweiler, R.E., and McLougal, S.E., 1971, Bedded-ore structures, Jefferson City Mine, Jefferson City, Tennessee, Econ. Geo1., v.66, no. 5, p. $763-769$.

Garmoe, W.J., 1968, Breccia structures in the Ontario Mine, Park City district, Utah, in Ridge, J.D., ed., Ore deposits of the United States, 1933-1967, AIME, New York, v. 2, p. 1127-1128.

Geehan, R.W, 1946, Exploration of Crowell fluorspar mine: U.S. Bur. Min. RI 3954, 9 p.

Geehan, R.W., and Benson, W.T., 1949, Investigation of the Yellow Pine zinc-lead Mine, Clark County, Nevada, U.S. Bur. Min. RI 4613, $15 \mathrm{p}$.

Geol. Soc. Amer., 1946, Geol. Soc. Amer. Memoir 15, p. 176-178. 1955, no. 1, Appalachian, an outline of the geology in the segment in Tennessee, North Carolina, and South Carolina, Guidebook 68 th annual meeting, New orleans.

1956, no. 1, Precambrian and northeastern Minnesota, Guidebook 69 th annual meeting, Minneapolis.

19 , Geol. Soc. Amer, Bult. v. 58, no. 12, p. 1085-1160.

1959, no. 4, Mineral deposits of eastern Pennsylvania, Guidebook 72nd annual meeting, Pittsburgh.

Geol. Soc. Amer. Southeastern Section, 1961, Geology of the MascotJefferson City zinc district, Tennessee, Structural geology along the eastern Cumberland escarpnent, Tennessee, Guidebook.

Georgia Univ., 1976, Geologic feasibility of talc and serpentinite bodies from the Appalachian Mountain region of eastern Inited States with regard to siting of radio-active waste repositories, part $I$, additional conclusions, $Y /$ OWI/SJB-4496/2, $30 \mathrm{p}$.

Geoscience Information Society, 1968, Geologic field trip guidebooks of North America, a union list incorporating monographic titles, guidebook and ephemeral: Houston, Geoscience information society, $97 \mathrm{p}$.

Gillerman, E., 1952, Flourspar deposits of Burro Mountains and vicinity, New Mexico: U.S. Geol. Survey BuII. 973-F, 289 p. 
1964, Mineral deposits of western Grant County, New Mexico, New Mexico Bur. Min. Res. Bul1, 83, 213 p.

Gilluly, J, 1935, Ajo district, in The copper district of Arizona, Copper resources of the world, 16th International Geological Congress: George Banda Publishing Co., Menasha, Wisconsin, p. 228-233.

1946, The Afo mining district, Arizona, U.S. Geol. Survey Prof. Paper 209, $112 \mathrm{p}$.

Gilmour, P., and Still, A.R., 1968, The geology of the Iron King Mine in Ridge, J.D., ed., Ore deposits of the Unjted States, 1933-1967, AIME, New York, v. 2, p. 1239-1257.

Goddard, E.N., 1966, Geologic nap and sections of the Zuni Mountains fluorspar district, Valencia County, New Mexico, U.S. Geol. Survey, misc. inv. map $I-454,3 \mathrm{pp}$.

Goldich, S.S., 1968, Geochronology in the Lake Superior region, Canada J. Earth Sci., V. S, no. 3, p. 715-724.

Gonzales, \$., and Wenner, D., 1975, Compents, geologic field trip, Chatsworth, Georgia talc district, Dept Geology, Univ. Georgia, Athens, Georgia, $6 \mathrm{p}$.

Goth, J.W., 1979, Molytdenarr--lower output from by-product sources contributes to continuing supply tightness, Eng. Hin. J., v. 180, no. 3, p. 122, 129 .

Gott, G.B., and Botbol, J.M., 1973, Zoning of major and minor metals in the Coeur d'Alene mining district in Jones, M.J., ed, geochenical exploration, 1972, Inst. Mining Metal1., London, p. 1-12.

1975, Possible extension of mineral belts, northern part of coeur d'Alene district, Idaho: J. Res. U.S. Geol. Survey, v. 3, no. 1, p. $1-7$.

Grant, A.R., 1969, Chemical and physical controls for base netal deposition in the Cascade Range of Washington: Washington Div. Min. Geol. Bull. 58, $107 \mathrm{p}$.

1973, Middle fork of the Snoqualmie prospect: Spokane, Bur. Min. Sup. File, Northwest Field Operation Center.

Gray, C., and Laphan, D.M., 1961, Guide to the geology of Cornwa11, Pa.: Pennsylvania Geol. Survey Bull. G35.

Gray, R.F., and others, 1968, Bishop Tungsten district, California, in Ore deposits of the United States, 1933-1967, Ridge, J.0., ed., AINE Trans., p. 1531-1554.

Greeley, M.N., 1978, The primary copper industry of Arizona in 1975-76, Arizona Dept. Min. Res. Special Report 2, 87 p. 
Griffitts, $W_{+} R_{+}$, Jahns, R.H., and Lemke, R.W., 1953, Part 3: Ridgeway Sandy Ridge district, Virginia and North Carolina, U.S. Geol. Survey Prof. Paper 248C, mica districts of the southeastern Piedront, p. $141-170$.

Griffitts, W.R., and Jahns, R.H., 1953B, Part 4, Outlying deposits in Virgina, U.S. Geol. Survey prof. Paper 24BC, mica deposits of the southern Piedront, p. 171-202.

Griffitts, W.R., and Olson, J.C., 1953C, Part 5: Shelby-Hickory district North Carolina, U.S. Geo1. Survey Prof. Paper 248D, mica deposits of the sourtheastern Piedmont, p. 203-281.

Griffitts, W.R., 1953D, part 7: Hartwell district, Georgia and South Carolina, v.S. Geo1. Survey Prof. Paper 248E, nica districts of the southern Piedmont, p. 293-316.

Griffitts, W.R., 1953E, Part 8: Outlying deposits in South Carolina, U.S. Geol. Survey Prof. Paper 248E, mica deposits of the southern Piedmont, p. 317-325.

Gross, S.0., 1968, Titaniferous ores of the Sanford lake district, New York, in Ridge, J.D., ed., Ore deposits of the United States, 1933-I967, AIME, New York, v. 1, p. 140-154.

Grout, F.F., and Wolff, J.F., 1955, The geology of the Cuyma district, Ninnesota--a Progress Report, Minnesota Geol. Survey Bu11. 36, $144 \mathrm{p}$.

Grybeck, D., 1977, Nap showing known mineral deposits of the Brooks range, Alaska, U.S. Geol. Survey Open File keport 77-166C, 45 p.

Hadley, J.R., and Goldsmith, R., 1963, Geology of the eastern Great Smokey Mountains, North Carolina and Tennessee, U.S. Geol. Survey Prof. Paper, 349B, p. Bl-B118.

Hagm1, R.D., and Trancynger, T.W., 1977, Sequence of deposition of the ore minerals at the Magmont Mine, Viburnum trend, southeast Missouri, Synposium on the geology and ore deposits of the Viburnum trend, southeastern Missouri, Ro11a, Mo., October 17-18, 1975

Hagner, A.F., and Collins, L.G., 1967, Magnetite ore formed during regional metanorphism, Ausable Magnetic district, New York, Econ. Geol, v. 62, no. 8, p. 1034-1071.

Hague, J.M., and others, 1956, Geology of the Franklin-Sterling axea, N.J., Geol, Soc. Amer. Bull., v. 67, no., p. 435-474,

Kainson, B.C., 1976, Pre excavation deep-hole stress measurements for design of underground chambers - case histories (chapter 36) in Robbins, R.J., and Conlon, R.J., eds., Proc. 1976 Rapid excavation and tunneling conference, Las Vegas, Nevada, June 14-17, 1976, AIME, New York. 
Haivala, 1963, The Bunker Hill Conpany operations, a history of the Bunker Hill Company, Idaho Bur. Min. Geol. Pamphlet 133, p. 35-59.

Hall, W.E., and others, 1958, Economic geology of the Darwin Quadrangle, Inyo County, California, Calif. Div. Min. Geol., Spec. Report Sl, p. $1-73$.

Hal1, W.E., and Mackevett, E.N., Jr., 1962, Geology and ore deposits of the Darwin Quadrangle, Inyo Comty, California, U.S. Geol. Survey Prof. Paper 368, 87 p.

Hal1, W.E., 1971, Geologic setting and mineralogy of Darwin lead-silverzinc deposits, Inyo County, California, Econ. Geol., v. 66, no. 8, p. 1267.

Hallof, P.G., Winniski, E., 1971, A geophysical case history of the lakeshore ore body, Geophysiçs, $v, 36$, no, $6,1232-1249$.

Hamilton, W., 1961, Geology of the Richardson Cove and Jones Cove Quadrangles, Tennessee, U.S. Geo1. Survey Prof. Paper 349A, p.A1-A55.

Hanilton, S.K., 1967, Copper nineralization in the upper part of the copper harbor conglomerate at White Pine, Michigan, Econ. Geol., v. 62 , no. 7, p. $885-904$.

Hamilton, $W_{+}$, and Nyers, W.B., 1967, The nature of batholiths, i.s. Geol. Survey Prof, Paper 554C,, p. C1-C30.

Hanrer, D.F., and Peterson, D.W., 1968, Geology of the Magma Mine area, Arizona, in Ridge, J,D., ed., Ore deposits in the Inited States 1933-1967, AIME, New York, v. 2, p. 1282-1310.

Han, T.M., 1968, Ore mineral relations in the Cuyuna sulphide deposit, Minnesota, mineraliut deposita, v. 3, no, 2, p. 109-134, (Abstr., German ) .

Hanley, J.B., Henrlch, E.H., and Page, L.R., 1950, Pegmatite investigations in Colorado, Wyoning, and Utah, 1942-1944, U.S. Geol. Survey Prof. Paper 227, 125 p.

Hansen, L.A., 1961, The stratigraphy of the Carr Fork Mines, Binghan mining district, Binghan, Utah, Cook, D.R., ed., Geology of the Binghas mining district and northern Oquirrh Nountains, Guidebook to the geology of Utah no. 16, Utah Geological Society, P. 70-80.

Hardeman, H.D., 1970, Zinc and copper mines in Tennessee, U.S. Bur. Min. Cong. J., v. 55, no. 11, p. 26-30.

Harper, H.E., and Reynolds, J.R., 1969, The Lakeshore copper deposit, Min. Cong. I., v. $55(11)$, D. 26-3n.

Harrer, C.M., 1966, Wyoning iron ore deposits, U.S. Bur, hines Infork. Circ. 8315, p. $39-42$.

Harrington, G.L., 1919, Tín nining in Seward Peninsula, U.S. Geol. Survey Bu11. 692G, p. 363-367. 
1919, Graphite mining in Seward Peninsula, U.\$. Geo1. Survey Bull. $692 \mathrm{G}, \mathrm{p}, 353-367$.

1921, Mining on Weward Peninsula: U.S. Geol . Survey Bull. 714F, p. $229-237$.

Harris, R.D., 1972, Investigation of a possible mineralogical control of roof failure at the White Pine Copper Mine (Michigan), MS thesis, Nich. Tech.

Harrison, J.E., and Wells, J.W., 1956, Geology and ore deposits of the Freeland-Lamartine district, GIear Creek County, Colorado, U.S. Geo1. Survey Bul1. 1032, p. 33-127.

Harrison, J.E., and Wells, J.D., 1959, Geology and ore deposits of the Chicago Creek area, Clear Creek County, Colorado, U.\$. Geol. Survey Prof. Paper 319, 92 p.

Hart. L.H., 1935, The Butte district, Mantana, in Copper resources of the world, 16th International Geological Congress, George Banda Publ. Co., Manasha, Wisc., p. 287-305.

Hawkes, H.E., 1952, Geol. Soc. Aner. Bu11., v. 63, no., p. 1260.

Hanley, C.C., and Wobus, R.A., 1977, General geology and petrology of the precambrian crystalline rocks, Park and Jefferson counties, Colorado, U.S. Geol. Survey, Prof. Paper 608B, p. B1-B77.

Heard, H.C., 1970, The influence of environment on the inelastic behavior of rock, in Proc. sytep. engineering with nuclear explosives: U.S. Dept. Comerce, Springfield, VA, V. 1, p. 127-142.

Hedder1y-\$mith, D.R., 1975, Geology of the \$unrise breccia pipe, Sultan Basin, Snohonish County, Washington, MS thesis, Seattle, Washington.

Heinrich, E.W., K1epper, H.R., and Jahns, R.H., 2953, Part 9, ThomastonBarmesville district, Georgia, U.S. Geol. Survey Prof. Paper 248-F, p. 327-376.

Heinrich, E.W., and Jahns, R.H., 1953, Part 10, Outlying deposits in Georgia, U.S. Geol. Survey Prof. Paper 248F, p. 377-400.

Heinrich, E.H. and 01 son, J.C., 1953, Part 1], Alabama district, U.S. Geol. Survey Prof. Paper 248G, p. 401-462.

Hendrix, T., 1962, Guidebook, Field geology in the Rocky Mountains (Geology G429), Indiana University, Bloomington.

Henton, P.M., 1974, Hydrogeological problens associated with waste disposal into abandoned coal workings, Water Serv., $v, 78$, no. 944, p. 349-352. 
Herdlick, J.A., 1947, Little Pittsburgh Pb-2n Mine, U.S. Bur. Hin. Rep. Inv. $3999,8 \mathrm{p}$.

Hernon, R.N., and Jones, H.R. 1968 , Ore deposits of the central mining district, Grant County, New Mexico, in Ridge, J.D., ed, Ore deposits of the United States, 1933-1967, AIME, New York, v. 2, p. 1211-1238.

Hershey, O.H., 1916, Origin and distribution of the ore in the Coeur d'Alene, San Francisco Min. Sci. Press, $32 \mathrm{p}$.

Hess, P.L., 1906, The York tin region, U.S. Geol. Survey Bull. 284, p. 145-147.

1912, Tin resources of Alaska, U.S. Geol. Survey Bul1. 520B, p. 8992.

Hester, J.G., and Edmonds, R.F., 1974, Bad Creek punped storage project, in Electric power and the civil engineer, ASCE, Power Division Specialty Conf., Boulder, Colorado, August 12-14, 1974, p. 241-263.

Hewitt, D.F., 1956, Geology and mineral resources of the Ivanpah Quadrangle, Califormia and Nevada, U.S. Geol. Survey Prof. Paper 275, $172 \mathrm{p}$.

Heyl, A.V., Jr., and Brock, M.R., Structural framework of the IllinoisKentucky mining district and its relation to mineral deposits, U.S. Geol. Survey Prof. Paper 424D, P. D3-D6.

Heyl, A.V., 1964, Oxidized zinc deposits of the United States, Part 3, Colorado, U.S. Geol. Survey Bull. $1135 \mathrm{C}$, $98 \mathrm{p}$.

Hey1, A.V., and Pearre, N.C., 1965, Copper, zinc, lead, iron, cobalt, and barite depasits in the Piednont upland of Maryland, Md. Geol. Survey Bull. 28, $72 \mathrm{p}$.

Hickok, W.0., 4th, 1933, The iron ore deposits at Cornwal1, Pennylvania, Econ. Geol., v. 28, no. , p. 193-255.

Hietanen, A., 1963, Idaho batholith near Pierce, Bungalow and Clearwater Comties, Idaho; metamorphic and igneous rocks along the northwest border zone of the Idaho batholith, v.S. Geol. Survey Prof. Paper $3440,42 \mathrm{p}$.

Hi11, J.M., 1933, Lode deposits of the Fatrbanks district, Alaska, U.S. Geol. Survey Bull. 849B, $163 \mathrm{p}$.

Hill, M.D., and Grimwood, P.D., 1978, Preliminary assessment of the radiological protection aspects of disposal of high-level waste in geologic formations, National Radiological Protection Board, Harwell, Didcot, OXON OXII ORQ, England, Report No, NRPB-R69, 75 p. 
Hillebrand, J.R., 1957, The Idarado Mine, Guidebook of southwestern San Juan Aountains, Eighth field conference, New Mexico Geo1, Soc., Socorro, New Mexico, p. 176-188.

1968, The Idarado Mine, Guidebook of San Juan - San Miguel - La Plata Region, New Mexico and Colorado, New Mexico Geol. Soc., 19th field conference, New Mexico Bur. Mines \& Mineral Resources, Socorro, New bexico, p. I30-140.

Ili lbert, L.S., 1969, Jranium resources of northwestern New Mexico, U.S. Geol. Survey Prof. Paper 603, $166 \mathrm{p}$.

Hinrichs, E.N., 1968, Geologic structure of Yucca Flat area, Nevada, in Eckel, E.B., ed., Nevada Test Site, Geol. Soc. Amer. Mem. 110, p. $239-246$.

Hobbs, S.W., and others, 1965, Geology of the Coeur d'Alene district, Shoshone County, Idaho, U.S. Geo1. Survey Prof. Paper 478, $139 \mathrm{P}$.

Hobbs, S.W., 1968, Geologic setting of metallic ore deposits in the northern Rocky Mountains and adjacent areas, in Ridge, J.D. ed., Ore deposits of the United States, 1933-1967, AIME, New York, v. 2, p. $1351-1372$.

Hoblss, S.H., and Fryklund, V.C., Jr., The Coeur d'Alene district, Idaho, in Ridge. J.D., ed., Ore deposits of the United States, 1933-1967, AIME, New York, p. 1417-1435.

Holser, W.T., 1950, Hetamorphism and associated mineralization in the Philipsburg region, Montana, Geol. Soc. Amer. Bull., v. 6l, p. 10531090 .

Honestake, 1976, 1876 Honestake Centennial, Honestake Mining Company, $93 \mathrm{p}$.

Honestake Mining Co., 1978, Homestake Mining Co. Annua1 Report 1977, Form 10K.

Homestake Mining Co., 1978, Homestake Annual Report, 1978.

Hoppe, R., 1976, Amax prepares to cave the Henderson after a decade and $\$ 400$ million in development, Eng. Min. $J_{,}$, v. 177, no, 1, p. 92-98.

Hore, R.E., 1915, Minera] resources of Michigan, Annual report of the Board of Geological and Biological Survey for 1914; Pub. 19, Geol. Series 16, Mich. Geol. Biol. Survey, $351 \mathrm{p}$.

Horino, F.G., and Aggson, J.R., 1978, Pillar failure analysis and in situ stress determinations at the Fletcher Mine near Bunker, Mo., U.S. Bur. Min. Report Invest, 8278, 19 p.

Horton, R.C., 1964, Fluorspar in Nevada, Nevada Bur. Min, Bul1. 65. 
Hose, R.K., Blake, M.C., Jr., and Snith, R.M., 1976, Geology and mineral resources of White Pine County, Nevada, Nevada Bur. Min. Geol. Bull. $85,105 \mathrm{~F}$.

Hosterman, J.W., 1956, Geology of the Murray area, Shoshone County, 1daho, U.S. Geol. Survey Bull. 1027-P, p. 725-748.

Hotz, P.E., 1953, Magnetite deposits of the Sterling Lake, N.Y. Ringwood, N.J. area, U.S. Geol. Strvey Bull. 982F, p. 153-244.

1954, Some magnetite deposits in New Jersey, U.S. Geol. Survey Bull. $995 \mathrm{~F}$, p. 201-253.

Hotz, P.E., and Willden, R., 1964, Geology and mineral resources of the Osgood Mountains Quadrangle, Humboldt County. Nevada, U.S. Geol. Survey Prof. Paper 431 , $128 \mathrm{p}$.

Hotz, P.E., 1971, Geology of lode gold district in the Kramath Mountains, Caljfornia and Oregon, I.S. Geol. Survey Bull. ]290, 91 p.

Howard, P.F., 1969, The geology of the Elizabeth Mine, Vermont, Vermont Geol. Survey, Econ. Geol, 5, 73 p.

Howd, F.H., and Drake, O.P., 1974, Economic deposits at Blue Hill, in Osberg, P.H., ed., Guidebook to fiejd trips in east central - north central Maine, New England Intercollegiate Geological Conference, 66th Annual Meeting.

Hubbard, H.A., 1975, Lower Keweenawan volcanic rocks of Michigan and Wisconsin, U.S. Geol. Survey J. Res., v. 3, no. 5, p. 529-541.

Huff, L.C., and Marranzino, A.P., 1961, Geochemical prospecting for copper deposits hidden beneath alluvium in the Pima district, Arizona, U.S. Geol. Survey Prof. Paper 424B, p. B308-B310.

Hunmel, C.l., 1975, Mineral deposits, occurrences, and associated altered rocks in southwest Seward Peninsula, western Alaska, U.S. Geol. Survey Open File Report 75-2.

Hunt, R.N., and Peacock, H.C., 1950, Lead and lead-zine ores of the Binghan district, Utah, 18th Int. Geol. Congr. Rept., Part 7, Section $F$, The geology, paragenesis, and reserves of the ores of lead and zinc, p. 92-96. Internationa] Geological Congress, London.

Hunt, C.B., Averitt, P., and Miller, R.L., 1953, Ceology and geography of the Henry Mountains region, Utah, U.S. Geol. Survey Prof. Paper $228,234 \mathrm{p}$.

Hunt, C.B., Cenozoic geology of the CoJorado Plateau, U.S. Geol. Survey Prof. Paper 279, $99 \mathrm{p}$.

Hunt, C.B., 1967, Physiography of the United States, W.H. Freeman Co., San Francisco, $480 \mathrm{p}$. 
Huntting, M.T., 1943, Nineral properties in Chalen County, Washington, Wash. Div. Geo1. Report Inv. no. 9, p, 34-36.

1956, Inventory of Washington Minerals, Part II - metallic minerals, Mash. Div. Mines Geol. Bull 37, v. 1-text, 428 p., v. 2-maps.

Hutchinson, M.H, 1961, Geology of the Lucky Friday Mine, Guidebook to the geology of the Coeur d'Alene mining district, Idaho, Idaho Bur. Min. Geol. Bul1. 16, p. 27-29.

Huttl, J.B., 1963, Getche1l mine resumes gold production, Eng. Min. J., v. 164 , no. 1 , p. $70-73$.

Hynd, J.G.S, Clelland, I.S. and Gillett, P.A., The construction of large underground excavations in Arizona copper mines, in Robbins, R.J., and Conlon, R.J., eds, Rapid excavation and tumneling conference symp., Las Vegas, Nevada, June 14-17, 1976, AIME, New York, p. 570-590.

Fdaho Bur. Mines Geol., 1961, Guidebook to the geology of the Coeur d'Alene mining district, Idaho Bur. Min. Geo1. Bu11. 16.

1963, The Coeur d'Alene mining district, Idaho Bur. Mines Geol. Pamph. 133, 103 p.

Idaho Bur. Min., Idaho Bur. Min. Geol. Pamph. 108, p. 18.

Idaho Dept, Labor Indust. Serv., 1977, The mineral industry of Idaho.

Idaho Dept. Labor Indust. Serv., 1978, Fourth, annual report of the Idaho Department of Labor and Industrial Services, Mineral Industry of Idaho, p. 17-55.

Illinois Department of Mines and Minerals, 1977, Annual coal, oil, and gas report, ninety-sixth coal report of llinois, $167 \mathrm{p}, 49 \mathrm{p}$. , 90 p., resp.

International Atomic Energy Agency, 1977, Site selection factors for repositiories of solid high-level and alpha-bearing wastes in geological formations, IAEA, Vienna, Technical Reports Series 177.

International Directory of Mining and Min. Proc. Operations, 1978.

Jackson, E.D., 1969, Chemical variation in coexisting chromite and olivine in chromitite zones of the Stillwater complex, in Wilson, H.D.B., ed., Magmatic ore deposits, a symposium, p. 41- $\overline{71}$.

Jackson, D., J978, Block caving keeps San Manuel conpetitive with neighboring open-pit copper mines, Eng. Mìn. J., v. 179, no. 6, p. 127136 .

Jalns, R.H., Griffitts, W.R+, and Heirich, E.W., 1952, Part I, General features, mica deposits of the southeastern Piedmont, U.S. Geol. Survey Prof. Paper 248A, p. 1-102. 
James, A.H., and Bemmen, W.H., 1962, Trace ferrides in the magnetite ores of the Ht. Hope Mine and the New Jersey Highlands, Econ. Geol, , v. 57, no. $3, p .439-449$,

James, H.L., Dutton, C.E., and Weir, K.L., 1967, Geology and magnetic data for northern Iron River area, Mich. Geol. Survey Report Invest, $\mathrm{RI}-4,46 \mathrm{p}$.

James, H.L., and others, 1968, Geology and ore deposits of the Iron River Crystal Falls district, Iron County, Michigan, U.S. Geol. Survey Prof. Paper $570,134 \mathrm{p}$.

James, A., 1973, Lead and zinc resources in Utah, Utah, Geol. Survey Special Studies 44, p. 29-31.

Jamison, 1978, Mine inventory.

Jansons, U., and Bottge, R.G., 1977, Econonic mining feasibility studies of selected mineral deposit types in the eastern Brooks Range, Alaska, U.S. Bur. Min. Open File Report 128-77, 96 p.

Johnson, C.H., 1947, Igneous metamorphism in the Orofino region, Idaho, J. Geol., v. 55, no. 6, p. 490-507.

1961, A brief description of Pilot Knob, Guidebook to the geology of the St. Francois Mountain area, Missouri Dept. Bus. Adm., Div. Geol. Survey \& Water Resources Rept. Invest. 26, p. 127, 128.

Johnson, M.C., 1970, The industries of Montana - agriculture and mineral industries, Montana Bur. Bus. Econ. Res., v. 1, Chapt. 1-2, Montana Economic Study Research Report Project

Johnson, M.G., Geology and mineral deposits of Pershing County, Nevada, Nevada Bur. Mines Geol. Bull. 89, 115 p.

Johnson, R.E., Graven, L.K., 1978, Preliminary mine planning at the Minnamax project, in Productivity in Lake Superior mining district Minn. Univ. Min. Symp. 39, Proc. 5lst Annual Meeting, Ninn. Section AIkE, Buluth, Minn., Jan. 11-13, 1978, p. 19.1-19.11.

Jolly, H.T., and Snith, R.E., 1972, Degradation and metamorphic differentiation of the Keweenawan tholeitic lavas of northern Nichigan,

J. Petrology, v. 13, no. 2, p. 273-309.

Jones, E.L., Jr., 1920, A reconnaissance of the Pine Creek district, Idaho, U.S. Geo1, Survey Bul1, 710A, p. 1-36.

Jones, W.R., ed., 1955, Geologic nap of the central mining district, Grant County, New Hexico (with summary of strata and intrussive rocks), U.S. Geo1. Survey Open File Report.

Jones, H.R., Hernon, R.M., and Pratt, W.P., 1961, Geologic events culminating in primary metallization in the central mining district, Grant County, New Mexico, U.S. Geol. Survey Paper 424C, p. C11-C16. 
Jonson, D.C., 1955, The geology of the Resurrection Nine, Lake County, Colorado, Ms thesis, Colorado Sch. of Mines.

Judd, W.R., 1959, Geological factors in choosing underground sites, Report R341, P. 255, 266

1969, Strain distribution around underground openings, statistical methods to complie and correlate rock properties and preliminary results, Technical Report 2, Directorate of Regulatory standards, U.S. Atomic Energy Comm., Washington, D.C. 20545, I09 p.

Kegel, W.G., 1975, Problems with underground refuse disposal, Society of Mining Engineers, AIME Trans, , v. 258, p. 280-283.

Keith, S.B., 1973, Index of mining properties in Cochise County, Arizona, Ariz, Bur. Mines Bull. 187, 98 p.

1974, Index of Mining properties in Pina County, Arizona, Ariz. Bur. Mines Bu1l. 189, $156 \mathrm{p}$.

1975, Index of mining properties in Santa Cruz County, Arizona, Ariz Bur. Mines Bul1. 191, $94 \mathrm{p}$.

1978, Index of mining properties in Yuma County, Arizona, Ariz. Bur. Geol. Min. Tech. Bull. 192, 185, p.

Kelley, $V_{+} C,, 1938$, Geology and ore deposits of the Darwin silver-1ead mining district, Inyo County, California, Calif. J. Mines Geol., v. 34 , no. 4, p. 503-562.

Kendall, E.W., 1972, Trend Orebodies of the Section 27 Mine, Ambrosia lake Uranium district, New Mexico, PhD thesis, 1972, Univ. Calif., $169 \mathrm{P}$.

Kendorski, F.S., and Mahtab, M.A., 1976, Fracture patterns and anisotrophy of San Manuel quartz monzonite, Eng, Geol. Bull., v. 13, no.l, p. 23-52.

Ken o'Brien Associates, 1968, Prelininary Report - Siting concepts and investigations, v. I, Task 2 - Field Investigation Warren AFB Study Area, 21 Dctober 1969.

1969 , Siting concepts and 1nvestigations, Part III - Re-evaluation of Tasks 1 \& 5 potential areas, 28 Feb. 1969.

Kendrick, R, , 1970, Induction caving of the Urad Mine, Mining Congress Journal, v. 56 , no. 10 , p. $39-44$.

Kern, 1972, Geology and economic deposits of the Slate Creek area, MS thesis, Idaho State Univ.,

Kerr, P.F., 1934, Geology of the tungsten deposits near Mill City, Nevada, Univ, Nevada Bull, v. 28 , no. 2, p. 7-46. 
Kerr Addison Annuaj Report, 1977.

Kerr Addison Annual Report, 1978.

Kesler, T.L., 1950, Geology and nineral deposits of the Cartersvłlle district, Georgia, U.S, Geol, Survey Prof. Paper 224, 97 p.

Kesten, S.N., 1961, Geology of the Galena Mine, in Gutdebook to the geology of the Coeur d'Alene mining district, Idaho, Idaho Bur. Wines Geo1. Bull. 16, p. 23-26.

1963, Geology of the Page and Gajena Mines, in The Coeur d'Alene mining district in 1963, Idaho Pur. Mines Geo1. Pamph. 133, p. 95-98.

King, P.B., 1964, Geology of the central Great Stoky Mountains, Tennessee, U.S. Geol. Survey Prof. Paper 349C, $148 \mathrm{p}$.

1969, The tectonics of North America - A discussion to accompany the tectonic map of North America, Scale 1:5,000,000, U.S. Geol. Survey Prof. Paper 628, 95 p.

1976, Precambrian geology of the United States, An explanatory text to accompany the geologic mas of the United States, U.S. Geol. Survey Prof. Paper 902, $85 \mathrm{p}$.

1978, The cenozoic rocks; a discussion to accompany the geologica1 map of the U.S., U.S. Geol. Survey Prof. Paper 904.

Kinkel, A.R., Jr., Ha11, W.E., and Albers, J.P., 1956, Geology and basemetal deposits of west Shasta copper-zinc district, Shasta County, California, U.5. Geo1. Survey Prof. Paper 285, 156 p.

Kinkel, A.R., Jr., 1962, The Ore Knob massive sulfide copper deposit, North Caroline - An example of recrystallized ore, Econ. Geol., v. 57, no. 7, p. 1116-1121.

1967, The Ore Knob copper deposit of North Carolina, and other masstve sulfide deposits of the Appalachtans, U.S. Geol. Survey Prof. Paper $558,58 \mathrm{p}$.

Kiepper, M.R., 1962, Emplacement of the Boulder batholith, AIRE Rocky Mountain Minera1s Conference, Butte, Montana,

Knoerr, A,H., 1956, San Manue1 - America's newest large copper producer, Eng. Mining, J., p. 157, no. 4, p. 75-100.

Knopf, A., 1908, The Seward Peninsula tin deposits, U.S. Geol. Survey Bu11. 345E, p. 251-267.

1908, Geology of the Seward Peninsula tin deposits, Alaska, U.S.

Geol. Survey Bull. 358, $71 \mathrm{p}$.

1957, The Boulder batholith of Montana, Amer. J. Sci., v 255, no. 2, p. $81-103$ 
Knox, R.G., 1968, Alaska Const. o 0il, \$10 million gamble with bornite, Feb. .

Konizeski, R.L., 1961, Preliminary report on the geology and groundwater resources of the northern part of the Deer Lodge Valley, Montana, Montana Bur. Mines Geo1. Bull. 21, 24 p.

Konizeski, R.L., Mckurtray, R.G., and Brietkrietz, A., 1962, Preliminary report on the geology and groundwater resources of the southern part of the Deer Lodge Valley, Hontana, Bur. Mines Geol. Bul1. 31, 24 p.

Krohn, D.H., and Weist, M.W., 1977, Principal information on Montana mines, Montana Bur. Mines Geol. Spec. Pub. 75, p. 57.

Kottlowski, F.E., and Foster, R.W., 1969, Exploration for mineral resources New Mexico Bur. Mines Circ. 101, p. 114.

Kum, 1970, MS thesis, Univ. Ideho, Noscow.

Kun, 1974, Idaho Bur. Mines E Geo1. Pamph. 156.

Laizure, C., 1921, Siskiyou County, Calif. Min. Bur. Rept. 17, p. 531.

Lapham, D.M., 1962, Geology froj Lebanon to Cedar Hill, April 16, 1962, in Northern Field Excursion Guidebook, International Mineralogical Assoc., Third Gen. Congr., Washington, D.C., Washington, D.C. Mineralogocial Society of America, p. 32-42.

1968, Triassic magnetite and diabase at Comwall, Pennsylvania, in Ridge, J.D., eds., Ore deposits of the U.S., AIME, New York, v. $\overline{1}$ p. $72-94$.

Laphan, D.M., Gray, C., 1973, Geology and origin of the triassic magnetite deposit and diabase at Cornwal1, Pennsylvania, Pennsylvania Geol. Survey Bul1. M-56.

lasky, S.G., Hoagland, A.D., 1950, Central mining district, New Mexico, 1Bth International Geol. Congr. Rept., Part 7, Section F, The geology, paragenesis and reserves of the ores of lead and zinc, International Geol. Congress, London, p. 97-110.

lawrence, E.F., 1963, Antimony deposits of Nevada, Nevada Bur. Mines Bull. $61,248 \mathrm{p}$.

Lawrence, R.A., 1968, Ore deposits of the southern Appalachians, in Ridge, J.D., ed., Ore deposits of the United States, 1933-1967, AIME, New York, v. 1, p. 162-168.

Lawson, D.C., 1979, Directory of mining enterprises for 1978, Mantana Bur. Mines Geol. Bull. 109, p. 7.

Lea, E.R., and Dill, D.B., Jr., 1968, Zinc deposits of the Ba1matEdwards district, New York, in Ridge, J.D., ed., Ore deposits of the United States, 1933-1967, AIME, New York, v. 1, p. 20-48. 
Lee, F.T., Abel, J.F., Ir., and Nichols, T.C., Jr., 1976, The relation of geology to stress changes caused by underground excavation in crysta1line rocks at Idaho Springs, Colorado, U.S. Geol. Survey Prof. Paper 965,47 p.

LeGrand, H.E., 1972, Overview of problems of mine hydrology, Soc. Mining Eng., AIME, Trans., v. 252, p. 362-365.

Leith, C.K., lund, R.J,, and Leith, A, 1935, Precanbrian rocks of the Lake Superior region, J.S. Geol. Survey Prof. Paper 184, 34 p.

Lemke, R.W., Jahns, R.H., and Griffitts, W.R., 1952, Part 2, Awelia district, U.S. Geol. Survey Prof. Paper 248B, Mica deposits of the southeastern Piednont, p. 103-139.

Lemmon, D.M., Dorr, J.V.N., 2nd, 1940, Tungsten deposits of the Atolia district, San Bernardino and Kern Counties, California, U.S. Geol. Survey Bull. 922H, p. 205-245.

leonard, B.F., and Buddington, A.F., 1964, Ore deposits of the St. Lawrence County nagnetite district, northwest Adirondacks, New York, I.S. Geol. Survey Prof. Paper 377, $259 \mathrm{pp}$.

Leonard, B.F., Mead, C.W., and Conklin, N., 1968, Silver-rich disseninated sulfides fron a tungsten-bearing quartz lode, Big Creek district, central Idaho, U.S. Geo1. Survey Prof. Paper 594C, p. C1-C24.

leone, R.J., Seasor, R.H., and Rohrbacher, T.J., 1971, Geology of the White Pine area, in thite, W.S., ed., Guidebook for field conference, Michigan Copper district, Sept. 30-0ct. 1971, MTU Press, p. 44-65.

Lesure, F.G., 1968, Mica deposits of the Blue Ridge in North Carolina, U.S. Geol. Survey Prof. Paper 577, $124 \mathrm{p}$.

Li, C.Y., 1942, Genesis of some ore deposits of southeastern Maine, Geol. Soc. Amer. Bul1., v. 53, no. 1, P. 15-51.

Lindgren, W., and Loughlin, G.F., 1919, Geology and ore deposits of the Tintic mithing district, Utah, U.S. Geol. Survey Prof. Paper 107, $282 \mathrm{p}$.

Lindgren, 1957, Utah Geo1. Soc. Guidebook 17, p. 120-123.

Lindner, E.N., and Halpern, J.A., 1978, In situ stress in North America; a compilation, Int, J. Rock Mech., Min. Sci. \& Geonech. Abstr. 15, P. 183-203.

Lloyd, R.J., 1965, Tennessee Department of Conservation, Div. of Geology, Tennessee Rocks and Minerals Rept., 1965.

lockard, D.W., and Rice, H.L., 1970, Preliminary investigation of a lowgrade gold deposit in Custer County, Idaho, U.S. Bur. Mines Open File Report OFR 5-71, $58 \mathrm{p}$. 
Loeltz, O.J., Phoenix, D.A., and Mason, H.G., 1955, Geology and groundwater resources of Buena Vista Valley, Pershing County, Nevada, Reconnaissance land classification of Buena Vista Valley, Pershing County, Nevada, Nevada Office of State Engineer, Water Resources Bull. 13, 51 p.

Logan, C.A., 1922, Quartz mining in the Allegheny district, California State Mining Bur., v, 18, p. 51.

1925, Siskiyou County, California Bur. Rept. 21, p. 428.

longwe11, C.R., and others, 1965 , Geology and mineral deposits of Clark County, Nevada, Nevada Bur. Mines Bul1. 62.

Loughl in, G.F., Koschmann, A.H., 1942, Geology and ore deposits of the Magdalena mining district, New Mexico, U.S. Geol. Survey Prof. Paper $200,168 \mathrm{p}$.

Love, W.H., 1966, The Ruby Hill project, Eureka, Nevada, in Nevada Bur. Mines Report 13, AIME Pacific Southwest Mineral Industry Conference, Sparks, Nevada, May 5-7, 1965, Part $A$, Exploration and mine development in Nevada, p. 85-107.

Love, J.D., 1970, Cenozoic geology of the Granite Moumtains area, central Wyoming, U.S. Geol. Survey Prof. Paper 495C, 154 p.

lovering, T.G., and Heyl, A.V., 1974, Jasperoid as a goide to mineralization in the Taylor mining district and vicinity near Ely, Nevada, Econ. Geol., v. 69, no. 1, p. 46-58.

Lovering, T.S., and others, 1949, Rock alteration as a guide to ore, East Tintic district, Utah, Econ, Geol., Monogr, 1,65 p.

Lovering, T.S., and Goddard, E.N., 1950, Geology and ore deposits of the Front Range, Colorado, J.S. Geol. Survey Prof. Paper 223, 319 p.

Lovering, T.S, and Tweto, $0 ., 1953$, Geology and ore deposits of the Boulder County tujgsten district, Colorado, U.S. Geol. Survey Prof. Papaer 245, $199 \mathrm{p}$.

Lovering, T.S., and Morris, H.T, 1965, Underground temperatures and heat flow in the East Tintic district, Utah, U.S, Geol. Survey Prof. Paper 504F, $28 \mathrm{p}$.

lovering, T.S., Tweto, 0., and lovering, T.G., 1978, Ore deposits of the Gilman district, Eagle County, Colorado, U.S. Geol. Survey Prof. Paper 1017, $90 \mathrm{p}$.

Lowe1I, J.D., 1958, Geology of the KaIanazoo orebody, San Manuel district, Arizona, Econ. Geol., v. 63, no. 6, p. 645-654.

Lowe]J, J.D., and Guilbert, J.M., 1970, Lateral and vertical alteration Mineralization zoning in porphyry ore deposits, Econ. Geol., v. 65 , no. 4, p. 373-408. 
Lowry, M.E., Lowhan, H.H., and Lines, G.C., 1976, Water Resources of the Bighorn Basin, northwestern Wyoming, U.S. Geol. Survey Hydrologic Investigations Atlas HA-512, Scale 1:250,000.

luedke, E.M., Wrucke, C.T., and Graham, J.A., 1959, Mineral occurrences of New York State with selected references to each locality, $\mathbf{U} . \mathbf{S}$. Geo1. Survey Bu1l 1072F, p. 38\$-444,

Hac Boyle, E., 1918, Mines and mineral resources of Sierra County, California State Min. Bur., v. 16, p. 54-54.

MacDonald, D.F., 1906, Economic features of northern Idaho and northwestern Hontana, U.S. Geol. Survey Bull, 285A, p. 41-52.

Hackenzie, Ii.B., and Bookstrom, A.A., 1976, Geology of the Majuba Hill area, Pershing County, Nevada, Nevada Bur. Mines Geol. Bull, 86, $23 \mathrm{p}$.

Macolm, J.B., 1962, Hamme mine reopening made feasible, Mining Eng., $v$. 14 , no. 4, p. 44-9.

Haevis, A.C., 1976, Chapter 40 - The problems of New York City tunneling projects, in Robbins, R.J., Conlon, R.J., eds., Rapid excavation and tunneling conference, Las Vegas, Nevada, June 14-17, 1976, p. 761-773.

Nagee, $M_{+}, 1968$, Geology and ore deposits of the Ducktown district, Tennessee, in Ridge, J.D., ed, Ore deposits of the United States, 1933-1967, AIME, New York, v. 1, p, 207-241.

Magma Copper Co., (no date, current), Detailed description of San Mamuel Mining Operation, $32 \mathrm{p}$.

Majtenyi, S.I., 1976, Chapter 6 - Horizonta1 site investigation systems, in Robbins, R.J., Conlon, R.J., eds., Rapid excavation and tunneling conference, Las Vegas, Nevada, June 14-17, 1976, AIME, New York, p. 64-80.

Mardirosian, C.A., 1973, Hining districts and mineral deposits of Arizona, map. 1974, Mining districts and mineral deposits of California, map. 1974, Mining districts and mineral deposits of Nevada, map. 1976, Mining districs and nineral deposits of Oregon, map. 1976, Mining districts and mineral deposits of Montana, map. 1976, Mining districts and mineral deposits of Washington, map. 1976, Mining districts and mineral deposits of Idaho, map. 
1977, Mining districts and mineral deposits of Alaska, map, scale $1: 2,500,000$.

Marsden, R.w., and others, 1968, The Mesabi Iron Range, Minnesota, in Ore deposits of the United States, 1933-1967, AIME, New York, v. 1, p. 518-537.

Marsden, R.W., 1968, Geology of the iron ores of the Lake Superior region of the United States, in Ore deposits of the United States, 19331967, ATME, New York, $\bar{v}$ 1, p. 489-506.

Martin, G.C., 1919, The Alaskan mining industry 1917, U.S. Geol. Survey Bul1. 692A, P. 11-42.

1920, The Alaskan mining industry in 1918, U.S. Geo1. Survey Bull. 712 A, p. 11-52.

MAS

Matson, E.J., and Trengove, R.R., 1957, Investigation of Fluorspar deposit, Kaiser Mine, Mineral County, Nevada, U.S. Bur. Mines RI 5344, $38 \mathrm{p}$.

Matzko, J.J., and Freeman, V.L., in Contributions to economic geology of Alaska, U.S. Geol. Survey Buli. 1155, 93 p.

Mayo, E.B., I941, Deformation in the interval Mt. Lyel1-Mt. Whitney, California, Geol. Soc. Amer. Bu11., v. 52, no. 7, p. 1001-1084.

McConnel, R.H., 1939, Bunker Hill ore deposits in complex fractures, Eng. Min. 1., v. 140, no. 8, p. 40-42.

kcConnel, R.H, 1961, The Bunker Hill Mine, in Guidebook to the geology of the Coeur d'Alene mining district, Idaho, Idaho Bur. Mines Geol. Bul1. 16.

McConnel, R.H., and Anderson, R.A., 1968, The metaline district, Washington, in Ore deposits of the United States, 1933-1967, AIME, New York, v. $2, \vec{p} .1460-1480$.

McDivitt, J.F., 1956, Economic evaluation and other minera1s iл southern Idaho, Idaha Bur. Hines \& Geo1. Panph. 111, p. 31-35.

McKinlay, P.F., 1957, Geology of Questa Quadrangle, Taos County, New Mexico, New Hexico Bur. Min. Bu11, 53, 23 p.

Mckinney, W.A., 1973, Solution mining, Nining Eng, v. 25, no. 2, p. 56* 57.

McKinstry, R.F., and Mikkola, A.R., 1954, The Fllzabeth Copper Mine, Verkiont, Econ. Geol, v. 49, no, 1, p. 1-30. 
Mcknight, E.T., 1974, Geology and ore districts of the Rico district, Colorado, U.S. Geol. Survey Prof. Paper 723, 300 p.

McWilliams, P.C., and Tesarik, D.R., 1978, Multivariate analysis techniquies with application in nining, U.S. Bur. Mines Inf. Circ., $v$. $8782,40 \mathrm{p}$.

Mertie, J.B., Jr., 1918, Lode mining and prospecting on Seward Peninsula, U.S. Geo1. Survey Bull. 662I, p. 425-449.

1918, Lode mining in the Fairbanks district, U.S. Geol. Survey Bull. $662 \mathrm{H}$, P. $403-424$.

Hetsger, R.W., Tennant, C.B., and Rodda, J. ., 1958, Geochemistry of the Sterling Hill zinc deposits, Sussex Co., New Jersey, Geol. Soc. Amer. Bull., V. 69, no. 6, p. 775-788.

Metsger, R.w., 1962, Notes on the Sterling Hill ore body, Ogdenburg, New Jersey, in Northern field excursion guidebook, Intemational Mineral Assoc. Third Gen, Congr., Washington, D.C., 1962, Washington, D.C. Meneralogical Soc., America, p. 12-18.

Meyer, C., and others, 1968, Ore deposits at Butte, Montana, in Ridge, J.D., ed., Deposits of the United States, 1933-1967, AIRE, New York, v. 2, p. $1373-1416$.

Michigan Academy of Science, Arts, and Letters, 1939, Section of geology and mineralogy - Ninth Ann. Geol. Excursion, Marquette and Nenominee districts.

Michigan Basin Geological Society, 196] - Annual Geological Excursion, Geologic features of parts of Houghton, Keweenaw, Baraga and Ontonagon Counties, Michigan.

Miller, R.N., 1973, Production history of the Butte district and geological function, past and present, Soc. Econ. Geol. Guidebook, Butte Field Meting, Fl-F11.

Miller, R.N., ed., 1973, Guidebook for the Butte Field Meeting of society of Econonic Geologists, Soc. Econ. Geol., Butte, Montana, August 18-21, 1973 .

Milre, P.C., 1978, Directory of Washington Mining Operations, 1977, Metalic mining operations, (non metallic operations and sand and gravel operations by C.W.. Nalker], Hashington division of Geology and Earth Resources, 01ympia, Washington, Inf. Circ. 63, $117 \mathrm{p}$.

Mineralgraphy of the silver bearing copper - lead ores of the Idarado Mine, Silverton district, Colorado, 1971, in Michigan Acad. Sci. Arts q Letters, Geology and Mineralogy Section Prog. Abstr., 1 p.

Minerals Yearbook, 1956, The mineral industry of New York. 
1959, The mineral industry of New York.

1967, The mineral industry of New York.

Minera1s Yearbook of Tenressee, 1965, Min. Ind. Tenn.

1975, Min. Ind, Tenn.

Mining Annual Revlew, 1978, Individual Company Reports, AMAX, p. 355. 1978, Individual Company Reports, AMax, p. 359,

Mining Congress Journal, 1977, v. 63, no. 9, p. 6-7,

Mining Magazine, 1975, Miami Fast copper deforred, Mining Magazine, v. 133, p. 157,159 .

1975, International mining survey, v. 133, p. 185, 187, 188, 189, 203, 204, September.

Minnesota Department of NaturaI Resources, Division of Minerais, Minerals exploration section, 1977, Mineral resources of a portion of the Duluth complex and adjacent rocks in St. Louis and lake Counties, northwestern Minnesota, Rept. 93, $74 \mathrm{p}$.

Missouri Dept. Labor \& Indust. Rel., 1977, Nining of the Dept. of Labor \& Industrial Relations of the State of Missouri, Statistical Report, $12 \mathrm{p}$.

Misterek, D.L., and others, Chapter 37 - Behavior studies for a highway tunnel, Rapid Excavation and Tunneling Conference, Las Vegas, Nevada, June 14-17, 1976, in Robbins, R.J., and Conlon R.J., eds., AIME, New York, 1976, p. $715-721$.

Mitcham, T.W., 1952, Signfficant spatial distribution patterns to minerals in the Coeur d'Alene district, Idaho, Science, v. 115, no, 2975, p. 11.

Moe, R.F., 1954, White Pine mine development, flat lying, deep seated ore calls for mobile equipment, conveyor haulage, Min. Eng., v. 6, no. 4, p. $381-386$.

Moen, H.S., 1976, Silver occurrences of Washington, Wash. Div. Geol. Earth Res. Bull 69, P. 30-33.

Moench, R.H., 1964, Geology of precambrian rocks, Idaho Springs district, Colorado, U.S. Geol. Survey Bul1. 1182A, p. Al-A70.

Noffit, F.H., 1935, Copper resources of A1aska, in Copper Resources of the World, l6th International Geological Congress, George Banda Publishing Co., Menasha, Wisconsin, p. 137-149.

Mognessensky, B., 1967, Structural analysis of the fracture pattern at White Pine Mine, Ontonagon County, Michigan, MS thesis, Michigan Tech., Houghton. 
Molybdenum Corporation of America (Moly Corp.), Annual Report 1972, 1973, $1974,1975,1976,1977$.

Montana College of Mineral Science and Technology, 1976, Eleventh Indust. Minerals Forum. Montana Bur. Mines - Geol. Spec. Pub. 74, $186 \mathrm{p}$.

Moore, W.J., Lanphere, M.A., and Obradovich, J.D., 1968, Chronology of intrusion, volcanism and ore deposition at Binham, Utah, Econ. Geol. v. 63 , no. 6, p. 612-621.

Moore, J.G., Geology and mineral deposits of Lyon, Douglas, and Ormaby Counties, Nevada, Nevada Bur. Mines Bull. 75, 45 p.

Morns, H.T., 1964, Discovery of the Burgin Mine, East Tintic mining district, in Mining geology and the base meta1s, Fifth Cento Symposium, Ankara, Turkey, Central Treaty Organization, p. 271-295.

Morris, H.T., 1957, General geology of the east Tintic mountains, Utah, in Cook, D.R., ed, Geology of east Tintłc mountains and ore deposits of the Tintic mining districts, Utah Geol. Soc. Guidebook Geol. Utah $12,176 \mathrm{p}$.

Morris, H.T., Lovering, T.S., and Goode, H.D., 1961, Stratigraphy of the East Tintic mountains, Utah, U.S. Geol. Survey Prof, Paper 361, 145 p.

Horris, H.T., 1968, The main Tintic mining district, Utah, in Ore deposits of the United States, 1933-1967, AINE, New York, v. 2, p. 1043-1073.

Wouat, M.M., and Clendenin, C.W., 1977, Geology of the Ozark Lead Company Mine, Viburnum trend, southeast Missoturi, Econ. Geol, , v. 72, no. 3, p. $398-407$.

Hue11er, W.H.T., 1974, The mineralogy, geology, and paragenesis of the 1208 oxide stope, defiance workings, Darwin Mine, Darwin, California, Ms thesis, Univ. Calif., Riverside.

Murray, J.W., and Staley, E.K., 1973, Underground operations at Superior, AMC Convention, Denver, Colorado, Sept.9-12, 1973 (Amer. Min. Congress)

Murphy, J.E., and Mejia, V.M., 1961, Underground geology at Iron Mountain, in Guidebook to the geology of the St. Francois Nountain area, Missouri Dept. Bus. \& Adn., Div. Geol, Survey \& Water Resources Rept. Invest. 26, p. 129-133.

Nash, J.T., 1973, Geochenical studies in the Park City district, in Dre fluids in the Mayflower Mine, Con, Geou, v. 68, no., p. 34-51.

Nash, J.T., 1978, Geologic map and cross sections of the Midrite Mine, Stevens County, Washington, U.S. Geol. Survey, Misc. Field study Map MF-943, scale $1 \div 1,200$.

Netuman, R.B., and Ne1son, W.H., 1965, Geology of the western Great Smokey Motuntains, Tennessee, U.S. Geol, Survey Prof. Paper 349D, P. D1-D81. 
New England Intercollegiate Geological Conference - 5lst Ann. Meeting Guldebook, 1959, Stratigraphy and structure of west central Vermont and adjacent New York.

New Mexico mines and mineral resources, 1977, Annual report, July $1975-$ June 1976.

Now York State Geological Association, 1968, 40th Annual Meeting Field Trip Guidebook, Trip D., Sterling and Franklin area in the highlands of New Jersey,.

Newmerk, N.M., Hall, W.J., and Hendron, A.J., 1974, Classification, engineering properties and field exploration of solls, intact rock and in situ rock masses, Report Nash-1301, Office of the Chief of Engineers, Dept. of the Arry, Hashington, D.C., 256 p.

Noble, J.A., and Harder, J.O., 1948, Stratigraphy and metamorphi sm in a part of the rorthern Black Hills and the Homestake Mine, Lead, South Dakota, Geol. Soc. Amer., Bull, v. 59, no. 9, p. 941-975.

Noble, J. $A_{+}$, Harder, J.0,, and Slaughter, A.1., 1949, Structure of a part of the northern Black Hills and the Homestake Mine, Lead, South Dakota, Geo1. Soc. Amer., Bu11., v. 60, no. 2, p. 321-352.

Nob1e, J.A., 1950, Ore mineralization in the Homestake Gold Mine, Lead, South Dakota, Geol. Soc. Aner., Bul1., v. 61, no. 3, P. 221-252.

Nolan, T.B., 1962, The Eureka mining district, Nevada, U.S. Geol, Survey Prof. Paper 406, $78 \mathrm{p}$.

Nolen, T.B., and Hunt, R.N., 1968, The Eureka mining district, Nevada, in Ridge, J.D., ed., Ore deposits of the United States, 1933-1967, AÏME, New York, v. 1, p. 966-991.

O'Brien, J.C., 1943, Current notes on the activity in the strategic ninerals, Redding Field district, Calif. Div. Mines Report 39, p. 324.

O'Brien, J.C., 1947, Mines and mineral resources of Siskiyou County, California Div. Mines Report 43, 425-427.

Office of the Federal Register, 1978, 30 mine resources, Revised July 1, $1978,982 \mathrm{p}$.

Ohio Division of Mines, 1977, 1977 Division of Mines Report, 120 p.

Ohle, E.l., 1968, Copper mineralization in the upper part of the copper harbor conglomerate at thite Pine, Michigan - Discussion, Econ. Geol., v. 63, no. 2, p. 190-191.

Oklahoma Department of Hines, 1977, Sixty-ninth Annual Report, Department of Mines, $48 \mathrm{p}$. 1978, Chief Mine Inspector, 1978 Annual Report, $\$ 3$ p. 
Olmstead, H.W., and Johnson, D.W., 1966, Inspiration geology, in Titley, S.R., and Hicks, C.L., eds, Univ. Ariz. Press, Tucson, 287 p.

Olson, J.C., 1953, Part 6, Outlying deposits in North Carolina, U.S. Geol, Survey Prof. Paper 248D, Mica depastts of the southeastern Piedmont, P. $2 \$ 3-292$.

Osterwald, F.H., and others, 1966, Miners1 resources of Wroning, Geo1. Survey Wyoming, Bul1, 50, 287 p.

Overstreet, W.C., and Bell, H., III, 1965, Geologic map of the crystalline rocks of South Carolina, U.S. Geol. Survey Misc. Geol. Invest., map $I-413$.

1965, The crystalline rocks of South Carolina, U.S. Geol. Survey Bull. $1183,126 \mathrm{p}$.

Paarlberg, N.L., and Evans, L.L., 1977, Geology of the Fletcher Mine, Viburmum Trend, southeast Missouri, Econ. Geol., v. 72, no. 3, p. 391-397.

Page, L.R., and others, 1953, Pegnatite investigations 1942-45, Black Hills, South Dakota, U.S. Geol. Survey Prof. Paper 247, 228 p.

Page, J.J., and Larrabee, D.M., 1962, Beryl resources of New Hampshire, U.S. Ceol. Survey Prof. Paper 353, 49 p.

Palache, C., 1935, The minerals of Franklin and Sterling Hill, Sussex County, New Jersey, U.S. Geol. Survey Prof. Paper 180, 135 p.

Pansza, A.J., Jr., 1971, Geology and ore deposits of the Silver City De Lamar - Flint Region, Owyhee County, Idaho, PhD thesis, Colorado Sch. Mines, Golden.

Pardee, J.T., 1918, Manganese at Butte, Montana, U.S. Geo1. Survey Bul1. $690 \mathrm{E}, 147 \mathrm{p}$.

Pardee, J.T., 1922, Deposits of manganese ore tn Montana, Utah, Oregon, and Washington, U.S. Geo1, Survey Bul1. 724C, p. 141-243.

Pardee, J.T., and Schrader, F.C., 1933, Metalliferous deposits of the greater Helena mining region, Nontana, U.S. Geol. Survey Bull, 842, $318 \mathrm{p}$.

Pardee, J.T., and Park, C.F., Jr., 1948, Gold deposits of the southern Piedmont, U.S. Geo1. Survey Prof. Paper 213, $156 \mathrm{p}$.

Parent, C.F., 1941, Relationships of manganese minerals in the Butte district, BS thesis, Montana Sch. Mines, Butte.

Park, C.F., Jr., 1968, Mineral deposits of the Pacific coastal region, in Ridge, J.D., ed., Ore deposits of the United States, 1944-1967, AIME, New York. 
Parker, J.M., 1963, Geologic setting of the Hanme Tungsten district, U.S. Geol. Survey Bu11. 1122G, 68 p.

Parker, R+L., and Sharp, W.N., 1970, Mafic-u1tramafic igmeous rocks and assoclated carbonatites of the Gem Park Complex, Custer and Frenont Counties, Colorado, U.S. Geol. Survey Prof. Paper 649, 24 p.

Patricio, J.G., and Beus, M.J., 1976, Determination of the in situ modulus of deformation in hard rock mines of the Coeur d'Alene district, rdaho, Symp. on Rock Mechanics, Snowbird, Utah, August 2S-27, 1976, Proc. 17, p. 489.1-489.7.

Patton, W.W., Jr., Miller, T.P., and Tailleur, I.L., 1968, Regional geologic map of the Shmknak and souther part of the Ambler River Quadran* g1es, Alaska, U.S. Geol. Survey Map I-554, scale 1:250,000.

Pavlides, 1962, Geology and manganese deposits of the Maple and Hovey Mountains area, Aroostook County, Maine (with a section on lithology and mineralogy of the deposits, by Louis Pavlides and Charles Milton), U.S. Geol. Survey Prof. Paper 362, $116 \mathrm{p}$.

Pay Dirt, 1970, Sept. 28, 1970

Pay Dirt, 1970, March, 1970.

Pay Dirt, 1975,

Pennepacker, E.N., 1932, Geology of the Robinson (Ely) mining district in Nevada, Mining and metallurgy, v. 13, no. 304, p. 163-168.

Peterman, Z.E., and Hildxeth, R.A., 1978, Reconnafssance geology and geochronology of the precambrian of the Granite Mountains, Wyoming, U.S. Geo1. Survey Prof. Paper 1055, 22 p.

Peters, W.C., 1978, Exploration and mining geology, John Wiley \& Sons, Inc.

Peterson, N.P., 1950, Lead and zinc deposits in the Globe-Miani district, Arizona, in Arizona zinc and lead deposits, Part I, Arizona Bur. Mines Geol. Ser. 18, Bu11. 156, p. 98-112.

Peterson, N.P., Gilbert, D.M., and Quick, G.L., 1951, Geology and ore deposits of the Castle Dome area, Gila County, Arizona, U.S. Geol. Survey Bu11. 971,134 p.

Peterson, N.P., 1954, Copper Cities copper deposit, Globe-Miami district, Arizona, Econ. Geol., v. 49, no. 4, p. 362-377.

Peterson, N.P., and Swanson, R.H., 1956, Geology of the Christmas Copper Mine, Gila County, Arizona, U.S. Geol. Survey Bul1. 1027H, p. 351-373.

Peterson, N.P., 1962, Geology and ore deposits of the, Globe-Miami district, Arizona, U.S. Geol. Survey Prof. Paper 342, 151 p. 
Phillips, C.H., Cornwall, H.R., and Rubin, M., 1971, A holocene orebody of copper oxides and carbonates at Ray, Arizona, Econ. Geo1, v, 66, no 3 , p. $495-498$.

Phinney, W.C., 1972, Duluth Conplex, histary and nomenclature, in Geology of Minnesota, a centennia1 volume, Minn. Geol. Survey, St. Paul, Minn., p. $333-360$.

Pierce, P., 1977, Brenmac-Sunrise Property, Bur. Mines MAS Deposit Summary Report, $62 \mathrm{p}$.

Pilkinton, H.D., 1970, Keystone Mines Exp. Prog., $61 \mathrm{p}$.

Pinger, A.w., 1974, A review of mineralogical, geological and mining activities in the Franklin area, Sussex County, New Jersey, Rocks Miner., v. 49, no. 4, p. 256, 271-273.

Piper, A.M., 1925, MS thesis, Univ. of Idaho.

1974, Rack types, also geologic and hydrologic settings, favorable to deep placement of high-1evel radioactive wastes, Report Y/OHI/SUB$3745 / 4,34 \mathrm{p}$.

1975, Hypothetical prototype sites of repositories for radioactive wastes: Certain metamorphic rocks and mudstone, Report $\mathrm{Y} / \mathrm{OWI} / \mathrm{SUB}$ $3745 / 4,34 \mathrm{p}$.

Pope, W., 1970, Geology and mineralogy of the Trump Fissure-Fault orebodyTrixie Mine, east Tintic district, Utah, WS thes1s, Brigham Young Univ., Provo, Utah.

Postel, A.W., 1952, Geology of Clinton County Magnetite district, New York, U.S. Geol, Survey Prof. Paper 237, BB p.

Power, W.R., Economic geology of the Georgia Marble district, p. $59-68$.

Pratt, H.R., and others, Physical and mechanical properties of selected geologic materials - a compendium, TR 75-3.

Pratt, H.R., Hustrulid, W.A., and Stephenson, D.E., 1978, Earthquake damage to underground facilities, Savannal River laboratory Report $0 \mathrm{P}-1513,84 \mathrm{p}$.

Pratt, H.R., ling1e, R., Schranf, T., 1979, Laboratory measured material properties of quartz monzonite, climax stock, Nevada test site, TR 79 50, submitted to Lawrence livermare laboratory.

Presse1 and others, Alaska D.G. \& GS Open File Report 28.

Price, R.C., 1972, Diggings and doings in Park City, 2nd ed., Univ. Utah Pres5, Salt Lake City, 1972.

Pride D.E., and Robinson, C.S., 1978, Multiple intrusion and hydrothermal 
Prinz, W.C., 1967, Geology and ore deposits of the Philipsburg district, Granite County, Montana, U.S. Geol. Survey bull. 1237, 66 p.

Proffett, J.M., 1973, Structure of the Butte district, Montana, Soc. Econ. Geol. Guidebook, Butte Field Meeting, Gl-G12.

Prucha, J.J., 1956, Geology of the Brewster Magnetite district of south eastern New York, New York State Nuseum Bu11, 43, p. 36-40.

Prucha, J.J., Scotford, D.M., and Sneider, R.M., 1968, Bedrock geology of parts of Putnam and Westchester Counties, New York and Fairfield County, Connecticut, New York State Museum Map and Chart Series 11, p. 22 .

Purdue, F.L., 1975, Geology and ore deposits of the Blackbird minind district, Idaho, MS thesis, New Mexico, Albuquerque.

Purdy, C.P., Jr., 1954, Directory of Washington miníng operations, Wash. Div, Mines Geo1, Inf. Circ. $23,73 \mathrm{p}$.

Quinlan, J.J., and Simos, J.G., 1968, The Mayflower Mine, in Erickson, A.J., Jr., Phillips, W.R., and Garmoe, W.J., Park City district, Utah Guidebook to the geology of Utah 22, Utah Geological society, p. 40-55.

Radabaugh, R.E., Merchant, J.S., and Brown, J.M., 1968, Geology and ore deposits of the Gilman (Red Cliff, Battle Mountain), district, Eagle County, Colorado, in Ridge, J.D., ed., Ore deposits of the United States, 1933-1967, AIME, New York, p. 641-664.

Ransey, R,H., 1953, White Pine Copper Mine, mill, and smelter construction stepped up as New Michigan project nears production stage, Eng. Min. J., v. 154 , no. 1, p. $72-87$.

Ranspott, L.D., 1979, Waste-isolation projects,

Ramspott, L,D., and others, 1979, Technical concept for a tesz of geologic storage of spent reactor fuel in the climax granite.

Ranta, D.E., and others, 1976, Geology of the Urad and Henderson molybdenite deposits - a review, in Epis, R.C., and Heimer, R.J., eds., Frofessional contributions of Colorado Sch. Mines, Studies in Colorado field geology, no. 8, p. 477-485.

Reed, R.C., 1979, Michigan preçnbrian, - Geology and minerals, Mining Congr. J., v. 65, no. 5, p. 46-51.

Reid, R.R., 1961, Guidebook to the geology of the Coeur d'Alene mining district, Idaho Bur. Mines Geo1. Bul1. 16, Moscow, Idaho, 37 p., a1so Pamph. 133, 103 p. 
Reid, R.R., and others, 1976, Fracture - stratigraphic controlled - metamorphic - hydrothermal ore bodies - the Bunker Hi11 Mine, Coeur d'Alene district, Idaho, USA, Abstr., Int. Geol. Congr, Absts. Congr. Geol. Int. Resumes 25, Section 4, Mineral deposits; 4A, Genesis of stratiform ore deposits, p. 182 .

Reinking, R.l., and Hibelink, P.A., 1973, Hineralogy of the altered San Juan formation at the Idarado Mine, Silverton district, Colorado, Econ. Geol., v. 68, no. 3, p. 407-412.

Richert, R.C., 1974, Mount fope project, studies of an underground site for developing peaking capacity, in Electric power and the civil engineer, Power Division, Specialty Conference, Boulder, Colorsdo, August 12-14, 1974, ASCE, New York, p. 265-277.

Ridge, J.D., 1958, Selected bibliographies of hydrothermal and magnatic minesal deposits, Geol. Soc. Amer. Mem. 75, Boulder, Colorado, 198 p.

Ridge, J.D,, ed, 1968, Ore deposits of the United States, 1933-1967, AIME,

1972, Annoted bibliographies of mineral deposits in the western hemisphere, Geol. Soc. Amer. Mem. 13l, Boulder, Colorado, 681 p.

Roales, R.J., Monzgomery, K.H., and Lehner, R.E., 1967, Geology and mineral resources of Eureka County, Nevada, Nevada Bur. Mines Bull. $64,152 \mathrm{p}$.

Robertson, A.F., and Roby, R.N., 1951. Hines and mineral deposits (except fuels), Judith Basin County, Montana, U.S. Bur. Mines Inf. Circ. IC$7602,48 \mathrm{p}$.

Robertson, J.M., 1975, Geology and wineralogy of some copper sulfide deposits near Mount Bohenia, Keweenaw County, Michigan, Econ. Geol., v. 70 , no 7, p. 1202-1224,

Robinson, R.F., and Cook, A., 1966, The Safford copper deposit, Lone Star mining district, Graham County, Arizona, in titley, S.R., and Hicks, C.L., eds., Geoiogy of the porphyry copper deposits, southwestern North America, Univ, Arizona press, Tucson, p. 25l-266.

Robinson, C.S., and others, 1974, Engineering geologic, geophysical, hydrologic and rock-mechanics investigations of the Straight Creek Tunnel Site and Pilot Bore, Colorado, U.S. Geol. Survey Prof. Paper $815,134 \mathrm{p}$.

Robinson, C.S., 1975, Ground water hydrology, Henderson Kine, Colorado, Mining Eng., v. 27, no. 12, p. 67 .

Rocky Mountain Association of Geologists - 1960 Guidebook for the Field Conference, B-3 Field Trip to Clinax, Colorado, Geology of the Climax molybdenite deposit; a progress report. 
Rogers, R.K., and Davis, J.H., 1977, Geology of the Buick Mine, Viburnum Trend, southeast Missouri, Econ. Geol, v. 72, no 3, p. 372-380.

Rose, R.L., 1969, Geology of parts of the Wadsworth and Churchill Butte Quadrangles, Nevada, Nevada Bur. Mines Bull, 71, 30 p.

Ross, C.P., 1934, Geology and ore deposits of the Casto quadrangle, Idaho, U.S. Geo1. Survey Bu11, $854,135 \mathrm{p}$. 1935, Copper in Idaho, in Copper resources of the world, 16th Int. Geological Congress, George Banda Publishing Co., Menasha, Wiscconsin, p. 261-269.

1937, Geology and ore deposits of the Bayhorse region, Custer County, Idaho, U.S. Geol. Survey Bul1. 877, 92 p.

Ross, C.P., and Forrester, J.D., 1958, Outline of the geology of Idaho, Idaho Bur. Mines Geol. Bull. No. $15,74 \mathrm{p}$.

Ross, C.P., 1963, The Belt Series in Montana, (with geologic map compiled by B.A.L. Skipp, and a section on paleontology criteria, by R. Rezak), U.S. Geol. Survey Prof. Paper 346,122 p.

Ross, C.S., 1935, Origin of the copper deposits of the Ducktown type in the southern Appalachian Region, U.S. Geol. Survey Prof. Paper 179, $165 \mathrm{p}$.

Ross, D.C., 1961, Geology and minera1 deposits of Mineral County, Nevada, Nevada Bur. Mines Bull, 58, $98 \mathrm{p}$.

Rothrock, H.E., Johnson, C.H., and Hahn, A.D., 1946, Fluorspar resources of New Mexico, New Mexico Bur. Mines, Min. Res. Bull, 21, p. 71-73, 176-190.

Rubly, G.R., 1938, Miami - Inspiration district, in Butler, B.S., and Wilson, E.D., and Razor, C.A., eds., Arizona Bur. Mines, Geol. Series 10 , Bul1. 143, p. 66-72.

Rudman, A.J., Summerson, C.H., and Hinzu, H.J., 1965, Geology of basement in midwestern U.S., AAPG Bull., v. 49, no. 7, p. 894-904.

Runnels, D.D., 1960, Econ. Geol., Mineralogy and sulfur isotopes of the Ruby Creek copper prospect, Burnite, Alaska, v. 64, no. 1, p. 75-90. 1963, The ore deposits of Ruby Creek, Cosmos Hi11s, Alaska, thesis, Harvard University.

Rupp. G.H., 1939, Block caving at the Sunrise Iron Mine, Wyoning, AJME Tech. Pub. 1067, $16 \mathrm{p}$. 
Sahinen, U., 1957, Mines and minera1 deposits, Missoula and Ravalli Countises, Montans, Montana Bur. Mines Geol. Bul1. 8, 63 p.

Sainsbury, C.L., and others, 1961, Beryllium in stream sediments from the tin-turgsten provinces of the Seward Peninsula, Alaska, in Short papers in the geologic and hydrologic sciences, articles $147 \overline{292}$, Geol. Survey Research 1961, U.S. Geol. Survey Prof. Paper 424C, p. $\mathrm{Cl6}-\mathrm{Cl} 7$.

St. Joseph Minerals Annual Report, 1978.

St. Joseph Minera1s Specia1 Release, 1979.

Sales, R.H., 1914, Ore deposłts at Butte, Montana, AIME Frans., v. 46, no. 8, p. 3-109.

Sales, R.H., and Meyer, C., 1948, Ha11+rock alteration, Butte, Montana, AIME Trans. , v. 178 , p. $9-35$.

Sales, R.H., 1954, Genetic relation between granites, porphyries, and associated copper deposits, First Jackling Lecture, Min. Eng, , $v_{+} 6$, no. 5 , p. 499-505.

Sanjines, R., 1967, Ore controls and the formation of the ore bearings structures in the Idarado Mines, San Miguel and Duray Counties, Colorado, MS thesis, North Dakota.

Santos, E.S., Hall, R.B., and Welsner, R.C., 1975, Mineral resources of the San Pedro Parks wilderness and vicinity, Rio Arriba and Sandoval Counties, New Hexico, U.S. Gool. Survey Bul1. 1385C, 29 p.

Savage, C.N., 1965, Geologic history of Pend Oreille Lake region in north Idaho, Idaho Bur. Mines Geol. Parph. 134, $16 \mathrm{p}$.

1967, Geology and mineral resources of Bonner County, Idaho Bur. Mines Geol. Co. Rept. 6, $131 \mathrm{p}$.

Schilling, J.H., 1956, Geology of the Questa Molybderum (Woly) Mine area, Taos County, New Mexico, New Mexico Bur. Mines Min. Res. Bull. S1, 87 p.

1960, Mineral resources of Taos County, New Hexico, New Mexico Bur.

Mines Min. Res. Bull. 71, 124 p.

1962, An inventory of molybdenun occurrences in Nevada, Nevada Bur. Geol., Report 2, p. 32 .

Schnidt, R.G., 1963, Geology and ore deposits of the Cuyuna north range, Minnesota, J.5. Geol. Survey Prof. Paper 407, $96 \mathrm{p}$.

1976, Geology of the precambrian $W$ (lower precambrian) rocks in western Gogebie County, Michigan, U.S. Geol. Survey Bull. 1407, 40 p. 
Schrader, F.C., 191S, Mineral deposits of the Santa Rita and Patagonia Mountains, Arizona, [with contributions by J.M. Hi11), U.S. Geol. Survey Bull. 582, $373 \mathrm{p}$.

Schwartz, G.W., 1953, Geology of the San Manuel copper deposit, Arizona, U.S. Geol. Survey Prof. Paper 256, 65 p.

Schwartz, 6.M., and Reid, I.L., 1955, Replacement and rock alteration in the Soudan iron ore deposit, Minnesota, AIME Trans., v. 202, p. 298300 .

Searls, F., Jr., 1948, A contribution to the published information on the geology and ore deposits of Goldfield, Nevada, Unî. Nevada Buli., $v, 42$, no. 5, Geol. Min. Ser. 48, 21 p.

Sequin, M.K., 1975, The use of geophysical methods for localizing the zones of coba1t and copper sulphides in Idaho. [Utilite d'emplor des methodes geophysiques pour localiser des zones de sulfures de cobalt et de cuivre en Idaho.) Nat. Can. (NCANAS), v. 100, no. 2, p. 177-186,

Sharp Bits, 1955, Geology - A brief history of two billion years, Sharp Bits, V. 6, no. 2, p. 2-19.

Shepard, W.M., Norris, H.T., and Cook, D.R., 1968, Geology and ore deposits of the east Tintic mining district, Utah, in Ridge, J.0., ed., Ore deposits of the United States, 1933-1967, AIME, New York.

Sheridan, D.M., Maxwe11, C.H., and Albee, A.1., 1967, Geology and uraniun deposits of the Ralston Buttes district, Jefferson County, Colorado, (with sections on paleozoic and younger sedimentary rocks), v.S. Geol. Survey Prof. Paper 520, 121 p.

Short, M.N., and Wilson, E.D., 1938, Magma Mine area, Superior, in Geology and ore deposits of the Tombstone district, Arizona, by Butler, B.S., Wilson, E.D., and Razor, C.A+, eds, Ariz. Bur. Mines, Geol. Series 10, Bu11. 143, p. 90-97.

Short, $M_{+} N_{+}$, and others, 1943, Geology and ore deposits of the superior mining area, Arizona, Univ. Ariz Bull., v. 145, no. 4, Ariz. Bur. Mines, Geol. Ser. 16, Bul1. 151 and Supplement.

Sicherman, A., and others, 1976, Pacific korthwest Metals and Min. Conf. 1976, BCMC, Geol. and Min. - Anbler, Alaska, Apri1, 1976.

Silverman, A., Long, A., and Kulp, J.L., 1960, Age of Coeur d'Alene mineralization; an isotopic study, (discussion of the gem stocks and adjacent ore bodies, Coeur d'Alene district, Idaho, by G.M., Crosby), AIME Trans., v, 217, p. 117-118.

Silversan, A., 1965, Economic geology of the Flint Creek Range, Billing Geol. Soc. Ann. Field Conf. 16, August 12-14, 1965, Univ. Montana, Missoula, p. 108-119. 
Simmons, W.K., 1950, Recent geological investigations in the Ducktown mining district, Tennessee, in Snyder, F.G., ed., Symposium on mineral resources of the southeastern United States, Univ. Tenn. Press. Knoxville, $236 \mathrm{p}$.

Simmons, H.W., and Fowells, J.E., 1966, Geology of the Copper Cities Mine, in Titley, S.R., and Hicks, C.L., eds., Geology of the porphyry copper deposits, southwestern North America (Wilson volume), Univ. Ariz. Press, Tucson, $287 \mathrm{p}$.

Sims, P.K, and Leonard, B.F,, 1952, Geology of the Andover mining district, Sussex County, New Jersey, N.J, Div. Plan \& Dev. Bull 62, Geol. Ser. $48 \mathrm{p}$.

Sims, P.K., 19\$3, Geology of the Dover Nagnetite district, Morris County, New Jersey, U.S. Geot. Survey Bull. $982 G, 305$ p.

1958, Geology and magnetite deposits of Dover district, Morris County, (with a description of the geologic section at Hibernia Mine by A.F. Buddington), U.S. Geol. Survey Prof. Paper 287, 162 p.

Sims, P.K., Drake, A.A., Jr., and Tooker, E.W., 1963, Econonic geology of the Central City district, Gilpin County, Colorado, Џ.S. Geol, Survey Prof. Paper 359, 231 p.

Sins, P.K., and others, 1963, Geology of uranium and associated ore deposits central part of the front range mineral belt, Colorado, U.S. Geol. Survey Prof. Paper 371, $119 \mathrm{p}$.

Sims, P.K., and Sheridan, D.M., 1964, Geology or uraniun deposits in the front range, colorado, (with sections by R.V. King, F.B., Moore, D.H. Richter, and J.D. Schlottmann), U.S. Geo1. Survey Bull, 1159, $116 \mathrm{p}$.

Sims, P.K., 1976, Precambrian tectonics and mineral deposits, Lake Superior region, Econ. Geol., v. 71, no. 6, p. 1092-1127.

Sims, S.J., 1968, The Grace Mine magnetite deposit, in Ridge, J.D., ed., Ore deposits of the United States, 1933-1967, AIVE, New York, v. 1, p. 108-124.

Sisselman, R., 1976, New exploration and development at lead; frosting on Homestake's 100th birthdey cake, Eng. Min. J., v. 1, no. 5, p. 90-96.

Shrivastava, J.N., and Proctor, P.9., 1962, Trace-elenent distribution in theSearchlight, Nevada, quartz monzonite stock, Geol. Soc. Aner. Spec. Paper 68, p. 270.

Skillings, D.N., 1975, Cities Service Co.'s Pinto Valley copper project, Skillings Min. Rev., July 19, 1975, p. 14-15, 18-21.

Sk111ings Mining Review, 1971, St. Joe opens new $\$ 30,000,000$ complex at Ba lnat, N.Y., October 23, p. 11-15. 1973, (Miani East). 
1975, (Miand East).

1975, Safford Phelps Dodge, v. 64, no. 8, Feb. 22, p. 1, 6.

1977, Red Mountain Mine, March 26.

1977, Oracle Ridge, v. 66, no. 33, p. 6.

1978, 0racle Ridge copper mining project, $v, 67$, no $2, p, 7,14$.

1979, May 5 .

Skinger, B.J., and Milton, D.J., 1955, The Elizabeth copper mine, Vermont, Econ. Geol., v. 50, no. 7, p. 751-752.

Skinner, E.H., 1972, Sumnary of physical properties from Crescent Mine, Coeur d'Alene district, Idaho, AIME Trans, v. 252, p. 359-360, App. 2.

Skinner, E.H., and others, 1975, Biaxial test results, Crescent Mine, Coeur $d^{\dagger} A l e n e$ mining district, in Hoskins, E.R., Jr., ed., Applications of rock mechanics, 15th Symp. Rock Mech, Custer State Park, South Dakita, September 17-19, 1973, Aner. Soc. Civil Eng., New York, p. $277-271$.

Slaughter, A.L., 1968, The Homestake Mine, in Ridge, J.D., ed., Ore deposits of the United States, 1933-1967, AIME, New York, v, 2, p. 14371459 .

Smedes, H.W., 1966, Geology and igneous petrology of the northern E1khorn Mountains, Jefferson and Broadwater Counties, Montana, U.S. Geol, Survey Prof. Paper 510, $116 \mathrm{p}$.

Snith, G.O., Bastin, E.S., and Brown, C.W., 1907, Geologic atlas of the United States, Penobscot Bay Folio, Maine, U.S. Geo1. Survey Folio 149 , $14 \mathrm{p}$.

Smith, P.S., 1908, Investigations of the mineral deposits of Seward Peninsula, U.S. Geo1. Survey Bul1. 345E, p. 206-250.

Snfth, P.S., and Eakin, H.M., 1912, The Shungnak Region, Kobuk Valley, U.S. Geo1. Survey Bull, 480J, p. 271-305.

Smith, P.S., 1913, The Noatak-Kobuk Region, Alaska, U.S. Geol. Sturvey Bul1. 536, $160 \mathrm{p}$.

1913, Lode mining near Falrbanks, U.S. Geol. Survey Btıll, 542F, p. $137-202$.

1913, An account of lode mining near Fairbanks, in A geologic reconnaissance of the Fairbanks Quadrangle, Alaska, Pringle, L.M., J.S. Geol. Survey Bul1. 525, $220 \mathrm{p}$.

Smith, P.S., and Hertie, J.B., Jr, 1930, Geology and mineral resources of northwestern AIaska, U.S. Geol. Survey Bul1. 815, 351 p. 
Smith, P.S., 1930, Mineral resources of Alaska in 1927, U.S. Geol. Survey Bul1. 810A, P. 1-64.

1930, Mineral industry of Alaska in 1928 , U.S. Geol. Survey Bull. 813A, p. I-72,

1932, Mineral industry of Alaska in 1929, U.S. Geol. Survey Bull. $824 A$, p. $1-81$.

Smith, P.S., and others, 1937, Mineral resources of Alaska, Report on progress of investigations in 1934, U.S. Geol. Survey Bull. 868, 389 p.

Smith, P.S., 1942, Occurrences of molybdenum minerals in Alaska, U.S. Geo1. Survey Bul1. 926C, p. 161-210.

Sith, H., 1975, Memorandum (Septermber 6, 1940), on reconmendations for exploration in the Mill City, Nevada, Tungsten district, U.S. Geol. Survey Open File Report $75-319,15 \mathrm{p}$.

Snapp, T., 1975, Bartholoma Au Mine reopens, Alaska Weekly, v. 6.

Snyder, F.G., and Emery, J.A., 1956, Geology in development and mining southeast Missouri lead belt, recomnended development of three classes of orebodies, AIME Trans, , $v .8$, no. 12, p. 1216-1224.

Snyder, F.G., 1969, Precambrian iron deposits in Missouri, in Milson, H.D.B., ed., Magmatic ore deposits, Lancaster, Pa., Econ. Geology Publishing Co., Econ. Geolgoy Monogr. 4, p. 231-239.

Soc. Econ. Geo1, 1973, Guidebook for Butte Field Meeting, Butte, Montana, Geo1. Dept., Anaconda Co., Butte, Montana, $150 \mathrm{p}$.

Soderberg, R.L., 1948, Mining methods of the Holden Mine, Howe Sound Co., Chelan Division, Holden, Wash., U.S. Bur. Mines Inf, Circ. 7448, 27 p.

Sorenson, R.E., 1947, Deep discoveries intensify Coeur d'Alene activities Eng. Hin. J., v. 148, no. 10, p. 70-78.

Spencer, A.C., 1917, Geology and ore depasits of Ely, Nevada, U.S. Geol. Survey Prof. Paper 96, $189 \mathrm{p}$.

Spengler, R.W., and others, 1979, Inventory of grantic masses in the State of Nevada, U.S. Geol. Survey Open File Report 79-235, 265 p.

Spurr, J.E., and Garrey, G.H., 1908, Economic geology of the Georgetown Quadrangle (together with the Empire district) Colorado (with general geology by Sydney H. Ba11), U.S. Geol. Survey Prof. Paper 63, p, $23-$ 422.

Staatz, M.H, and Trłtes, A.F., 1955, Geology of the Quartz Creek pegmatite district, Gunnison County, Colorado, U.S. Geol. Survey Prof. Paper 265, $111 \mathrm{p}$. 
Stagtz, M.H., Bunker, C.M., and Bush, C.A., 1971, Geochenical prospecting for thoritin veins by strean-sediment sampling, Lembi Pass Quadrangle, Idaho and Montana, U.S. Geol. Survey Prof. Paper 750C, p. C136-C140.

Staatz, M.H., 1972, Geology and description of the thoriun-bearing veins, Lemhi Pass Quadrangle, Idaho and Hontana, U.\$, Geol. Survey Bull. $1351,94 \mathrm{p}$.

Stanford Research Institute, World minerals availability report, v. 3., 1976 .

Steidtmann, E., and Cathcart, S.H., 1922, Geology of the York tin deposits, Alaska, U.S. Geol. Survey Bu1l. 733,130 p.

Steidtmann, E., 1933, The iron ore deposits of Pilot Knob, Missouri, in Mining districts of the eastern states, 16th Int. Geol. Congr., Guidebook 2 , p. 68-73.

Steven, T.A., Ratte, J.C., 1965, Geology and structural control of ore deposition in the Creede District, San Juan Mountains, Colorado, U.S. Geol. Survey, Prof. Paper 487, 90 p.

Steven, T.A., 1968, Ore deposits in the centrgl San Juan Mountains, Colorado, in Ridge, J.D., ed., Ore deposits of the United States, 19331967, AIME, New York, v. 1, p. 706-713.

Steven, T.S., and Eaton, G.P., 1975, Environment of Ore deposition in the Creede mining district, San Juan Mountains, Colorado, I. Geologic, hydrologic and geophysical setting, Econ. Geol., v. 70, no. 6, p. 1023-1037.

Stewart, J.H., McKee, E.H., and \$tager, H.K., 1977, Geology and mineral deposits of Lander County, Nevada, Part 1 - Geology, Part Ir - Mineral deposits, Nevada Bur. Mines Geol. Bull. 88, 106 p.

Stol1, W.C., 1950, Mica and bery1 pegmatites in Idaho and Montana, U.S. Geo1. Survey Prof. Paper 229, 64 p.

Stout, J.J., 1974, Potential pumped storage projects that would use existing reservoirs, in Engineering foundetion conference, converting in pumped storage facilities, Franklin Pierce College, Rindge, N.H., Amer. Soc. Civil Eng., New York, p. 221-252.

Stowe, C.H., comp., 1979, Utah mineral industry operator directory 1979, Utah Geol. Miner. Survey Circ. 58, 69 p.

Stringham, B., 1953, Mining Eng., v. 5, no. 12, p. 1278-1282.

1958, Relationship of ore to porphyry in the Basin and Range Province U.\$.A., Econ. Gea1., v. 53, no. 7, p. 806-822.

1960, Relationship of ore to porphyry in the Basin and Range Province, U.S.A., Econ. Geol., v, S5, no, 8, p. 1622-1630. 
Strout, J.L., and Conrad, S.G., 1958, Explanatory text for geologic map of North Carolina, North Carolina Div. Min. Res. Bull. 71,51 p-

Stuckey, J.L., 1968, Mineral resources of North Carolina, in North Carolina - Its geology and mineral resources, North Carolina Dept. Conserv. \& Development, p. 2B3-2B4.

Sweeney, P.H., Harrison, E.D., and Bradley, M., 1977, Geology of the Magmont Mine, Viburnum Trend, southeast Missouri, Econ. Geol., v. 72, no. 3, p. 365-374.

Tabor, R.W., and Crowder, D.F., 1969, On batholiths and volcanoes intrusions and eruption of late cenozoic magnas in the Glacier Peak area, North Cascades, Nashington, 1.5. Geo1. Survey Prof. Paper 604, $65 \mathrm{p}$.

Temnessee Division of Geology, 1977, 1976 Directory of Tennessee mining and oil and gas operations, $134 \mathrm{p}$. 1979, List of publications, Tenn. Div. Geol., Nashville, 33 p.

Tenney, J.B., 1935, The copper deposits of Arizona, in Copper resources of the world, 16th Int. Geological Congr., George Banda Publishing Co., Menasha, Wisconsin, p. 167-235.

1935, Bisbee district (section in the Copper districts of Arizona), in Copper resources of the world, 16th Int. Geological Congr., George Banda Publishing Co., Nenasha, Hisc., p. 221-228.

Terra Tek, Inc., 1975, A geology compendium of the continental United States - with application to deep-based systems, DNA 3874 , prepared for defense nuclear agency.

Tesch, C.L., 1974, Production and development activities at the Homestake Gold Mine, Lead, South Dakota, Ann. Miner. Sump., Proc. 17, p. 102113.

Thomas, L.A., 1966, Geology of the San Manuel orebody, in Titley, S.R., and Hicks, C.L., eds, Geology of the porphyry copper deposits, southwestern North America, Univ. Ariz. Press, Tucson, $287 \mathrm{p}$.

Thomas, R. A., 1977, Montana's giant Berkeley Pit Girds for another 22 years, Eng. Min. J., v. 178, no. 6, P. 107-109.

Thomas, Fundamentals of mining, Australian University.

Thompson, G.A., and Buck. F., 1968, Treasure mountain home, Deseret Book Co., Salt Lake City.

Thompson, T.B., 1976, Geology of the down-dropped block, Leadville district, Colorado, in Hoodward, L.A., and Northrup, S.A., eds., Tectonics and mineral resources of southwestern North America (Vincent KeJley vol.), New Mexico Geol. Soc. Spec. Pub. 6, 218 p. 
Tilling, R.I., Klepper, M.R., and Gbradovich, J.D., 1968, K-Ar ages and time span of emplacement the Boulder batholith, Montana, Amer. J. Sci., v. 266, p. 671-689.

Tillman, D.A., 1975, Mining in Vermont, Tower Publishing Co., Portland, $M E, 95 \mathrm{p}$.

Tri-state Geological Field Conference, 1953, Guidebook, 17th Arr. Field Conference, northern Wisconsin.

Tschanz, C.M., and Pampeyan, E.H., 1970, Geology and mineral deposits of Lincoln County, Nevada, Nevada Bur. Mines Bul1. 73, p. 140-147.

Tucker, W.G., 1972, Review of rining 1922, Redding Fleld Div., Calif. Min. Bur. Rept. 19, p 8.

Tung, P.Y.J., 1968, A study of the wall rocks and their relationship to the orebody at the Calloway Nine, Ducktown, Tennessee, its thesis, Tennessee.

Tung, P.Y.J., 1969, Wal1 rock mineral as semblages, Calloway Mine, Tennessee, Geol. Soc. Amer., Abstr., 1969, southeast section, Part 4, p. p. $82-83$.

Turney, A., 1978, Directory of active mines in Arizona (includes sand and gravel producers), Ariz. Dept. Miner. Res. D-4(78), 26 p.

Twenhofel, W.S., 1953, Potential Alaskan mineral resources for proposed electrochenical and electronetallurgical industries in the upper Lynn Canal area, Alaska, U.S. Geo1. Survey Circ. 252, 14 p.

Tweto, 0., 1968, Leadville district, Colorado, in Ridge, J.D., ed., Ore deposits of the United States, 1933-1967, AIME, New York, v. 1, p. $681-705$.

1968, Geologic setting and interrelationships of mineral deposits in the mountain province of Colorado and south central Wyoming, in Ridge, J,S., ed., Ore deposits of the United States, 1933-1967, AIME, New York, v. 1, p. 551-588.

1977 , Nomenclature of precambrian rocks in Colorado, U.S. Geol. Survey Bull. 1422D, $22 \mathrm{p}$.

Tweto, 0., and Lovering, T., 1977, Geology of the Minturn 15-rinute Quadrangle, Eagle and Summit Counties, Colorado, U.S. Geol. Survey Prof. Paper 956, $96 \mathrm{p}$. 
Unpleby, J,B., 1913, A preliminary account of the ore deposits of the Loon Creek district, J.S. Geol. Survey Bull. 530A, p. 66-74. 1913, Geology and ore deposits of lemhi County, Idaho, U.S. Geol. Survey Bul1. 258, $182 \mathrm{p}$. 1924, The Osburn Fault, Idaho, J. Geol., v. 32, no. 7, p. 601-614.

Umpleby, J.B., Westgate, L.G., and Ross, C.P., 1930, Geology and ore deposits of the Hood River Region, Ideho (with a description of the Minnie Moore and nearby mines), U.S. Geol. Survey Bull. 814, 250 p.

Union list of geological field trip guidebooks of North Anerica, 1978 by Paul Wilson, Houston, Texas, compiled and edited by Guldebook and Ephemeral haterials Conmittee, Geoscience Inf. Society, 97 p.

U.S. Bureau Mines, 1971, Bureau of mines mineral yearbook, area reports, 1973 , U.S. Bur. Mines, $V, 2$, p. 246-247.

1974, Mineral supply, Bur. Mines Inf. Circ. 8654, Bur. Mínes availability system and resource classification manual, $199 \mathrm{p}$.

1976, State liaison Officers, Mining and mineral operations in the New England and mid-atlantic states, a visitor guide, U.S. Bur. Mines Spec. Pub. 10-76, 72 p.

1979, Active mineral operations in 1978, Idaho Bur. Mines Mert.

U.S. Bureau Mines and U.S. Geol. Survey, 1976, Principjes of the mineral resource classification system of the U.S. Bur. Mines and U.S. Geol. Survey, P. Al-A5.

U.S, Bureau Mines State Liaison Offices, 1976A, U.S. Bur. Mines, Mining and mineral operations in the U.S., a visitor guide, Report HD 9506 U6306, New England and mid Atlantic states, $72 \mathrm{p}$.

1976B, Mining and mineral operations in the U.S., a visitor guide, Report Hd 9506 U63U66, Pacific states, $70 \mathrm{p}$.

1976C, Mining and mineral operations in the U.S., a visitor guide, Report HD 9506 U63U64, Rocky Hountain states, 87 p.

19760 , Mining and mineral operations in the U.S., a visitor guide, Report HD 9506 U66U63, South Atlantic states, $61 \mathrm{p}$.

1977, Mining and mineral operations in the north-central states, a visitor guide, U.S. Bur. Mines Spec. Pub. HD 9606 U63U65, J20 p.

1977, Nining and mineral operations in the south-centra] states, a visitor guide, U.S. Bur. Mines Spec. Pub. HD 9506 v63067, $168 \mathrm{p}$.

U.S. Geol, Survey - Bureau Mines, 1968, Minera1 resources of the Appalachian region, U.S. Geol. Survey Prof. Paper 580, $492 \mathrm{p}$. 
U.S. Geol. Survey - Geologic and Water Resources Divisions, 1961, Short papers in the geologic and hydrologic sciences (articles 1-146), U.S. Geol. Survey Prof. Paper 424B, p. Bl-B344.

1961B, Geologic survey research, Symopsis of geologic and hydrologic results, U.S. Geol. Survey Prof. Paper 242 A, p. Al-Al94.

U.S. Geol. Survey, 1976, Granite-bimetallic Mine, CRIB W013436.

Utah Geological Society, 1957, 12th Gutdebook to the geology of Utah, Geology of the east Tintic Mountains and ore deposits of the Tintic mining districts.

1957, Utah Geo1. Soc. Guidebook 12, Ore Deposits of the Tintic Standard, north Lily and Eureka lily Mines, by Malcolu B. Kildale, p. 103-137.

Van Alstine, R.E., 1974, Geology and mineral deposits of the Poncha Springs SE Quadrangle, Chaffee County, Colorado, U.S. Geol. Survey Prof. Paper $829,19 \mathrm{p}$.

Vanderwilt, J.W., and King, R.U., 1955, Hydrothermal alteration at the clinax molybdenite deposit, AIME Trans., v. 202, p. 41-53.

Van Noy, R.M., Petersen, N.S., and Gray, J.J., 1970, Kyanite resources in the northwestern United States, an investigation of selected kyanite-group mineral deposits, U.\$. Bur. Mines Rept. Invest. RI 7426 , $81 \mathrm{p}$.

Varnes, D.J., 1963, A - Geology and ore deposits of the south Silverton mining area, San Juan County, Colorado, U.S. Geol. Survey Prof. Paper 378 , p. Al-A56.

Visnes, N., 1957, Sand filling at the Galena Mine, Mining Eng., v. 9, no. 1. P. 49-52.

Von Schonfeldt, H., 1970, An experimental study of open-hole hydraulic fracturing as a measurenent method with particular enphasis on field tests, Corps of Engineers, Missouri River Div., Tech. Rept. MRD-3-70, p. $37-68$.

Waddell, G.G., 1963, Mining nethods and costs, Deep Creek zinc-lead Mine, Goldfield Consolidated Mines Co., Stevens County, Wash., U.S. Bur.

Mines Inf. Clre. $8174,39 \mathrm{p}$.

1966, In situ measurements of rock deformation in a vein-type deep mine, U.S. Bur, Mines Rept. Invest. $6747,47 \mathrm{p}$.

Walschmidt, N.A., 1925, Deformation in ores, Coeur d'Alene district, Idaho, Econ. Geol., v. 20, no. 6, p. 573-586,

Wall Street Journa1, Ju1y 25, 1977, p. 12,

Septenber 2, 1977, p. 22

December 2, 1977, p. 25.

January $4,1978, p, 9$. 
Wallace, C.A., Klepper, M.R, French, A.B., and Scarborough, D.M., 1978, Prelinfnary geologic nap of the northwestern part of the Rutte $\mathrm{I}^{0} \times 2$ quadrangle, Montana, $5 . S$. Geo1. Stirvey Oper

File Report $7 R-371$.

Wa1lace, R.E., and others, 1961, Tectonic setting of the Coeur d'Alene district, Idaho, Idaho Bur. Min. Geol. Bu11. 16, p. 3-5.

Wallace, S.R., and others, 1968, Multiple intrusion and mineralization at Climax, Colorado, in Ridge, ed., Ore deposits of the United States, 1933-1967, AIME, New York, v. 1, p. 605-640.

Wa11ace, S.R+, and others, 1978, Geology of the Urad and Henderson molybdenite deposits, Clear Creek County, Colorado (with a section on a comparison of these deposits with those at Climax, Colorado), Econ. Geol, v. 73, no. 3, p. 325-368.

Wallace miner, April 19, 1979.

April 26, 1979 .

1979, Sunshine mine to become major in world silver market; 3 year plan: no. 12 shaft will be developed, hay $17,1979$.

1979, Bunker Hill Co., Zinc gripes about OSHA regulations, June 7 , 1979 .

1979, District mine net profits at all-time high of $\$ 37,321,483$,

July 5,1979 , p. 1 .

July $12,1979$.

Watowick, S.W., Graven, L.K., 1978, A preliminary geological view of the Minnamax copper-nickel deposit in the Duluth Gabbro at the Minfamax project, in Productivity in the lake Superior mining district, Minn. Univ., Min. Supp. 39, p. 19.1-19.11, Proc. 51st annual meeting, Minn. section of AIME, Duluth, Minn., January 11-15, 1978.

Weaver, C.E., 1976, Waste storage potential of triassic basins in southeast U.S., GIT, Office of Waste Isolation, Dak Ridge, V/OWI/SUB-7009/2, $26 \mathrm{p}$.

Weed, W.H., 1900, Geology of the Little Belt Mountains, Montana, (with notes on the mineral deposits of the Neihart, Barket, Yogo and other districts accompanied by a report on the petrography of the igneous rocks of the district, by L.V. Pirsson), U.S. Geol. Survey 20 th Ann. Rept., Part III, e., p. 257-581.

1912, Geology and ore deposits of the Butte district, Montana, U.S. Geol. Survey Prof. Paper 74, 262 p.

Weege, R.J., and Pollock, J.P., 1966, Exploration methods in the copper country, Keweenaw Peninsula, Michigan, in Papers presented at the AIME Pacific Southwest Mineral Industry Conference, Sparks, Nevada, Nay 5-7, 1965, Session on north anerican exploration and nine development, Part C, p. 5i-61. 
Heege, R.J., and others, 1972, The geology of two new mines in the native copper district of Michigan, Econ. Geo1, v. 67, no. 5, p. 622-633.

Weige1, W.W., 1965, The inside story of Missouri's exploration boom, Part I, Eng. Min. J., v. 166, no. 11, p. 76-86, 170, 172.

We1s, P.L., 1961, Bleaching in the Coeur d'Alene district, Idaho, in Guidebook to the geology of the Coeur d Alene mining district, Idaho, Idaho Bur. Mines Geol. Bul1. 16, p. 11-13.

Weissenborn, A.E., and Moen, W.S., 1974, Uranium in Washington, in Energy resources of Washington, Wash. Div. Geol. Earth Res. Inf. Circ. 50, p. 83-97.

Wenner, D., and Gonzales, S., 1975, Geologic feasibility of talc and serpentinite bodies from the Appalachian Mountain region of eastem United States with regard to siting of radioactive-waste repositories, final report, slbmitted to Union Carbide Corp., Oak Ridge National Laboratories, Oak Ridge, Tennessee, 55 p.

Henner D.B, 1976, Geologic feasibility of talc and serpentinite bodies from the Appalachian Mountain region of eastern United States with regard to siting of radioactive-waste repositories, Part I - Additional conclusions relating to ultranafic rocks, Part II - Field investigations of talc and serpentinite deposits, subnitted to Union Carbide Corp., Oak Ridge National Labs., 0ak Ridge, Tennessee, 27 p.

Hestern Miner, 1967, The Urad Molybdenum Mine, Climax Molybdenum Co., Western Niner, $v, 40$, no. 10, p. 56-59.

Western Mining Directory, Inc,, 1978, howell Publishing Co., Denver, Colorado, $v .1$, no. 1 .

Western Mining News, 1978-1979, Directory of Nines for Idaho, Montana and Washington, Western Mining News Publishers, Spokane, Washington.

Wetze1, N., Benjamin, D., and Larson, C.E., 1979, Manganese resources of the Butte District, Montana, U.S. Bur. Mines Mas Rept., Feb., 1979.

Wharton, H.M., and others, 1975, Guidebook to the geology and ore deposits of selected mines in the Virburmun Trend, Missouri, Missouri Dept.

Nat. Resources, Geol. Survey Rept. Invest. 58.

Wheeler, H.P., Jr., and Eckaxd, W.E., 1952, Underground storage of natural gas In coal-mining areas, U.S. Bur. Mines If. Circ. 7654., 11 p.

White, B.G., 1978, Beltian 'ore strata' in the Coeur d'Alene niring district, Northwest Geol., v. 7, p. 39-46.

White, D.L., 1974, Geology of the Pittsburg landing-Big Canyon Creek area, Snake River Canyon, Idaho and Oregon, Northwest Science, V. 48, no. 1. p. 72-79.

White, L., 1976, Trackless mining on a small scale, Inspiration's Black Pine silver mine, Eng. Hin. J., v. 177, no. 9, p. 98-100. 
White, W.S., Cornwal1, H.R., and Swanson, R.W., 1954, Bedrock geology of the Ahneek Quadrangle, Michigan, U.S. Geol. Survey map GQ-27.

White, W.S., and Wright, J.5., 1954, The White Pine Copper district, Ontonagon County, Michigan, Econ. Geol., v. 49, no. 7, p. $675+716$.

White, W.S., 1956, Regional structural setting of the Michigan native copper district, in Snelgrove, A.K., ed., Geological exploration, Inst. Lake Superior Geology, Houghton, Mich., 109 p.

1960, The White Pine Copper district, Econ. Geo1., v. 55, no. 2, p. 402-409.

White, H.S., and Hright, J.C., 1966, Sulfide-mineral zoning in the basal none-șuch shaIe, northern Michigan, Econ. Geol., v. 61, no. 7, p. 1171-1191.

White, W.S., 1968, The native copper deposits of northern Michigan, in Ridge, J.D., ed., Ore depasits of the United States, 1933-1967, AIME, New York, v. 1, p. 303-325.

1971, Society of Economic Geologists, Guidebook Field Conference, Michigan copper district, September 30-October 2, 1971, Michigan Tech. Univ. Press., Houghton, $82 \mathrm{p}$.

1971, A paleohydrologic model for mineralization of the white Pine copper deposit, northern Michigan, Econ. Geol., v. 66, no. 1, p. 1-13.

White Pine Copper Co., Geol. Staff, 1974, Reinterpretation of structure White Pine Mire, White Pine, Michigan, (Abstract), Inst. Lake Superior Geol. Abstr. \& Field Guides 29, p. 30-31.

Wiebelt, F.J., and Ricker, S., 1950, Investigation of the Atolia tungten mines, Sar Bernardino County, California, U.S. Bur. Mines Rept. Invest. $4627,25 \mathrm{p}$.

Hillden, R., 1964, Geology and mineral deposits of Humboldt County, Nevada, Nevada Bur. Mines Bull. 59, 154 p.

villden, R., and Speed, R.C., 1974, Geology and mineral deposits of churchill County, Nevada, Nevada Bur. Mines Geol. Bull. 83, 95 p.

Milliams, D.R., Trexler, B.D., and Ra1ston, D.R., 1975, Preliminary results of isvestigations of water resource problens related to mining in the Blackbird district, Idaho, Geol. Soc. Amer. Abstr. Prograns, Rocky Mountain section, 28th Annual Meeting, v. 7, no. 5, p. 651-652.

Willianson, J.V., 1974, Antilon Lake puraped storage project, in Electric power and the civil engineer, Power Division, Specialty Conference, Boulder, Colorado, August 12-14, 1974, ASCE, p. 439-465.

Wilson, E.D., 1950, Chapter 7, Superior area, in Arizona zinc and lead deposits, Part I, Arizona Bur. Mines, Geol. Ser. 18, p. 84-98. 
1962, A resume of the geology of Arizona, Ariz. Bur. Mines Bul1, 171, $140 \mathrm{p}$.

Hinograd, I.J., 1974, Radioactive waste storage in the arid zone, EOS Trans. Amer. Geophys. Union (Washington, D.C.), 1974, v. 55, no. 10, p. $884-894$.

Witkind, I.J., 1973, Igneous rocks and related mineral deposits of the Barker Quadrangle, Little Belt Mountains, Mont., U.S, Geol. Survey Prof. Paper 752, 58 p.

Woakes, M., 1959, Potassium-argon dates of the mineralization at Butte, Montana, MS thesis, Univ. Calif., Berkeley, $43 \mathrm{p}$.

Hood, H.B., 1972, Fluorspar, Eng. Min. J., v. 173, no. 3.

Woodward, Clyde, Sherard Associates, 1968, Final report-update siting criteria investigations, v. 1, part 25.

Worl, R.G., and others, 1974, Fluorite in U.S., U.S. Geol. Survey map $M R-60$.

World Mines Register, 1976-1977, Miller Freeman Publications, San Francisco, p. 170-204. 1979-1980, Miller Freenan Publications, San Francisco.

Wor1d Mining, 1976, October. 1977, June.

1977, Continental materials and Uлion Miniere to develop Oracle Ridge, v. 30, no. 11, p. 171 .

Wracher, D.A., 1975, Geology of the Pilot Knob magnetite deposit, southeastem Missouri, Ho. Geol. Survey, Rep. Invest. 61, Studies in precambrian geology of Missouri, p. 155-163.

Wharton, H.M., 1974, King of the Iron Mountain, Missouri clains largest and fourth largest underground iron mines in the nation, Mo. Miner. Ind. News, v. 14, no. 12, p. 194-195.

Wyoming Directory of Manufacturing and Mining, 1978, Ashworth, T., ed., Nyoming Dept, Econ. Planning and Development, Cheyenne.

Wyoming Geological Assoc. 1971, Field Conference Guidebook, Casper, Wyoning, 1954-1971.

Wyoming Inspector of Nines 1972, Annual Report. 1973, Annua1 Report. 1974, Annual Report. 
1975, Arnual Report.

1976, Annual Report.

1977, Annual Report.

1978, Annua1 Report.

Nyoming Mineral Diviston, 1978, Wyoming Mineral Yearbook, 1977, Wyoming State Dept. Econ. Plan. Devel., Cheyenne.

Yardley, D.H., 1975, Hydrology of some deep mines in precambrian rocks, Y/OWI/SUB-4367/1.

Yardley, D.H., and Goldich, S.S., 1975B, Prelininary review of precambrian shield rocks for potential waste repository, $Y / 0 w 1 / S U B-4367 / 2$.

Yates, R.G., Thompson, G.A,, 1959, Geology and quicksilver deposits of the Terlingua district, Texas, U.S. Geol. Survey Prof. Paper 312, 114 p.

Young, E.J, 1977, Geologic, radionetric, and mineralogic maps and underground workings of the Schwatzwalder uranium mine and area, Jefferson County, Colorado, U.S. Geol. Survey, Open File Report 77-725, 41 p.

Young, W.E., 1947, Iron deposits, Iron County, Utah, U.S. Bur. Mines, RI $4076,102 \mathrm{p}$.

Young, R.S., 1968, Mineral exploration and development in Maine, in Ridge J.D., ed., Ore deposits of the United States, 1933-1967, AIME, New York, v. 1, p. 125-139.

Youngberg, E.A., and Wi1son, T.L., 1952, The geology of the Holden Mine, Econ. Geol, v. 47, no. 1, p. 1-12.

Yousefpout, M.J., 1977, Geology and contact pyrometasomatic ore deposits at the Continental Mine, Fierro, New Mexico, MS thesis, Colorado Sch. Mines, Golden, Colorado. 


\section{$\underline{\mathrm{NOOEX}}$}

This index serves as a subject key to the Bibliography. The index begins with headings of a general nature. Following these listings, the index uses as subjects primarily state, region, county, mining district, and mine names. Included are listings of underground workings not in classes 1 and 2 .

To make the Bibliography easier to use, author and year of publication identify each reference dealing with a specific area or site. Page numbers where given refer to information on an underground working described in the body of this report. 
General

Acres American 1975

Acres American $1975 \mathrm{~B}$

Acres American 1976

AILE, 1970

Anderson, 1973

Ash, 1974

Asher, 1978

Billings, 1942

Blair, 1955

Brown, 1970

Cording, 1971

Cording, 1975

Cummins, 1973

Deere, 1969

Dir. Reg. Standards, 1974

Doe, 1978

Dravo Corp., 1974

Edgerton, 1974

Eng. Hin. J., 1977

Eng. Hin. J., 1978

Flint, I957

Hanilton, 1967

Heinrich, 1953B

Hunt, 1967

International Directory of Mining and Min. Proc. Oper., 1978 Janki son, 1978

Judd, 1959

Judd, 1969

Ken O'Brien Assoc., 1968

Ken O'Brien Assoc., 1969

Kerr Addison, 1977

Kerr Addison, 1978

King, 1969

King, 1976

King, 1978

LeGrand, 1972

Lindner, 1978

Majtenyi, 1976

Mckinney, 1973

McWillians, 1978

Mining Ann. Rev., 1978

Misłng Mag. I975

Misterek, 1976

Newmark, 1974

Office of the Fed, Register, 1978

Peters, 1978

Ridge, 1958

Ridge, 1972

Rudman, 1965

Union List of Geological field Trip Guidebooks of North Amer, 1978

U,S. Bur, Mines, 1966 
General (cont.)

U.S. Bur, Mines, 1968

U.S. Bur. Mines, 1971

U.S. Bur. Mires, 1974

U.S. Bur. Mines, 1976

U.S. Bur. Mines, 1976B

U.S. Bur. Mines, $1976 \mathrm{C}$

U.S. Bur. Mines, 1976D

U.S. Bur. Mines, $1976 \mathrm{E}$

U.S. Bur. Mines, $1976 \mathrm{~F}$

1.S. Geo1. Survey, Water Res. Div., 1961

U.S. Geol. Survey, Water Res. Div., 1961B

Waddell, 1966

Wa1lace Miner, Apr 19/79

Wallace Miner, Apr 26/79

Wallace Miner, May $17 / 79$

Wallace Miner, June $7 / 79$

Wallace Miner, July $5 / 79$

Wallace Miner, July $12 / 79$

Weaver, 1976

Western Mining Directory, 1978

Wheeler, 1952

Winograd, 1974

Woodward, 1968

World Mines Register, 1976

Yardley, 1975

Yardley, 1975B

Mineral Deposits

Batemen, 1949

Beal 1, 1973

Brown, 1968

Buddington, 1959

Buddington, 1963

Cameron, 1954

Clark, 1968

Dellinger, 1956

Elevatorski, 1978

Eng. Min. J., 1965

Farquhar, 1974

Geosci. Inf. Soc., 1968

Goldich, 1968

Goth, 1979

Hilpert, 1969

Hobbs, 1968

Jahrs, 1952

Nuclear Power

Desai, 1976

Waste Isolation \& Storage

Ballou, 1978

Belitzky, 1977

Bostrom, 1970

Brunton, 1977 
Waste Isolation \& Storage (cont.)

Champlin, 1967

Cobbs, 1975

Cobbs Eng., 1976

Fenix है Scisson, 1978

Georgia Univ, , 1976

Henton, 1974

Hil1, 1978

IAEA, 1977

Kege1, 1975

Piper, 1974

Piper, 1975

Pratt, 1978

Winograd, 1974

Water Storage

Cairney, 1973 
Alabama

Heirrich, $1953 \mathrm{C}$

Alaska

Jansons, 1977

Mardirosian, 1977

Moffit, 1935

Smith, 1937

Arctic Camp Mine

Brosege, 1977

Dillon, 1977

Forbes, 1973

Fritts, 1970

Grybeck, 1977

Patton, 1968

Rumnels, 1960

Rumnels, 1963

Sichermann, 1976

Bartholomae Mine

Brooks, 1912

Brooks, 1921

Brooks, 1922

Brooks, 1923

Brooks, 1924

Brooks, 1925

Chapin, 1919

Cobb, 1972

Hill, 1933

Martin, 1920

Mertie, 1918

Smith, 1913

Sinith, 1913B

Smith, 1930

Smith, 1930B

Snapp, 1975

Bornite Mine

Berg, 1967

Brooks, 1921

Cobb, 1972

Cobb, 1972B

Cobb, 1973

Cox, 1973

Fritts, 1970

Knox, 1968

Lund, 1961

Matzko, 1963

Sicherman, 1976

Smith, 1911

Smith, 1913

Smith, 1930

Imuruk Basin Graphite Mine

Brooks, 1918

Cathcart, 1922 
Alaska (cont.)

Harrington, 1919

Mertie, 1918

Smith, 1908

Jualin Mine

Eakin, 1918

Lost River Mine

Adkinson, 1975

Brooks, 1907

Brooks, 1910

Brooks, 1913

Brooks, 1914

Brooks, 1915

Brooks, 1916

Brooks, 1918

Brooks, 1921

Brooks, 1921B

Brooks, 1922

Cathcart, 1922

Chapin, 1914

Collier, 1904

Collier, 1904B

Collier, $190 \$$

Eakin, 19ls

Harrington, 1919

Harrington, 1921

Hess, 1906

Hess, 1912

Humunel, 1975

Knopf, 1908

Knopf, 1908B

Martin, 1919

Martin, 1920

Mertie, 1918

Sainsbury, 1961

Smith, 1930

Sintth, 1932

Smith, 1942

Steidtmann, 1922

Twenhofel, 1953

McCarty Mine

Pilkington, 1970

Arizons

Ariz, Bur, of Aines, 1950

Bureau of Mines, 1973

Dare, 1959

Greeley, 1978

Hunt, 1956

Hynd, 1976

Keith, 1973

Keith, 1975

Keith, 1978 
Arizona (cont.)

Mardirosian, 1973

Pay Dirt, 1975

Tenney, 1935

Turney, 1978

Wilson, 1962

Ajo District

Gilluly, 1935

Gilluly, 1946

Bagdad Area

Anderson, 1955

Butler, 1938

Dunning, 1959

Banner District

Eastlick, 1968

Bisbee District

Tenney, 1935

Christmas Mine

Dunning, 1959

Eastl ick, 1968

Peterson, 1956

Gila County

Simnons, 1966

Gila Cotinty/Castle Dome Area

Peterson, 1951

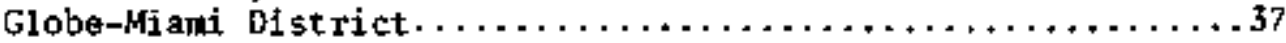

Peterson, 1954

Peterson, 1962

Helvetia District

Creasey, 1955

Iron King Mine

Gilmour, 1968

Kalamazoo Мiлe $\ldots \ldots \ldots \ldots \ldots \ldots \ldots \ldots \ldots \ldots \ldots \ldots \ldots \ldots \ldots \ldots, \ldots 4$

lowe11, 1968

Lowe 11, 1970

Schwartz, 1953

Thomas, 1966

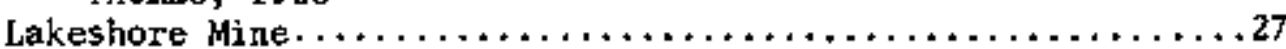

Board, 1977

Cobbs, 1976

Eng. Min, $J_{+}, 1969$

Eng. Mìn. J, 1978

Eng. Min. J., 1979

Ha1lof, 1971

Harper, 1969

Pay Dirt, 1970

Magma (Superior) Mine

Dunning, I959

Ettinger, 1935

Hanmer, 1968

Murray, 1973

Short, 1938

Short, 1943 
Arizona (cont.)

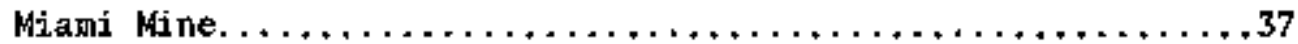

Rub1y, 1938

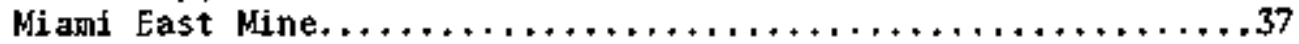

Carter, 1975

Dunning, 1959

Fletcher, 1960

MAS

Mining Ann. Rev., 1978

Mining Mag., 1975

Olmstead, 1966

Peterson, 1951

Peterson, 1954

Peterson, 1962

Rubly, 1938

Skillings, 1973

Skillings, 1975

Wall Street Journal, 1969

Oracle Ridge

Eng. Min. J., 1974

Min. Congress Journal, 1977

Skillings Mining Rev., 1977

Skillings Mining Rev., 1978

World Mining, 1977

Pima District

Huff, 1961

Keith, 1974

Pinal County

Ray

Creasey, 1967

Phillips, 1971

Red Mountain Mine

Corn, 1975

Pay Dirt, 1970

Schrader, 1915

Skillings fining Rev, , I977

world Mining, 1976

Safford Phelps Dodge

Robinson, 1966

Skillings Mining Rev., 1975

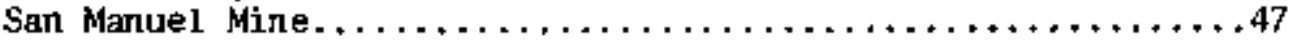

Buchanan, 1960

Creasey, 1965

Dumning, 1959

Jackson, 1978

Kendorski, 1976

Knoerr, 1956

lowel1, 1970

Schwartz, 1953

Thomas, 1966

Arkansas

Stroud, 1969 
Basin \& Range

Stringham, 1958

Stringham, 1960

\section{California}

Bur. of Mines, 1973

Calif. Div. of Mines \& Geol., 1979

Hot 2, 1971

Hardirosian, 1974

Atolia District

Leienran, 1940

Wiebelt, 1950

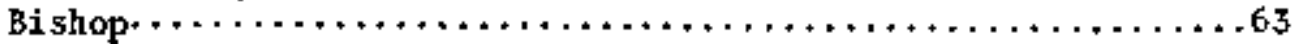

Bateman, 1956

Bateman, 1965

Gray, 1968

Mays, 1941

Darwin Mine

Czamanske, 1975

Ha11, 1958

Hall, 1962

$\mathrm{Hal1}, 1971$

Kel1ey, 1938

Mueller, 1974

French Gulch - Deadwood bist.

Albers, 1961

Grey Eagle Mine

Aubrey, 1908

Brow, 1916

Calif. Div. of Mines \& Geol., 1947

Laizure, 1921

Logan, 1925

O'Brien, 1943

O'Brien, 1947

Tucker, 1922

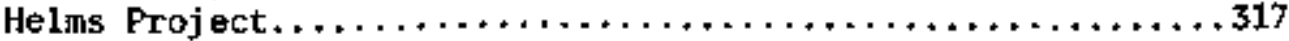

Вateлал, 1965

Haimson, 1976

Inyo County

Baternan, 1950

Ivanpah Quadrangle Hewitt, 1956

Oriental Mine

Calif. J. Min. Geol., 1956

Calson, 1956

Clark, 1970

Ferguson, 1913

Ferguson, 1932

Logan, 1922

Mac Boyle, 1918

Pine Creek Nine $\ldots \ldots \ldots \ldots \ldots \ldots \ldots \ldots \ldots \ldots \ldots \ldots \ldots \ldots \ldots \ldots \ldots$

Bateman, 1956

Bateman, 1965 
Califortia (cont.)

Gray, 1968

MAS

Ridge, 1972

Hest Shasta District

Kinke1, 1956

\section{Colorado}

Burbank, 1935 ,

Bur. Mines, 1973

Colo, Bur. Mines, 1971

Colo. Min. Assoc., 1978

Dare, 1959

Dowding, 1976

Hanley, 1950

Heyl, 1964

Hunt, 1956

Tweto, 1968

Tweto, 1977

Tweto, Lovering, 1977

Central City District

Sims, 1963

Chicago Creek Area

Harrison, 1959

Climax Mine..............................

Anax, 1974

Butler, 1933

CRIB

Eckel, 1947

MAS

Mining Anл. Rev., 1978

Ridge, 1972

Rocky Mountain Assn. Geol., 1960

Vanderwilt, 1956

Wallace, 1968

Colorado Sehool of Mines............................. 109

Lovering, 1950

Moench, 1964

Creede District

Steven, 1965

Steven, 1975

Cripple Creek District

Lovering, 1950

Eagle Mine

Radabaugh, 1968

Eastern Breckenridge Mining District

Pride, 1978

Freeland-Lamartine District

Harrison, 1956

Front Range

Lovering, 1950

Sims, 1963

Sims, 1964

Garfield Quadrangle

Dings, 1957 
Colorado (cont.)

Gem Park Complex

Parker, 1970

Georigetown Quadrangle

Spurr, 1908

Gilman District

Lovering, 1978

Golden Gate Canyon

Adaras, 1956

Henderson Mine.

Eckel, 1947

Eng. Min. J., 1965

Eng. Min. J., 1975

Eng. Min. J., 1975B

Eng. Min. J., 1976

Goth, 1979

Hoppe, 1976

Kendrick, 1970

Lovering, 1950

Min. Ann, Rev, 1978

Ranta, 1976

Robinson, 1975

Idaho Springs-Central City Area...................109

Rocky Mountain Assn. Geol., 1960

Idarado Wine

Hillebrand, 1957

Hillebrand, 1968

Michigan Acad. Sci. \& Letters, Geol. \&्ष Mineral, 1971

Reinking, 1973

Sanjines, 1971

1a P1ata District

Eckel, 1949

Leadville District

Ebbley, 1949

Emmons, 1927

Thompson, 1976

Tweto, 1968

Hountain Province

Tweto, 1968

Mosquito Range

Behre, 1953

Poncha Springs

Van Alstine, 1974

Quartz Creek Pegmatite District

Staatz, $195 \$$

Resurrection Mine

Jonson, 1955

Rico District

McKnight, 1974

San Juan Mountains

Burbank, 1961

Burbank, 1968

Steven, 1965

Steven, 1968 
Colorado (cont.)

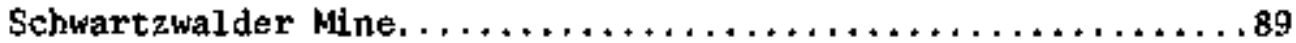
Eng. Min. J., 1978

MAS

Sheridar, 1967

Sims, 1964

Sherman Mine

Courtright, 1974

Si1verton Mining Area

Varnes, 1963

Straight Creek Tuлnel

Robinson, 1974

Tarryall Region

Hawley, 1977

Tenmile District

Bergendahl, 1971

Tungsten Distriet

lovering, 1953

Urad Mine. . . . . . .

Eckel, 194 ?

Eng. Min. J., 1965

Eng. Min. J., 1975

Eng. Min. J., 1976

Goth, 1979

Hoppe, 1976

Kendrick, 1970

Lovering, 1950

Mining Ann. Rev., 1978

Ranta, 1976

Wa1lace, 1978

Westem Miner, 1967

Georgia

Cartersville Distriet

Kesler, 1950

Chatsworth District

Gonzales, 1975

Hartwell Djstriet

Griffitts, 1953

Piedmont Manganese Be1t

Beck, 1946

Overstreet, 1965

Thomaston-Barnesville District

Heinrich, 1953

Idaho

Bond, 1978

Bur. Min., 1973

Hietaren, 1963

Idaho Dept. Labor \& Ind. Services, 1977

Idaho Dept. Labor \& Ind. Services, 1978

Johnson, 1947

Lee, 1976

Mardirosian, 1976 
Idaho (cont.)

Ross, 1935

koss, 1958

Stoll, 1950

Umpleby, 1924

Western Mining News, 1978-79

White, 1974

Alamo Mine

Savage, 1965

Blackbird Mine

Hawkes, 1952

Hoivitt, 1956

Purdue, 1975

Sequin, 1973

Williams, 1975

Bunker Hill Mine

Caddey, 1974

Conway, 1972

Haivala, 1963

Idaho Bur. Min. Geol., 1963

McConnel, 1939

McConne1, 196]

Reid, 1976

Cago No. 12 Mine

Anderson, 1961

Staatz, 1971

Staatz, 1972

Clayton Siver Mine

C1ayton Silver Mines, 1978

Coeur d'Alene District. . . . . . . . . . . . . . . . . 125

Anderson, 1967

Carter, 1976

Chan, 1969

Chan, 1972

Conway, 1972

Crosby, 1969

Frykliund, 1961

Fryklund, 1964

Full , 1955

cott, 1973

Gott, 1975

Hershey, 1916

Hietanen, 1963

Hobbs, 1965

Hobbs, 1968

Hosterman, 1956

Idaho Bur, Min, 1961

Idaho Bur. Min., 1963

Idaho Dept. Labor \& Indust. Services, 1978

Mitcham, 1952

Reid, 1961

Reid, 1976

Roales, 1973

Ross, 1935

Ross, 1958 
Idaho (cont.)

$$
\begin{aligned}
& \text { Silvertian, } 1960 \\
& \text { Skinner, } 1972 \\
& \text { Sorenson, } 1947 \\
& \text { Unpleby, } 1924
\end{aligned}
$$

U.S. Bur, of Mines, 1971

Wallace, 1961

Wallace Miner, 1979

Weis, 1961

White, 1978

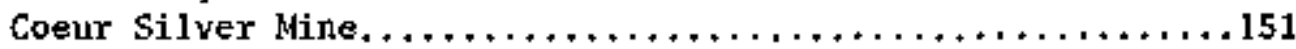

Carter, 1976

Eng. Min. J., 1976

Eng. Min. J., 1977

Fryklund, 1964

Hobbs, 1965

Wallace Miner, 1979

Conjecture Mine

Calkins, 1909

Kun, 1970

Kun, 1974

MacDona1d, 1906

Copper Camp Mine

Cater, 1973

Crescent Mine

Hobbs, 1965

Skinner, 1972

Skinner, 1975

Dayrock Hine.

Acres American, 1975

Carter, 1976

Cobbs Engineering, 1976

Farsuin, 1961

Fryklund, 1964

Idaho Bur. Min. Geol., 1963

Deep Creek Nountains

Carr, 1961

Dworshak Dan Site

Deere, 1969

Johnson, 1947

Galena Mine

Ageton, 1967

Blake, 1971

Blake, 1972

Chan, 1967

Chan, 1969

Kesten, 1961

Kesten, 1963

Visnes, 1957

Golden Sunbeam Mine

Lockard, 1971

Ross, 1937

Golden Sunrise Mine

lockard, 1971 
Idaho (cont.)

Hercules Mine Crosby, 1959

Stringham, 1953

Hecla Hine Waldschmidt, 1925

Highland-Surprise Mine Arnold, 1962 Fryk1und, 1955

Hoodoo Mine Kerm, 1972

Ima Mine Ca1laghan, 1941 Geo 1. Soc. An. Umpleby, 1913

little Pittsburg Mine Herdlick, 1947

Lost Packer Mine.

Bond, 1978

Crib, $197 \mathrm{~A}$

Idaho Dept. Labor \& Indust. Services, 1977

Ross, 1958

Umpleby, 1911

U.S.Bur. Mines, 1979

Lucky Friday Mine

Hobbs, 1965

Hutchinson, 1961

Monitor Mine

Roales, 1973

Murray Area

Hosterman, 1956

Page titne

Idaho Bur. Min. Geol., 1963

Kesten, 1963

Peacock Hine

Cook, 1954

Phi Kappa Mine

Ump1eby, 1930

Sidney Mine

Jones, 1920

Silver City Region

Asher, 1968

Pansza, 1971

Silver Sumit Mine

Chan, 1972

South Mountain Aine

Bennet, 1975

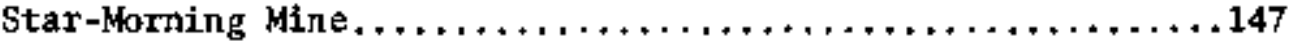

Chan, 1972

Eng. Min. J., 1977

Fryklund, 1964

Gott, 1975

Hobbs, 1965

Idaho Bur. Min, Geol., 1963 
Idaho (cont.)

$$
\begin{aligned}
& \text { Patricio, } 1976 \\
& \text { Sorenson, } 1947 \\
& \text { Waddel 1, } 1966 \\
& \text { Steen Mine } \\
& \text { Anderson, } 1953 \\
& \text { Ross, } 1934 \\
& \text { Unp1 eby, } 1913 \\
& \text { Success Mine } \\
& \text { Crosby, } 1969 \\
& \text { Piper, } 1925 \\
& \text { Sunshine Mine } \\
& \text { Colson, } 1961 \\
& \text { Colson, } 1963 \\
& \text { Patricio, } 1976 \\
& \text { Whitedelph hine } \\
& \text { Anderson, } 1930 \\
& \text { Anderson, } 1946 \\
& \text { Anderson, } 1947 \\
& \text { Savage, } 1967
\end{aligned}
$$

Illinois

Bur. of Mines, 1973

Hey1, 1961

I11. Dept. Min. Minera1, 1977

Kentucky

Hey1, 1961

Lake Suporior

Broderick, 1956

leith, 1935

Marsden, 1968

Маiле

Bur. of Mines, 1973

Dale, 1907

Doyle, 1966

Doyle, 1967

Young, 1968

Black Hawk (2nd Pond) -B1ue Hill Mine $\ldots \ldots \ldots \ldots \ldots \ldots \ldots \ldots$

Canadian Nines Handbook, 1978

CRIB

Doyle, 1966

Eng. Min. J., 1965

Kerr Addison, 1977

Kerr Addison, 1978

Li, 1942

Snith, 1907

Young, 1968

Kerr An. Blue Hill Joint Venture

Earl, 1950

Howd, 1974

Li, 1942 
Maine (cont.)

Maple \& Hovey Hountains

Pavlides, 1962

Patapsco Mine

Heyl, 1965

Penobscot Bay Quadrangle

Smith, 1907

Michigan

Bur. of Mines, 1973

Comwall, 1947

Cornwal1, 1956

Cornwa11, 1956 B

Davidson, 1955

Eng. Min. J., 1974

Hore, 1915

Hubbard, 1975

James, 1967

Jolly, 1972

Michigan Acad. of Sci., Axts, G Letters, 1939

Michigan Basin Geol. Soc., 1961

Reed, 1979

Sins, 1976

White, 1953

White, 1956

White, 1968

Wh1te, 1971

Yardley, 1975

Calumet

Benedict, 1952

White, 1966

Centennial Mine

Yardley, 1975

Copper District

Broderick, 1935

Broderick, 1946

But ]er, 1929

Weege, 1972

White, 1956

Crystal Fal1s bistriet

James, 1968

Gogebic County

Schnidt, 1976

Homestake Copper

Yardley, 1975

Hecla Mine

Benedict, 1952

Keweenaw Peninsula

Heege, 1966

Keweenaw County

Robertson, 1975

Macleod Mine

Yardley, 1975 
Michigan (cont.)

Marquette District Anderson, 1968

Cannon, 1976

Menominee Iron-Bearing District

Bayley, 1904

Bayley, 1966

Dutton, 1968

Upper Peninstila

Brooks, 1873

White Pine Mine

Ransey, 1953

White Pine Copper Deposit

Brown, 1971

Brown, 1973

Brown, 1974

Eng. Min, J., 1965

Ensign, 1968

Hamilton, 1967

Harris, 1972

Leone, 1971

Moe, 1954

Mognessensky, 1967

Chle, 1968

White, 1954

White, 1960

White, 1971

White Pine Copper Co., 1974

Yard1ey, 1975

\section{Minnesota}

Bur. of Mines, 1973

Geol. Soc. Am., 1956

Mtnnesota Dept. of Natural Resources, 1977

Sims, 1976

Yardley, 1975B

Babbitt Lake

Bonnickson, 1972

Cuynura Range

Beltrawe, 1977

Grout, 1955

Han, 1968

Schnidt, 1963

Mesabi Iron Range

Marsden, 1968

Minnamax Project $\ldots \ldots \ldots \ldots \ldots \ldots \ldots \ldots \ldots \ldots \ldots \ldots \ldots \ldots \ldots$

Bonni schsen, 1972

CRIB

Eng. Min. J., 1976

Fairhurst, 1979

Johnson, 1978

MAS

Minnesota Dept, of Natural Resouxces, 1977

Phinney, 1972 


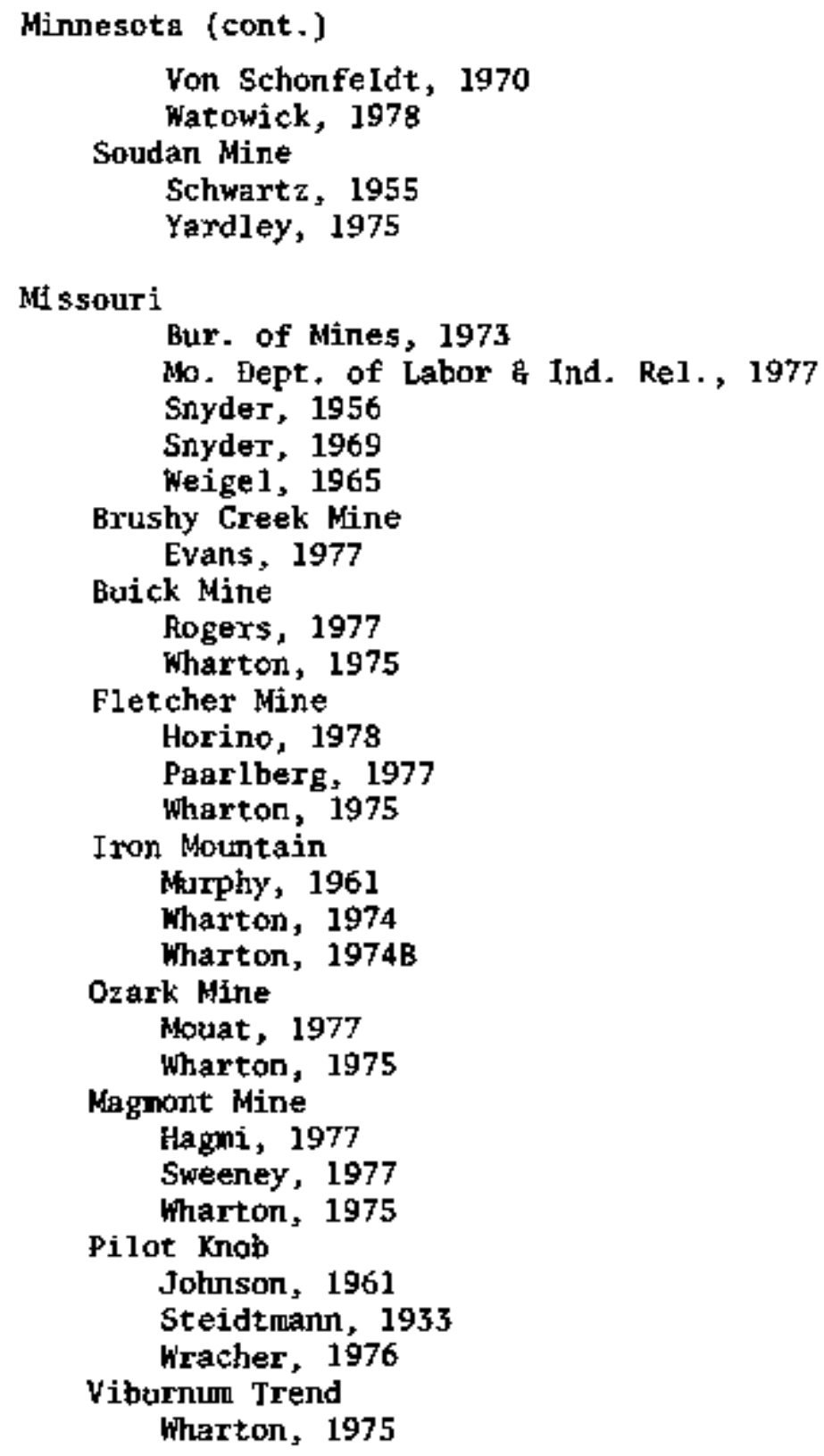


Montana (cont.)

Be1t Series

Ross, 1963

Black Pine Mine $\ldots \ldots \ldots \ldots \ldots \ldots \ldots \ldots \ldots \ldots \ldots \ldots \ldots \ldots \ldots 17 \ldots \ldots \ldots$

Enmons, 1913

Holser, 1950

Krohn, 1977

Prinz, 1967

Ross, 1963

Silverman, 1965

Tilling, 1968

White, 1976

Block P. Mine

Econ. Geol., 1938

Boulder Batholith

Butte Billingsley, 1918

Soc. Econ. Geol., 1973

Butte Manganese District

B1ake, 1888

Davis, 1949

Hart, 1935

Meyer, 1968

Miller, 1973

Pardee, 1918

Pardee, 1922

Parent, 1941

Sales, 1914

Heed, 1912

Hetzel, 1979

Butte Mining District \& Butte Underground Nines.........183

Billingsley, 1918

K1 epper, 1962

Knopf, 1957

Meyer, 1968

Miller, 1973

Proffett, 1973

Sales, 1914

Sales, 1948

Sales, 1954

Thomas, 1977

Woakes, 1959

Ga1t-Queen Mine

Weed, 1900

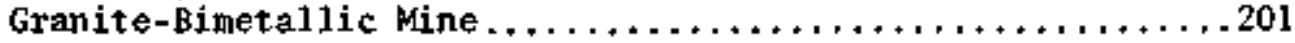

Enmons, 1913

Eng. Min. J., 1965

Krohn, 1977

Lawson, 1979

Prinz, 1967

Ridge, 1972

Silverman, 1965

Tilling, 1968

U.S. Geol. Survey (CRIB), 1976 
Montana (cont.)

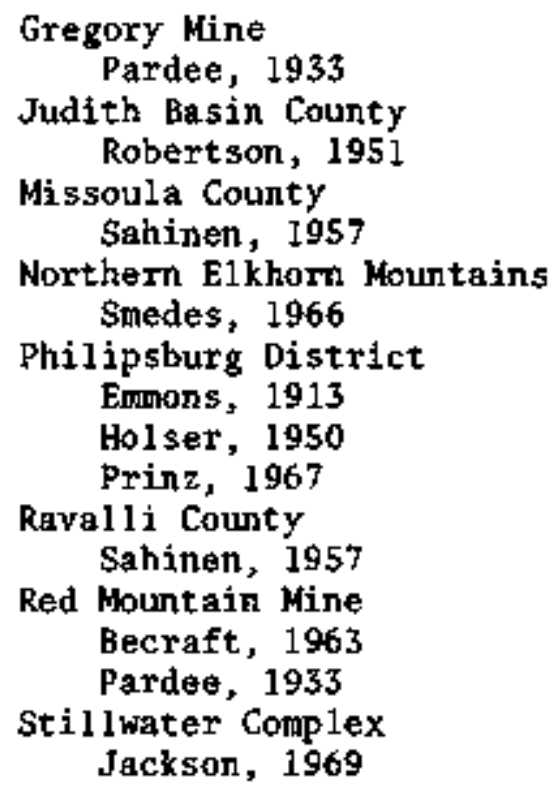

Nevada

Bur. of Kines, 1973

Hose, 1976

Johuson, 1977

Loeltz, 1955

Longwe11, 1965

Moore, 1969

Spengler, 1979

Hillden, 1974

Anary Prospect

Horton, 1964

Wor1, 1974

Baxter Mine

Nat son, 1955

Mats on, 1956

Crowell Mine

Geehan, 1946

Wood, 1972

Eureka Mining District

Nolan, 1962

Nolan, 1968

Roberts, 1967

Getchel1 Mine

Hutt1, 1963

Hillden, 1964

Goldfield

Searls, 1948

Gooseberry Mine

Rose, 1969

Ivanpah Quadrangle

Hewitt, 1956

Lander County

Stewart, 1977 
Nevada (cont.)

Majuba Hil1 Area

Mac Kenzie, 1976

will City Tungsten District

Hotz, 1964

Kerr, 1934

Lawrence, 1963

Nevada Univ, Bul1, , 1934

Solith, 1975

Mineral County

Ross, 1961

Nevada Test Site

Duba, 1974

Ecke1, 1968

Heard, 1970

Hinrichs, 1968

Pratt, 1975

Pratt, 1979

Ramspott, 1979

Ramspott, 1979B

Nye County

Cornwa11, 1972

Pan American Mine

Eng. Min. $J_{+}, 1967$

Nevada Bur. Min., 1970

Ramsey Mine

Rose, 1969

Ruby Hill Project

Love, 1966

Ruth Kimberley Underground

Adair, 1960

Pennepacker, 1932

Spencer, 1917

Searchlight

\$hrivastava, 1962

Silver Dyke

Geol. Soc. An., 1946

Nevada Bur, of Min., 1961

Nevada Bur. of Min., 1962

Storey County

Bonham, 1969

Taylor District

Drewes, 1962

Lovering, 1974

Tem Piute Operations . . . . . . . . . . . . . . . . . . . 209

Cobbs Eng., 1976

Eng. Min. J., 1974

Eng. Min. J, 1977

Tschanz, 1970

Washoe County

Bonham, 1969

Yellow Pine Mine

Geehan, 1949 
New Hanpshire

Page, 1962

New Jersey

Buddington, 1966

Hotz, 1954

Franklin Area

N.Y. State Geol. Assac., 1968

Palache, 1935

Pinger, 1974

Morris County/Dover Magnetite

Sims, 1953

Sims, 1958

Nount Hope kine and scrub oaks Mine $\ldots \ldots \ldots \ldots \ldots \ldots \ldots \ldots 217$

Acres American, 1975

Collins, 1968

Eng. Min. J., 1977

Eng. Min. J., 1978

James, 1962

Richert, 1974

Sims, 1958

Stanford Res. Inst, , 1976

Sterling Mine

Callahan, 1966

Hague, 1956

Netsger, 1958

Metsger, 1962

N.Y. State Geo1. Assoc., 1968

Palache, 1935

Pinger, 1974

Sussex County/Ardover Mining District

Sins, 1952

New Mexico

Bur, of Mines, 1973

Hunt, $19 \$ 6$

Burro Chief Mine

Gillernan, 1952

Gillerman, 1964

Burro Motntains

Gillerman, 1952

N.M. Bur. of Mines

Central Mining District

Hernon, 1968

Jones, 1955

Jones, 1961

lasky, 1950

Continental kine

Forrester, 1972

Yousefpour, 1977

Magdalena District

Loughlin, 1942

Questa Mine ...........

Eng. Nin. J., 1978 
New Mexico (cont.)

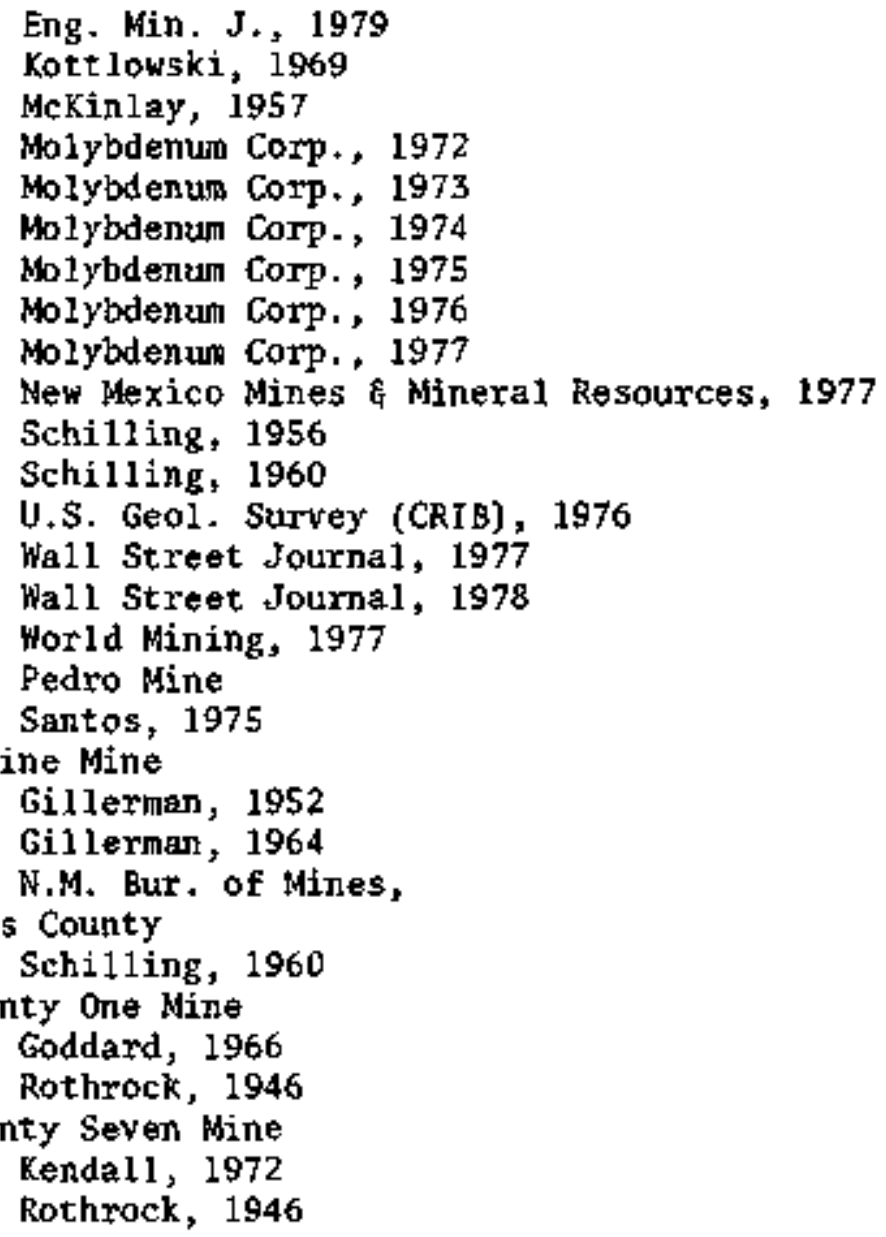


New York (cont.)

Croton Magnetite Iron wines

Colony, 1921

Prucha, 1956

Prucha, 1968

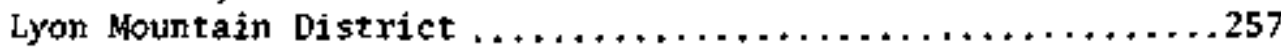

Alling, 1942

Minera1s Yearbook, 1956

Minera1s Yearbook, 1959

Minerals Yearbook, 1967

Postel, 1952

Ridge, 1972

Magnetite District

Hagner, 1967

Leonard, 1964

Postel, 1952

St. Lawrence Co. Magnetite District

Buddington, 1962

Sanford Lake District

Gross, 1968

Sterling Lake

Hotz, 1953

North Caroling

Bur. of Mines, 1973

Counci1, 1954

Geol. Soc. An., 1955

Griffitts, $1953 E$

Hadley, 1963

lesure, 1968

Olson, 1953

Stuckey, 1958

Ore Knob Mine

Ballard, 1948

Fullagar, 1967

Kinkel, 1962

Kinkel, 1967

Lawrence, 1968

Stuckey, 1968

Ridgeway-Sandy Ridge District

Griffitts, 1953

Shelby-Hickory District

Griffitts, 1953C

Tungsten Queer

Argyle, 1946

Espenshade, 1947

Foose, 1978

Macolm, 1962

Parker, 1963

Ohio

Byer1y, 1976

Ohio Div. Min., 1977

Oklahoma

Ok. Dept. Min., 1977

ok. Dept. Min., 1978 
Oregon

Bur. Min., 1973

Hotz, 1971

Mardirosian, 1976

Pacific Coastal Region

Park, 1968

Pennsylvania

Bur. Min., 1973

Geol. Soc. Am., 1959

Cornwall Mine

Davidson, 1965

Gray, 2961

Hickok, 1933

Lapham, 1962

Laphan, 1968

Lapham, 1973

Grace Mine

Agarwal, 1973

Basu, 1976

Biemesderfer, 1961

Bingham, 1957

Sims, 1968

\section{South Carolina}

Geo1. Soc. Ant., 1955

Bad Creek Pumped Storage Project

Haimson, 1976

Hester, 1974

Overstreet, 1965

Hartwell District

Griffitts, $1953 \mathrm{D}$

Piedmont Manganese Beit

Beck, 1946

Overstreet, 1965

South Dakota

Homestake Mine ...............................265

Chinn, 1970

Cobbs Eng., 1976

CRIB

Eng. Min. J., 1976

Hendrix, 1962

Hobbs, 1976

Hobbs, 1978

Homestake Mining Co., 1976

Homestake Mining Co, 1977

Honestake Mining Co., 1978

Noble, 1948

Noble, 1949

Noble, 1950

Page, 1953

Sharp Bits, 1955

Sisselman, 1976

Slaughter, 1968

Tesch, 1974 
Southern Piedmont Region

Acres Americen, 1978

Pardee, 1948

Tennessee

Bur. Min., 1973

Geol. Soc. An., 1955

Geol. SE Section, 1961

Hadley, 1963

Hamilton, 1961

King, 1964

Lloyd, 1965

Minerals Yearbook, 1965

Minerals Yearbook, 1975

Nevanan, 1965

Tennessee Div. Geol., 1977

Tennessee Div. Geol., 1969

Boyd Mine

Cammarota, 1976

Emmons, 1926

Ross, 1935

Burra Burra Mline

Cammarota, 1976

Ross, 1935

Cherokee Mine

Camnarota, 1976

Hardeman, 1970

Calloway Mine

Camnarota, 1976

Tung, 1968

Tung, 1969

Ducktown District $\ldots \ldots \ldots \ldots \ldots \ldots \ldots \ldots \ldots \ldots \ldots \ldots \ldots \ldots 285$

Acres Anerican, 1975

Cox, 1973

Emmons, 1926

International Directory of Mining \& Min. Proc. Opert, , 1978

Lloyd, 1965

Magee, 1968

Minerals Yearbook of Temnessee, 1965

Simmons, 1950

World Mines Register, 1979

Elinwood

Callahan, 1977

Eureka Mine

Ros5, 1935

Jefferson City Mine

Fulweiler, 1971

Ore Knob Mine

Ross, 1935

Texas

Bur, of Min., 1973

Yates, 1959 
Jtah

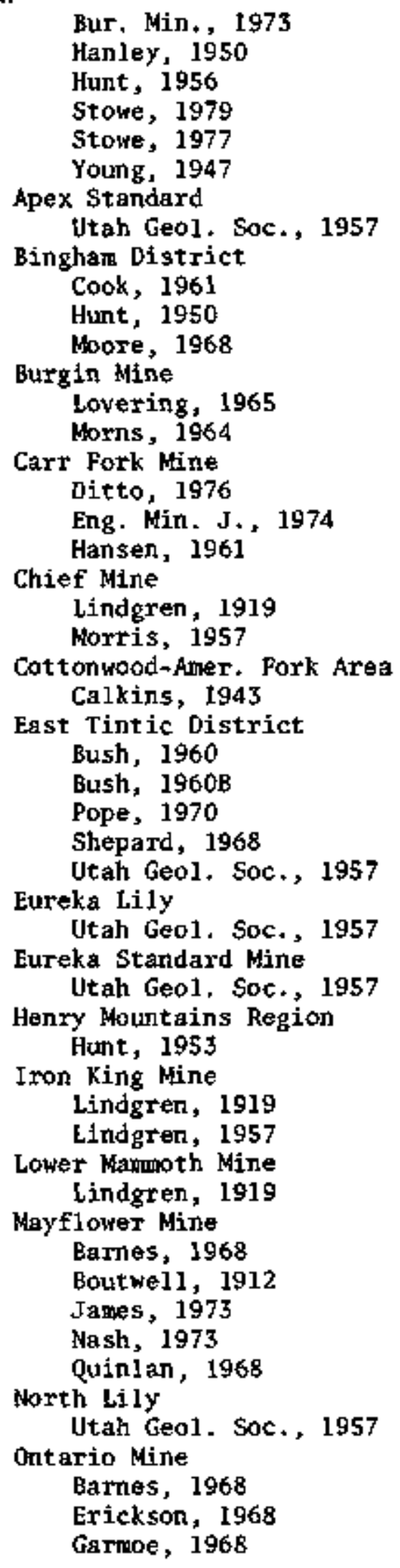


Uțah (cont.)

Pacific Nine

Butler, 1916

Park City District

Price, 1972

Quinlan, 1968

Tintic

Thompson, 1968

lovering, 1949

Norris, 1961

Morris, 1968

Utah Geol. Soc., 1957

Trixie Nine

Boutwe11, 1904

Butler, 1920

Lovering, 1965

Pope, 1970

Vermont

Barton, 1978

Canney, 1965

New England Intercollegiate Geol. Conf. Ann. Meeting Guidebook, 1959 Tillman, 1975

Elizabeth Mine

Griffitts, $2953 \mathrm{~B}$

Howard, 1969

McKinstry, I954

Skinner, 1955

Amelia District

Lemke, 1952

Ridgeway-Sandy Ridge District

Griffitts, 1953

\section{Mashington}

Bur. Min., 1973

Culver, 1945

Fox, 1977

Grant, 1969

Huntting, 1943

Huntting, 1956

Mardirosian, 1976

Milne, 1978

Moen, 1976

Purdy, 1954

Western Mining News, 1978-79

Antilon lake Pumped Storage

Hillianson, 1974

Deer Creek Mine

Hadde11, 1963

Glacier Peak Area

Tabor, 1969

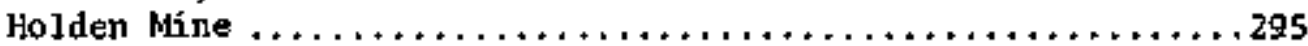

Carzon, 1945

Carter, 1967 
Utah (cont.)

Crowder, 1959

Grant, 1969

Huntting, 1943

Huntting, 1956

Moen, 1976

Park, 1968

Purdy, 1954

Soderberg. 1948

Tabor, 1969

Youngberg, 1952

Metaline District

McConne1, 1968

Middle Fork

Grant, 1973

Midnight Mine

Becraft, 1963

Nash, 1978

Heissenborm, 1974

Sumrise Breccia Deposit

Pierce, 1977

United Copper Claim

Bancroft, 1914

Benunington, 1951

Clark, 1968

Van Stone Mine Area

Cox, 1968

Wisconsin

Bur, Min, , 1973

Dutton, 1970

Hubbard, 1975

Sims, 1976

Tri-State Geol. Field Conf., 1953

Yardley, 1975B

Henominee Iron-Bearing District

Bayley, 1966

hyoming

Bur. Мiл., 1973

Hanley, 1950

Osterwald, 1966

Wyoming Dis. of Manf, and Mining, 1978

Wyoming Geol. Assoc., 1971

Wyoming Inspector of Mines - Annual Rep., 1972

Wyoming Inspector of Wines - Annual Rep., 1973

Wyoming Inspector of Hines - Annual Rep., 1974

Wyoming Inspector of Mines - Annual Rep., 1975

Wyoming Inspector of Wines - Annual Rep., 1976

wyoming Inspector of Mines - Annual Rep., 1977

Wyoming Inspector of Mines - Annua1 Rep., 1978

Hyoming Mineral Division, 1978 


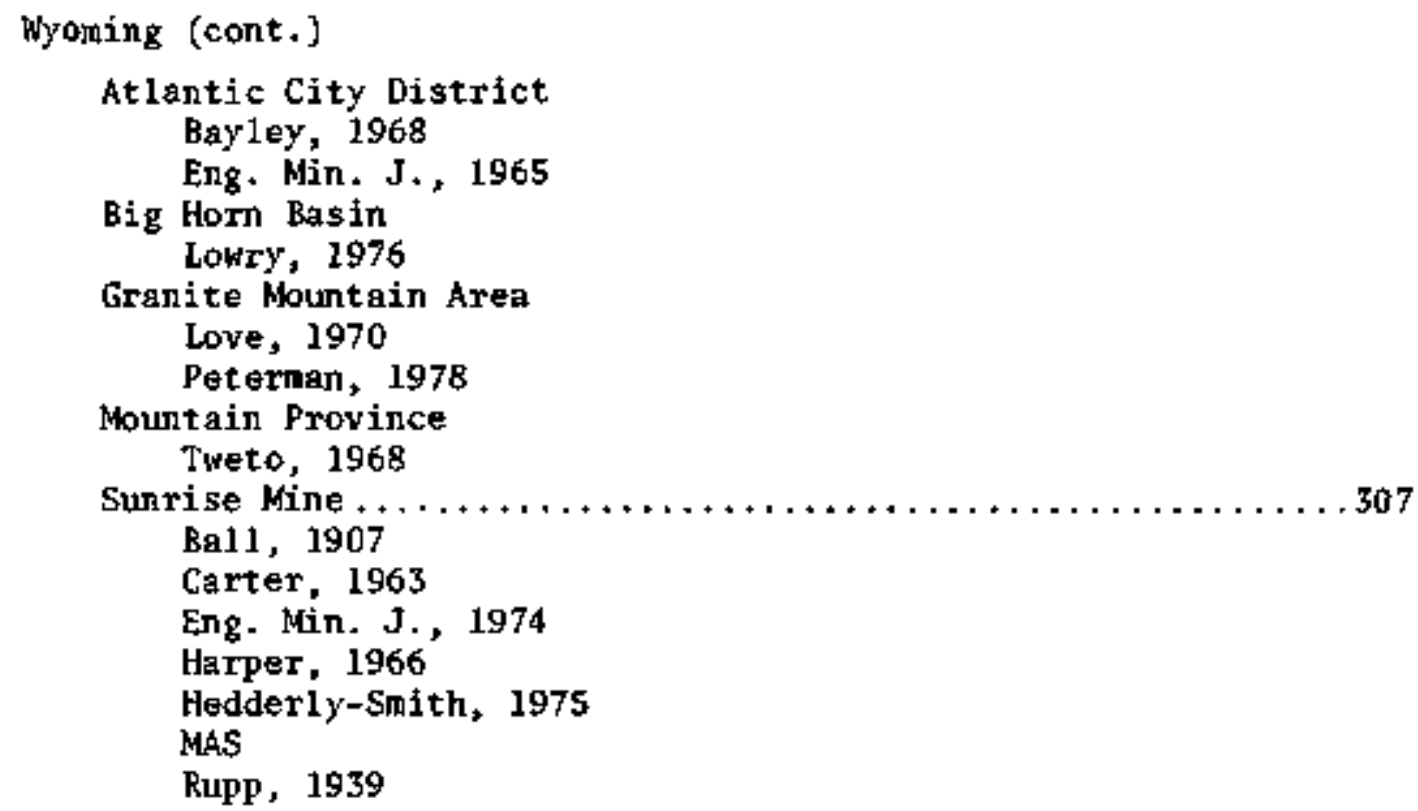





\section{APPENDIX I - SOURCES OF INFORMATION}

The MAS Data Base

The Hinerais Availability System (MAS) data base of the U.S. Bureau of

Mines is used for storage and retrieval of mineral deposit information. As described in the MAS Deposit Infornation Kanual, 1978:

"The systen provides an auditable procedure to continuously monitor the present and potential availability of mineral supplies to the United States in the context of many paraneters that inpinge upon supply, such as mining costs, beneficiation, shelting, refining, transportation, infrastructure, environment, land use, labor, productivity, technology efficiencies, supply specifications, operating capacities, deposit life, and political factors, including taxation, ownership, access, and international relations. WAS classifies the identified resources that are reserves and systemat1cally outlines the factors that linit other known resources from being reserves. Resource and reserve nomenclature is used according to joint U.S. Geological Survey and Bureau of Mines agreement as published in USGS Bulletin 1450-A in 1976."

Information in the MAS data base is grouped into five data sets. These categories are: deposit location, deposit definition, development plan, product definition, and environmental assessment. Information from the first two data sets--deposit location and deposit definition--were utilized. Those data sets which are complete contain the following information, as described in the MAS Deposit Information Manual 1978:

"a. The deposit location base data set encompasses location, topography, and rame of the deposit. Backup data sets include information on additional names, oumership, public land survey, references and conments.

b. The deposit definition base data sets contain information on commodities, quantities of resource, and assays of commodities in the resource. Backup data includes published reserve information, exploration and production histories, deposit geometry, 1ithology, and mineralogy." 
The MAS data base was queried for information on all nines having data on rock type. This request produced printouts of $\$ 929$ mines, both surface and underground. Exhibit 1 is an example of the MAS printout for the San Manuel nine.

The CRIB Data Base

The U.S. Geologfcal Survey's Computerized Resources Information Bank (CRIB) is available for public use through Information Systems Prograns at the University of oklahoma by means of the General Electric Mark III Service.

"The Mineral Resources Data Book of the U.S. Geological Survey" User's Gulde (1976) describes the data base as,

"Information in the record consists of descriptive text, numeric data, codes, and certain key words. Some topics accomodated are: Name, Location, Comodity Information, Description of deposit, Geology, Production, Reserves, Potential resources, and References. Approxinate 1 y 400 data items are available, although al1 400 data items are never used in a given record. Sone 40 percent of the data items are organized into fixed-length fields or contain controlled information, such as key words. The remaining 60 percent contain free text entries."

General queries made to the CRIB data base included:

1) mines in crystalline rock with workings deeper than 600 feet, and

2) all information on the mines researched in detail.

A sample CRIB printout is shown in Exhfbit 2.

GEOREF, the Geological Reference file compiled by the American Geological Institute, covers the geoscience literature fron 3000 journals, as we1l as conferences, symposia and nonographs, in the areas of geology, econonic geology, engineering-environmental geology, geochemistry, geochronology, geomorphology, igneous and metamorphic petrology, solid earth geophysics and stratigraphy. 
Coverage a1so includes books, goverment docunents, special reports and theses, as well as citations from the Bibliography and Index of Geology.

The characterization of GEOREF was extracted from Orbit, A world of Information, and Orbit User banual for GEOREF, published by SOC Search Service, Santa Monica, California.

GEOREF was queried for information on specific mine sites. A sample citation is shown in Exhibit 3.

Other Sources of Information

Other sources of information included the following publications with a 1ist of items covered by each.

1) $1977 \mathrm{E} / \mathrm{MJ}$ International Directory of Mining and Mineral Processing Operations, Mining Information Services, Engineering and Mining Journal, McGraw-Hill, New York, N.Y.

All underground mines were listed, regardless of comodity mined. Information includes:

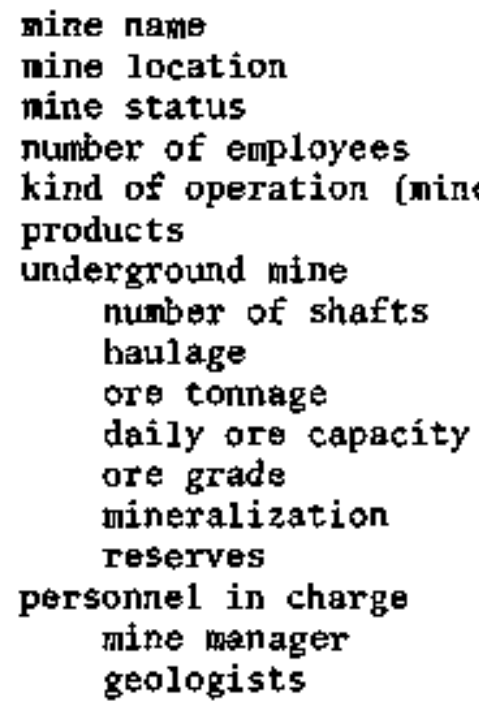

2) Published State Directories of Aining Operations. Various items of information - usually commodity nined and mine location. 
3) Survey of Active and Inactive Mines for Possible Use in In Situ Test Facilities Y/OWI/SUB-76/16514, Cobbs Engineering, Geotechnical Consulting, 5200 \$outh Yale, Tulsa, Oklahoma.

Data on all mines listed in this report as being in erystalline or high-grade metamorphic rock were extracted. Complete data sheets include the following information:

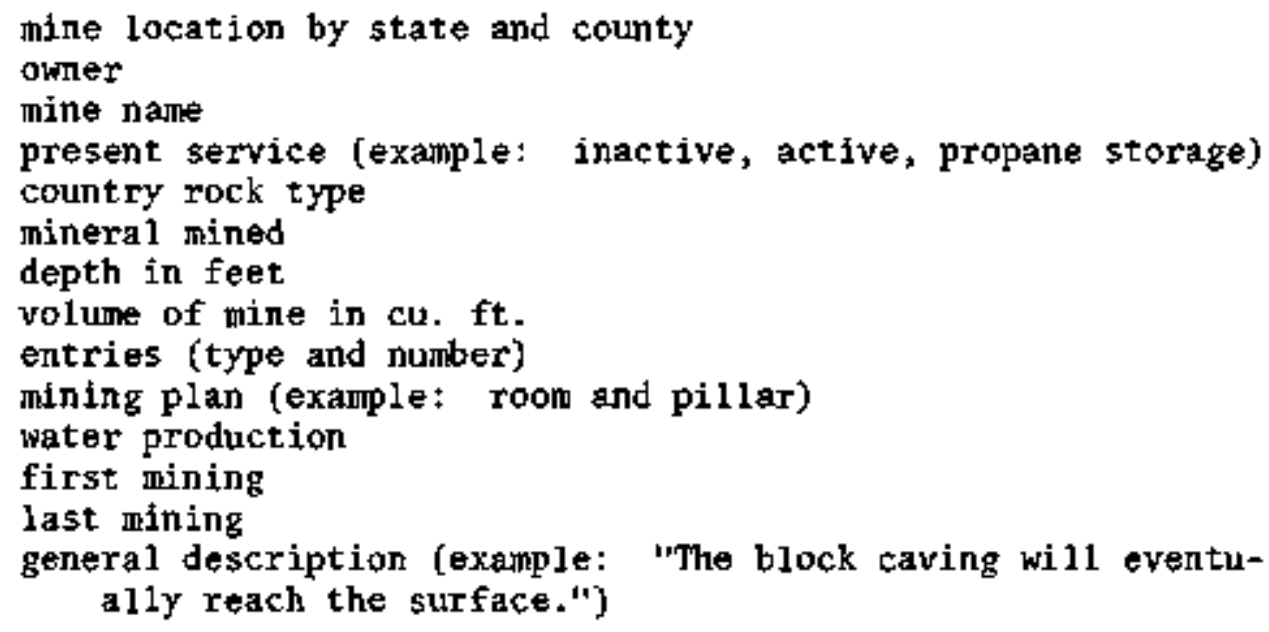

4) Jamison report, J.C. Berkeley, 1978, Inventory of Mines.

Complete data sheets include the following information:

mine name

location (state and county)

ore

country rock

location and direction from nearby town or eity (or section, township, and range) owner 


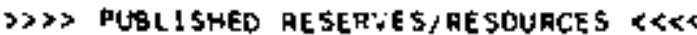
OUAMTI IY INDOCGHULAT IVEI ANO GRADE

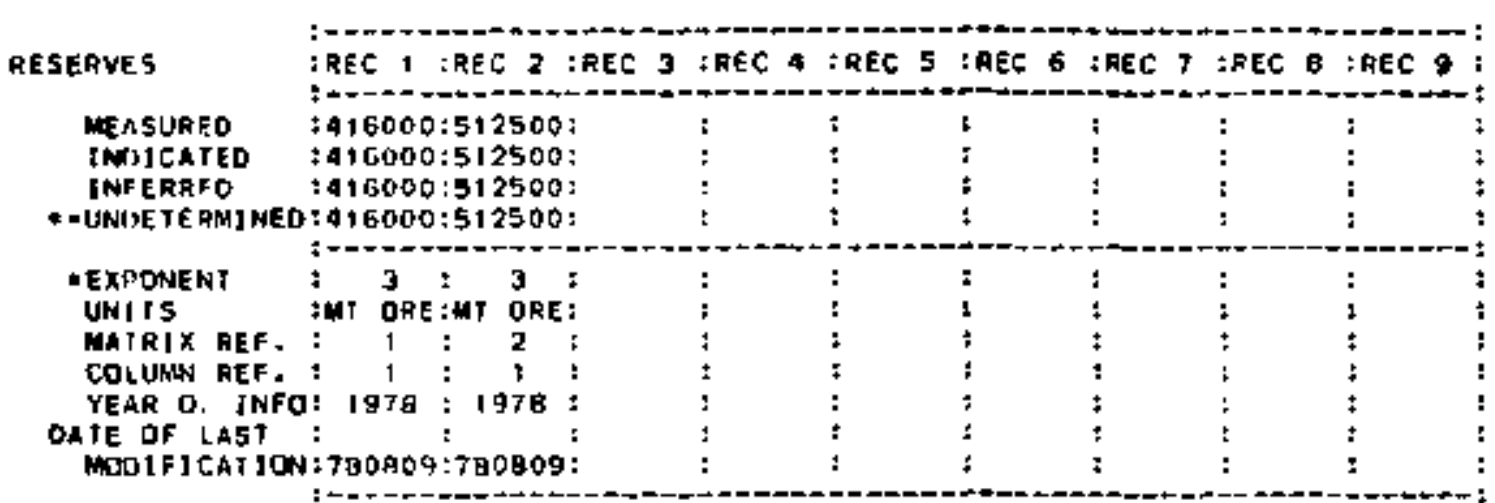

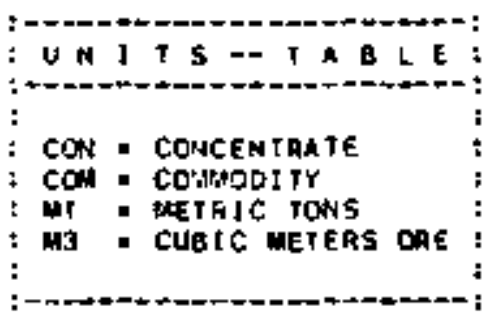

-ALL OURNTITIES ARE EXPRESSED IIMES to TO THIS PONEA FOR A GIVEN COLUMN. - EUN IOENT I, JABLE AS MEASUFED, JNDICATED, OR JNFERAED

GHAOE N5SAY/FOAM

$C U$
100
$A O$
$C U$
$M 0$
$M G$
$A U$

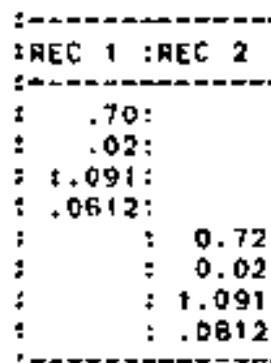

GRADE UNTIS MT-PCT g-SULFIDE G/MT G/MT WT-pCt 9-sulfjoe MT-ACT g-SULF JOE GitiT G/at
DATE OT LAST Modeticalion

JUL 0.7. 1978 JUL 03, 1979 ofc ors, 197A DEC O.1, 1979 ALO 04. 1978 Abr ou, 1978 Dec 05. 1978
LINE NO.

01 02 04 01 02 03

AESERVES - REMAGKS

Col: D1 SAN MANUEL OREBODY

CDL: D2 KALNATOO DFE BODY 
MATRIX NUWEER: 1 COLUWN NU'ABER: 1

TYPE OR ORE BOOY: OISSEMIIATED:STDCKWORK WDE OF ORIGIN: HYOROTHERIAL :OXIDAIION SHAPE DF ORE BOOY: HASSIVE

DHE CONIROLS: 1GNECUS : GAULTING

DI:GREF DF WALLROCK ALTERAT TON: MOOERATE

TYDE OF WALLAOCK ALTERATIOH:

POTASSIC

MATRIX NUMBER: 2 COLUMN MUTHEEA I

TYPE OF ORE 8DOY: OISSEMTTATEO: SIOCKMORK MIOE OF ORICIN: HYDROTHERAAL :OXIDATJON SHAPE OF ORE DODY: Mass

OHE CONThOLS: I TNEOUS

DEGREF OF WHLCROCK ALTERATION: MOOERATE

DEGREF OF HALCROCK ALTERATION:

$$
\text { POtASSIC }
$$

\section{WATRIX NUMBER: RECORO NUMBER:}

FORMATJON NAME: [GNEOUS JNTRUSIVE AGE 0 FORanation: U CREt

AGE O FORAATLONZ U CRE
DEPTH IO MFNERALIZLT LON II'M WETERSI

THICKNESS OF UNCOTSOLIOATES MATEA IAL I [H METERSI

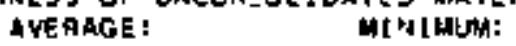

AVERAOE OIMENSIONS OF MINEAALJZATION IIN HE TEPS

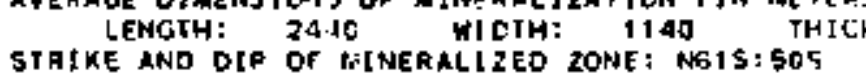

DELTH TO M] NERALITATIOH (JU METERS)

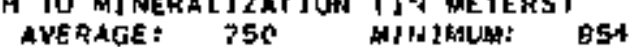

THICKMESS DF UNCOTIOLIOATED MATERIAL IJN METEKS AVY

AVERAGE DJMENS IOH'3 OF DJNERALJZATION IIM MEIERS I

LENGTH: 2110 WOTH; 11 dQ INICKNESS:

$\gg P$ LITHOLOGY = DATA SET SKKK

AELATION5HIP OF MIMEAALIZATION TO DEFORHATION: MIN ARECEDING OEF

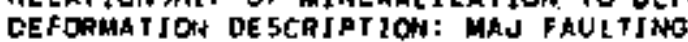

AGE DF DEFORAATION: PALEOC

$\gg \gg$ MJNERALS - OATA SET $\ll \ll$

MaIAE

ctiss

GFAIN 5I2E

AMEUNT UNJTS

CHRLCOCI TE

CIIRYSOCOLLA

CuPRl TE

MLLrederite

GOLD

St?VER

CHALCOPYRITE

CMALCOPYRITE

SIUIUES

OXIDES \{EXCLUDJMG SID2) VARJABLE

SULFJOES VAREABLE

VART ABLE

UNKMONH

SULF1OES
\$ULFIOES

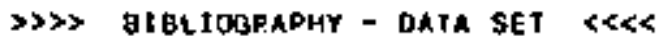


DRTE DAINTED: WRR 22,1979

DEPOSI TAME: SAH maNUEL / KaLANAZOO
MTHERALS AVALAGILITY SYSTEM

DEPOSIT LISTINO

PAGE

SEQUENCE MUJHBER: 0040210001

\section{SET AEFERENCE}

LINE MO.

002

003

004

006

007

009

cots

010

012

014

015

016

017

018

019
GY HARRY $K$. BUFKE AND JOSEPH F. SHIFLEY, SOCIETY OF MINJMG EHGINEERS, PRERRINT NO, $65810,1965$.

NEWMOHT MINING PROSPEXTUS. 5-5-69. TOH+S AND GRADE

FRCN DUGLIC RELATIDHS DEPI.: "IHE PLANT ANO "THE MINE-

GETERAL INFORMTIOU PUBL ICATIONS - E CLELLENT INFOFMATION

MAGHA FACTS - 7-1-77, COMPANY LITERATUPE

WATERAL AND VERTICAL ALTERATION-MINERALIZATION ZONING

IN PORPHYRY OAE DEOOSITS Bi J. DAVID LOWELL AND JOWN M.

GUlLERT F ROM ECDNOינC GEOLOGY, JUNE-ULY, 1970, NO, 4 .

DRE IRANSPORTATION AT SAN MANUEL OF C.F. CIGLIAMA.

HAY, 1OSA. MINING EHGTHEERING.

MINIMG, HIL ING, AND SWELTING WETHODS, SAN MHNUEL COPPEA

CORP. . PJ JAL COUNTY, ARJZGHA, BY $V . B$. OALE, BUREAU OF MJNS 1.6. Bro4, 1962.

HISTOFY ANO OEVELOFMENT OF THE SMM MAVLUEL MTNE gY JOHH $F$.

GUCHANAM hNO FRATIX H. BUCHELLA FROA: AJME VOL. 217.

FEgRUARY, 1960.

SAN MANUEL-ENGSNEERTHO AND MIN1NG JOURHAL, ADR1L, 1956, P.TS 
! I MINEFRAL PF SOURCES F ILE IO
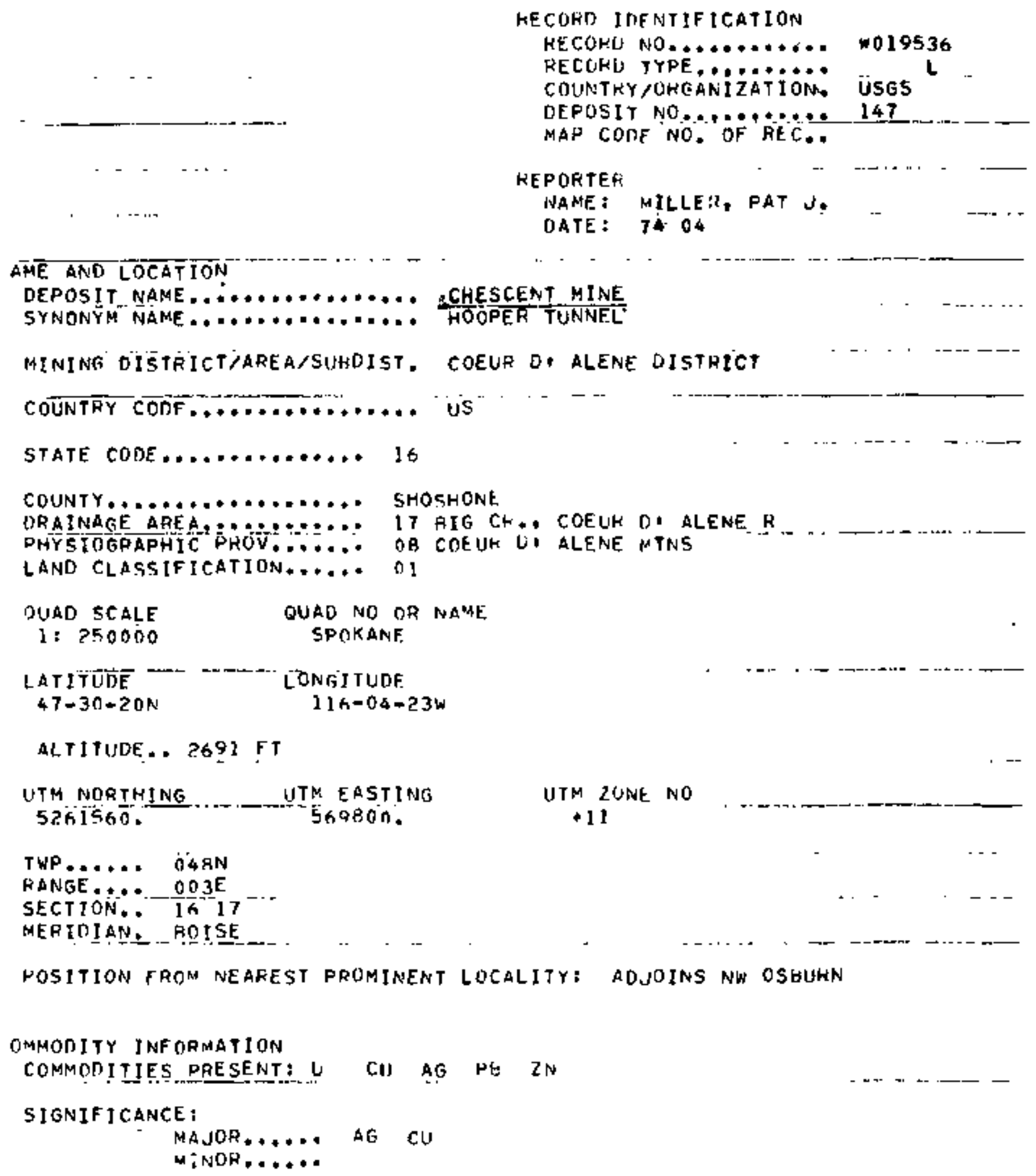

EXHIBIT 2. Printout of data on the Crescent Mine from the CRIB database, compiled by U.S. Geological Survey, computer searches by University of Oklabona, Norman, Oklahoma. 
452

COPROOICT.

BYPROUUCT ...

POTENTIAL..

OCCUHHENCE. U

DRE MATERTALS TMINERALS, HOCKS,ETC.):

PITCHRLFNDE OP URANINITE CHALCOHYRITE; TR-TRAHEUHITE; GALENAF SPHALERITE

COMMOTITY COMMENTS:

MINE IS IN THE PAGE * GALFNA MINERAL HELT. AVEHAGED 55 OZ. AGYTON ON

$33000-3500$ FT LEVELS.

ANALYTICAL. DATA \{GENERAL\}

2 CHANNEL SAMPLES GY IJSGS ASSAYEL 0.026 \& 11 AND $0.048 \%$ U $0.633 \%$ U30B

HIGHEST ASSAY; $0.19 \%$ U3OB AVERAGE U CONTEMT.

INEPAL ËCONÓOAIICS FACTOKS

ECONOMIC COMMENTS:-

BECAIISE OF CONTINUING OECLINF IN GHADE OF ORE MINED, B. H. EXPECTS

CRESCENTT MINE OPERATJONS DISCONTINUED AT END OF 1975

XPLORATION AND DEVELOHMENT

STATUS OF EXPLOR, OR DEV.

YEAR OF DJSEDVERY....... IABA ?

PROPERTY IS ACTIVF

NATURE OF DISCOVERY .... A

PRESENTZLAST TWNAR.:.... THE BUNKER HILL CO,

PRESENT/LAST OPERATOK.... THE BUNKER HILL CN.

WORK DONE PY USGS

YFAR WORK TYPE GFOLOGIST AND HESULTS

1) 1953 GEOCHET F. C. AFMSTRONG

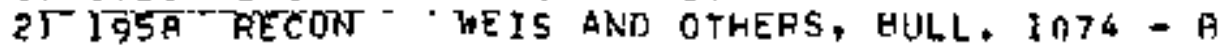

311964 OTHEH V. C. FFYKLUND, PROF. PAPFR 445

WORK DONE HY OTHER OHGANIZATIONS

YEAR WOPK TYPE OPGANIZATION AND RESULYS

1) 1975 CAMPILE USHM, 1974 +1N1AG ACTIVITIES LIST

EXPLOR. AND DEVELOP. COMMENS:

7 PATENTED CLAIMS. DIAMOND DPILLING

L.SCRIPTJON OF DEPOSIT

DEPOSIT TYPES:

VE IN

FOAM/SHAPE OF DEPOSIT:

SI7E /OIRECTIONAL DATA

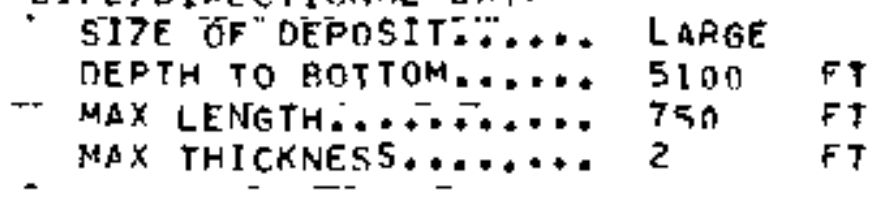


SSTRIKF OF OREKODY.... N 75 DFG h

LOWER ALHAMBRA VEIN ISIOENITE - TEIHAHEIIHITE FIKST UISCOVEREO 400 FT

BELON SEA LFVEL

SCRIPTTION OFF "WOHKINGS

UNDE RGROUND

DESCRIP. OF UNDEFGRND WOKKINGS

DAY DEPTH OF WORKINGS DÉLOW SURFACE, -140\% FT

$\div$ LENGTH OF WURKINGS............... 2452 FT

DESCFIP. OF OPEN WORKINGS (SURFACE OF UNOERGOR.U)

COMMENTS DESCPIP, OF TOPKINGSI:

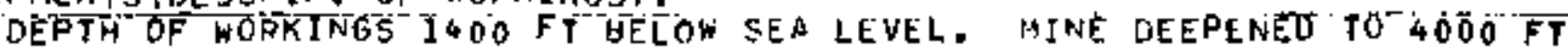

LEVFL IN 1970 . LENGTH OF WORKIRGS GJVEN ABOVE FOR DEVELOPMENT GY 1966

RODUCTION

YES

MEDIUM PRŌDUCTION

ANNUAL PRODUCTION TURE anO COMMOOITIES)

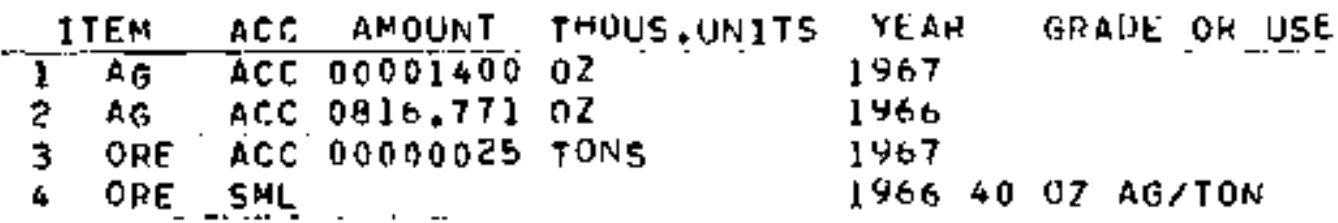

UURCE OF INFOFMATION.:- SPOKANE CHPGAICLE. JAN. 20. 1969: MAY 20,1968 1 MAP. JT. 1967

ESERVES ONLY...

\begin{tabular}{|c|c|c|c|c|c|c|c|c|c|c|}
\hline & EM & & $A C C$ & AMOUNT & THOUS UNITS & $Y E A R$ & GHADE OF & USt. & & \\
\hline 1 & ORE & $A G$ & $E S T$ & $\overline{00000073}$ & ToNS & 1974 & $29.40 Z$ & $A G / T O N \bar{T}$ & PROVEN & \\
\hline 2 & ORE & $A G$ & FST & 000036.5 & TONS & 1974 & $38.40 Z$ & AG/TON; & PHOGAELE & \\
\hline 3 & QRE & $\overline{A G}$ & F.ST & 000027.6 & TONS & 1973 & 34.302 & $A G / T O N T$ & PROVEN & \\
\hline 4 & ORE & AG & EST & 000017.3 & TONS & 1973 & $34.3 \quad 0 z$ & TON & PKOHAELE. & \\
\hline 5 & ORF & $\dot{A} G$ & $F S T$ & 00003 & TONS & 1972 & 402 & TH: & PROVEN & \\
\hline 6 & ORE & $A[3$ & FȘ & 000024.3 & TONS & 1972 & .402 & AG/TOM! & PROGABLE & \\
\hline
\end{tabular}

SOURCE OF JNFOKMATIDN GULF RESOURCFS 1974 MNNUAL REPT.

TOLOGY AND MINERALOGY

AGE.NAMMES_CF HOST ROCKS......... HEC HUARTZITE

PERTINENT MINFRALOGY............. CALCITÉ G WUAPTZ; SIUEKITE

IMPOHTANT ORF. CONTHOL OR LOCUS..... FAULT 
GEOLZOGY (SUPPLETENTARY INFORMATION)

REGIONAL GEOKOGY

MAJÓR REGIONAL STRUCTURES. * OSUUKN FALLT

LOCAL GEOLOGY

- AGE/NAMES OF FQRMATIONS OR ROCK TYPES

1) PAEC - ST. REGIS FORMATICA = GLARTZITE, ARGILLITE

2) PREC WALLACF FORMATJON = CALC. QUJARTZITE, ARGILLITE

SIGNIFICANT LOCAL STRIJCTURES:

AL HAMBRA FAULT, BRECCIATION

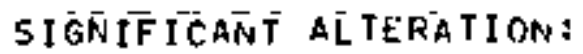

FE_ = OXIOFS. SERICJTE, PYRITE

ENERAL REEFEREMICES

11 COOK, E. F, 1955, PROSPECTING FUK UHANILIM, THORJUM, ANO TUNGSTEN IN IDAHOI IDAHO BUH. MINES AND GEOLOEY PAMFH. $102,53 \mathrm{P}$.

2) WEI5. P. L, ARMSTWONG, F, C., AKD ROSENHLUIM, S., 1958 . RECONNAISSANCE FOR RAOIOACTIVE MINERALS IN WASHIAGTON, IDAHO, AND WESTERTN MONTANA, I9SE

- $1955:$ U.S. GEOL. SUHVFY BULL. $1074 * \mathrm{H}, 4 \mathrm{~A}$.

3) FRYKLUND, V. C. JR. 1964, ORE DEPOSJT OF THE COEUR D. ALENE DISTRICT, SHOSHONE COUNTY, $10 A H O:$ USGS PROF. PAPER $445,103 \mathrm{P}$.

4) USAM, 1975, ACTJVITY OF IDAHO NINING PKOPERTIES, 1974, USGM. BOISE, 6I P.

5) SPOKANE CHRONJCLE, FEA. 24, 1972 ; MAY 25,1970 ; AP.18, 1967 ! MAR: 27,1975

6) WESTERN MINING NEWS, 1974 - TS UIRECTORY OF MINES IN IOAHO' ICOEUR DALENES) AND WASHINGTON, P. 33 
$-1-$

ACCESSIOW MUER

TITLE

AUTHORS

SOHACE

DDCLINEWT TYPE

ISSUE

CATEGORY CODES

JGDEX TERHS

COORDIMATE\$

$-2-$

ACELSSJON MUMgER

TJTLE

HUTHORS

SOURCE

DOCUNENT TYPE

ISSUE

CATEGOAY CODES

I HOEX TERINS

COORDIHATES

$-3-$

ACEESSION HURER

TITIE

AUTHORS

ORGAHIZATIOHAL SOUACE SOURCE

DDCINENT TYPE

I\$SULE

CATEEORY COOES

IHOEX TERAS

COOROJMATES
77-39103

Prelieinury geologic nap of the Leadville 1 degress $x$ 2 degress budrengle, northrestern coloredo

Tweto, 0.; Moench, R. H.; Resd, J. C., JP.

u. \$, Gool. Surv., Mist, field \$tud, Map (LSA) (XMF $(50)$, Wo. MF-760, unpaginated p., 1976, 900L. eap, SCALE: 1:230,000

S (Sertal); mow (monographtc)

77-3 7721 (áibliography and Index of beclogy)

2-14 (Areal geology, maps \& charts)

Grant County; Gorfield County; Eogle county; Lake County; Sueit County; Mesa County; Pitkin County; Alo elanco County; nfolorado; areal geology; naps; northwest: Leadiville guadrande; United states; geologit.

M390000; H60000; v1060000; 1080000 .

\section{$77-33023$}

Prel iafinary eap of Lands $L$ fod depostts, Lendvilla 1 degretes by 2 degrees quedrangle, colorodo

colton, R. B.; Holligen, J. h+; inderson, L. H.;

Patter son, P, E.

U. S. Geol. Surr., Misc. Field 5tud, Wap (U5A)

(VimFSD), No. MF-701, unpaginated p., 1975, environ. geol. 300, SCALE: 1:250,000

S (Sortaliz Wow (monggraphic)

77-33696 (Bubllogreohy and Indek of Geology)

2-14 (Areal geology, maps \& tharts)

Chaffee County; Delia county; Eaqle county; Garfield

county; Grand County; Gunnison County; Lake Gounty;

Hese County; Perk Countys Pitkin county; R to elanco

County; Routt County; \$unnit county; *tolorido;

environmental geology geologic hazards; landslides;

*maps: morthuest; leadville buedrangle; lnited

States.

h390000; 1400000; w1060000; 1080000 .

$77-31991$

Gravitstionsl spresoing of steep-sided ridses ("seckung"') in Colorado

Redlaruch-thal, D. H.; Varné, D. J.; Colton, R, B.

U. S, Geol. Surv, Mennlo Park, CaLif. USA

J. Res. U. \$. GeOl. Surv, (USA) (JRG\$AH), Vol, 5, HO,

3, p. 359-363, 1977, 10 Ref., illus.

5 (Serial); ANL (Analytic)

77-31334 (eibliography and Index of Geology)

2-23 (Surficial gedlogy, geoporphology)

Lake County 3 Dolores countyz San Higual Countyz *Colorado; *geomorphology; asss wovenents; eentral; southwest; Leddville; Bold Esol- Mountain; DoLores Peok; sackungen; ridgss; steep; trenches; inted States; Rocky Mountsins; Bald Eagle Mountains; tengineer ing geology; olope gtability; ttectoniss; gravity oliding; grabuns.

M370000; M393000; $\$ 1060000 ; 11090000$.

EXHIBIT 3. Bibliographic references dealing with the Leadvilie quadrangle, Colorado (from the GeoRef database on $5 D C$ Search Service). 



\section{APPENDIX 2. MINES IN CRYSTALLINE ROCKS}

\section{CONSIDERED FOR STUDY}

Table 1 lists by state the numbers of underground mines, mines in rocks other than crystalline and metamorphic, and mines in crystalline or metanorphic rock. Also 11sted are the numbers of ciass 1 and class 2 mines and civil works by state.

The 285 mines and nining districts considered for study for this report are listed in table 2 in alphabetical order by mine name. Also included are the state and county in which each nine is located. 


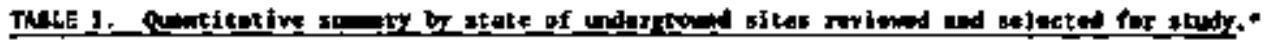

\begin{tabular}{|c|c|c|c|c|c|c|c|c|c|}
\hline \multirow[b]{2}{*}{ State } & \multirow[b]{2}{*}{$\begin{array}{l}\text { Oristwal } \\
\text { tothl }\end{array}$} & \multirow{2}{*}{$\begin{array}{l}\text { Surfuce ond } \\
\text { indateround } \\
\text { mines }\end{array}$} & \multirow{2}{*}{$\begin{array}{l}\text { Whet aot in } \\
\text { trystijlitimo } \\
\text { rockt }\end{array}$} & \multirow{2}{*}{$\begin{array}{c}\text { Whas in } \\
\text { trorttel lime } \\
\text { rock }\end{array}$} & \multirow{2}{*}{ 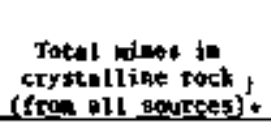 } & \multicolumn{3}{|c|}{ 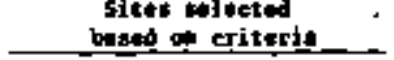 } & \multirow[b]{2}{*}{$\begin{array}{l}\text { Tatal } \\
\text { sikest }\end{array}$} \\
\hline & & & & & & $\begin{array}{l}\text { Cless } 1 \\
\text { renes }\end{array}$ & $\begin{array}{l}\text { Closs } 1 \\
\text { ciril works }\end{array}$ & $\begin{array}{c}\text { Class } 2 \\
\text { enthet }\end{array}$ & \\
\hline ALABARAS & 23 & sis & 6 & 33 & 33 & - & & . & - \\
\hline ALstra & 62 & 40 & 2 & 30 & 36 & - & & - & $=$ \\
\hline ARIZONA & 92 & , 58 & 10 & 48 & sI & 3 & & 2 & $\mathbf{5}$ \\
\hline ARKANSAS & 26 & 19 & I6 & 3 & 3 & $=$ & & $=$ & $=$ \\
\hline EULFFARNA & $3 \mathbf{1}$ & 258 & 33 & 205 & 210 & $\mathbf{l}$ & 1 & 1 & 3 \\
\hline costhato & 1444 & 1312 & t 1086 & 224 & 230 & 4 & & j & s \\
\hline CONECTICUT & s & 7 & 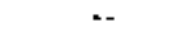 & 7 & 7 & $=$ & & - & - \\
\hline DELAMHARE & -- & -- & 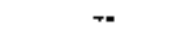 & $-*$ & -- & $=$ & & - & - \\
\hline FLORLOA & 504 & $\ldots$ & 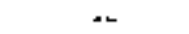 & $\ldots$ & $\ldots$ & - & & $=$ & - \\
\hline COJOPAith & 21 & 2 & 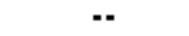 & 2 & 3 & $=$ & & - & . \\
\hline HWiks]11 & 4 & - & -- & - & - & $=$ & & - & $=$ \\
\hline cosun & 163 & 155 & 53 & 102 & 128 & 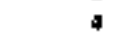 & 1 & 2 & 7 \\
\hline JLEJWOIS & 52 & 47 & 4 & I & 1 & $=$ & & - & . \\
\hline INDeraw & 10 & 10 & 10 & $\therefore$ & 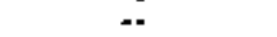 & $=$ & & - & . \\
\hline$[0 \mathrm{ard}$ & 5 & 5 & 5 & $m$ & 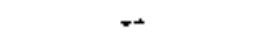 & - & & - & - \\
\hline kassass & $\$ 3$ & 53 & $\$ 3$ & $\because$ & $=$ & - & & - & + \\
\hline KEXTUKKY & $5 s$ & 49 & 45 & 4 & 1 & - & & . & $=$ \\
\hline Lonisiant & 4 & 1 & 4 & $\cdots$ & +2 & - & & - & - \\
\hline HAINE & 41 & 15 & i & 14 & 15 & 1 & & - & I \\
\hline HARTLAND & 26 & 14 & $\bar{z}$ & 12 & 12 & $=$ & & - & $=$ \\
\hline RASSAOGNSETTS & 4 & j & - & $\mathbf{1}$ & $z$ & - & & $\approx$ & - \\
\hline HICHLGN & $3 \mathbf{s}$ & 29 & 4 & 25 & 27 & . & & 2 & 2 \\
\hline NUSEESOTA & s5 & 2 & $\ldots$ & 2 & 4 & j & & i & 2 \\
\hline MQSSISSIPPJ & 2 & $\omega$ & $\boldsymbol{~}$ & - & $=-$ & . & & $=$ & $=$ \\
\hline HISsoun] & 313 & 245 & 340 & 5 & 15 & - & & $=$ & $=$ \\
\hline mextexh & 265 & 224 & 4 & 220 & 220 & 4 & & 2 & 6 \\
\hline TIERAASW & 4 & 4 & 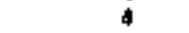 & $=-$ & - & - & & - & $=$ \\
\hline NEVADA & 18: & 129 & 49 & 79 & 97 & 1 & $\mathbf{I}$ & f & 9 \\
\hline MEK .MUMPSHTRE & 7 & 6 & $\ldots$ & 6 & 6 & $=$ & & : & $=$ \\
\hline KEW JERSEY & 11 & 10 & $\mathbf{1}$ & 9 & 10 & 2 & & 1 & 3 \\
\hline NEF MERJCO & 214 & 182 & 50 & 132 & 133 & i & & $i$ & 3 \\
\hline XET Yokx & 15 & II & 6 & 5 & 7 & 2 & & $=$ & i \\
\hline NORTI GAOSLITH & 82 & 60 & $\ldots$ & 60 & $6 i$ & $=$ & & 2 & 2 \\
\hline WOKIH DHKOTA & -- & - & $\because$ & $\cdots$ & $\because$ & - & & - & - \\
\hline CHIO & I6 & 11 & II & . & $=$ & - & & - & - \\
\hline Whithath & 119 & 116 & 116 & $=$ & 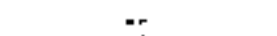 & + & & - & - \\
\hline CRESGON & 67 & 43 & 14 & 79 & 37 & $=$ & & - & - \\
\hline MES'SYUKNIR & 36 & 26 & 12 & 14 & $j$ & - & & - & - \\
\hline WHOE JSLAND & $\ldots$ & $\ldots$ & -2 & $=$ & $\therefore$ & . & & $=$ & $=$ \\
\hline ȘGUTH CARtLLIM & 8 & 4 & $\therefore$ & 4 & 4 & $=$ & $\mathbf{I}$ & 1 & i \\
\hline SOITH DAKOTA & 85 & 66 & 25 & 41 & 4 & $\mathbf{J}$ & . & - & $\mathbf{I}$ \\
\hline TEXYYESSEE & 200 & 137 & 132 & 5 & jo & 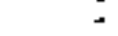 & & IV & i \\
\hline Texis & 4 & $3 t$ & 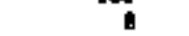 & 3 & 3 & $=$ & & $=$ & $=$ \\
\hline ITHA & 1310 & 1223 & 3056 & 167 & 172 & - & & 3 & 3 \\
\hline YEFWOT & 9 & 6 & $\because$ & 6 & & & & & \\
\hline $\begin{array}{l}\text { YERGINIA } \\
\text { MASHTSTOH }\end{array}$ & 29: & 24 & 16 & 8 & 4 & i & & $;$ & ; \\
\hline & 92 & 80 & 17 & 33 & 4] & J & & 3 & . \\
\hline $\begin{array}{l}\text { WEST VIRGLHIA } \\
\text { VISTOKSIR }\end{array}$ & 19 & 12 & 6 & 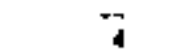 & $\overline{4}$ & 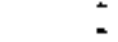 & & $=$ & 2 \\
\hline monjes & 66 & 29 & 22 & $i$ & 9 & $\mathbf{1}$ & & $\cdot$ & $\mathbf{1}$ \\
\hline Tothls & 5929 & $\sqrt{7.5}$ & 3225 & IES: & T679 & 26 & $\pi$ & 36 & 66 \\
\hline
\end{tabular}

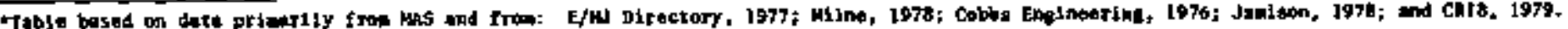

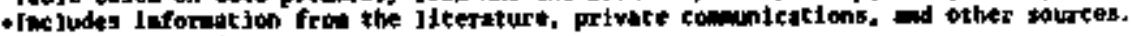

i Duetione District 
Hines considered for study, listed alphabetically along with state and county.

Allouez Conglomerate No. 1., Michigan, Houghton Co.

Allouez Conglomerate No, 2, Mich1gan, Houghton Co.

Alta Mine, Montana, Jefferson Co.

Amador Mine, Montana, Mineral Co.

Amalgamated Larder Mine, Nevada, Lincoln Co.

Amazon Mine, Idaho, Shoshone Co.

Amry Prospect, Nevada, Esmeralda Co.

Apex Standard Mine, Utah, Utah Co.

Arctic Camp, Alaska, Ambler River Co.

Ashland Mine, Oregon, Jackson Co.

At 2antic \& Brighton, Colorado, Gilpin Co.

At lantic Mines, Hyoming, Fremont Co.

Atolia District, California, San Bernardino, Kern Cos.

Babbitt Lake Exploration Prospect, Minnesota, St. Louís Co.

Babbit Mine, Montana, Sanders Co.

Bagdad Mine Aree, Arizona, Yavapai Co.

Balmat-Edwards District, New York, St. Lawrence Co.

Balmat, New York, St. Lahrence Co.

Baltic Anygdaloid, Michigan, Houghton Co.

Banner Mine, Idaho, Boiso Co.

Bartholonae, Alaska, Fairbanks Co.

Baxter Mine, Nevada, Mineral Co.

Black Cloud, Colorado, lake Co.

Black Hawk (Second Pond) - Blue Hil1 Mine, Maine, Hancock Co.

Black Pine Mine, Montana, Granite Co.

Black Rock Mine, Califormia, Mono Co.

Blackbird Mine, Idaho, Lemhi Co. 


\section{Block P Hire, Montana, Judith Basin Co.}

Boise-Rochester Mine, Idaho, Elmore Co.

Borianna Mine, Arizona, Mohave Co.

Bornite, Alaska, Ambler River Co.

Boyd Mine, Tennessee, Polk Co.

Brushy Creek Mine, Missouri, Reynolds Co.

Buffalo Mine, Idaho, Elmore Co.

Buick Mine, Hissouri, Iron Co.

Bulldog Mountain Project, Colorado, Mineral Co.

Bullion District, Nevada, Lander Co.

Bunker Hill Mine, Idaho, Shoshone Co.

Burgin Mine, Utah, Utah Co.

Burra Burra Mine, Tennessee, Polk Co.

Burro Chief Hine, New Mexico, Grant Co.

Butte Manganese District, Montana, Silver Bow Co.

Butte Highlands Mine, Montana, Silver Bৃow Co.

Butte Mining District and Butte Underground Mines, Mont., Silver Bow Co.

Cago No. 12, Idaho, Lemhi Co.

Calera Mine, Idaho, Lemhi Co.

Calloway Mine, Tennessee, Polk Co.

Calunet, No. 1, Michigan, Hought on Co.

Calumet, No. 2, Michigan, Houghton Co.

Campbird Mine, Colorado, Ouray Co.

Canisteo Mine, Minnesota, Itasca Co.

Carr Fork Mine, Utah, Tooele Co.

Centennial, No. 3-6, Michigan, Houghton Co.

Cherokee Mine, Tennessee, Polk Co.

Chief Mine, Utah, Juab co. 
Christmas Mine, Arizona, Gila Co.

Clayton Mine, Idaho, Custer Co.

Clinax Hine, Colorado, Lake Co.

Coeur Mine, Idaho, Shoshone Co.

Colorado School of Mines Mine, Colorado

Conjecture Mine, Idaho, Bonner Co.

Consolidated Silver, Idaho, Shoshone Co.

Constitution Mine, Idaho, Shoshone Co.

Continental Underground, New Mexico, Grant Co.

Copper Canp, Idaho, Valley Co.

Copper Hil1 Operations, Tennessee, Po1k Co.

Copper King, Arizona, Yavapai Co.

Cornwall Mine, Pennsylvania, Lebanon Co.

Cranberry Magnetite, North Carolina, Avery Co.

Crescent, Idaho, Shoshone Co.

Croton Magnetite Iron Mine, New York, Putnan Co.

Crowell Mine, Nevada, Nye Co.

Culchote, Tennessee, Polk Co.

Cuyuna Range Exploration Prospect, Minnesota, Crow Wing Co.

Dacotah Mine, Montana, Cascade Co.

Dan Tucker Mine, Nevada, Churchill co.

Darwin Mine, California, Inyo County

Dayrock Nine, Idaho, Shoshone Co.

Deep Creek Mine, Washington, Stevens Co.

Deer Trail Mine, Jtah, Juab Co.

Douglas Mine, Idaho, Shoshone Co.

Ducktown District, Tennessee, Polk Co.

Eagle Mine, Colorado, Gilman Co. 
East Tennesssee, Tennessee, Polk Co. Edwards, New York, St. Lawrence Co. Elizabeth Mine, Vermont, Orange Co. Elmwood No. 1, Tennessee, Polk Co. Ely Prospect, Minnesota, Lake Co. Eureka Bullion Mine, Utah, Utah Co. Eureka li1y Mine, Utah, Utah co. Eureka Mine, Tennessee, Polk Co. Eureka Standard Nine, Utah, Utah Co. Fletcher Mine, Młssouri, Reyrolds Co. Florence Mine, Montana, Cascade Co. Frisco Mine, Idaho, Shoshone Co. Galena Unit, Idaho, Shoshone Co. Galt-Queen, Montana, Cascade Co. Georgia Mine, Georgia, Chatsworth $\mathrm{Co}$. Germania Mine, Washington, Stevens Co. Getchell Mine, Neváda, Humboldt Co. Gilman Mine, Colorado, Eagle Co. Gold Hunter Mine, Idaho, shoshone Co. Golden Sunbeam, Idaho, Custer Co. Gooseberry Mine, Nevada, Storey Co. Grace Mine, Pennsylvanta, Berks Co. Granite-Bimeta11ic Mine, Montana, Granite Co. Gregory, Montana, Jefferson Co. Grey Eagle, California, Siskiyou Co. Grey Eagle Mine, Montana, Jefferson Co. Ground Hog Mine, New Mexico, Grant Co. Hall-Interstate Nine, Idaho, Valley Co. 
Hamme Tungsten District, Tungsten Queen, North Carolina, Vance Co. Hanover Mine, New Mexico, Grant co. Hecla Mine, Idaho, Shoshone Co. Henderson, Colorado, Grand \& Clear Creek Cos. Hercules Mine, Idaho, Shoshone Co. High land-Surprise Mine, Idaho, Shoshone Co. Hillside Mine, Arizona, Yavapai Co. Holden Mine, Washington, Chelan Co. Honestake Mine, South Dakota, Lawrence Co. Hoo Doo, Idaho, Custer County

Houghton No. 1., Michigan, Houghton Co. Hyatt, New York, St. Lawrence

Idarado Mine, Colorado, Ouray \& San Míguel Cos. Ilmenite Mines on Anorthosites, New York Ina Mine, Idaho, Lemhi Co. Imaruk Basin Graphite, Alaska, Teller Co. Independence Mine, Nevada, Lander Co. Indian Creek Div., Missouri, Hashington Co. Indiana, Michtgan, Ontonagon Co. Iron Dyke Mine, Oregon, Baker Co. Iron King Mine, Utah, Utah Co. Iron Mountain, Nissouri, st. Francois Co. Iroquois, Michigan, Keweenat Co. Isabe1la, Tennessee, Polk co. Jefferson City Nine, Tennessee, Polk Co. Johnson Mine, Vernont, Lamoille Co. Jualin, Alaska, Juneau Co. 
Kalamazoo, Arizona, Final co.

Kearsarge Amygdaloid Na. 1., Michigan, Houghton Co.

Kearsarge Amygdaloid No. 2., Michigan, Houghton Co.

Kentuck Mine, Idaho, Lemhi Co.

Kerr American Blue Hill Joint Venture, Maine, Hancock Co.

Keystone Nine, Colorado, Gunnison County

Kingston, Michigan, Keweenaw Co.

Kingston, No. 1, Michigan, Houghton Co.

Kingston, No. 2, Nichigan, Houghton Co.

Lakeshore Mine, Arizona, Pinal Co.

Last Resort Vein, Idaho, Custer Co.

Latest Out Mine, Idaho, Lenhi Co.

Leadville Unit, Colorado, lake Co.

Liberal King Mine, Idaho, Shoshone Co.

Little Pittsburg Mine, Idaho, Shoshone Co.

London, Tennessee, Polk Co.

Lost Packer Mine, Idaho, Custer Co.

Lost Pilgria Mine, Idaho, Valley Co.

Lost River, Alaska, Teller Co.

Lower Mammoth Mine, Utah, Juab co.

Lucky Friday Mine, Idaho, Shoshone Co.

Lyon Moumtain District New York, Clinton Co.

Magna, (Superior) Mine, Arizona, Pinal Co.

Magnont Mine, Missouri, Iron Co.

Mary, Tennessee, Polk Co.

Mather Mine, Michigan, Marquette.Co.

Mather B. Mìne, Michigan, Marquette Co. 
Mayflower Mine, Utah, Wasatch Co.

McCarty, Alaska, Livengood Co.

Mertaac Mines, Nevada, White Pine Co.

Miami East, Arizona, Gila Co.

Middle Fork Property, Washington, King Co.

Midnite Mine, Washington, Stevens Co.

Mill City, Nevada, Pershing Co.

Minnamax Site, Minnesota, St. Louis Co.

Minnie Moore Mine, Idaho, Blaine Co,

Miscellaneous Anygdaloids No. 1, Michigan, Houghton Co.

Miscellaneous Amygdaloids No. 2, Michigan, Houghton Co.

Misceltaneous Fissure No, 1, Michigan, Houghton Co.

Miscellaneous Fissures No. 2, Michigan, Houghton Co.

Morarch Mine, Idaho, Elmore Co.

Monitor Mine, Idaho, Shoshone Co.

Morning Mine, Idaho, Shoshone Co.

Mt. Hope Iron Mine, New Jersey, Morris Co.

New Light Mine, Washington, Whatcom Co.

New Market Mins, Tennessee, Jefferson Co.

North Lily Mine, Utah, Utah Co.

North Pole-Columbia Lode Mine, Oregon, Baker Co.

old Dick, Arizona, Yavapai Co.

01d Tennessee, Tennessee, Polk Co.

old Timer Mine, Nerada, White Pine Co.

Ontario Mine, Utah, \$mlunit co.

Ophir Nine, Utah, Tooele Co.

Oracle Ridge, Arizona, Pina Co.

Ore Knob Mine, North Carolina, Ashe Co. 
Oriental Mine, Califormia, Sierra co.

Osceola No. 1, Michigar, Houghton Co.

Osceola No. 2, Michigan, Houghton Co.

Ozark Mine, Missouri, Reyrolds Co.

Pacific, Utah, Utah Co.

Page Mine, Idaho, Shoshone Co.

Pan American Mine, Nevada, Lincoln Co.

Park City Mine, Utah, Summit Co.

Patapsco Mines, Maryland, Carroll Co.

Pend Oreille Mine, Washington, Pend Oreille Co.

Pewabic No. 1, Michigan, Houghton Co.

Pewabic No, 2, Michigan, Houghton Co.

Phi Kappa Mine, Idaho, Custer Co.

Piedmont Manganese Belt, Ga - Sc., Georgia, Lincoln Co.

Pilot Knob Mine, Missouri, Iron Co.

Pine Creek Mine, California, Inyo co.

Pittsburg-Idaho Mine, Idaho, Lenhi Co.

Polk County, Tenressee, Polk Co.

Poorran Mine, Idaho, Owyhee Co.

Questa Mine, New Mexico, Taos Co.

Records Vault, Vtah-little Cottonwood Canyon, Salt lake Co.

Red Bluff, Idaho, Valley Co.

Red Mountain, Montana, Lewis \& Clark Co.

Red Mountain Property, Arizona, Santa Cruz Co.

Resurrection Mine, Colorado, Lake Co.

Rich Gulch Mine, Idaho, Owyhee Co.

Robinson District, Nevada, Wite Pine Co. 
Rock Creek, Montana, Sanders Co.

Ruby Hil1 Mine, Nevada, Eureka Co.

Safford Thelps Dodge, Axizona, Graham Co.

San Francisco District, Utah, Beaver Co.

Sar Manue1, Arizona, Pina1 Co.

San Pedro Míne, New Mexico, Valencia Co.

Schwartzwalder Mine, Colorado, Jefferson Co.

Scrub Oaks, New Jersey, Morris Co.

Searchlight District, Nevada, Clark Co.

Seneca, Michigan, Keweenaw Co.

Septembex Group, California, Mono Co.

Sherman Mine, Colorado, Lake Co.

Sherman Mine, Idaho, Shoshone Co.

Sherwood Mine, Michigan, Iron Co.

Sherwood Mine, Washington, Stevens Co.

Shrine Mine, New Mexico, Grant Co.

Sidney Mine, Idsho, Shoshone Co.

Silver City Region, Idaho, Wyhee Co.

Silver Crystal Mine, Idaho, Shoshone Co.

Silver Dyke, Nevada, Mineral Co.

Silver King Mines, Nevada, Lander Co.

Silverton Operations, Colorado, San Juan Co.

Sixteen-to-one Mine, Nevada, Esmeralda Co.

Snowbird, Idaho, Valley Co.

Soudan Mine, Minnesota, Saint Louis Co.

South Mountain Mine, Idaho, Wyhee Co.

Springfield Mine, Maryland, Carroll Co. 
St. Patrick Mining Co., Nevada, Lincoln Co.

Standard-Manuoth Mine, Idaho, shoshone Co.

Star-Morning Mine, Idaho, Shoshone Co.

Star Mine, Idaho, Shoshone Co.

Steen Mine, Idaho, Lemhi Co.

Sterling Hine, New Jersey, Sussex Co,

Success Mine, Idaho, Shoshone Co.

Sullivan Operations, Missouri, Washington Co.

Sutmit King Mine, Nevada, Churchill Co.

Sunbeam Mine, Utah, Juab Co.

Sunrise Breccia Deposit, Washington, Snohomish Co.

Sunrise, Hyoning, P1atte Co.

Sunset Nine, Idaho, Shoshone Co.

Sunset Mine, Hashington, Snohomish Co.

Sunshine Mine, Idaho, Shoshone Co.

Superior Mine, Arizona, Pinal Co.

Stutton No, 2 Mine, Nevada, Pershing Co.

Tag Mine, Nevada, Pershing Co.

Tanarack Nine, Idaho, Shoshone Co.

Taylor Mine, Nevadg, White Pine Co.

Ten Piute Operations, Nevada, Lincoln Co.

Tennessee Mines Div., Tennessee, Knox \& Jefferson Co.

Thonas "w" Nine, Nevada, Lander Co.

Tiger-Poorman Mine, Idaho, Shoshone Co.

Tilly Foster Magnetite Mine, New York, Putnam Co.

Tintic Standard Mine, Utah, Utah Co.

Trixie Mine, Utah, Utah Co.

Troy Mine, Montana, Lincoln Co. 
Tungsten Group, Nevada, Pershing Co.

Tungsten Queen Mine, North Carolina, Vance Co.

Twenty-one Mine, New Mexico, Valencia Co.

Twenty-seven Mine, New Mexico, Valencia Co.

United Copper Clain, Washington, Stevens Co.

Unity Mine, Idaho, Idaho Co.

Urad Mine, Colorado, Ouray co.

Viburnum Div., Missouri, Iron Co.

Ward Mountain Mine, Nevada, white Pine Co.

White Pine Mine, Michigan, Ontonagon Co.

Whitedelph Mine, Idaho, Bonner Co.

Woodrat Mountain Kyanite Prospect, Idaho, Idaho Co. 
